Prepared in cooperation with the BUREAU OF LAND MANAGEMENT, ARIZONA DEPARTMENT OF WATER RESOURCES, CITY OF SIERRA VISTA,

U.S. DEPARTMENT OF DEFENSE and the U.S. ENVIRONMENTAL PROTECTION AGENCY

\title{
Hydrologic Requirements of and Consumptive Ground-Water Use by Riparian Vegetation along the San Pedro River, Arizona
}

Scientific Investigations Report 2005-5163 
Inside Front Cover

This page left blank intentionally. 


\section{Hydrologic Requirements of and Consumptive Ground-Water Use by Riparian Vegetation along the San Pedro River, Arizona}

Compiled by James M. Leenhouts, Juliet C. Stromberg, and Russell L. Scott

Chapter A

Study Overview

By James M. Leenhouts', Juliet C. Stromberg'르, and Russell L. Scott ${ }^{3}$

Chapter B

Hydrology of the San Pedro Riparian National Conservation Area

By James M. Leenhouts ${ }^{1}$

Chapter C

Relations between Streamflow Regime and Riparian Vegetation

Composition, Structure, and Diversity within the San Pedro

Riparian National Conservation Area

By Juliet C. Stromberg' ${ }^{2}$, Sharon J. Lite', Mark Dixon'2, Tyler Rychener ${ }^{2}$, and Elizabeth Makings ${ }^{2}$

Chapter D

Determining the Riparian Ground-Water Use within the San Pedro Riparian National Conservation Area and the Sierra Vista Subwatershed

By Russell L. Scott ${ }^{3}$, David G. Williams ${ }^{4}$, David C. Goodrich ${ }^{3}$, William L. Cable ${ }^{3}$, Lainie R. Levick ${ }^{3}$,

Roberta McGuire ${ }^{3}$, Rico M. Gazal ${ }^{4}$, Enrico A. Yepez ${ }^{4}$, Patrick Ellsworth ${ }^{4}$, and Travis E. Huxman ${ }^{5}$

Prepared in cooperation with the

BUREAU OF LAND MANAGEMENT, ARIZONA DEPARTMENT OF WATER RESOURCES,

CITY OF SIERRA VISTA, U.S. DEPARTMENT OF DEFENSE, and the

U.S. ENVIRONMENTAL PROTECTION AGENCY

Scientific Investigations Report 2005-5163

U.S. Department of the Interior

U.S. Geological Survey

${ }^{1}$ U.S. Geological Survey, Arizona Water Science Center, Tucson, Arizona.

${ }^{2}$ School of Life Sciences, Arizona State University, Tempe, Arizona.

${ }^{3}$ Southwest Watershed Research Center, U.S. Department of Agriculture, Agricultural Research Service, Tucson, Arizona.

${ }^{4}$ Department of Renewable Resources, University of Wyoming, Laramie, Wyoming.

${ }^{5}$ Department of Ecology and Evolutionary Biology, University of Arizona, Tucson, Arizona. 


\section{U.S. Department of the Interior \\ P. Lynn Scarlett, Acting Secretary}

\section{U.S. Geological Survey \\ P. Patrick Leahy, Acting Director}

\section{U.S. Geological Survey, Reston, Virginia: 2006}

For product and ordering information:

World Wide Web: http://www.usgs.gov/pubprod

Telephone: 1-888-ASK-USGS

For more information on the USGS — the Federal source for science about the Earth, its natural and living resources, natural hazards, and the environment: World Wide Web: http://www.usgs.gov

Telephone: 1-888-ASK-USGS

Any use of trade, product, or firm names is for descriptive purposes only and does not imply endorsement by the U.S. Government

Although this report is in the public domain, permission must be secured from the individual copyright owners to reproduce any copyrighted materials contained within this report.

Suggested citation:

Leenhouts, J. M., Stromberg, J.C., and Scott, R.L., eds., 2006, Hydrologic requirements of and consumptive groundwater use by riparian vegetation along the San Pedro River, Arizona: U.S. Geological Survey Scientific Investigations Report 2005-5163, 154 p. 


\section{Cooperative Arrangements}

The studies documented in this report were the result of cooperative arrangements beginning in 2001 that were made to address water-resource concerns in the Sierra Vista Subwatershed identified by the Upper San Pedro Partnership, a consortium of 21 Federal State, and local agencies and organizations. The U.S. Geological Survey, in cooperation with the Bureau of Land Management (BLM) and the Arizona Department of Water Resources (ADWR), conducted a study of the hydrology of the San Pedro Riparian National Conservation Area (chapter B). In 2002, the city of Sierra Vista joined the cooperative effort. Arizona State University, in cooperation with the BLM and ADWR, conducted a study of the relations between streamflow regime and riparian vegetation composition, structure, and diversity in the conservation area (chapter C). The U.S. Department of Agriculture, Agricultural Research Service, in cooperation with the BLM, Department of Defense, and U.S. Environmental Protection Agency, conducted a study to determine the riparian ground-water use within the conservation area and the Sierra Vista Subwatershed (chapter D).

\section{Acknowledgments}

The authors are grateful to the Upper San Pedro Partnership for the initiation of this project and for technical and logistical support. We would also like to thank the Fort Huachuca Meteorological Support team, staff from the Bureau of Land Management, and especially all the rest of the staff from the U.S. Department of Agriculture's Agricultural Research Service in Tucson and Tombstone, Arizona, for their invaluable support of this work. The careful technical reviews by David Anderson, Joan Blainey, James Eychaner, William Simonds, David Stannard, and Steve Wiele (U.S. Geological Survey), Susan Moran (U.S. Department of Agriculture, Agricultural Research Service), Robert MacNish (U.S. Geological Survey, retired), and James Fogg (Bureau of Land Management) were instrumental in improving this document. Suggestions provided by members of the Upper San Pedro Partnership Technical Committee also were appreciated. The efforts of John Callahan and Tracey Suzuki (U.S. Geological Survey) were essential in creating illustrations, editing, and preparing this report.

This work could not have been completed without personnel and equipment provided by SAHRA (Sustainability of semi-Arid Hydrology and Riparian Areas) under the STC Program of the National Science Foundation, Agreement No. EAR-9876800. Additional personnel were provided through a U.S. Environmental Protection Agency Water and Watersheds Research Program grant. 
This page left blank intentionally. 


\section{Contents}

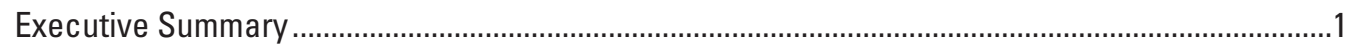

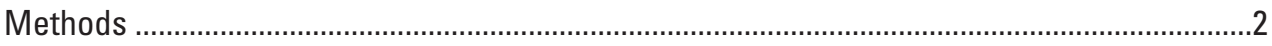

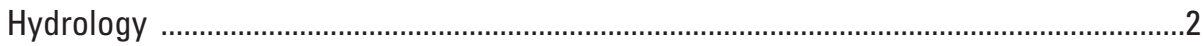

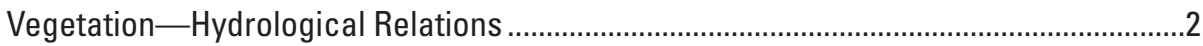

Riparian Condition Index ........................................................................................

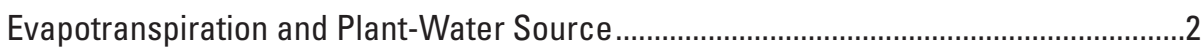

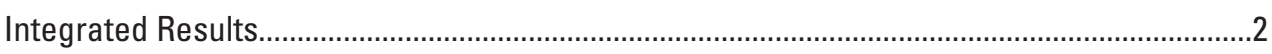

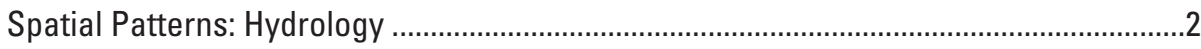

Spatial Patterns: Riparian Condition Class ......................................................................

Temporal Variability: Hydrology and Vegetation.................................................................

Water Use and Water Needs by Vegetation Type............................................................

Velvet Mesquite Woodland and Shrubland ..........................................................

Fremont Cottonwood-Goodding Willow Forest ....................................................

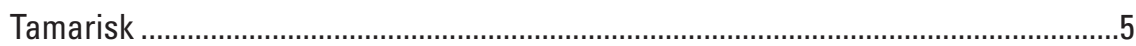

Sacaton and Other Herbaceous Vegetation on Flood Plains and Terraces ............5

Seepwillow Shrublands .....................................................................................

Streamside Wetland Vegetation and Open Channels ...............................................6

Scaling-Up Water-Use Estimates to the Basin Level Vegetation Mapping .......................6

\section{Chapter A}

Introduction

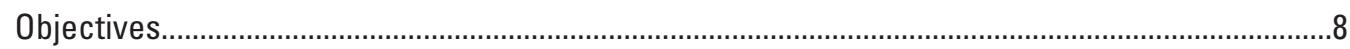

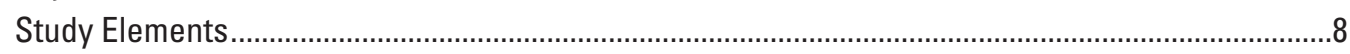

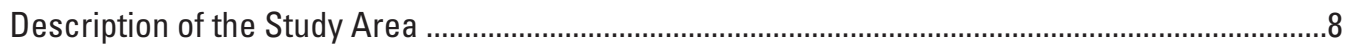

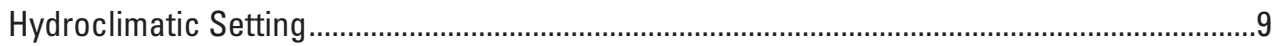

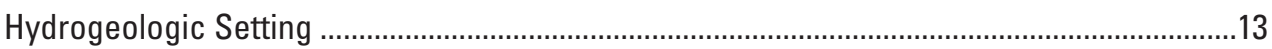

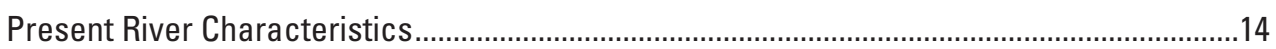

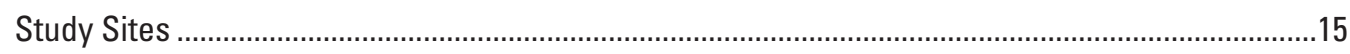

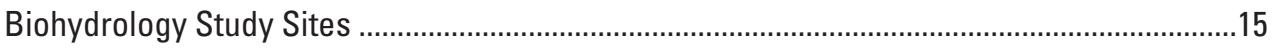

Reaches and Condition Classes ...................................................................................18

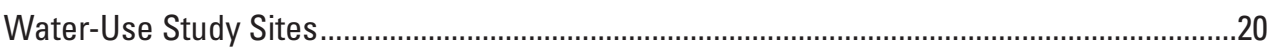

Precipitation and Streamflow during the Study Period.................................................................

\section{Chapter B}

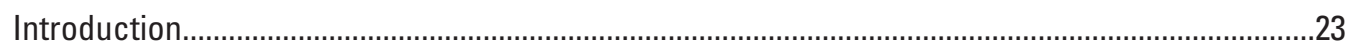

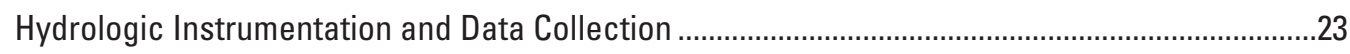

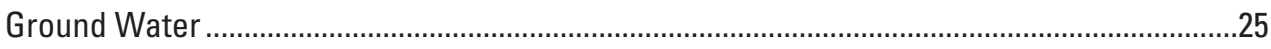

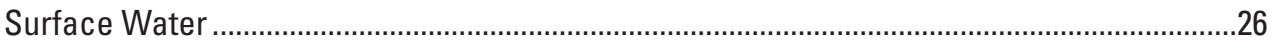

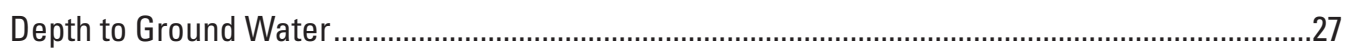

Temporal and Spatial Variability of Ground-Water Levels in Piezometers .............................27 


\section{Contents - Chapter B, continued}

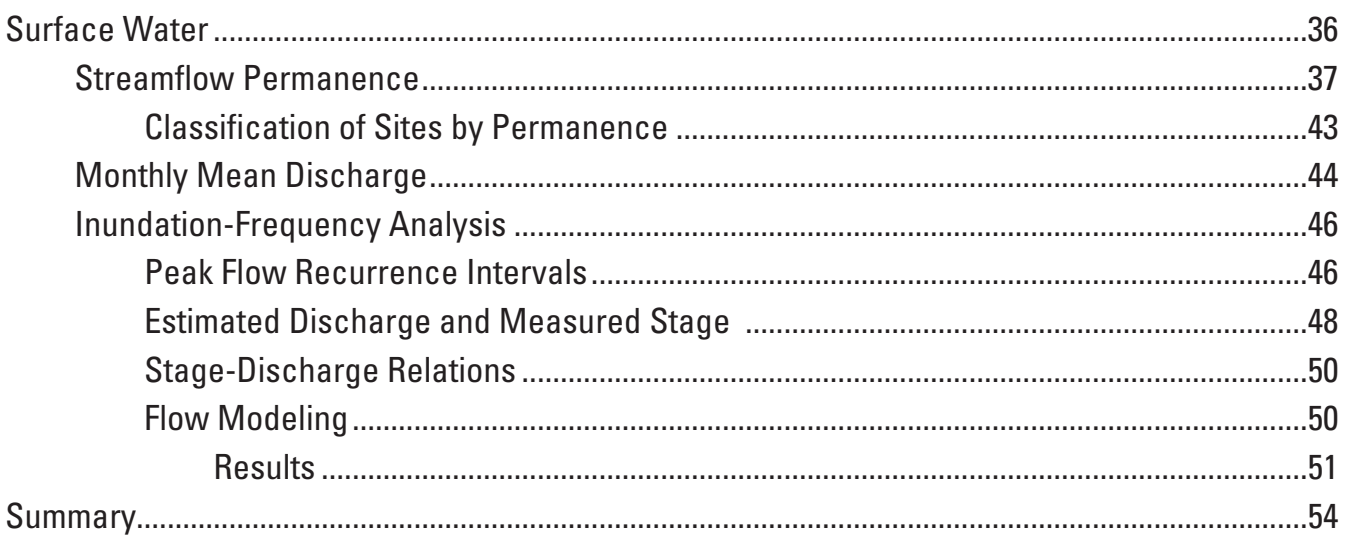

\section{Chapter C}

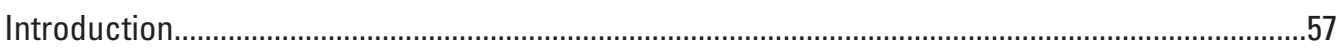

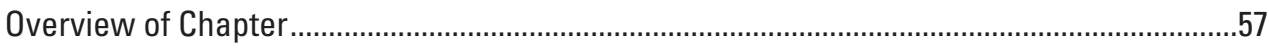

Overview of Environmental Flow Assessment …………........................................................5

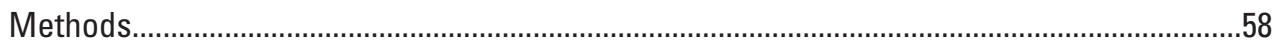

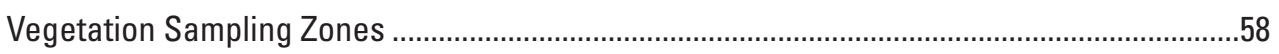

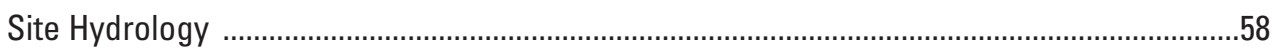

Biohydrology Analysis: Riparian Vegetation Biomass Structure and Species Richness...............59

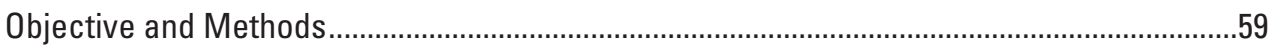

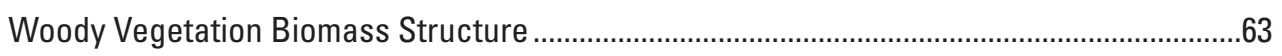

Plant Species Richness ................................................................................................66

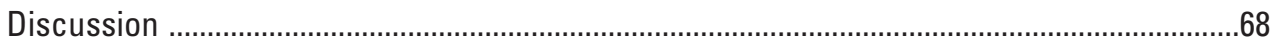

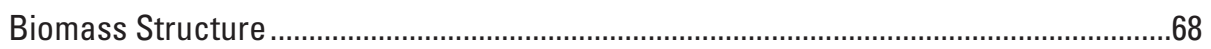

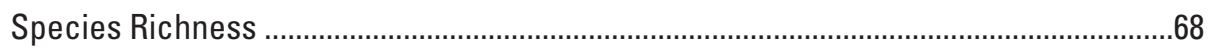

Biohydrology Analysis: Influence of Hydrology on Woody-Plant Species ....................................69

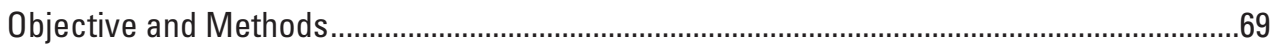

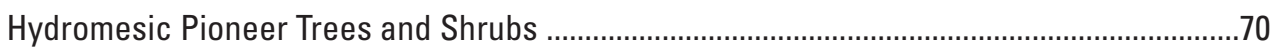

Mesic Pioneer Trees and Shrubs.........................................................................................

Mesic Competitor Trees and Shrubs ..............................................................................

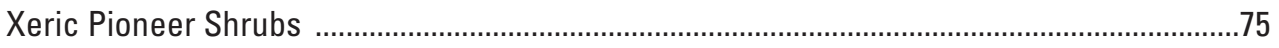

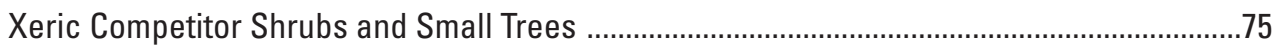

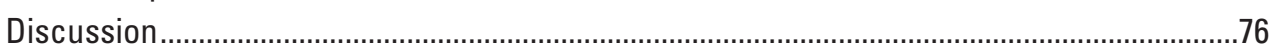

Fremont Cottonwoods and Goodding Willows ............................................................76

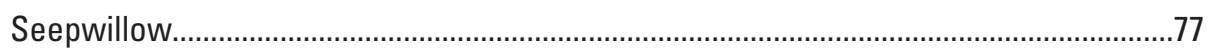

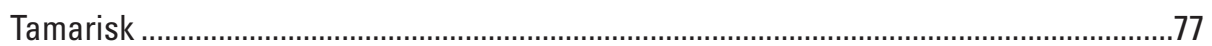

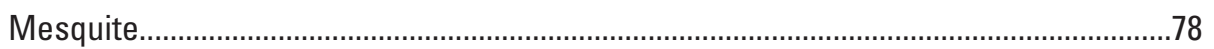

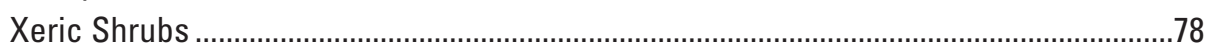

Biohydrology Analysis: Influence of Hydrology on Herbaceous Plant Species ..............................78

Hydric Herbaceous Perennials ........................................................................................ 


\section{Contents-Chapter C, continued}

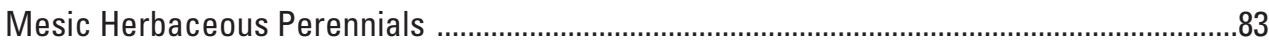

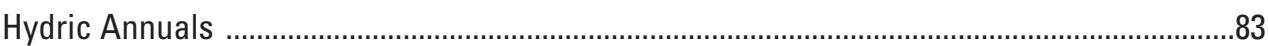

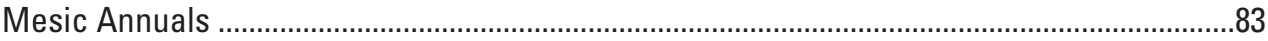

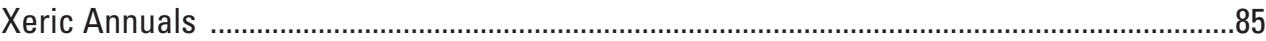

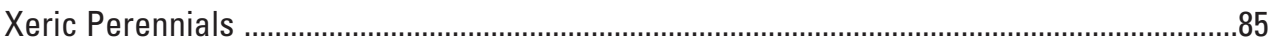

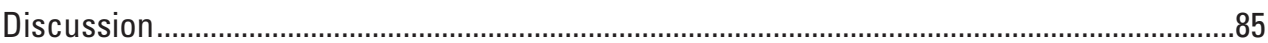

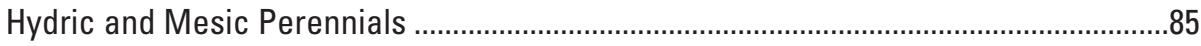

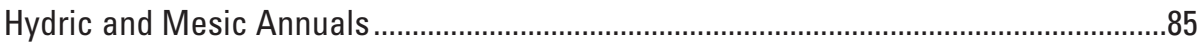

Xeric Annuals and Perennials ......................................................................................86

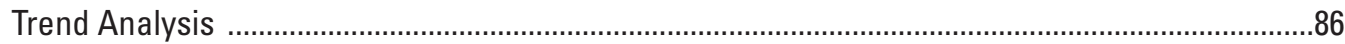

Relative Abundance of Fremont Cottonwood, Goodding Willow, and Tamarisk .....................86

Trends in Fremont Cottonwood-Goodding Willow Establishment Rates...................................89

Simulation of Fremont Cottonwood-Goodding Willow Establishment:

"Recruitment Box" Analysis ..............................................................................92

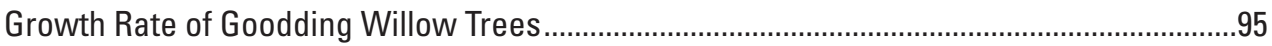

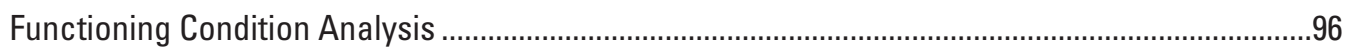

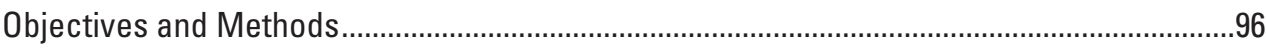

Condition Class Overview, by Reach .................................................................................99

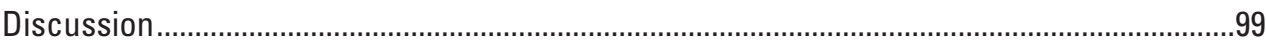

Functional Changes along the Water-Availability Gradient ..................................................102

Biodiversity Maintenance ..............................................................................................102

Maintaining Plant Biodiversity ............................................................................102

Maintaining Animal Biodiversity ...........................................................................102

Maintaining Endangered Riparian Species ........................................................102

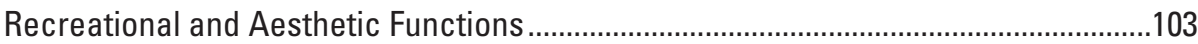

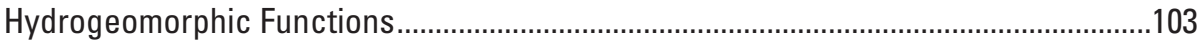

Energy Dissipation and Flood-Velocity Reduction ...............................................103

Sediment Detention and Sediment Dynamics ........................................................103

Streambank Erosion Prevention and Channel Maintenance .................................103

Enhancing Bank Storage and Ground-Water Recharge ........................................103

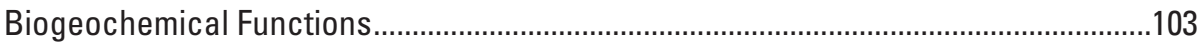

Water-Quality Purification and Nutrient Cycling and Retention ............................104

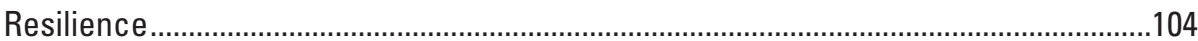

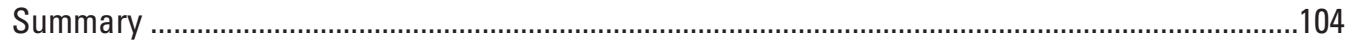

\section{Chapter D}

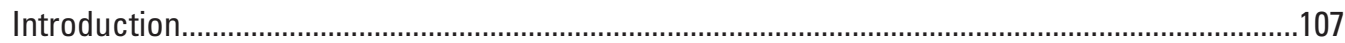

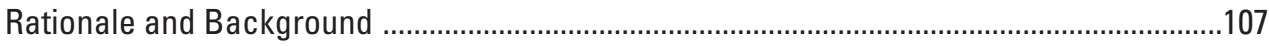

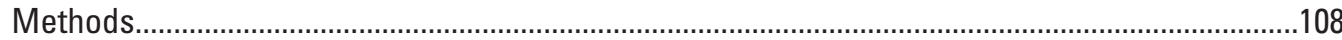

Mesquite Woodland Evapotranspiration .............................................................................108

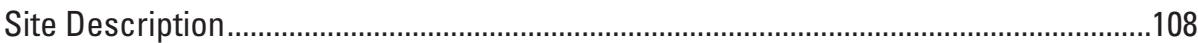

Meteorological Instrumentation ............................................................................108 


\section{Contents-Chapter D, continued}

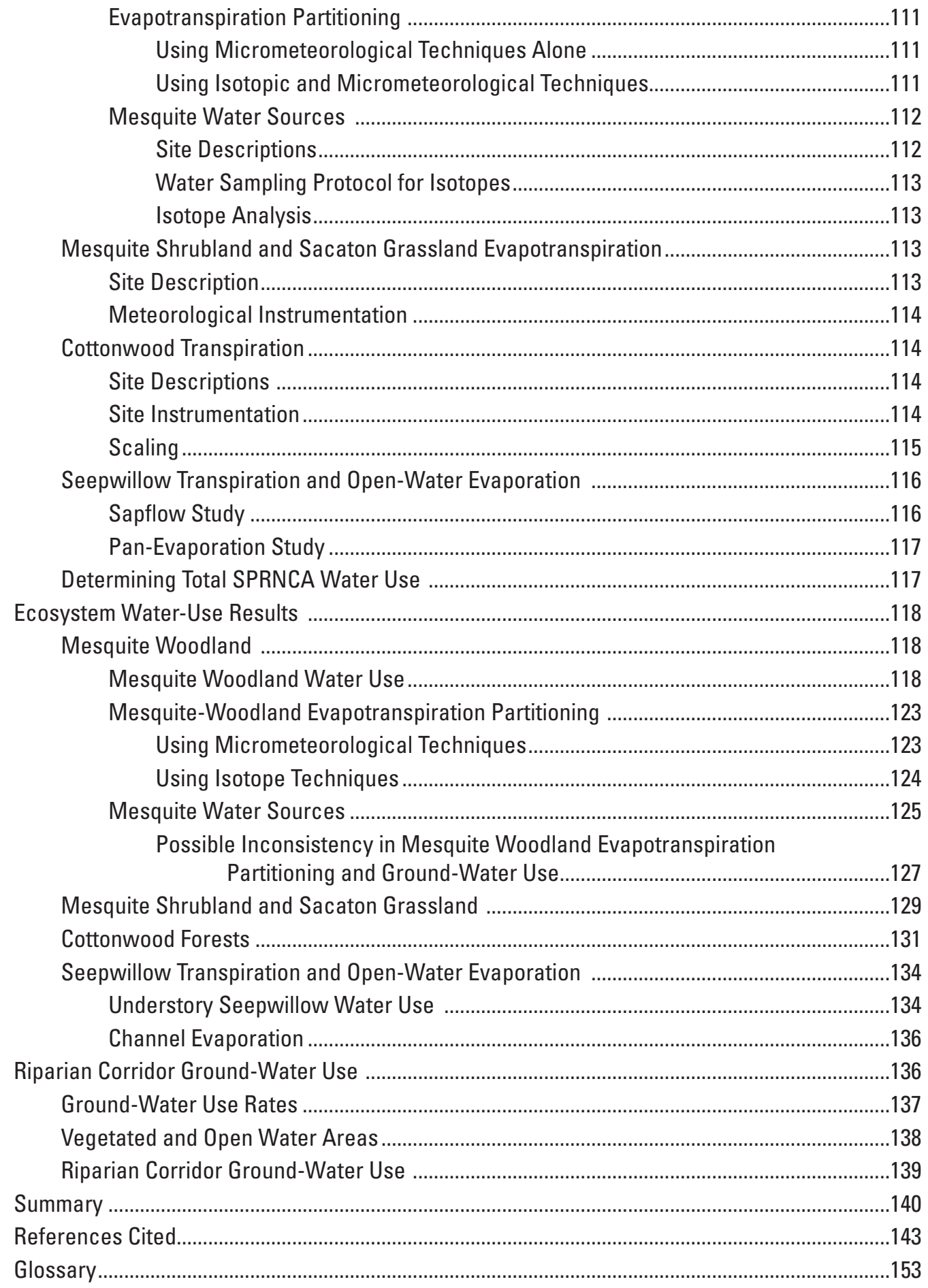




\section{Figures}

1. Maps showing the boundaries of the Sierra Vista Subwatershed, 14 reaches of the San Pedro River within the San Pedro Riparian National Conservation Area (SPRNCA), and locations of streamflow-gaging stations, biohydrology sites, supplemental riparian study sites, and evapotranspiration sites, Upper and Lower Basins, Arizona

2. Hydrology and biohydrology data-collection transect across the San Pedro River at Palominas site, SPRNCA, Upper San Pedro Basin, Arizona.

3. Geologic section perpendicular to the San Pedro River near State Highway 90, SPRNCA, Upper San Pedro Basin, Arizona.

4. Photographs showing active post-entrenchment channel of the San Pedro River during the summer, SPRNCA, Upper San Pedro Basin, Arizona

5. Areal view of the Palominas study site showing approximate locations of biohydrology belt transects, hydrologic monitoring equipment, and meteorological station, SPRNCA, Upper San Pedro Basin, Arizona

6. Map showing the location of the study area showing the 16 biohydrology sites in the SPRNCA, Upper San Pedro Basin, Arizona

7. Diagram showing installation of electrical-resistance and temperature sensors in drilled sections of 5.1-cm (2-in. diameter) polyvinyl chloride (PVC) pipe.

8. Graph showing monthly average water-level elevations in a Palominas site piezometer, SPRNCA, Upper San Pedro Basin, Arizona.

9. Graph showing representative hydrographs from each of the 16 biohydrology study sites in the SPRNCA, Upper San Pedro Basin, Arizona

10. Areal view of the Palominas study site showing regional hydraulic-gradient direction and hydrology/biohydrology transect orientation, SPRNCA, Upper San Pedro Basin, Arizona....

11. Diagram showing hypothetical examples of mirroring ground-water levels from the monitored side to the unmonitored side of a river.

12. Areal view of St. David site showing regional hydraulic-gradient direction, hydrology/biohydrology transect, and piezometers, SPRNCA, Upper San Pedro Basin, Arizona

13. Areal view of Lewis Springs site showing regional hydraulic-gradient direction, hydrology/biohydrology transect, and piezometers, SPRNCA, Upper San Pedro Basin, Arizona

14-18. Graphs showing:

14. Calculated monthly average water-table elevations, SPRNCA, Upper San Pedro Basin Arizona.

15. Data collected at the Fairbank site to determine percentage of time flow was present in the SPRNCA, Upper San Pedro Basin, Arizona.

16. Percentage of time in each month that flow was present at the 16 biohydrology study sites, SPRNCA, Upper San Pedro Basin, Arizona

17. Percentage of time in each month that flow was present at U.S. Geological Survey streamflow-gaging stations San Pedro River at Palominas (09470500) and San Pedro River near Tombstone (09471550), SPRNCA, Upper San Pedro Basin, Arizona.

18. Stage-discharge relations from modeled and measured stage estimated discharge analyses at each of the 16 biohydrology study sites, SPRNCA, Upper San Pedro Basin, Arizona 


\section{Figures-Continued}

19. Boundaries of the 14 reaches of the San Pedro River within the SPRNCA and locations of biohydrology and supplemental riparian study sites,

Upper and Lower San Pedro Basins, Arizona.

20. Surveyed cross section for the Palominas site hydrology/biohydrology transect, showing vegetation patches and modeled river stages for 2-year and 25-year return-period floods, SPRNCA, Upper San Pedro Basin, Arizona..

21-40. Graphs showing:

21. Mean maximum vegetation height (flood-plain zone) plus one standard deviation for sites classified into three hydrology classes for 12 unburned biohydrology study areas, SPRNCA, Upper San Pedro Basin, Arizona.

22. Relative widths of shrublands and woodlands in the flood plain of the 16 biohydrology study sites in relation to annual streamflow permanence, SPRNCA, Upper San Pedro Basin, Arizona

23. Relative width of terrace vegetation patches classified as herbaceous-dominated and woody-dominated in relation to elevation of 20 biohydrology and supplemental study sites, SPRNCA, Upper San Pedro Basin, Arizona.

24. Multiyear overlay of dry-season streamside-zone herbaceous species cover and richness values, in relation to streamflow permanence at study sites, Upper and Lower San Pedro Basins, Arizona

25. Herbaceous species richness (per square meter) during the premonsoon season of four years, within the SPRNCA streamside zone, Upper San Pedro Basin, Arizona .....

26. Flood-plain herbaceous cover and species richness, during the dry summer season of 3 years and the monsoon season of 4 years, SPRNCA, Upper San Pedro Basin, Arizona..

27. Basal area of Fremont cottonwood, Goodding willow, and tamarisk in relation to streamflow permanence of San Pedro River sites, Upper and Lower San Pedro Basins, Arizona.

28. Stem density of Fremont cottonwood and Goodding willow within the San Pedro River flood plain, in relation to annual maximum depth to ground water and annual ground-water fluctuation, 16 biohydrology study sites, SPRNCA, Upper San Pedro Basin, Arizona.

29. Distribution of depth to ground water along the San Pedro River, SPRNCA, Upper San Pedro Basin, Arizona.

30. Mean number of Fremont cottonwood and Goodding willow stemsize classes, and mean flood-plain cover of seepwillow baccharis, within the 16 biohydrology study sites classified into three hydrology classes, SPRNCA, Upper San Pedro Basin, Arizona

31. Width of vegetation patches dominated by velvet mesquite forests, woodlands, and shrublands within the San Pedro River terrace sampling zone, by site, SPRNCA, Upper San Pedro Basin, Arizona

32. Cover values for several common herbaceous species in the San Pedro streamside zone during premonsoon and monsoon periods of 2002, in relation to annual streamflow permanence at the site, SPRNCA, Upper San Pedro Basin, Arizona. 


\section{Figures-Continued}

33. Distribution of common herbaceous perennial plant species across depth-to-ground-water gradients in the San Pedro River flood plain, SPRNCA, Upper San Pedro Basin, Arizona ...

34. Overlay of streamside-zone site values, SPRNCA, Upper San Pedro Basin, Arizona.

35. Mean cover of hydric, mesic, and xeric annuals/biennials in relation to elevation of the fluvial surface above the thalweg during the dry and wet seasons of 2000, SPRNCA, Upper San Pedro Basin, Arizona

36. Hydric herbaceous cover (annual and perennial) in the streamside zone during the premonsoon season, SPRNCA, Upper San Pedro Basin, Arizona

37. Flow mapping during June 2002 within 14 reaches of the SPRNCA, Upper San Pedro Basin, Arizona

38. Stem density of Fremont cottonwood and Goodding willow, by age class, within SPRNCA flood plains, Upper San Pedro Basin, Arizona, classified by hydrologic condition

39. Simulated first-year seedling recruitment of Fremont cottonwood and Goodding willow at a perennial and an intermittent-wet site along the Upper San Pedro River, SPRNCA, Upper San Pedro Basin, Arizona

40. Branch-growth increment of Goodding willow, SPRNCA,

Upper San Pedro Basin, Arizona

41. Schematic diagram depicting the three major hydrologic reach types and corresponding vegetation patterns along the Upper San Pedro River, Upper San Pedro Basin, Arizona..

42. Map showing riparian ecological condition classes for 14 reaches and streamflow presence for June 2002 within the SPRNCA, Upper San Pedro Basin, Arizona..

43. Map showing location of study area and evapotranspiration study sites in the SPRNCA, Upper San Pedro Basin, Arizona.

44. Diagram showing sap-flow sensor unit used for the heat balance method, SPRNCA, Upper San Pedro Basin, Arizona.

45. Maps showing the vegetation distribution for an example reach of the SPRNCA near Boquillas, Upper San Pedro Basin, Arizona

46-70. Graphs showing:

46. Total monthly precipitation during 2001-03 at the Charleston mesquite site, SPRNCA, Upper San Pedro Basin, Arizona.

47. Data indicating ground-water use by mesquite at the Charleston mesquite site, SPRNCA, Upper San Pedro Basin, Arizona, May 2002.

48. Cumulative fluxes of precipitation and evapotranspiration for 2001, 2002, and 2003 at the Charleston mesquite site, SPRNCA, Upper San Pedro Basin, Arizona

49. Availability of near-surface soil moisture at the Charleston mesquite site, SPRNCA, Upper San Pedro Basin, Arizona.

50. Average weekly woodland evapotranspiration for 2001, 2002, and 2003 at the Charleston mesquite site, SPRNCA, Upper San Pedro Basin, Arizona. 


\section{Figures-Continued}

51. Evidence of the ability of mesquite roots to redistribute soil moisture at the Charleston mesquite site, SPRNCA,

Upper San Pedro Basin, Arizona.

52. Total daily evapotranspiration from the Charleston mesquite site and ET partitioning into overstory/understory sources, and an estimate of tree transpiration calculated by using ground-water fluctuations and the method of White (1932) with a storage coefficient of 0.04, SPRNCA, Upper San Pedro Basin, Arizona ..

53. Charleston mesquite site evapotranspiration, SPRNCA, Upper San Pedro Basin, Arizona.

54. Isotopic evapotranspiration partitioning in relation to seasonal precipitation at the Charleston mesquite site, SPRNCA, Upper San Pedro Basin, Arizona.

55. Seasonal trends of average weekly evapotranspiration-flux components calculated by using the isotopic-flux partitioning and the eddy-covariance derived distributed measurements of evapotranspiration at the Charleston mesquite site, SPRNCA, Upper San Pedro Basin, Arizona.

56. Mesquite transpiration-source partitioning for the Charleston mesquite, Lewis Springs, and Moson sites for the 2000 growing season, SPRNCA, Upper San Pedro Basin, Arizona

57. Mesquite transpiration sources at the Charleston mesquite site, 2001 and 2002 growing seasons, SPRNCA, Upper San Pedro Basin, Arizona.

58. Water-source partitioning for the Lewis Springs and Moson sites, 2001 and 2002 growing seasons, SPRNCA, Upper San Pedro Basin, Arizona.

59. Total tree-transpiration flux from May 1 to November 17 for 2001, 2002, and 2003 at the Charleston mesquite site, SPRNCA, Upper San Pedro Basin, Arizona.

60. Cumulative fluxes of precipitation and evapotranspiration at all eddy-covariance sites for 2003: mesquite woodland and sacaton grassland and mesquite shrubland, SPRNCA, Upper San Pedro Basin, Arizona.

61. Weekly average evapotranspiration for all eddy-covariance sites for 2003: mesquite woodland and sacaton grassland and mesquite shrubland, SPRNCA, Upper San Pedro Basin, Arizona.....

62. Vapor-pressure deficit and measured cottonwood transpiration for July 4-9, 2003 (day of year 185-190), SPRNCA, Upper San Pedro Basin, Arizona.

63. Vapor-pressure deficit and measured cottonwood transpiration for August 8-13, 2003 (day of year 220-225), SPRNCA, Upper San Pedro Basin, Arizona.

64. Relation of measured cottonwood transpiration to vapor-pressure deficit and depth to ground water at the Boquillas and Lewis Springs sites, SPRNCA, Upper San Pedro Basin, Arizona..

65. Seasonal cottonwood transpiration at the Boquillas and Lewis Springs sites, 2003, SPRNCA, Upper San Pedro Basin, Arizona 


\section{Figures-Continued}

66. Daily reference crop evapotranspiration and measured transpiration of cottonwood trees at the Boquillas and Lewis Springs sites, 2003,

SPRNCA, Upper San Pedro Basin, Arizona...

67. Seasonal cottonwood transpiration at the Boquillas and Lewis Springs sites, 2003, SPRNCA, Upper San Pedro Basin, Arizona.

68. Comparison of seepwillow transpiration with reference crop evapotranspiration at the Lewis Springs site, 2003, SPRNCA, Upper San Pedro Basin, Arizona.

69. Comparison of seepwillow with cottonwood transpiration at the Lewis Springs site, 2003, SPRNCA, Upper San Pedro Basin, Arizona.

70. Measured open-water evaporation compared to calculated openwater evaporation at the Lewis Springs site, 2003, SPRNCA, Upper San Pedro Basin, Arizona.

\section{Tables}

1. Summary of U.S. Geological Survey streamflow-gaging station information, Sierra Vista Subwatershed, Upper San Pedro Basin, Arizona

2. Biohydrology, supplemental riparian, and evapotranspiration/water-source study sites, Upper and Lower San Pedro Basins, Arizona .............................................16

3. Recent fires in the SPRNCA riparian corridor, Upper San Pedro Basin, Arizona............17

4. Hydrogeomorphic traits of reaches of the San Pedro River, SPRNCA, Upper San Pedro Basin, Arizona.....

5. Locations of the 16 biohydrology and 10 supplemental study sites, SPRNCA, Upper San Pedro Basin, Arizona..

6. Average streamflow at U.S. Geological Survey streamflow-gaging station San Pedro River at Charleston (09471000) and total precipitation at the National Weather Service Tombstone precipitation-gaging station, Upper San Pedro Basin, Arizona 2000-2003 ...

7. Summary of hydrologic monitoring equipment at the biohydrology sites, SPRNCA, Upper San Pedro Basin, Arizona.

8. Permanent streamflow-gaging stations from which data were used in the surface-water analyses, Upper and Lower San Pedro Basins, Arizona

9. Streamflow permanence at the 16 biohydrology study sites, SPRNCA, Upper San Pedro Basin, Arizona..

10. Regression equation parameters and estimates of error calculated for site to streamflow-gaging station discharge correlation analysis for the 16 biohydrology study sites in the winter, spring/fall, and monsoon periods, SPRNCA, Upper San Pedro Basin, Arizona.

11. Estimated monthly mean flow at the 16 biohydrology study sites, SPRNCA, Upper San Pedro Basin, Arizona. 


\section{Tables-Continued}

12. Drainage area and peak discharge at streamflow-gaging stations for 2-, 5-, 10-, 25-, and 50-year recurrence-interval floods, Upper and Lower San Pedro Basins, Arizona ....

13. Estimated peak flows at each of the 16 biohydrology study sites for the 2-, 5-, 10-, 25-, and 50-year recurrence-interval floods, SPRNCA, Upper San Pedro Basin, Arizona

14. Inundation elevation at each of the 16 biohydrology study sites for the 2-, 5-, 10-, 25-, and 50-year recurrence-interval floods, SPRNCA, Upper San Pedro Basin, Arizona.

15. Hydrologic characteristics of the 16 biohydrology study sites, SPRNCA, Upper San Pedro Basin, Arizona.

16. Means and standard deviations of hydrologic variables for biohydrology sites, classified into three hydrologic classes, SPRNCA, Upper San Pedro Basin, Arizona..

17. Correlation coefficients between SPRNCA flood-plain vegetation structure traits and three site attributes, Upper San Pedro Basin, Arizona

18. Correlation coefficients between SPRNCA flood-plain vegetation structure traits and three site attributes, Upper San Pedro Basin, Arizona

19. Correlation coefficients between vegetation structure traits and site elevation, for the terrace zone, SPRNCA, Upper San Pedro Basin, Arizona

20. Correlation coefficients between woody species richness values and environmental variables, SPRNCA, Upper San Pedro Basin, Arizona.

21. Correlation coefficients between streamside-zone herbaceous vegetation and water-year streamflow permanence, for premonsoon and monsoon sampling periods, Upper and Lower San Pedro Basins, Arizona.

22. Correlation coefficients between herbaceous plant abundance and environmental site variables, SPRNCA, Upper San Pedro Basin, Arizona

23. Correlation coefficients between woody-species basal area or coverand site-water availability indicators for the SPRNCA flood-plain zone, Upper San Pedro Basin, Arizona.

24. Correlation coefficients between woody species basal area or cover in the San Pedro River, Arizona, flood plain and site elevation, flood-plain width, and total stream power of the 100-year recurrence-interval flood, SPRNCA, Upper San Pedro Basin, Arizona

25. Mean ground-cover values of herbaceous species, by functional group, within the streamside zone, SPRNCA, Upper San Pedro Basin, Arizona

26. Mean ground-cover values of herbaceous plants, by functional group, in the flood plain during premonsoon and monsoon seasons, SPRNCA, Upper San Pedro Basin, Arizona.

27. Correlation coefficients between herbaceous plant cover and plot surface elevation above the thalweg, SPRNCA, Upper San Pedro Basin, Arizona

28. Correlation coefficients between streamside-zone herbaceous vegetation and water-year streamflow permanence, for premonsoon and monsoon sampling periods, SPRNCA, Upper San Pedro Basin, Arizona 


\section{Tables-Continued}

29. Importance values for tamarisk, within age classes and for the population as a whole, at 20 biohydrology and supplemental sites within the SPRNCA, Upper San Pedro Basin, Arizona..

30. Patch width of Fremont cottonwood, Goodding willow and tamarisk in the SPRNCA, Upper San Pedro Basin, Arizona, flood-plain zone, by stem size class.

31. Stem density and basal area of Fremont cottonwood, Goodding willow and tamarisk in the SPRNCA, Upper San Pedro Basin, Arizona, flood-plain zone, by stem size class

32. Site, streamflow-gaging stations, and ground-water levels for sites used in STELLA II model runs, SPRNCA, Upper and Lower San Pedro Basins, Arizona.

33. Growth and mortality model parameters for each species, Upper San Pedro Basin, Arizona.

34. Scoring values for indicator variables

35. Condition scores for the 16 biohydrology and 10 supplemental study sites within the SPRNCA, Upper San Pedro Basin, Arizona

36. Condition score and class for SPRNCA reaches, Upper San Pedro Basin, Arizona

37. Means and standard deviations of hydrologic variables for SPRNCA sites classified by condition class, Upper San Pedro Basin, Arizona.

38. Previous estimates of ground-water use by the riparian system along the San Pedro River within the Sierra Vista Subwatershed, Upper San Pedro Basin, Arizona...

39. Ordinary linear regression coefficients for energy-balance closure and mean quantities of the energy-balance components in equation 3 for the Charleston mesquite site, SPRNCA, Upper San Pedro Basin, Arizona.

40. Ordinary linear regression coefficients for energy balance closure and mean quantities of the energy-balance components in equation 3 at the sacaton grassland and mesquite shrubland locations at the Lewis Springs site in 2003, SPRNCA, Upper San Pedro Basin, Arizona .

41. Structural characteristics of cottonwood clusters at the Lewis Springs and Boquillas sites, SPRNCA, Upper San Pedro Basin, Arizona.

42. Water balance for the mesquite growing season at the Lewis Springs and Charleston mesquite sites, SPRNCA, Upper San Pedro Basin, Arizona

43. Water balance at the Charleston mesquite site during the growing season, SPRNCA, Upper San Pedro Basin, Arizona.

44. Estimated distribution of water sources for mesquite transpiration at the Charleston mesquite, Lewis Springs, and Moson sites, SPRNCA, Upper San Pedro Basin, Arizona, 2000-2002

45. Mesquite transpiration flux by source and total flux for the 2001-03 for the growing seasons at the Charleston mesquite site, SPRNCA, Upper San Pedro Basin, Arizona..

46. Seasonal water-balance totals of measured and derived water fluxes at the Charleston mesquite site, SPRNCA, Upper San Pedro Basin, Arizona.

47. Water balance for the growing season at the Lewis Springs and Charleston mesquite sites for 2003, SPRNCA, Upper San Pedro Basin, Arizona 


\section{Tables-Continued}

48. Reach length, average flood-plain width, seepwillow percent cover, and estimated total seepwillow amount for each reach, SPRNCA,

Upper San Pedro Basin, Arizona.

49. Estimated riparian canopy area, open-water area, and ground-water use for 2003 along the main stem of the San Pedro River, SPRNCA, Upper San Pedro Basin, Arizona

50. Ground-water use rates by vegetation type per unit vegetation area for 2003, Upper San Pedro Basin, Arizona

51. Total canopy or open-water area covered by the ground-water-using groups along the San Pedro River between the U.S. Geological Survey streamflow-gaging stations San Pedro River at Palominas (09470500) and San Pedro River near Tombstone (09471550) using the maps of Goodrich, Scott, and others (2000) and this study, Upper San Pedro Basin, Arizona.

52. Estimated riparian canopy area, open-water area, and ground-water use for 2003 along the main stem of the San Pedro River from the international border with Mexico to the U.S. Geological Survey streamflow-gaging station, San Pedro River near Tombstone (09471550), Upper San Pedro Basin, Arizona.

53. Estimated Babocomari riparian canopy area, open-water area, and ground-water use for 2003, Upper San Pedro Basin, Arizona

\section{Compact Disc (in pocket at back of report)}

Format: American Standard Code for Information Interchange (ASCII), Windows Excel, and Adobe Acrobat PDF

Operating system used: Windows XP Professional

File names: 1_README.TXT (4 KB)

Appendix 1.xls (52 KB) Appendix 5.xls (24.5 KB)

Appendix 2.xls (411 KB) Appendix 6.xls (22.5 KB)

Appendix 3.xIs (618 KB) Appendix 7.xls (124 KB)

Appendix 4.xls (354 KB) Appendix 8.pdf (1.5 MB) 


\section{Conversion Factors and Datums}

\begin{tabular}{|c|c|c|}
\hline Multiply & By & To obtain \\
\hline \multicolumn{3}{|c|}{ Length } \\
\hline centimeter $(\mathrm{cm})$ & 0.3937 & inch (in.) \\
\hline millimeter (mm) & 0.03937 & inch (in.) \\
\hline meter $(\mathrm{m})$ & 3.281 & foot $(\mathrm{ft})$ \\
\hline kilometer $(\mathrm{km})$ & 0.6214 & mile (mi) \\
\hline \multicolumn{3}{|c|}{ Area } \\
\hline hectare (ha) & 2.471 & acre \\
\hline square kilometer $\left(\mathrm{km}^{2}\right)$ & 247.1 & acre \\
\hline square meter $\left(\mathrm{m}^{2}\right)$ & 10.76 & square foot $\left(\mathrm{ft}^{2}\right)$ \\
\hline square centimeter $\left(\mathrm{cm}^{2}\right)$ & 0.1550 & square inch $\left(\mathrm{ft}^{2}\right)$ \\
\hline \multicolumn{3}{|c|}{ Volume } \\
\hline cubic meter $\left(\mathrm{m}^{3}\right)$ & 0.0002642 & million gallons (Mgal) \\
\hline cubic centimeter $\left(\mathrm{cm}^{3}\right)$ & 0.06102 & cubic inch $\left(\right.$ in.$\left.^{3}\right)$ \\
\hline cubic meter $\left(\mathrm{m}^{3}\right)$ & 35.31 & cubic foot $\left(\mathrm{ft}^{3}\right)$ \\
\hline \multicolumn{3}{|c|}{ Flow rate } \\
\hline cubic centimeters per hour $\left(\mathrm{cm}^{3} / \mathrm{yr}\right)$ & 0.0610 & cubic inches per hour (in. ${ }^{3} / \mathrm{hr}$ ) \\
\hline cubic meter per year $\left(\mathrm{m}^{3} / \mathrm{yr}\right)$ & 0.000811 & acre-foot per year (acre-ft/yr) \\
\hline cubic meter per second $\left(\mathrm{m}^{3} / \mathrm{s}\right)$ & 35.31 & cubic foot per second $\left(\mathrm{ft}^{3} / \mathrm{s}\right)$ \\
\hline kilograms per day $(\mathrm{kg} / \mathrm{d})$ & 2.20 & pounds per day $(\mathrm{lb} / \mathrm{d})$ \\
\hline \multicolumn{3}{|c|}{ Mass } \\
\hline $\operatorname{gram}(\mathrm{g})$ & 0.03527 & ounce, avoirdupois (oz) \\
\hline \multicolumn{3}{|c|}{ Pressure } \\
\hline kilopascal $(\mathrm{kPa})$ & 0.295 & inches of mercury (in. of $\mathrm{Hg}$ ) \\
\hline megapascal (mPa) & 295 & inches of mercury (in. of $\mathrm{Hg}$ ) \\
\hline \multicolumn{3}{|c|}{ Specific Weight } \\
\hline Newtons per cubic meter $\left(\mathrm{N} / \mathrm{m}^{3}\right)$ & 0.006366 & pounds per cubic $\mathrm{ft}\left(\mathrm{lb} / \mathrm{ft}^{3}\right)$ \\
\hline \multicolumn{3}{|c|}{ Velocity } \\
\hline meters per second $(\mathrm{m} / \mathrm{s})$ & 3.281 & feet per second $(\mathrm{ft} / \mathrm{s})$ \\
\hline \multicolumn{3}{|c|}{ Power flux } \\
\hline Watts per $\mathrm{m}^{2}$ (Watts per square meter) & 0.0685 & $\begin{array}{l}\text { foot pounds per second square foot } \\
\left(\mathrm{ft}-\mathrm{lb} / \mathrm{s}-\mathrm{ft}^{2}\right)\end{array}$ \\
\hline \multicolumn{3}{|c|}{ Power } \\
\hline Joules per second $(\mathrm{J} / \mathrm{s})$ & 0.7376 & foot pound force per second (ft lb/s) \\
\hline Watts (W) & 0.7376 & foot pound force per second (ft lb/s) \\
\hline \multicolumn{3}{|c|}{ Mass flow rate } \\
\hline grams per hour $(\mathrm{g} / \mathrm{hr})$ & 0.00220 & pounds per hour $(\mathrm{lb} / \mathrm{hr})$ \\
\hline \multicolumn{3}{|c|}{ Mass flux } \\
\hline $\begin{array}{l}\text { grams per square centimeter hour } \\
\left(\mathrm{g} / \mathrm{cm}^{2}-\mathrm{hr}\right)\end{array}$ & 0.4877 & $\begin{array}{l}\text { pounds mass per square foot hour } \\
\left(\mathrm{lbm} / \mathrm{ft}^{2}-\mathrm{hr}\right)\end{array}$ \\
\hline \multicolumn{3}{|c|}{ Specific heat } \\
\hline $\begin{array}{l}\text { Joules per gram degree Centigrade } \\
(\mathrm{J} / \mathrm{g}-\mathrm{C})\end{array}$ & 0.185 & $\begin{array}{l}\text { Foot pounds force per pound mass degree } \\
\text { Fahrenheit (ft-lbf/lbm-F) }\end{array}$ \\
\hline \multicolumn{3}{|c|}{ Flux density } \\
\hline $\begin{array}{l}\text { cubic centimeters per square centimeter } \\
\text { second }\left(\mathrm{cm}^{3} / \mathrm{cm}^{2}-\mathrm{s}\right)\end{array}$ & 0.394 & $\begin{array}{l}\text { cubic inches per square inch second } \\
\left(\text { in. }^{3} / \mathrm{in}^{2} \text {-s) }\right.\end{array}$ \\
\hline
\end{tabular}


Temperature in degrees Celsius $\left({ }^{\circ} \mathrm{C}\right)$ may be converted to degrees Fahrenheit $\left({ }^{\circ} \mathrm{F}\right)$ as follows:

$$
{ }^{\circ} \mathrm{F}=\left(1.8 \mathrm{x}^{\circ} \mathrm{C}\right)+32
$$

Vertical coordinate information is referenced to the North American Vertical Datum of 1988 (NAVD 88).

Horizontal coordinate information is referenced to the North American Datum of 1983 (NAD 83).

Altitude, as used in this report, refers to distance above the vertical datum.

\section{Acronyms}

\begin{tabular}{|c|c|}
\hline ADWR & Arizona Department of Water Resources \\
\hline ANOVA & analysis of variance \\
\hline AZMET & Arizona Meteorological Network \\
\hline BLM & Bureau of Land Management \\
\hline DEM & digital elevation model \\
\hline DOY & day of year \\
\hline ET & evapotranspiration \\
\hline $\mathrm{ET}_{\mathrm{o}}$ & standardized reference evaporation \\
\hline GIS & geographic information system \\
\hline GPS & Global Positioning System \\
\hline HEC-RAS & Hydrologic Engineering Center's-River Analysis System \\
\hline IRGA & infrared gas analyzer \\
\hline LAI & leaf area index \\
\hline LiDAR & Light Ranging and Detection \\
\hline $\mathrm{N}$ & number of observations \\
\hline$n$ & site sample size \\
\hline NAD 83 & North American Datum of 1983 \\
\hline NAVD 88 & North American Vertical Datum of 1988 \\
\hline NEE & Net ecosystem exchange of carbon dioxide \\
\hline PAI & plant area index \\
\hline PET & potential evapotranspiration \\
\hline PVC & polyvinyl chloride \\
\hline REBS & radiation energy balance systems \\
\hline$S$ & $\begin{array}{l}\text { specific yield of the soil in which daily fluctuation of the water table takes } \\
\text { place (eq. 4). } \quad T_{\text {well }}=S_{y}(24 r \pm s)\end{array}$ \\
\hline$s$ & net fall or rise of the water table during a 24 -hour period \\
\hline SALSA & Semi-Arid Land-Surface-Atmosphere program \\
\hline SEE & standard error of estimate \\
\hline SPRNCA & San Pedro Riparian National Conservation Area \\
\hline $\mathrm{T}$ & transpiration \\
\hline TDP & thermal dissipation probe \\
\hline USDA-ARS & U.S. Department of Agriculture, Agricultural Research Service \\
\hline UA & University of Arizona \\
\hline USGS & U.S. Geological Survey \\
\hline USPP & Upper San Pedro Partnership \\
\hline UTM & Universal Transverse Mercator \\
\hline UW & University of Wyoming \\
\hline VPD & vapor pressure deficit \\
\hline
\end{tabular}




\section{Executive Summary}

The Upper San Pedro Basin in Cochise County, Arizona, hosts a growing population of human residents as well as several Federal establishments including the Fort Huachuca Army Installation, Coronado National Monument and National Forest, and the Bureau of Land Management's San Pedro Riparian National Conservation Area (SPRNCA). Ground water is currently the primary source of water for human residents. It also sustains the health of the riparian ecosystem and provides base flows for the San Pedro River.

The Upper San Pedro Basin is divided into the Sierra Vista and Benson Subwatersheds. Most of the SPRNCA is contained within the Sierra Vista Subwatershed. The largest municipalities in the Sierra Vista Subwatershed are Sierra Vista, Bisbee, Tombstone, and Huachuca City. Development distributed in rural parts of the watershed is increasing. Fort Huachuca is also an important component of the economy within the Sierra Vista Subwatershed and in southern Arizona in general. The total population in the subwatershed is about 72,500 . Water outflow from the subwatershed, including water withdrawn by pumping, exceeds natural inflow to the regional aquifer within the subwatershed. As a result, ground-water levels in parts of the subwatershed are declining and groundwater storage is being depleted. The continued decline of ground-water levels upgradient from perennial river reaches will eventually diminish the base flow of the San Pedro River and imperil the riparian vegetation within the SPRNCA.

Residents of the subwatershed have responded to these water issues by forming the Upper San Pedro Partnership (USPP). The USPP is a consortium of 21 agencies and organizations formed to ensure long-term water needs are met, both for the residents of Sierra Vista Subwatershed and for the portion of the SPRNCA within the subwatershed. The USPP determined that specific information regarding the water needs of the riparian system is needed in order to reach the goal of meeting the water needs of the people and the riparian system. The USPP assembled a multidisciplinary team of researchers and initiated a study, detailed in this document, to evaluate the water needs of the riparian system within the SPRNCA. The term "water needs," in this context, refers both to riparian water use through evapotranspiration (ET) and to the hydrologic conditions needed to sustain levels of riparian condition. The term "riparian" refers to transitional areas between terrestrial and aquatic ecosystems that depend on the existence of surface or subsurface water flows. The riparian corridor in the SPRNCA is a band along the San Pedro River that encompasses low-flow channel bars, streambanks, and post-entrenchment flood plains, as well as pre-entrenchment terraces at a higher elevation than the current flood plain. The corridor is vegetated, in part, by phreatophytic plants that use ground-water from the stream alluvium.
This study is a coordinated effort by the U.S. Geological Survey (USGS), the U.S. Department of Agriculture, Agricultural Research Service (USDA-ARS), and Arizona State University, with assistance from the U.S. Army Corps of Engineers, the University of Wyoming, and the University of Arizona. The specific objectives of the study were:

1. To determine the water needs of riparian vegetation through the riparian growing season and throughout the SPRNCA to ensure its long-term ecological integrity;

2. To quantify the total water use of riparian vegetation within the SPRNCA; and

3. To determine the source of water used by key riparian plant species within the SPRNCA.

To meet these objectives, the study was divided into three elements: (1) a characterization of the status and variability of hydrologic factors within the riparian system (USGS), (2) a riparian biohydrology study to relate spatial and temporal aspects of riparian changes and condition to the hydrologic variables (Arizona State University), and (3) a water-use evapotranspiration (ET) study to quantify annual consumptive ground-water use by riparian transpiration and direct evaporation from the stream channel (USDA-ARS) in cooperation with the U.S. Army Corps of Engineers, the University of Wyoming, and the University of Arizona.

Twenty-six sites within the SPRNCA were selected for collection of vegetation data from three primary streamflow regimes (perennial, intermittent-wet, intermittent-dry), which include the principal vegetation communities. Detailed hydrologic-condition data were collected at a subset of 16 of these sites, called the SPRNCA biohydrology sites. Water-use and water-source data were collected at a subset of 5 of the 16 biohydrology sites. Vegetation data also were collected at supplemental sites within the SPRNCA boundary in the Upper San Pedro Basin and in the Lower San Pedro Basin. In addition to information about vegetation and geomorphic conditions, hydrologic data collected at the 16 biohydrology sites were used to delineate 14 reaches that were internally homogenous in terms of streamflow hydrology (spatial intermittence of streamflow) and geomorphology (channel sinuosity and flood-plain width).

Although this overall study consisted of three elements, the elements were closely coordinated to derive integrated results. Specifically, the connection between water demand, water availability, and riparian functioning represents a synthesis of the study elements. The effects of intra- and inter-annual as well as spatial variability of hydrologic and riparian factors were observed in each of the three study elements. 


\section{Methods}

\section{Hydrology}

The hydrologic factors studied at the 16 SPRNCA biohydrology sites included: (1) depth to ground water beneath the riparian vegetation; (2) percentage of time surface flow existed in the channel (streamflow permanence); (3) monthly mean stream discharge; and (4) inundation elevations corresponding to various flood recurrence intervals $(2,5,10$, 25 , and 50 years). Hydrologic monitoring began in summer 2000 and concluded in October 2003.

Ground-water depths were measured in piezometers installed at each site and extrapolated to cross sections perpendicular to the stream channel. Streamflow permanence was estimated by using a combination of stream-stage recorders, temperature recorders, electrical-resistance recorders, and visual observations during site visits. Monthly mean discharge was estimated by correlating discharge measurements at the sites to long-term records from the three permanent streamflow-gaging stations within the SPRNCA. Inundation elevations were estimated through modeling and measurements of high-water marks left by a flood in October 2000. Gaging-station records were used to evaluate the streamflow permanence observed at the sites in the context of long-term conditions.

\section{Vegetation-Hydrological Relations}

To quantify relations between site hydrology and riparian vegetation structure, composition, and species diversity, vegetation data were collected at the 16 biohydrology sites during 2001 and 2002 and at 4 additional sites in 2003 for a total of 20 sites distributed among 14 reaches (see chapter A for a discussion of reaches). To reduce the great floristic diversity of plant species within the SPRNCA (608 known vascular plant species) into ecologically meaningful groups, individual species were classified into 1 of 12 functional groups. Relations of vegetation with streamflow permanance, ground-water depth and fluctuation, and average flood intensity at a site were determined using correlation analysis, for each functional group, for several of the most common plant species, and for various measures of vegetation biomass structure. Effects on vegetation of site elevation and recent fire also were analyzed. Short-term response of riparian vegetation to rain and flooding was determined by making intra- and inter-annual comparisons of herbaceous cover and composition. To assess longer-term vegetation trends, changes in the relative abundance of three pioneer woody species (Fremont cottonwood, Goodding willow, and tamarisk) within age classes were assessed for the 14 reaches. Branch growth rate of willow, a drought-sensitive tree, was measured within each reach, and values were related to streamflow and groundwater variables.

\section{Riparian Condition Index}

A Riparian Condition Index was developed by using a suite of field-measured vegetation traits that are sensitive to changes in streamflow permanence and (or) ground-water levels along the San Pedro River. This index is designed to diagnose and monitor changes in riparian vegetation condition from changes in surface- and ground-water conditions. The model underlying the index was developed by using data from 17 sites (in the Upper and Lower San Pedro Basins) and validated by using data from 10 upper basin sites not included in model development. In application of the assessment model, field data on nine vegetation measures (indicators) are collected, the scoring range for each indicator is determined from provided tables, and the scores are averaged to obtain an overall site index. Site index scores allow for placement into condition classes ranging from class 1 to class 3 . Each condition class is associated with particular ranges for site hydrology, vegetation structure, and ecosystem functional capacity. Condition class 1 indicates ecological conditions reflecting low water availability. Class 2 indicates intermediate conditions, whereas class 3 represents the wettest conditions currently occurring along the river. The distribution of the SPRNCA riparian lands among condition class was determined by collecting data on the bioindicators at 26 sites distributed within the 14 reaches.

\section{Evapotranspiration and Plant-Water Source}

In order to provide improved estimates of groundwater use by the riparian vegetation and evaporation from the free-water surface within the SPRNCA and within the Sierra Vista Subwatershed, riparian ET was measured during March 2001 to December 2003 at seven locations among the five water-use study sites using a combination of sap-flow and eddy-covariance measurements. From these efforts, total ET was determined for the 2003 growing season because measurements were available at all sites during the year. Then, using a combination of water-balance and stable-isotope techniques, the amount of the 2003 ET that was derived from ground water was estimated for each of the major cover types (cottonwood trees along perennial and intermittent reaches, mesquite woodlands, sacaton grasslands, and direct evaporation from the stream). Finally, these ground-water use estimates were combined with cover amounts derived from a new vegetation map of the SPRNCA and the Babocomari River, the Upper San Pedro River's major tributary, to determine total riparian ground-water use.

\section{Integrated Results}

\section{Spatial Patterns: Hydrology}

The availability of water to the riparian system is a function of factors such as depth to ground water and streamflow permanence. These hydrologic factors vary 
throughout the SPRNCA. Streamflow permanence was found to serve as a general indicator of hydrologic condition, and was used to group water availability spatially into three classes. A perennial location is defined as having flow present 100 percent of the year (class 3), an intermittent-wet location has flow present from 60 to 99 percent of the year (class 2), and an intermittent-dry location has flow present less than 60 percent of the year (class 1).

Using these streamflow-permanence classes, the hydrology study sites within the SPRNCA can be divided into areas of higher and lower water availability. In general, the wettest conditions (class 3 ) occupy about the central third of the length of the river and drier conditions (classes 1 and 2) dominate the upstream and downstream thirds of the riparian system within the SPRNCA.

The permanence calculations illustrate that large flood events can temporarily change the spatial patterns of water availability. In October 2000, a 12 to 25 year recurrenceinterval flood stored substantial water in the stream banks and alluvial aquifer. Ground-water storage derived from this flood released slowly for about 12 months and maintained flow in the river at places that were dry during parts of later study years.

Ground-water conditions at study sites were classified by annual ground-water fluctuation and maximum dry season monthly-mean depth to water averaged across the study cross section. The shallowest maximum ground-water depths, averaged across the riparian system, are observed at perennial (class 3) sites. Seasonal variations in ground water at perennial sites are fractions of a meter. Depths to ground water are greater at intermittent-wet (class 2) and intermittentdry (class 1 ) sites. The seasonal variability of ground-water levels is higher at class 2 and class 1 sites; variations of greater than $3 \mathrm{~m}$ in piezometer water levels were observed at class 1 sites between fall/early summer low-water levels (when transpiration was high), and winter high-water levels (when transpiration was low). The large ground-water level variations at intermittent sites were not observed for about 12 months following the October 2000 flood. The degree of streamflow permanence and the ground-water conditions in the stream alluvium are interrelated and are controlled, in part, by influx from the regional ground-water system. Perennial conditions dominate at locations where the regional and stream alluvium aquifers are hydraulically connected and an upward hydraulic gradient exists. Intermittent streamflow dominates where the regional and stream alluvium aquifers are isolated, and where downward hydraulic gradients exist.

Elevation of flood inundation is largely site specific and is controlled by stream-channel geometry and friction factors at the site and in the immediate downstream area. A spatially related factor controlling floodflows is increasing drainage area moving downstream. As a result, peak flows for particular recurrence-interval floods are higher at downstream sites.

\section{Spatial Patterns: Riparian Condition Class}

The riparian condition class scores of the 14 SPRNCA reaches reflected the underlying spatial variation in hydrology. Overall, 39 percent of the SPRNCA riparian corridor fell within condition class 3,55 percent in condition class 2 , and 6 percent in condition class 1 .

At class 3 sites (and reaches), flood-plain vegetation is characterized by tall, dense, multiaged cottonwood-willow forests and woodlands with intermixed areas of riparian grassland-forblands and only small patches of shrubland. Drought-tolerant and deep-rooted pioneer species, such as tamarisk, are subdominant in the forests. The stream channel is lined by dense and diverse herbaceous cover, including an abundance of aquatic emergents, such as bulrush, and other obligate wetland and facultative wetland species, such as Torrey rush and scouring rush. At class 2 sites (and reaches), cottonwood and willow remain as the dominant pioneer trees in the flood plain, but tamarisk presence is increased, and cottonwoods and willow trees undergo dry-season declines in water use and productivity. Major changes in the herbaceous vegetation occur between classes 2 and 3. Streamside cover of hydric plants is reduced owing to loss of perennial streamflow. Many of the hydric perennial herbs have been replaced by mesic perennials, such as bermuda grass.

In the transition from class 2 to class 1, major changes occur in woody vegetation composition and structure in the flood plain. Hydrologic thresholds for cottonwood and willow survivorship have largely been exceeded and only a few age classes of these species persist in favorable microsites. Deep-rooted phreatophytes, typically tamarisk, have replaced shallower-rooted species. Structurally, the flood plain is dominated by shrublands with limited upper canopy cover. Streamside herbaceous cover is sparse in the summer dry season and is dominated by mesic species, such as bermuda grass.

The vegetation characteristics of the three condition classes provide some measure of the changes in vegetation structure and composition that might occur in response to future changes in base flow and ground-water availability. For example, if streamflow became more intermittent and depth to the alluvial ground-water table increased, herbaceous species, such as bulrush and rushes, would decline in abundance, and streamside-zone species composition would shift towards species, such as bermuda grass. Across the flood plain, cottonwood-willow recruitment rates would decrease and mortality rates would increase; cottonwood-willow forests could give way to tamarisk shrublands. Structurally, riparian woodlands would give way to riparian shrublands, and canopy height and upper canopy vegetation volume would decrease. A reverse scenario would occur if streamflows became more permanent and alluvial ground-water became shallower and more stable. 
In all three condition classes, periodic floods of varying size and timing increase diversity by providing the physical disturbance that allows for establishment of a wide range of ruderal and pioneer plant species.

\section{Temporal Variability: Hydrology and Vegetation}

Temporal variability during the study period (2000-2003) was dominated by two types of events: (1) regularly varying annual precipitation and temperature cycles, and (2) a large flood in October 2000-an atypical event. The beginning of the study was marked by the October 2000 flood with concomitant high precipitation and water availability. The remaining years of the study were characterized by lower than average precipitation.

Intra-annual variability was largely controlled by seasonal cycles of precipitation and ET. A typical year in the Sierra Vista Subwatershed includes two rainfall regimes, one of frontal origin in the cool winter months and a second, monsoonal-type pattern in July and August. During this study, however, winter precipitation amounts were below average. Evapotranspiration waxed and waned throughout each year, primarily in response to the temperature-controlled growing season. Seasonal changes in precipitation and ET influenced hydrologic factors such as depth to ground water, the permanence of streamflow, and streamflow amounts. Groundwater levels were highest and streamflow was greatest either in the winter, when ET was low, or in the summer because of precipitation-generated floods. Patterns of and changes in riparian vegetation correlated with hydrologic factors that indicated the level of water availability. For woody species, for example, high variability in ground-water levels or deep ground-water levels or low streamflow permanence were most correlated with a decreased abundance of cottonwood and willow. Many herbaceous plant groups responded to increased water availability provided by summer monsoonal rains and floods by increasing in cover and (or) species richness. Groups that showed strong seasonal patterns included riparian annuals, upland annuals, and mesic and xeric perennials.

Interannual variability was represented by the flood of October 2000 and drier than average conditions during the remainder of the study. The flood's magnitude at the upstream end of the SPRNCA has a recurrence interval of about 25 years, and the magnitude at the downstream end has a 12-year recurrence interval. The effects of this flood influenced the system for about 12 months. Ground-water levels remained elevated and of lower annual variability than in the following years of drier than normal conditions. After the flood receded, the San Pedro River flowed at times and in places where it was increasingly dry toward the end of the study. Specific responses in the riparian vegetation were a short-term increase in wetland herbaceous cover along the stream channel, in which several wetland plants were present at sites where they were absent in drier years, and an increase in herbaceous plant species richness across the flood plain, in which disturbance-related annuals showed the greatest post-flood increase. Other factors, such as annual branch growth rate of willow, were highest in the post-flood year. Periodic flooding, both on the scale of the October 2000 flood and smaller floods, is also important in creating the disturbance required for establishment of new generations of woody plants.

Changes have also been occurring at larger time scales than were considered for this study. Historical evidence and photographs cited by Hereford (1993) document large changes in the vegetation assemblage along the river in the time since it entrenched in the late 19th and early 20th centuries. This study indicates that rates of cottonwood and willow recruitment within the SPRNCA have declined in recent decades, likely owing to long-term geomorphic adjustments that are contributing to greater channel stability. This study also found that the relative abundance of tamarisk to that of cottonwood-willow has changed over time at some San Pedro River sites. Recent increases in tamarisk abundance can be indicative of decreasing site water availability but can reflect population expansion caused by increases in seed availability. The riparian system is dynamic and responds both to natural and human-induced factors over short and long time scales.

\section{Water Use and Water Needs by Vegetation Type}

\section{Velvet Mesquite Woodland and Shrubland}

Distribution Patterns.-Mesquite was widely distributed among sites and among fluvial surfaces, being abundant at dry and wet sites and on flood plains and terraces. Abundance of mesquite was related to site elevation (trees were larger and more abundant at downstream sites) and to average flood intensity, but not to site water-availability factors.

Water Use.-Although mesquite is the most abundant vegetation type within the San Pedro riparian corridor, its water use was identified as the most uncertain (Goodrich, Scott and others, 2000). Multiyear ET observations from a mature mesquite woodland and a mesquite shrubland indicate that (1) both used substantially more water than previously estimated, and (2) their water use was nearly equal on a per unit canopy area basis. Growing-season totals of mesquite woodland ET were $694 \mathrm{~mm}$ in 2001, $638 \mathrm{~mm}$ in 2002, and $676 \mathrm{~mm}$ in 2003. Stable-isotope measurements revealed considerable seasonal variation in the proportion of mesquite transpiration derived from ground water at several sites. Mesquite used a combination of surface (recent precipitation) and ground-water sources. A third source of mesquite water was the deep (1-10 m) vadose zone and likely was a mix of both surface-water and ground-water sources. The use of these sources depended on their availability through the season. There was a tendency toward proportionally less ground-water use in mesquite stands that had comparatively less access to ground water (owing to a deeper water table). Nevertheless, mesquite at all sites used substantial quantities of ground water. Total annual ground-water use at a mesquite 
woodland site was determined by two methods (water-budget method and isotope-partitioning method), and results from the methods were not in agreement. Recent studies at this site reveal that mesquite can redistribute significant amounts of water between deep and shallow soil layers during winter and summer months through its extensive root system (Hultine and others, 2004), and this likely was a reason for the disagreement. At this time, there is no method available to quantify the water redistributed by the mesquite or to determine whether the source of deep vadose zone moisture was from precipitation or ground-water sources. The waterbalance approach resulted in mesquite woodland seasonal ground-water use amounts of $488 \mathrm{~mm}$ in 2001, $394 \mathrm{~mm}$ in 2002, and $510 \mathrm{~mm}$ in 2003; these values were about 50-percent higher than the estimates yielded by the isotopic analysis. The water-balance value was used because it involved fewer assumptions and less extrapolation of the data collected. This amount likely was conservatively high because the possible redistribution of antecedent rainfall was ignored using this approach.

\section{Fremont Cottonwood-Goodding Willow Forest}

Distribution Patterns.-Cottonwood-willow forests are present mainly in the active flood plain; a few old cottonwood trees are present on the terraces. The cottonwood-willow forests declined in abundance and age-class diversity along spatial gradients of decreasing streamflow permanence and ground-water depth, and gave way to tamarisk shrublands as average ground-water depths across the flood plain exceeded $3 \mathrm{~m}$. Presence of shallow ground water throughout the growing season, with little decline during dry seasons (less than $1 \mathrm{~m}$ annual fluctuation), allows for maintenance of dense, multiaged cottonwood-willow forests. Overall, the forests were dense and multiaged where annual maximum ground-water depths averaged less than about $3 \mathrm{~m}$, streamflow permanence was greater than about 60 percent, and intraannual ground-water fluctuation was less than about $1 \mathrm{~m}$. Although present in the intermittent reaches, cottonwoods and willows have lower abundance and age-class diversity than in the perennial reaches.

Water Use.-Cottonwood sap flow was measured during most of the 2003 growing season to estimate transpiration along a perennial and an intermittent reach. A cottonwood stand at the perennial reach transpired a total of $966 \mathrm{~mm}$, about 20 percent more water on a per-canopy-area basis than previous estimates. Cottonwood transpiration along the intermittent reach was $484 \mathrm{~mm}$ in 2003, considerably less than at the perennial reach, and was greatly reduced as the watertable levels declined in the premonsoon season. Lower rates of cottonwood forest transpiration at the intermittent reach were the result of physiological stress caused by the greater depths and fluctuations in ground-water levels and the sparser density of leaves at the stand level. Roughly 40 percent of the cottonwood forests in the SPRNCA were classified as being on intermittent reaches. Cottonwood source water sampling results (Snyder and Williams, 2000) indicate that all of the $966 \mathrm{~mm}$ of perennial cottonwood transpiration was derived from ground water. Cottonwood transpiration at the intermittent reach used $410 \mathrm{~mm}$ of ground water.

\section{Tamarisk}

Distribution Patterns.-In contrast to the patterns of cottonwood and willow, tamarisk abundance increased at dry sites. The increase in abundance of tamarisk along site gradients of decreasing streamflow permanance likely was due, in part, to reduced competitive interactions with more hydrophytic species at the dry sites. Tamarisks tend to form shrublands, whereas cottonwoods form woodlands; thus, the relative abundance of shrublands in the flood plain increased at drier sites, whereas that of woodlands decreased.

Water Use.-Currently (2004), there is a relatively small amount of tamarisk in the SPRNCA; it is limited primarily to the dry, northerly reaches. For the SPRNCA water-use estimates, ET rates and ground-water use patterns of tamarisk were assumed to be similar to those of mesquite.

\section{Sacaton and Other Herbaceous Vegetation on Flood Plains and Terraces}

Distribution Patterns.-Sacaton, a mesic perennial grass, occupies more area of the upper San Pedro River flood plain than any other herbaceous plant species. Sacaton also is abundant on terraces, but herbaceous cover was quantified only for flood plains. Two other mesic-perennial grasses, bermuda grass and Johnson grass, also have extensive cover on flood plains. These common flood-plain plants show some seasonal variance and likely use a variety of water sources, including ground water, rain fall, and flood water, depending, in part, on seasonal availability. Some plant groups, including riparian annuals, upland annuals, and xerophytic perennials, increased sharply in abundance following the summer monsoonal rains and floods, suggesting primary reliance on seasonal water sources

Water Use.-Total growing-season ET for a sacaton grassland was $554 \mathrm{~mm}$ in 2003; $374 \mathrm{~mm}$ of ET was derived from ground water ( as calculated by using a water-budget method). The ground-water use of sacaton contradicted previous understanding. The contradiction likely was due to the shallow depth to ground water at the site (about $3 \mathrm{~m}$ ). High-resolution elevation measurements were used to delineate the area where the land-surface elevation was within $3 \mathrm{~m}$ of the river stage. This area was used as an estimate of the area where the depth to ground water was less than $3 \mathrm{~m}$. The amount of sacaton within this area was determined by intersecting this delineated region with the vegetation map. About 30 percent of the total sacaton area within the SPRNCA fell within this region. All sacaton that was within this region was assumed to have the ground-water use of the sacaton measured in 2003. 


\section{Seepwillow Shrublands}

Distribution Patterns.- Seepwillow is an evergreen shrub that forms thickets on low-lying flood plains adjacent to the stream channel. Seepwillow was most abundant on surfaces where the annual maximum (2002 data) groundwater depth was $2.1 \mathrm{~m}$. Seepwillow had sparse cover at the intermittent-dry sites.

Water Use.-Seepwillow transpiration was measured using sap-flow methods as a preliminary step toward quantifying its ground-water use, which had previously been ignored. Measurements made for this study indicated that seepwillow transpiration on a per unit canopy area basis was nearly as large in magnitude as that of any of the major ground-water-using vegetation types studied. Although the total amount of seepwillow in the SPRNCA cannot be determined from the vegetation map used in this study, a rough approximation using transect cover data (chapter C) indicates that the total area probably is low compared to the area for other vegetation types. Thus, total ground-water use by seepwillow likely was small compared to water-use by other major cover types in the SPRNCA, and it was omitted from the ground-water use budgets.

\section{Streamside Wetland Vegetation and Open Channels}

Distribution Patterns.-Among all herbaceous plant groups analyzed, the wetland perennials showed the strongest correlation with surface-water availability. Rushes, bulrush, and other wetland perennial herbs depend on shallow, inflowing ground water to sustain stream base flows and moisten surface soils. This group had high abundance only at sites with perennial or near-perennial streamflow, declining sharply in abundance as flows became intermittent. This group currently covers a small area in the SPRNCA, forming narrow (generally less than 1-m-wide) strips along the edge of the perennial streamflow. As sites became increasingly intermittent, the channel bar became vegetated by more mesic species, including bermuda grass.

Water Use.-Wetland vegetation ET was not quantified owing to the relatively small area that the vegetation occupies. Evaporation from the river surface was determined by computing a potential evaporation total for 2003 using meteorological data and multiplying this total by a reduction factor to account for the effect of shading and entrenchment that would reduce the evaporation rate relative to an unsheltered open-water estimate. Measurements of evaporation from small pans distributed throughout the nearstream environment at one site were made to compute the reduction factor during a limited period. By using this relation, the total evaporation from the river was calculated to be $1,156 \mathrm{~mm}$ for 2003 .

\section{Scaling-Up Water-Use Estimates to the Basin Level Vegetation Mapping}

The use of a new vegetation map produced by the U.S. Army Corps of Engineers (2001) resulted in large changes in the computed amounts of vegetation within the SPRNCA relative to the map used by Goodrich, Scott and others (2000), who produced the most recent estimates of riparian ground-water use prior to this study. The new map provided a range for percent cover of the dominant vegetation type in each polygon; therefore, the exact amount of vegetation could not be calculated. It was necessary to clip this map to the approximate extent of the riparian corridor. Reach-level information (chapter C) was used to enumerate the amount of cottonwood-willow forest along perennial or intermittent reaches. An additional calculation delineated the sacaton grasslands in regions having elevations within $3 \mathrm{~m}$ of the river stage in order to delineate sacaton that used ground water.

Total vegetation and open-water areas were multiplied by their respective ground-water-use rates as determined by measurements made in 2003 to determine riparian ground-water use. For 2003, the total ground-water use by riparian vegetation within the SPRNCA was $13,113,000-15,759,000 \mathrm{~m}^{3}$ (10,630-12,775 acre-ft). Mesquite ground-water use was the dominant component of the water budget followed by cottonwood-willow, open-water, sacaton, and tamarisk ground-water use, in that order. The estimate of the riparian ground-water use along the San Pedro River within the Sierra Vista Subwatershed [from the international border with Mexico to the USGS streamflow-gaging station, San Pedro River near Tombstone (09471550)] during 2003 was $9,065,000-11,112,000 \mathrm{~m}^{3}(7,350-9,010$ acre-ft)]. This estimate is 12 to 37 percent higher than the 1997 estimate of Goodrich, Scott, and others (2000) for 1997 owing to the combined use of the new vegetation map and the new water-use estimates. Corell and others (1996) estimated an average of $8,758,000 \mathrm{~m}^{3} / \mathrm{yr}(7,100 \mathrm{acre}-\mathrm{ft} / \mathrm{yr})$ for this reach for 1985-91. Combining results for the Babocomari River and the San Pedro River, this study estimated that $11,840,000-14,867,000 \mathrm{~m}^{3}(9,600-12,055$ acre-ft) of ground water was consumptively used by the riparian corridor within the Sierra Vista Subwatershed in 2003. This estimate was $25-57$ percent greater than the 9,498,000 $\mathrm{m}^{3} / \mathrm{yr}$ (7,700 acre-ft/yr) of Corell and others (1996) owing in part to a large disparity between the estimates for the Babocomari. It is important to recognize the influence of interannual climatic variability on these estimates. For example, interpretation of only 3 years of data indicates that the annual mesquite ground-water use varied by as much as 30 percent (relative to 2003). It is reasonable to expect that the functioning of other vegetation communities are similarly affected by climate variability and that the riparian water use fluctuates to a similar degree. 


\title{
Chapter A
}

\section{Study Overview}

\author{
By James M. Leenhouts' ${ }^{1}$, Juliet C. Stromberg ${ }^{2}$, and Russell L. Scott ${ }^{3}$
}

\section{Introduction}

The Upper San Pedro Basin hosts a growing population of human residents as well as a remarkable riparian ecosystem along the San Pedro River in Cochise County, Arizona. Ground water is the primary source of water for the residents of the Sierra Vista Subwatershed of the basin; ground water also sustains the base flow of the San Pedro River and provides a consistent plant water source for parts of the riparian ecosystem. An act of Congress in 1988 formally protected much of the riparian ecosystem as the San Pedro Riparian National Conservation Area (SPRNCA), which is managed by the Bureau of Land Management (BLM). Without adequate management of water resources throughout the subwatershed, the viability of the riparian system and (or) the area communities could be at risk.

The Upper San Pedro Partnership (USPP) is a consortium of 21 agencies and organizations formed to ensure that longterm water needs are met for the Sierra Vista Subwatershed. The USPP has established a planning goal to

“...ensure an adequate long-term ground-water supply is available to meet the reasonable needs of both the area residents and property owners (current and future) and the San Pedro Riparian National Conservation Area...."

A key management question in the Upper San Pedro Basin is, "What hydrologic conditions, availability of water for consumptive use, and sources (surface or ground water) of water are required to maintain a healthy riparian corridor?" The USPP responded to this question by initiating the SPRNCA water-needs study detailed in this report. The term "water needs," in this context, refers both to the quantity of water used by the riparian system and to the relation between hydrologic conditions and riparian conditions.

In 2001, the U.S. Geological Survey (USGS), in cooperation with the BLM and the Arizona Department of Water Resources (ADWR), began a study of the hydrology

${ }^{1}$ U.S. Geological Survey, Arizona Water Science Center, Tucson, Arizona.

${ }^{2}$ School of Life Sciences, Arizona State University, Tempe, Arizona.

${ }^{3}$ Southwest Watershed Research Center, U.S. Department of Agriculture, Agricultural Research Service, Tucson, Arizona. of the San Pedro Riparian National Conservation Area (chapter B). In 2002, the city of Sierra Vista joined the cooperative effort. Arizona State University, in cooperation with the BLM and ADWR, began a study of the relations between streamflow regime and riparian vegetation composition, structure, and diversity in the conservation area (chapter C). The U.S. Department of Agriculture, Agricultural Research Service (USDA-ARS), in cooperation with the BLM, Department of Defense, and U.S. Environmental Protection Agency, began a study to determine the riparian ground-water use within the conservation area and the Sierra Vista Subwatershed (chapter D).

The existence of a riparian ecological system relies on available water from a river and its associated groundwater system. Riparian systems are particularly sensitive to hydrologic changes (Nilsson and Berggren, 2000). Changes in hydrologic conditions caused both by ground-water pumping and to surface-water diversions have been shown to produce changes in arid-region riparian system stand structure and species composition (Stromberg and Patten, 1990; Stromberg and others, 1996). Numerous studies have also illustrated the relation between in-stream flow characteristics and ecosystem condition (Richter and others, 1997; Rosenberg and others, 2000; Tharme, 2003).

Many wetland and riparian systems in arid regions have been lost or altered owing to ground-water pumping and streamflow depletion (Stromberg and others, 2004). Interest in the future of the San Pedro River has intensified because consumption of ground water by growing communities will increase over time unless conservation measures and (or) other sources of water can mitigate usage. Much of the annual flow volume in the river is from runoff generated by summer monsoon storms, but the extended duration of water availability required for a healthy riparian system stems from upward hydraulic gradients that cause shallow ground water to discharge to the river. The issue of concern is that ground-water pumping, particularly if increased in intensity, will eventually lower the water table and reduce or reverse existing upward hydraulic gradients (Pool and Coes, 1999), and thus negatively impact riparian vegetation and wildlife habitat. 
This study addressed the riparian water needs question from varied perspectives. The riparian-condition biohydrology assessment described herein quantifies the spatial and temporal patterns of water needed to maintain the vegetation in various condition classes, each of which represent various types of vegetation structure, composition, and functional capacity. Measurements of evapotranspiration (ET) rates of various riparian plant associations, when linked with maps of the location and abundance of the vegetation types, provide a measure of the total consumptive water needs of the riparian vegetation in the corridor. The intent of the SPRNCA waterneeds study is not only to define the hydrologic requirements of the SPRNCA ecosystem, but also to provide information useful for the potential development of management strategies to reduce the consumptive water uses within the SPRNCA without resulting in any negative effects on riparian resources.

This study cannot, by itself, be used to determine how specific amounts and locations of ground-water consumption for human needs will change particular parts of the riparian system. The effects of ground-water consumption on the riparian system are dependant on where and when water is pumped as well as by the hydrologic properties of the aquifer system. This study does provide information useful for making management decisions that, if combined with a deterministic ground-water model, could help predict riparian-system responses to ground-water consumption.

\section{Objectives}

The overall objectives of the water-needs study are to (1) determine the temporal and spatial water needs of riparian vegetation within the SPRNCA, (2) quantify the total consumptive water use of riparian vegetation now present within the SPRNCA, and (3) determine the sources of water consumed by key riparian plant species within the SPRNCA.

\section{Study Elements}

This study used expertise from several disciplines for the collection and analysis of data needed to address the objectives. The resulting effort has been a multi-investigator project involving five separate entities: the USDA-ARS, Arizona State University, the University of Arizona (UA), the University of Wyoming (UW), and the USGS. The resulting work, as presented in this report, is divided into three segments. The following paragraphs describe the individual segments. Integrated information from all three segments is presented in the Executive Summary.

Characterizing temporal and spatial aspects of hydrologic factors was a key requirement for describing in detail the water needs of the San Pedro's riparian system. The role of the USGS was to determine the magnitude and variability of these factors. The factors studied were depth to ground water in the riparian area, degree of streamflow intermittency (herein called "streamflow permanence"), mean streamflow discharge, and flood-inundation frequency. Results from this part of the study are presented in chapter B.

The riparian biohydrology part of the water-needs study related spatial and temporal aspects of riparian vegetation to the hydrologic variables. Specific objectives addressed by researchers at Arizona State University were to (1) quantify relations between riparian vegetation traits (biomass structure, species composition, species diversity, population age structure) and site hydrology (ground-water levels, base flows, floodflows); (2) assess decadal-scale temporal trends in riparian-forest composition, within relatively uniform reaches of the river; and (3) develop a quantitative multimetric rating system for riparian-ecosystem functioning condition, map the functioning condition by reach, and describe the hydrologic conditions needed to maintain various levels of ecosystem function. Results from this part of the study are presented in chapter $\mathrm{C}$.

The water-use (ET) aspect of the SPRNCA water-needs study quantified annual consumptive ground-water use by riparian transpiration and direct evaporation from the stream channel. Researchers at the USDA-ARS, with assistance from the UW and the UA, collected site-specific direct measurements of ET from dominant ecosystem types and scaled these measurements to the full SPRNCA and to the Sierra Vista Subwatershed. A key component to this work included partitioning vegetation water use between groundwater and surface-water sources. Results from this part of the study are presented in chapter D.

\section{Description of the Study Area}

The San Pedro River runs from its headwaters in Canenea, Mexico, north through the Upper and Lower San Pedro Basins to its confluence with the Gila River at Winkelman, Ariz. (fig. 1). The upper and lower basins are separated at a location called "the narrows" about $20 \mathrm{~km}$ downstream from the town of Benson, Ariz. The results and interpretations contained in this study pertain to the SPRNCA (fig. 1) in the Upper San Pedro Basin although some supporting data have been collected downstream from the SPRNCA both in the upper and lower basins.

The SPRNCA was created by a United States Congressional act in 1988 to protect and enhance the natural resources of this desert-riparian system, and was the first such designation of riparian conservation in the country. The biological importance of the river stems from the ecosystem contrast between the riparian system and the surrounding area. The riparian system supports a diverse biota and is a primary corridor for migrating birds. The riparian corridor provides habitat for more than 400 bird species, and the Upper San Pedro Basin supports the second highest 
known number of mammal species in the world (Goodrich, Chehbouni, and others, 2000). The SPRNCA is about $235 \mathrm{~km}^{2}$ in area and consists of a strip of land about 3 to $4 \mathrm{~km}$ wide that surrounds the San Pedro River and extends from the international boundary north about $60 \mathrm{~km}$ to near the town of St. David, Ariz. (fig. 1).

The SPRNCA encompasses the river, its associated riparian corridor, and some adjacent upland vegetation. The term "riparian" refers to transitional areas between terrestrial and aquatic ecosystems that depend on the existence of surface- or subsurface-water flows (National Research Council, 2002; Arizona Riparian Council, 2004). The riparian corridor in the SPRNCA is a band along the river that encompasses low-flow channel bars, streambanks, and post-entrenchment flood plains, as well as pre-entrenchment terraces at a higher elevation than the current flood plain (fig. 2) vegetated, in part, by phreatophytic plants that use ground-water in the stream alluvium.

About 75 percent of the SPRNCA lies in the Sierra Vista Subwatershed of the Upper San Pedro Basin; a downstream portion lies in the Benson Subwatershed (fig. 1). The Sierra Vista Subwatershed occupies the portion of the basin upstream from USGS streamflow-gaging station, San Pedro River near Tombstone (09471550), and it is entirely within the United States. The drainage area of the Upper San Pedro Basin upstream from the Sierra Vista Subwatershed, however, is located in Mexico. The Benson Subwatershed occupies the remainder of the basin downstream from the Tombstone gaging station.

The Sierra Vista Subwatershed supports a human population of about 72,500 (Department of Economic Security, 2003) that is distributed among the unincorporated rural areas and the municipalities of Bisbee, Sierra Vista, Huachuca City, and Tombstone. Sierra Vista, the subwatershed's largest city, had a population of about 40,430 in 2003 (Department of Economic Security, 2003), which includes about 9,000 permanent residents of Fort Huachuca.

Long-term streamflow information is available for three gaging stations in the study area, one of which began operation in 1904. Data from these sites show the variability of streamflow permanence that affects the riparian system throughout the SPRNCA (table 1). The seasonal pattern of mean flow at each streamflow-gaging station reflects seasonal patterns of precipitation and ET. Floodflows caused by a monsoonal weather pattern are concentrated in July and August. Mean winter flows are elevated by a flood component as well as by reduced uptake of water by riparian plants. The lowest flows tend to occur in the spring and fall months when runoff is low but evaporation is high. Streamflow permanence is a function of location. Toward the upstream and downstream ends of the SPRNCA, streamflow is intermittent. A reach in the middle of the SPRNCA, from about
$14 \mathrm{~km}$ upstream to $4 \mathrm{~km}$ downstream from USGS streamflowgaging station, San Pedro River at Charleston (09471000), is perennial.

As a result of widespread interest in the system, the basin has been studied intensively by scientists from a variety of fields. Examples of fields and studies include: geology (Gray, 1965; Haynes, 1968; Hayes, 1970; Drewes, 1996; Force, 1996); geophysics (Halverson, 1984; Gettings and Houser, 2000; Fleming and others, 2002); hydrology (Freethey, 1982; Vionnet and others, 1997; Pool and Coes, 1999; Goode and Maddock, 2000; Whitaker, 2000); soil science (McGuire, 1997); and plant sciences (Stromberg and others, 1996; Schaeffer and others, 2000; Scott, Shuttleworth, and others, 2000; Snyder and Williams, 2000).

\section{Hydroclimatic Setting}

The climate in the Upper San Pedro Basin is semiarid, but a wide range in elevation causes significant variations in vegetation, precipitation, and temperature. Elevation along the river ranges from 1,300 $\mathrm{m}$ at the United States-Mexico border to $1,025 \mathrm{~m}$ at the downstream end of the basin, and the highest mountains extend to $2,900 \mathrm{~m}$. Variability in elevation strongly influences climate in the basin; annual rainfall averages $750 \mathrm{~mm}$ in the mountains and $300 \mathrm{~mm}$ on the low basin floor.

Along the upper San Pedro River valley, temperatures range from a mean maximum temperature of $26.8^{\circ} \mathrm{C}$ to a mean minimum temperature of $7.1^{\circ} \mathrm{C}(1971-2000$ averages recorded in Benson, Ariz.). Annual precipitation amounts for 1971-2000 are $313 \mathrm{~mm}$ in Benson, Ariz.; $356 \mathrm{~mm}$ in Tombstone, Ariz.; and $386 \mathrm{~mm}$ in Sierra Vista, Ariz., although rainfall in this area is highly variable, both spatially and temporally. About 25 percent of the average annual precipitation is from winter frontal storms during November through February that typically are longer in duration and less intense than storms during the remainder of the year. During winter, most of the vegetation is inactive and nighttime frosts are common. From April through June, days are typically dry and hot. During the period around July through September, the region is under the influence of the North American Monsoon (Adams and Comrie, 1997) which imports moist tropical air that combines with intense surface heating to form highintensity, short-duration convective storms. About 60 percent of the annual precipitation in the valley occurs during this monsoon period (Goodrich, Chehbouni, and others, 2000). The woody riparian species typically become dormant in October or November because of the colder temperatures. Herbaceous species become dormant or senesce because of the colder temperatures and (or) decreased water availability following the monsoon season. 


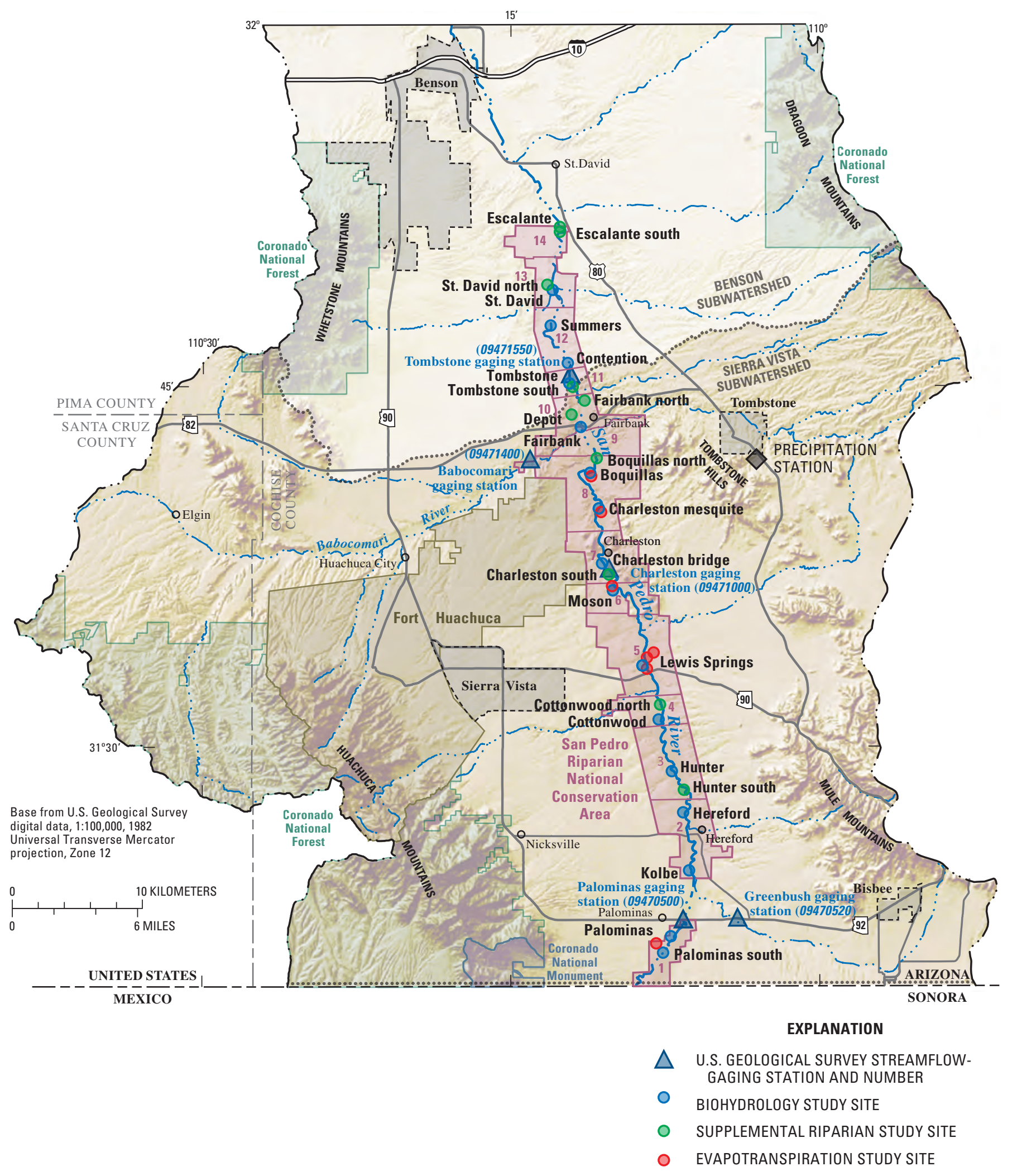

Figure 1. Boundaries of the Sierra Vista Subwatershed, 14 reaches of the San Pedro River within the San Pedro Riparian National Conservation Area, and locations of streamflow-gaging stations, biohydrology sites, supplemental riparian study sites, and evapotranspiration sites, Upper and Lower San Pedro Basins, Arizona. 


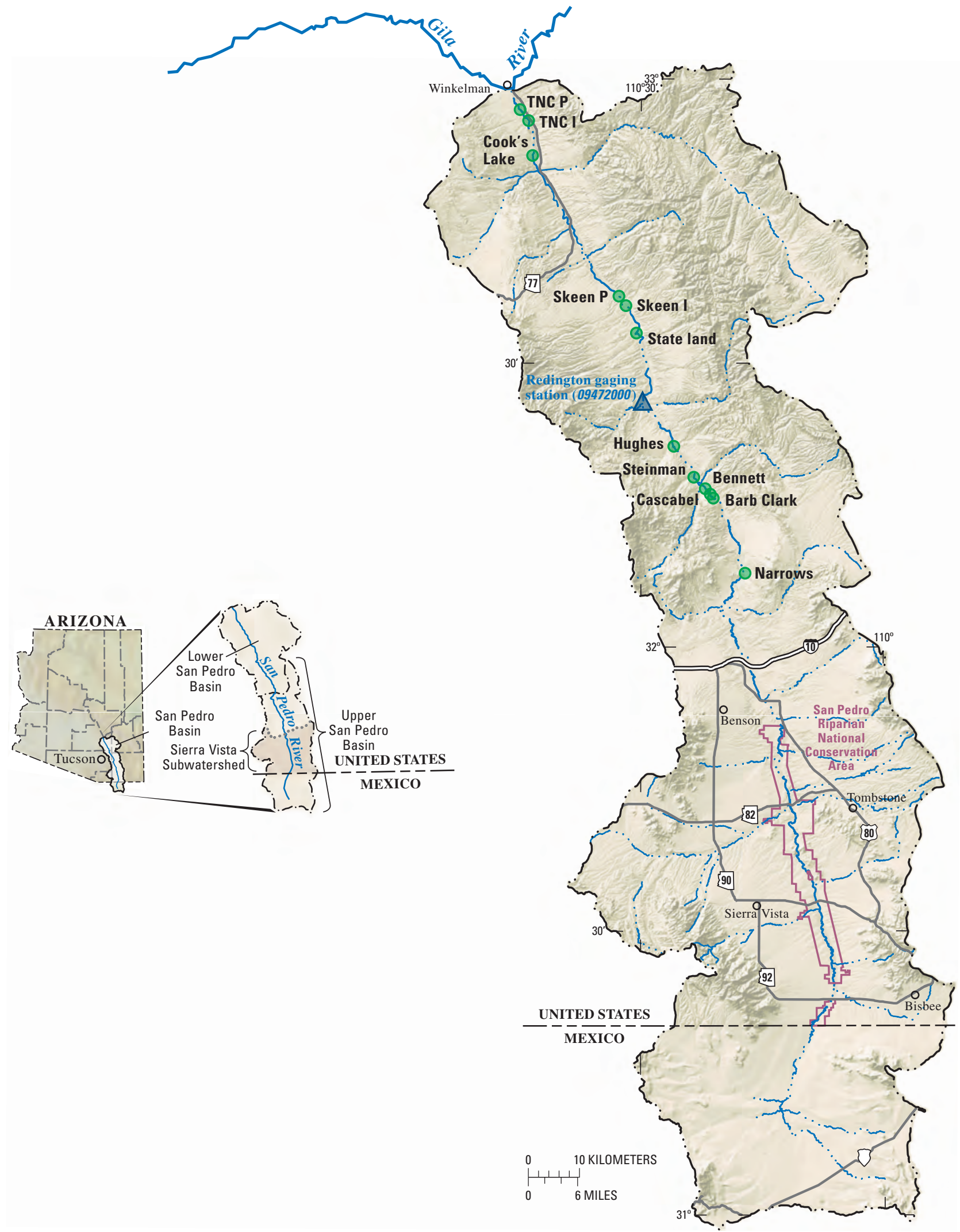

Figure 1. Continued. 


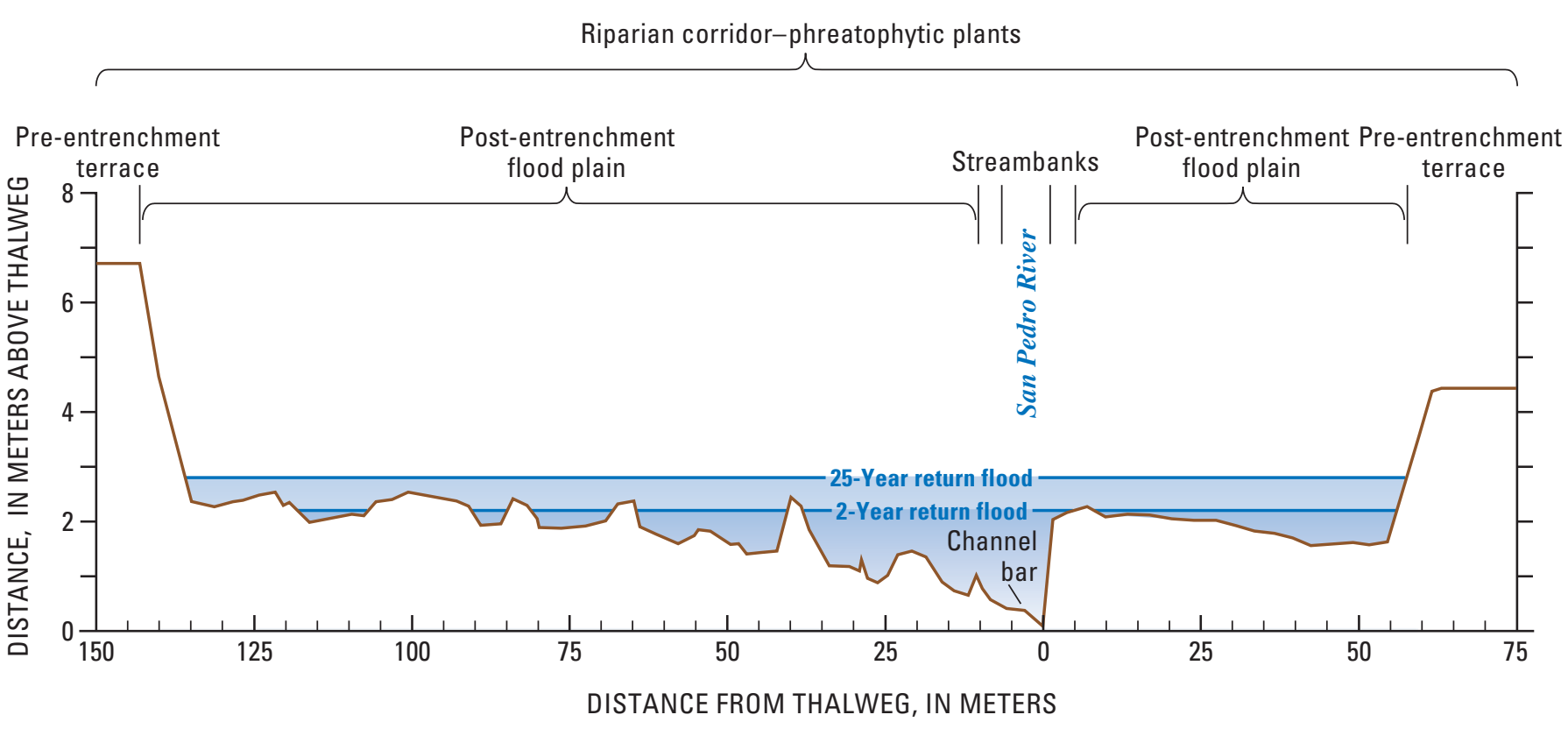

Figure 2. Hydrology and biohydrology data-collection transect across the San Pedro River at Palominas site, San Pedro Riparian National Conservation Area, Upper San Pedro Basin, Arizona.

Table 1. Summary of U.S. Geological Survey streamflow-gaging station information, Sierra Vista Subwatershed, Upper San Pedro Basin, Arizona

$\left[\mathrm{km}^{2}\right.$, square kilometers; $\mathrm{m}^{3} / \mathrm{s}$, cubic meters per second]

\section{U.S. Geological Survey streamflow-gaging stations}

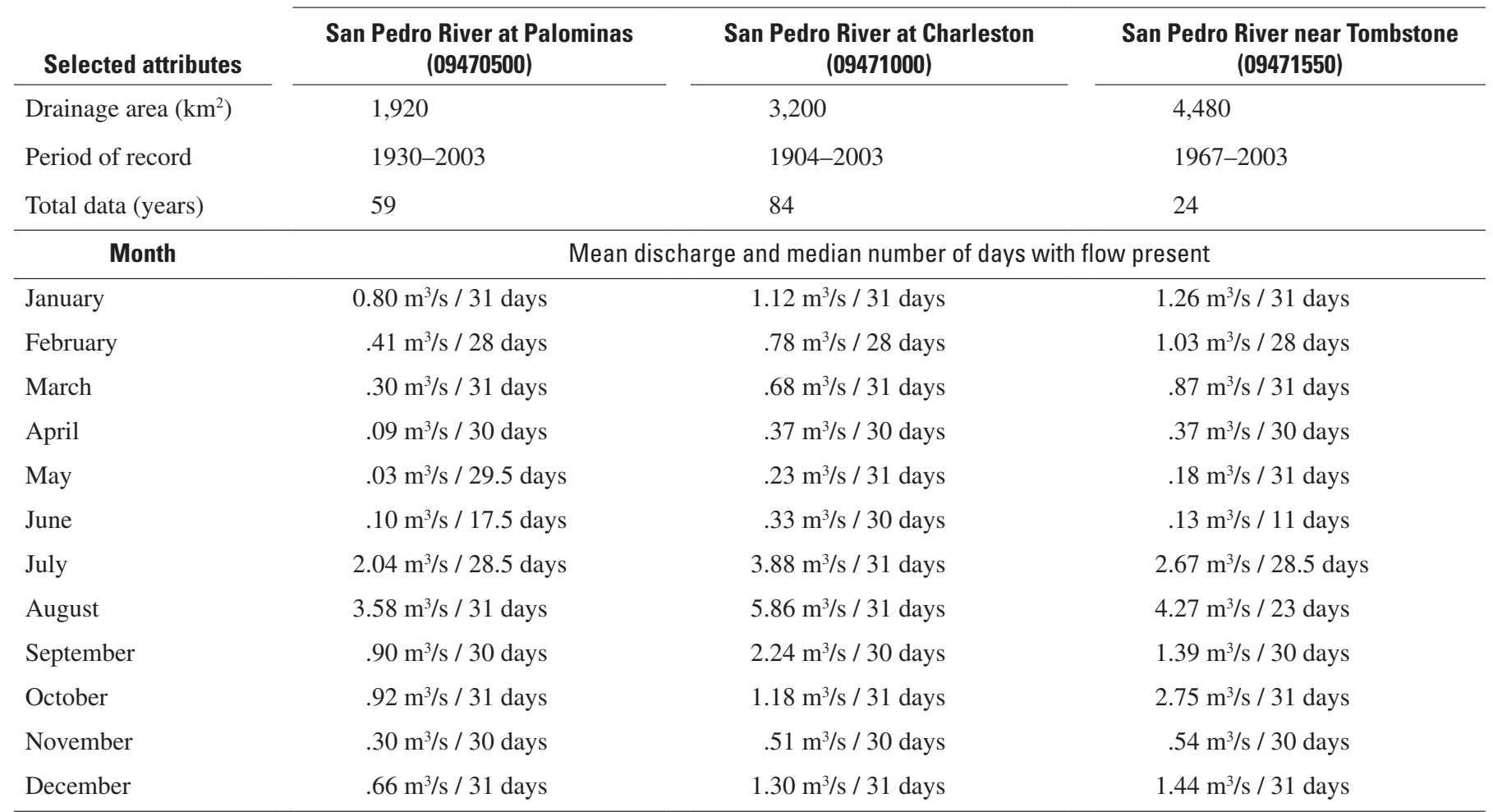




\section{Hydrogeologic Setting}

The San Pedro River flows through a classic basin and range physiography. Basins have formed in the grabens between block-faulted mountain ranges and have filled with Miocene through early Pleistocene sediments eroded from the uplifted blocks. The result is a series of relatively linear and parallel northwest-trending mountain/basin complexes (Brown and others, 1966).

The Upper San Pedro Basin is bounded on the east by the Mule and Dragoon Mountains and on the west by the Huachuca and Whetstone Mountains. The Huachuca, Whetstone, and Dragoon Mountains are composed largely of granite, limestone, dolomite, conglomerate, and claystone ranging in age from Precambrian to Cretaceous (Drewes, 1996). The Mule Mountains consist of early Precambrian schist unconformably overlain by Mesozoic conglomerate, red mudstone, siltstone, and limestone (Hayes, 1970).

The earliest sedimentary unit in the basin is the Oligocene to lower Miocene Pantano Formation (Gettings and Houser, 2000). It is described by Brown and others (1966) as semiconsolidated brownish-red to brownish-grey conglomerate, and according to Gettings and Houser (2000) it is as much as $700 \mathrm{~m}$ thick at the southern end of the study area. The Pantano Formation yields water through fractures to many wells in the Sierra Vista area and may be an important water-bearing unit in some locations (Pool and Coes, 1999).

Overlying the Pantano Formation are alluvial sediments that are as much as about $225 \mathrm{~m}$ thick (Pool and Coes, 1999) and, for the purposes of this study, are classified into three groups; basin-fill sediments, terrace deposits, and stream alluvium (fig. 3). The basin-fill sediments are generally classified into upper and lower units. The lower basin fill is Miocene to Pliocene in age and consists largely of interbedded gravel and sandstone, but can include clay, siltstone and silt (Pool and Coes, 1999). Sorting in gravel beds and sandstones is generally poor, and degree of cementation is variable (Brown and others, 1966). In most of the basin, the lower basin-fill sediments serve as an important water-bearing unit; its thickness ranges from about 50 to $100 \mathrm{~m}$.

The upper basin-fill sediments consist of Pliocene to Pleistocene-age reddish-brown clay, silt, sand, and gravel that are generally weakly cemented (Pool and Coes, 1999). The lithology grades from gravels with high permeability in the fan deposits along the flank of the Huachuca Mountains to relatively impermeable silts and clays near Charleston, Ariz. The upper basin-fill sediments host the major water-bearing aquifers near the basin margins and near Mexico (Pool and Coes, 1999). Thickness of the upper basin-fill sediments is $120 \mathrm{~m}$ or less.

The terrace deposits began forming in the middle Pleistocene when changes in the climatic regime caused a transition from deposition to erosion (Brown and others, 1966). The deposits mark the location of the San Pedro River through the process of several episodes of downcutting and extend from the base of the mountains to the San Pedro's current flood plain. The terrace deposits form a veneer near the mountains but could be as much as 15 to $30 \mathrm{~m}$ thick in erosional channels near the current San Pedro River (Pool and Coes, 1999). The sediments are a poorly sorted mixture of gravel, sand, and clay from local sources (Brown and others, 1966). Deposition of the present stream alluvium followed the last episode of downcutting.

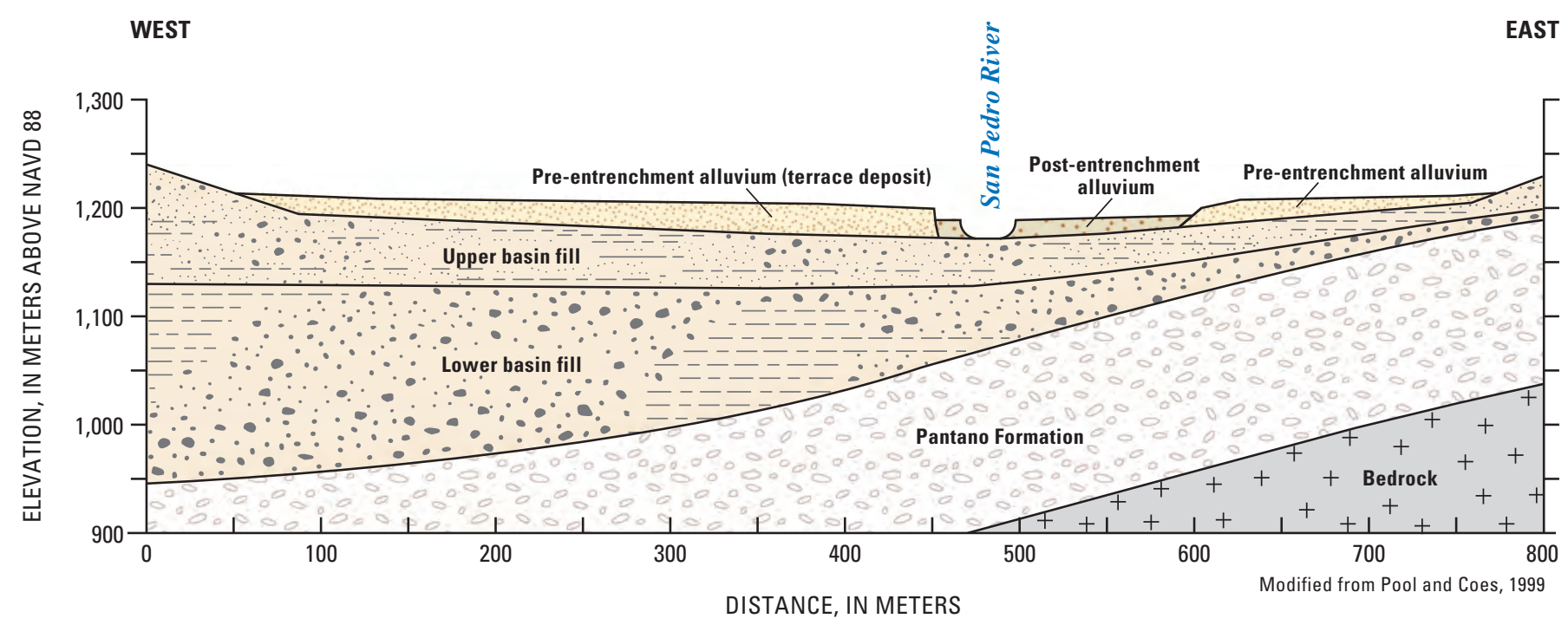

Figure 3. Geologic section perpendicular to the San Pedro River near State Highway 90, San Pedro Riparian National Conservation Area, Upper San Pedro Basin, Arizona. 
The youngest terrace deposits, the modern stream alluvial sediments, are the units of primary interest to this study as they wholly contain the riparian system. The modern stream alluvium is subdivided into the pre-entrenchment and postentrenchment units (figs. 2 and 3). They are Holocene in age, generally $7 \mathrm{~m}$ or less in thickness and as much as $1.5 \mathrm{~km}$ wide. The post-entrenchment alluvium is equivalent to the present-day flood plain. The pre-entrenchment alluvium is at a higher elevation, is only rarely flooded, and is basically flat lying. In this report, the pre-entrenchment alluvium is also called the terrace. Portions of the pre-entrenchment terrace in the SPRNCA were cleared for agricultural use in the mid-20th century.

The pre-entrenchment alluvium was deposited prior to an entrenchment of the river that occurred about 1890 (Hereford, 1993). Interpretation of historical accounts (Hendrickson and Minckley, 1984) indicate that prior to entrenchment, cienegas (marsh lands) were nearly continuous in the inner San Pedro River valley. The pre-entrenchment alluvium is texturally consistent with a mostly lowenergy depositional environment and consists largely of clay, silt, and fine sand with interbedded sand and gravel (Pool and Coes, 1999). The post-entrenchment alluvium consists primarily of sand and gravel because higher stream-flow velocities in the entrenched river have resulted in a higher-energy depositional environment. The postentrenchment alluvium has much higher permeability than the pre-entrenchment alluvium (Pool and Coes, 1999). In places along the river, the channel could have cut completely through the pre-entrenchment deposits (fig. 3) and therefore be in direct contact with the upper basin fill.

The ultimate cause of entrenchment is attributed to a series of large floods beginning in 1881 and to system disturbance by a high-intensity earthquake on May 3, 1887 (Hereford, 1993). The epicenter of the earthquake was centered about 50-75 km southeast of the upper San Pedro River valley. Proposed factors in the increased flood magnitude include changes in climate and (or) land use. Once entrenchment began it progressed rapidly and by 1908 was continuous throughout the most of the study area. The river is now an entrenched, sinuous fluvial system that has widened relative to conditions immediately following entrenchment (Hereford, 1993).

Historical evidence and photographs cited in Hereford (1993) document large changes in the vegetation assemblage along the river following entrenchment. Vegetation just prior to entrenchment included grasses associated with the marshy cienega environment. Dense forests of riparian trees were not prevalent in the pre-entrenchment period or after entrenchment until the late 1930s. Ground and aerial photographs taken after 1930 show a progressive increase in the extent and density of the riparian forest in the entrenched channel; riparian forest cover stabilized around 1970 (Kepner and others, 2002).

\section{Present River Characteristics}

Throughout the study area, the present channel is entrenched about 1 to $10 \mathrm{~m}$ below its pre-entrenchment flood plain. The river in the SPRNCA is an interrupted perennial stream. A continuous perennial reach in the middle of the SPRNCA extends about $14 \mathrm{~km}$ upstream and $4 \mathrm{~km}$ downstream from the Charleston gaging station (fig. 1). The upstream reach between the international boundary and the continuous perennial reach consists of alternating reaches of intermittent and perennial flow (interrupted perennial). The river reach north of the continuous perennial reach to the downstream end of the study area near St. David is intermittent and becomes generally drier approaching St. David (fig. 4).

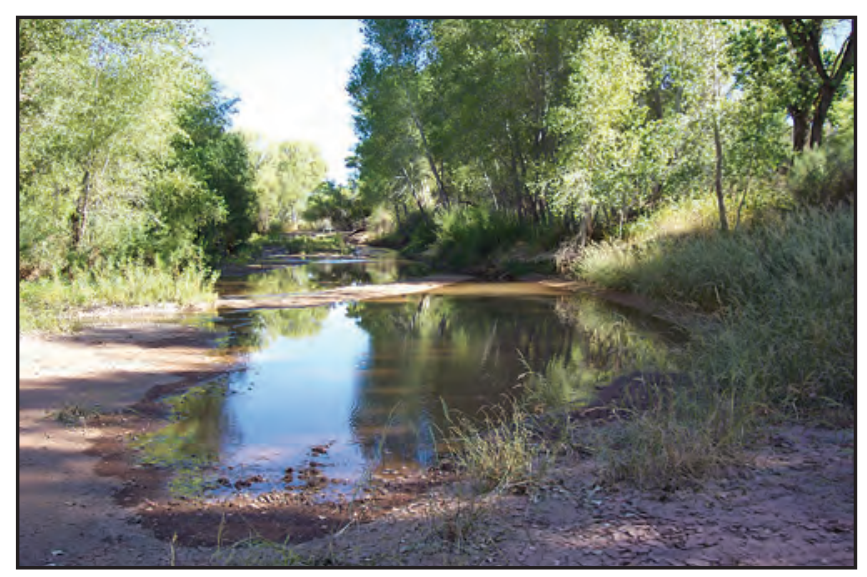

A. Moson

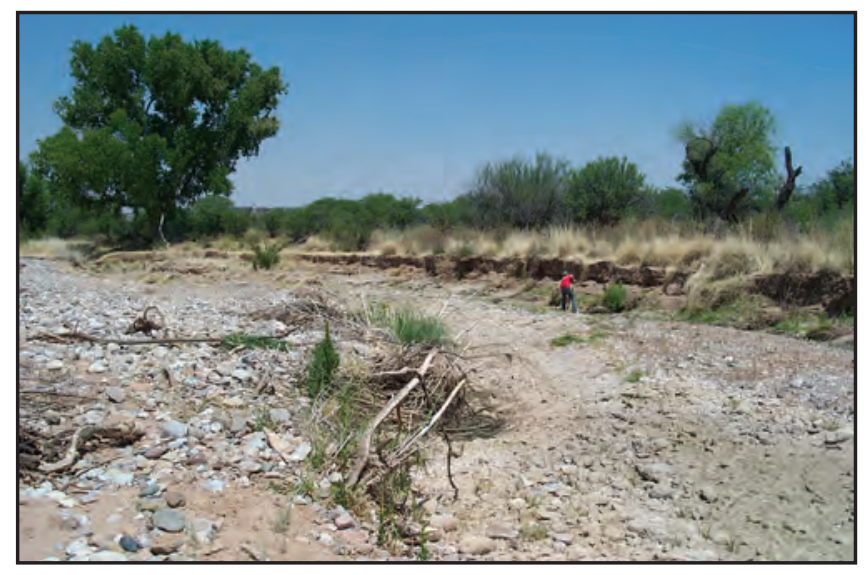

B. Contention

Figure 4. Active post-entrenchment channel of the San Pedro River during the summer, San Pedro Riparian National Conservation Area, Upper San Pedro Basin, Arizona. $A$, Perennial Moson site; $B$, Intermittent Contention site. 
A dense riparian forest lines most of the entrenched channel but changes in character spatially between the upstream and downstream ends of the study area. Between the international boundary and the downstream end of the continuous perennial reach, the riparian forest in the channel is composed mainly of broadleaf deciduous trees, such as Fremont cottonwood (Populus fremontii), Goodding willow (Salix gooddingii), and other desert riparian species, including seepwillow (Baccharis salicifola; Hereford, 1993; Stromberg and others, 1996). The pre-entrenchment alluvial terrace, where not previously cleared for agriculture, is vegetated largely by velvet mesquite (Prosopis velutina) woodlands and sacaton (Sporobolus wrightii) grassland (Stromberg and others, 1996). Downstream from the continuous perennial reach, the in-channel vegetation transitions to domination by mesquite (Proposis velutina) and tamarisk (Tamarix ramosissima or T. chinensis; Hereford, 1993).

\section{Study Sites}

The specific study locations within the SPRNCA were selected to represent the variability of riparian vegetation and hydrologic factors in the riparian system. The overall water-needs study comprised three specific elements: (1) ground-water and surface-water hydrology, (2) riparian biohydrology, and (3) riparian water use through ET. The hydrology and riparian biohydrology elements were intrinsically related because specific hydrologic information was used in the biohydrology analysis and interpretation. As a result, the hydrology and riparian biohydrology study sites were generally collocated; every hydrology monitoring location accompanied a riparian biohydrology monitoring location, although the biohydrology study included additional supplemental sites at which limited hydrologic parameters were monitored. Twenty-six riparian study sites (16 biohydrology and 10 supplemental) were established in the SPRNCA; hydrologic factors were studied at the 16 biohydrology sites (fig. 1 and table 2). Twelve supplemental riparian study sites were also established in the Lower San Pedro Basin. The supporting information from the supplemental sites in the SPRNCA and in the Lower San Pedro Basin was used in the biohydrology analysis (table 2).

For the hydrologic analysis, supporting information from other locations, primarily from streamflow-gaging stations not collocated with biohydrology sites, were used to relate results to longer and more detailed streamflow records.

The water-use element of the study was limited by the needs and constraints of the measurement techniques to five study sites, each collocated with a biohydrology site (fig. 1). Measurements at these representative sites were scaled up to larger areas. The selected sites, however, represented variations both in vegetation type and in spatial water availability (table 2).

\section{Biohydrology Study Sites}

In the Upper San Pedro Basin, 16 primary sites were established within the SPRNCA where both hydrologic and riparian biohydrologic data were collected (fig. 1, table 2). The site locations were selected to represent the range of hydrologic and riparian conditions present within the SPRNCA. Ten supplemental riparian study sites were established within the SPRNCA, but limited hydrologic data were collected at these supplemental sites. Data were also obtained for 12 additional supplemental sites (fig. 1 and table 2) in the lower basin, to provide for a larger spatial gradient of water availability.

A biohydrology site consisted of a river segment about $500 \mathrm{~m}$ in length. At each site, two to five belt transects (each 20-m wide) were established, spaced about 100-m apart. Transects were perpendicular to the river flow and extended on both sides of the river from the channel thalweg (low point) to the approximate edge of the active (100-year) flood plain. As many as three of these transects then extended laterally for an additional $100 \mathrm{~m}$ on the upper river terraces (fig. 5). These additional 100-m lateral swaths generally did not encompass the full extent of the upper-terrace riparian zones, which in some cases extend laterally for several hundred meters. They did, however, encompass a representative segment of the upper-terrace vegetation.

Hydrologic-data collection (chapter B) to support the biohydrology study focused on one of the belt transects at each of 16 biohydrology sites (table 2). Stream-stage recorders and piezometers were installed such that they were collocated, as best possible, on or near a biohydrology transect (fig. 5).

As part of the hydrologic analysis, one land-surface topographic transect was surveyed along a line near the center of the belt transect at each site that was monitored for hydrologic factors (chapter B). The transect at each biohydrology site where hydrologic data were collected is called the hydrology/biohydrology transect.

Two biohydrology sites (Charleston bridge and Tombstone) were collocated with permanent streamflowgaging stations (table 2). One site (Palominas) was about $1 \mathrm{~km}$ upstream from the USGS streamflow-gaging station, San Pedro River at Palominas (09470500).

From 1994 to 2003, there were at least six large fires, which encompassed about 10 percent of the entire SPRNCA and from 10 to 30 percent of the riparian subset (table 3 ). Fires were concentrated in upper elevations of the river corridor. Many areas have obvious signs of recent fire, including charcoal and fire-damaged trees. Because wildfires influence riparian-vegetation structure and succession, study sites were selected in both burned and unburned areas.

Hydrologic data collection began in summer 2000 at 4 sites and in 2001 at 12 sites. Hydrologic data collection concluded in October 2003. Riparian biohydrology data were collected between 2000 and 2004. 
Table 2. Biohydrology, supplemental riparian, and evapotranspiration/water-source study sites, Upper and Lower San Pedro Basins, Arizona

[SPRNCA, San Pedro Riparian National Conservation Area]

\begin{tabular}{|c|c|c|c|c|c|c|}
\hline \multirow[b]{2}{*}{ Site name } & \multicolumn{2}{|c|}{ Site location } & \multirow{2}{*}{$\begin{array}{l}\text { Approximate } \\
\text { downstream } \\
\text { distance from the } \\
\text { United States- } \\
\text { Mexico border } \\
\text { (kilometers) }\end{array}$} & \multirow[b]{2}{*}{$\begin{array}{l}\text { Part of } \\
\text { San Pedro } \\
\text { Basin }\end{array}$} & \multirow[b]{2}{*}{$\begin{array}{l}\text { Within } \\
\text { SPRNCA }\end{array}$} & \multirow[b]{2}{*}{ Data-collection elements } \\
\hline & $\begin{array}{c}\text { UTM } \\
\text { northing, } \\
\text { zone } 12 \mathrm{~N} \\
\text { (meters) }\end{array}$ & $\begin{array}{c}\text { UTM } \\
\text { easting, } \\
\text { zone } 12 \mathrm{~N} \\
\text { (meters) }\end{array}$ & & & & \\
\hline Palominas south & 3469500 & 583000 & 3 & Upper & Yes & Hydrology, riparian data \\
\hline $\begin{array}{l}\text { Palominas streamflow- } \\
\text { gaging station }\end{array}$ & 3471900 & 584500 & 6 & Upper & Yes & Long-term gaging station \\
\hline Kolbe & 3475900 & 585100 & 10 & Upper & Yes & Hydrology, riparian data \\
\hline Hereford & 3480300 & 584600 & 15 & Upper & Yes & Hydrology, riparian data \\
\hline Cottonwood north & 3488700 & 582500 & 23 & Upper & Yes & Supplemental riparian data \\
\hline Lewis Springs & 3491700 & 581600 & 26 & Upper & Yes & $\begin{array}{l}\text { Hydrology, riparian data, evapotranspiration } \\
\text { (basic meteorology, sap flow, plant isotopes, } \\
\text { eddy covariance) }\end{array}$ \\
\hline Moson & 3497700 & 579000 & 34 & Upper & Yes & $\begin{array}{l}\text { Hydrology, riparian data, evapotranspiration } \\
\text { (plant isotopes) }\end{array}$ \\
\hline Charleston south & 3498600 & 578700 & 34.5 & Upper & Yes & Supplemental riparian data \\
\hline Charleston bridge & 3499500 & 578100 & 35 & Upper & Yes & $\begin{array}{l}\text { Hydrology, riparian data, long-term gaging } \\
\text { station }\end{array}$ \\
\hline Depot & 3510800 & 575700 & 47 & Upper & Yes & Supplemental riparian data \\
\hline Fairbank north & 3511900 & 576700 & 48 & Upper & Yes & Supplemental riparian data \\
\hline Tombstone south & 3513000 & 575700 & 49.5 & Upper & Yes & Supplemental riparian data \\
\hline Tombstone & 3513200 & 575700 & 50 & Upper & Yes & $\begin{array}{l}\text { Hydrology, riparian data, long-term } \\
\text { gaging station }\end{array}$ \\
\hline Contention & 3514900 & 575400 & 52 & Upper & Yes & Hydrology, riparian data \\
\hline Summers & 3517800 & 574000 & 55 & Upper & Yes & Hydrology, riparian data \\
\hline St. David & 3520300 & 574300 & 58 & Upper & Yes & Hydrology, riparian data \\
\hline St. David north & 3520800 & 573800 & 58.5 & Upper & Yes & Supplemental riparian data \\
\hline Escalante south & 3525200 & 574700 & 63 & Upper & Yes & Supplemental riparian data \\
\hline Escalante & 3525200 & 574700 & 63 & Upper & Yes & Supplemental riparian data \\
\hline Narrows & 3555600 & 567100 & 100 & Upper & No & Supplemental riparian data \\
\hline Barb Clark & 3569500 & 561200 & 115 & Lower & No & Supplemental riparian data \\
\hline Cascabel & 3573300 & 557700 & 119 & Lower & No & Supplemental riparian data \\
\hline
\end{tabular}


Table 2. Biohydrology, supplemental riparian, and evapotranspiration/water-source study sites, Upper and Lower San Pedro Basins, Arizona-Continued

\begin{tabular}{lc|ccccc}
\hline & \multicolumn{2}{c}{ Site location } & $\begin{array}{c}\text { Approximate } \\
\text { downstream }\end{array}$ & & & \\
\cline { 2 - 5 } \multicolumn{1}{c}{ Site name } & $\begin{array}{c}\text { UTM } \\
\text { northing, } \\
\text { zone 12N } \\
\text { (meters) }\end{array}$ & $\begin{array}{c}\text { UTM } \\
\text { easting, } \\
\text { zone 12N } \\
\text { distance from the } \\
\text { United States- } \\
\text { (meters) }\end{array}$ & $\begin{array}{c}\text { Mexico border } \\
\text { (kilometers) }\end{array}$ & $\begin{array}{c}\text { Part of } \\
\text { San Pedro } \\
\text { Basin }\end{array}$ & $\begin{array}{c}\text { Within } \\
\text { SPRNCA }\end{array}$ & Data-collection elements \\
\hline Bennett & 3574100 & 557300 & 120 & Lower & No & Supplemental riparian data \\
Steinman & 3575500 & 556900 & 131 & Lower & No & Supplemental riparian data \\
Hughes & 3577300 & 555200 & 124 & Lower & No & Supplemental riparian data \\
State Land & 3598900 & 546800 & 149 & Lower & No & Supplemental riparian data \\
Skeen I & 3604800 & 545100 & 155 & Lower & No & Supplemental riparian data \\
Skeen P & 3605400 & 545000 & 156 & Lower & No & Supplemental riparian data \\
Cook's lake & 3636200 & 525600 & 193 & Lower & No & Supplemental riparian data \\
TNC I & 3643100 & 524600 & 200 & Lower & No & Supplemental riparian data \\
TNC P & 3644200 & 524000 & 201 & Lower & No & Supplemental riparian data \\
\hline
\end{tabular}

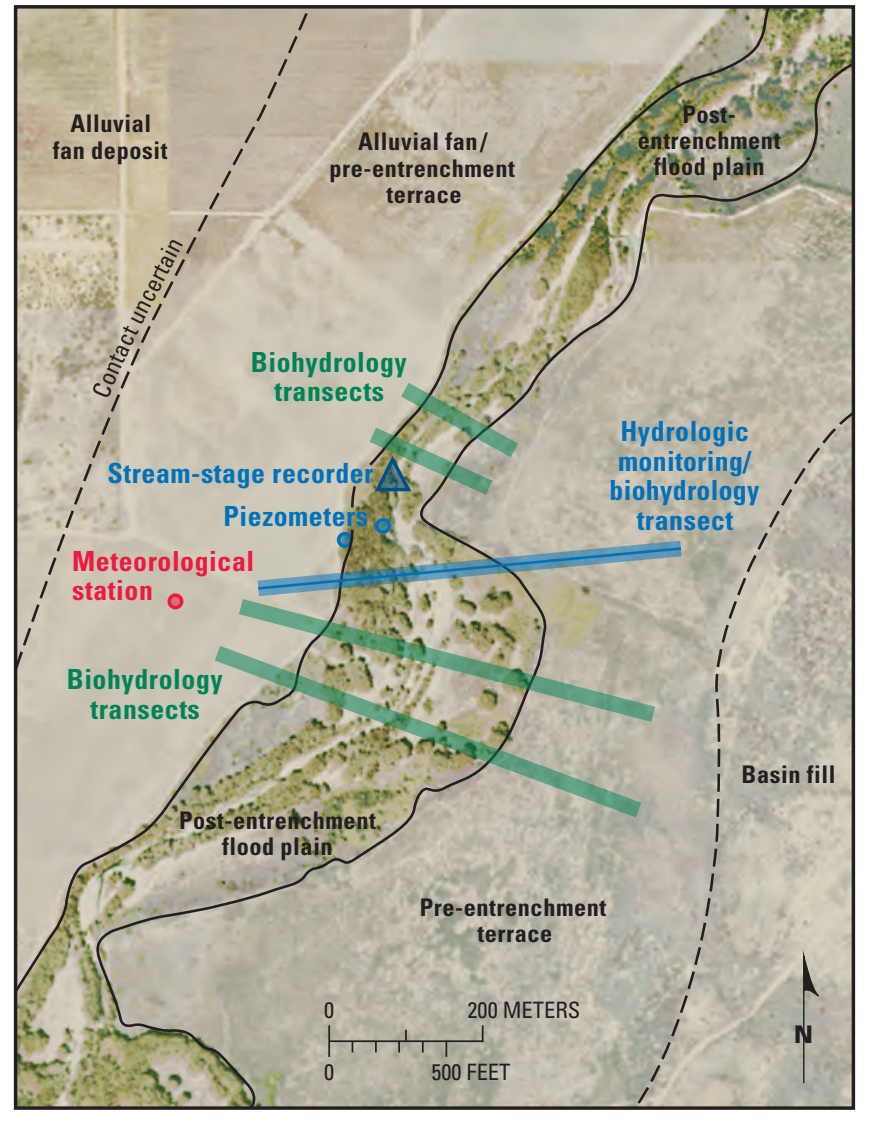

Figure 5. Areal view of the Palominas study site showing approximate locations of biohydrology belt transects, hydrologic monitoring equipment, and meteorological station, San Pedro Riparian National Conservation Area, Upper San Pedro Basin, Arizona.
Table 3. Recent fires in the San Pedro Riparian National Conservation Area riparian corridor, Upper San Pedro Basin, Arizona

[ $\mathrm{km}^{2}$, square kilometers]

\begin{tabular}{lccc}
\hline $\begin{array}{c}\text { Fire name and } \\
\text { general location }\end{array}$ & Date & \multicolumn{1}{c}{ Cause } & $\begin{array}{c}\text { Approximate } \\
\text { area burned } \\
\mathbf{( k m}^{2} \mathbf{l}\end{array}$ \\
\hline Palominas-1994 & January 1994 & Unknown & 2.1 \\
Hereford & March 1999 & Powerline blowdown & Unknown \\
Lewis Springs & May 1998 & Human, accidental & 1.8 \\
Charleston & June 1999 & Unknown & 1.0 \\
Palominas-2003 & April 2003 & Human, campfire & 6.1 \\
\hline
\end{tabular}




\section{Reaches and Condition Classes}

The riparian corridor in the SPRNCA was divided into relatively homogeneous reaches on the basis of similarity in two key physical controls on riparian-vegetation structure: streamflow hydrology (spatial intermittency) and geomorphology (channel sinuosity and flood-plain width). The Upper San Pedro Community Monitoring Network, in an initiative spearheaded by The Nature Conservancy, annually monitors the spatial extent of perennial flow in the river. During the early summer premonsoon season, volunteers walk the river and map the boundaries of the surface flow using Global Positioning System (GPS) receivers. These results yield a flow-permanence map that shows the location of surface flow during the summer dry season, when surface flow is at a minimum. The 2002 flow map was used to calculate the extents of surface flow in preliminary $3-\mathrm{km}$ segments of the river; the segments were placed into one of five spatial intermittency classes. Channel sinuosity was calculated by first dividing the river into $3-\mathrm{km}$ segments and then dividing stream length by straight length. The segments were then classified into one of three sinuosity classes. Flood-plain width classes were based on field measurements and included three categories: wide (unconstrained), medium, and narrow (flood-plain development constrained by geologic features). The final reaches that maximize within-reach homogeneity (table 4) were determined by visually examining overlays of geographic information system (GIS) covers of streamflow intermittency, sinuosity, and flood-plain width.

Fourteen reaches were delineated, spanning a $62-\mathrm{km}$ length of the San Pedro River in the SPRNCA (fig. 1).

Reach lengths range from 2.5 to $8.1 \mathrm{~km}$, with an average of
$4.4 \mathrm{~km}$. The highest elevation reach is at 1,295 m, and the lowest at $1,108 \mathrm{~m}$. Generally, reaches in the downstream portion of the SPRNCA (reaches 9 through 13) are the driest, whereas reaches in the middle section (2 through 7) are the wettest. Stream permanence is low in reach 13 partly because most of the river water is seasonally diverted into the St. David ditch from an earthen dam (which is then typically breached by monsoon floods). The flood plain is relatively narrow and constrained (generally $<100 \mathrm{~m}$ wide) in the reaches between the Charleston Hills area (Charleston bridge site) and Tombstone site (reaches 7 through 11). The flood plain in other areas is as wide as $350 \mathrm{~m}$.

Vegetation data for condition-class assessment were collected at the 16 biohydrology and 10 supplemental sites. The 16 biohydrology sites were instrumented by the USGS for characterization of hydrologic parameters. At least one biohydrology site was present in each reach, with the exception of reaches 10 and 14, which had no biohydrology sites (table 5). Four of the supplemental SPRNCA riparian study sites were established in 2003; six additional supplemental sites were established in 2004 to provide full reach coverage on the nine vegetation bioindicators used in the Riparian Assessment Model (see "Functioning Condition Analysis" section). The 26 biohydrology/supplemental sites within the SPRNCA (16 biohydrology + 10 supplemental) were distributed among the reaches so as to have 2 sites per reach in cases where there was internal variation in burn history (recently burned and unburned areas) or streamflow patterns (interrupted stream reaches with alternating segments of perennial and intermittent flow).

Table 4. Hydrogeomorphic traits of reaches of the San Pedro River, San Pedro Riparian National Conservation Area, Upper San Pedro Basin, Arizona

\begin{tabular}{|c|c|c|c|c|c|}
\hline $\begin{array}{l}\text { Reach } \\
\text { number }\end{array}$ & $\begin{array}{c}\text { Sinuosity } \\
\text { (meter per meter) }\end{array}$ & $\begin{array}{l}\text { Spatial extent of perennial } \\
\text { flow in June } 2002 \\
\text { (percent of reach) }\end{array}$ & $\begin{array}{l}\text { Mean } \\
\text { flood-plain width } \\
\text { (meters) }\end{array}$ & $\begin{array}{l}\text { Reach length } \\
\text { (kilometers) }\end{array}$ & $\begin{array}{c}\text { Cumulative distance from the } \\
\text { United States-Mexico border, } \\
\text { (kilometers) }\end{array}$ \\
\hline 2 & 1.37 & 87 & 186 & 7.6 & 8 \\
\hline 3 & 1.43 & 69 & 223 & 6.1 & 16 \\
\hline 5 & 1.16 & 100 & 216 & 6.5 & 24 \\
\hline 6 & 1.36 & 100 & 156 & 3.0 & 31 \\
\hline 7 & 1.37 & 99 & 123 & 4.1 & 34 \\
\hline 8 & 1.58 & 51 & 177 & 5.8 & 38 \\
\hline 9 & 1.13 & 0 & 61 & 3.1 & 44 \\
\hline 12 & 1.58 & 34 & 355 & 4.7 & 51 \\
\hline 13 & 1.16 & 0 & 276 & 3.9 & 55 \\
\hline 14 & 1.65 & 2 & 232 & 2.5 & 59 \\
\hline
\end{tabular}


Table 5. Locations of the 16 biohydrology and 10 supplemental study sites, San Pedro Riparian National Conservation Area, Upper San Pedro Basin, Arizona

\begin{tabular}{|c|c|c|c|c|c|c|}
\hline $\begin{array}{l}\text { Reach } \\
\text { number }\end{array}$ & Site name & Site type & \multicolumn{2}{|c|}{ Site location } & $\begin{array}{l}\text { Approximate } \\
\text { elevation of river } \\
\text { (meters) }\end{array}$ & Fire history \\
\hline 1 & Palominas south & Biohydrology & 3469500 & 583000 & 1,295 & Burned \\
\hline 2 & Kolbe & Biohydrology & 3475900 & 585100 & 1,274 & Unburned \\
\hline 2 & Hereford & Biohydrology & 3480300 & 584600 & 1,265 & Burned \\
\hline 3 & Hunter south & Supplemental & 3482100 & 584500 & 1,250 & Unburned \\
\hline 5 & Lewis Springs & Biohydrology & 3491700 & 581600 & 1,234 & Burned \\
\hline 6 & Moson & Biohydrology & 3497700 & 579000 & 1,213 & Unburned \\
\hline 7 & Charleston south & Supplemental & 3498600 & 578700 & 1,207 & Unburned \\
\hline 7 & Charleston bridge & Biohydrology & 3499500 & 578100 & 1,204 & Burned \\
\hline 8 & Charleston mesquite & Biohydrology & 3503700 & 577900 & 1,189 & Unburned \\
\hline 8 & Boquillas & Biohydrology & 3506400 & 577300 & 1,181 & Unburned \\
\hline 11 & Tombstone south & Supplemental & 3513000 & 575700 & 1,161 & Unburned \\
\hline 11 & Tombstone & Biohydrology & 3513200 & 575700 & 1,158 & Unburned \\
\hline 12 & Contention & Biohydrology & 3514900 & 575400 & 1,154 & Unburned \\
\hline 12 & Summers & Biohydrology & 3517800 & 574000 & 1,135 & Unburned \\
\hline 13 & St. David & Biohydrology & 3520300 & 574300 & 1,128 & Unburned \\
\hline 13 & St. David north & Supplemental & 3520800 & 573800 & 1,122 & Unburned \\
\hline 14 & Escalante south & Supplemental & 3525200 & 574700 & 1,109 & Unburned \\
\hline 14 & Escalante & Supplemental & 3525200 & 574700 & 1,108 & Unburned \\
\hline
\end{tabular}




\section{Water-Use Study Sites}

The intents of the water-use study element (chapter D) were to calculate an overall SPRNCA riparian-vegetation and open-water consumptive ground-water use estimate and to determine the sources of water used by mesquite. One or more types of water-use data (including ET, meteorological, and water-source data) were collected at each of 5 biohydrology study sites (fig. 1, table 2). To estimate SPRNCA-wide riparian ground-water use, total ET was measured in representative dominant plant communities at 3 of these 5 biohydrology sites (fig. 1, table 2). The amount of the measured total ET that was derived from ground water was determined by using a variety of methods. Finally, these estimates of annual ground-water use were scaled up to the full area of the SPRNCA. The water-use study element was plant-community based, not reach based as were the hydrology and biohydrology elements; therefore, ET was not measured within each biohydrology belt transect, or even at each biohydrology site. Water-use data were collected from March 2001 to December 2003.

Techniques used to estimate transpiration from mesquite and sacaton were different from those used for cottonwood and seepwillow stands. As a result, the particular techniques applied at a site differed depending on which type of vegetation was being studied. For example, measurement of mesquite transpiration used eddy correlation, a technique with a measurement area of tens to hundreds of meters in dimension - an area far larger than the biohydrology belt transects. Mesquite stands of suitable dimension and uniformity were located at the Charleston mesquite and Lewis Springs sites. Likewise, a sacaton study facility was established at the Lewis Springs site in a broad pre-entrenchment terrace occupied by a sacaton grassland. Cottonwood and seepwillow transpiration were measured using sap-flow measurement techniques, and the study sites were established near the Boquillas and Lewis Springs biohydrology sites (fig. 1). The inclusion of two sites for both the cottonwood and mesquite studies was intended to relate plant ground-water use to differences in site hydrology. Data to determine the source of water used by mesquite were collected at the Charleston mesquite, Moson, and Lewis Springs sites. Finally, a comparative analysis of meteorological forcing was completed, including data collected in 2001-03 from instruments on meteorological towers near the Charleston mesquite, Lewis Springs, and Palominas sites.

\section{Precipitation and Streamflow during the Study Period}

The period of hydrologic data collection (2000-2003) was too short to resolve long-term hydrologic conditions or trends using only the data collected for this study. Long-term hydrologic data more suitable for discerning long-term conditions and trends were also available for this study and include streamflow at the Charleston gaging station and precipitation collected at the National Weather Service Tombstone, Ariz., precipitation-gaging station. Although a comprehensive statistical-trend analysis is beyond the scope of this report, some basic statistics are presented in the following discussion to compare conditions during the study with long-term average conditions.

Annual average statistics for precipitation collected at the Tombstone precipitation-gaging station and streamflow discharge recorded at the Charleston gaging station help evaluate climate during the study relative to long-term records (table 6). Both precipitation and streamflow data indicate that calendar year 2000 was wetter than the long-term average and that 2001, 2002, and 2003 (only precipitation data available) were drier than the long-term average. Owing to probable high spatial variability, precipitation records from a single station may not accurately represent precipitation in the basin. Records of total annual streamflow include both base-flow and runoff components, and, therefore, are influenced by basinwide precipitation amounts. Seasonal average streamflow data from the Charleston gaging station (table 6) indicate that most of the above-average moisture in 2000 occurred in the fall when remnant moisture from tropical storms entered Arizona and caused substantial runoff in October. Winter runoff during the study, except in 2001, was between one-half and onequarter of the long-term average.

Frequent floodflows occur in the summer in response to monsoon precipitation. Monsoon-season floods had peak instantaneous discharges of $233 \mathrm{~m}^{3} / \mathrm{s}$ (August 7, 2000), $117 \mathrm{~m}^{3} / \mathrm{s}$ (August 14, 2001), $19 \mathrm{~m}^{3} / \mathrm{s}$ (July 26, 2002), and $83 \mathrm{~m}^{3} / \mathrm{s}$ (July 25, 2003) at the Charleston gaging station. A large flood occurred in October 2000 following $15.5 \mathrm{~cm}$ of rain at the Tombstone precipitation-gaging station. Flood waters had instantaneous peak flows on October 23, 2000, of $450 \mathrm{~m}^{3} / \mathrm{s}$ at the Palominas gaging station and $494 \mathrm{~m}^{3} / \mathrm{s}$ at the Charleston gaging station; these floods have recurrence intervals of 25 and 12 years, respectively. 
Table 6. Average streamflow at U.S. Geological Survey streamflow-gaging station, San Pedro River at Charleston (09471000) and total precipitation at the National Weather Service Tombstone precipitation-gaging station, Upper San Pedro Basin, Arizona 2000-2003

$\left[\mathrm{m}^{3} / \mathrm{s}\right.$, cubic meters per second; na, data not available. Winter is January, February, and March; spring is April, May, and June; summer is July, August, and September; fall is October, November, and December]

\begin{tabular}{|c|c|c|c|c|c|}
\hline \multicolumn{6}{|c|}{ Average streamflow } \\
\hline $\begin{array}{c}\text { Period } \\
\text { (calendar year) }\end{array}$ & $\begin{array}{c}\text { Annual } \\
\left(\mathrm{m}^{3} / \mathrm{s}\right)\end{array}$ & \multicolumn{4}{|c|}{ Season } \\
\hline 2000 & 2.84 & 0.28 & 0.41 & 3.20 & 7.33 \\
\hline 2002 & .26 & .41 & .14 & .39 & .12 \\
\hline 2003 & na & .27 & .12 & .58 & na \\
\hline${ }^{1}$ Record & 1.51 & .86 & .31 & 3.99 & .99 \\
\hline \multicolumn{6}{|c|}{ Total precipitation } \\
\hline $\begin{array}{c}\text { Period } \\
\text { (calendar year) }\end{array}$ & $\begin{array}{c}\text { Annual } \\
\text { (centimeters) }\end{array}$ & $\begin{array}{c}\text { Winter } \\
\text { (centimeters) }\end{array}$ & $\begin{array}{c}\text { Spring } \\
\text { (centimeters) }\end{array}$ & $\begin{array}{c}\text { Summer } \\
\text { (centimeters) }\end{array}$ & $\begin{array}{c}\text { Fall } \\
\text { (centimeters) }\end{array}$ \\
\hline 2000 & 49 & 2.0 & 7.8 & 16.0 & 23.0 \\
\hline 2001 & 30 & 6.5 & 4.4 & 16.4 & 3.0 \\
\hline 2002 & 24 & 2.5 & 0 & 17.4 & 4.4 \\
\hline 2003 & 27 & 5.0 & .05 & 16.4 & 5.3 \\
\hline${ }^{2}$ Record & 36 & 5.7 & 2.5 & 21.0 & 6.1 \\
\hline
\end{tabular}

${ }^{1}$ Streamflow-1904-2002, 84 years of record.

${ }^{2}$ Precipitation-1893-2003, 85 years of record. 
This page left blank intentionally. 


\title{
Chapter B
}

\section{Hydrology of the San Pedro Riparian National Conservation Area, Arizona}

\author{
By James M. Leenhouts ${ }^{1}$
}

\section{Introduction}

Availability of water in the study area for riparian vegetation was quantified by location and through time as the first step in characterizing water needs for the San Pedro Riparian National Conservation Area (SPRNCA). Chapter A described the overall issues addressed by the study, the study area, and the site-based approach used in all study components. This chapter presents aspects of the physical hydrology of the system.

The various plant species represented in the SPRNCA differ in their primary method of obtaining water, in their tolerance of varying water availability, and in the conditions needed for propagation. Some plants rely on rainwater that moistens the soil near land surface, whereas others grow deep roots and draw from the permanent ground-water table; the depth to ground water affects which plants inhabit different parts of the landscape. Some plants require access to water year around, whereas others can survive seasonal drought; the permanence and amount of streamflow at the surface affects the distribution of these plant groups. The ability of plants to reproduce depends on water availability and seed and nutrient distribution; these factors are partly controlled by how often parts of the landscape are inundated by flood waters.

This chapter presents calculated estimates for four hydrologic factors that likely influence the structure, composition, and diversity of the riparian vegetation in the study area: (1) depth to ground water beneath the hydrology/biohydrology transect at each site, (2) temporal presence of flow (streamflow permanence) in the stream channel, (3) monthly mean discharge, and (4) frequency of flood inundation. Results for these four factors are presented for the 16 biohydrology study sites introduced in chapter A that encompass the range of biologic and hydrologic conditions found in the SPRNCA.

The ground-water aspect of the study is based on data collected from the piezometers installed at each study site. The results describe how ground-water levels vary both across the SPRNCA and through the period of the study. Data from site piezometers were extrapolated to estimate depth to ground water beneath each of the hydrology/biohydrology transects for specific months of high and low water levels, for water years, and for the period of record.

The three surface-water aspects of the study are interpreted from a variety of data, including data from stream-stage and discharge measurements at the sites, long-term records of permanent streamflow-gaging stations,

${ }^{1}$ U.S. Geological Survey, Arizona Water Science Center, Tucson, Arizona. streamflow-presence sensors, and topographic surveys of the hydrology/biohydrology transects. Streamflow permanence is reported as the percentage of time in each study month and for each study site that flow was present in the channel. Permanence is shown to vary both among sites and through the course of the study. Monthly mean discharge is reported for each site and varies in time and space similarly to streamflow permanence. Finally, the section concerning flood inundation reports the peak flood elevation on each hydrology/biohydrology transect for various statistical recurrence-interval flows.

Hydrologic-data collection for the study built on the foundation of three long-term U.S. Geological Survey (USGS) streamflow-gaging stations: San Pedro River at Palominas (09470500), San Pedro River at Charleston (09471000), and San Pedro River near Tombstone (09471550). Ground-water and surface-water data collection began in summer 2000 at four sites. Data collection commenced at 12 other sites in June or July 2001. The most recent data considered in the preparation of this report were collected in September 2003.

\section{Hydrologic Instrumentation and Data Collection}

Various hydrologic instruments were installed at the 16 biohydrology study sites (fig. 6) to collect ground-water and surface-water data. In addition, data from three longterm streamflow-gaging stations-Palominas, Charleston, and Tombstone-provided essential historical information as well as site-specific data. Details about the sites, including the rationale for site selection and how sites were used in each study component, are presented in chapter A. This section describes the hydrologic monitoring equipment and how it was deployed at the sites (table 7). Additional details, including locations and naming conventions, are listed in appendix 1.

In keeping with the site-based approach to the biohydrology study, hydrologic monitoring equipment was installed within about $200 \mathrm{~m}$ of the corresponding hydrology/ biohydrology study transect at each of the 16 biohydrology sites. A plan view of a typical study site, Palominas (fig. 5), shows the physical relation of hydrologic monitoring devices and the surveyed hydrology/biohydrology transect. Ideally, ground-water and surface-water devices at all sites would have been collocated on the biohydrology transects with piezometers on both sides of the river. Limitations in accessibility, use of pre-existing wells, and considerations of channel geometry, however, often prevented positioning instrumentation directly along the transects. 


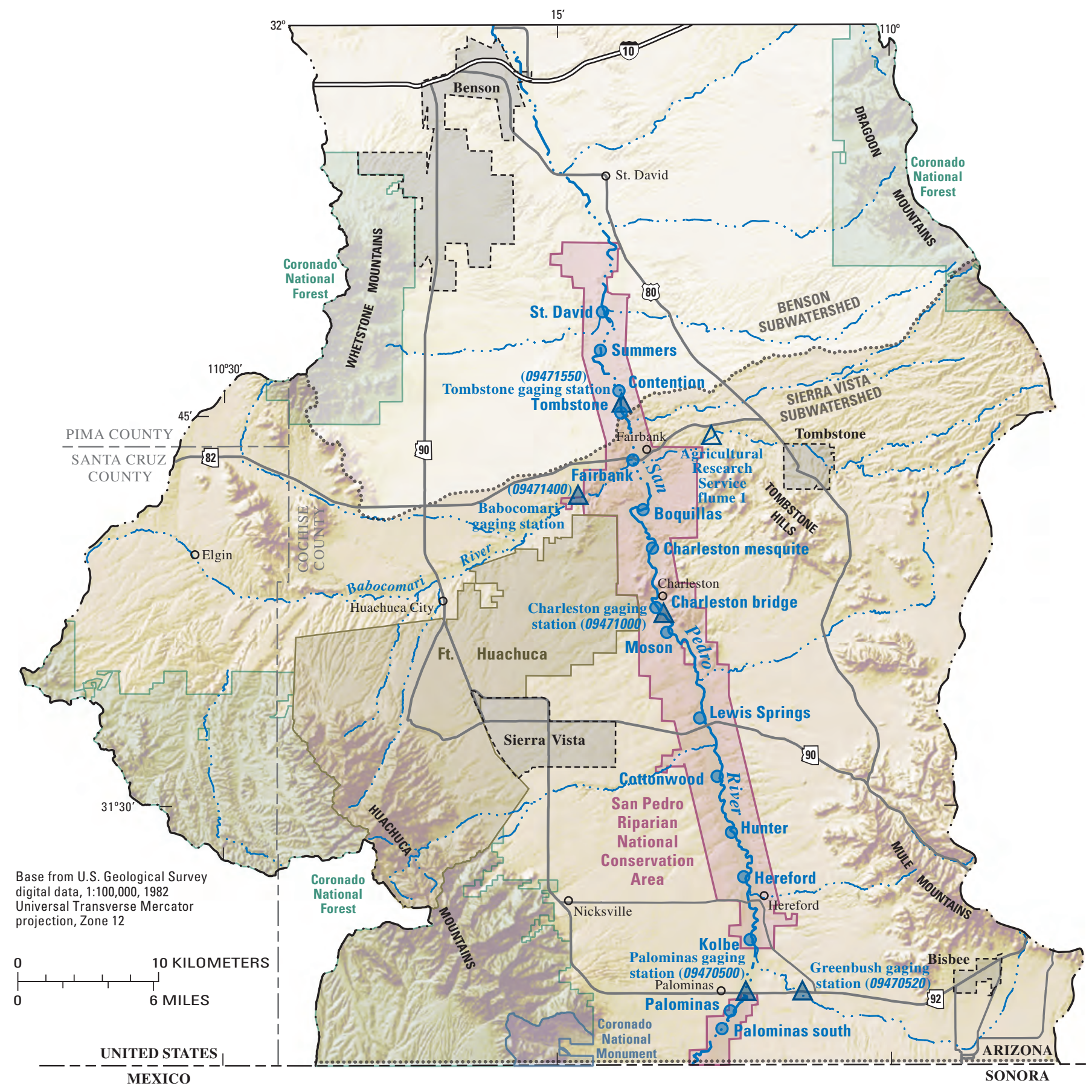

EXPLANATION

$\triangle$ U.S. GEOLOGICAL SURVEY STREAMFLOW-
GAGING STATION AND NUMBER

O BIOHYDROLOGY STUDY SITE

Figure 6. Location of the study area showing the 16 biohydrology sites in the San Pedro Riparian National Conservation Area, Upper San Pedro Basin, Arizona. 
Table 7. Summary of hydrologic monitoring equipment at the biohydrology sites, San Pedro Riparian National Conservation Area, Upper San Pedro Basin, Arizona

[NA, not applicable]

\begin{tabular}{|c|c|c|c|c|c|}
\hline Site name & $\begin{array}{l}\text { Approximate downstream } \\
\text { distance from the } \\
\text { United States-Mexico border } \\
\text { (kilometers) }\end{array}$ & $\begin{array}{c}\text { Number of } \\
\text { piezometers }\end{array}$ & $\begin{array}{l}\text { Average } \\
\text { distance from } \\
\text { transect } \\
\text { (meters) }^{1}\end{array}$ & $\begin{array}{l}\text { Type of } \\
\text { surface-water } \\
\text { device }\end{array}$ & $\begin{array}{l}\text { Streamflow- } \\
\text { presence } \\
\text { sensors }\end{array}$ \\
\hline Palominas south & 3 & 3 & 3 & Temporary recorder & Yes \\
\hline Palominas & 5 & 8 & 75 & Temporary recorder & No \\
\hline Palominas streamflow-gaging station ${ }^{2}$ & 6 & 0 & NA & Permanent gage & No \\
\hline Hereford & 15 & 8 & 10 & Temporary recorder & No \\
\hline Hunter & 18 & 4 & 100 & Temporary recorder & Yes \\
\hline Cottonwood & 22 & 7 & 125 & Temporary recorder & No \\
\hline Lewis Springs & 26 & 6 & 10 & Temporary recorder & No \\
\hline Boquillas & 43 & 5 & 20 & Temporary recorder & Yes \\
\hline Fairbank & 46 & 3 & 90 & Temporary recorder & Yes \\
\hline Tombstone & 50 & 1 & 5 & Permanent gage & No \\
\hline Contention & 52 & 5 & 25 & Temporary recorder & Yes \\
\hline Summers & 55 & 2 & 45 & Temporary recorder & Yes \\
\hline St. David & 58 & 2 & 5 & Temporary recorder & Yes \\
\hline
\end{tabular}

${ }^{1}$ Average distance calculated considering only the subset of piezometers used to estimate ground-water depth beneath the transects.

${ }^{2}$ Not part of a biohydrology transect or evapotranspiration site, but streamflow data were used in hydrologic analyses.

\section{Ground Water}

At each of the 16 biohydrology sites, ground-water levels were monitored with piezometers installed specifically for the project or, occasionally, with existing wells. Because depth to the water table was the primary interest of the ground-water aspect of the study, most piezometers installed were screened near the water table. At some locations, however, deep and shallow nested piezometer pairs and piezometers screened in the regional aquifer system that were installed as part of a concurrent study were included in the monitoring network. From one to eight piezometers were monitored at each site; 65 piezometers were monitored for the project.

Several methods were used for piezometer installations, including hollow-stem and solid-stem augers, Geoprobe direct-push technology, and hand pounding; as a result, construction materials and total depth varied from hole to hole. Selection of well-casing material depended on the drilling technique. Hand-pounded wells were cased with 2.54-cm diameter galvanized-steel pipe. Geoprobe-drilled piezometers were cased with $3.8-\mathrm{cm}$ diameter galvanized-steel pipe, 2.54-cm diameter schedule 40 polyvinyl chloride (PVC) pipe, or $5.08-\mathrm{cm}$ diameter schedule 40 PVC pipe. The screens were selected from one of three choices that matched the well casings. The 2.54-cm diameter galvanized pipe was matched with a screen consisting of a $2.54-\mathrm{cm}$ diameter, 0.3-m long galvanized steel pipe that had about forty-eight 0.48 -cm (3/16-inch) diameter drilled holes resulting in an open area of about 3 percent. The two diameters of PVC well casing were matched to equal diameter slotted commercial well screens of either 1.5-m or 3-m lengths. Slot widths in the commercial screens were $0.5 \mathrm{~mm}$ and total open area was about 15 percent. Additional information about piezometer locations and construction is listed in appendix 1. Piezometers were developed by pumping and surging until pumped water ran clear.

Each piezometer was equipped with a pressure transducer and combined data logger programmed to collect measurements at 30-minute intervals. Sites were visited every 3 to 4 months throughout the project to manually measure water levels and to download data from the loggers. 


\section{Surface Water}

Various surface-water data were collected at each site to satisfy the three surface-water objectives of the hydrologic analysis-(1) determine streamflow permanence, (2) estimate monthly mean flow, and (3) estimate inundation frequency along the hydrology/biohydrology transects. Data collected to meet these objectives included stream stage and discharge, and indications from temperature and electrical resistance sensors used to determine the presence or absence of water in the stream channel. Topographic surveys of the hydrology/biohydrology transects were used as part of the inundation analysis.

A stream-stage recorder was installed at each of the 14 study sites that were not collocated with an existing USGS streamflow-gaging station. These recorders were constructed from $2.5-\mathrm{cm}$ diameter galvanized-steel pipe laid in a trench between a point on the bank and a quiescent spot in the stream. A reference point for stage measurements, consisting of a steel fence post driven into the streambed, was installed at each stream-stage recorder. The plan view of the Palominas site (fig. 5) shows the relation between the stream-stage recorder, the piezometers, and the hydrology and biohydrology transects. Stage was recorded every 30 minutes with a recording pressure transducer/datalogger. Appendix 1 lists naming, location, and reference point-elevation information for each stream-stage recorder.

Two sites, Charleston bridge and Tombstone, were collocated with the Charleston and Tombstone gaging stations, respectively. The presence of the permanent stations eliminated the need for stream-stage recorders at these two sites. A third permanent streamflow-gaging station, Palominas, was about $1.4 \mathrm{~km}$ downstream from the Palominas study site. Discharge data from each of these streamflow gages were used in the calculations of monthly mean discharge and flood inundation. In addition, long-term data from streamflowgaging stations were used to place perspective on streamflow observed during the study period relative to long-term flows and to provide a reference for streamflow permanence. The streamflow record for the Charleston gaging station is the longest in the SPRNCA and is continuous back to 1935; data are discontinuous from 1904 to 1935.

Direct measurements of stream discharge were used in the site-specific calculations of monthly mean discharge. Discharge was measured at stage-recorder equipped sites about 1 to 3 times per month during the monsoon season and about every 1 or 2 months through the remainder of the year. Discharge was measured at streamflow-gaging stations approximately monthly and in response to runoff as part of the regular station-maintenance program.

Part of the information used to determine streamflow permanence was derived from temperature and electricalresistance sensors installed in the streambed at the intermittent streamflow sites Palominas south, Hunter, Boquillas, Fairbank, Contention, Summers, and St. David. Onset TidbiT temperature recorders were installed in two configurations:
(1) in stock form as received from the vendor (Constantz and others, 2000) and (2) in the modified form described by (Blasch and others, 2002). Modification involved the removal of the device's thermistor such that the cut wire leads were left exposed. Prepared in this way, the device is rendered a simple continuity tester that indicates whether a circuit is completed between the exposed wires. The circuit is closed when water is present and open when water is absent. Henceforth in this report, the modified TidbiT sensors are referred to as electrical-resistance sensors.

The stock temperature sensors and electrical-resistance sensors were mounted inside drilled sections of about $15-\mathrm{cm}$ long by $5.1-\mathrm{cm}$ diameter PVC pipe and tethered to a 0.9-m steel fence post using 3.2-mm diameter aircraft cable (fig. 7). The electrical-resistance sensor was tethered to the top of the fence post, and the stock sensor was attached below the midpoint. A hole was dug about $30 \mathrm{~cm}$ deep in the streambed sediments at the lowest point in the channel, and the fence post was hammered in until its top was about $7 \mathrm{~cm}$ above the channel grade. The hole was then backfilled with native material, leaving the stock sensor about $30 \mathrm{~cm}$ below grade and the electrical-resistance sensor resting on the surface.

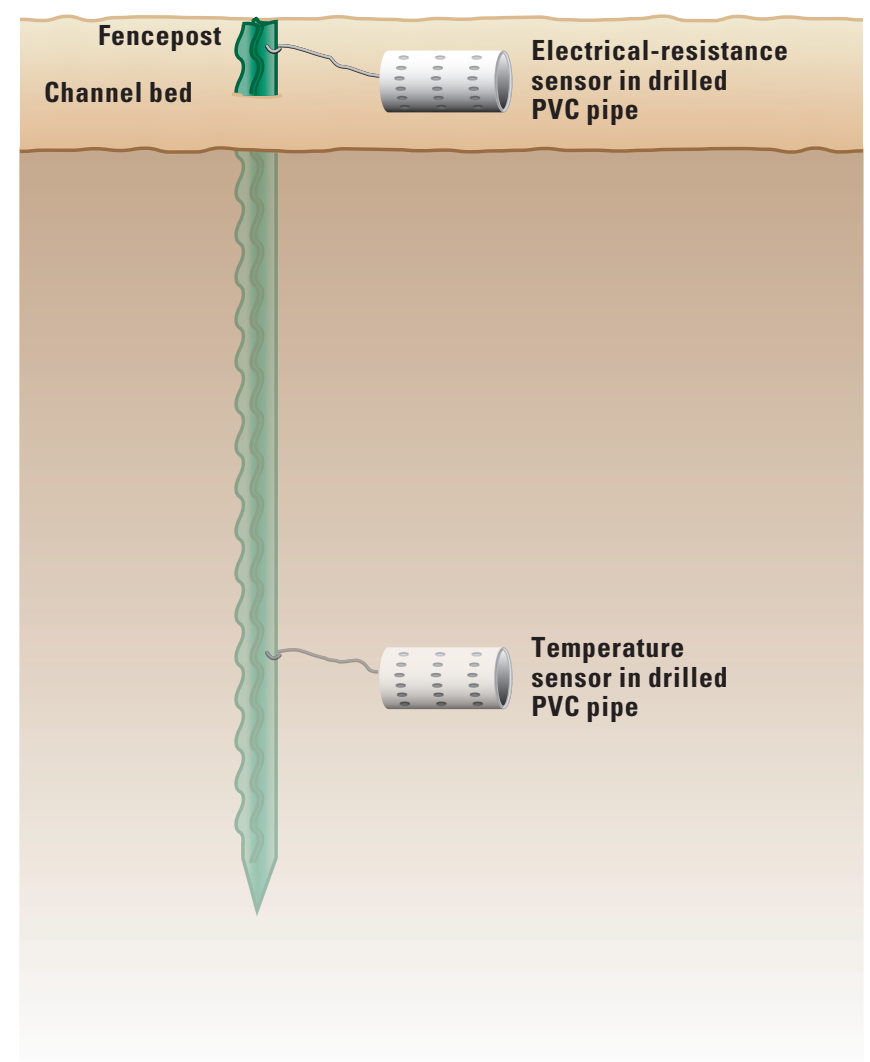

Figure 7. Installation of electrical-resistance and temperature sensors in drilled sections of 5.1-cm (2-in. diameter) polyvinyl chloride (PVC) pipe. 
Data on geographic location, and land-surface relief were essential for calculating water-table elevations, hydraulic gradients, and flood-inundation levels. At each site, a permanent benchmark was installed and all observation locations, including piezometer and stage-recorder measure points, and transect topography were referenced to it.

The benchmarks were surveyed with the static-GPS technique using Trimble 4800 dual-frequency GPS receivers and the National Geodetic Survey Continuously Operating Reference Stations. With static GPS surveys, point positioning may generally be achieved to centimeter horizontal and vertical resolution relative to global reference systems. Measure points on piezometers and stage recorders and points along each transect were surveyed using a combination of techniques with the following instruments: Trimble 4800 real time kinematic-GPS, Nikon DTS-450 total station, and Zeiss DiNi 12 digital level. The Trimble 4800 real-time kinematic-GPS instrument provides centimeter horizontal and vertical resolution within a local area (of tens of kilometers) relative to a fixed reference point. Total station is an optical surveying technique that can generate centimeter to subcentimeter horizontal and vertical point resolutions in a local area (of hundreds of meters) relative to a fixed reference point. Leveling is an optical surveying technique that provides vertical position information with millimeter resolution relative to a fixed local reference point, but only provides approximate horizontal positioning. The selection of surveying technique depended on terrain and vegetation cover. The surveys yielded a northing and easting coordinate, and land-surface elevation for each surveyed point except at Lewis Springs where only land-surface elevation and distance along the transect were obtained. Each hydrology/biohydrology transect was surveyed once; it was assumed that the topography did not change significantly during the study period.

\section{Depth to Ground Water}

A fundamental hydrologic control of riparian-plant processes is depth to ground water beneath the land surface. One goal in characterizing the hydrology within the SPRNCA was quantifying temporal and spatial aspects of depth to ground water, both at the SPRNCA and individual site scales. At the SPRNCA scale, temporal and site-to-site differences in water levels measured in piezometers were examined. At the individual site scale, depth to water beneath the surveyed hydrology/biohydrology transects were estimated from measurements in piezometers for the period of record, for water years, and for months during the study in which water levels were at extreme highs or lows.

\section{Temporal and Spatial Variability of Ground- Water Levels in Piezometers}

The depth to water observed in a piezometer near a river varies through time as the hydrologic system responds to varying flow and ET conditions. The depth is also a function of whether a piezometer is installed adjacent to a gaining or losing river reach.

For this study each site was monitored with one to eight piezometers or wells, some of which were screened in the recent stream alluvium and some in the regional aquifer system. One to five piezometers at each site were screened in the recent alluvium and were located near or on a hydrology/biohydrology transect.

Water levels were measured in piezometers screened at depths of 2 to $60 \mathrm{~m}$ along or near the hydrology/biohydrology transect at each site at 30-minute intervals throughout the period of monitoring. Such high-frequency data collection yielded temporal resolution beyond the needs of the biohydrology study but was less expensive and more reliable than making monthly manual measurements.

To simplify analysis, monthly average water-level elevations were computed from the 30-minute data (appendix 2). Examination of these data from a piezometer at the Palominas site (fig. 8) show that water-level elevations generally exhibit two local minima and two local maxima each year (henceforth termed 'minima' and 'maxima,' or 'extrema' months). The minima occur at warm/dry times in early summer (June or July) and again in the fall (October or November); at both times, ET and temperatures are high and precipitation is low.

The maxima occur in the late summer (August) during the monsoon season and again in the winter (February or March) cool period. The summer maxima occur because the characteristic late summer monsoonal weather pattern generates runoff that recharges and raises the water table near the river. The winter maxima occurs because frost in the late fall halts plant transpiration and the ground-water system recovers until transpiration begins again in March and April.

The same pattern of two maxima and minima per year is present in the long-term streamflow records in years without unusually high flows. No winter or spring runoff events occurred during the study period that could have influenced the observed winter maxima. The effects of a large runoff event in October 2000 did temporarily influence the annual minima-maxima pattern. Statistical information in Pope and others (1998) indicates that the statistical recurrence interval for the October 2000 flood ranged from 25 years toward the southern end of the study area to about 12 years toward the northern end. Slow release of stored recharge from this event eliminated the fall 2000 minima (fig. 8). 


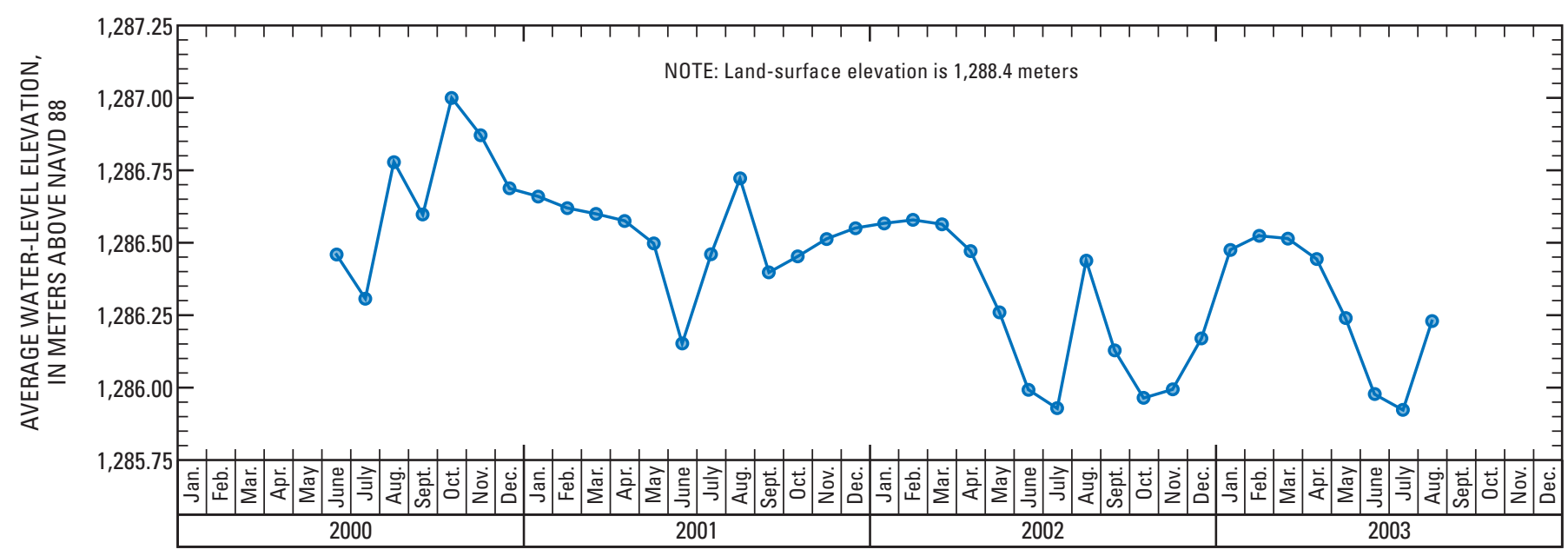

Figure 8. Monthly average water-level elevations in a Palominas site piezometer (PAL-LS), San Pedro Riparian National Conservation Area, Upper San Pedro Basin, Arizona.

A representative ground-water hydrograph from each site (fig. 9) illustrates differences in ground-water response throughout the SPRNCA. The most notable difference from site to site is in variability of response to annual onset and cessation of ET. Hydrographs from sites in the perennial reach, such as Moson (fig. 9H), exhibit relatively little change between the winter water-level maxima in March and the spring/fall water-level minima in June and October. Hydrographs from sites in the intermittent reach at the upstream end of the study area, such as Palominas south (fig. 9A), show an intermediate level of variability. In the driest areas at the downstream end of the study area, such as at the Contention site (fig. 9N), water levels show the largest variability - up to $3 \mathrm{~m}$ seasonally. The availability of regional ground water to support perennial flow in the river also appears to control the level of annual ground-water fluctuation in the stream alluvium.

\section{Depth to Ground Water below Hydrology/Biohydrology Transects}

Approach.-Spatial variability of depth to ground water beneath the hydrology/biohydrology transects is a function both of land-surface and water-table topography. Along a transect across the San Pedro River, land-surface topography is much more variable than the water-table surface and therefore largely controls depth to water. A possible assumption in calculating ground-water depth is that the water table within the confines of the transects was flat and level. Data from piezometers showing local and regional gradients, however, indicate that such an assumption is not generally valid. Piezometer data were, therefore, used to improve the definition of the magnitude and direction of the ground-water table slope within the extent of the transects. The reported depth to ground-water (appendix 3) beneath the hydrology/biohydrology transects results from the combination of surveyed land-surface and estimated ground-water topography.

Limitations in the number and distribution of piezometers at each site required the use of both interpolation and extrapolation techniques to calculate depth to water. At many sites, piezometers were not collocated with the hydrology/biohydrology transect, but were shifted upstream or downstream. The average separation between piezometers used in the calculations and the associated hydrology/biohydrology transect was about $50 \mathrm{~m}$; the maximum was $200 \mathrm{~m}$ at the Contention site. In addition, at all sites except Lewis Springs and St. David, piezometers were installed only on one side of the river. The following discussion explains how the interpolation and extrapolation were used to estimate depth to ground water below the hydrology/biohydrology transect at the Palominas site.

For the first step, the magnitude and direction of the regional gradient component was determined. The direction of the regional gradient was estimated using maps by tracing the general direction of the river over the scale of site separation (fig. 10). This direction defined the coordinate system used in calculations. Using the Palominas site as an example, the magnitude of the regional gradient component was calculated from ground-water elevations measured at Palominas and at the nearest upstream and downstream sites (Palominas south and Kolbe), and from the along-river distances between the sites. The between-site distances used in the calculation (1.4 and $5.4 \mathrm{~km}$ from Palominas to Palominas south and Palominas to Kolbe, respectively) were along-river measurements that omitted meanders. The ground-water elevations were the monthly average values for March 2002 from the shallow near-stream piezometer at each site; the values used to estimate the Palominas site regional gradient were 1,291.0, 1,286.8, and 1,271.7 $\mathrm{m}$ for Palominas south, Palominas, and 
Kolbe sites, respectively. Ground-water elevations from March 2002 were used because water levels were stable at all sites and not influenced by runoff events. Only shallow piezometers (those screened close to the water table) were considered because the measured hydraulic head best represented the elevation of the water table. Because plant roots are influenced only by the physical location of the water table and not by the direction and magnitude of flow, vertical gradients were not considered. The resulting average regional gradient at the Palominas site is 0.003 .

For all 16 biohydrology sites, the average distance between sites was $3.6 \mathrm{~km}$; the least separation was $1.4 \mathrm{~km}$, and the greatest separation was $7 \mathrm{~km}$. The regional gradient ranged from 0.0026 to 0.0037 and generally was larger at downstream sites. To ascertain the variability in the regional gradient if data from other months were considered, a regional gradient was estimated for each site for each of the waterlevel maxima and minima months. The maximum deviation from the February/March 2002-calculated gradients was 19 percent at the Contention site for a gradient estimated using November 2002 data. The average of the maximum deviations considering all sites and all months was 4 percent.

For the second step, ground-water elevations beneath the hydrology/biohydrology transects at the locations of the piezometers were estimated. At the Palominas site, two piezometers oriented in a line away from the river provided data for the calculation. Each was the shallow piezometer of a nested pair; the shallow piezometers provided the best measurement of the water-table elevation, which represents the integrated sum of horizontal and underlying vertical gradients and is the most important ground-water factor for plants. A complication at the Palominas site, however, is that the instrumentation and hydrology/biohydrology transect are noncolinear; the piezometers were installed about $80 \mathrm{~m}$ and $65 \mathrm{~m}$ downstream from the transect (fig. 10). To estimate ground-water elevation beneath points on the hydrology/biohydrology transect, data from each piezometer were projected parallel to and directly up the regional gradient to an intersection with the transect. The projected intersection point along the hydrology/biohydrology transect was constant in all subsequent calculations. At the Palominas site, the estimated water level at the cross-section intersection point was higher than the water level measured in the piezometer by the separation distance ( 65 and $80 \mathrm{~m}$ for the two piezometers) multiplied by the regional gradient $(0.003)$. Therefore, the resultant projected water levels at the transect were $24 \mathrm{~cm}$ and $20 \mathrm{~cm}$ higher than those measured in the piezometers. A water-level elevation was estimated at each intersection point for averages of extrema months, the average for the period of record, and the average for each water year in the record.

Estimating the elevation of the water table at all surveyed points beneath the hydrology/biohydrology transects was the third step in the depth-to-water calculations. At the four sites with only one useable piezometer (Cottonwood, Charleston bridge, Charleston mesquite, and Tombstone), the water table was assumed to have a regional gradient but to be level perpendicular to the river. At sites like Palominas, where two wells were available to calculate gradients, the water-level elevations projected to the cross sections were then used to estimate the depth to water on the monitored side of the river using a simple linear interpolation/extrapolation:

$$
E_{u}=d_{k 1-u} \frac{E_{k 2}-E_{k 1}}{d_{k 1-k 2}}+E_{k 1},
$$

where

$$
\begin{aligned}
& E_{u}=\text { ground-water elevation at unknown point, } \\
& E_{k 1}=\text { known ground-water elevation at piezometer } \\
& \text { or projected point closest to river on transect, } \\
& E_{k 2}=\text { known ground-water elevation at piezometer } \\
& \text { or projected point on transect farthest } \\
& \text { from river, } \\
& d_{k 1-k 2}=\text { distance along transect between two known } \\
& \text { points-positive direction moving away } \\
& \text { from river, and } \\
& \begin{aligned}
& d_{k 1-u}= \text { distance between known point } 1 \text { and an } \\
& \text { unknown point. }
\end{aligned}
\end{aligned}
$$

At the three sites with three usable piezometers, equation 1 was applied to each of the two segments between the three piezometers.

The two-point gradient calculation used in equation 1 assumes that the water table between the two points is planar. The validity of this assumption depends on the scale of examination, but was assumed true within the limits of the distances between piezometers and between piezometers and the ends of the hydrology/biohydrology transects. The assumption was tested using water-level data collected near the free surface from three piezometers along a line trending away from the river that were all screened in the pre-entrenchment alluvium. Only the Lewis Springs site had three piezometers arranged appropriately; at other sites with three piezometers, projection along the regional gradient was needed to estimate ground-water elevations along a line and (or) the piezometers spanned the post- and pre-entrenchment alluvium. Average water-table elevations were estimated for the three in-line piezometers at the Lewis Springs site over the common period of record (February 2001 through July 2003). The difference in average ground-water elevation between the piezometers closest (at $12 \mathrm{~m}$ ) and farthest (at $176 \mathrm{~m}$ ) from the river was $0.31 \mathrm{~m}$. The ground-water elevation in the middle piezometer ( $75 \mathrm{~m}$ from the river) deviated from a linear fit between the nearest and farthest piezometer ground-water elevations by $0.5 \mathrm{~cm}$. Because the hydrology/biohydrology transect extended only about $20 \mathrm{~m}$ beyond the farthest piezometer, the water table was considered essentially linear within the study confines. A similar analysis at the Kolbe site, where projection of piezometer data was required and where piezometers were installed in both the pre- and post- entrenchment alluvium, showed greater deviation from linearity. There, the difference in average ground-water elevation between the piezometers closest (at $25 \mathrm{~m}$ ) and farthest (at $95 \mathrm{~m}$ ) from the river was $0.30 \mathrm{~m}$. 


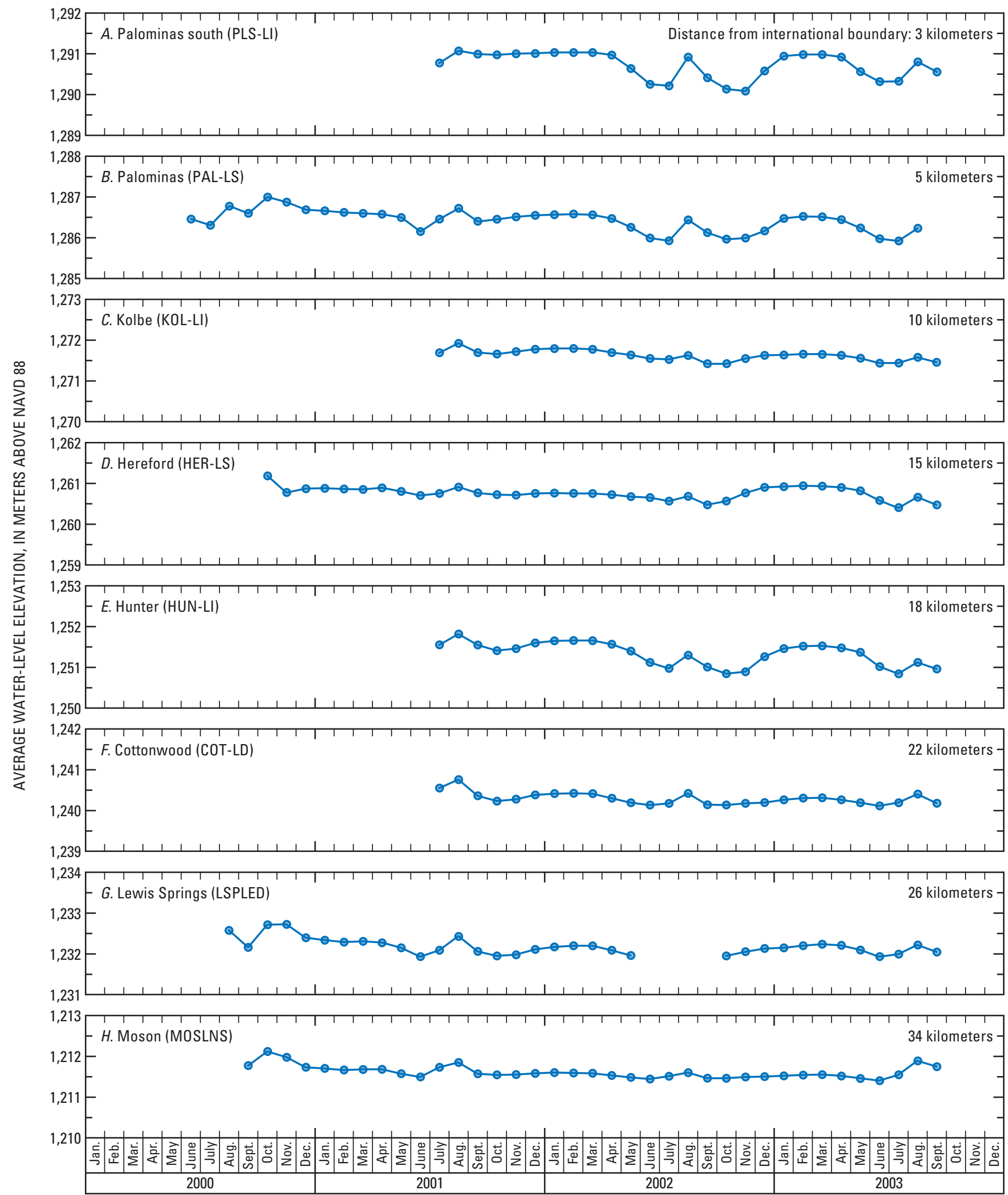

Figure 9. Representative hydrographs from each of the 16 biohydrology study sites in the San Pedro Riparian National Conservation Area, Upper San Pedro Basin, Arizona. See appendix 1, table 1-C, for piezometer details. 


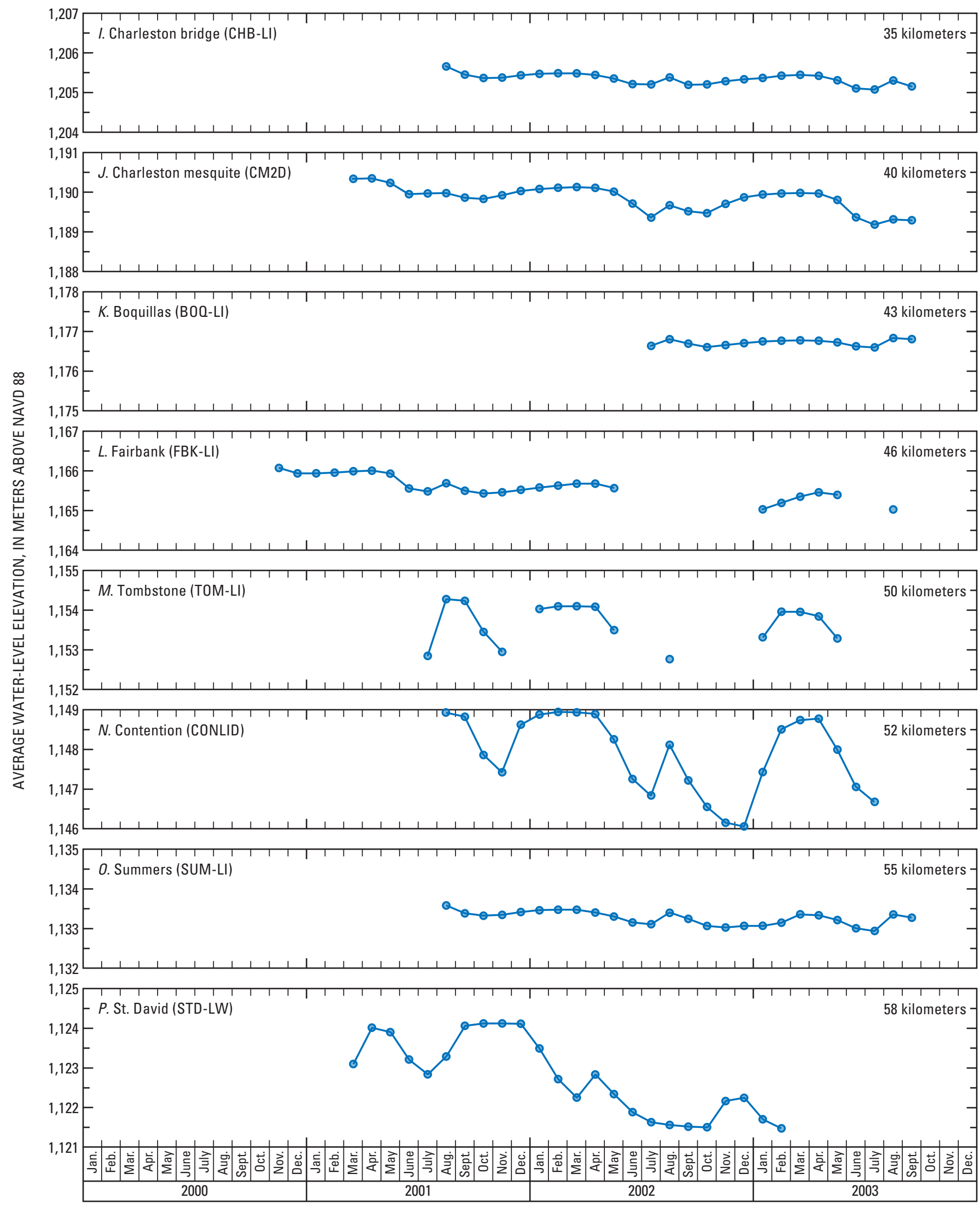

Figure 9. Continued. 


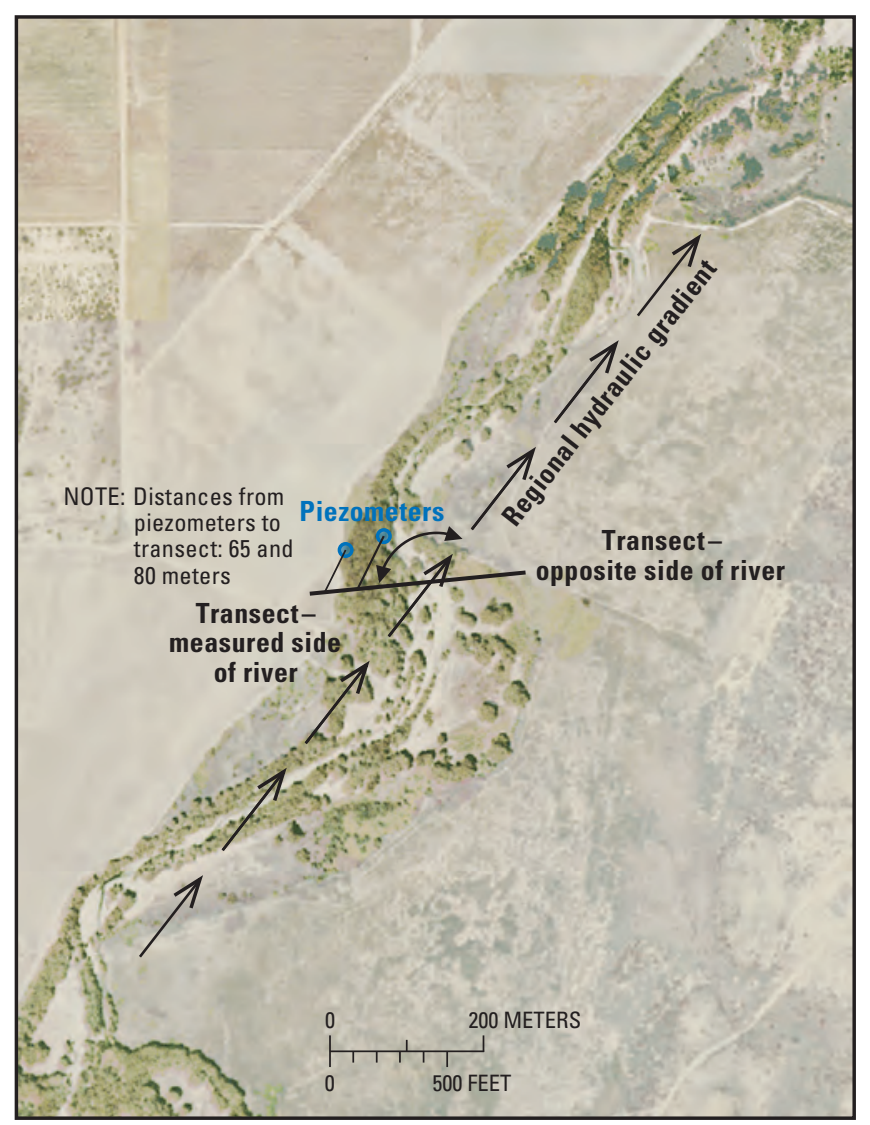

Figure 10. Areal view of the Palominas study site showing regional hydraulic-gradient direction and hydrology/biohydrology transect orientation, San Pedro Riparian National Conservation Area, Upper San Pedro Basin, Arizona.

The ground-water elevation in the middle piezometer (50 $\mathrm{m}$ from the river) deviated from a linear fit between the nearest and farthest piezometer ground-water elevations by about $12 \mathrm{~cm}$. The differences in water-table linearity between the sites suggest that the heterogeneity of the pre-entrenchment to post-entrenchment alluvium transition caused a difference in water-table slopes.

The fourth step was estimating the water-table elevation on the side of the river opposite from the piezometers. At all sites, the water-table topography on the unmonitored side was assumed to be a mirror image of the monitored side with the reflection point at the thalweg. Because the hydrology/biohydrology transects were often not perpendicular to the regional gradient, the ground-water elevation on the monitored side of the river could not be directly equated to the opposite side. Even if the water table is assumed to be symmetrical on either side of the river, depth to water along a transect that is nonperpendicular to the line of symmetry will not be symmetrical (fig. 11) unless the water table is completely flat. The technique to project ground-water elevations from the monitored to the opposite side of the river borrows from the classic apparent-dip problem solved in structural geology applications (Ragan, 1985). In its original context, the apparent-dip solution enables calculation of the true magnitude and direction of dip (or slant) of a geologic bed from field observations of apparent dips. For the hydrologic application in this study, apparent dips were represented by the regional gradient and the transect gradient. The apparentdip solution required the assumption that the water table is planar between measurement points, and that opposite sides of the river are mirror images of each other. Hydrologic circumstances do exist wherein one side of a river may be gaining while the other is losing, but except for data from the Lewis Springs and St. David sites, data were not available to test the symmetry assumption.

The final step in the calculations was to estimate depth to water beneath each surveyed point in each hydrology/biohydrology transect by subtracting the groundwater elevation from the land-surface elevation (appendix 3 ). Also included in appendix 3 are the surveyed land-surface elevations relative to NAVD 88 and the horizontal locations relative to the NAD 83. Depth-to-water values in appendix 3 represent depths extrapolated from the minima and maxima of the monthly average ground-water levels measured in one or more piezometers at each site. The depths to water in appendix 3 are listed to the nearest $1 \mathrm{~cm}$ to reflect the accuracy of the techniques used to survey land-surface topography. Reporting to $1 \mathrm{~cm}$ enables comparison of relative differences in depths to water at adjacent survey points even though the error in the estimate is a function of several factors, including distance from known points (piezometers). For example, two surveyed points along a transect separated by $2 \mathrm{~m}$ horizontally might be separated by $20 \mathrm{~cm}$ vertically. Because the land-surface topography is much more variable than the ground-water surface, the difference in depth to water at the two points is primarily a function of the land-surface elevation.

The cumulative uncertainty in the estimates of depth to water beneath the hydrology/biohydrology transects is a function of the accuracy of distance from known points, the estimates of magnitude and direction of the regional gradient, and the local site heterogeneity. In addition, the degree to which assumptions are met at each site influences the accuracy of results. At most sites, the amount of data was insufficient to estimate cumulative error; typically all available data were needed for calculations leaving no independent observations with which to check accuracy.

At the St. David and Lewis Springs sites, independent data were available from piezometers that were not used for depth-to-water calculations. At the St. David (fig. 12) site, where the river is losing water to the aquifer, two piezometers were installed on the east side of the river and one was installed on the west side. All three piezometers are along the hydrology/biohydrology transect so no projection along the regional gradient was required. The three piezometers were installed in the post-entrenchment alluvium. Data from piezometers on the east side of the river were used to estimate depth to water on both sides of the river. 


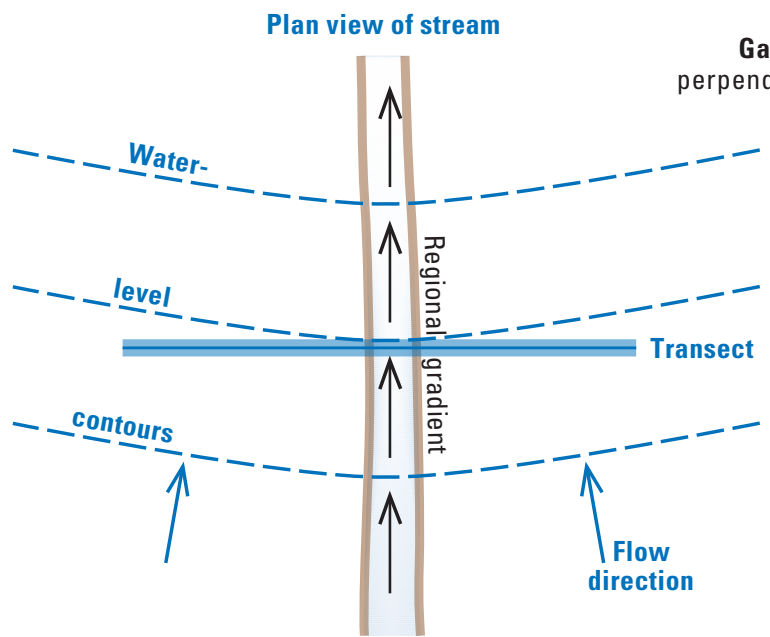

Gaining reach-Transect perpendicular to regional gradient
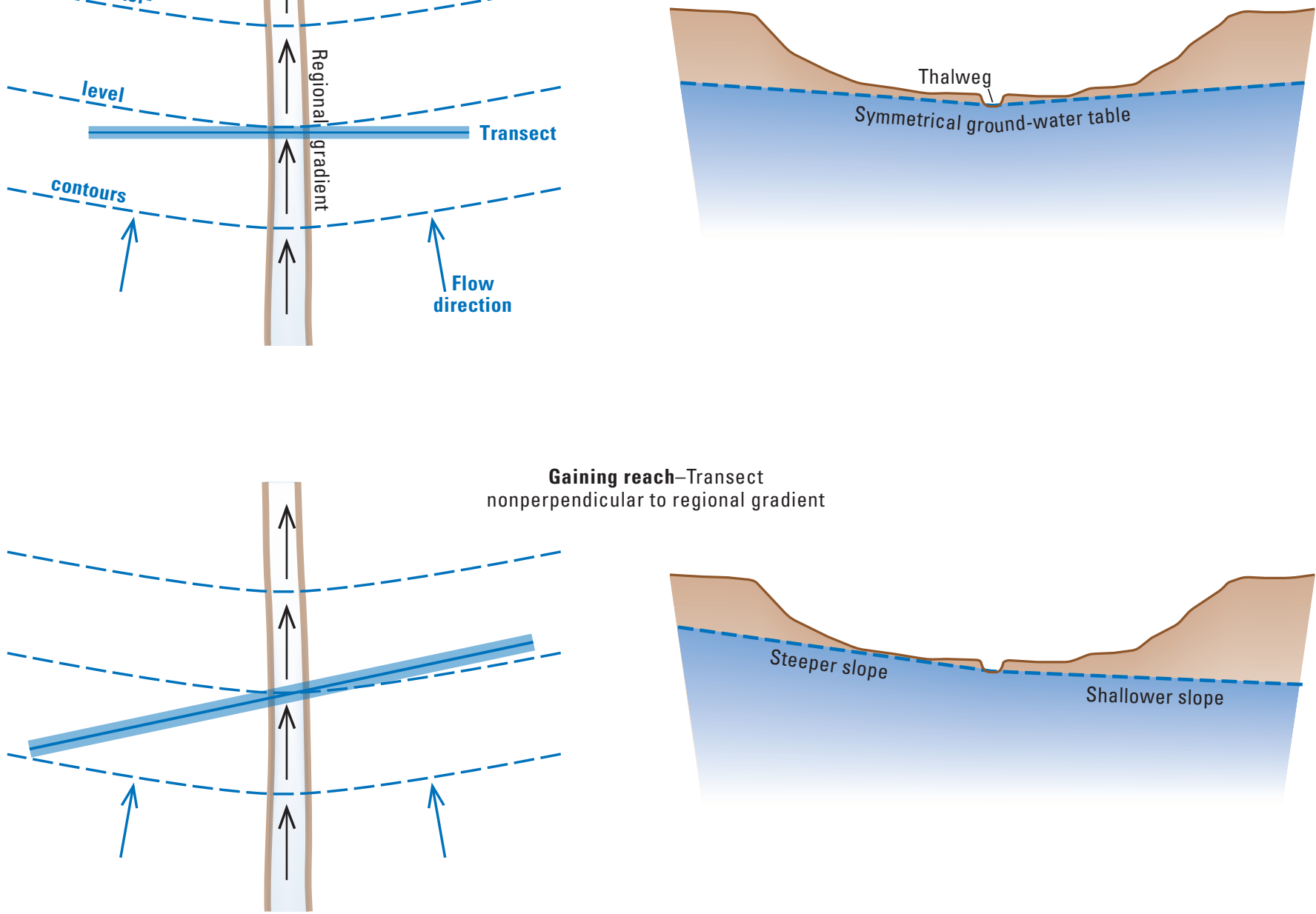

Gaining reach-Transect onperpendicular to regional gradient

Neutral reach-Transect
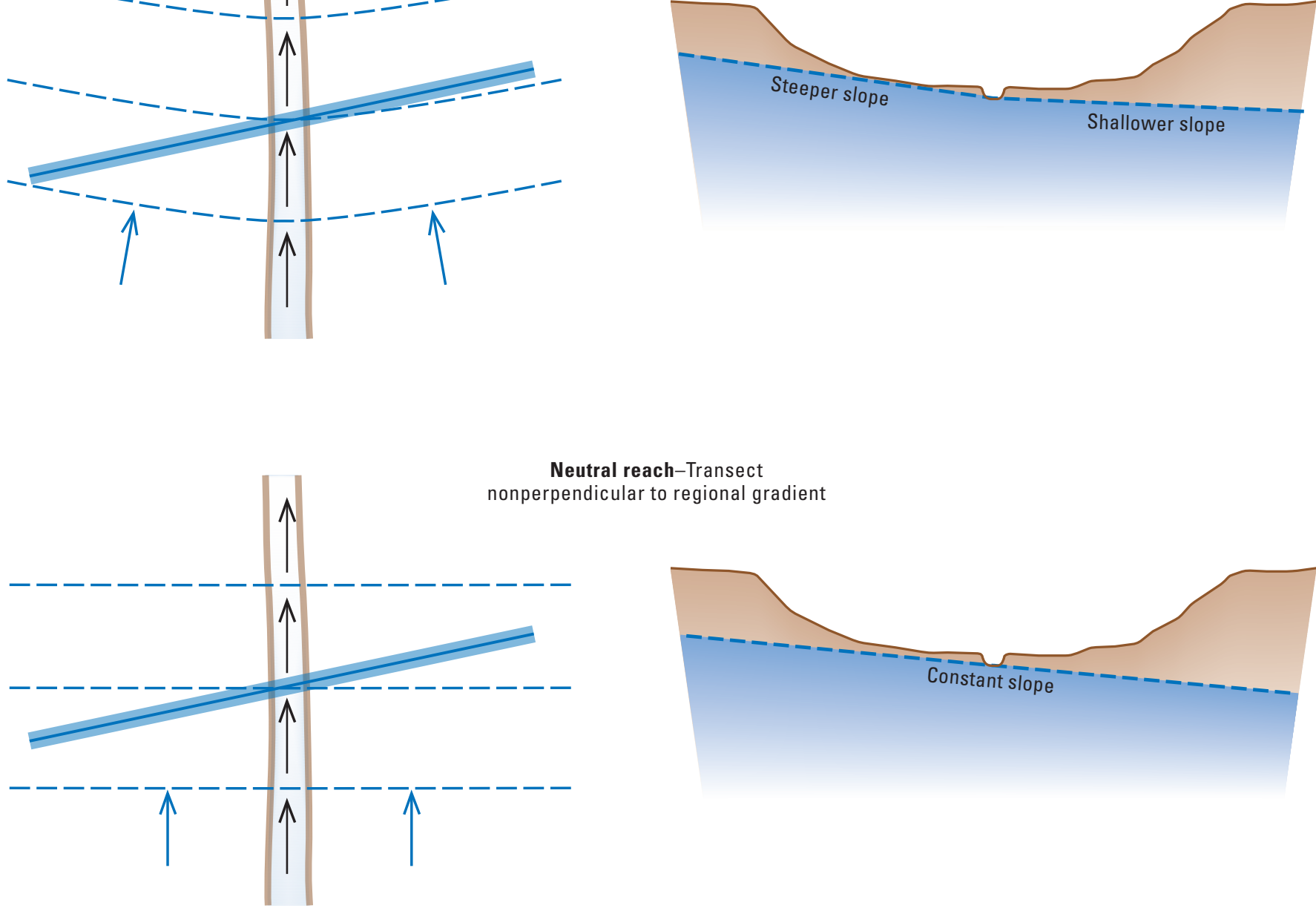

Figure 11. Hypothetical examples of mirroring ground-water levels from the monitored side to the unmonitored side of a river. 


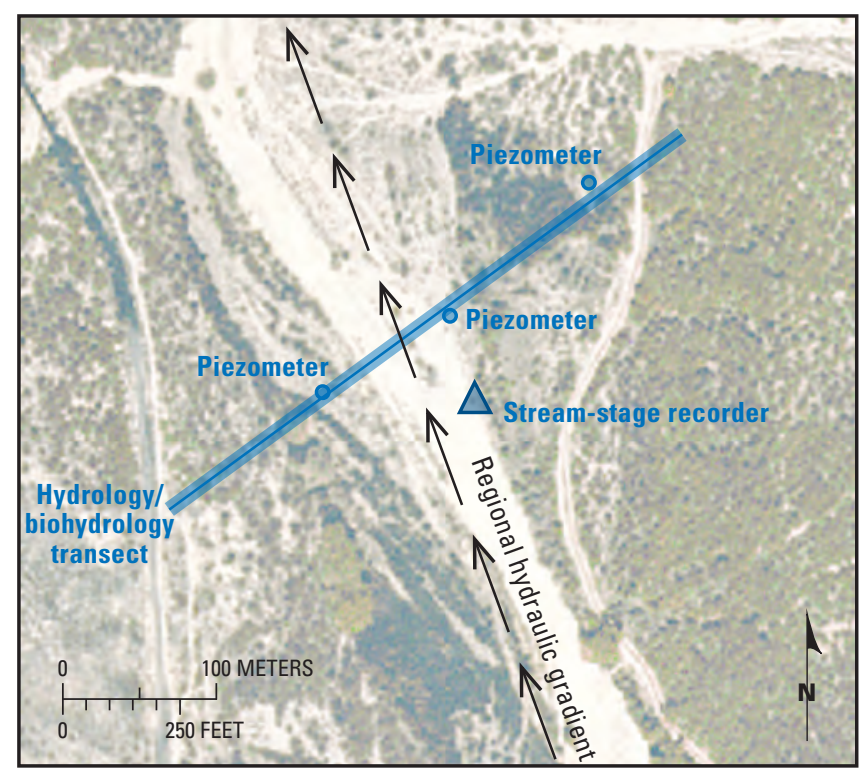

Figure 12. Areal view of St. David site showing regional hydraulic-gradient direction, hydrology/biohydrology transect, and piezometers, San Pedro Riparian National Conservation Area, Upper San Pedro Basin, Arizona.

The difference between projected and measured ground-water elevations averaged for the extrema months at the west-side piezometer was $3 \mathrm{~cm}$. A more useful measure is the difference per horizontal meter of distance from the nearest point along the hydrology/biohydrology transect used in the depthto-water calculations. At the St. David site, the west-side piezometer is about $105 \mathrm{~m}$ from the near-stream east-side piezometer (fig. 12). Therefore, the difference between measured and projected ground-water elevation per meter of projection is 0.00033 .

At the Lewis Springs site where the river is gaining, three piezometers, all on the western side of the river, were used to estimate depth to water (fig. 13). These piezometers were screened in the pre-entrenchment alluvium. Two additional piezometers on the east side were used to compare projected and measured water levels. The east side piezometers, however, were not located on the hydrology/biohydrology transect, so water levels were projected downgradient to intersect it. In addition, the east-side piezometer closest to the river was screened in the post-entrenchment alluvium, whereas the other east-side piezometer was installed in the pre-entrenchment alluvium. As a result, the differences between measured and projected east-side water levels include errors in the direction and magnitude of the regional gradient and errors from hydrologic heterogeneity. At the Lewis Springs site, the difference between east-side water levels projected from west-side wells and east-side measured water levels was $0.0027 \mathrm{~m} / \mathrm{m}$. This translates to a 54-cm discrepancy at the end of a projected 200-m hydrology/biohydrology transect.

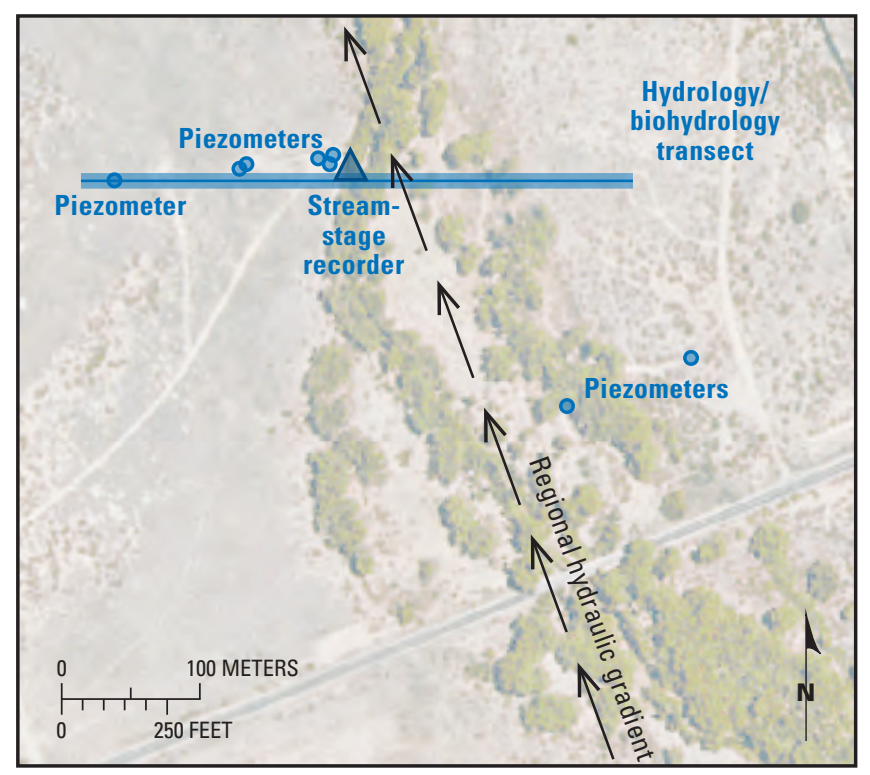

Figure 13. Areal view of Lewis Springs site showing regional hydraulic-gradient direction, hydrology/biohydrology transect, and piezometers, San Pedro Riparian National Conservation Area, Upper San Pedro Basin, Arizona.

Results.-Selected calculated monthly average groundwater elevations relative to surveyed hydrology/biohydrology transects are shown for the Palominas, Lewis Springs, and Fairbank sites (fig. 14). These sites represent a range of intermittent to perennial streamflow reaches within the study area. Calculated ground-water elevations at the Palominas site (fig. 14A) reflect the oblique angle of the transect to the direction of the regional gradient. The gradient lines plotted to the left of the thalweg have a lower slope than the gradient lines to the right of the thalweg. The western (left) side of the transect at the Palominas site trends up the regional gradient, whereas the eastern (right) side trends down (fig. 10). The transect gradient on the eastern (right) side includes a downgradient component of the regional gradient, whereas the west (left) side has an upgradient component. The hydrology/biohydrology transects at the Lewis Springs (fig. 14B) and Fairbank sites (fig. 14C) were both approximately perpendicular to the regional gradient; this is reflected in the symmetry of ground-water levels on either side of the thalweg.

Streamflow at the Palominas site is intermittent; the river typically flows in the winter low-ET months and summer high-runoff months and is dry in the fall and early summer. The calculated ground-water elevations (fig. 14A) are consistent with the timing of flow in the channel. The October 2002 water-level minima coincides with a no-flow period in the channel: the water-table surface lay below the thalweg. In contrast, February 2003 water levels were high enough to support flow. Calculated mean ground-water elevations from October 2000 have been included on figure 14A to illustrate the highest levels observed during the study. 

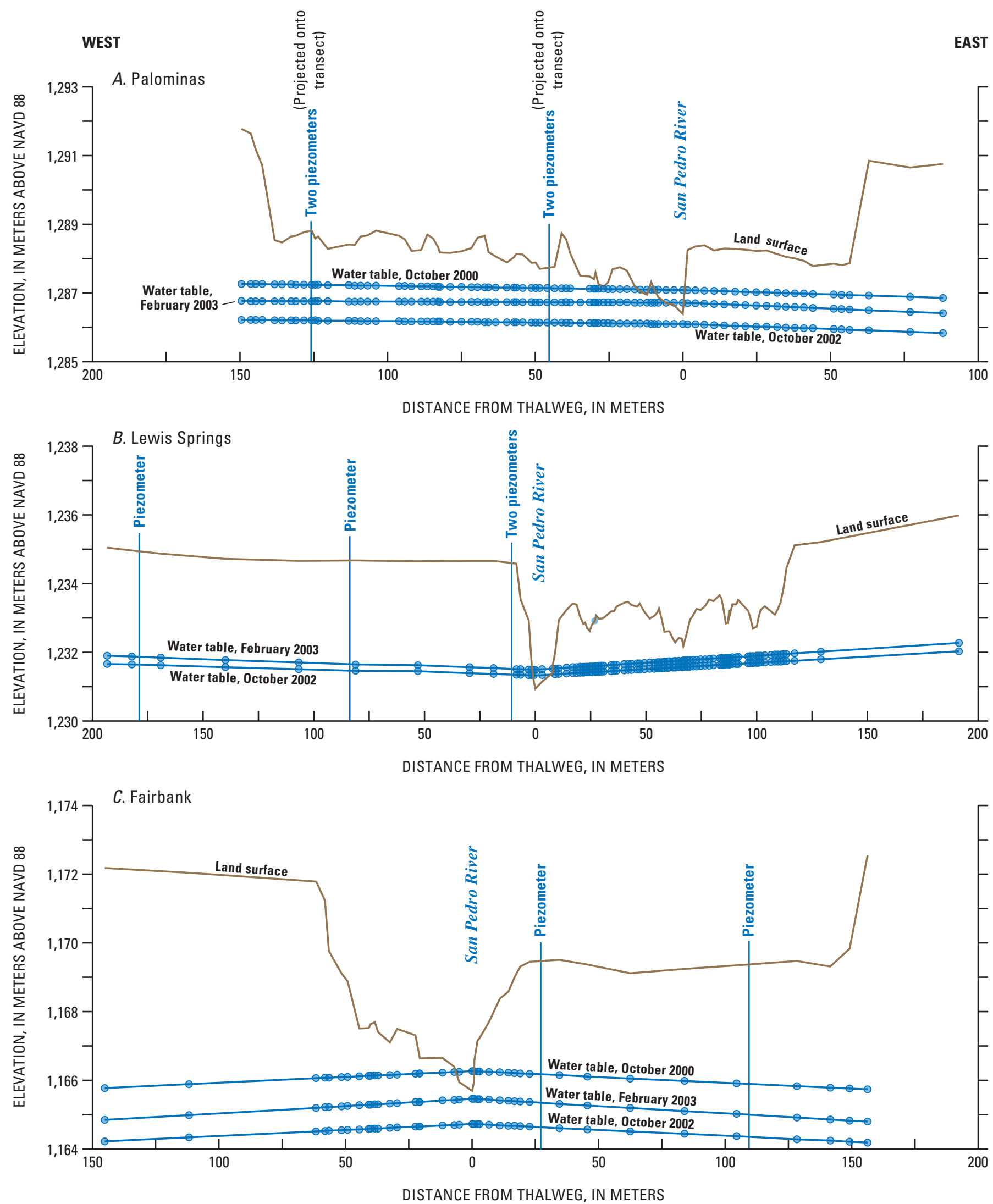

Figure 14. Calculated monthly average water-table elevations, San Pedro Riparian National Conservation Area, Upper San Pedro Basin Arizona. $A$, Palominas; $B$, Lewis Springs; $C$, Fairbank. 
Water levels at the Lewis Springs hydrology/ biohydrology transect (fig. 14B) are consistent with the perennial streamflow observed at the site. First, the horizontal gradient depicted in the figure indicates flow toward the stream during both the warm (October 2002) and cool (February 2002) periods. Second, the water-level variability between warm and cool periods is small relative to that for the Palominas and Fairbank sites. Finally, the ground-water elevation at the thalweg is above the thalweg elevation at all times. Water levels at the Fairbank site (fig. 14C) reflect the intermittent streamflow conditions in that area. Horizontal gradients at all times indicate flow horizontally away from the stream. The water-level variability between warm and cool periods is greater than at the Lewis Springs site, and among the data plotted, the water table only intersects the thalweg during October 2000.

\section{Surface Water}

Three factors that characterize streamflow in the study area are important to the overall study: (1) the amount of time in a given period that flow is present in the stream channel (streamflow permanence), (2) the comparative data on mean flow at each site during the study period, and (3) the information about the frequency with which different parts of the riparian zone are inundated by floods. Streamflow permanence and mean flow are indicators of water availability on a monthly to yearly time scale. Flood inundation frequency indicates short-term water availability at various elevations as well as the recurrence intervals of floods that distribute seeds and nutrients through the riparian system.

In analyzing each of the three factors, it is essential to recognize the physical processes that control streamflow and the cyclic timing with which these processes occur. Flow in the San Pedro River is dominated by the interaction between precipitation, ET, and exchanges with the regional ground-water system. Flows from the regional aquifer to the stream are relatively constant throughout the year. ET and most precipitation processes, however, cycle in annually recurring intervals. As a result, flows in the river channel can be described in three distinct annually recurring time segments: (1) a winter period when ET is low, (2) a period of high ET and low streamflow in the spring and fall, and (3) the monsoon period of high ET but with sufficient rainfall to produce runoff. An additional condition that profoundly affects flow is the irregularly recurring large flood event, such as the October 2000 flood. Definition of these categories was essential in determining monthly mean flow.

For the purposes of this study, the winter period is defined as the period between November 1 and March 31. During this period, flow in the river is typically supported by inflows from the regional-aquifer system and runoff from storms. During the course of this study, however, no appreciable winter runoff occurred, so winter flow was dominated by base flow. ET is low in winter so most water leaves the system as streamflow. Because ET losses are low, flow volumes in upstream perennial reaches are sufficient to maintain flow in downstream reaches that lack a regional ground-water contribution; therefore, flow, occurs at all locations.

The spring/fall period occurs twice each year, between April 1 to early July and again between early September to October 31. During this period, the primary source of water to the river is upwelling from the regional aquifer; flow derived from runoff of rainfall is rare. ET is much higher than in winter, so losses from the riparian vegetation are much higher. Streamflow at the sites during these times is dependent not only on regional and downstream alluvial contributions, but also on removal by ET. As a result, sites without inflow from the regional-aquifer system are intermittent and become dry during this period.

The monsoon period is defined by the summer-monsoon rainy season, which primarily includes July and August, but may also span into June and September. Contrary to the fixed demarcation separating the winter from the spring/fall periods, the monsoon period is defined differently each year depending on when the first and last monsoon-generated runoff events occur. During this period, ET is high, but precipitation and runoff are also high so that flow in the river is influenced by runoff and bank-storage releases. Flow presence and volume at any point along the river are dependent on where the precipitation occurred and which tributary channels were active.

An additional condition of flow occurs during extreme high-flow events, such as the October 2000 flood. This flood resulted from widespread precipitation that activated tributaries throughout the watershed. Unlike runoff from spatially limited monsoon events in the summer, discharge in the stream during the October 2000 flood increased consistently downstream within the SPRNNCA as additional tributaries contributed flows. For several months after flood runoff ceased, flow in the river was dominated by discharge of water stored during the flood.

The analyses of streamflow permanence, monthly mean flow, and flood inundation at each of the 16 biohydrology sites are supported by data from an existing network of streamflow-gaging stations (fig. 6 and table 8). Two of the biohydrology sites, Charleston bridge and Tombstone, are collocated, respectively, with the Charleston and Tombstone gaging stations. In addition, the gaging station at Palominas is about $1.4 \mathrm{~km}$ downstream from the Palominas biohydrology study site (fig. 6). Data from these streamflow-gaging stations, including long-term flows, in-study flows, and peak discharges, were used in various aspects of the streamflow analysis. Data from two additional USGS streamflow-gaging stations on tributaries of the San Pedro River, Babocomari River near Tombstone (09471400) and Greenbush Draw (09470520), and one USDA-ARS streamflow-gage at flume 1 on Walnut Gulch, were used in the flood-inundation analysis. Data from the USGS streamflow-gaging station, San Pedro River at Redington (09472000), downstream from the SPRNCA and outside the Sierra Vista Subwatershed, were also used in the inundation-frequency analysis. 
Table 8. Permanent streamflow-gaging stations from which data were used in the surface-water analyses, Upper and Lower San Pedro Basins, Arizona

\begin{tabular}{lccc}
\hline \multicolumn{1}{c}{$\begin{array}{c}\text { Streamflow-gaging station } \\
\text { name and number }\end{array}$} & $\begin{array}{c}\text { Drainage area } \\
\text { (square kilometers) }\end{array}$ & Years of record & \multicolumn{1}{c}{ Operator } \\
\hline San Pedro River at Palominas (09470500) & 1,920 & 59 & U.S. Geological Survey \\
San Pedro River at Charleston (09471000) & 3,200 & U.S. Geological Survey \\
San Pedro River near Tombstone (09471550) & 4,480 & 24 & U.S. Geological Survey \\
San Pedro River near Redington (09472000) & 7,530 & 40 & U.S. Geological Survey \\
Babocomari River near Tombstone (09471400) & 800 & 4 & U.S. Geological Survey \\
Greenbush Draw near Palominas (09470520) & 270 & U.S. Geological Survey \\
Walnut Gulch at Flume 1 near Tombstone (Flume 1) & 150 & 37 & Agricultural Research Service \\
\hline
\end{tabular}

\section{Streamflow Permanence}

The second objective of the overall hydrologic characterization was to determine, at each of the 16 biohydrology study sites, when flow occurs in the channel. Streamflow permanence, as defined here, is a measure of the degree of streamflow intermittency. It quantifies the amount of time in a given period that flow is present in the stream channel. A perennial stream or reach of stream is one that flows continuously; an intermittent stream, or reach of stream, is one that flows only at certain times when it receives water from springs or surface-water sources not directly related to precipitation runoff (Meinzer, 1923). In the San Pedro River, an intermittent reach flows when water from the regional aquifer enters the stream within the reach, when streamflow from upstream enters the reach, and (or) when flood-induced bank storage is released. Degree of streamflow permanence is controlled by the interaction of regional-aquifer inflow, ET processes, and flood processes. The 16 biohydrology sites represent the extreme ranges of streamflow permanence observed within the SPRNCA. Perennial streamflow (100 percent permanence in every month) is found in the reach between the Cottonwood site and an unknown point between the Charleston bridge and Charleston mesquite sites, as well as at other specific locations such as the Kolbe site. Streamflow permanence is less than 100 percent at most locations south of the Cottonwood site, and at all sites north of Boquillas. The lowest permanence (driest condition) was observed at the most northerly site, St. David. All intermittent sites exhibited higher streamflow permanence in the year following the October 2000 flood than in the remaining study years, and permanence generally declined throughout the study.

Approach.-Several lines of evidence, including data from temperature dataloggers, electrical-resistance sensors, site visits, and stream-stage recorders were examined to determine streamflow permanence at the study sites. Data collected from the Fairbank site were compiled to estimate streamflow permanence (fig. 15). The four types of data plotted are temperature, relative electrical conductance obtained from the electrical-resistance sensors, measured discharge, and stream-stage elevation. Excepting the temperature record, the data shown in figure 15 are generally unambiguous with regard to indication of water in the channel.

The first line of evidence indicating flow in the channel was the measurement of water depth by the stream-stage recorders (fig. 15D). These data provided a reliable record of when water was present at the pressure transducer; if the transducer reported a positive gage pressure, water was present. Missing line segments on the chart represent times when water was not detected by the transducer. Because of the active scour and deposition of sediments, there were times and places when a stream-stage recorder's pressure transducer was out of the water even though the river was still flowing; at Fairbank and other intermittent sites, the stream-stage recorder was occasionally observed out of water. The other lines of evidence helped to better evaluate the presence of surface-water flow in the channel when the stream-stage recorders indicated no water was present.

Discharge was measured at stream-stage recorder equipped sites about 1 to 3 times per month during the monsoon period and about every 1 or 2 months throughout the remainder of the year. The notes from these measurements provided corroboration of the stage-recorder data. Notes and photographs taken during site visits to maintain equipment, survey cross sections, or download data from the piezometers and stage recorders were also important in confirming flow in the channel. Non-zero discharge measurements correspond well with the stage-recorder's indications of flow presence (fig. 15). 

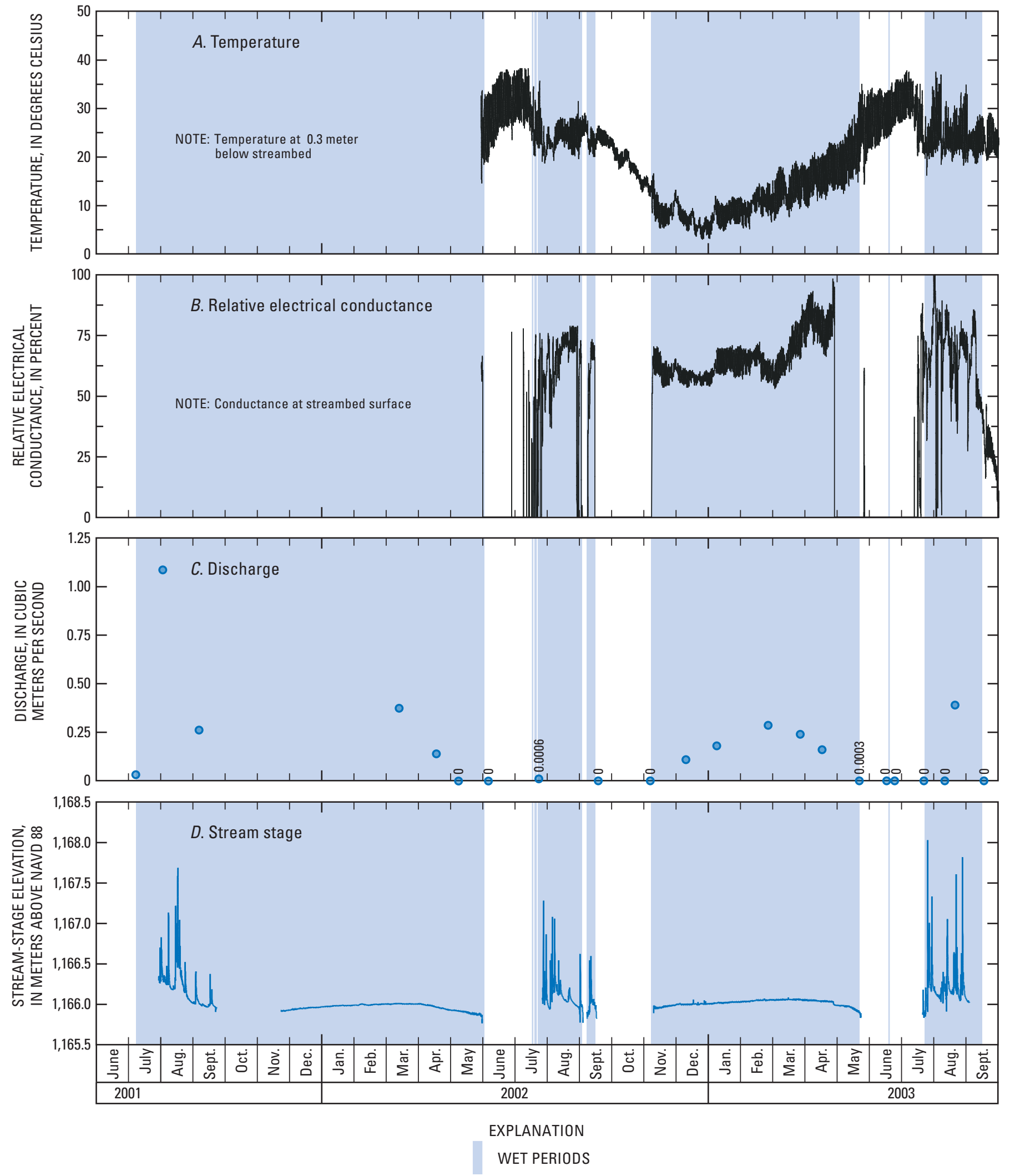

Figure 15. Data collected at the Fairbank site to determine percentage of time flow was present in the San Pedro River, San Pedro Riparian National Conservation Area, Upper San Pedro Basin, Arizona. A, Temperature; B, Relative conductance from electricalresistance sensor; $C$, Measured discharge; $D$, Stream stage. 
Temperature sensors buried in the stream channel (fig. 7) provided data intended to confirm the presence of flow in the channel. Temperature dataloggers were installed in the streambed at 14 locations near 7 of the study sites (St. David, Summers, Contention, Fairbank, Boquillas, Hunter, and Palominas south). Ideally, the data collected by the stock devices aid in determination of flow presence by recording temperature perturbations and changes in the daily diurnal temperature fluctuations caused by the onset and cessation of flow (Constantz and others, 2000). The collected temperature data, however, were commonly ambiguous or inconsistent with the other records of flow presence (fig. 15A). The temperature record commonly would indicate flow onset correctly, but the cessation of flow generally was poorly defined. For example, the June 2002 data (fig. 15A) show the large diurnal temperature fluctuations expected in a dry channel. In July 2002 the data show a reduction in diurnal temperature fluctuations that corresponds with the first indication by the stream-stage recorder of water presence in the channel (fig. 15D). In September, however, the stage-recorder data and site visits show that flow ceased, but the temperature record - at least when viewed alone-does not show a change in thermal response that clearly indicates flow was absent from the channel. One explanation is that flow onset commonly involves a rapid change in the thermal regime surrounding the temperature logger as water quickly infiltrates relatively dry soil, particularly if the channel has been dry for months. The cessation of flow, however, involves a more gradual change in the moisture content of the soil and, therefore, changes in the thermal regime are more gradual. Another factor that changes the thermal environment surrounding the sensor is burial depth; deeper burial results in more muted responses to daily temperature fluctuations. Therefore, a flow can change temperature response both through the introduction of water and by depositing or scouring sediment. If a flow does deposit or scour sediment, then the thermal response in the dry river prior to the flow will differ from the thermal response in the dry river after the flow simply because of changes in burial depth. A visit to the Fairbank site in January 2003 revealed that about $0.3 \mathrm{~m}$ of additional sediment had been deposited over the temperature sensor from the summer 2002 monsoon flows. Differences between the thermal variations in June 2002 and those in October 2002 could have been caused by this additional sediment (fig. 15).

During the study, flows deposited sediment at the Fairbank site (as much as about $0.3 \mathrm{~m}$ ), in a reach just downstream from the Contention site, and at the St. David site (as much as about $0.6 \mathrm{~m}$ ), and scoured as much as about $0.3 \mathrm{~m}$ at the Palominas site south and as much as $0.3 \mathrm{~m}$ in a reach just upstream from the Contention site. These study sites were locations of deposition or scour, but not both, during the course of data collection. Changes in sediment were not noted at the other sites. Sediment movement generally transitioned from scour in the southern (upstream) reaches to increasing deposition in the downstream direction. The scour at the Palominas south site resulted in the loss of the recording devices. The only flows of sufficient magnitude to move significant sediment during the period of temperature data collection occurred in July and August of each summer.
The electrical-resistance sensors (figs. 7 and 15B) provided varying results, but their data were generally more easily interpreted than data from the stock temperature sensors. Ideally, these sensors indicate electrical continuity when water is present and no connection when water is absent. The electrical-resistance sensors were initially installed on the surface of the streambed. When sensors remained on the streambed surface, the collected data clearly indicated continuity when water was present and an open circuit when water was absent. Because of the low moisture-retention capacity of coarse sand, electrical-resistance sensors that were buried in sand also quickly responded to flow cessation. When flows buried the devices in clay, detection of flow cessation became ambiguous. Owing to the high moistureretention capacity of clay sediments, the electrical circuit remained completed for an unrecorded, time (likely days to weeks) after cessation of streamflow was indicated by stream-stage recorder records or site visits.

If a site visit revealed that an electrical-resistance sensor had been buried in clay, data from that sensor was disregarded during the estimated buried period. At the Fairbank site, the sensor was buried from time to time, but only in sand. Data plotted in figure 15B show electrical-resistance expressed as percent of the maximum observed by that sensor during the study. The relative electrical conductivity reported by the sensor increases to about 50 to 75 percent when flow is present and decreases to about 0 when flow is absent. A comparison of relative electrical conductivity (fig. 15B) to the stream-stage recorder data (fig. 15D) shows close correlation for indicated flows.

A false indication of flow presence could occur when ponds remain in the stream channel after streamflow ceases. Site-visit information was used to correct the record for such false indications.

Although the various individual indications of flow presence were ambiguous at times for a particular site, the multiparameter approach to data collection generally revealed a clear indication of when and where the stream was flowing. Site visits and photographs provided corroboration for the other data. Temperature records generally provided a better indication of flow onset than cessation, particularly after long dry periods, so use of the temperature records was weighted toward identifying flow onset.

Results. - Interpretation of the available data at each site provided dates when surface-water flow was present in the channel. Conversion of these dates to percentage of time in each month with flow at each site reveals temporal and spatial patterns of streamflow permanence (fig. 16). Several flow-presence characteristics were interpreted from these results. The upstream reach from the Palominas south site to the Hunter site has interrupted-perennial flow. A span of uninterrupted-perennial flow dominates the center of the study area from the Cottonwood site downstream to the Charleston bridge site, and interrupted-perennial flow extends from an unknown location between the Charleston bridge site and the Charleston mesquite site to the Boquillas site. The downstream reach from the Fairbank to the St. David sites has intermittent flow with increasingly long dry periods toward the St. David site. Also evident, particularly in calendar year 2002, is the timing of flow each year with respect to ET and the monsoon rainy season. 

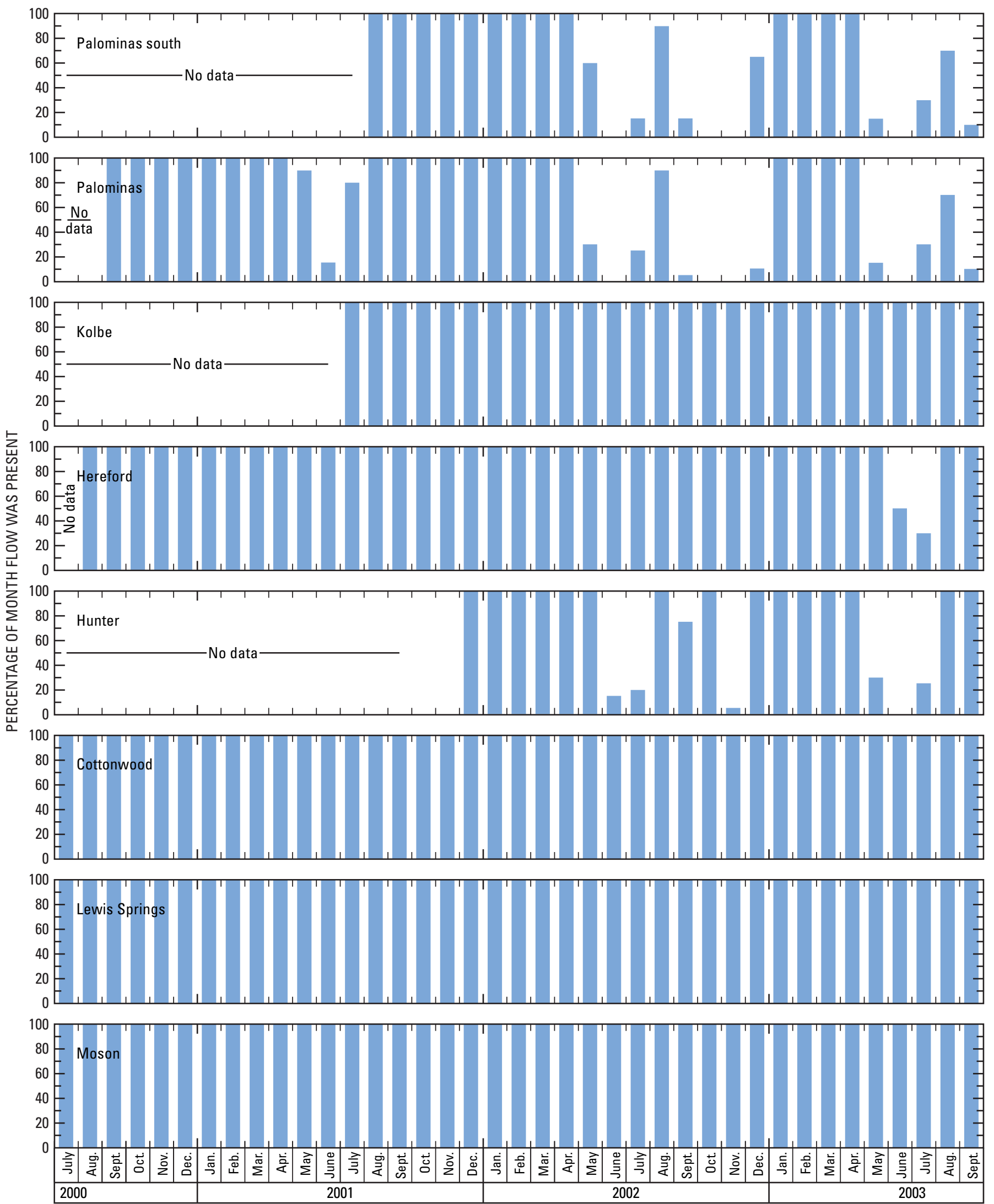

Figure 16. Percentage of time in each month that flow was present at the 16 biohydrology study sites, San Pedro Riparian National Conservation Area, Upper San Pedro Basin, Arizona. 

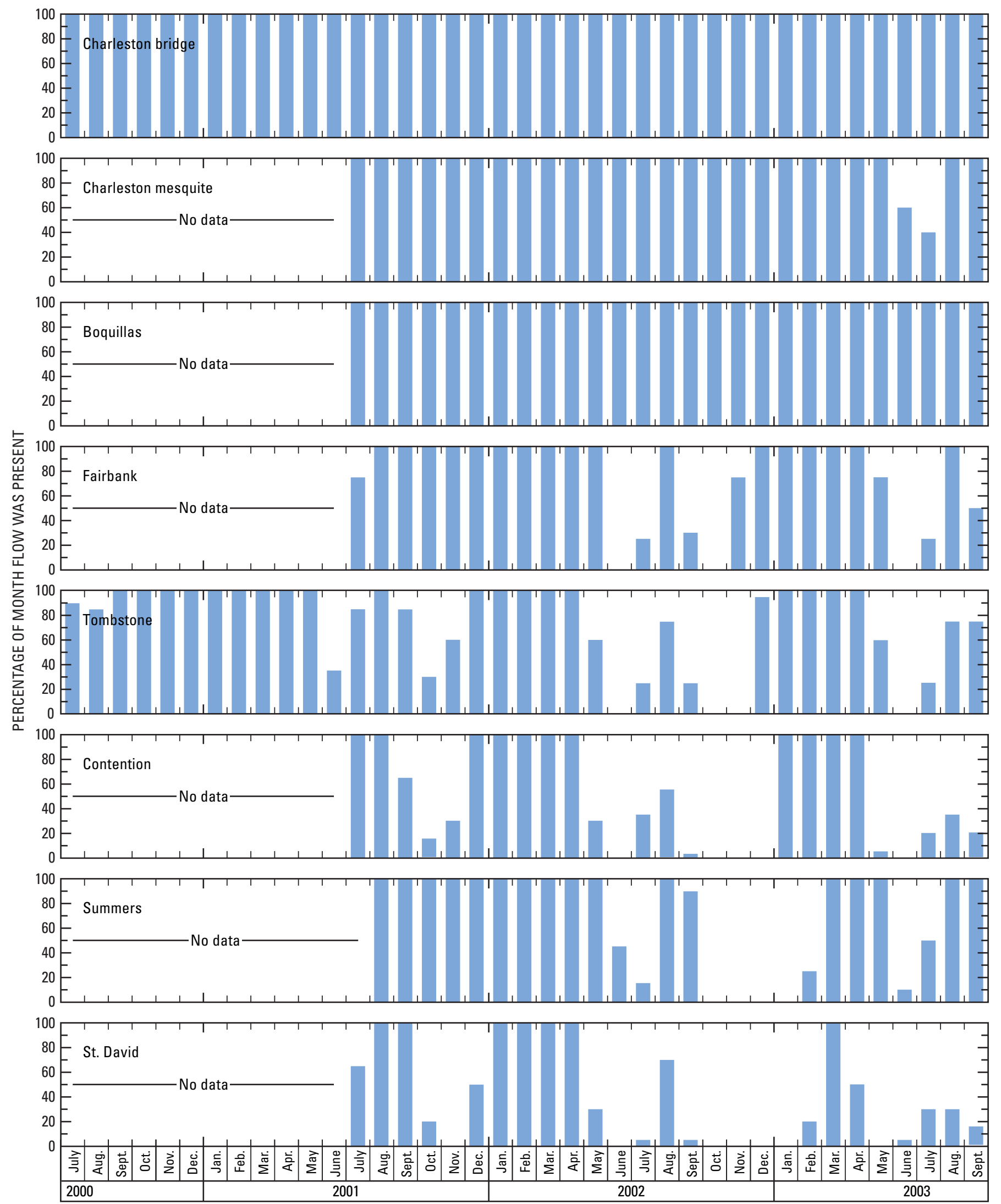

Figure 16. Continued. 
In May and June, ET increases to near-maximum rates owing to high temperatures, low humidity, and long days. The high ET, combined with minimal precipitation, causes the river to cease flowing at all except the perennial sites. In July and August, the monsoon precipitation pattern generates sufficient runoff and bank storage to maintain flow to the beginning or ending of September, depending on the site. In September or October, the monsoon precipitation ceases, humidity decreases, and ET remains high, causing the flow to cease again in the intermittent reaches. In late fall and in winter when ET decreases, ground-water levels rise and flow returns at all sites. In the reach between the Fairbank and the St. David sites, winter streamflow returns progressively later with increasing distance downstream, especially in 2002-03.
The effect of the October 2000 flood is evident in streamflow permanence (fig. 16). Within the intermittent sections of river, stage records at the Palominas, Hereford, and Tombstone sites indicate that flow continued at these three sites in the fall of 2000, sustained by the release of stored water. In spring 2001, the river ceased flowing at the Palominas and Tombstone sites, but for a shorter duration than during the same period in 2002 and 2003. In fall 2001, the river continued to flow at the Palominas site without interruption but ceased briefly at the Tombstone site. The river continued to flow without interruption at the Hereford site until June 2003.

Long-term statistical data from the Palominas, Charleston, and Tombstone gaging stations provide context for the permanence values determined during this study (fig. 17).

\section{A. Palominas streamflow-gaging station}

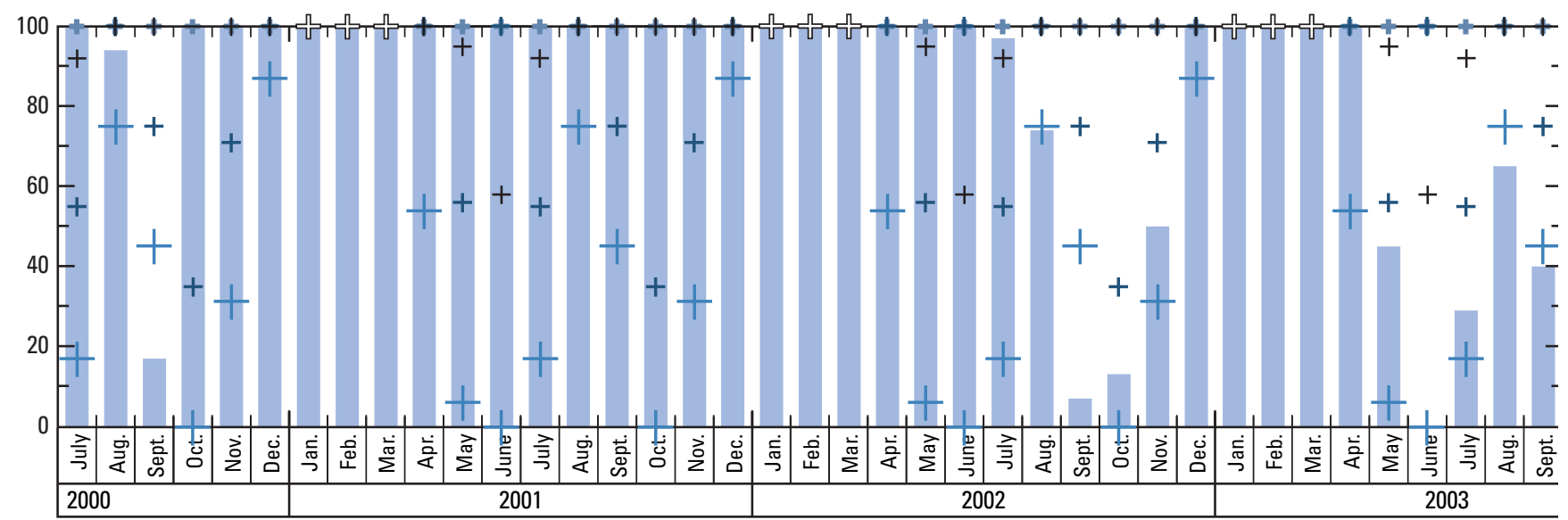

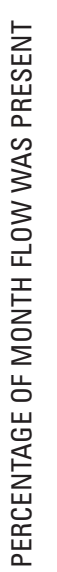

B. Tombstone streamflow-gaging station

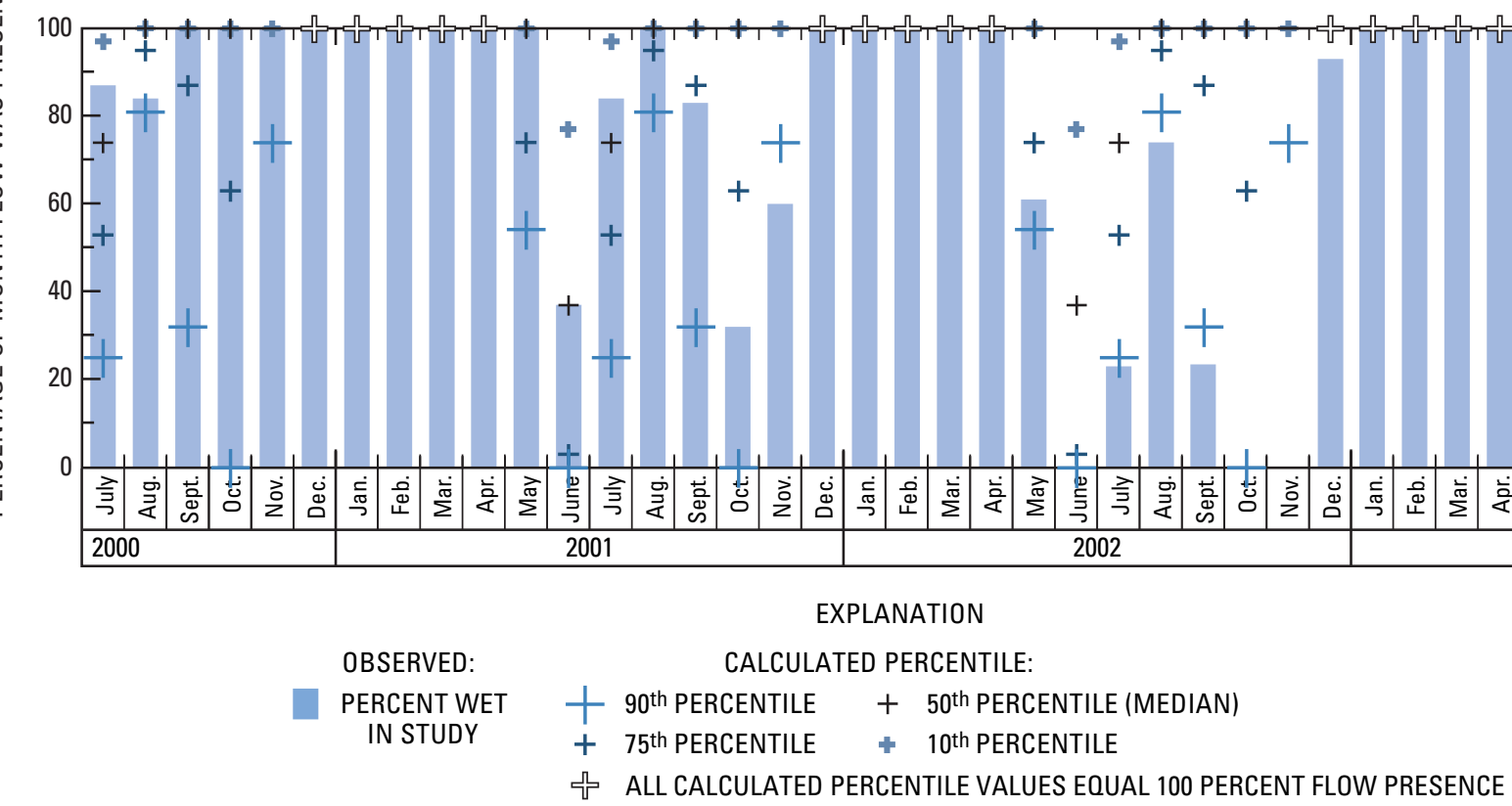

Figure 17. Percentage of time in each month that flow was present at the U.S. Geological Survey streamflow-gaging stations San Pedro River at Palominas (09470500) and San Pedro River near Tombstone (09471550), San Pedro Riparian National Conservation Area, Upper San Pedro Basin, Arizona. 
At the Palominas gaging station, streamflow permanence was greater than the median in July 2000 but less than the 90th percentile in September (90 percent of Septembers in the period of record were wetter). From October 2000 to July 2002, streamflow permanence at Palominas gaging station was greater than the median owing to release of bank storage. After July 2002, when stored water from October 2000 had drained from the system, permanence decreased to near the 90th percentile. The 10th- and 25th-percentile permanence at the Palominas gaging station is perennial flow. At the Tombstone gaging station, permanence was between the 90th and 75th percentile in September 2000. In spring 2001, permanence increased to about the median, but through the remainder of the study permanence decreased to about the 90th percentile. At the Charleston gaging station, permanence was 100 percent during every month both historically and in this study.

Over the course of the study, dry periods existed at all intermittent sites and increased in duration similar to what was observed at the Palominas and Tombstone gaging stations. Two factors likely contributed to these increasinglength dry periods. The first is that the October 2000 flood occurred near the beginning of the study, and the ground-water recharge from this flow drained back into the river during the several subsequent months. The second factor is that annual precipitation in 2001, 2002, and 2003 was lower than the long- term average (table 6). The decreasing streamflow permanence in the river during the study period likely reflects, at least in part, the change in climate from wetter than average in 2000 to drier than average during the remainder of the study.

\section{Classification of Sites by Permanence}

For the purpose of correlating hydrologic factors with some riparian vegetation factors, the biohydrology study (chapter C) categorized each of the study sites with respect to water availability into 1 of 3 classes. The classes were based on annual streamflow permanence in water years 2002 and 2003. The perennial class includes only sites with annual streamflow permanence of 100 percent (class 3). The intermediate class, termed intermittent-wet, includes sites with permanence of 60 to 99 percent of each water year (class 2). The driest class, termed intermittent-dry, includes sites with streamflow permanence of less than 60 percent (class 1). Increasing dryness during the study is evident in the transition of some sites to drier classes (table 9). In addition, the spatial aspect to water availability is evident; wettest conditions are prevalent in about the center third of the riparian corridor within the SPRNCA, intermediate conditions in the upstream third, and the driest conditions in the downstream third. See chapter $\mathrm{C}$ for additional details.

Table 9. Streamflow permanence at the 16 biohydrology study sites, San Pedro Riparian National Conservation Area, Upper San Pedro Basin, Arizona

\begin{tabular}{|c|c|c|c|c|}
\hline \multirow[b]{2}{*}{ Site name } & \multicolumn{2}{|c|}{ Streamflow permanence } & \multicolumn{2}{|c|}{ Permanence class } \\
\hline & $\begin{array}{l}2002 \text { water year } \\
\text { (percent wet) }\end{array}$ & $\begin{array}{l}2003 \text { water year } \\
\text { (percent wet) }\end{array}$ & $\begin{array}{c}2002 \\
\text { water year }\end{array}$ & $\begin{array}{c}2003 \\
\text { water year }\end{array}$ \\
\hline Palominas south & 73 & 49 & 2 & 1 \\
\hline Palominas & 71 & 45 & 2 & 1 \\
\hline Hereford & 100 & 90 & 3 & 2 \\
\hline Hunter & 68 & 63 & 2 & 2 \\
\hline Cottonwood & 100 & 100 & 3 & 3 \\
\hline Lewis Springs & 100 & 100 & 3 & 3 \\
\hline Charleston mesquite & 100 & 92 & 3 & 2 \\
\hline Boquillas & 100 & 100 & 3 & 3 \\
\hline Fairbank & 80 & 69 & 2 & 2 \\
\hline Tombstone & 65 & 61 & 2 & 2 \\
\hline Contention & 56 & 40 & 1 & 1 \\
\hline Summers & 88 & 49 & 2 & 1 \\
\hline St. David & 48 & 21 & 1 & 1 \\
\hline
\end{tabular}




\section{Monthly Mean Discharge}

The third objective of hydrologic characterization was to estimate monthly mean discharge during the study period at each of the 16 biohydrology study sites. This analysis did not attempt to determine long-term discharges at the sites. Three sites, Palominas, Charleston bridge and Tombstone, were at or near permanent streamflow-gaging stations that operated continuously through the study period. Monthly mean discharges at these three sites were calculated directly from the streamflow-gaging station records. Discharges at the remaining 13 sites were estimated by correlating discharge records from the streamflow-gaging stations to the discharge measurements made at each of these sites. Once the correlation was determined for each site, the streamflowgaging station records were used to project monthly mean discharge at each site.

Earlier studies attempted to estimate streamflow statistics at ungaged sites (Hortness and Berenbrock, 2001) by correlating various watershed characteristics to runoff and base flow. These efforts, however, were generally intended to estimate streamflow at locations far removed from streamflow-gaging stations or even in different watersheds. For this study, sites were established along a common channel, each less than $13 \mathrm{~km}$ from a permanent streamflow-gaging station. As a result, streamflow at ungaged sites was estimated by using a series of linear regressions relating discharges measured at each site to discharges recorded at one or more permanent streamflow-gaging stations.

Monthly mean flows in the San Pedro River during the course of the study were controlled by the same processes that control streamflow permanence: precipitation, ET, regional ground-water inflow, and irregularly occurring extreme high-stage events, such as the October 2000 flood. Because the precipitation and ET processes occur at regularly recurring intervals, three distinct seasonal periods were delineated: (1) a winter period, (2) a spring/fall period, and (3) a monsoon period. The winter period corresponds approximately to winter months when ET is low, and when rainfall and runoff, at least during this study, were low. During average climate years, rainfall and runoff during the winter period are greater than they were during this study. The spring/fall period consists of spring, early summer, and fall when temperatures are warm and riparian vegetation is actively transpiring, but precipitation and runoff are low. The monsoon period is largely constrained to July and August when temperatures and ET are high and precipitation from typically high-intensity afternoon thunderstorms results in high streamflows.

Approach. - Because different physical processes control flow in the river in each of these seasonal periods, the instantaneous-discharge values for each site were separated, prior to regression analysis, into the three regularly recurring seasonal periods. The junctures between the winter and spring/fall periods were the same in each year: November 1 and March 31. The junctures between the spring/fall periods and the monsoon period, however, varied in each year and were determined by the timing of the first and last monsoon runoff events in each monsoon period.
Each discharge measurement at a site was paired with the corresponding discharge(s) recorded at one or two of the nearest gaging stations. In the winter and spring/fall, flow was relatively stable owing to the lack of runoff. Travel time from the streamflow-gaging station to the sites in these periods was impossible to determine, so site discharge measurements could not be paired with specific streamflowgaging station discharge values. As a result, each site discharge measurement was paired with a 4-hour average discharge calculated from the 15-minute data recorded at the streamflow-gaging station(s).

During the monsoon periods, flows varied rapidly in time. Consequently, measured site discharge values were paired with instantaneous discharge values, rather than averaged values, from the streamflow-gaging stations. In order to pair the appropriate discharge values, an estimate of flood-peak travel time from nearby streamflow-gaging stations to each site was used. Travel times were calculated using two flood events by averaging the difference in time between the first stage rise recorded at a streamflow-gaging station and the first stage rise at each site. Three characteristics were used to select flood events: (1) a rapid and easily identifiable initial stage increase, (2) a lack of preceding or following events that could cause ambiguity, and (3) a commonality of record between a site and the closest upstream and downstream streamflow-gaging stations. Three events were selected (July 23, 2001; August 14, 2001; July 23, 2003). All three events were not recorded at each site, however, either because of missing record, or because an event did not pass through a site. At least two of the three events were recorded at each site. Travel times of the recorded events between the closest upstream and downstream streamflow-gaging stations and the site were then averaged. An instantaneous-discharge value at a gaging station was then paired with the discharge measured at each site depending on the calculated travel time between the streamflow-gaging station and the site (appendix 4).

For every site, several series of linear regression equations were computed that provided a best fit between recorded discharge values at one or two nearby gaging stations and discharge measurements made at the site. At each site, separate regression equations were fitted to data from each of the winter, spring/fall, and monsoon time periods. In addition, separate equations were fitted between a given site and each gaging station used for correlation.

The quality of regression equations was judged according to the standard error of estimate (SEE), which is a measure of the fit of a regression equation to observed data and is expressed in the units of the data (table 10). In this case, the SEE is a comparison between the measured discharge at each site and each fitted linear regression. The advantage of the SEE over $r^{2}$ (coefficient of determination) is that the goodness of fit between measured and predicted values is expressed in units of discharge $\left(\mathrm{m}^{3} / \mathrm{s}\right)$. Once the error of prediction is calculated in units of discharge, the error can be expressed as a percentage of mean discharge. 
Table 10. Regression equation parameters and estimates of error (standard error of estimate and error as percent mean flow) calculated for site to streamflow-gaging station discharge correlation analysis for the 16 biohydrology study sites in the winter, spring/fall, and monsoon periods, San Pedro Riparian National Conservation Area, Upper San Pedro Basin, Arizona

[M, slope; B, intercept; $r^{2}$, goodness of fit; N, number of observations; SEE, standard error of estimate; $\mathrm{m}^{3} / \mathrm{s}$, cubic meters per second; USGS, U.S. Geological Survey; i.d., insufficient data for regression ( $n$ less than 4 or $r$-squared less than 0.8 ); ---, no streamflow-gaging station used for correlation]

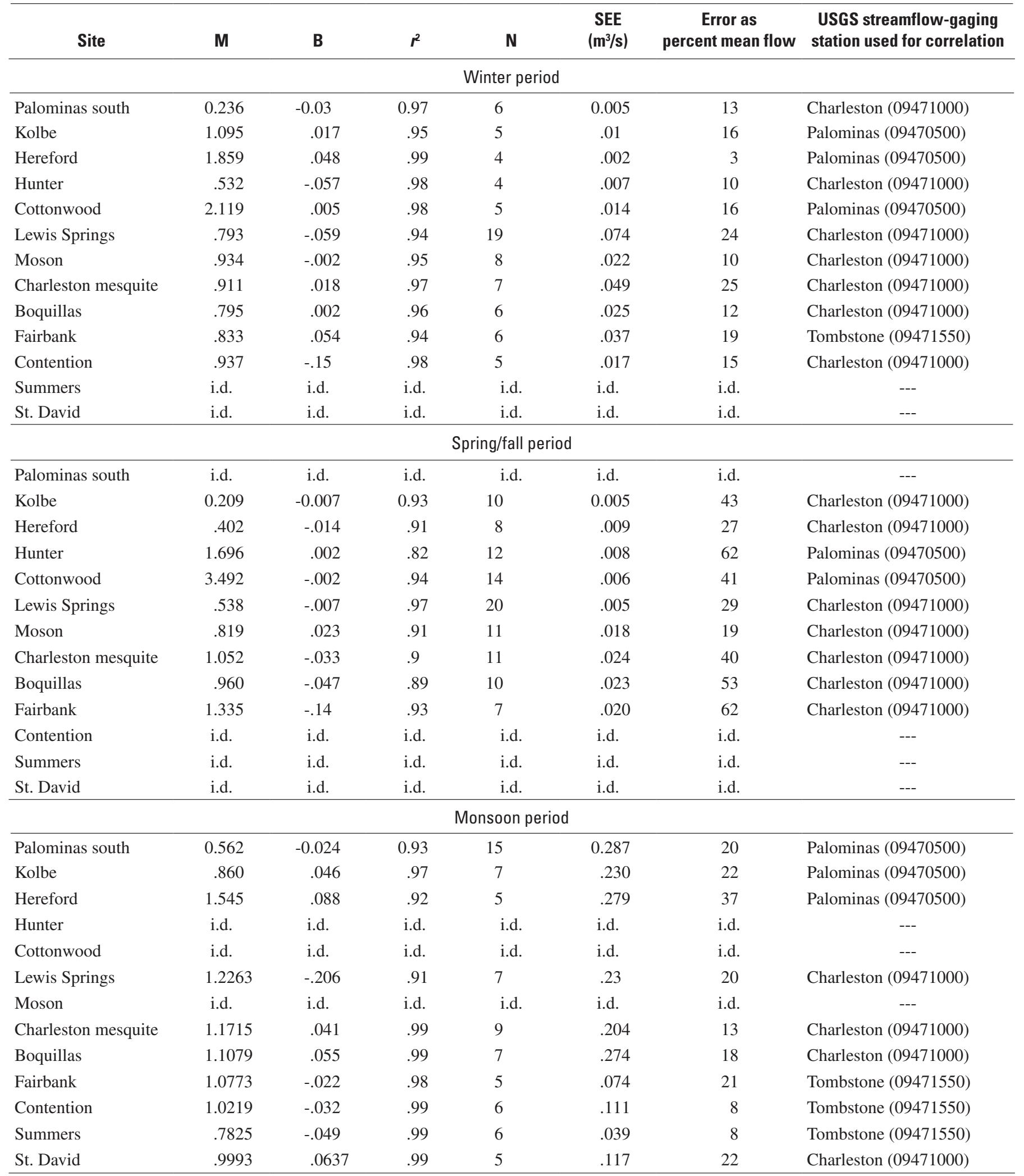


Both the SEE and the error as a percentage of observed flows are useful in evaluating results. For example, in cases where the magnitude of mean flow is low, deviations between measurements and predictions tend to have a low magnitude, and the SEE appears to be small. As a percentage of the mean flow, however, the SEE may represent a large percentage of the mean. The smallest SEE values and the largest errors as percentages of mean flow are both associated with the spring/fall period when flows are low (table 10). At the Hunter site, the error as a percentage of mean flow for the spring/fall period is 62 percent, but this error reflects a deviation of only $0.008 \mathrm{~m}^{3} / \mathrm{s}$ between measured and predicted discharge.

For sites where regressions were calculated by using data from the two nearest gaging stations, the equation with the lowest error was used to estimate monthly mean discharge at the study site. In these cases, the gaging station used for the correlation is listed in table 10. Values of SEE from all the regressions range from 0.003 to $0.292 \mathrm{~m}^{3} / \mathrm{s}$ (including those regression equations omitted from table 10 because they failed to meet the sufficient data criterion) and average $0.07 \mathrm{~m}^{3} / \mathrm{s}$.

Errors expressed as percentages of mean flow range from 3 to 97 percent and have a mean of 26 percent. In several instances, the quantity of available data was insufficient to calculate relations between the study sites and streamflowgaging stations, particularly at the northern study reach where the channel was often dry. Specifically, data were considered insufficient and no regression was attempted if fewer than four discharge measurements were available, and no regression was accepted with an $r^{2}$ value less than 0.80 .

Monthly mean discharge in October 2000 through January 2001 at each site not collocated with a permanent streamflow-gage was calculated using a procedure different from that just described. The peak discharge during the October 2000 flood far exceeded the instantaneous-discharge values used to create the regression relations; the regression equations could not be accurately extrapolated to predict such large flows. The regional nature of the event, however, resulted in relatively consistent changes in discharge along the course of the river. Discharge at the study sites was determined using a 2-step process. First, the downstream changes in peak discharge at the three gages were calculated as a function of drainage area. Then, the peak discharge/drainage area relation from step 1 was used to estimate peak discharge at each site.

Discharges for the Palominas, Charleston bridge and Tombstone sites were calculated directly from the Palominas, Charleston, and Tombstone gaging-station records. At sites and in months where available data were insufficient to estimate flow, but the flow-permanence calculations indicated a dry channel, a zero flow was assumed.

Results. - The estimated discharge values (table 11) show that the annual cycling of discharge is controlled by changes in ET, runoff, and bank-storage processes. The highest annually observed flows occurred during the monsoon period in July and August, and the lowest flows occurred in the spring/fall period. The reduction of ET in November corresponds with an increase in flow during the winter period. Calculated monthly mean flows (table 11) generally correspond with the estimated occurrence of flows (fig. 16) from the streamflowpermanence calculations. Discrepancies result, in part, because the two factors were independently calculated. The monthly mean flow values are calculated from the relation of a few site discharge values with continuously collected data at nearby streamflow-gaging stations. The streamflow-permanence values were calculated by using only water-presence data collected at each site. A conceivable discrepancy would occur, for example, at a site where flow has ceased, but water is still ponded. The nearby streamflow-gaging station data might indicate zero discharge, but the stream-stage recorder, temperature, and electrical-resistance sensors would still indicate water was present. Observations during site visits limited the occurrence of such discrepancies.

\section{Inundation-Frequency Analysis}

The final aspect in the hydrological characterization of the study sites was the development of stage-discharge relations that were used to determine inundation frequency along the 16 hydrology/biohydrology transects. Flood inundation influences the riparian system by redistributing seeds and nutrients, scouring sediments and plants, and providing water to seedlings and established plants on the streambanks.

Several types of data were used in the development of stage-discharge relations, or rating curves, for each site. Stage recorders at 14 sites provided continuous readings of stream stage. Interpolated peak discharges recorded at nearby permanent streamflow-gaging stations were paired with site stream-stage recorder readings to generate parts of the rating curves. High-water marks from the October 2000 flood were surveyed and provided a measure of high stage at all sites except St. David. The topographic surveys of each study cross section provided stream-geometry data. Each of these types of data were used to support the development of a flow model that generated rating curves for each site.

Peak discharge for each site was estimated for 2- to 50-year recurrence intervals using a drainage-area weighted interpolation from permanent streamflow-gaging stations. The rating curves generated for each site were then combined with the peak-discharge recurrence data to estimate the frequency of inundation along the hydrology/biohydrology transect for each site that could then be used by other investigators in the overall study.

\section{Peak Flow Recurrence Intervals}

Determination of flood-inundation frequency requires that an estimate be made, for each study site, of the peak discharges associated with particular statistical flood-recurrence intervals. 


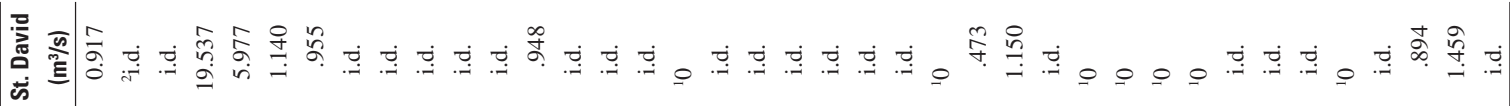

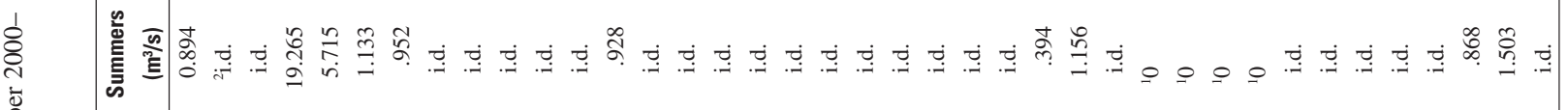

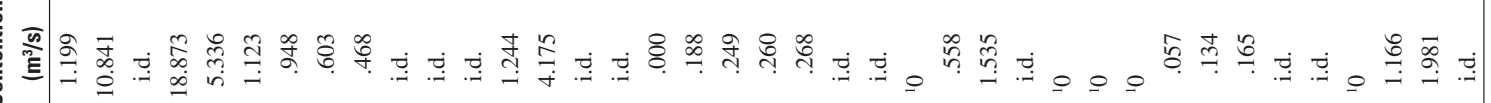

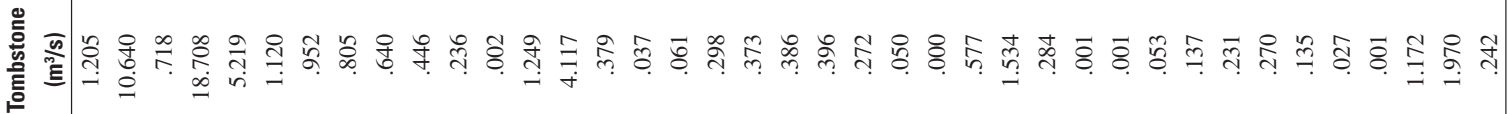

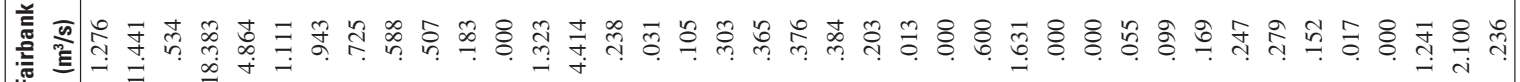

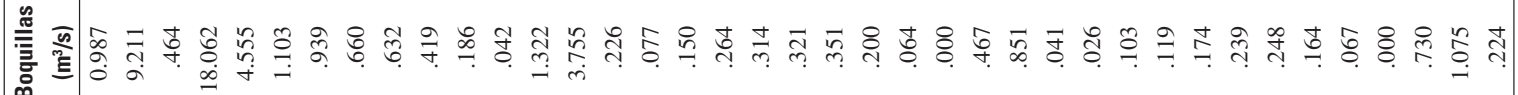
竞 产

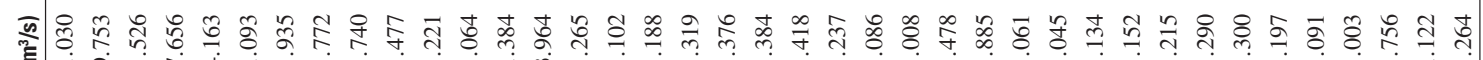
总

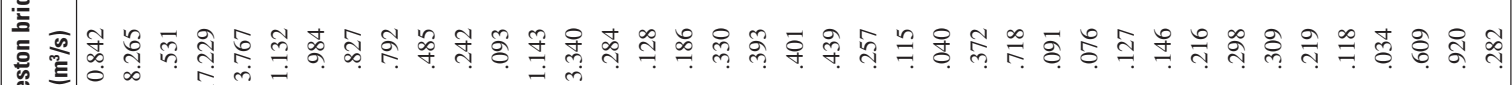
政 敦

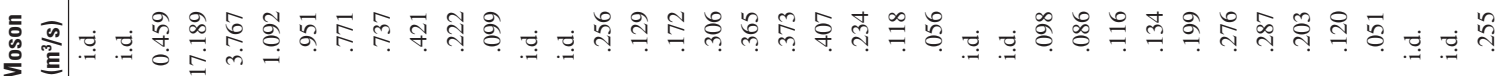
요유

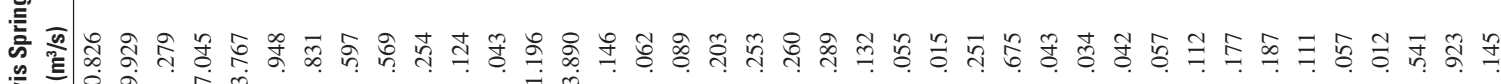
产

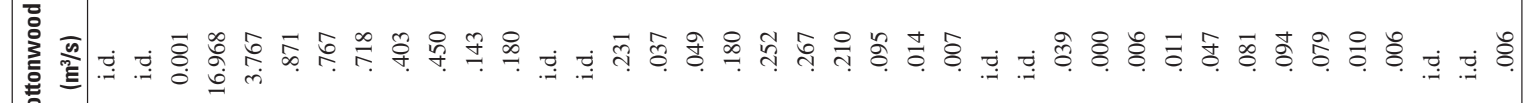

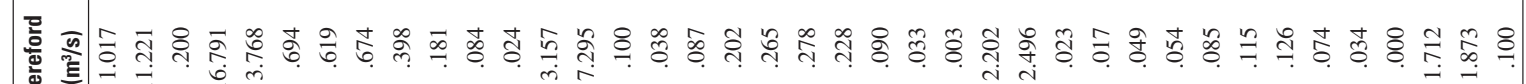

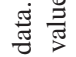

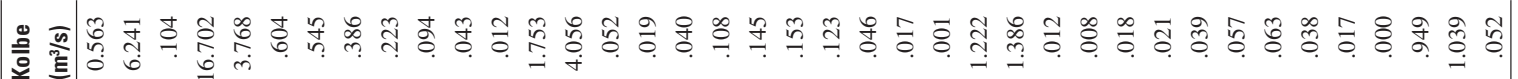

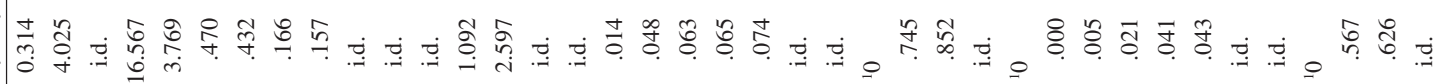


At each study site, expected peak discharges were estimated for floods having recurrence intervals of $2,5,10$, 25 , and 50 years. A flood having, for example, a 50-year recurrence interval has a 2-percent probability of being equaled or exceeded in any one year and, over the long-term, would be equaled or exceeded on average once every 50 years. The assignment of a particular recurrence interval to a flow is not meant to imply that a flood of that magnitude is expected to occur at that time interval.

Peak-discharge recurrence intervals were estimated for each of the study sites by drainage-area-weighted interpolation from three permanent gaging stations: Palominas, Charleston, and Redington. Peak discharges from 55 years of record for Palominas, 80 years of record for Charleston, and 64 years of record for Redington were used in the calculations. The Tombstone gaging station is near sites in the northern part of the study area, but data from the station were not used in the calculations owing to the short (19 years) period of record. Pope and others (1998) computed the magnitude and probability of instantaneous peak flows at each of the streamflow-gaging stations (table 12).

Peak flows at the study sites were estimated by linear interpolation of the ratio of discharge to drainage area between upstream and downstream streamflow-gaging stations (table 13). The equations were based on drainage areas determined from geographic information systems (GIS) methods. Peak discharges at two study sites upstream from the uppermost streamflow-gaging station were calculated from the equations used to extrapolate between Palominas and Charleston.

\section{Estimated Discharge and Measured Stage}

Stream-stage recorder data were collected at all sites between mid-summer 2001 and fall 2003. At most sites, the stage-recorders were collocated with the surveyed cross sections; therefore, the stage data were applicable to inundation along the cross sections. At a few sites, the recorder was situated significantly upstream or downstream from the cross section; stage from the recorders at these sites is not applicable to inundation along the associated hydrology/biohydrology transect. The 30-minute recording frequency of the stage recorders provided sufficient resolution to capture peak stage during flows that could be paired with estimated or measured discharge.

Perhaps the most valuable stage data collected were the high-water records and marks created by the October 2000 flood. The flood was recorded at stage recorders installed at the Hereford, Lewis Springs, and Moson sites. At all other sites except St. David, high-water marks from the October 2000 flood were located and measured during the crosssection surveying. When combined with estimated discharge, these stage values provided a high-flow calibration point for the stage-discharge relation calculations.
Peak-discharge values that matched measured stage values were needed to generate rating curves for each site. Peak discharges at each site were estimated by linear interpolation from peak discharges at nearby gaging stations. The interpolations were calculated from selected sets of peak discharges recorded at the gaging stations between summer 2000 and fall 2003 that could clearly be identified at each set of two adjacent streamflow-gaging stations and at each biohydrology site. Seventeen flows were selected for interpolation between the San Pedro River at Palominas and the San Pedro River at Charleston. Eighteen flows were selected for interpolation between the San Pedro River at Charleston and the San Pedro River near Tombstone (appendix 5). The discharges measured at the sites as part of the monthly mean flow analysis were not peak discharges and were smaller in magnitude than the 2-year flood; therefore, these values were not considered in the peak-flow analysis.

As the first step to interpolate peak discharges at the sites, peak discharges at the streamflow-gaging stations for the selected flows were extracted from the station records and converted to peak flow per unit drainage area. The change in discharge per unit drainage area between each set of two streamflow-gaging stations-Palominas/Charleston and Charleston/Tombstone-was then calculated for each flow. Discharge at a given site for a given flow was calculated by applying the drainage area of the particular site to the change in discharge per unit drainage area between the upstream and downstream gaging stations for the particular flow. Two study sites (Charleston bridge and Tombstone) were collocated with, or were near, the streamflow-gaging stations, and discharge values from the streamflow-gaging station records were used for these sites. Five sites (Palominas, Palominas south, Contention, Summers, and St. David) were not located between any two streamflow-gaging stations in the study area. The Redington gaging station is $75 \mathrm{~km}$ downstream from St. David and was considered too distant for inclusion in the analysis. Discharge at Palominas, Palominas south, Contention, Summers, and St. David was estimated by linear extrapolation using the same equations for change in discharge per unit drainage area as described previously. At Palominas south, for example, discharge was extrapolated from the equations describing the change in discharge per unit drainage area between the Palominas and Charleston gaging stations.

Peak discharge for the selected flows generally decreased in the downstream direction, likely as a result of channel losses, increased downstream dispersion of flood fronts, and lack of substantial tributary inflows. Contrarily, the flood of October 2000 increased in peak discharge between the Palominas and Tombstone gaging stations, indicating substantial tributary inflows. For the October 2000 flood, peak discharges at the study sites were estimated using a linear interpolation/extrapolation technique except that gaged tributary inputs from Greenbush Draw and the Babocomari River were used to weight locations of changes in streamflow. Peak discharges of 15 and $25 \mathrm{~m}^{3} / \mathrm{s}$ were recorded at Greenbush Draw and the Babocomari River, respectively. 
Table 12. Drainage area and peak discharge at streamflow-gaging stations for 2-, 5-, 10-, 25-, and 50-year recurrence-interval floods, Upper and Lower San Pedro Basins, Arizona

[Source: Pope and others (1998); $\mathrm{km}^{2}$, square kilometers; $\mathrm{m}^{3} / \mathrm{s}$, cubic meters per second]

\begin{tabular}{|c|c|c|c|c|c|c|c|}
\hline \multirow[b]{2}{*}{$\begin{array}{l}\text { U.S. Geological Survey } \\
\text { streamflow-gaging station }\end{array}$} & \multirow[b]{2}{*}{$\begin{array}{l}\text { Station } \\
\text { number }\end{array}$} & \multirow[b]{2}{*}{$\begin{array}{l}\text { Drainage area } \\
\qquad\left(\mathrm{km}^{2}\right)\end{array}$} & \multicolumn{5}{|c|}{ Flood peak flows } \\
\hline & & & $\begin{array}{l}\text { 2-year } \\
\left(\mathrm{m}^{3} / \mathrm{s}\right)\end{array}$ & $\begin{array}{l}\text { 5-year } \\
\left(\mathrm{m}^{3} / \mathrm{s}\right)\end{array}$ & $\begin{array}{c}\text { 10-year } \\
\left(\mathrm{m}^{3} / \mathrm{s}\right)\end{array}$ & $\begin{array}{l}\text { 25-year } \\
\left(\mathrm{m}^{3} / \mathrm{s}\right)\end{array}$ & $\begin{array}{c}\text { 50-year } \\
\left(\mathrm{m}^{3} / \mathrm{s}\right)\end{array}$ \\
\hline San Pedro River at Palominas ${ }^{1}$ & 09470500 & 1,920 & 155 & 263 & 342 & 447 & 526 \\
\hline San Pedro River near Redington ${ }^{3}$ & 09472000 & 7,580 & 204 & 430 & 628 & 931 & 1,194 \\
\hline
\end{tabular}

${ }^{1}$ Flood peak flows are based on periods of record for 1926, 1930-33, 1935-41, and 1950-96.

${ }^{2}$ Flood peak flows are based on periods of record for 1916-96.

${ }^{3}$ Flood peak flows are based on periods of record for 1926, 1931-41, and 1943-96.

Table 13. Estimated peak flows at each of the 16 biohydrology study sites for the 2-, 5-, 10-, 25-, and 50-year recurrence-interval floods, San Pedro Riparian National Conservation Area, Upper San Pedro Basin, Arizona

[ $\mathrm{km}^{2}$, square kilometers; $\mathrm{m}^{3} / \mathrm{s}$, cubic meters per second]

\begin{tabular}{|c|c|c|c|c|c|c|}
\hline \multirow[b]{2}{*}{ Site } & \multirow[b]{2}{*}{$\begin{array}{l}\text { Drainage area } \\
\qquad\left(\mathrm{km}^{2}\right)\end{array}$} & \multicolumn{5}{|c|}{ Flood peak flows } \\
\hline & & $\begin{array}{c}\text { 2-year } \\
\left(\mathrm{m}^{3} / \mathbf{s}\right)\end{array}$ & $\begin{array}{l}\text { 5-year } \\
\left(\mathrm{m}^{3} / \mathbf{s}\right)\end{array}$ & $\begin{array}{c}\text { 10-year } \\
\left(\mathrm{m}^{3} / \mathrm{s}\right)\end{array}$ & $\begin{array}{c}\text { 25-year } \\
\left(\mathrm{m}^{3} / \mathrm{s}\right)\end{array}$ & $\begin{array}{c}50 \text {-year } \\
\left(\mathrm{m}^{3} / \mathrm{s}\right)\end{array}$ \\
\hline Palominas south & 1,820 & 153 & 260 & 337 & 434 & 499 \\
\hline Palominas & 1,860 & 154 & 262 & 341 & 443 & 510 \\
\hline Kolbe & 2,270 & 160 & 280 & 382 & 538 & 674 \\
\hline Hereford & 2,360 & 161 & 284 & 391 & 558 & 709 \\
\hline Hunter & 2,450 & 163 & 288 & 400 & 579 & 744 \\
\hline Cottonwood & 2,490 & 163 & 289 & 404 & 588 & 760 \\
\hline Lewis Springs & 2,750 & 167 & 301 & 430 & 648 & 861 \\
\hline Moson & 3,100 & 172 & 317 & 465 & 729 & 998 \\
\hline Charleston bridge & 3,200 & 173 & 319 & 471 & 743 & 1,021 \\
\hline Charleston mesquite & 3,270 & 201 & 319 & 467 & 746 & 1,023 \\
\hline Boquillas & 3,330 & 201 & 321 & 470 & 748 & 1,025 \\
\hline Fairbank & 3,370 & 201 & 322 & 471 & 750 & 1,026 \\
\hline Tombstone & 4,480 & 209 & 350 & 511 & 798 & 1,069 \\
\hline Contention & 4,495 & 209 & 350 & 512 & 799 & 1,069 \\
\hline Summers & 4,595 & 210 & 353 & 515 & 803 & 1,073 \\
\hline St. David & 4,790 & 211 & 357 & 522 & 811 & 1,081 \\
\hline
\end{tabular}


The interpolated flows in the San Pedro River were increased by the measured tributary flow amounts at the confluence points. Since few tributaries join the San Pedro River between the Tombstone gaging station and the St. David site, peak discharge was assumed to decrease downstream from the gaging station. The rate of decline was based on observed peak discharges of flows from summer 2000 to fall 2003 at the Charleston and Tombstone gaging stations for which the gaging stations on major tributaries (Babocomari River and Walnut Gulch) registered zero flow. The assumption of decreasing flow downstream from the Tombstone gaging station for the October 2000 flood is supported by the peak discharge recorded at the Redington gaging station. The peak discharge at the Tombstone gaging station was $580 \mathrm{~m}^{3} / \mathrm{s}$, whereas the peak discharge at the Redington gaging station was $140 \mathrm{~m}^{3} / \mathrm{s}$.

\section{Stage-Discharge Relations}

Determining the statistical frequencies with which particular elevations along each hydrology/biohydrology transect are inundated with flood waters requires an estimate of the specific relation between stage and discharge (rating curve) at each site. The stage-discharge relations for this study were initially calculated with a one-dimensional steady-flow model. Model calculations were performed using HEC-RAS 3.1 (U.S. Army Corps of Engineers, 2002).

The modeled stage-discharge relations were checked against measured stage (from stage recorders or surveyed as high-water marks) paired with estimated discharge for the selected flood events during the study. Where a discrepancy occurred, the rating curve and site were examined and one of the two ratings would be used for inundation frequency calculations. As an example, the modeled and estimateddischarge/measured stage ratings would likely differ at site with a nearby downstream constriction if the constriction was not included in the model. Given the known weakness in the simulation of the site, the estimated-discharge/measured stage would then be used for further calculations.

The stage-discharge relations in this study best represent conditions observed during the study period. Although the San Pedro River channel has largely stabilized (Hereford, 1993), temporal changes in channel geometry and vegetation will change the stage-discharge relation. Predictions for inundation by statistically extreme (larger) flows are particularly subject to such errors because, on average, the channel and vegetation will change more between flows that are less likely to occur than between flows that are more likely to occur.

\section{Flow Modeling}

Flow modeling was performed using HEC-RAS 3.1 (U.S. Army Corps of Engineers, 2002), which is a one-dimensional steady-flow model that calculates water-surface elevations at specified discharges by combining the Manning equation and the energy equation into a step-backwater algorithm. HEC-RAS 3.1 was selected as it allowed all the collected data to be stored, modified, and calculated as a single package.

The model relates discharge to an energy gradient, a friction-loss coefficient, and a cross-sectional flow area. The depth of water at a particular discharge is a function of the area, the hydraulic radius, the downstream water-surface elevation, and the longitudinal water-surface slope or "energy gradient."

In the present study, cross-section surveys at each study site provided data needed to determine area and hydraulic radius. At most sites, only one cross section was surveyed, so channel slope was defined regionally by the elevation difference and distance between the site and the nearest upstream and downstream hydrology/biohydrology transects.

The step-backwater method calculates stage for a particular discharge by iteratively balancing the total energy between two cross sections oriented perpendicular to streamflow and stepping upstream to additional cross sections. The balancing of the energy equation between two cross sections assumes that the changes in stream geometry are reasonably represented by the cross sections. If the cross sections are separated by a distance larger than the scale of variation in channel shape along the stream, some factors cannot be represented in a physically meaningful way. With the widely spaced cross sections used in this study, the energy and momentum equations are effectively reduced to a balance between channel friction and the difference in water surface elevation between cross sections. As applied in this study, HEC-RAS functions similarly to a slope-conveyance algorithm (Rantz and others, 1982). This simplified calculation yields predictions of local stage at specified discharges that are less accurate than predictions that can be obtained by using cross sections spaced on the scale of channel variability.

Manning's roughness coefficient, $n$, was an important model input parameter and served as a calibration variable. The $n$ values were assigned individually to each cross section by using observations from site visits and examination of ground and aerial photographs. Values were selected from descriptive tables provided in HEC-RAS documentation (U.S. Army Corps of Engineers, 2002) and the judgment of experienced USGS staff. Initial $n$ values were assigned to the nearest 0.005 . Each cross section was generally divided into three or four zones, although one or two additional 
zones were included at a few sites to account for unusual topography and vegetation; each zone could be assigned a unique $n$ value. At each site, separate zones were delineated to represent the active channel and the left and right overbank areas. Typically, one $n$ value was assigned to the active channel and a different value was assigned to the left and right overbank areas. At many sites, the left and right overbank areas were assigned the same value because they had similar characteristics. The term "overbank" as applied here refers, at most locations, to the channel area above the boundary between the active channel and the post-entrenchment alluvium. The San Pedro River in the SPRNCA generally has two sets of banks; one separating the active channel from the post-entrenchment alluvium, and one that defines the entrenchment and separates the post-entrenchment alluvium from the topographically higher pre-entrenchment alluvium. Separate $n$-value zones were assigned to the pre- and postentrenchment surfaces at sites where the surfaces are clearly delineated. Large floods are required to inundate portions of the pre-entrenchment alluvium.

Although HEC-RAS functioned as a slope-conveyance algorithm as applied this study, the various data collected were used to improve the modeled stage-discharge relations. In particular, high-water records and marks generated by the October 2000 flood were used to increase the accuracy of modeled stage. At the St. David site, no high-water marks were measured. The model was calibrated by adjusting $n$ values to match modeled stage to stage determined from the site high-water marks left by peak flows. The $n$ values were varied within a range of about \pm 0.005 during calibration . Care was taken to keep the final $n$ values consistent with known site characteristics. Measured stage and estimated discharge from the October 2000 flood was also used to check, and where appropriate, modify the modeled ratings. With these data incorporated, the model provides a physical basis for interpolating or extrapolating stages at the cross sections.

\section{Results}

The following discussion presents the stage-discharge relations calculated (fig. 18) for each hydrology/biohydrology transect. Because the inundation-frequency analysis considered statistical recurrence intervals of 2 to 50 years, the focus in rating-curve generation was matching discharges between about 100 and 1,000 m³ (table 13). Both the model-generated and estimated-discharge/measured-stage data were considered. The measured discharge values were mostly less than $1 \mathrm{~m}^{3} / \mathrm{s}$ so they were not used to generate the stage-discharge relations.

The 10 sites where the model-generated rating curves reasonably match both the October 2000 high-water marks and the estimated-discharge/measured-stage data, especially within the 100 to $1,000 \mathrm{~m}^{3} / \mathrm{s}$ range, are Palominas south, Palominas, Hereford, Hunter, Moson,
Charleston mesquite, Boquillas, Fairbank, Summers, and Contention. At Charleston bridge and Tombstone, no stage data specific to the study transects were available, so the estimated-discharge/measured-stage data were only compared to the October 2000 high-water mark. No high-water mark from the October 2000 flood was surveyed at the St. David site, although stage data were collected. The model-generated inundation-elevation values for these 13 sites were accepted and used. At 3 other sites (Kolbe, Cottonwood, and Lewis Springs), the modeled rating curve deviated from the October 2000 high-water marks, the estimated-discharge/measured-stage, or both.

At the Kolbe site (fig. 18C), the surveyed cross section is collocated with the stream-stage recorder. The plotted data indicate that the modeled rating curve falls below both the surveyed October 2000 high-water mark and the stagerecorder derived data. Attempts to fit the modeled rating to the October 2000 high-water mark by adjusting $n$ values within reasonable ranges were not successful. Since the stage-recorder measurements at this site represent stage along the hydrology/biohydrology transect, a rating curve was fitted to the estimated-discharge/measured-stage data using techniques suggested in Rantz and others (1982). The fitted curve represented by the dashed line on figure $18 \mathrm{C}$ was used to determine inundation elevation infrequency at the Kolbe site.

The modeled ratings at the Cottonwood site (fig. 18F) and the Lewis Springs site (fig. 18G), when visually extrapolated to low flows, do not extend through the stage-recorder measurements. In the case of the Lewis Springs site, the stream-stage recorder is collocated with the hydrology/biohydrology transect, so a new rating curve was fitted to the estimated-discharge/measured-stage data. At the Cottonwood site, the stream-stage recorder is about $150 \mathrm{~m}$ downstream from the surveyed transect; therefore, the stage-recorder data were not considered directly applicable to inundation along the hydrology/biohydrology transect. Because the channel geometry at the stream-stage recorder differed from that at the transect, and because the model was run using the transect geometry, the model rating curve was accepted and used.

Peak flow data for the 2-, 5-, 10-, 25-, and 50-year recurrence interval floods were combined with stage-discharge relations created for each hydrology/biohydrology transect to calculate flood-inundation elevations (table 14). At all sites except Kolbe and Lewis Springs, the modeled rating curve was used to calculate inundation elevation. For the Kolbe and Lewis Springs hydrology/biohydrology transects, ratings fitted to estimated-discharge/measured-stage data were used to calculate inundation elevation. 


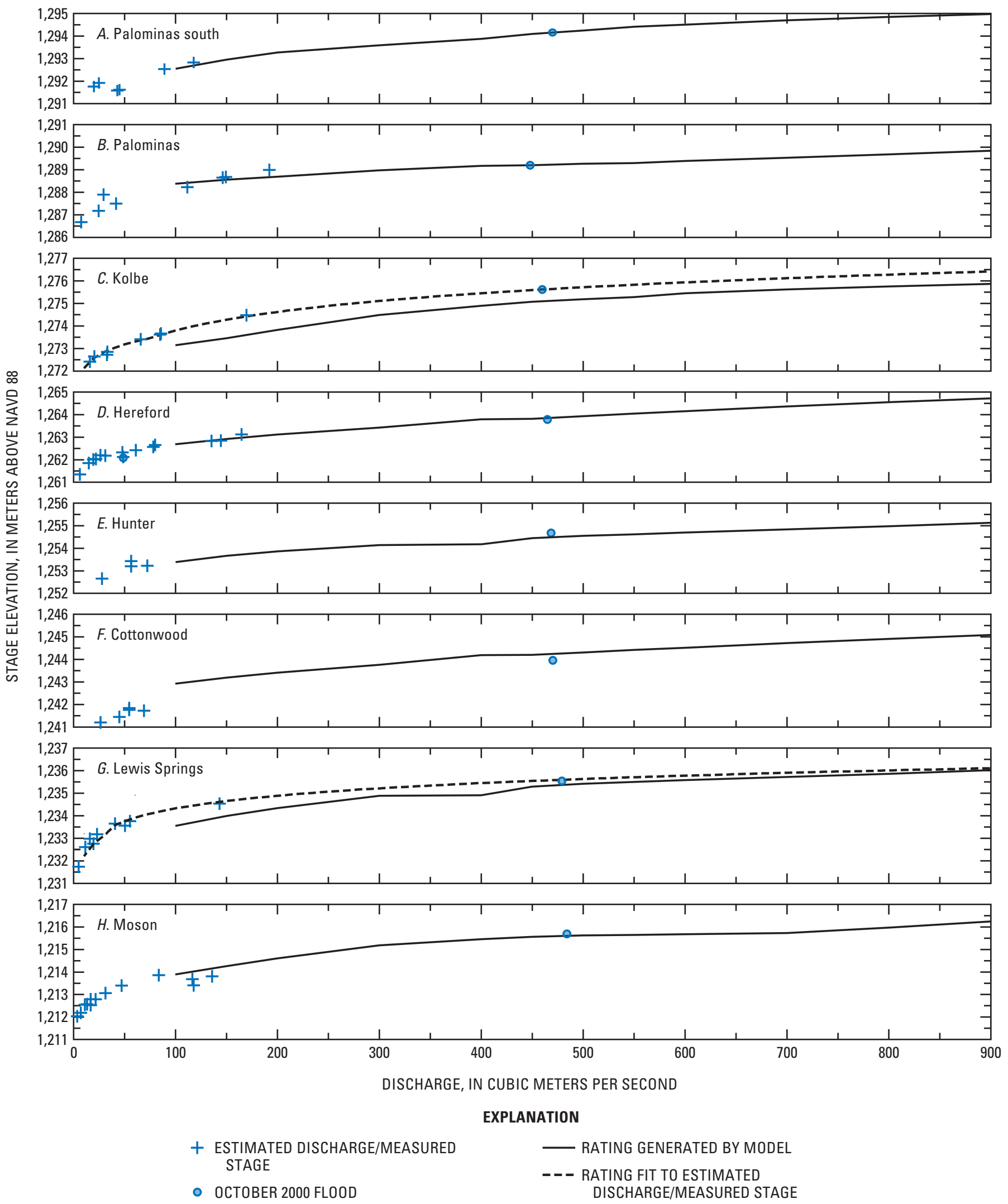

Figure 18. Stage-discharge relations from modeled and measured stage estimated discharge analyses at each of the 16 biohydrology study sites, San Pedro Riparian National Conservation Area, Upper San Pedro Basin, Arizona. 


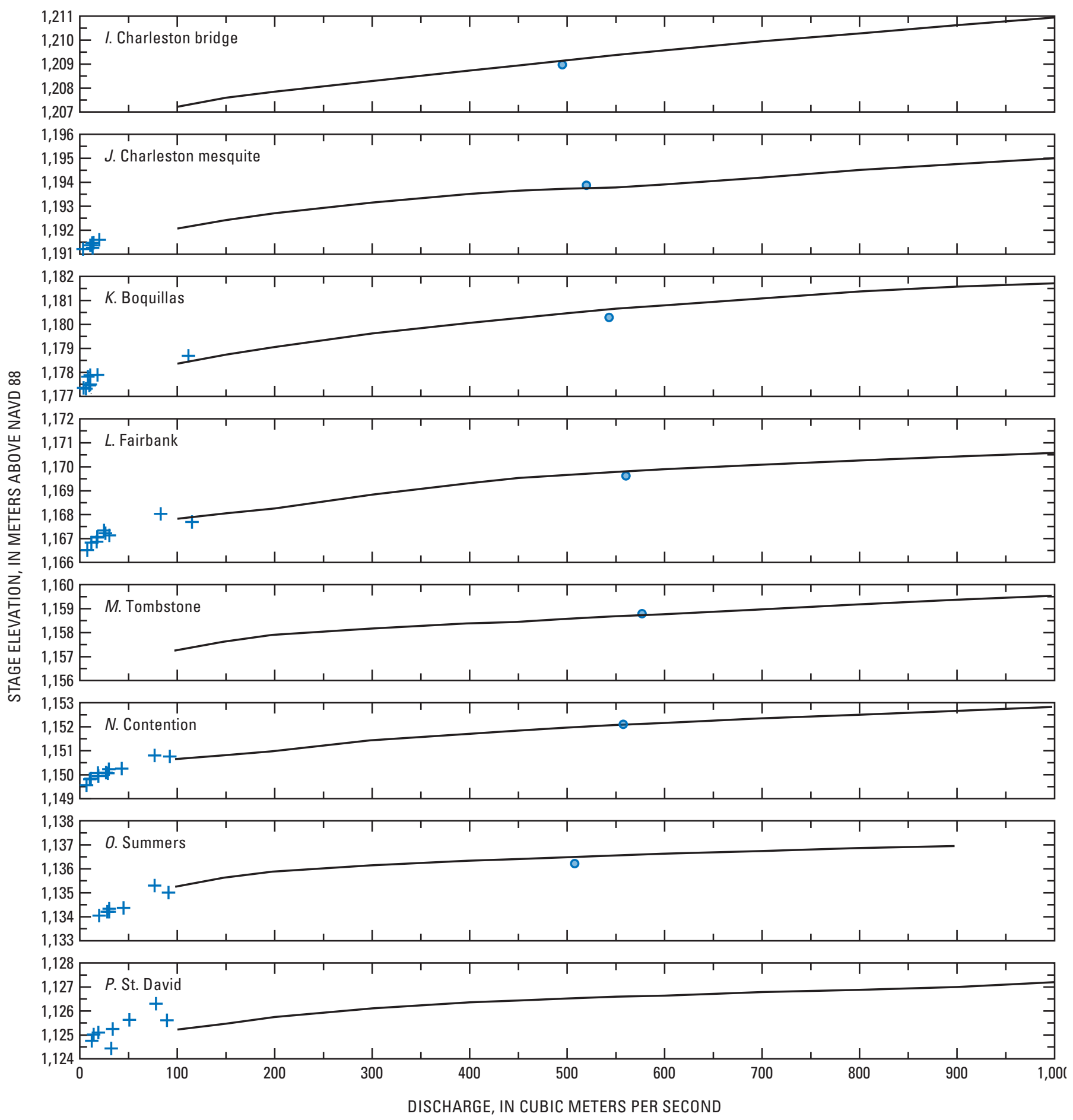

Figure 18. Continued. 
Table 14. Inundation elevation at each of the 16 biohydrology study sites for the 2-, 5-, 10-, 25-, and 50-year recurrence-interval floods, San Pedro Riparian National Conservation Area, Upper San Pedro Basin, Arizona

\begin{tabular}{lccccc}
\hline & \multicolumn{4}{c}{ Inundation elevation (above NAVD of 1988) } \\
\cline { 2 - 5 } \multicolumn{1}{c}{ Site } & $\begin{array}{c}\text { 2-year } \\
\text { (meters) }\end{array}$ & $\begin{array}{c}\text { 5-year } \\
\text { (meter) }\end{array}$ & $\begin{array}{c}\text { 10-year } \\
\text { (meters) }\end{array}$ & $\begin{array}{c}\text { 25-year } \\
\text { (meters) }\end{array}$ & $\begin{array}{c}\mathbf{5 0 - y e a r ~} \\
\text { (meters) }\end{array}$ \\
\hline Palominas south & $1,293.0$ & $1,293.5$ & $1,293.7$ & $1,294.0$ & $1,294.3$ \\
Palominas & $1,288.6$ & $1,288.9$ & $1,289.1$ & $1,289.2$ & $1,289.3$ \\
Kolbe & $1,274.4$ & $1,275.0$ & $1,275.4$ & $1,275.8$ & $1,276.1$ \\
Hereford & $1,263.0$ & $1,263.4$ & $1,263.8$ & $1,264.1$ & $1,264.4$ \\
Hunter & $1,253.7$ & $1,254.1$ & $1,254.2$ & $1,254.7$ & $1,254.9$ \\
Cottonwood & $1,243.2$ & $1,243.7$ & $1,244.2$ & $1,244.5$ & $1,244.8$ \\
Lewis Springs & $1,234.8$ & $1,235.2$ & $1,235.5$ & $1,235.8$ & $1,236.1$ \\
Moson & $1,214.4$ & $1,215.2$ & $1,215.6$ & $1,215.8$ & $1,216.5$ \\
Charleston bridge & $1,207.7$ & $1,208.4$ & $1,209.0$ & $1,210.1$ & $1,211.0$ \\
Charleston mesquite & $1,192.7$ & $1,193.2$ & $1,193.7$ & $1,194.3$ & $1,195.1$ \\
Boquillas & $1,179.1$ & $1,179.7$ & $1,180.4$ & $1,181.2$ & $1,181.8$ \\
Fairbank & $1,168.1$ & $1,168.9$ & $1,169.9$ & $1,170.2$ & $1,170.6$ \\
Tombstone & $1,156.9$ & $1,157.3$ & $1,157.6$ & $1,158.2$ & $1,158.6$ \\
Contention & $1,151.0$ & $1,151.5$ & $1,152.0$ & $1,152.5$ & $1,152.9$ \\
Summers & $1,135.9$ & $1,136.2$ & $1,136.5$ & $1,136.8$ & $1,137.0$ \\
St. David & $1,125.8$ & $1,126.3$ & $1,126.6$ & $1,126.9$ & $1,127.4$ \\
\hline
\end{tabular}

\section{Summary}

This chapter presents hydrologic data to support the riparian biohydrology study (chapter C) of the San Pedro River in the SPRNCA. The results presented here quantify four hydrologic variables important to riparian health and diversity: (1) depth to ground water beneath hydrology/biohydrology transects, (2) percentage of time streamflow persists in the channel at each study site (streamflow permanence), (3) monthly mean stream discharge at each study site, and (4) inundation frequency along the hydrology/biohydrology transect at each of the 16 biohydrology study sites.

Sixteen sites were established along the San Pedro River within the confines of the SPRNCA to represent a variety of hydrologic and vegetative conditions. Crosssectional hydrology/biohydrology transects were identified and marked at each site. Piezometers were installed at each study site and stream-stage recorders, temperature sensors, and electrical-resistance sensors were installed at selected sites. The long-term streamflow-gaging stations at Palominas, Charleston, and Tombstone were used as part of the data-collection network.
Depths to ground water beneath survey points along the hydrology/biohydrology transects were determined using water-level data collected in piezometers at each site. The piezometer data were used to estimate the water-level gradient underlying the hydrology/biohydrology transect on the same side of the river as the piezometers. Many of the transects were not perpendicular to the regional gradient so that the estimated gradient on the measured side of the river could not be extended directly to the opposite side. Instead, the water-level gradient beneath the transect on the monitored side of the river and the regional gradient were treated as apparent dips and used to estimate the true dip direction and magnitude. The true dip was mirrored to the opposite side of the river and used to estimate the water-level gradient beneath the transect as an apparent dip. Depth to water beneath the surveyed points showed an annual cyclic variability with lows in the early summer and fall and highs in the mid-summer monsoon period and the winter months. The magnitude of this variability was much greater at sites where streamflow is intermittent than at sites with perennial flow.

The percentage of time surface water persisted in the channel (streamflow permanence) was estimated on a monthly basis by using evidence from stream-stage recorders, 
site visits, discharge measurements, temperature recorders, and electrical-resistance sensors. Study results indicate a continuous perennial reach between the Cottonwood and an unknown location between the Charleston bridge and Charleston mesquite sites. Interrupted-perennial flow exists between Palominas south and Hunter and from an unknown location between Charleston bridge and Charleston mesquite to Boquillas. The downstream reach from Boquillas to St. David has intermittent flow with increasingly long dry periods in areas closer to St. David. The temporal pattern of flow illustrates several aspects of the system: (1) release of storage from a large flood in October 2000 maintained flow in the river in most areas for about 12 months, (2) after stored water from October 2000 had drained, the intermittent sites stopped flowing in the early summer and again in the fall when precipitation was low and ET was high, and (3) percentage of monthly dry time increased during the study period. Analysis of long-term records at the Palominas and Tombstone gaging stations showed higher streamflow permanence for 90 percent of the record than in 2003.

The analysis of temporal patterns of streamflow helped identify three annually recurring periods in which streamflow is controlled by the interaction between precipitation, ET and regional ground-water inflow. A winter period occurs from November through March when ET, precipitation, and runoff are low, and flow is present at all sites at least part of the time. A spring/fall period occurs during the spring/early summer months of April through June and the fall months of September and October when ET is high but precipitation and runoff are low. Flows in this period include the lowest values each year, and the river dries up at many sites. A monsoon period occurs during the summer monsoon season (July and August) when ET is high but substantial rains generate runoff and bank storage. An additional condition that profoundly affects streamflow is the irregularly recurring flood event. The flows of October 2000 caused sufficient bank storage to perturb the annual cycle of streamflow for about a year.

Monthly mean streamflow was estimated at 13 ungaged study sites by correlating measured discharges at the sites with discharges recorded at 3 permanent streamflowgaging stations (Palominas, Charleston, and Tombstone). Regression relations were calculated between discharge measurements at each site and discharge at the closest two streamflow-gaging stations. Separate regressions were calculated for measurements collected during each of the three annually recurring streamflow periods because different processes control flow in each of the periods. The quality of estimation provided by each regression was judged by the SEE and the error relative to mean measured flow. Values of SEE from all the regressions range from 0.003 to $0.292 \mathrm{~m}^{3} / \mathrm{s}$ and average $0.07 \mathrm{~m} / \mathrm{s}$. Errors expressed in percent of mean flow range from 3 to 97 percent, and the mean error is 26 percent.

Flood-inundation calculations for recurrence intervals of $2,5,10,25$, and 50 years provided estimates of the statistical frequency with which specific elevations along the study cross sections are submerged as a result of high flows. Two techniques were used to estimate inundation frequency: modeling using HEC-RAS and rating-curve development from estimated-discharge and measured stage. 
This page left blank intentionally. 


\title{
Chapter C
}

\section{Relations between Streamflow Regime and Riparian Vegetation Composition, Structure, and Diversity within the San Pedro Riparian National Conservation Area, Arizona}

\author{
By Juliet C. Stromberg', Sharon J. Lite', Mark Dixon', Tyler Rychener', and Elizabeth Makings ${ }^{1}$
}

\section{Introduction}

\section{Overview of Chapter}

This chapter details and summarizes efforts to determine the temporal and spatial water needs of riparian vegetation within the SPRNCA. Specific research goals were to: (1) quantify relations between riparian vegetation traits (biomass structure, species composition, species diversity, population-age structure) and site hydrology (ground-water levels, base flows, floodflows); (2) assess temporal trends in riparian forest composition within relatively uniform reaches of the river; and (3) develop a quantitative, multimetric rating system for riparian ecosystem functioning condition, map the functioning condition by reach, and describe the hydrologic conditions needed to maintain various levels of ecosystem function.

Reaches and study sites are described in chapter A. Three sections address relations between stream hydrology and riparian vegetation. The section titled "Biohydrology Analysis: Biomass Structure and Species Diversity” focuses on community-level attributes (biomass structure, species richness), and the following two sections focus on particular plant species and functional groups. The "Trend Analysis" section examines spatial patterns and temporal trends in establishment rates of two of the dominant woody plants [Fremont cottonwood (Populus fremontii), Goodding willow (Salix gooddingii)] and examines patterns of abundance of these trees relative to that of tamarisk, a deeper-rooted riparian species. The section titled "Functioning Condition Analysis" draws from the findings of the prior sections to provide a synthesis of the response of the riparian ecosystem to changes in water availability; here a model is described for assessing the riparian ecosystem as a function of hydrology-sensitive indicators. This section also describes the distribution of vegetation in various condition classes over the length of the SPRNCA. Appendix 6 lists the common and associated scientific names for plants included in this study.

${ }^{1}$ School of Life Sciences, Arizona State University, Tempe, Arizona.

\section{Overview of Environmental Flow Assessment}

Growing human populations are placing increasing demands on freshwater resources that are altering water regimes and contributing to degradation and loss of functioning for many riverine ecosystems (Nilsson and Svedmark, 2002). Riparian areas provide services of direct importance to society, such as drinking or irrigation water, but also provide functions of indirect import, such as groundwater recharge, flood-water dissipation, water purification, sediment detention, and biodiversity maintenance (National Research Council, 2002). A challenge for environmental managers is to design and implement programs that allow a balance between societal water needs and the water needed to sustain freshwater ecosystems (Naiman and others, 2002; Richter and others, 2003).

A global recognition of the environmental degradation resulting from hydrological alteration of rivers has led to the establishment of the science of environmental flow assessment. Environmental flow assessments determine "to what extent the flow regime of a river can be altered for the purpose of water resource development and management while maintaining an acceptable level of ecosystem integrity" (Tharme, 2003). One product of an environmental flow assessment is a description of ecosystem conditions under various hydrologic regimes. Ideally, this assessment should incorporate different spatial and temporal scales (Nilsson and Svedmark, 2002).

Early approaches to flow assessment focused on instream habitat. The Tennant (1976) approach, for example, uses summary tables of flow statistics to recommend water needs for maintaining fish habitat. Habitat-rating approaches use quantitative analysis of hydrologic, hydraulic, and biological data to estimate the flow regime that will support desired species and ecosystem functions (Reiser and others, 1989). During the last 10-20 years, the holistic approach, which recommends hydrologic regimes for the maintenance of the entire riverine ecosystem, inclusive of aquatic and riparian components, has become popular (Ward and Stanford, 1987; Petts, 1989). This approach relies on quantitative flow-ecology models and commonly incorporates tools from earlier methods, including threshold-based analyses (King and Louw, 1998; King and others, 2003). 
The holistic approach encompasses flow needs (surface and subsurface) of riparian vegetation (Hughes and Rood, 2003; Tharme, 2003). Researchers have used hydrological models to predict or assess change in vegetation (Van Diggelen and others, 1991; Nestler and Long, 1997), and, conversely, used vegetation as an indicator of water availability levels (Wierda and others, 1997; Reid and Brooks, 2000). Various studies have quantified effects of water reduction on riparian vegetation, and quantified the water levels needed to maintain specific attributes of the riparian plant community, such as plant species diversity and richness, species composition, vegetation structure and abundance, establishment and survival of dominant tree species, and plant growth and vigor (Stromberg and Patten, 1990, 1995; Smith and others, 1991; Stromberg and others, 1992; Shafroth and others, 1998, 2000, 2002; Johnson and others, 1999; Scott and others, 1999; Muñoz-Reinoso, 2001; Capon, 2003; Cooper and others, 2003).

A key management question in the Upper San Pedro Basin is, "How much water is required to maintain a healthy riparian corridor?" The studies in this chapter have addressed this water needs question from varied perspectives. Measurement of evapotranspiration (ET) rates of various riparian plant associations, when linked with maps of the location and abundance of the vegetation types, provides a measure of the total consumptive water needs of the riparian vegetation in the corridor (see chapter D). The riparian condition assessment described herein augments this approach by specifying the spatial and temporal patterns of water that have maintained the vegetation in various condition classes, each of which represent various types of vegetation structure and composition and functional capacity. This chapter examines present ecosystem conditions at many sites in order to understand how the ecosystem at one site might change in response to a change in the hydrologic regime.

\section{Methods}

A study site consisted of a river segment about $500 \mathrm{~m}$ in length (fig. 19). At each site, two to five biohydrology belt transects (20 m wide) were established, spaced about $100 \mathrm{~m}$ apart. Transects were perpendicular to the river flow and extended on both sides of the river from the channel thalweg (low point) to the approximate edge of the active (100-year) flood plain. Three of these transects then extended laterally for an additional $100 \mathrm{~m}$ on the upper river terraces. These additional 100-m lateral swaths generally did not encompass the full extent of the upper terrace riparian zones, which in some cases extend laterally for several hundred meters. They did, however, encompass a representative segment of the upper terrace vegetation. See chapter A for additional information about the study sites.

\section{Vegetation Sampling Zones}

At each site, vegetation was sampled in plots (or quadrats) within three fluvial zones, which are refered to as the streamside, flood plain (post-entrenchment alluvium), and terrace (pre-entrenchment alluvium) zones (fig. 2). Each of these zones contains vegetation that is part of the riparian system. The streamside zone comprises low fluvial surfaces associated with active channel bars and streambanks and is typically quite narrow $(<10 \mathrm{~m})$. The flood plain, as defined by Graf (1988), is "the surface adjacent to the channel, separated from the channel by banks, and built of materials deposited in the present regime of the river". This is consistent with Leopold's (1997) statement that "the flood plain is defined as the flat area bordering a stream, constructed by the river in the present climate and inundated during periods of high flow." Vegetation and geomorphic characteristics were used to delineate this flood-plain zone. The cottonwood-willow forests (with the exception of a few old-growth patches) generally define the flood-plain zone. Mean flood-plain width ranged among sites from $63 \mathrm{~m}$ (Tombstone) to $378 \mathrm{~m}$ (Contention). The flood-plain zone also can be considered as consisting of several low terraces, each of which has different elevations above the thalweg and different inundation frequencies (Hereford, 1993).

The terrace is referred to in this report as the preentrenchment surface that is elevated substantially above the channel bed (usually by at least $5 \mathrm{~m}$ ). The terraces are typically vegetated by mature mesquite bosques, dense sacaton grasslands, or old-field vegetation (on fallow fields; fig. 20). A few old cottonwoods persist on terraces in some areas. Terrace riparian vegetation extends for several hundred meters from the flood plain and grades gradually into upland (nonphreatophytic) vegetation.

\section{Site Hydrology}

Hydrologic data were collected by U.S. Geological Survey (USGS) personnel at one hydrology/biohydrology transect at each of the 16 biohydrology sites (chapter B). USGS personnel measured depth to ground water at nested piezometers installed in the flood plain (post-entrenchment) alluvium and this information was used to estimate depth to the water table for each vegetation patch and to obtain flood-plain-weighted annual mean, maximum, and minimum depths to ground water for each site (table 15). The groundwater surface under the flood plain was interpolated from the well points and from river depth; depth to ground water across the flood plain was calculated as the difference between the land surface and ground-water elevations at each survey point (see chapter B, appendix 3). Water-table fluctuation was calculated as the difference between the flood-plain-weighted values for minimum winter depth (monthly average during the wettest month of the NovemberMarch wet season) and maximum summer depth (monthly 
average during the driest month of the early summer or fall dry seasons). One site (Cottonwood) did not have reliable ground-water information and was excluded from the ground-water analysis. At the U.S. Geological Survey streamflow-gaging station, San Pedro River near Tombstone (09471550), ground water briefly dropped below the bottom of a piezometer and ground-water depth values may be deeper than those reported.

The USGS also provided data on streamflow permanence (see chapter B). Annual streamflow permanence is defined as the percentage of days in the water year in which any surface flow was present in the river. Data were available for water years 2001 (subset of sites), 2002, and 2003. The data set for 2001 was augmented by hydrology data collected by Lite (2003). Lite (2003) calculated streamflow-permanence data from 12 monthly site visits to detect flow presence/absence; values are similar to those calculated using the daily flow measurements of the USGS.

For some comparisons, water year 2002 streamflow permanence data were used to divide the sites into three categories: (1) perennial, (2) intermittent-wet (flow permanence from 60 to 90 percent), and (3) intermittent-dry (flow permanence less than 60 percent; table 16).

\section{Biohydrology Analysis: Riparian Vegetation Biomass Structure and Species Richness}

\section{Objective and Methods}

Objective.- Quantify relations between site hydrology and riparian vegetation biomass structure and species richness.

Methods. - Vegetation patch types were characterized along biohydrology transects using a rule-based system that classifies types as a function of dominant overstory and mid-story species, tree-size class, and plant-cover values within three strata (groundcover of 0-1 m, mid-story of 1-5 m, and canopy cover of $>5 \mathrm{~m}$ in height). Patches were classified into one of five physiognomy categories following rules developed for the National Vegetation Classification system: forest (canopy layer $>60$ percent), woodland (canopy cover of 25-60 percent), shrubland (canopy $<25$ percent and mid-stratum $>25$ percent), grassland or forbland (groundcover $>25$ percent), and open (groundcover <25 percent; Grossman and others, 1998).

The total patch width and relative width (as a percentage of the flood plain or terrace zones) of the various patch types was calculated for each transect and averaged across transects to obtain site values.

In each patch, a $10 \times 20 \mathrm{~m}\left(200 \mathrm{~m}^{2}\right)$ plot or quadrat (long axis perpendicular to the biohydrology transect) was sampled for woody-stem density and diameter, by species. Diameter was measured at ankle height. Data were collected separately for live and dead individuals. Shrub cover, by species, was measured using the line intercept method along two, 10-m lines per study plot. Canopy cover was measured by species using a spherical densiometer, at three points within each 200- $\mathrm{m}^{2}$ plot, and includes all canopies above $1 \mathrm{~m}$ (mid-story and canopy layer).

Vegetation volume encompasses horizontal and vertical dimensions and is an indicator of biomass structure and wildlife habitat quality. Three measurements of vegetation volume were taken per plot, using the vertical line intercept method (Mills and others, 1991). For these measurements, a 9.5-m pole, marked in meters and decimeters, was extended vertically from the ground surface through the canopy, and the number of decimeter "hits" was recorded within each meter interval. A hit was defined as any vegetation within a $10-\mathrm{cm}$ radius of the pole, per vertical decimeter. Canopy heights above $9.5 \mathrm{~m}$ were estimated as either three or seven hits per interval, by species. These estimations were based on comparisons with lower intervals where hits can be directly measured. All of these woody-vegetation measurements were scaled to the site level by first weighting the plot means by the width of each respective patch along the transect, and then taking averages across transects. The canopyheight measurements were used to determine the maximum vegetation height recorded along each flood-plain transect. Woody-species richness was counted within each $200-\mathrm{m}^{2}$ study plot and within a 20-m-wide belt that spanned the floodplain and terrace zones.

In each patch, cover of herbaceous vegetation, by species, was estimated within a $1-\mathrm{m}^{2}$ plot, using cover classes (Mueller-Dombois and Ellenberg, 1974). If a patch was wider than $50 \mathrm{~m}$, one additional plot was sampled in each additional 25-m increment. Within the streamside zone of each biohydrology transect, herbaceous data were collected in five, $1-\mathrm{m}^{2}$ plots. Herbaceous species richness was measured within the plots and in a 1-m-wide belt transect that spanned the flood-plain/terrace zone. Herbaceous data were collected in the early summer dry season (May-June) and late summer monsoonal wet season (August-September). Herbaceous data were scaled to the site level by averaging values across plots.

To determine the importance of site hydrology on vegetation biomass structure and richness, vegetation patterns were analyzed at the site level using Pearson product-moment correlation analysis. Data were analyzed separately for vegetation in the flood-plain zone and terrace zone, and for some variables, in the streamside zone. Vegetation variables included site averages for vegetation volume, upper-canopy vegetation volume, woody-plant basal area, woody-plant stem density, vegetation height, canopy cover, herbaceous cover, relative widths of the five physiognomic vegetation types, plot-level herbaceous species richness, and transect-level woody-species richness. 


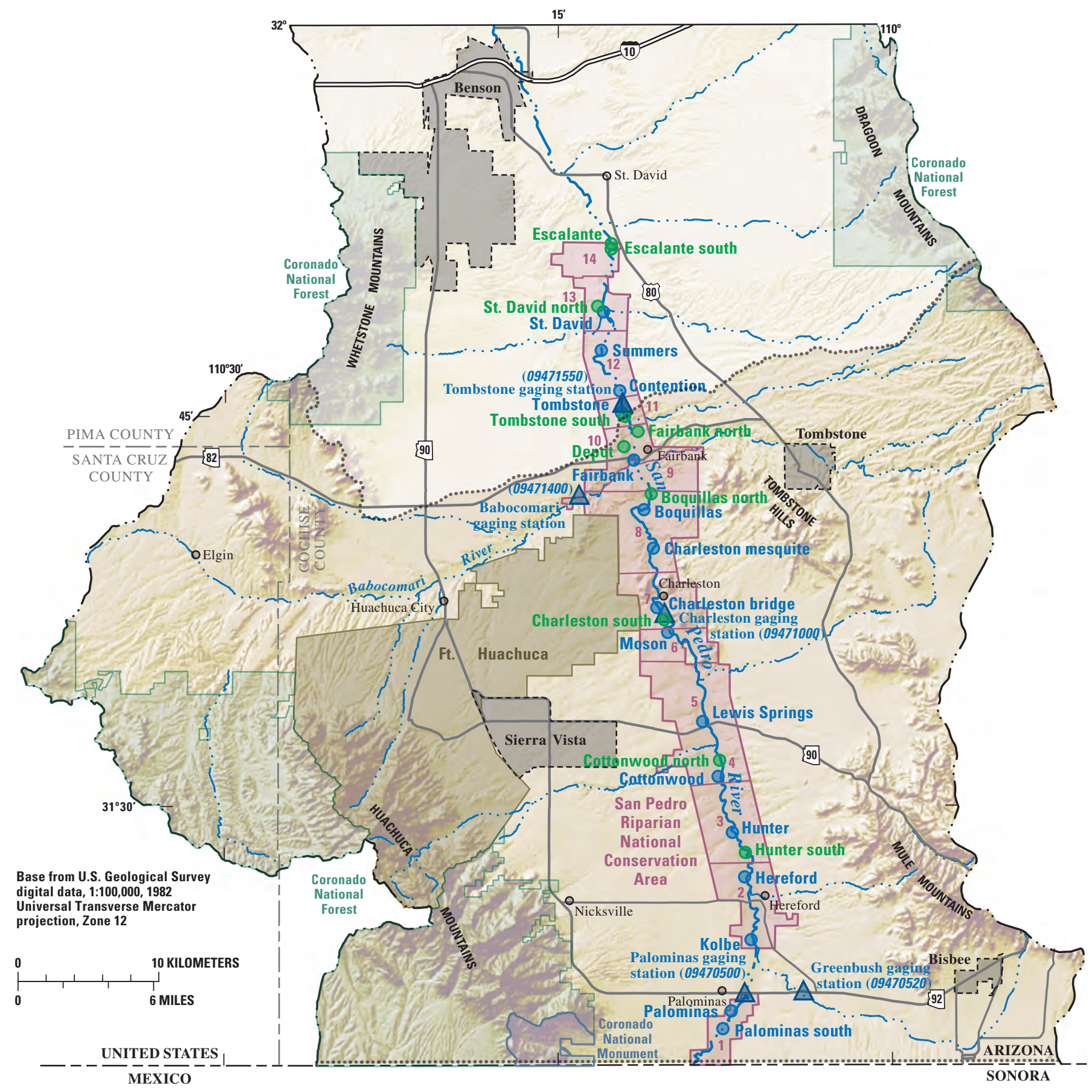

EXPLANATION

\section{$\triangle$ U.S. GEOLOGICAL SURVEY STREAMFLOW- GAGING STATION \\ O BIOHYDROLOGY STUDY SITE \\ O SUPPLEMENTAL RIPARIAN STUDY SITE}

Figure 19. Boundaries of the 14 reaches of the San Pedro River within the San Pedro Riparian National Conservation Area and locations of biohydrology and supplemental riparian study sites, Upper and Lower San Pedro Basins, Arizona. 


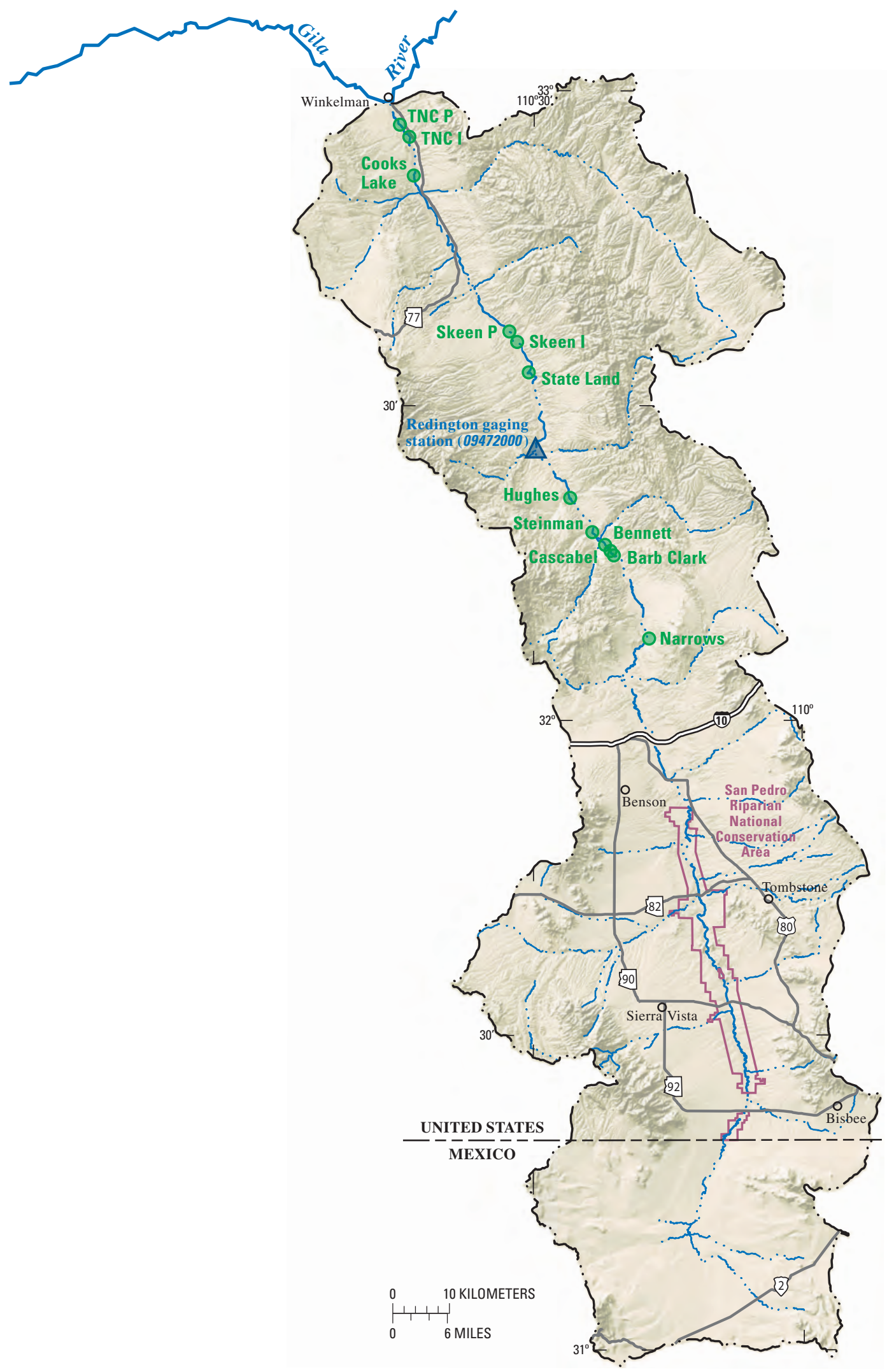

Figure 19. Continued. 


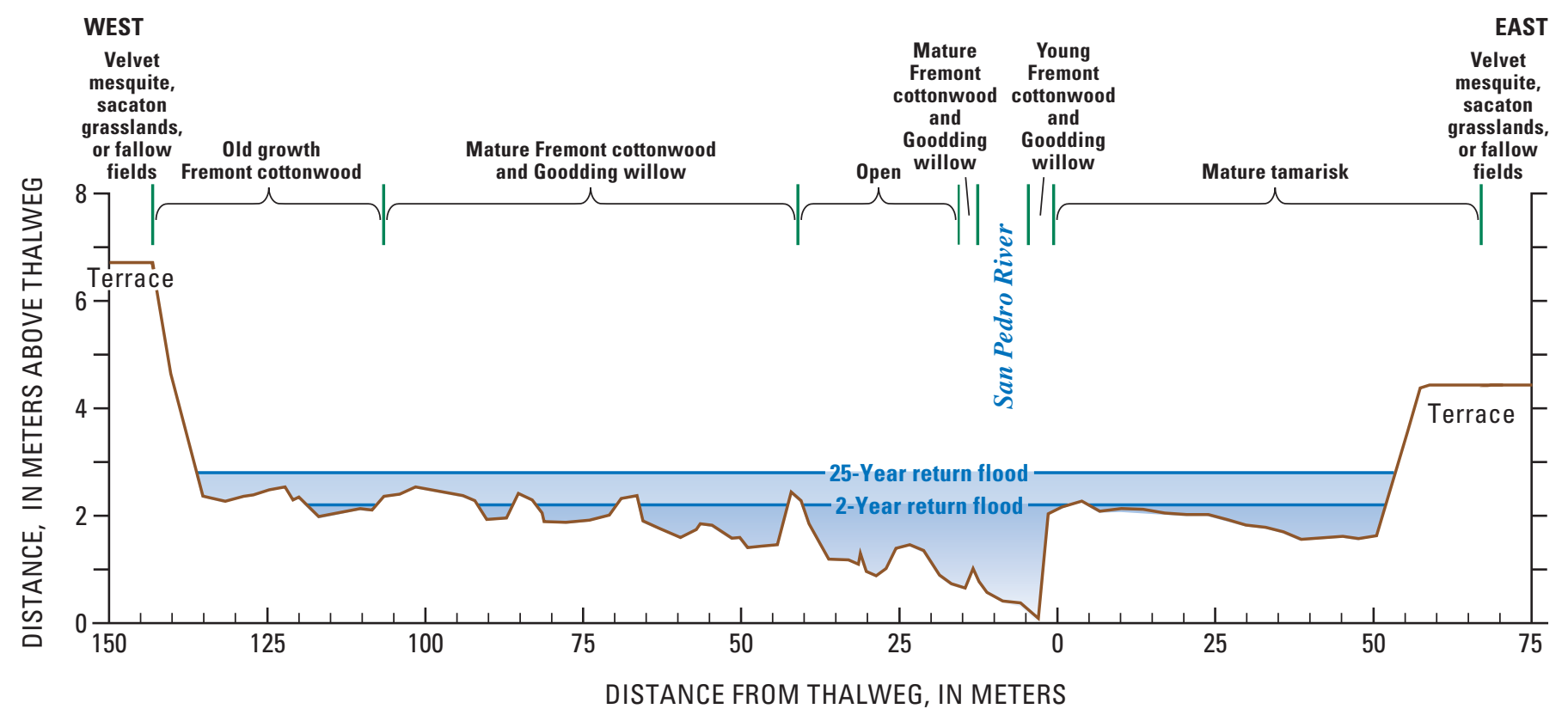

Figure 20. Surveyed cross section for the Palominas site hydrology/biohydrology transect, showing vegetation patches and modeled river stages for 2-year and 25-year return-period floods, San Pedro Riparian National Conservation Area, Upper San Pedro Basin, Arizona.

Table 15. Hydrologic characteristics of the 16 biohydrology study sites, San Pedro Riparian National Conservation Area, Upper San Pedro Basin, Arizona

[min, minimum; max, maximum; N/s, newtons per second; ---, no data]

\begin{tabular}{|c|c|c|c|c|c|c|c|c|c|}
\hline \multirow[b]{2}{*}{$\begin{array}{l}\text { Reach } \\
\text { number }\end{array}$} & \multirow[b]{2}{*}{ Site name } & \multirow{2}{*}{$\begin{array}{c}\text { Streamflow } \\
\text { permanence } \\
2002 \text { water year } \\
\text { (percent) }\end{array}$} & \multirow{2}{*}{$\begin{array}{c}\text { Streamflow } \\
\text { permanence } \\
2003 \text { water year } \\
\text { (percent) }\end{array}$} & \multicolumn{4}{|c|}{$\begin{array}{l}\text { Flood-plain ground-water depth, } \\
2002 \text { water year }\end{array}$} & \multicolumn{2}{|c|}{ Flood stream power } \\
\hline & & & & $\begin{array}{l}\text { Mean } \\
\text { (meters) }\end{array}$ & $\underset{\text { (meters) }}{\text { Min }}$ & $\begin{array}{c}\text { Max } \\
\text { (meters) }\end{array}$ & $\begin{array}{l}\text { Max-min } \\
\text { (meters) }\end{array}$ & $\begin{array}{l}\text { 10-year } \\
\text { flood } \\
\text { (N/s) }\end{array}$ & $\begin{array}{c}\text { 100-year } \\
\text { flood } \\
(\mathrm{N} / \mathrm{s})\end{array}$ \\
\hline 1 & Palominas south & 73 & 49 & 2.4 & 2.2 & 3.0 & 0.8 & 11,341 & 22,922 \\
\hline 1 & Palominas & 71 & 45 & 1.7 & 1.5 & 2.1 & .6 & 4,164 & 9,967 \\
\hline 2 & Hereford & 100 & 90 & 1.1 & 1.1 & 1.3 & .2 & 4,259 & 11,949 \\
\hline 3 & Hunter & 68 & 63 & 1.8 & 1.5 & 2.2 & .7 & 13,981 & 21,140 \\
\hline 4 & Cottonwood & 100 & 100 & --- & --- & --- & --- & 4,697 & 16,454 \\
\hline 5 & Lewis Springs & 100 & 100 & 1.7 & 1.5 & 1.8 & .3 & 12,788 & 18,670 \\
\hline 8 & Charleston mesquite & 100 & 92 & 2.6 & 2.4 & 3.1 & .8 & 18,063 & 62,451 \\
\hline 8 & Boquillas & 100 & 100 & 2.3 & 2.2 & 2.3 & .1 & 7,995 & 25,615 \\
\hline 9 & Fairbank & 80 & 69 & 3.4 & 3.1 & 3.9 & .7 & 12,149 & 33,595 \\
\hline 11 & Tombstone & 65 & 61 & 3.1 & 2.3 & 4.2 & 1.9 & 17,210 & 51,455 \\
\hline 12 & Contention & 56 & 40 & 3.0 & 2.2 & 4.2 & 2.0 & 14,183 & 27,448 \\
\hline 12 & Summers & 88 & 49 & 2.1 & 1.9 & 2.3 & .3 & 12,917 & 65,172 \\
\hline 13 & St. David & 48 & 21 & 2.5 & 1.7 & 3.5 & 1.8 & 23,453 & 26,913 \\
\hline
\end{tabular}


Table 16. Means and standard deviations of hydrologic variables for biohydrology sites, classified into three hydrologic classes, San Pedro Riparian National Conservation Area, Upper San Pedro Basin, Arizona

$[ \pm$, plus or minus $]$

\begin{tabular}{|c|c|c|c|c|c|c|}
\hline (8) & Perennial & $100 \pm 0$ & $98 \pm 4$ & $1.8 \pm 0.6$ & $2.0 \pm 0.7$ & $0.3 \pm 0.2$ \\
\hline (2) & Intermittent-dry & $52 \pm 6$ & $29 \pm 16$ & $2.8 \pm 0.3$ & $3.8 \pm 0.5$ & $1.9 \pm 0.2$ \\
\hline
\end{tabular}

Hydrology variables included site values for streamflow permanence, annual mean and maximum depth to ground water (spatially and temporally averaged across the flood plain), and annual extent of ground-water fluctuation. Unless otherwise indicated, statistical analyses were conducted using ground-water values for the 2002 water year and using streamflow permanence values averaged across water years 2002 and 2003.

Biomass structure and species richness were analyzed in relation to average long-term flood intensity at a site, as indicated by total stream power of the 10- and 100-year recurrence-interval floods (table 15), using values for the SPRNCA resulting from flow modeling (see chapter B). Total stream power for the recurrence-interval floods for the 16 SPRNCA biohydrology sites was calculated with HEC-RAS 3.1 using hydrologic and cross-section data supplied by the USGS. Total stream power $(\Omega)$, derived from Gordon and others (1992) may be expressed as

$$
(\Omega)=\gamma R S V W
$$

where

$$
\begin{aligned}
\gamma & =\text { unit weight of water }\left(9,799 \mathrm{~N} / \mathrm{m}^{3}\right) \\
R & =\text { hydraulic radius }(\mathrm{m}) \\
S & =\text { hydraulic slope, } \\
V & =\text { velocity }(\mathrm{m} / \mathrm{s}), \text { and } \\
W & =\text { width }(\mathrm{m}) .
\end{aligned}
$$

To account for effects of fire, correlation coefficients were calculated between hydrology and vegetation variables using data that included all biohydrology study sites (four of which were burned recently) and data that included only unburned sites $(n=12)$. Vegetation variables were related to mean flood-plain width (for flood-plain zone vegetation) and to site elevation (which is synonymous with distance downstream) by using correlation analysis.
Prior to statistical analysis, percentage values (for example, plant cover, streamflow permanence) were square-root transformed to approximate normal distributions. For assessment of statistical significance, alpha was set at 0.10 and beta at 0.90 , to minimize the chances of committing a "Type II" error in which one fails to detect a relationship when one exists (an issue of concern in conservation-focused studies). This alpha level was chosen because of the relatively small site sample sizes and the complexity of riparian ecosystems, in which many environmental factors interact to shape the riparian vegetation.

\section{Woody Vegetation Biomass Structure}

Only a few biomass structure variables varied significantly with water availability at the site scale. The strongest correlation was for vegetation height. Wetter sites had significantly higher values for maximum flood-plain vegetation height, reflecting the capacity of wetter sites to support tall hydromesic trees such as cottonwood (tables 17 and 18). Mean maximum vegetation height at the two driest SPRNCA sites (Contention and St. David) was $13 \pm 0 \mathrm{~m}$, compared to $21 \pm 4 \mathrm{~m}$ at the eight wettest sites (appendix 7, table 7-A; figure 21). Appendix 6 lists the common and associated scientific names for plants included in this study. Riparian zone fire reduced canopy height, so the relations with hydrology variables were generally weaker when including burned sites in the data set.

Mean flood-plain vegetation volume ranged among SPRNCA sites from 1 to $3.7 \mathrm{~m}^{3} / \mathrm{m}^{2}$, whereas vegetation volume in the upper canopy layers (above $8 \mathrm{~m}$ ) ranged among sites from 0 to $2.0 \mathrm{~m}^{3} / \mathrm{m}^{2}$ (appendix 7, table 7-B). 
Table 17. Correlation coefficients ( $r$ values) between San Pedro Riparian National Conservation Area flood-plain vegetation structure traits and three site attributes (streamflow permanence, maximum depth to ground water, and ground-water fluctuation), Upper San Pedro Basin, Arizona

$[n$, site sample size; $r$, correlation coefficient; $p$, level of significance; NS, not significant at $p$ less than $0.10 ;>$, greater than; significant correlations (at $p<0.10$ ) are shown in bold]

\begin{tabular}{|c|c|c|c|c|c|c|c|c|}
\hline \multirow[b]{3}{*}{ Vegetation structure trait } & \multicolumn{8}{|c|}{ Correlation variable } \\
\hline & \multicolumn{4}{|c|}{ Streamflow permanence } & \multicolumn{2}{|c|}{$\begin{array}{c}\text { Maximum depth to } \\
\text { ground water } \\
(n=11)^{1} \\
\end{array}$} & \multicolumn{2}{|c|}{$\begin{array}{c}\begin{array}{c}\text { Ground-water } \\
\text { fluctuation }\end{array} \\
(n=11)^{1} \\
\end{array}$} \\
\hline & $r$ & $p$ & $r$ & $p$ & $\boldsymbol{r}$ & $p$ & $r$ & $p$ \\
\hline & \multicolumn{8}{|c|}{ Woody-vegetation attributes } \\
\hline Vegetation volume $>8$ meters & .26 & NS & .05 & NS & -.09 & NS & -.27 & NS \\
\hline Vegetation volume & .01 & NS & -.19 & NS & .02 & NS & -.03 & NS \\
\hline Canopy cover & .11 & NS & -.19 & NS & -.11 & NS & -.39 & NS \\
\hline Basal area & .44 & NS & .31 & NS & .29 & NS & -.09 & NS \\
\hline Woodland & .67 & 0.02 & .50 & 0.05 & -.50 & NS & -.75 & 0.01 \\
\hline Shrubland & -.65 & .02 & -.70 & .00 & .44 & NS & .53 & NS \\
\hline Herbaceous & -.08 & NS & .17 & NS & .05 & NS & -.75 & .01 \\
\hline Open & .39 & NS & .23 & NS & -.48 & NS & -.37 & NS \\
\hline
\end{tabular}

${ }^{1}$ Unburned sites only.

Table 18. Correlation coefficients ( $r$ values) between San Pedro Riparian National Conservation Area flood-plain vegetation structure traits and three site attributes (total stream power of the 100-year recurrence flood as a measure of flood intensity, site elevation, and flood-plain width), Upper San Pedro Basin, Arizona

[ $n$, site sample size; $r$, correlation coefficient; $p$, level of significance; NS, not significant at $p$ less than 0.10 ; significant correlations (at $p<0.10$ ) are shown in bold]

\begin{tabular}{|c|c|c|c|c|c|c|c|c|}
\hline \multirow[b]{4}{*}{ Vegetation structure trait } & \multicolumn{8}{|c|}{ Correlation variable } \\
\hline & \multicolumn{4}{|c|}{100 -year recurrence flood total stream power } & \multirow{2}{*}{\multicolumn{2}{|c|}{$\begin{array}{c}\text { Elevation } \\
(n=20)\end{array}$}} & \multirow{2}{*}{\multicolumn{2}{|c|}{$\begin{array}{l}\text { Flood-plain width } \\
\qquad(n=20)\end{array}$}} \\
\hline & \multicolumn{2}{|c|}{$(n=16)$} & \multicolumn{2}{|c|}{$(n=12)^{1}$} & & & & \\
\hline & $r$ & $p$ & $r$ & $p$ & $r$ & $p$ & $r$ & $p$ \\
\hline & \multicolumn{8}{|c|}{ Woody-vegetation attributes } \\
\hline Maximum height & 0.35 & NS & 0.29 & NS & 0.12 & NS & 0.17 & NS \\
\hline Stem density & .38 & NS & .28 & NS & -.71 & 0.00 & .46 & 0.04 \\
\hline \multirow[t]{2}{*}{ Basal area } & .48 & .06 & .49 & NS & -.16 & NS & -.29 & NS \\
\hline & \multicolumn{8}{|c|}{ Relative patch width } \\
\hline Forest & 0.41 & NS & 0.35 & NS & -0.02 & NS & -0.06 & NS \\
\hline Woodland & .21 & NS & .36 & NS & .23 & NS & -.19 & NS \\
\hline
\end{tabular}

${ }^{1}$ Unburned sites only. 


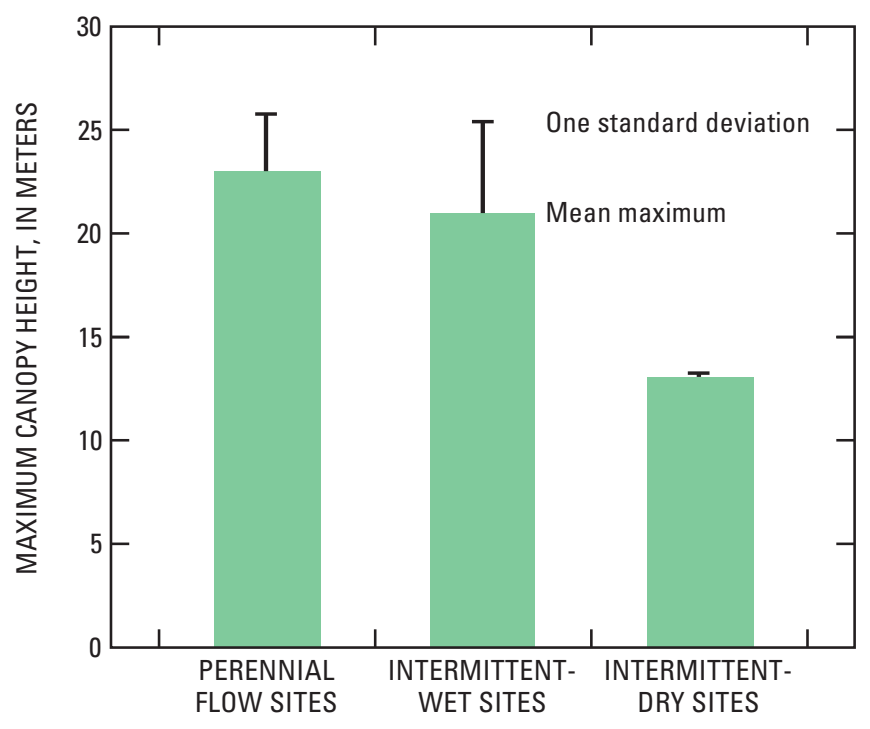

Figure 21. Mean maximum vegetation height (flood-plain zone) plus one standard deviation for sites classified into three hydrology classes (see table 16) for 12 unburned biohydrology study areas, San Pedro Riparian National Conservation Area, Upper San Pedro Basin, Arizona.

Neither vegetation volume measured correlated with surface- or ground-water availability. Although plant species composition shifted along site water-availability gradients (see following section), the plant species at wet and dry sites retained high vegetation volume. Similarly, because floodplain canopy cover encompassed the contribution from a range of tree species (from mesic species such as tamarisk to hydromesic species such as cottonwood), canopy cover at the site scale did not vary significantly with site hydrology. Woody-plant stem density decreased weakly with streamflow permanence, perhaps reflecting increases in multistemmed shrubs at the drier sites (table 17). Only a few biomass structure variables were related to flood stream power (table 18).

Vegetation biomass structure on the terrace varied strongly with site elevation (table 19), for reasons speculated on in the following discussion. Canopy cover, vegetation volume, and basal area all increased at lower elevations for data sets including and excluding burned sites.

For the flood-plain zone, two of five vegetation structure types varied in relative abundance with site hydrology (table 17). Relative patch width of the shrubland type (composed largely of tamarisk) increased at drier sites (those with more intermittent flow; fig. 22). Relative patch width of shrublands ranged among sites from 63 percent (Contention) to less than 10 percent (Hereford, Lewis Springs, Moson, Charleston bridge; table 7-B in appendix 7). Relative width of the woodland patch type (largely composed of cottonwood), in contrast, increased at wetter sites.
Table 19. Correlation coefficients ( $r$ values) between vegetation structure traits and site elevation, for the terrace zone, San Pedro Riparian National Conservation Area, Upper San Pedro Basin, Arizona

[ $n$, site sample size; $r$, correlation coefficient; $p$, level of significance; NS, not significant at $p$ less than 0.10 ; significant correlations (at $p<0.10$ ) are shown in bold]

\begin{tabular}{|c|c|c|c|c|}
\hline \multirow{4}{*}{$\begin{array}{c}\text { Vegetation } \\
\text { structure traits }\end{array}$} & \multicolumn{4}{|c|}{ Correlation variable } \\
\hline & \multicolumn{4}{|c|}{ Elevation } \\
\hline & \multicolumn{2}{|c|}{$(n=20)$} & \multicolumn{2}{|c|}{$(n=16)^{1}$} \\
\hline & $r$ & $\boldsymbol{p}$ & $r$ & $p$ \\
\hline & \multicolumn{4}{|c|}{ Woody-vegetation biomass structure } \\
\hline Canopy cover & -0.85 & 0.00 & -0.84 & 0.00 \\
\hline Stem density & -.31 & NS & -.21 & NS \\
\hline Vegetation volume & -.58 & .01 & -.55 & .03 \\
\hline Maximum height & -.43 & .06 & -.27 & NS \\
\hline \multirow[t]{2}{*}{ Basal area } & -.71 & .00 & -.63 & .01 \\
\hline & \multicolumn{4}{|c|}{ Relative patch width } \\
\hline Forest & -0.65 & 0.00 & -0.59 & 0.02 \\
\hline Woodland & -.35 & NS & -.25 & NS \\
\hline Shrubland & -.77 & .00 & -.72 & .00 \\
\hline Herbaceous & .87 & .00 & .84 & .00 \\
\hline Open & -.08 & NS & -.10 & NS \\
\hline
\end{tabular}

${ }^{1}$ Unburned sites.

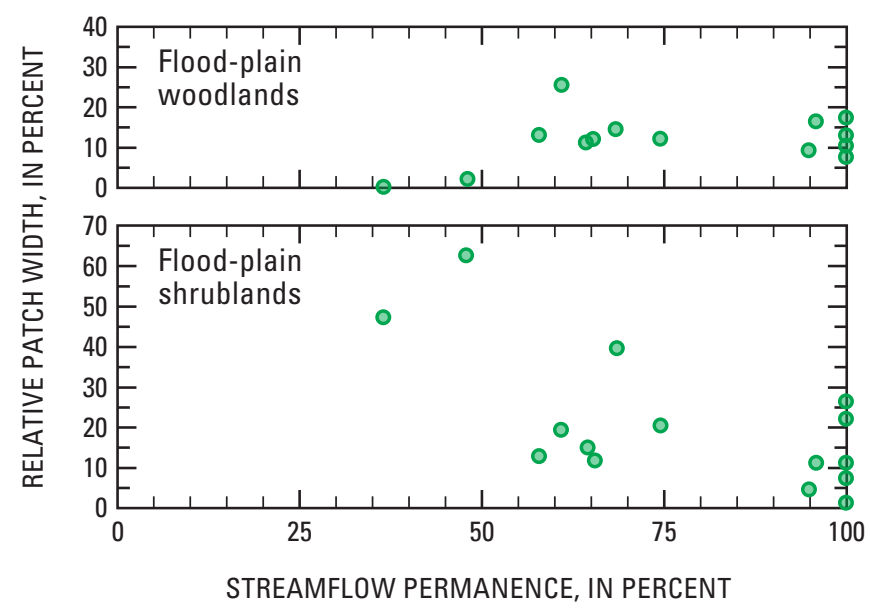

Figure 22. Relative widths of shrublands and woodlands in the flood plain of the 16 biohydrology study sites in relation to annual streamflow permanence (average of 2002 and 2003 water years), San Pedro Riparian National Conservation Area, Upper San Pedro Basin, Arizona. 
On terraces, several patch types varied in abundance with elevation/distance downstream: Forest and shrubland patches increased with distance downstream, whereas relative cover of the herbaceous (namely, grassland/forbland) patch type decreased (table 19). A transition zone is evident at about 1,200 m elevation, near the Charleston bridge site, with woody patch types becoming considerably more abundant downstream of this elevation (fig. 23). No systematic effect of fire, however, is evident in the figure. Within the flood plain, the herbaceous and shrubland patch types varied with elevation and distance in similar fashion to patterns on the terrace.
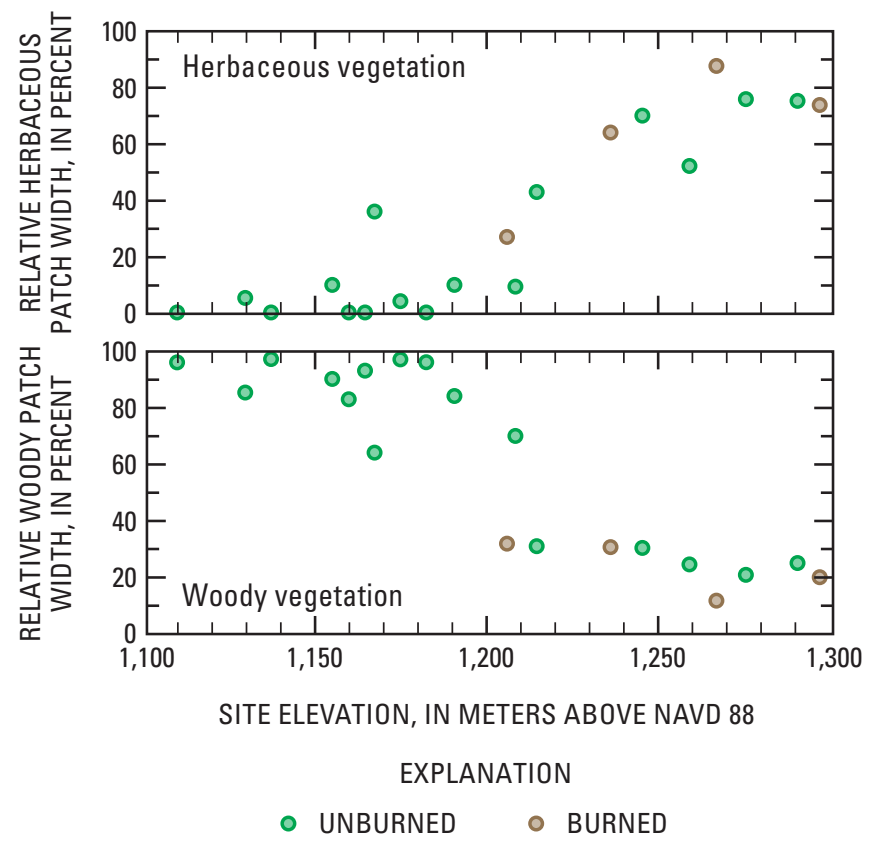

Figure 23. Relative width of terrace vegetation patches classified as herbaceous-dominated and woody-dominated (shrublands, woodlands, forests) in relation to elevation of 20 biohydrology and supplemental study sites, San Pedro Riparian National Conservation Area, Upper San Pedro Basin, Arizona.

\section{Plant Species Richness}

The total richness of woody species (combined flood plain and terrace values in belt biohydrology transects) did not vary significantly with site water availability, nor did total richness of woody species classified as hydromesic or mesic (table 20). Woody species richness did not vary with flood stream power of any recurrence interval.

During the summer dry season, herbaceous species richness and cover in the streamside zones increased among sites in relation to increased streamflow permanence (table 21). Richness values declined to about one or two species per square meter at sites with streamflow permanence below about 40 percent (fig. 24).
Table 20. Correlation coefficients ( $r$ values) between woody species richness values (per belt transect) and environmental variables, San Pedro Riparian Conservation Area, Upper San Pedro Basin, Arizona

[ $n$, site sample size; $r$, correlation coefficient; $p$, level of significance; NS, not significant at $p$ less than 0.10 ; significant correlations $($ at $p<0.10)$ are shown in bold]

\begin{tabular}{|c|c|c|c|c|c|c|c|c|}
\hline & \multicolumn{8}{|c|}{ Correlation variable } \\
\hline & \multicolumn{2}{|c|}{$\begin{array}{l}\text { Elevation } \\
\qquad(n=20)\end{array}$} & \multicolumn{2}{|c|}{$\begin{array}{c}\text { Transect } \\
\text { width } \\
(n=20)\end{array}$} & \multicolumn{2}{|c|}{$\begin{array}{l}\text { Streamflow } \\
\text { permanence } \\
\qquad(n=16)\end{array}$} & \multicolumn{2}{|c|}{$\begin{array}{l}\text { Maximum } \\
\text { depth } \\
\text { to ground } \\
\text { water } \\
\text { (n=15) }\end{array}$} \\
\hline & $\boldsymbol{r}$ & $\boldsymbol{p}$ & $\boldsymbol{r}$ & $\boldsymbol{p}$ & $\boldsymbol{r}$ & $\boldsymbol{p}$ & $r$ & $\boldsymbol{p}$ \\
\hline \multicolumn{9}{|c|}{ Belt transect richness } \\
\hline All woody species & -0.33 & NS & 0.15 & NS & -0.33 & NS & 0.16 & NS \\
\hline $\begin{array}{l}\text { Hydromesic and } \\
\text { mesic species }\end{array}$ & -.13 & NS & .45 & 0.05 & -.26 & NS & -.07 & NS \\
\hline Xeric species & -.38 & 0.10 & -.10 & NS & -.25 & NS & .28 & NS \\
\hline
\end{tabular}

Table 21. Correlation coefficients ( $r$ values) between streamside-zone herbaceous vegetation and water-year streamflow permanence, for premonsoon and monsoon sampling periods, Upper and Lower San Pedro Basins, Arizona

[ $n$, site sample size; $r$, correlation coefficient; $p$, level of significance; NS, not significant at $p$ less than 0.10; significant correlations (at $p<0.10$ ) are shown in bold. Data for 2000 and 2001 include sites in the Upper and Lower San Pedro Basins (Stromberg and others, 2005)]

\begin{tabular}{|c|c|c|c|c|c|c|c|c|c|c|}
\hline & \multicolumn{2}{|c|}{$\begin{array}{c}\text { Pre- } \\
\text { monsoon, } \\
\text { all years } \\
(n=62)\end{array}$} & \multicolumn{2}{|c|}{$\begin{array}{c}\text { Pre- } \\
\text { monsoon } \\
2000 \\
(n=18)\end{array}$} & \multicolumn{2}{|c|}{$\begin{array}{c}\text { Pre- } \\
\text { monsoon } \\
2001 \\
(n=23)\end{array}$} & \multicolumn{2}{|c|}{$\begin{array}{c}\text { Pre- } \\
\text { monsoon } \\
2002 \\
(n=13)\end{array}$} & \multicolumn{2}{|c|}{$\begin{array}{c}\text { Pre- } \\
\text { monsoon } \\
2003 \\
(n=8)\end{array}$} \\
\hline & $r$ & $\boldsymbol{p}$ & $r$ & $p$ & $r$ & $\boldsymbol{p}$ & $r$ & $p$ & $r$ & $p$ \\
\hline $\begin{array}{l}\text { Cover, } \\
\text { all species }\end{array}$ & 0.67 & 0.00 & 0.76 & 0.00 & 0.45 & 0.03 & -0.07 & NS & 0.52 & NS \\
\hline \multirow{3}{*}{$\begin{array}{l}\text { Species } \\
\text { richness }\end{array}$} & .72 & .00 & .84 & .00 & .05 & NS & .38 & NS & .81 & 0.01 \\
\hline & \multicolumn{2}{|c|}{$\begin{array}{l}\text { Monsoon, } \\
\text { all years } \\
(n=62)\end{array}$} & \multicolumn{2}{|c|}{$\begin{array}{c}\text { Monsoon } \\
2000 \\
(n=18)\end{array}$} & \multicolumn{2}{|c|}{$\begin{array}{c}\text { Monsoon } \\
2001 \\
(n=23)\end{array}$} & \multicolumn{2}{|c|}{$\begin{array}{c}\text { Monsoon } \\
2002 \\
(n=14)\end{array}$} & \multicolumn{2}{|c|}{$\begin{array}{c}\text { Monsoon } \\
2003 \\
(n=5)\end{array}$} \\
\hline & $r$ & $\boldsymbol{p}$ & $r$ & $\boldsymbol{p}$ & $r$ & $\boldsymbol{p}$ & $r$ & $p$ & $r$ & $p$ \\
\hline $\begin{array}{l}\text { Cover, } \\
\text { all species }\end{array}$ & -0.18 & NS & -0.13 & NS & -0.26 & NS & -0.49 & 0.09 & 0.77 & NS \\
\hline $\begin{array}{l}\text { Species } \\
\text { richness }\end{array}$ & -.06 & NS & -.17 & NS & -.11 & NS & -.14 & NS & -.54 & NS \\
\hline
\end{tabular}



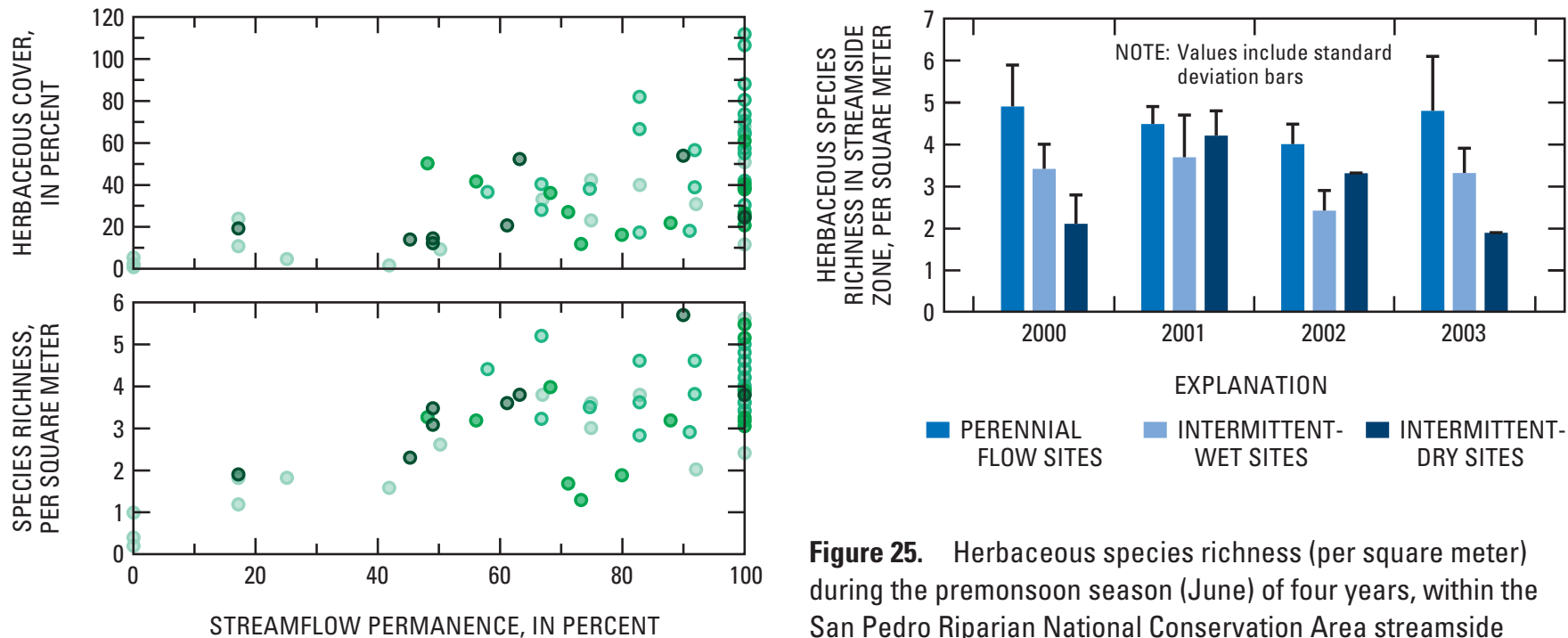

Figure 25. Herbaceous species richness (per square meter) during the premonsoon season (June) of four years, within the San Pedro Riparian National Conservation Area streamside zone, Upper San Pedro Basin, Arizona. Sites are classified into one of three hydrology classes (see table 16 in chapter C). Values are means (plus one standard deviation) of one to seven sites per class.

Figure 24. Multiyear overlay of dry-season streamside-zone herbaceous species cover and richness values, in relation to streamflow permanence at study sites, Upper and Lower San Pedro Basins, Arizona. Each data point represents a study site. Lower Basin data are from Stromberg (unpublished data). Lower Basin sites are those located between the geological constriction called the Narrows and the San Pedro River confluence with the Gila River (Huckleberry, 1996).

During the post-flood year, 2001, when streamflows were elevated throughout the SPRNCA, herbaceous species richness in the streamside zone was high in all hydrologic site types, including those classified as intermittent-dry (fig. 25). In other years, perennial-flow sites had the greatest species richness values.

Herbaceous species richness and cover in the flood plain (fig. 26) increased after the summer rains and floods. In the monsoon season, water was less limiting, and herbaceous species richness and cover generally did not vary among sites with measures of surface- or ground-water availability (tables 21, 22).

Herbaceous species cover and richness in the flood plain varied between years with different flood and rainfall patterns. Greatest premonsoon cover and richness occurred in the post-flood year, 2001 (fig. 26).
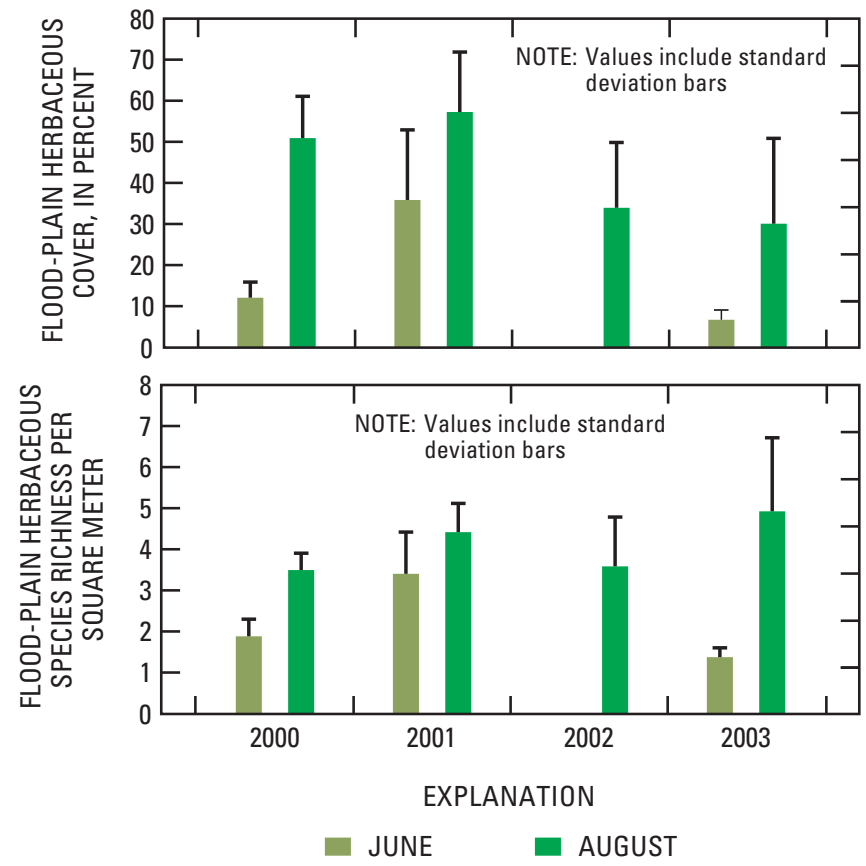

Figure 26. Flood-plain herbaceous cover and species richness, during the dry summer season of 3 years and the monsoon season of 4 years (data are not available for June 2002), San Pedro Riparian National Conservation Area, Upper San Pedro Basin, Arizona. Values are means (plus one standard deviation) of 2 to 11 sites (perennial or intermittent-wet) per sampling season. 
Table 22. Correlation coefficients ( $r$ values) between herbaceous plant abundance and environmental site variables, San Pedro Riparian Conservation Area, Upper San Pedro Basin, Arizona

[ $n$, site sample size; $r$, correlation coefficient; $p$, level of significance; NS, not significant at $p$ less than 0.10 ; significant correlations (at $p<0.10$ ) are shown in bold. Ground-water depth data are the annual mean for 2002 as averaged across the flood plain; streamflow permanence is for water year 2002; vegetation data are flood-plain averages for the monsoon season of 2002]

\begin{tabular}{|c|c|c|c|}
\hline \multicolumn{4}{|c|}{ Correlation variable } \\
\hline $\begin{array}{c}\text { Ground-water } \\
\text { depth } \\
(n=11)\end{array}$ & $\begin{array}{l}\text { Streamflow } \\
\text { permanence } \\
\qquad(n=12)\end{array}$ & $\begin{array}{c}\text { Tree canopy } \\
\text { cover } \\
(n=12)\end{array}$ & $\begin{array}{c}\text { Elevation } \\
\qquad(n=12)\end{array}$ \\
\hline$p$ & $p$ & $p$ & $r$ \\
\hline \multicolumn{4}{|c|}{ August 2002} \\
\hline
\end{tabular}

Cover (all species)

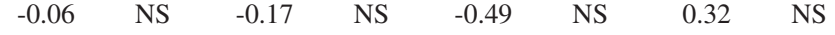

Species richness (number per square meter)

\begin{tabular}{lllllllll}
.06 & NS & -.05 & NS & .13 & NS & $\mathbf{- . 5 1}$ & 0.09 \\
\hline
\end{tabular}

Wetland indicator score

.45 NS $-.17 \quad \mathrm{NS}$ $.24 \quad$ NS $-.49 \quad$ NS

\section{Discussion}

\section{Biomass Structure}

The changes in biomass structure of the flood-plain vegetation observed along the SPRNCA water-availability gradients reflect underlying changes in resource availability, which allow for dominance by plant species with different growth forms. The wetter sites can sustain tall, productive cottonwood trees, with high values for canopy height and woodland coverage, whereas shorter, shrubbier and more deep-rooted species (notably tamarisk) predominate at drier sites (see next section). The increase in woody-plant stem density at sites with low streamflow permanence reflects the abundance of tamarisk at dry sites.

Shifts from woodlands to shrublands, and declines in canopy height, also were observed along site water-availability gradients in a study conducted by Lite and Stromberg (2005) across the Upper and Lower Basins of the San Pedro River. Another change observed along the entire river was for upper canopy $(>8 \mathrm{~m}$ ) vegetation volume to decrease significantly among sites as streamflows became more intermittent. This change similarly reflects a compositional shift from cottonwoods and willows, which have dense foliage in the upper canopy layers, to tamarisk, which has dense vegetation only in the lower and mid-stratum layers.
The lack of major changes in biomass with flood stream power may reflect the relatively small variance in flood intensities over the length of the SPRNCA. Flood magnitudes increase moderately with distance downstream in the SPRNCA, reflecting the increase in watershed area. For example, a 5-year recurrence-interval flood at the Palominas south site (reach 1) is estimated to have a peak discharge of $260 \mathrm{~m}^{3} / \mathrm{s}$ compared to $357 \mathrm{~m}^{3} / \mathrm{s}$ at the St. David site (reach 13; chapter B, table 13). The power of flood peaks at the 10-year recurrence interval varies among sites by a factor of ten (table 15). Along the entire river, however, there are larger ranges of flood magnitude and intensity, and vegetation does vary with flood patterns: vegetation height declined both at dry sites and sites with high flood stream power; vegetation was tallest at sites having the combination of wet conditions and lower intensity floods (Lite, 2003). Stem density along the entire river increased among sites in relation to increased total flood stream power (50-year recurrence-interval flood); young, small trees were abundant at the high-disturbance sites.

On the terraces, biomass structure patterns were strongly linked to site elevation (through distance downstream). The terrace patterns encompassed a shift from woody-plant dominance (primarily mesquite) at lower elevations to grass dominance (sacaton and other species) at higher elevations. The elevation gradient along the San Pedro River integrates complex changes in climate (rainfall and temperature), fire intensity and frequency (more prevalent in upper elevations), and flood intensity (lower total stream power of 100-year flood at higher elevations; $r=-0.59, n=16, p=0.02$ ). The decline in woody vegetation abundance with elevation thus may be caused by a variety of factors. Frequent rainfall may favor shallower-rooted grasses over deeper-rooted trees (Burgess, 1995), and rainfall events may be more frequent at the higher elevation sites. Frequent or intense frosts at the higher elevations may favor grasses by causing mortality of mesquite trees (Glinski and Brown, 1982). Fire may be more frequent at the upper elevation sites, perpetuating grasslands over woody vegetation types. Or, the patterns may reflect different landuse histories with respect to vegetation clearing and wood harvest.

\section{Species Richness}

Theory holds that low availability of resources (such as water) can limit diversity (Grime, 1973; Pollock and others, 1998). Researchers in semiarid regions throughout the world have observed perennial streamflows and high soil moisture to be positively associated with riparian-zone plant species diversity (Tabacchi and others, 1996; Ali and others, 2000) and to be important for maintaining particular groups of species (Fossati and others, 1999). This is consistent with findings of high streamside-zone herbaceous-species richness at perennial-flow sites (as measured during the summer dry season) in the SPRNCA. 
The lack of correlation of woody-species richness with surface flow and ground-water variables in the SPRNCA contrasts with a pattern found for the entire San Pedro River, wherein the total richness (as well as diversity) of woody species in flood plains, and of a hydromesic subset, increased among sites in relation to increased streamflow permanence (Lite, 2003). The lack of significant correlation for the SPRNCA data set may reflect the smaller water-availability gradient as well as the confounding effects of site elevation. Richness of woody species, particularly of the xeric subset, increased significantly with increased downstream distance within the SPRNCA. This pattern is similar to patterns observed for woody species along riparian corridors in Colorado (Baker, 1990).

Flood disturbance also influences species richness. Richness values can increase substantially after floods in response to increased availability of resources (water, space, light, and soil nutrients) made available by flood disturbance. Floods contribute to high species richness, in part, by increasing streamflow permanence, raising ground-water levels, and inundating flood-plain soils (Bagstad and others, 2005). Floods also entrain and deposit seeds (Merritt and Wohl, 2002) and may increase diversity by increasing heterogeneity of riparian soil seed banks. In particular, flooding increases richness of ruderal plants, which are species that have life-history traits, such as high growth rate and short life-span (annual), that adapt them for life in disturbed areas (Grime, 1974, 1977; see next section). All these factors may have contributed to the high levels of herbaceous species richness observed in 2001 following the large October 2000 flood (Bagstad and others, 2005).

Along the length of the San Pedro River, herbaceous species richness during 2001 varied among sites as a function of total stream power of the October 2000 flood (Bagstad and others, 2005). The relationship was consistent with the intermediate disturbance hypothesis (Pollock and others, 1998), with herbaceous species richness initially increasing among sites as stream power increased, and then showing some decline at sites with the greatest stream power. This net gain in species richness is similar to patterns observed along another river in the Sonoran Desert, at which species richness increased following a 10-year recurrence-interval flood that inundated and scoured the forest understory and reduced the abundance of the few dominant species (Stromberg, Richter and others, 1993).

Woody and herbaceous plant species typically respond differently to environmental factors (Sagers and Lyon, 1997). Along the SPRNCA, as well as along the entire river, woody species richness did not vary with average intensity of floods of given recurrence intervals; however, relations with specific recent large floods were not examined. Although woody pioneer species (which are by definition flood-adapted) increased significantly in richness with flood intensity (total stream power of 10-year recurrence-interval flood), competitor species (specifically, late-successional species) declined in richness at the low-disturbance sites, resulting in no net difference among sites in species richness (Lite and others, 2005).

\section{Biohydrology Analysis: Influence of Hydrology on Woody-Plant Species}

\section{Objective and Methods}

Objective.-Quantify relations between riparian vegetation composition and site hydrology (ground water, base flows, floodflows), and assess the relative importance of the hydrologic factors to specific groups of woody riparian-plant species.

Methods.-To identify the relative importance of hydrologic factors to different groups of riparian plants, an inferential approach was used to examine spatial and temporal patterns of riparian-plant abundance in relation to spatio-temporal patterns of availability of surface water, ground water, flood water, and rainfall. Patterns were analyzed individually for abundant species and for plants classified into functional groups. The functional group approach was used because of the high plant species diversity in the San Pedro riparian corridor (appendix 7, tables 7-C and 7-D). To date, 608 vascular-plant species have been identified within the SPRNCA (Makings, 2003)

Species were classified into functional groups on the basis of growth form (herbaceous versus woody), water relations, and disturbance relations. Water-relation classification was founded on reported values on wetland indicator scores for Southwest Region 7, as listed in the USDA PLANTS National Database (U.S. Department of Agriculture, Natural Resources Conservation Service, 2002). These scores range from 1 (obligate wetland) to 4 (facultative upland), and depend on the probability of species occurrence in wetland habitats, and thus serve to sort species along a water-availability gradient. Generally, obligate wetland and facultative wetland species were classified as hydric riparian (or Hydromesic riparian), facultative upland species as mesic riparian, and non-wetland (upland) species as xeric riparian. These classifications were refined through literature review and observations of plant distribution patterns. Hydric and hydromesic riparian species have high water needs and likely rely primarily on ground water or stream base flows. Mesic riparian species have intermediate water needs and likely are facultative phreatophytes that opportunistically use floodwater and rainwater. Xeric riparian species have low water needs and largely subsist on rainfall, with opportunistic use of other water sources. A literature review of plant life history traits was used to designate plants for the disturbance classification. Annual or biennial life span (versus perennial life span) was used an indicator of ruderal tendency and adaptation to high disturbance for herbaceous plants. Woody plants are designated as pioneer, disturbance-dependent species according to traits, including high reproductive output, small seed size, and morphological adaptations for wind dispersal of seeds. 
Pearson product-moment correlation analysis was used to detect statistically significant relations between abiotic variables and abundance of each plant functional group and of common species. This included analysis of longitudinal patterns (differences between sites along the length of the river, in relation to streamflow permanence, ground-water depth, site elevation, and flood-plain width) and of lateral patterns (patterns of plant abundance along flood-plain plots in relation to plot elevation above the channel thalweg and in relation to estimated depth to ground water, recent flood inundation level, and inundation frequency). Longitudinal patterns were analyzed by using data sets consisting of all SPRNCA sites and by using the subset of unburned sites. Plot inundation frequencies for these calculations were determined from modeled stage-discharge relations (chapter B). For common species, mean and median values were calculated for depth to ground water and inundation frequency by using data from all plots in which the species occurred.

Results.-Results are presented by functional group, beginning with hydric species and ending with xeric.

\section{Hydromesic Pioneer Trees and Shrubs}

Cottonwood and willow have the greatest basal area of all tree species in the San Pedro River flood plain. Mean basal area averages about six times higher for cottonwood than willow, although stem density values for the two species are fairly similar (appendix 7, table 7-E). Seepwillow baccharis (Baccharis salicifolia) is the most abundant shrub in the San Pedro flood plain. Emory baccharis (Baccharis emoryi), a morphologically similar species, also is present, and its cover values are lumped with those of Seepwillow in the summary tables (appendix 7, table 7-F). Other species in this functional group within the SPRNCA are the relatively common narrow leaf willow (Salix exigua) and the less common yewleaf willow (Salix taxifolia) and Arizona sycamore (Platanus wrightii).

Individual and combined basal area of cottonwood and willow in the flood plain increased among SPRNCA sites as streamflow permanence increased, whereas stem density increased as ground water (annual mean and maximum) became shallower and had less intra-annual fluctuation (table 23; figs. 27 and 28). The median of the annual maximum depth to ground water beneath surfaces occupied by cottonwood was $2.0 \mathrm{~m}$; the median value for willow was $1.8 \mathrm{~m}$ (fig. 29). Median depth-to-ground water values were shallower for young cohorts than for old cohorts. Basal area of cottonwood and willow were higher at sites with greater average long-term flood intensities (table 24).

Cottonwood and willow typically occur in linear bands or patches across the flood plain; each patch consists of similar-aged trees that established after the same flood event. Size-class richness of the cottonwood-willow populations, measured as the number of $10-\mathrm{cm}$ basal diameter classes present in the flood plain, increased among sites as annual maximum ground-water depth decreased (table 23 and fig. 30).

Seepwillow is a tall (up to $3.5 \mathrm{~m}$ ), shallow-rooted evergreen shrub. It was the dominant hydromesic pioneer shrub, ranging in cover from 1 to 8 percent among sites (flood-plain zone). Its cover did not vary significantly with site hydrology in the SPRNCA (table 17), but it had low cover at the two driest sites (fig. 30). In the SPRNCA flood plains, seepwillow was most abundant on surfaces where the annual maximum ground-water depth averaged $2.1 \mathrm{~m}$ (fig. 29).

\section{Mesic Pioneer Trees and Shrubs}

Tamarisk (and related species and hybrids), a small tree to large shrub, was abundant at some study sites. Tree tobacco (Nicotiana glauca) and desert willow (Chilopsis linearis), both small trees, also were included in this group of facultative phreatophytes. Both of these latter species had low abundance in the SPRNCA flood plain.

The spatial distribution pattern of tamarisk contrasted with that of cottonwoods and willows in that tamarisk basal area and density (and abundance of mesic pioneer trees combined) decreased among sites as conditions became wetter (table 23). Species dominance thus shifted from cottonwood-willow to tamarisk as sites become drier (fig. 27). This shift also is evidenced by significant correlations between importance values (measures of comparative relative abundance of the species) and site streamflow permanence and annual maximum ground-water depth (see "Trend Analysis" section. Within the SPRNCA, the mean of the annual maximum depth to ground water beneath surfaces occupied by tamarisk $(2.9 \mathrm{~m})$ was greater than that for cottonwoods $(2.1 \mathrm{~m})$ and Goodding willows (1.9 m; fig. 29)

\section{Mesic Competitor Trees and Shrubs}

Velvet mesquite was the most abundant member of the mesic competitor trees, and this group and was abundant on flood plains and terraces. Other tree species in this group included net-leaf hackberry (Celtis reticulata), Arizona walnut (Juglans major), Mexican elderberry (Sambucus nigra ssp. cerulea), Texas mulberry (Morus microphylla), and western soapberry (Sapindus saponaria), all of which have fleshy, animal-dispersed fruit. Velvet ash (Fraxinus velutina), a tree which produces relatively large, wind-dispersed seeds, also was relatively common. Tree of heaven (Ailanthus verticillatus), white mulberry (Morus alba), edible fig (Ficus carica), and honey locust (Gleditsia triacanthos) had low abundance. All the mesic competitor shrubs (golden current, Ribes aureum; Mojave seablite, Sueada moquinii) and woody vines (sorrel vine, Cissus trifoliate; Virginia creeper, Parthenocissus quinquefolia; poison ivy, Toxicodendrum radicans; canyon grape, Vitis arizonica) had low abundance. 
Table 23. Correlation coefficients ( $r$ values) between woody-species basal area or cover and site-water availability indicators for the San Pedro Riparian National Conservation Area flood-plain zone, Upper San Pedro Basin, Arizona

$[n$, site sample size; $r$, correlation coefficient; $p$, level of significance; NS, not significant at $p$ less than 0.10 ; significant correlations (at $p<0.10)$ are shown in bold. Correlation coefficients are provided for each functional group and for dominant species within each group]

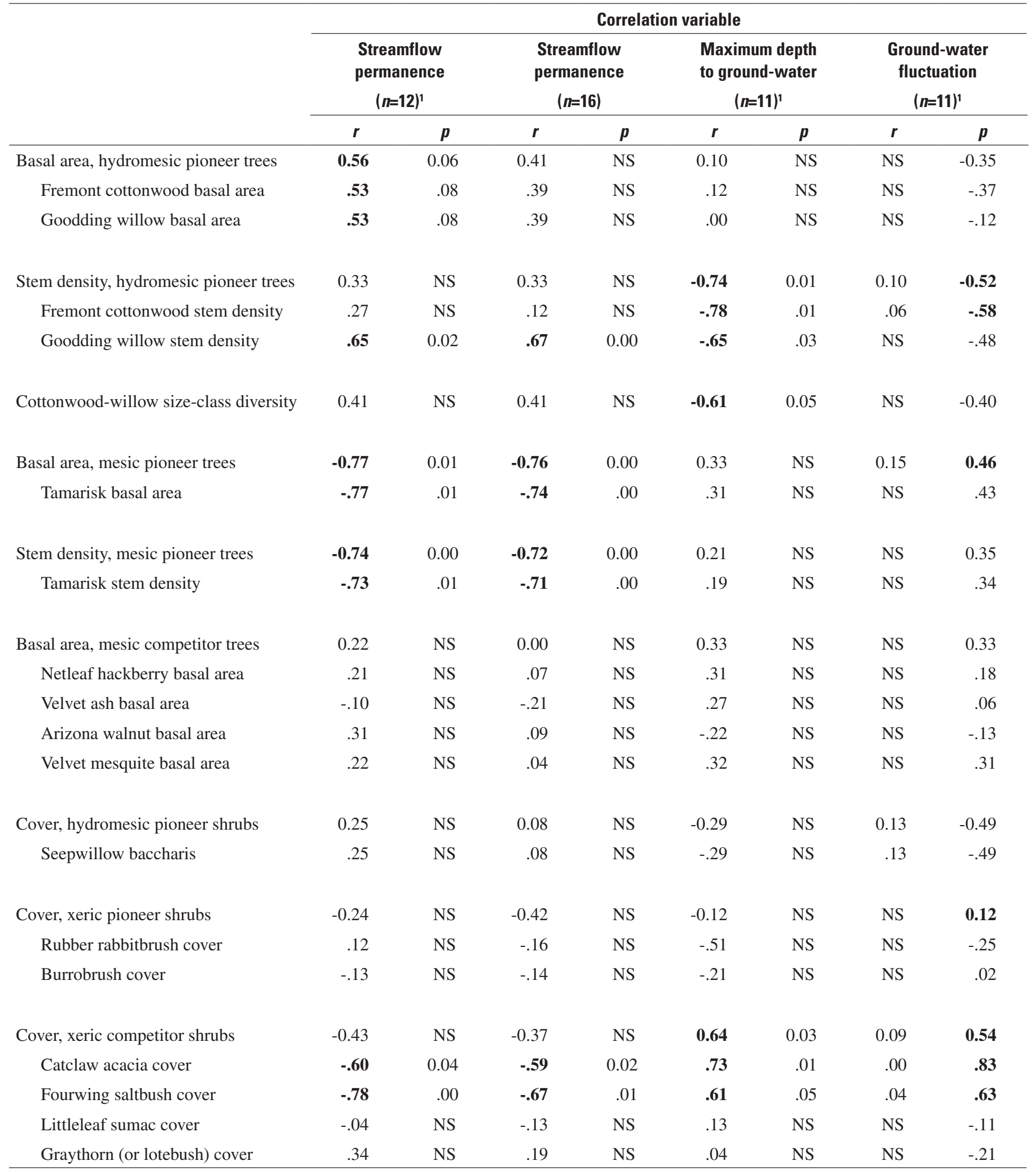

${ }^{1}$ Burned sites excluded. 

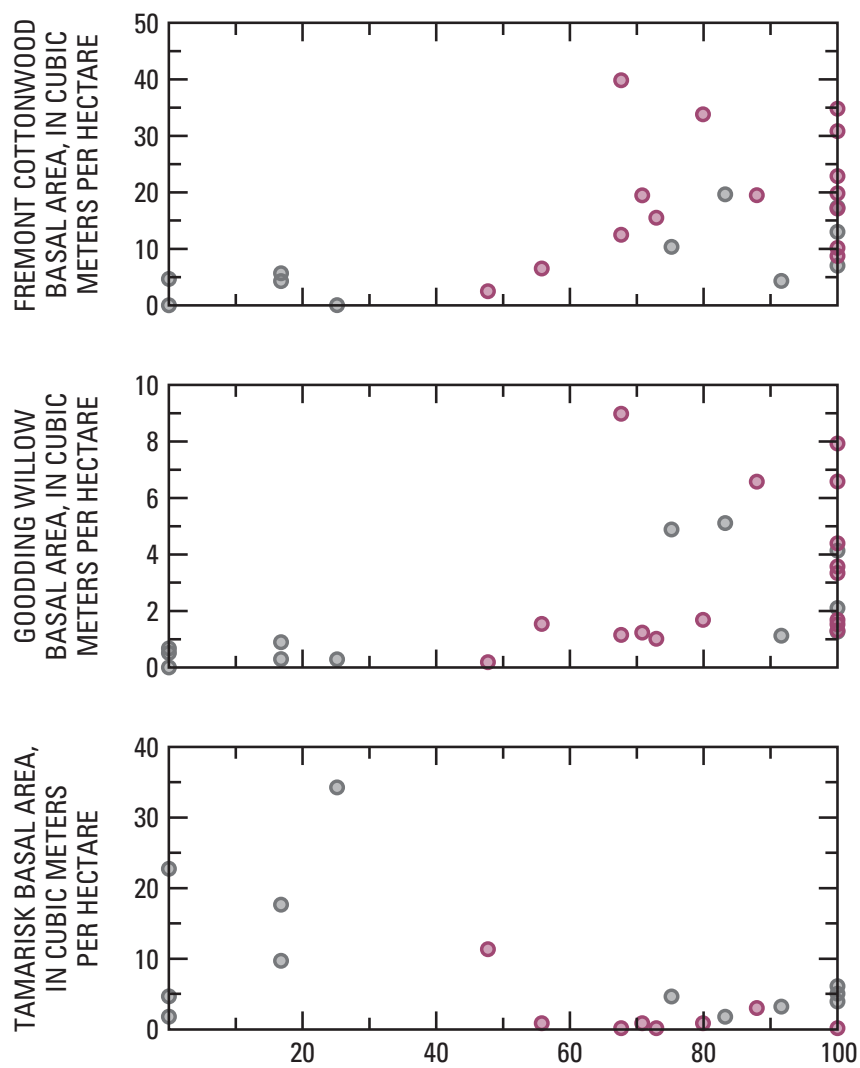

STREAMFLOW PERMANENCE (2002 WATER YEAR), IN PERCENT

EXPLANATION

- PRIMARY BIOHYDROLOGY
SITES
(LITE, 2003)

Figure 27. Basal area of Fremont cottonwood, Goodding willow, and tamarisk in relation to streamflow permanence of San Pedro River sites, Upper and Lower San Pedro Basins, Arizona. Each data point represents a site. Data are shown for the 16 biohydrology study sites in the San Pedro Riparian National Conservation Area, and for the 12 supplemental riparian sites in the Lower San Pedro Basin, Arizona (Lite, 2003).

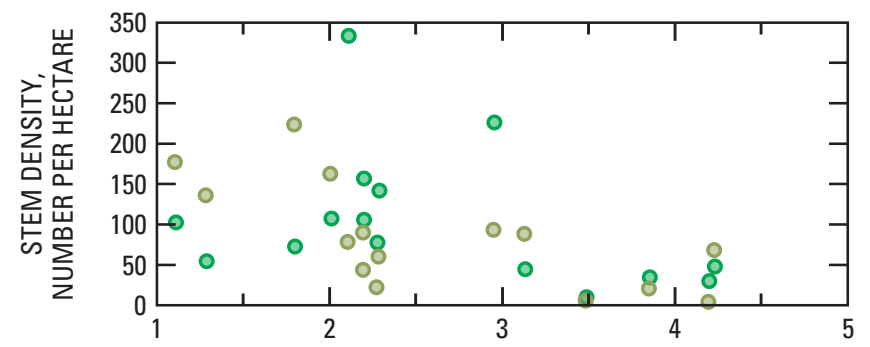

ANNUAL MAXIMUM DEPTH TO GROUND WATER, IN METERS

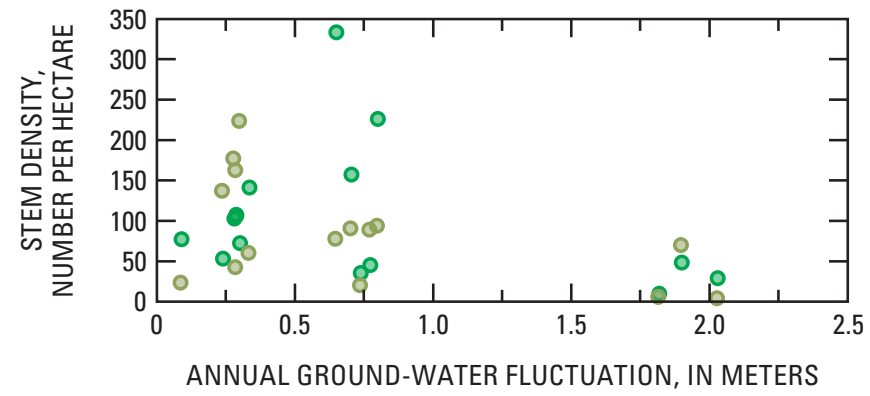

EXPLANATION

- FREMONT COTTONWOOD O GOODDING WILLOW

Figure 28. Stem density of Fremont cottonwood and Goodding willow within the San Pedro River flood plain, in relation to annual maximum depth to ground water and annual ground-water fluctuation (as averaged across the flood plain, 2002 water year), at the 16 biohydrology study sites, San Pedro Riparian National Conservation Area, Upper San Pedro Basin, Arizona. 
A. Dominant tree species

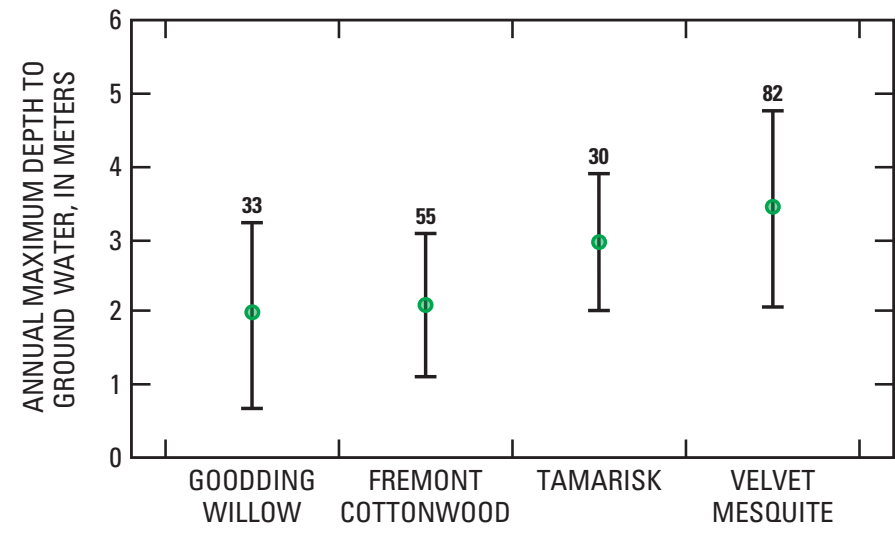

C. Dominant shrub species

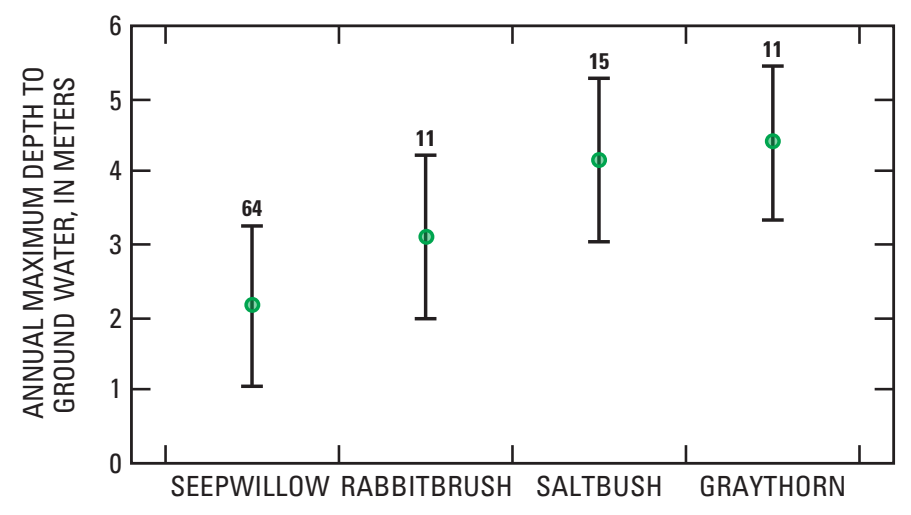

B. Pioneer tree age classes

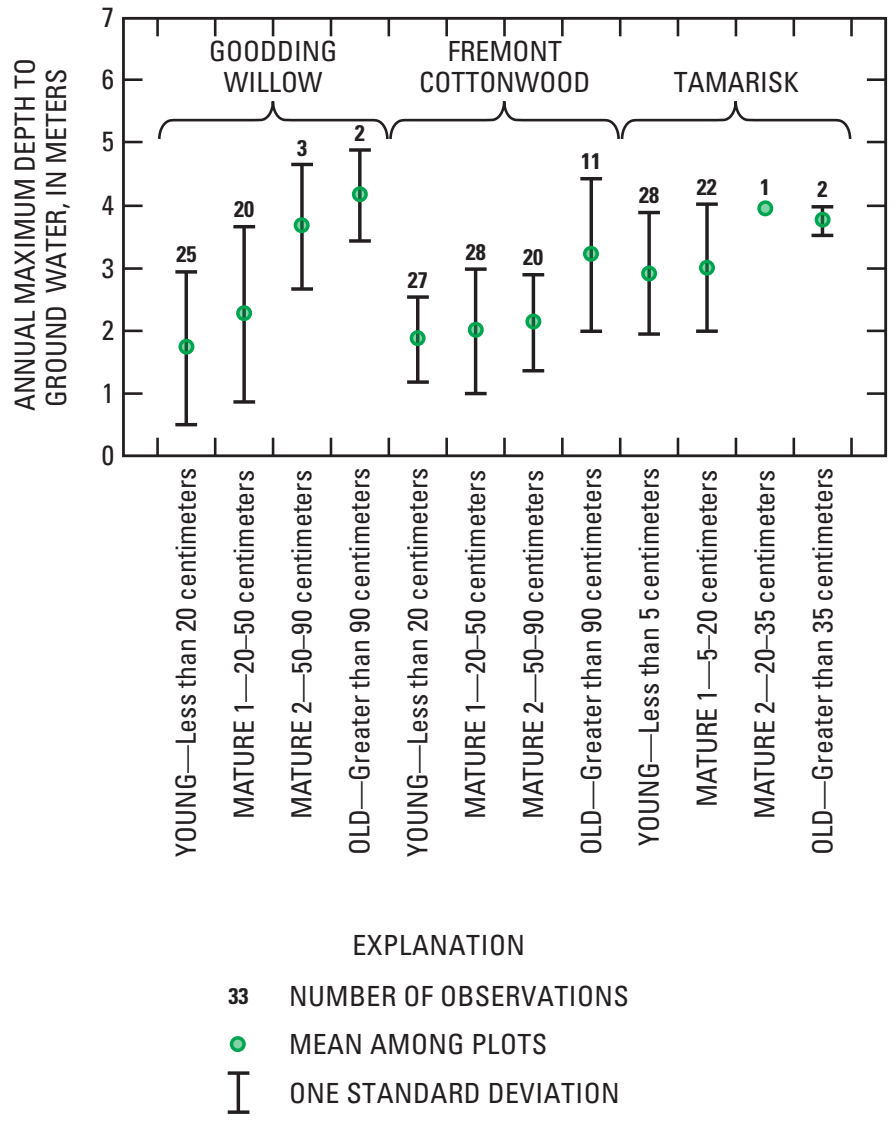

NOTE: Distributions are based on the vegetation sampling plots in which each species occurred (out of a total of 172 sampled floodplain plots). Annual maximum ground-water depths are for water year 2002.

Figure 29. Distribution of depth to ground water along the San Pedro River, San Pedro Riparian National Conservation Area, Upper San Pedro Basin, Arizona. A, Dominant tree species; $B$, Pioneer tree age classes, and; $C$, Dominant shrub species. 
Table 24. Correlation coefficients ( $r$ values) between woody species basal area or cover in the San Pedro River, Arizona, flood plain and site elevation, flood-plain width, and total stream power of the 100-year recurrence-interval flood, San Pedro Riparian Conservation Area, Upper San Pedro Basin, Arizona

[ $n$, site sample size; $r$, correlation coefficient; $p$, level of significance; NS, not significant at $p$ less than 0.10 ; significant correlations (at $p<0.10)$ are shown in bold. Correlation coefficients are provided for each functional group and for dominant species within each group]

\begin{tabular}{|c|c|c|c|c|c|c|}
\hline & \multicolumn{6}{|c|}{ Correlation variable } \\
\hline & \multicolumn{2}{|c|}{$\begin{array}{l}\text { Total flood stream power } \\
\text { (100-year flood) } \\
(n=16)\end{array}$} & \multicolumn{2}{|c|}{$\begin{array}{l}\text { Site elevation } \\
\quad(n=20)\end{array}$} & \multicolumn{2}{|c|}{$\begin{array}{l}\text { Flood-plain width } \\
\qquad(n=20)\end{array}$} \\
\hline & $r$ & $p$ & $r$ & $p$ & $r$ & $p$ \\
\hline Basal area, hydromesic pioneer trees & 0.59 & 0.02 & 0.03 & NS & -0.34 & 0.15 \\
\hline Fremont cottonwood basal area & .55 & .03 & .07 & NS & -.30 & -.30 \\
\hline Goodding willow basal area & .64 & .01 & -.15 & NS & -.25 & -.25 \\
\hline Stem density, hydromesic pioneer trees & -0.37 & NS & 0.63 & 0.00 & -0.27 & NS \\
\hline Fremont cottonwood stem density & -.22 & NS & .43 & .03 & -.05 & NS \\
\hline Goodding willow stem density & -.33 & NS & .48 & .06 & -.49 & .03 \\
\hline Cottonwood-willow size-class diversity & 0.15 & NS & 0.39 & 0.09 & 0.28 & NS \\
\hline Basal area, mesic pioneer trees & 0.25 & NS & -0.58 & 0.01 & 0.43 & 0.06 \\
\hline Tamarisk basal area & .22 & NS & -.59 & .01 & .41 & .07 \\
\hline Stem density, mesic pioneer trees & 0.32 & NS & -0.56 & 0.01 & 0.46 & 0.04 \\
\hline Tamarisk stem density & .32 & NS & -.57 & .01 & .44 & .05 \\
\hline Basal area, mesic competitor trees & 0.57 & 0.02 & -0.56 & 0.01 & 0.02 & NS \\
\hline Netleaf hackberry basal area & .32 & NS & -.38 & .09 & .20 & NS \\
\hline Velvet ash basal area & .02 & NS & .15 & NS & .02 & NS \\
\hline Arizona walnut basal area & -.14 & NS & .38 & .10 & .15 & NS \\
\hline Velvet mesquite basal area & .60 & .02 & -.62 & .00 & -.03 & NS \\
\hline Cover, hydromesic pioneer shrubs & 0.11 & NS & -0.24 & NS & -0.15 & NS \\
\hline Seepwillow baccharis cover & .11 & NS & -.24 & NS & -.15 & NS \\
\hline Cover, xeric pioneer shrubs & -0.30 & NS & 0.33 & NS & -0.16 & NS \\
\hline Rubber rabbitbrush cover & -.22 & NS & .40 & 0.09 & .27 & NS \\
\hline Burrobrush cover & -.22 & NS & .47 & .05 & -.32 & NS \\
\hline Cover, xeric competitor shrubs & 0.07 & NS & -0.42 & 0.06 & -0.12 & NS \\
\hline Catclaw acacia cover & .17 & NS & -.54 & .02 & .10 & NS \\
\hline Fourwing saltbush cover & -.02 & NS & -.54 & .02 & .11 & NS \\
\hline Littleleaf sumac cover & .15 & NS & .02 & NS & -.03 & NS \\
\hline Graythorn (or lotebush) cover & .18 & NS & -.42 & .08 & -.18 & NS \\
\hline
\end{tabular}




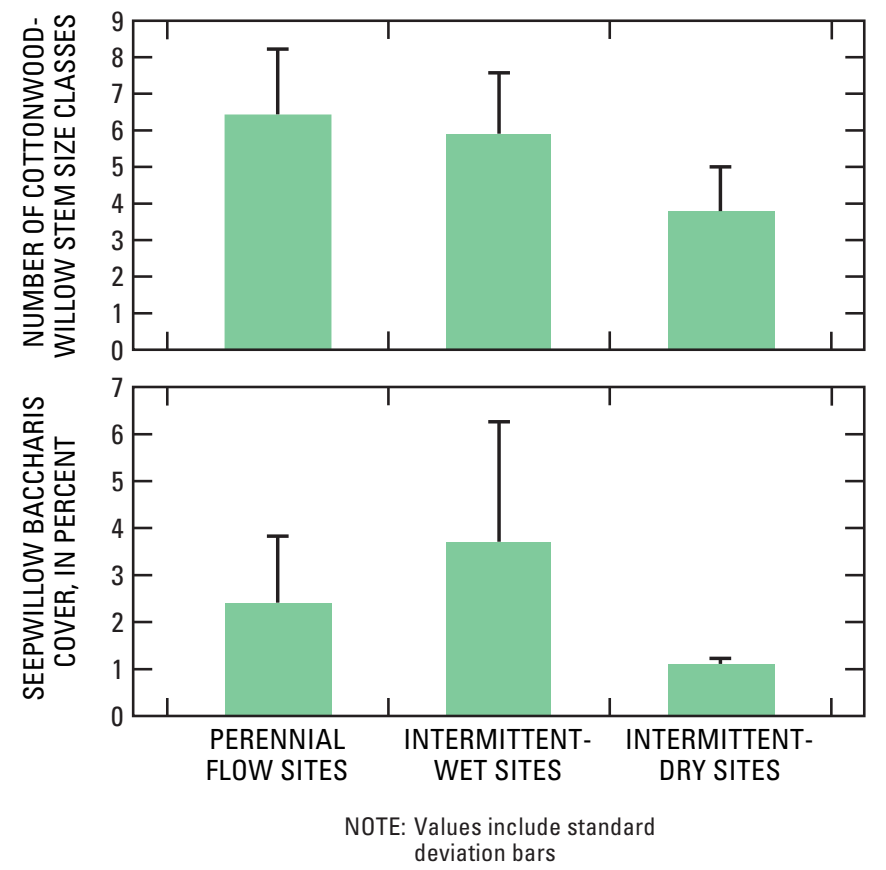

Figure 30. Mean number of Fremont cottonwood and Goodding willow stem-size classes (10-cm-diameter increments), and mean flood-plain cover of seepwillow baccharis, within the 16 biohydrology study sites classified into three hydrology classes (see table 16), San Pedro River National Conservation Area, Upper San Pedro Basin, Arizona.

In the SPRNCA, mesquite grows on flood plains and terraces over a wide range of plot elevations, depths to ground water, and inundation frequencies. Among sites, stem density and basal area of mesquite in the flood plain did not vary with site wetness, nor did combined stem density of mesic competitors. Site elevation and flood intensity were correlated with mesquite abundance; mesquite increased significantly in basal area with increased distance downstream and increased flood intensity (table 24). Along this longitudinal river gradient, the mesquite patches on riparian terraces shifted from young, shrublands at the upper reaches to older, taller, and denser woodlands and forests in the lower reaches (fig. 31).

\section{Xeric Pioneer Shrubs}

The most common species in the xeric pioneer shrub group were the shrubs rubber rabbitbrush (Ericameria nauseousa) and burro brush (Hymenoclea monogyra).

Desert broom (Baccharis sarothroides), burroweed (Isocoma tenuisecta), and threadleaf snakeweed (Gutierrezia microcephala) also were relatively abundant.

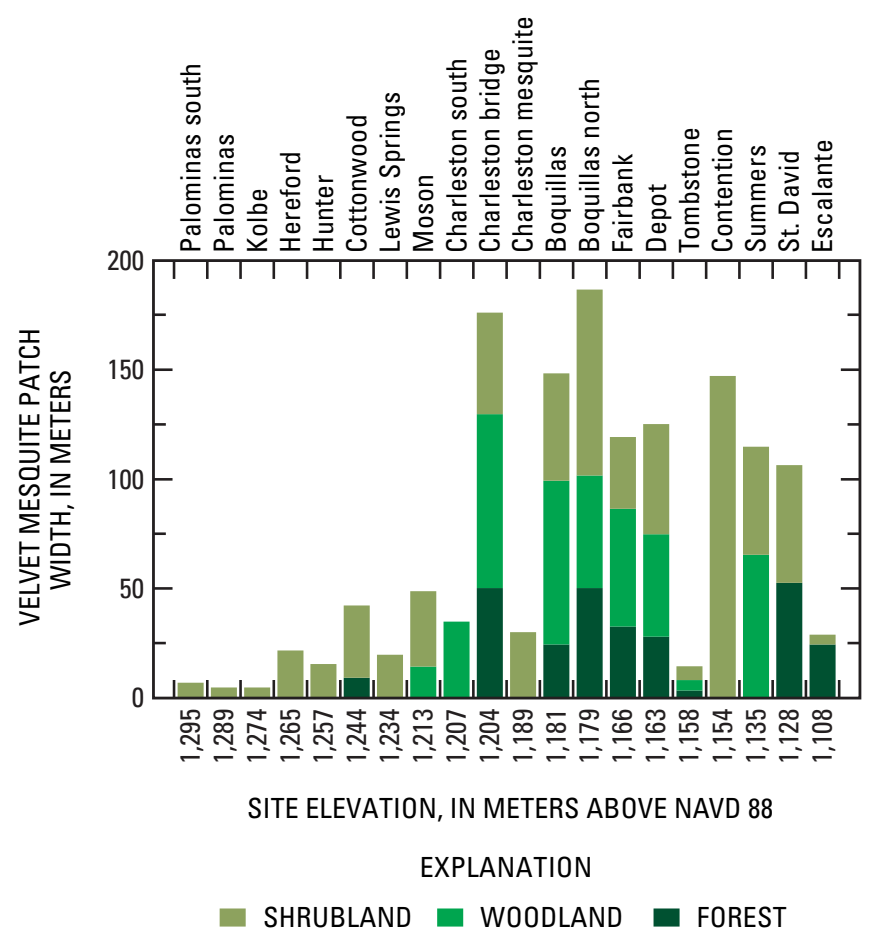

Figure 31. Width of vegetation patches dominated by velvet mesquite forests, woodlands, and shrublands within the San Pedro River terrace sampling zone, by site, San Pedro Riparian National Conservation Area, Upper San Pedro Basin, Arizona. (Forests, woodlands, and shrublands are physiognomic structure types that differ in canopy and mid-stratum cover.)

Threadleaf ragwort (Senecio flaccidus), yerba de pasmo (Baccharis pteronoides), and sweet bush (Bebbia juncea) were sparse. Some of these species occur primarily on disturbed flood-plain surfaces (such as coarse sediment deposits), whereas other species grow on disturbed flood-plain surfaces, disturbed areas of terraces (appendix 7, tables 7-F and 7-G), and uplands.

Combined cover of species in this group declined as streamflow permanence increased, reflecting increases of certain species (including desert broom) at drier sites. Burro brush ranged among SPRNCA sites from 0 to 2 percent cover. Its cover did not vary with hydrologic factors, but did increase weakly with distance upstream. Rubber rabbitbrush ranged in flood-plain zone cover from 0 to 6 percent among sites, and occurred on flood-plain surfaces with a median depth to ground water of $2.7 \mathrm{~m}$ (fig. 29). Its cover was not significantly related to ground-water depth.

\section{Xeric Competitor Shrubs and Small Trees}

The xeric competitor shrubs and small trees group consists of drought-tolerant and flood-intolerant species that typically occur on aggraded (high-elevation, infrequent 
inundation) portions of the flood plain and on river terraces and uplands. The most abundant species in this group on the flood plain were little-leaf sumac (Rhus microphylla), graythorn [lotebush (Ziziphus obtusifolia)], and fourwing saltbush (Atriplex canescens); the most abundant species on the terrace were graythorn, fourwing saltbush, and catclaw acacia (Acacia greggii). Other species in this group include whitethorn acacia (Acacia constricta), longleaf jointfir (Ephedra trifurca), and pale desert-thorn (Lycium pallidum; appendix 7, table 7-C).

Cover of this group on flood plains and terraces increased with distance downstream (decreasing elevation; table 24) paralleling the shift from herbaceous-dominated vegetation types in upper reaches to woody-dominated types in lower reaches. Within the flood plain, this group increased among sites as annual maximum depth to ground water increased. Individually, two shrubs in this group, fourwing saltbush and catclaw acacia, increased in flood-plain zone cover among sites as ground water deepened and increased in intra-annual fluctuation. Although the correlation was significant, the range of cover among sites was low for both species ( 0 to 2 percent cover among sites), and thus the effect was minor.

\section{Discussion}

\section{Fremont Cottonwoods and Goodding Willows}

Among the woody-plant groups analyzed, the hydromesic pioneer trees were the most sensitive to changes in water availability. These findings are expected, given that cottonwood and willow are shallow-rooted, obligate to near-obligate phreatophytes (Busch and others, 1992; Smith, Devitt and others, 1998; Snyder and Williams, 2000). Cottonwood and willow are sensitive to drought at all life stages and undergo stem dieback as water tables decline (Tyree and others, 1994; Horton and others, 2001b). Species from both genera have low thresholds of plant water potential at which xylem embolism (disruption of water flow in the conductive tissue by water vapor) and cavitation (breakage of the water column) may occur (Pockman and Sperry, 2000; Amlin and Rood, 2002). Because fine roots are concentrated in the capillary fringe, just above the water table, these species are sensitive to fluctuation in water-table depth, particularly in coarser soils with a narrower capillary fringe. Ground-water level decline during the hot summer dry season can strand roots above the water level, reduce tree productivity and, in some cases, cause death. Seasonal declines of $1 \mathrm{~m}$ have caused mortality of saplings of cottonwood and willow (Shafroth and others, 2000). Mature cottonwood trees have been killed by abrupt, permanent drops in the water table of $1 \mathrm{~m}$, with lesser declines $(0.5 \mathrm{~m})$ reducing stem growth (Scott and others, 1999, 2000).
Although ground-water depth and fluctuation were related to measures of abundance of cottonwood and willow, the variable that explained most variance in the basal area of these species was, surprisingly, streamflow permanence. Directly or indirectly, streamflow permanence is an important indicator of San Pedro River forest composition and structure. Surface water can provide a water source for young trees that line the low-flow channel (Smith and others, 1991), and surface water can raise local humidity levels and provide an essential buffer to high evaporation rates along arid region rivers (Horton and others, 2001a). Streamflow permanence, however, as analyzed in this study, likely serves as a surrogate for the degree of long-term ground-water fluctuation under the flood plain, rather than as a direct influence on vegetation. Sites with perennial flow tend to be situated in gaining reaches, where inflowing ground water would sustain stable, shallow ground-water levels even during times of extended drought. At the highly intermittent sites, which typically are in losing reaches, ground-water depths and fluctuations likely have periodically exceeded the levels observed in this short-term study, and exceeded survivorship tolerance ranges for cottonwood and willow. Ground-water fluctuation during water year 2002 was nearly $2 \mathrm{~m}$ at three SPRNCA biohydrology sites (Tombstone, St. David, and Contention), which is in the range of values lethal to cottonwoods and willows; fluctuations were less than $1 \mathrm{~m}$ for most sites along the SPRNCA. The intra-annual fluctuations discussed here represent values averaged across the flood plain; fluctuations typically are smaller near the channel and greater at the flood-plain perimeter.

Stem-size class richness (a surrogate for age-class richness), is low for cottonwoods and willows at dry sites along the San Pedro River. This relation likely is caused by increased mortality of sensitive age classes and to reduced birth rate. At dry sites, ground-water depths may recede too rapidly following floods to sustain seedlings, resulting in infrequent recruitment (see "Trend Analysis" section). Overall, forests of cottonwood and willow were dense and multiaged among sites where annual maximum ground-water depths averaged less than about $3 \mathrm{~m}$, streamflow permanence was greater than about 60 percent, and intra-annual groundwater fluctuation was less than about $1 \mathrm{~m}$. Beyond these values, size-class diversity or overall abundance was low. For example, at the Tombstone site, where ground water was deep, cottonwoods had high basal area owing to the presence of a few, large, old-growth trees, but low stem density and low age-class diversity. The combination of high basal area, high stem density, and high age-class diversity, however, was found only at wet sites, such as Hereford and Moson.

These threshold values for ground-water depths are consistent with values reported for the survival of mature cottonwood and willow trees along other rivers in the deserts (Mojave, Sonoran, and Chihuahuan) of the southwestern United States. Low-density cottonwood forests occur along dry riverbeds where water tables are only seasonally high or where mean depths exceed 5 m (Zimmerman, 1969). Dense, 
multiaged forests of cottonwood-willow, however, occur along perennial or intermittent rivers where depth to ground water remains less than about $3 \mathrm{~m}$ (Stromberg and others, 1991; Anderson, 1995; Shafroth and others, 1998; Shafroth and others, 2000; Horton and others, 2001a, b). At the Hassayampa River, for example, willow and cottonwood underwent physiological stress, observed as canopy dieback and reduced photosynthetic rates, as depth to ground water exceeded $3 \mathrm{~m}$ (Horton and others, 2001b). On the Bill Williams River, where river regulation has produced stable seasonal ground-water levels, both species were in good physiological condition at sites where depth to ground water was less than $4 \mathrm{~m}$ (Horton and others, 2001a).

Within the SPRNCA, there was a positive correlation between cottonwood-willow basal area and flood intensity. Flood-intensity changes over the length of the San Pedro River also influence the size and age structure of the cottonwood and willow populations (Lite, 2003). Flood stream power increases with distance downstream, reflecting the larger drainage basin and greater total runoff, but then declines somewhat at the northern end of the Lower San Pedro Basin as the stream gradient declines, more than $100 \mathrm{~km}$ downstream from the SPRNCA. At sites with higher flood stream power, the frequencies of plant scour, sediment erosion, and channel movement increase, thus creating more opportunities for pioneer tree establishment and creating more turnover (more births and deaths) within the cottonwood and willow population. With increasing distance downstream, the mean size (and age) of the cottonwood populations declines, and flood plains are dominated by increasingly younger trees. The SPRNCA, in comparison to the lower reaches of the river, is vegetated largely by older cohorts of cottonwoods and willow.

Fire disturbance also influences cottonwood and willow mortality and regeneration processes (Stuever, 1997). A study of four fires (Tyler Rychener, Arizona State University, unpublished data) indicates that, within the areas of the SPRNCA that have burned recently, the area occupied by cottonwood-willow patches has declined, on average, by one-third. Fire frequency may be high at present in the SPRNCA because of a high fuel-load (seasonally high cover of dry grass) in combination with high rates of fire ignition from increased human presence. Most of the recent fires have been human-caused by power utility lines or campfires from recreationists or migrants, and most have been in winter or spring rather than in the June-July lightning season (table 3). Fire mortality has resulted in low basal area of willow and cottonwood at some burned sites. Willow, however, has high stem density at some burned sites, owing to abundant post-fire resprouting, a common fire response for this species (Busch, 1995; Ellis, 2001). A small amount of post-fire resprouting of cottonwoods also has been observed.

\section{Seepwillow}

Seepwillow has most root mass limited to either unsaturated sediments or the top of the saturated zone (Gary, 1963; Schade and others, 2001). The degree to which seepwillow relies on ground water is not well researched, but Williams and others (1998) found that it used mostly ground water rather than soil water. Although its cover was not significantly correlated with site water availability in this study, it did have low cover at the driest sites. Another factor that can influence seepwillow abundance is livestock grazing. Although the SPRNCA corridor is currently ungrazed (except by trespass cows), it is possible that past differences in grazing intensity influenced abundance. The flavinoids and other chemical compounds in the resinous, odorous seepwillow leaves likely are less palatable than those of many other woody riparian species, allowing seepwillow to increase under grazing.

\section{Tamarisk}

Similar to cottonwood and willow, tamarisk is a pioneer species that produces many small wind- and water-dispersed seeds and requires bare, moist, mineral soils for seedling establishment (Stromberg and Chew, 2002). In contrast to these hydromesic trees, tamarisk is a deep-rooted, facultative phreatophyte that obtains water from both the water table and soil profile and tolerates a high degree of water stress (Busch and others, 1992; Busch and Smith, 1995; Horton and Clark, 2001; Glenn and Nagler, 2005). The pattern of shifting dominance from tamarisk to cottonwood-willow along site water-availability gradients likely is a result both of competitive interactions and species-specific differences in environmental tolerance ranges. Tamarisk has deeper roots and physiologic tolerance for drought, and thus can dominate at the dry sites.

At wetter sites, it likely is out-competed by cottonwood. Under conditions where water is not limiting and where cottonwood seeds are present, cottonwood seedlings have been shown to competitively reduce the growth rates of tamarisk seedlings (Sher and others, 2000; Sher and others, 2002).

Modeling studies along the San Pedro River have been used to help identify hydrologic thresholds at which the shift in dominance from cottowood-willow to tamarisk occurs (Lite and Stromberg, 2005). These results suggest that the cottonwood-willow forests will give way to tamarisk should the San Pedro River flows become increasingly intermittent, and that, conversely, tamariskdominated sites may shift towards cottonwood-willows should long-term streamflow permanence increase. 


\section{Mesquite}

Mesquite, net-leaf hackberry, Arizona walnut, and velvet ash are facultative phreatophytes that use a combination of ground water and soil water depending on environmental setting (Williams and others, 1998; Galuszka and Kolb, 2002; Hultine and others, 2003). Mesquite has a dimorphic root system, with deep tap roots (15 m or more) that allow for uptake of ground water, and wide-spreading lateral roots that allow for uptake of rain and flood water from surface soils (Stromberg, 1993; Stromberg, Wilkins and Tress, 1993; Snyder and Williams, 2003). These and other traits allow mesquite to be abundant in a variety of habitats, including the San Pedro River flood plain, terrace, and adjacent uplands.

The decline in mesquite basal area and height with distance upstream may reflect several processes. Colder temperatures and greater likelihood of frost in the upper elevation sites can reduce mesquite growth rates and cause more frequent dieback from frost at the upper elevations (Glinski and Brown, 1982), or dense cover of grass species at the higher elevations may result in competitive reductions in mesquite establishment. High flood intensities may provide mesquite with more frequent opportunities to establish in the flood plain by removing competitive grass cover. The spatial pattern of mesquite basal area and height also can relate to fire frequency. Fire can shift mesquite physiognomy from woodlands to shrublands, and has been more frequent in upstream reaches. Older mesquite trees that are top-killed by fire have the ability to resprout from buds at the base of the tree that are protected from fire damage by soil and (or) bark, whereas younger mesquites do not (Reynolds and Bohning, 1956; Busch, 1995; McPherson, 1995, 1997). Fire of low to moderate frequency, in some areas, can perpetuate a low, multistemmed growth for mesquite. Additionally, the pattern can reflect differences in land-use histories.

\section{Xeric Shrubs}

The group of xeric pioneer shrubs is drought tolerant, as evidenced by xerophytic adaptations, such as small leaves. They are adapted to disturbance through traits such as production of abundant, wind-dispersed seeds (for example, desert broom) or ability to propagate vegetatively (for example, burrobrush). Research on water relations is limited for most species in this group, with the exception of rabbitbrush. Rabbitbrush abundance in the SPRNCA was not correlated with ground-water depth. The species is phreatophytic in some settings with roots extending $4 \mathrm{~m}$ into the soil (Groeneveld and Crowley, 1988). At sites in the Great Basin, adult survivorship and growth corresponded more closely to depth to ground water than total annual precipitation, and plants were denser in wetter areas (Toft, 1995). Water scarcity can limit the establishment and growth of rabbitbrush (Donovan and Ehleringer, 1991, 1992; Donovan and others, 1993). Nonphreatophytic subspecies of rabbitbrush that exist on rainfall, however, occur in some regions (Elmore and others, 2003).
The xeric pioneer shrubs group underwent a small increase at sites with decreased streamflow permanence, whereas cover of the xeric competitor shrubs in the flood plain showed a small increase at sites with deep ground water. This can reflect the ability of the xeric pioneer species to thrive at the sites with highly fluctuating water tables, and perhaps reflects reduced competition from more hydromesic species at such sites.

\section{Biohydrology Analysis: Influence of Hydrology on Herbaceous Plant Species}

This section describes quantitative relations between the composition of herbaceous plant communities and site hydrology using methods parallel to those in the previous section on woody plants. The relative importance of the hydrologic factors to specific groups of species is discussed.

\section{Hydric Herbaceous Perennials}

The most abundant species in the hydric herbaceous perennials group along the upper San Pedro River are smooth scouring rush (Equisetum laevigatum), hardstem bulrush (Schoenoplectus acutus), and Torrey rush (Juncus torreyi; appendix 7, table 7-H). Some species, including hardstem bulrush and cattail (Typha latifolia and T. domingensis), are tall, aquatic-emergent macrophytes, whereas others, including watercress (Rorippa nasturtium-aquaticum) and water speedwell (Veronica anagallis-aquatica), spread out across the water surface (Rejmankova, 1992). Most hydric herbaceous perennial species, including smooth horsetail, Torrey rush, sand spikerush (Eleocharis montevidensis), and baltic rush (Juncus arcticus var. balticus), spread clonally through rhizomes or stolons.

Cover of hydric perennial herbs was more abundant in the streamside zone (table 25) than the flood-plain zone (table 26). Across the flood plain, this group declined in cover with increasing elevation above the channel bed (a variable correlated with depth to ground water and inundation frequency) in dry and wet seasons alike; low-lying, nearchannel surfaces had the greatest cover (table 27). Among sites, cover in the streamside zone was greatest where perennial flow occurred and declined as streamflow became more intermittent (table 28). Some hydric herbaceous perennial species, including hardstem bulrush and Torrey rush, had measurable cover only at perennial sites, whereas others, including smooth scouring rush, maintained sparse cover at intermittent-wet sites (fig. 32). The fluvial surfaces supporting these hydric perennials were frequently inundated and were underlain by shallow ground water. For example, scouring rush grew on surfaces that were inundated once every 2 years and where the mean of the annual maximum depth to ground water was $1.4 \mathrm{~m}$ (fig. 33). 
Table 25. Mean ground-cover values (percent) of herbaceous species, by functional group, within the streamside zone, San Pedro Riparian Conservation Area, Upper San Pedro Basin, Arizona. Also shown are total (aggregate) herbaceous cover, herbaceous species richness, and the wetland indicator score (ranging from 1 to 5, with 1 indicating wettest conditions), San Pedro Riparian National Conservation Area, Upper San Pedro Basin, Arizona

$\left[\right.$ no./ $/ \mathrm{m}^{2}$, number per square meter; $n$, site sample size. Sites are classified into hydrology classes (perennial, intermittent-wet, and intermittent-dry; table 16 ); values are averages of 5 to 25 plots per site]

\section{Mean ground-cover values}

\begin{tabular}{|c|c|c|c|c|c|c|c|c|c|c|}
\hline & $\begin{array}{c}\text { Hydric } \\
\text { perennial } \\
\text { (percent) }\end{array}$ & $\begin{array}{c}\text { Hydric } \\
\text { annual } \\
\text { (percent) }\end{array}$ & $\begin{array}{c}\text { Mesic } \\
\text { perennial } \\
\text { (percent) }\end{array}$ & $\begin{array}{c}\text { Mesic } \\
\text { annual } \\
\text { (percent) }\end{array}$ & $\begin{array}{c}\text { Xeric } \\
\text { perennial } \\
\text { (percent) }\end{array}$ & $\begin{array}{c}\text { Xeric } \\
\text { annual } \\
\text { (percent) }\end{array}$ & $\begin{array}{c}\text { Total } \\
\text { cover } \\
\text { (percent) }\end{array}$ & $\begin{array}{c}\text { Species } \\
\text { richness } \\
\text { (percent) }\end{array}$ & $\begin{array}{c}\text { Wetland } \\
\text { indicator } \\
\text { score } \\
\left(\mathrm{no} . / \mathrm{m}^{2}\right)\end{array}$ & $\begin{array}{c}\text { Site } \\
\text { sample size } \\
(n)\end{array}$ \\
\hline \multicolumn{11}{|c|}{ June 2000} \\
\hline Perennial & 33 & 16 & 2 & 2 & 0 & 1 & 54 & 4.9 & 1.6 & 2 \\
\hline Intermittent-dry & 0 & 1 & 2 & 2 & 0 & 1 & 6 & 2.1 & 2.8 & 2 \\
\hline \multicolumn{11}{|c|}{ June 2001} \\
\hline Perennial & 22 & 21 & 10 & 5 & 0 & 0 & 58 & 4.5 & 2.2 & 7 \\
\hline Intermittent-wet & 2 & 9 & 11 & 4 & 0 & 0 & 27 & 3.7 & 2.9 & 3 \\
\hline Intermittent-wet & 2 & 2 & 15 & 4 & 0 & 0 & 23 & 2.4 & 3.6 & 5 \\
\hline Intermittent-dry & 0 & 1 & 42 & 2 & 0 & 2 & 47 & 3.3 & 4.0 & 2 \\
\hline \multicolumn{11}{|c|}{ June 2003} \\
\hline Perennial & 5 & 11 & 20 & 3 & 0 & 1 & 40 & 4.8 & 2.9 & 2 \\
\hline Intermittent-wet & 2 & 2 & 15 & 3 & 0 & 1 & 23 & 3.3 & 3.5 & 5 \\
\hline Intermittent-dry & 0 & 0 & 17 & 1 & 1 & 0 & 19 & 1.9 & 4.0 & 1 \\
\hline \multicolumn{11}{|c|}{ August 2000} \\
\hline Intermittent-wet & 5 & 5 & 39 & 5 & 0 & 0 & 56 & 2.5 & 3.6 & 3 \\
\hline Intermittent-dry & 0 & 8 & 44 & 10 & 1 & 3 & 65 & 2.8 & 3.7 & 2 \\
\hline \multicolumn{11}{|c|}{ August 2002} \\
\hline Perennial & 10 & 2 & 13 & 2 & 0 & 1 & 28 & 3.1 & 2.6 & 6 \\
\hline Intermittent-wet & 3 & 1 & 27 & 1 & 0 & 0 & 32 & 2.4 & 3.6 & 6 \\
\hline Intermittent-dry & 0 & 4 & 33 & 5 & 1 & 1 & 43 & 4.4 & 3.8 & 2 \\
\hline \multicolumn{11}{|c|}{ August 2003} \\
\hline Perennial & 36 & 0 & 4 & 1 & 0 & 0 & 42 & 1.9 & 2.7 & 2 \\
\hline Intermittent-wet & 1 & 2 & 25 & 3 & 0 & 1 & 34 & 3.5 & 3.7 & 3 \\
\hline
\end{tabular}


Table 26. Mean ground-cover values (percent) of herbaceous plants, by functional group, in the flood plain during premonsoon and monsoon seasons, San Pedro Riparian Conservation Area, Upper San Pedro Basin, Arizona. Also shown are total (aggregate) herbaceous cover, herbaceous species richness, and the wetland indicator score (ranging from 1 to 5 , with 1 indicating wettest conditions)

[no. $/ \mathrm{m}^{2}$, number per square meter; $\mathrm{n}$, site sample size. Sites are classified into hydrology classes (perennial, intermittent-wet, and intermittent-dry; table 16)]

Mean ground-cover values

\begin{tabular}{|c|c|c|c|c|c|c|c|c|c|c|}
\hline & $\begin{array}{c}\text { Hydric } \\
\text { perennial } \\
\text { (percent) }\end{array}$ & $\begin{array}{c}\text { Hydric } \\
\text { annual } \\
\text { (percent) }\end{array}$ & $\begin{array}{c}\text { Mesic } \\
\text { perennial } \\
\text { (percent) }\end{array}$ & $\begin{array}{c}\text { Mesic } \\
\text { annual } \\
\text { (percent) }\end{array}$ & $\begin{array}{c}\text { Xeric } \\
\text { perennial } \\
\text { (percent) }\end{array}$ & $\begin{array}{c}\text { Xeric } \\
\text { annual } \\
\text { (percent) }\end{array}$ & $\begin{array}{c}\text { Total } \\
\text { cover } \\
\text { (percent) }\end{array}$ & $\begin{array}{c}\text { Species } \\
\text { richness } \\
\left(\mathrm{no} . / \mathrm{m}^{2}\right)\end{array}$ & $\begin{array}{c}\text { Wetland } \\
\text { indicator } \\
\text { score }\end{array}$ & $\begin{array}{c}\text { Site } \\
\text { sample size } \\
(n)\end{array}$ \\
\hline \multicolumn{11}{|c|}{ June 2000} \\
\hline Perennial & 3 & 2 & 9 & 2 & 1 & 0 & 17 & 2.1 & 3.4 & 2 \\
\hline Intermittent-dry & 0 & 0 & 6 & 0 & 1 & 0 & 8 & 1.4 & 4.2 & 2 \\
\hline \multicolumn{11}{|c|}{ June 2001} \\
\hline Perennial & 2 & 5 & 24 & 4 & 2 & 2 & 39 & 3.8 & 3.8 & 6 \\
\hline \multicolumn{11}{|c|}{ June 2003} \\
\hline Intermittent-wet & 2 & 0 & 3 & 0 & 1 & 0 & 7 & 1.4 & 3.6 & 2 \\
\hline \multicolumn{11}{|c|}{ August 2000} \\
\hline Perennial & 1 & 16 & 25 & 5 & 4 & 4 & 54 & 3.6 & 3.6 & 2 \\
\hline Intermittent-wet & 2 & 4 & 21 & 1 & 4 & 17 & 50 & 3.0 & 4.2 & 2 \\
\hline Intermittent-dry & 0 & 5 & 22 & 13 & 9 & 1 & 49 & 3.8 & 3.9 & 2 \\
\hline \multicolumn{11}{|c|}{ August 2002} \\
\hline Perennial & 1 & 1 & 25 & 2 & 2 & 4 & 34 & 4.2 & 4.0 & 6 \\
\hline Intermittent-wet & 3 & 1 & 24 & 2 & 3 & 1 & 34 & 2.9 & 3.8 & 5 \\
\hline Intermittent-dry & 0 & 1 & 11 & 3 & 10 & 7 & 33 & 5.1 & 4.4 & 1 \\
\hline \multicolumn{11}{|c|}{ August 2003} \\
\hline Perennial & 0 & 0 & 39 & 39 & 2 & 3 & 48 & 4.7 & 4.2 & 2 \\
\hline Intermittent-wet & 2 & 2 & 9 & 4 & 3 & 1 & 23 & 5.0 & 4.0 & 3 \\
\hline
\end{tabular}


Table 27. Correlation coefficients ( $r$ values) between herbaceous plant cover (by functional group) and plot surface elevation above the thalweg, San Pedro Riparian Conservation Area, Upper San Pedro Basin, Arizona

$[r$, correlation coefficient $p$, level of significance; NS, not significant; significant correlations (at $p<0.10$ ) are shown in bold. Values shown are significant at $\mathrm{p}<0.05$ on the basis of a sampling of 105 plots among 6 sites]

\begin{tabular}{|c|c|c|c|c|c|c|c|c|}
\hline Functional group & \multicolumn{2}{|c|}{ June 2000} & \multicolumn{2}{|c|}{ August 2000} & \multicolumn{2}{|c|}{ June 2001} & \multicolumn{2}{|c|}{ August 2001} \\
\hline Hydric perennials & -0.21 & 0.03 & -0.20 & 0.04 & -0.31 & 0.00 & -0.19 & 0.06 \\
\hline Hydric annuals & -.40 & .00 & .04 & NS & -.54 & .00 & .14 & NS \\
\hline Mesic perennials & .06 & NS & -.08 & NS & -.02 & NS & .01 & NS \\
\hline Xeric perennials & .07 & NS & .31 & .00 & .13 & NS & .25 & .01 \\
\hline Xeric annuals & -.18 & NS & .49 & .00 & .09 & NS & .31 & .00 \\
\hline
\end{tabular}

Table 28. Correlation coefficients ( $r$ values) between streamside-zone herbaceous vegetation and water-year streamflow permanence, for premonsoon and monsoon sampling periods, San Pedro Riparian Conservation Area, Upper San Pedro Basin, Arizona

[ $n$, site sample size; $r$, correlation coefficient $p$, level of significance; NS, not significant; significant correlations (at $p<0.10)$ are shown in bold. Values shown are significant at $p<0.05$ on the basis of a sampling of 105 plots among 6 sites; $p$-values are indicated for correlations significant at $p<0.10]$

\begin{tabular}{|c|c|c|c|c|c|c|c|c|}
\hline \multirow{2}{*}{$\begin{array}{c}\text { Streamside zone, } \\
\text { premonsoon }\end{array}$} & \multicolumn{2}{|c|}{$\begin{array}{c}\text { Premonsoon } 2000 \\
(n=6)\end{array}$} & \multicolumn{2}{|c|}{$\begin{array}{l}\text { Premonsoon } 2001 \\
(n=9)\end{array}$} & \multicolumn{2}{|c|}{$\begin{array}{c}\text { Premonsoon } 2002 \\
(n=13)\end{array}$} & \multicolumn{2}{|c|}{$\begin{array}{c}\text { Premonsoon } 2003 \\
(n=8)\end{array}$} \\
\hline & $r$ & $p$ & $r$ & $p$ & $r$ & $p$ & $r$ & $\boldsymbol{p}$ \\
\hline Wetland indicator score & -0.75 & 0.09 & -0.68 & 0.03 & -0.79 & 0.00 & -0.65 & 0.08 \\
\hline \multicolumn{9}{|c|}{ Cover, by functional group } \\
\hline Hydric annuals & .84 & .04 & .52 & NS & .71 & .01 & .96 & .00 \\
\hline Mesic perennials & -.10 & NS & -.55 & .10 & -.76 & .00 & .03 & NS \\
\hline Mesic annuals & -.23 & NS & .15 & NS & .51 & .08 & .49 & NS \\
\hline $\begin{array}{c}\text { Streamside zone, } \\
\text { monsoon }\end{array}$ & \multicolumn{2}{|c|}{$\begin{array}{l}\text { Monsoon } 2000 \\
\qquad(n=6)\end{array}$} & \multicolumn{2}{|c|}{$\begin{array}{l}\text { Monsoon } 2001 \\
\quad(n=10)\end{array}$} & \multicolumn{2}{|c|}{$\begin{array}{c}\text { Monsoon } 2002 \\
(n=14)\end{array}$} & \multicolumn{2}{|c|}{$\begin{array}{c}\text { Monsoon } 2003 \\
(n=5)\end{array}$} \\
\hline Wetland indicator score & -0.59 & NS & -0.52 & NS & -0.67 & 0.01 & -0.67 & NS \\
\hline \multicolumn{9}{|c|}{ Cover, by functional group } \\
\hline Hydric perennials & 0.68 & NS & 0.60 & 0.09 & 0.74 & 0.00 & 0.83 & 0.08 \\
\hline Hydric annuals & -.83 & 0.04 & -.28 & NS & -.18 & NS & -.78 & NS \\
\hline Mesic perennials & -.64 & NS & -.47 & NS & -.64 & .01 & -.68 & NS \\
\hline Mesic annuals & -.63 & NS & -.74 & .02 & -.23 & NS & -.70 & NS \\
\hline
\end{tabular}



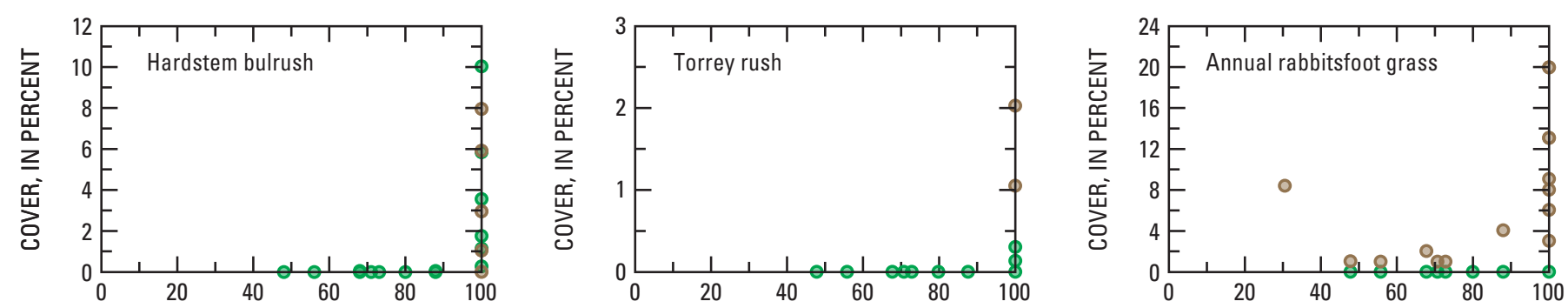

ANNUAL STREAMFLOW PERMANENCE, IN PERCENT
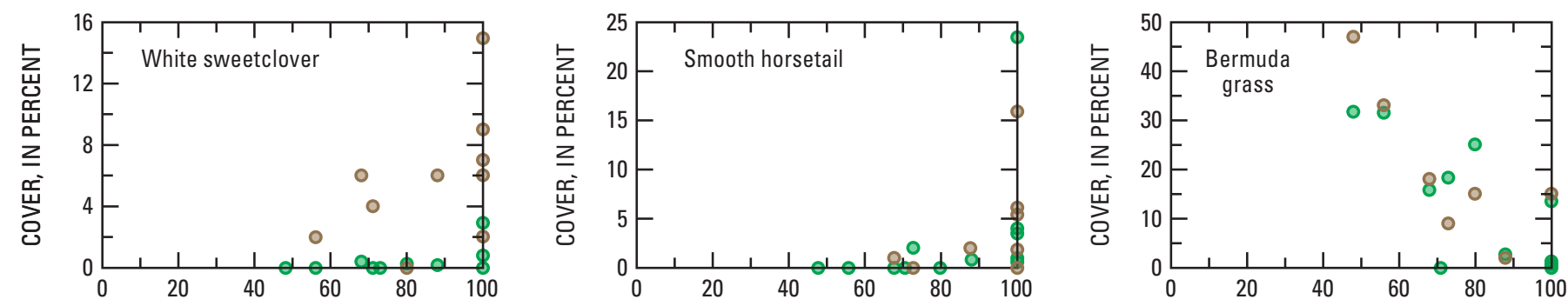

ANNUAL STREAMFLOW PERMANENCE, IN PERCENT

EXPLANATION

- DRY SEASON ○ WET SEASON

Figure 32. Cover values for several common herbaceous species in the San Pedro River streamside zone during premonsoon and monsoon periods of 2002, in relation to annual streamflow permanence at the site (2002 water year), San Pedro Riparian National Conservation Area, Upper San Pedro Basin, Arizona. Each data point represents a site mean.

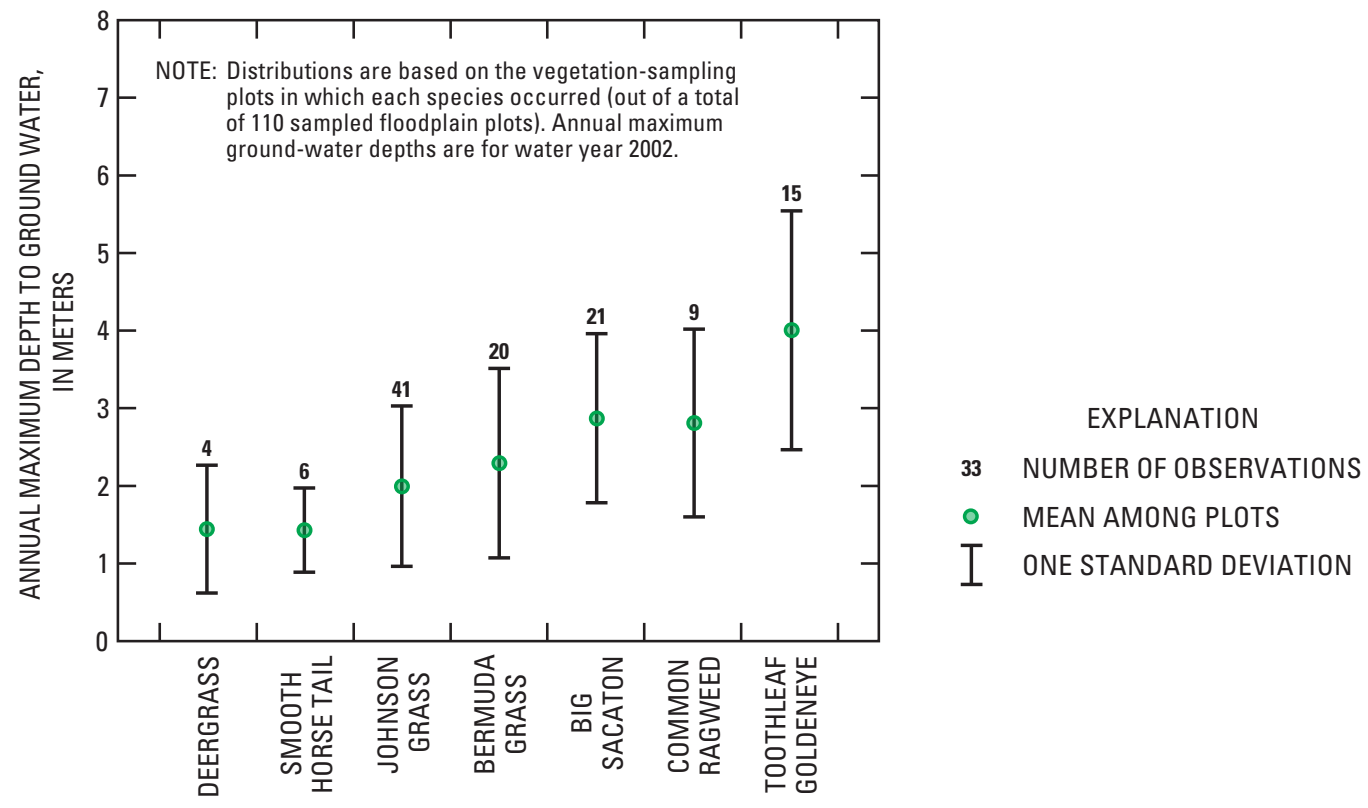

Figure 33. Distribution of common herbaceous perennial plant species across depth-to-ground-water gradients in the San Pedro River flood plain, San Pedro Riparian National Conservation Area, Upper San Pedro Basin, Arizona. Values shown are the mean of the annual maximum ground-water depth during the 2002 water year plus and minus one standard deviation. 
Cover of hydric perennials was high at some sites in 2001, likely because of the increased streamflows in the year after the October 2000 flood (fig. 34). Weighted average wetland-indicator scores for the streamside vegetation (calculated by averaging the relative cover of plants within each wetland indicator class by class weights from 1 through 5) were lower (wetter) in 2001 than in 2002 and 2003, reflecting greater relative cover of hydric species at the sites in 2001 (fig. 34). Hydric perennials showed little variation in cover between the summer dry and wet seasons (tables 25 and 26).

\section{Mesic Herbaceous Perennials}

In all sampling seasons, the mesic perennials were the most abundant herbaceous plants in the flood plain (table 26). The most abundant species in this group was big sacaton, a large bunch grass that roots to a depth of at least $3.8 \mathrm{~m}$. The second and third most abundant species were rhizomatous grasses: Johnson grass (Sorghum halapense) and bermuda grass (Cynodon dactylon), moderately drought-tolerant species that root to a depth of about $1.5 \mathrm{~m}$. Vine mesquite (Panicum obtusum), a rhizomatous grass, and cuman ragweed (Ambrosia psilostachya), a rhizomatous forb, also were common, as were several other bunch grasses, including deergrass (Mulhenbergia rigens), alkali sacaton (Sporobolus airoides), and sand and spike dropseed (Sporobolus cryptandrus and S. contractus).

Unlike the hydric perennials, which grew mainly on low fluvial surfaces, the mesic herbaceous perennials had broad distribution in the flood plain. They occurred in areas above and below the summer flood-inundation zone, and spanned a broad range of depths to ground water. Bermuda grass, for example, grew on plots that were inundated on average once every 2 to every 50 years, and where the mean of the annual maximum depth to ground water was $2.5 \mathrm{~m}$ (fig. 33).

For several of the seasonal data sets, cover of mesic perennials in the streamside zone decreased among sites in relation to decreasing streamflow permanence (table 28), whereas that of the hydric perennials increased. This pattern was largely driven by the response of bermuda grass. During the 2002 monsoon season, for example, cover of bermuda grass increased as streamflow permanence decreased (fig. 32).

Most of the common mesic perennials were present throughout the summer, but increased in cover from the dry to wet season (table 26).

\section{Hydric Annuals}

The composition of the hydric annual community varied seasonally, with some species present primarily during the early summer, some present during the later summer monsoon, and yet others present throughout the full summer growing season.
All premonsoon data sets indicated that hydric annuals increased in streamside cover among sites in relation to increasing streamflow permanence. Dry-season cover of hydric annuals declined laterally across flood plains with increasing plot elevation above the thalweg and with correlated variables including depth to ground water and distance from the channel, indicating dry-season reliance on surface water and (or) shallow ground water.

The most abundant hydric annual in the streamside zone during early summer was annual rabbitsfoot grass (Polypogon monspeliensis). It grew at intermittent sites but had greatest cover at perennial sites (fig. 32). This small, shallow-rooted species has the bulk of its roots in the top 10 to $20 \mathrm{~cm}$ of soil (Cornwall, 1998). It was present in early summer and completed its life-cycle prior to monsoon rains. Barnyard grass (Echinochloa crus-galli), curlytop knotweed (Polygonum lapathifolium), and Pennsylvania knotweed (Polygonum pensylvanicum) were abundant in the streamside zone in early summer and persisted through late summer.

During the monsoon rain and flood season, streamflows were present at most sites in the SPRNCA and cover of hydric annuals was not positively correlated with annual streamflow permanence. During late summer, hydric annuals had a broader lateral range across the flood plain than they did earlier in the summer, with greatest cover in the zone inundated by the monsoon floods (fig. 35). In 2000, the average maximum surface elevation (above thalweg) inundated by the monsoon floods was $2.6 \pm 0.5 \mathrm{~m}$. Hydric annuals in late summer 2000 peaked in cover on plots that were 0.5 to $3 \mathrm{~m}$ above the thalweg, suggesting a positive response to flood inundation.

During 2001, streamflows were elevated over much of the San Pedro River owing to recharge from the October 2000 flood. Some sites that were intermittent during 2000 had year-round flow during 2001. In response, hydric annuals were abundant in 2001 (fig. 36).

\section{Mesic Annuals}

Patterns of the mesic annuals varied seasonally. The mesic annuals increased in cover among sites in relation to increasing streamflow permanence during one of four premonsoon seasons and declined in cover with increasing plot elevation (and related variables) during the dry season, suggesting association with streamflows and near-channel shallow ground water (tables 27 and 28). In one monsoon season, in contrast, cover of mesic annuals declined among sites in relation to increasing streamflow permanence, perhaps reflecting competitive interactions with hydric species at the wetter sites.

Mesic annuals, like hydric annuals, had a broader lateral range across the flood plain in the wet season than in the dry season (fig. 35). During the wet season of 2000, mesic annuals were present on high fluvial surfaces above the inundated area, suggesting that germination was triggered by rainfall, but cover peaked on plots 1 to $3 \mathrm{~m}$ above thalweg, which is within the zone inundated by the August 7-8, 2000, monsoon flood (mean maximum level of inundation of $2.6 \pm .5 \mathrm{~m}$ ). 

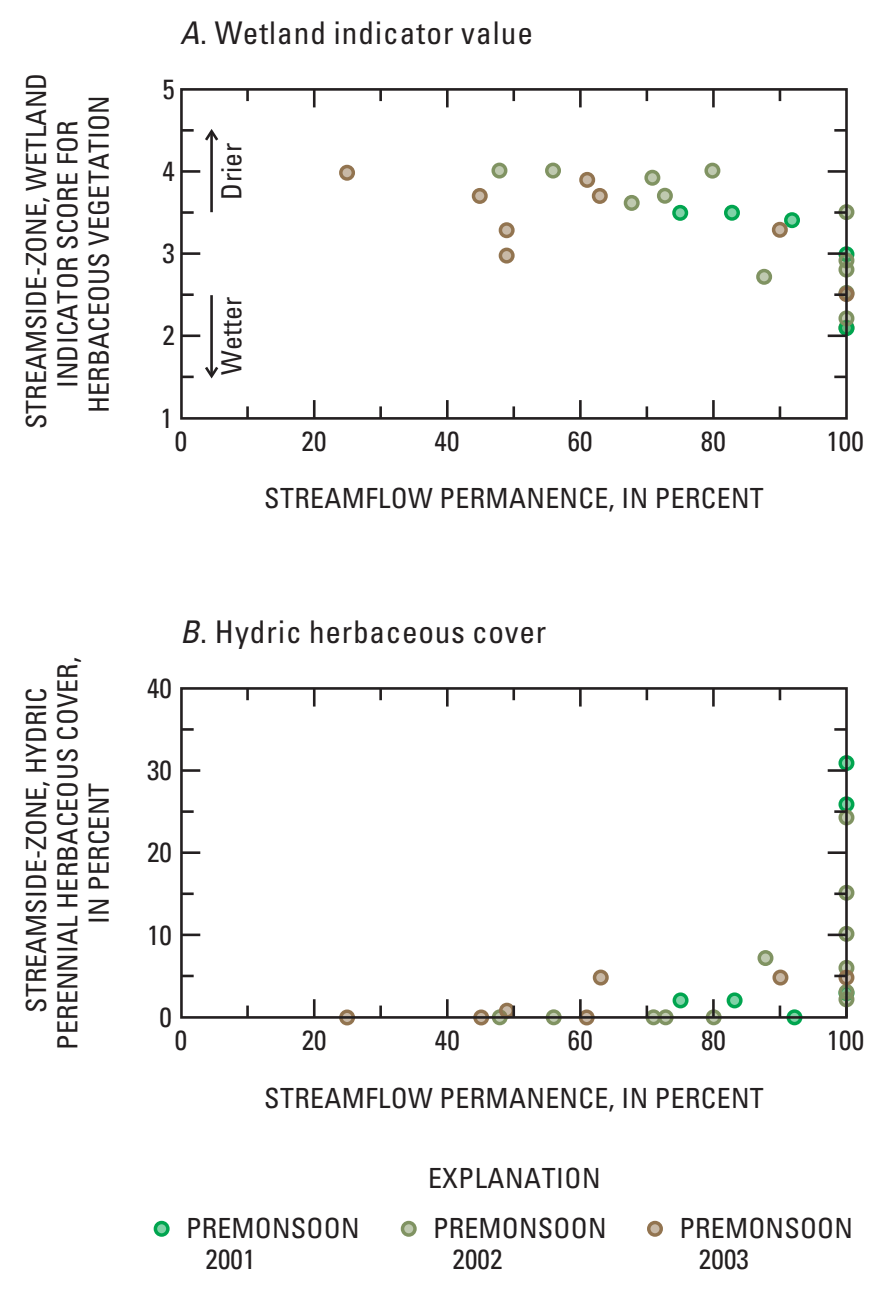

Figure 34. Overlay of streamside-zone site values, San Pedro Riparian National Conservation Area, Upper San Pedro Basin, Arizona. $A$, Wetland indicator values; $B$, Hydric herbaceous cover, during a wet year (water year 2001), intermediate year (water year 2002), and dry year (water year 2003) in relation to site streamflow permanence.

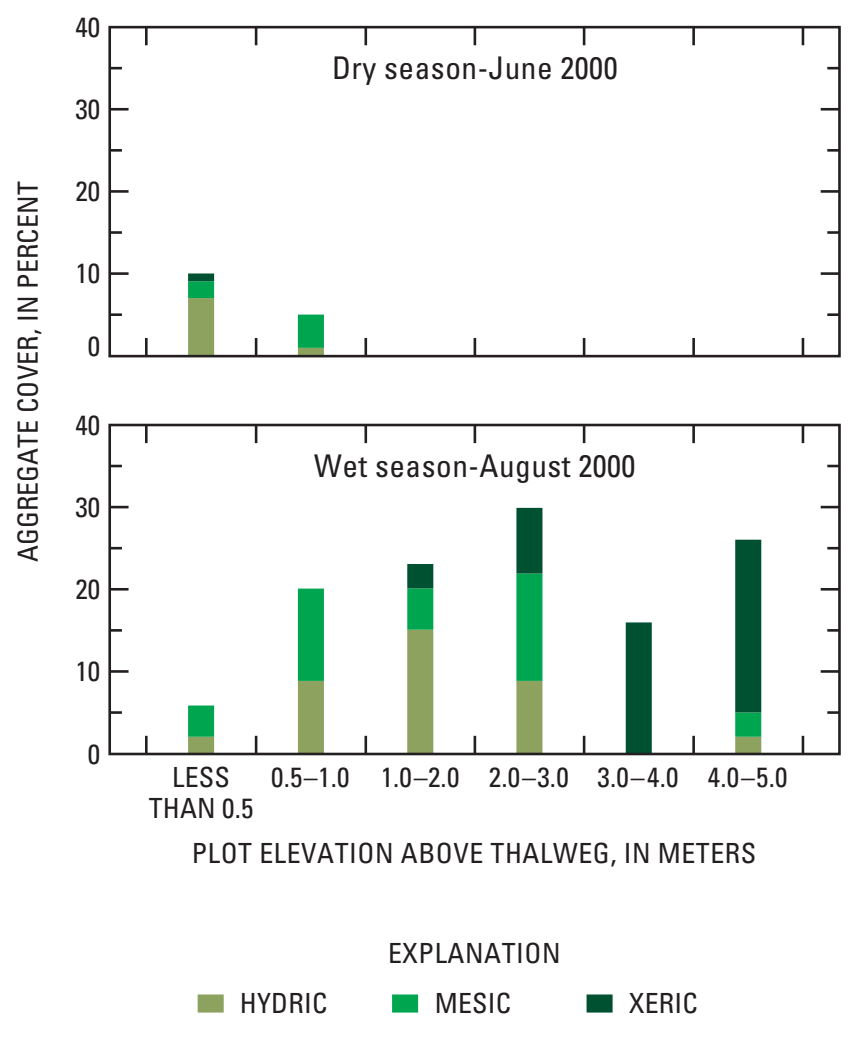

Figure 35. Mean cover of hydric, mesic, and xeric annuals/biennials in relation to elevation of the fluvial surface above the thalweg during the dry and wet seasons of 2000, San Pedro Riparian National Conservation Area, Upper San Pedro Basin, Arizona.

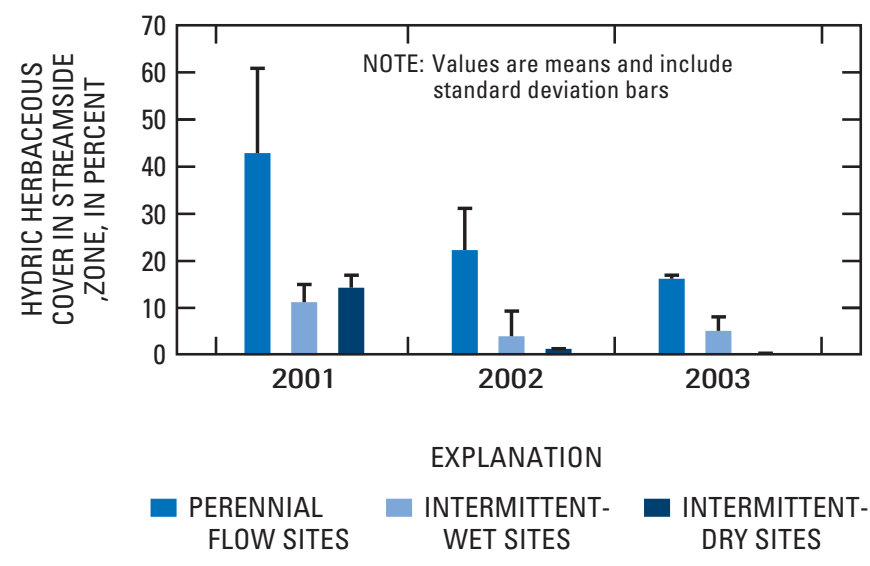

Figure 36. Hydric herbaceous cover (annual and perennial) in the streamside zone during the premonsoon season (June), San Pedro Riparian Conservation Area, Upper San Pedro Basin, Arizona. 
The most abundant mesic annual species during the premonsoon season was white sweetclover (Melilotus alba). White sweetclover declined among sites as streamflow permanence declined (fig. 32) but maintained greater cover than its hydric annual counterpart (rabbitsfoot grass) at intermittent sites. White sweetclover and annual yellow sweetclover (Melilotus indicus) both began to senesce by August. The most common mesic annual during the monsoon season was rough cocklebur (Xanthium strumarium). It grew on plots that were inundated, on average, once every 2 years.

\section{Xeric Annuals}

Xeric annuals form the most species-rich functional group in the San Pedro River flood plain, comprising over one-third of the species recorded at study sites. Across the flood plain, xeric annuals were distributed primarily on high fluvial surfaces, above flood-inundation zones and well above the alluvial water table. On such surfaces, rainfall would be the most likely water source for germination and growth of shallow-rooted annual plants. The xeric annuals had greatest cover during sampling seasons with abundant rainfall, including the monsoon seasons and the premonsoon period of 2001 (table 26).

New Mexico copperleaf (Acalypha neomexicana), Mexican fireplant (Euphorbia heterophylla), Transpecos morning-glory (Ipomoea cristulata), Mexican panicgrass (Panicum hirticaule), and tepary bean (Phaseolus acutifolius) were among the species recorded during the monsoon season. New Mexico goosefoot (Chenopodium neomexicanum), bristly nama (Nama hispidum), and skyblue phacelia (Phacelia crenulata) were among the cool-season species present during early summer. Several species, including Wright's saltbush (Atriplex wrightii), pitseed goosefoot (Chenopodium berlandieri), Fremont goosefoot (Chenopodium fremontii), and Thurber's pepperweed (Lepidium thurberi) were present in early and late summer.

\section{Xeric Perennials}

Xeric perennials were a species-rich functional group. Many of the common xeric perennials in the SPRNCA flood plain were grasses: spidergrass (Aristida ternipes), sideoats grama (Bouteloua curtipendula), Lehmann's lovegrass (Eragrostis lehmanniana), tobosa grass (Pleuraphis mutica), and streambed bristlegrass (Setaria leucopila). Among the common forbs were weakleaf burr ragweed (Ambrosia confertiflora) and toothleaf goldeneye (Viguiera dentata). Within the San Pedro River flood plain, xeric perennials increased in cover with plot elevation above the thalweg (table 27). They showed high temporal variation in cover (table 26), being sparse during dry periods (for example, premonsoon of 2000) and having greater cover during wetter periods (for example, premonsoon of 2001, post-monsoon seasons).

\section{Discussion}

\section{Hydric and Mesic Perennials}

Of all the plant functional groups analyzed, the hydric perennials are most sensitive to changes in water availability. The species in this group are intolerant of drought and typically grow in near-channel areas where soils are saturated by stream water or inflowing ground water (Yatskievych and Jenkins, 1981; Grace, 1989; Stromberg and others, 1996; Dixon and Johnson, 1999). The lack of increase in hydric perennial cover from the dry to wet season suggests use of permanent riparian water sources, such as stream base flows or shallow ground water. A shift from perennial to intermittent flow causes sharp declines in cover of bulrush and other similar species.

The mesic perennials, in contrast, are a moderately drought-tolerant group that likely use a wide range of water sources. The shift observed in the streamside zone from hydric perennial herbs to bermuda grass is analogous to the compositional shift from hydromesic pioneer trees (cottonwood-willow) to mesic pioneer trees (tamarisk) along site water-availability gradients, and may reflect competitive exclusion of bermuda grass by hydric perennials under wetter conditions, and (or) intolerance of prolonged soil saturation by bermuda grass.

The late-summer increase in cover of the mesic perennials can be caused by a range of factors, including high rainfall, raised alluvial ground-water levels associated with summer flooding, direct effects of flood inundation, and (or) increased humidity levels. Some species, such as big sacaton, may have increased in seasonal productivity by shifting from deep water sources to shallow water sources (Dawson and Pate, 1996). Studies of big sacaton along the San Pedro River suggest extensive use of shallow soil water derived from rainfall during the monsoon season (Scott, Shuttleworth and others, 2000) and some dry-season use of ground water in flood-plain habitats where ground-water depth is less than about $4 \mathrm{~m}$ (Tiller, 2004).

The hydric and mesic perennials both grew on surfaces that were frequently inundated. Many of the plants in these groups, including cattail, bulrush, bermuda grass and Johnson grass, have capacity for clonal spread. Clonal growth is adaptive in disturbed sites, as the capacity for growth from multiple, lateral nodes increases probability of survivorship and regrowth after burial by sediment or fragmentation by flood scour (Menges and Waller, 1983; Prach and Pysek, 1994; Freidman and others, 1996).

\section{Hydric and Mesic Annuals}

Abundance and composition of the annual-plant community change seasonally and annually in response to changes in water availability and flood disturbance. During 
the premonsoon season, the hydric annuals that are present are typically restricted to channel bars and other disturbed fluvial surfaces, and depend on stream base flows and inflowing ground water to provide adequate water. The mesic annuals also depend largely on base flows and inflowing ground water to provide adequate water during the premonsoon dry season, but have somewhat greater tolerance for dry soils.

Cover of hydric and mesic annuals increased in response to late summer flooding and rains. Warm-season annuals, such as jungle rice (Echinochloa colona), can complete their life cycle during the monsoon season and thrive along primary or secondary channels at sites with intermittent streamflow. Some of the hydric and mesic annuals were present on fluvial surfaces above summer inundation zones, suggesting rain-triggered germination, but cover was high in soils wetted by the seasonal monsoon flood pulse. The annual plants may be responding to seasonally elevated ground-water levels and rainfall, as well as to flood water in the soil column. Some of the species in this group have moderately deep roots [for example, $2.2 \mathrm{~m}$ for common sunflower (Helianthus annuus; Jaafar and others, 1993)] and could access water in the zone of capillary rise above the water table across much of the flood plain. Studies in other regions also show positive response of herbaceous-macrophyte productivity and species richness to seasonal flooding (Robertson and others, 2001).

Abundance of these hydric and mesic annuals is influenced by large floods. In addition to responding positively to the disturbance associated with large floods, the annuals benefit from increased streamflow permanence and elevated ground-water tables. Large-scale flooding can increase cover and richness of the hydric annuals along interrupted (spatially intermittent) river reaches, as evidenced by the 2001 data set.

Many of the hydric and mesic annuals found in the San Pedro River flood plain are widely distributed along flooded river banks in many regions (Blais and Lechowicz, 1989; McLaughlin, 2004). Others, such as San Pedro matchweed (Xanthocephalum gymnospermoides), have more limited distribution.

\section{Xeric Annuals and Perennials}

Species composition shifts along the flood plain from hydric, flood-tolerant species on low fluvial surfaces to more xeric and flood-intolerant species on the higher surfaces. The prevalence of xeric annuals and perennials on high fluvial surfaces (above summer flood inundation zones) as well as these plants' increased cover during rainy seasons suggests that seasonal rains provide the primary moisture source for germination and growth.

Several of the xeric perennials in the San Pedro River flood plain, including spidergrass, sideoats grama and Lehmann's lovegrass, also are common in desert grassland habitats. Many of the xeric annuals are characteristic "desert annuals" that complete their life-cycle during the short rainy season in open, undisturbed desert uplands as well as in riparian zones. The bimodal rainfall pattern in the study area allows for two seasonally distinct groups of these rainfall-dependent annuals.

Although largely rain-dependent, flood disturbance likely contributes to the high diversity of the xeric annuals present in the flood plain (Bagstad and others, 2005). Many of the common xeric annuals in the flood plain, including needle grama (Bouteloua aristidoides) and sandbur (Cenchrus spinifex), also are associated with disturbed areas of desert uplands or urban habitats (such as road edges; Parker, 1972). Floods create the bare, moist mineral soils needed for seedling establishment of annuals (Smith, Keevin, and others, 1998) by redistributing sediments and removing competitive plant species (for example, Johnson grass). Floods also create a more favorable environment for germination of small-seeded plants by removing litter cover (Nilsson and others, 1999; Xiong and others, 2001a and b).

\section{Trend Analysis}

This section focuses on recruitment, growth, and age-structure patterns of the dominant pioneer tree species in the San Pedro River flood plain.

\section{Relative Abundance of Fremont Cottonwood, Goodding Willow, and Tamarisk}

Objective.-Assess long-term (decadal scale) changes in relative abundance of cottonwood-willow and tamarisk.

Methods.-Compositional shifts from cottonwood and willow to tamarisk can be an indicator of recent changes in site hydrology. Tree-stem density and basal area data collected at 20 SPRNCA study sites was categorized by species and age class and used to calculate the importance values needed to assess trends for compositional shifts. Importance values indicate the abundance of a particular species relative to abundance of all species in the community; they were calculated for this study by using the following modification of the Curtis and MacIntosh (1951) formula: importance value is the sum of the relative basal area and relative stem density, divided by two. Importance values were calculated for tamarisk, cottonwood, and willow within each of four age classes: young (<10 years), mature-1 (11-30 years), mature-2 (31-50 years), and old ( $>50$ years). Tree age was inferred from size-age regression equations calculated by using data collected along the San Pedro River (Stromberg, 1998a). Because trees grow at different rates depending on their growing conditions, some slow-growing trees may be misclassified into a younger age class and vice versa. The use of a small number of coarse-grained size classes, each with a fairly large range, decreases the chances of such classification errors. Cottonwood and willow, trees with stem diameters less than $20 \mathrm{~cm}$ were placed in the young class, those with stems $20-50 \mathrm{~cm}$ were in the mature-1 class, stems $50-90 \mathrm{~cm}$ were in 
the mature- 2 class, and with stems greater than $90 \mathrm{~cm}$ were in the old class. Tamarisk with stems less than $5 \mathrm{~cm}$ were in the young class, those with stems $5-20 \mathrm{~cm}$ were in the mature-1 class, those with stems $20-35 \mathrm{~cm}$ were in the mature- 2 class, and those with stems greater than $35 \mathrm{~cm}$ were in the old class. Each class includes plants that established from seed and through vegetative reproduction. Weighted averages for stem density and basal area within age classes were calculated per flood-plain transect by weighting plot-level values by relative patch widths. Site values are based on means of three to five biohydrology transects; reach values are averages of one or two sites per reach.

Results. - The importance value of tamarisk (versus cottonwood and willow) was higher in drier areas. Among sites, tamarisk importance value was negatively correlated with streamflow permanence $(r=-0.70, p=0.01, n=16)$ and positively correlated with annual mean $(r=0.50, p=0.06$, $n=15)$ and annual maximum $(r=0.57, p=0.03, n=15)$ depth to ground water. The importance value also was correlated with site elevation $(r=-0.55, p=0.02, n=20)$.

At the reach level, tamarisk importance value was negatively correlated with the spatial extent (in percent) of dry-season surface flow in 2002 ( $r=-0.74, p=0.01, n=14)$. Tamarisk's importance value was low $(<10$ percent) in all reaches in which perennial flows predominated, and thus was low in much of the middle section of the SPRNCA (reaches 2 through 7; fig. 37).

Tamarisk's importance value was moderate (19 percent) in the interrupted reach (reach 1) at the southern tip of the SPRNCA. Importance values for tamarisk were high (26 to 92 percent) in the dry, northerly reaches (reaches 9, 12, 13 , and 14) where perennial flows were present along a third of the reach or less. The highest importance value (92 percent) was recorded in reach 13, below the St. David diversion ditch. Reach 11 (Tombstone streamflow-gaging station), however, had a low tamarisk importance value ( 9 percent) despite moderately dry conditions.

Patterns of tamarisk importance values across age classes varied among reaches (fig. 37) and sites (table 29). For most of the wet reaches $(2,3,4,5,6,7$, and 10$)$, the pattern was stable; importance values were near zero for all age classes. In the driest reach (13), values were above 60 percent for all age classes. In six reaches, tamarisk importance values were higher in the younger pioneer-tree/shrub age classes than in older classes, suggesting a shift in relative abundance from cottonwood-willow to tamarisk over recent decades. These reaches with trends for increasing tamarisk importance values are reach 1 (Palominas area), 8 and 9 (Boquillas-Fairbank area), 11 (Tombstone area), 12 (Contention area), and 14 (Escalante area). Similar patterns are apparent when examining the relative width of vegetation patches dominated by each of the three pioneer tree species (table 29).

Discussion.-Regionally, many factors influence the relative abundance of cottonwood, willow, and tamarisk. Tamarisk is favored at sites with deep water levels, high soil salinity, livestock grazing, and suppressed winter/spring flooding (Stromberg and Chew, 2002). Within the SPRNCA, there is a natural flood regime, salinity is low owing to frequent flooding, and livestock grazing is limited to accidental (trespass) grazing. Thus, water availability likely is a key factor currently influencing the relative dominance of cottonwood, willow, and tamarisk. The increase in the tamarisk importance value in younger age classes observed at several SPRNCA sites may reflect local changes in river conditions and may be indicative of progressive site drying. Within the Lower San Pedro Basin, there are some reaches in which the reverse pattern is apparent, and tamarisk importance values decline in younger age classes; this may be attributable to local changes in river management which have included reduced rates of agricultural ground-water pumping and cessation of livestock grazing (Stromberg, 1998a, unpublished data). The fact that trends differ along the river suggests that local river conditions are influencing tree species composition.

A. Importance value

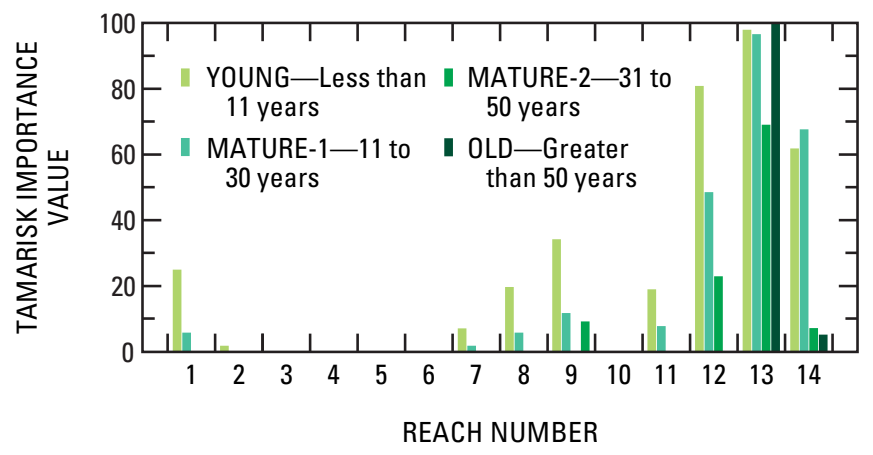

$B$. Percentage of reach with perennial flow

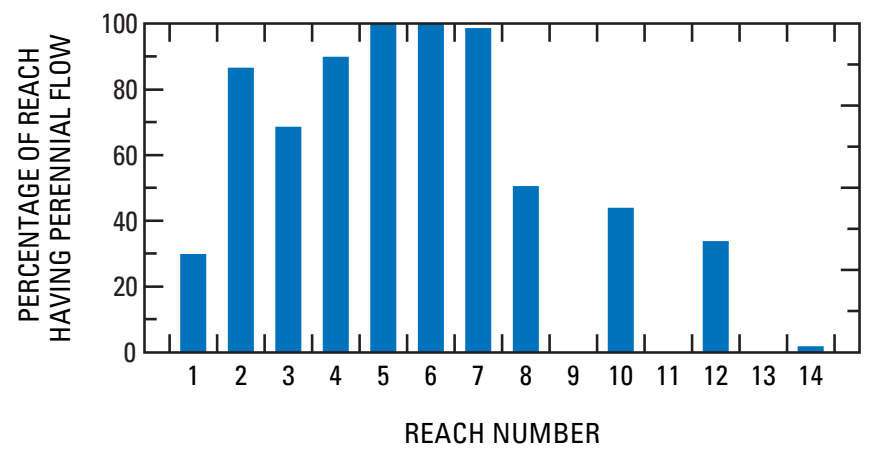

Figure 37. Graphs based on flow mapping during June 2002 within 14 reaches of the San Pedro Riparian National Conservation Area, Upper San Pedro Basin, Arizona. $A$, Importance value of tamarisk, relative to that of Fremont cottonwood and Goodding willow by age class; $B$, Percent of indicated reach of the San Pedro River having perennial flow. 
Table 29. Importance values for tamarisk (relative to that of Fremont cottonwood and Goodding willow), within age classes and for the population as a whole, at 20 biohydrology and supplemental sites within the San Pedro Riparian National Conservation Area, Upper San Pedro Basin, Arizona. Also shown are the relative widths of vegetation patches dominated by tamarisk (versus cottonwood or willow), by age class and for all age classes combined

[Importance values are based on relative abundance in terms of stem density and basal area. The importance value for cottonwood and willow is equal to 100 minus the tamarisk importance value; Stem classes: Old, age greater than 50 years; Mature-2, age from 31 to 50 years; Mature-1, age from 11 to 30 years; Young, age less than 11 years]

\begin{tabular}{|c|c|c|c|c|c|c|c|c|c|c|}
\hline \multirow[b]{2}{*}{ Stem class: } & \multicolumn{5}{|c|}{$\begin{array}{l}\text { Tamarisk importance value } \\
\text { (percent) }\end{array}$} & \multicolumn{5}{|c|}{$\begin{array}{l}\text { Tamarisk patch width } \\
\text { (percent) }\end{array}$} \\
\hline & Old & Mature-2 & Mature-1 & Young & All & Old & Mature-2 & Mature-1 & Young & All \\
\hline \multicolumn{11}{|l|}{ Site name } \\
\hline Palominas south & 0 & 0 & 0 & 6 & 4 & 0 & 0 & 0 & 0 & 0 \\
\hline Palominas & 0 & 0 & 11 & 44 & 35 & 0 & 0 & 6 & 85 & 8 \\
\hline Kolbe & 0 & 0 & 0 & 4 & 2 & 0 & 0 & 0 & 0 & 0 \\
\hline Hereford & 0 & 0 & 0 & 0 & 0 & 0 & 0 & 0 & 0 & 0 \\
\hline Hunter & 0 & 0 & 0 & 0 & 0 & 0 & 0 & 0 & 0 & 0 \\
\hline Cottonwood & 0 & 0 & 0 & 0 & 0 & 0 & 0 & 0 & 0 & 0 \\
\hline Lewis Springs & 0 & 0 & 0 & 0 & 0 & 0 & 0 & 0 & 0 & 0 \\
\hline Moson & 0 & 0 & 0 & 0 & 0 & 0 & 0 & 0 & 0 & 0 \\
\hline Charleston south & 0 & 0 & 0 & 0 & 0 & 0 & 0 & 0 & 0 & 0 \\
\hline Charleston bridge & 0 & 0 & 5 & 13 & 12 & 0 & 0 & 0 & 0 & 0 \\
\hline Charleston mesquite & 0 & 0 & 8 & 35 & 24 & 0 & 0 & 0 & 0 & 0 \\
\hline Boquillas & 0 & 0 & 4 & 4 & 3 & 0 & 0 & 0 & 0 & 0 \\
\hline Boquillas north & 0 & 0 & 0 & 0 & 0 & 0 & 0 & 0 & 0 & 0 \\
\hline Fairbank & 18 & 0 & 23 & 67 & 52 & 0 & 0 & 0 & 0 & 0 \\
\hline Depot & 0 & 0 & 0 & 0 & 0 & 0 & 0 & 0 & 0 & 0 \\
\hline Tombstone & 0 & 0 & 8 & 19 & 9 & 0 & 0 & 0 & 0 & 0 \\
\hline Contention & 0 & 32 & 53 & 91 & 57 & 0 & 0 & 56 & 0 & 27 \\
\hline Summers & 0 & 13 & 44 & 72 & 52 & 5 & 8 & 66 & 0 & 17 \\
\hline St. David & 100 & 69 & 97 & 98 & 92 & 100 & 0 & 100 & 0 & 100 \\
\hline Escalante & 5 & 7 & 68 & 62 & 54 & 0 & 10 & 51 & 100 & 28 \\
\hline
\end{tabular}

Tamarisk abundance also is influenced by seed availability. Tamarisk populations may still be in an expansion phase within parts of the SPRNCA; low importance at some sites may simply reflect seed limitation, and recent increases at some sites may simply reflect increased seed availability. Although tamarisk has been present in southeastern Arizona since the early 1900s (Horton, 1964), it has only become abundant in the region in the past half century. Tamarisk was first observed along the Gila River in 1916 (on a denuded flood plain after a large flood; Robinson, 1965), but did not become abundant there until the 1940s and 1950s (Turner, 1974). The oldest tamarisk directly aged along the San Pedro River date to the 1950s (Stromberg, 1998a). Within the SPRNCA, tamarisk had high importance values within the old and mature-2 age classes in only one reach (13, St. David area). The river has been diverted into the St. David irrigation canal for more than a century, and thus the hydrologic conditions that allowed for abundant establishment of tamarisk (and reduced establishment and survival of cottonwood and willow) have been present for long periods. The tamarisk population in the St. David area may have served as a source of seeds that were slowly dispersed to upstream sites by wind.

Differences in tamarisk abundance among SPRNCA sites also may reflect climatic differences. The negative correlation between the tamarisk importance value and site elevation may reflect sensitivity of the local ecotype of tamarisk to cool temperatures and frequent frosts, or may be an artifact of the predominance of drier sites at lower elevations. In Montana, tamarisk was found to be less competitive than cottonwood and willow at high-elevation, cold-temperature sites (Lesica and Miles, 2001). A similar phenomenon may be occurring at cooler reaches of the SPRNCA, although patterns of cold-air drainage and air temperatures along the length of the SPRNCA are not well understood. 


\section{Trends in Fremont Cottonwood-Goodding Willow Establishment Rates}

Objective.-Assess spatial patterns and temporal changes in cottonwood-willow establishment rates.

Methods. - Cottonwood and willow abundance at 20 SPRNCA study sites was examined by size class to infer patterns of change over time. Stem density of cottonwood and willow within four size/age classes (young, mature-1, mature-2, and old) at each site and reach was determined by using the same methods indicated in the previous section. Mean patch widths, by size class, were calculated for each site.

Results.-Overall in the SPRNCA, patches of pioneer forest trees (cottonwood, willow, and tamarisk combined) occupy an average of 27 percent (standard deviation of 17 percent) of the flood plain. When focusing just on cottonwood and willow patches, old patches ( $>50$ years) currently occupy the most area of all four age classes; average width is $27 \mathrm{~m}$ per site. Mature-2 (31-50 years), mature-1 (11-30 years), and young (<11 years) cottonwood and willow patches, respectively, occupy average widths of $12 \mathrm{~m}, 11 \mathrm{~m}$, and $1 \mathrm{~m}$ per site (table 30).

Spatially across the SPRNCA, the width of the pioneer forest patches increases linearly as a function of flood-plain width $(r=0.71, p<0.01, n=20)$, reflecting increased area available for seedling recruitment at sites where the flood plain is widest. There is less cottonwood- and willow-patch area in the narrower, constrained flood plain in the vicinity of reaches 7 through 11 (from the Charleston Bridge site to the Tombstone site) than in other reaches of the SPRNCA.

Population structures varied among sites in relation to differences in hydrologic conditions. Sites with perennial and intermittent-wet flow (with the exception of the Kolbe site) have age structures characteristic of stable populations (increasingly higher stem densities in progressively younger age classes) when examining pooled values for cottonwoods and willows (table 31 and fig. 38). This age structure also occurs for sites in the two reaches for which hydrologic data were not available (reach 10, Depot area; and reach 14, Escalante area).

At several sites in the dry northerly reaches, there are fewer stems in the young class than in the mature-1 class. Reaches with low rates of recent cottonwood-willow establishment include reach 9 (Fairbank area), 11 (Tombstone area), and 12 (Contention area). The site with the lowest rates of cottonwood and willow recruitment is St. David where few cottonwood and willow stems are present in any age class, likely owing to the long history of stream diversion. The low densities of young plants likely are due in part to rapid and high seasonal declines in ground-water levels during potential recruitment years.

Discussion.-Establishment patterns of cottonwood and willow are integrally linked with flood patterns. Both are relatively short-lived (about 100 to 150 years) trees that have temporally specialized reproduction strategies. Conditions for establishment are not consistently favorable at any given location year after year, so cohorts of these trees establish only during occasional favorable years. The timing of floodflows is critical, as both species produce seeds that are viable during the relatively brief period when high spring flows are usually declining and exposing base, damp sediments Fenner and others, 1984). A typical pattern is for fall or winter floods to scour and redeposit flood-plain sediments, creating a patchwork of potential seed beds for these plants to establish without competition from an existing overstory; seed beds are then moistened as flood waters recede during spring. Goodding willow disperses seeds somewhat later in the season than does cottonwood (although the dispersal period overlap) and, as the flood waters recede, establishes on sites that are lower and closer to the stream.

The rates of flood-water recession and water-table decline during establishment years influence seedling survival. During spring when flood waters are receding and seedlings are establishing on sediment bars, ground-water declines of greater than 1 to $3 \mathrm{~cm}$ per day can cause seedling death (Segelquist and others, 1993; Mahoney and Rood, 1998; Shafroth and others, 1998; Amlin and Rood, 2002). Sustained ground-water declines throughout the summer to levels below 1 or $2 \mathrm{~m}$ below land surface (depending on soil texture, weather, and species) also can preclude establishment of the new cohort (Kalischuk and others, 2001; Amlin and Rood, 2002). Willow seedlings are less tolerant of water-table decline than cottonwood seedlings (and more tolerant of inundation) and show greatest growth under no water-table decline (continually saturated soils; Horton and Clark, 2001; Amlin and Rood, 2002).

The low densities of cottonwood and willow seedlings at several sites in the northern tier of the SPRNCA likely are due to local hydrologic conditions. Water levels may recede too rapidly in potential establishment years to allow for high seedling survivorship in these areas, or subsequent ground-water fluctuations may have exceeded mortality thresholds for saplings or adults. Recruitment box simulations (see "Simulation of Fremont Cottonwood-Goodding Willow Establishment: 'Recruitment Box' Analysis" section) indicate that low and rapidly declining water levels at sites in this northern tier can impede cottonwood and willow establishment.

The width of pioneer-tree recruitment bands within the SPRNCA has declined in recent decades (Stromberg, 1998a). Reductions in recruitment band width in the SPRNCA appear to be part of a long-term geomorphic response to past events. The San Pedro riparian ecosystem has undergone extensive change in hydrology, morphology, and vegetation over past centuries (Hereford, 1993; Huckleberry, 1996). The present disturbance-driven ecosystem, dominated by pioneer trees, differs from the marshland conditions described by explorers in the 1800s, prior to channel incision (Davis, 1982; Hastings and Turner, 1965). During the first half of the 20th century, after channel incision, the flood plain of the San Pedro River widened considerably and cottonwood-willow forests increased in abundance. Since that time, the channel of the San Pedro River has stabilized after at least 55 years of instability (Hereford, 1993) and cottonwood-willow establishment in the upper basin appears to be declining in response. 
Table 30. Patch width of Fremont cottonwood, Goodding willow and tamarisk in the San Pedro Riparian National Conservation Area, Upper San Pedro Basin, Arizona, flood-plain zone, by stem size class (and thus estimated age class)

[Stem classes: Old, age greater than 50 years; Mature-2, age from 31 to 50 years; Mature-1, age from 11 to 30 years; Young, age less than 11 years; $\mathrm{cm}$, centimeter]

\begin{tabular}{|c|c|c|c|c|c|c|c|c|c|c|c|c|}
\hline & \multicolumn{4}{|c|}{ Fremont cottonwood } & \multicolumn{4}{|c|}{ Goodding willow } & \multicolumn{4}{|c|}{ Tamarisk } \\
\hline Stem class: & Old & Mature-2 & Mature-1 & Young & Old & Mature-2 & Mature-1 & Young & Old & Mature-2 & Mature-1 & Young \\
\hline Stem class size $(\mathrm{cm})$ : & $>90$ & $50-90$ & 20-50 & $<20$ & $>90$ & $50-90$ & $20-50$ & $<20$ & $>35$ & $20-35$ & $5-20$ & $<5$ \\
\hline Site name & \multicolumn{12}{|c|}{ Patch width (meters) } \\
\hline Palominas & 18 & 16 & 43 & 1 & 0 & 0 & 3 & 0 & 0 & 0 & 3 & 4 \\
\hline Kolbe & 6 & 19 & 11 & 2 & 0 & 5 & 7 & 0 & 0 & 0 & 0 & 0 \\
\hline Hereford & 15 & 16 & 0 & 1 & 0 & 0 & 3 & 0 & 0 & 0 & 0 & 0 \\
\hline Lewis Springs & 25 & 15 & 7 & 0 & 0 & 0 & 2 & 0 & 0 & 0 & 0 & 0 \\
\hline Moson & 62 & 45 & 18 & 0 & 0 & 0 & 2 & 0 & 0 & 0 & 0 & 0 \\
\hline Charleston south & 0 & 0 & 8 & 0 & 0 & 0 & 0 & 0 & 0 & 0 & 0 & 0 \\
\hline Charleston bridge & 13 & 2 & 4 & 0 & 1 & 0 & 0 & 0 & 0 & 0 & 0 & 0 \\
\hline Charleston mesquite & 11 & 4 & 4 & 0 & 10 & 0 & 1 & 0 & 0 & 0 & 0 & 0 \\
\hline Boquillas & 6 & 3 & 1 & 0 & 0 & 3 & 0 & 0 & 0 & 0 & 0 & 0 \\
\hline Summers & 95 & 41 & 12 & 5 & 0 & 4 & 0 & 0 & 5 & 4 & 23 & 0 \\
\hline St. David & 0 & 0 & 0 & 0 & 0 & 0 & 0 & 0 & 45 & 0 & 79 & 0 \\
\hline Escalante & 14 & 16 & 6 & 0 & 0 & 0 & 5 & 0 & 0 & 2 & 12 & 3 \\
\hline
\end{tabular}


Table 31. Stem density and basal area of Fremont cottonwood, Goodding willow and tamarisk in the San Pedro Riparian National Conservation Area, Upper San Pedro Basin, Arizona, flood-plain zone, by stem size class (and thus estimated age class)

[Stem classes: Old, age greater than 50 years; Mature-2, age from 31 to 50 years; Mature-1, age from 11 to 30 years; Young, age less than 11 years; $\mathrm{cm}$, centimeter]

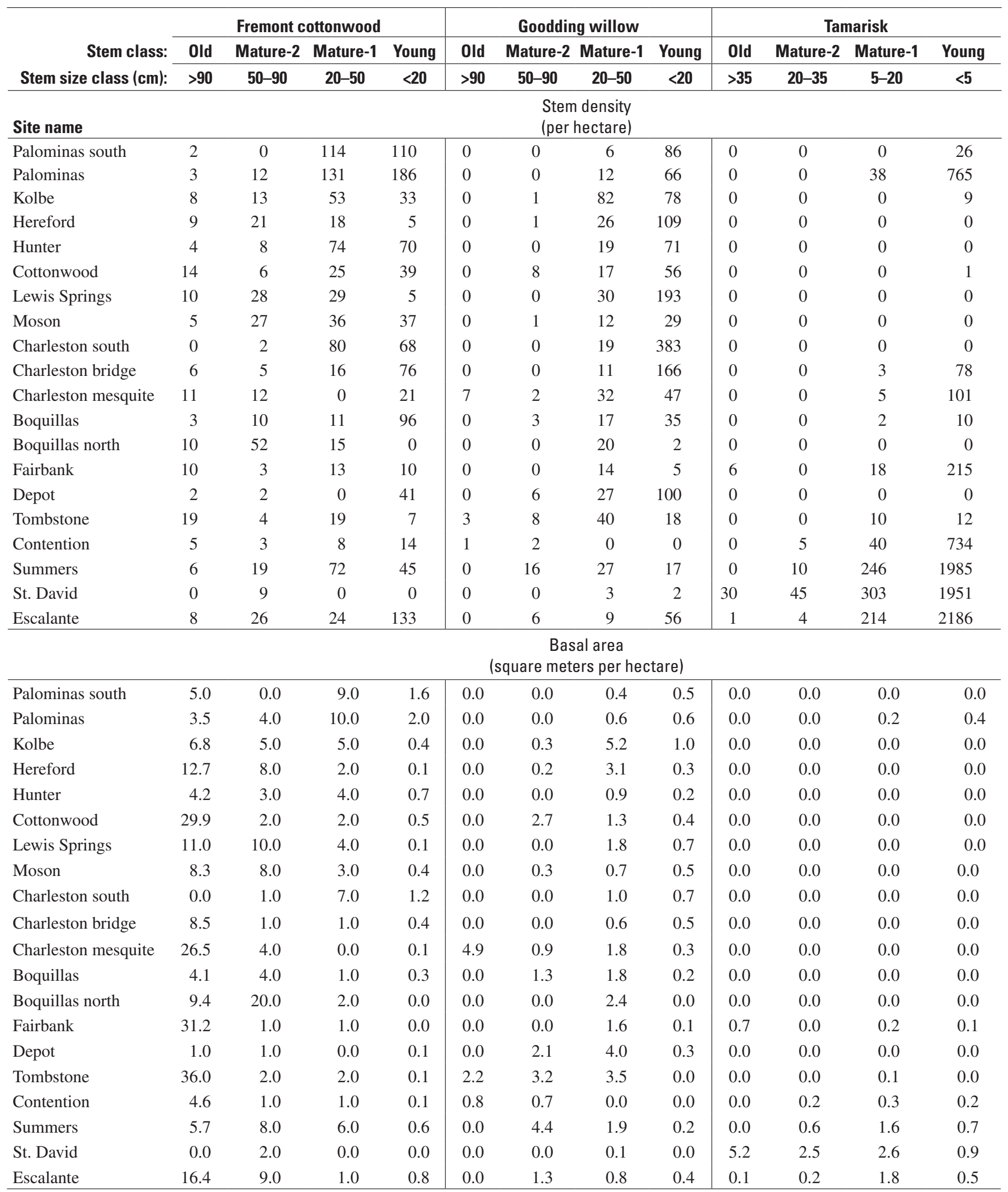



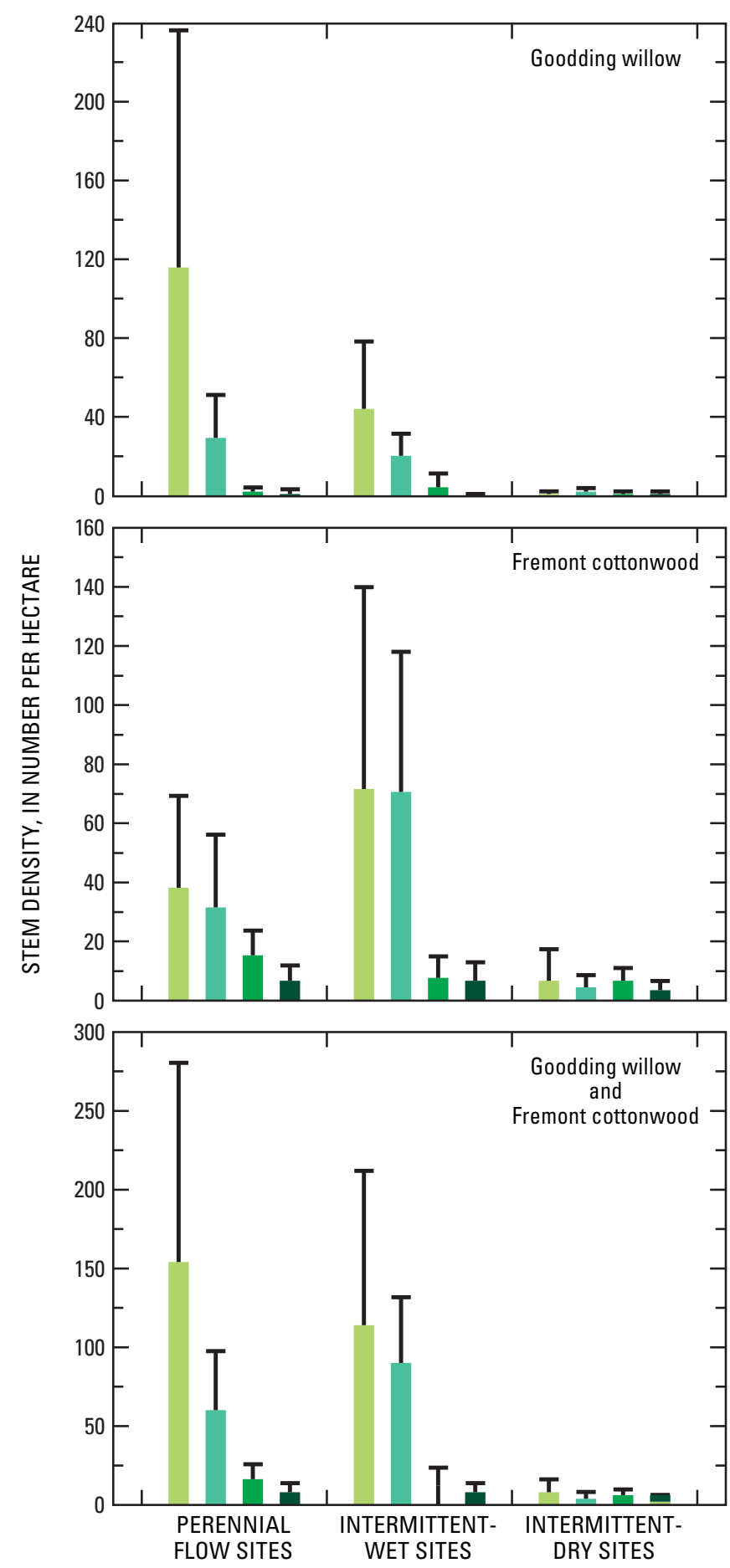

NOTE: Data shown are means of sites ( $n=8,6$, and 2, respectively) classified by hydrologic condition. Values include standard deviation bars

\section{EXPLANATION}

YOUNG - Less than 11 years $\quad$ MATURE-2-31 to 50 years
MATURE-1-11 to 30 years $\quad$ OLD-Greater than 50 years

Figure 38. Stem density of Fremont cottonwood and Goodding willow, by age class, within San Pedro Riparian National Conservation Area flood plains, Upper San Pedro Basin, Arizona, classified by hydrologic condition (see table 16).

\section{Simulation of Fremont Cottonwood-Goodding Willow Establishment: "Recruitment Box" Analysis}

Objective.-Simulate potential cottonwood and willow establishment under three hydrologic scenarios.

Methods.-A computer model was developed to simulate seedling establishment of four species of pioneer riparian shrubs and trees along the San Pedro River: cottonwood, willow, seepwillow, and tamarisk. The model is based on the recruitment box concept (Mahoney and Rood, 1998), which specifies the timing of flood events and rate of flow recession that are optimal for germination and successful establishment of riparian cottonwood seedlings. The model presented here expands the recruitment box to include other woody species, as well as the effects of alluvial water-table dynamics, flood scour, and competition from herbaceous vegetation on seedling establishment in Southwestern riparian ecosystems. Model results are presented for cottonwood and willow establishment under recent historic flows (1988-2002) at three sites that represent the range of ground-water depths and riparian condition classes along the Upper San Pedro River.

The model was developed the model using the STELLA II dynamic simulation software package (ISEE Systems, Lebanon, NH). The model simulates changes in firstyear seedling numbers at 5-day intervals as a function of local seasonal ground-water conditions and a time series of historic (1988-2002) flow conditions. The model was parameterized and run for three sites with different flow regimes: the Kolbe site has perennial flow, the Palominas site has intermittentwet flow, and the Contention site has intermittent-dry flow. Ratings from HEC-RAS modeling and field calibration at each site (chapter B) were used to calculate river stage for a flow of given magnitude. USGS streamflow-gaging station records for the San Pedro River at Charleston (09471000) and the San Pedro River at Palominas station (09470500) were used for the Kolbe site and Palominas site, respectively. Records for the USGS streamflow-gaging stations San Pedro River near Redington (0947200); San Pedro River at Redington Bridge near Redington (09471550); and San Pedro River at Tombstone (09471550) were used for the Contention site (table 32).

Baseline seasonal ground-water conditions were represented by the minimum (summer) and maximum (winter) monthly ground-water levels at the riverbed in a dry year (2002) for each of three study sites (table 32). Temporary increases in the water table that were associated with increases in streamflow from storm runoff were also simulated. It was assumed that ground-water levels at the stream would increase to the level of the mean river stage or to the plot elevation $(0.5 \mathrm{~m})$, whichever was lower, and then would decline exponentially to the base level for the season over the course of one month, unless subsequent floodflows raised the groundwater level again. Only flows in excess of $0.006 \mathrm{~m}^{3} / \mathrm{s}$ were assumed to influence alluvial ground-water levels. 
Table 32. Site, streamflow-gaging stations, and ground-water levels for sites used in STELLA II model runs, San Pedro Riparian Conservation Area, Upper and Lower San Pedro Basins, Arizona

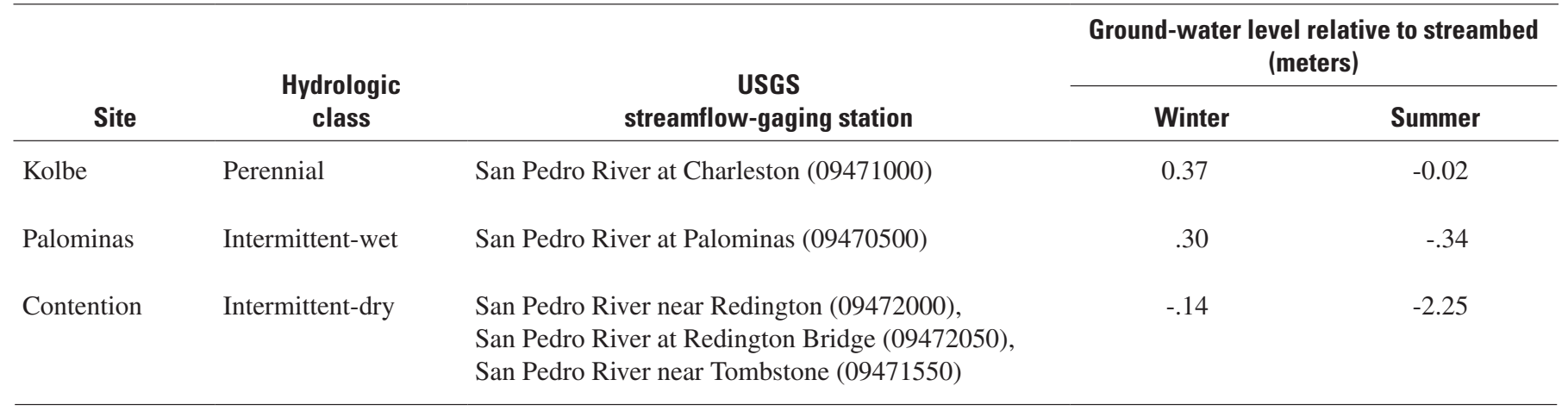

Initial seedling establishment was modeled as a function of seed availability, surface moisture, and vegetative cover. Establishment in this context means a seedling that survives to the end of its first calendar year. This prototype version of the model does not represent plant mortality beyond the first year and does not represent differences among sites and years in the total area of streamside habitat available for seedling establishment. Projected seedling densities are best understood as an index of the suitability of hydrologic conditions for seedling establishment given available streamside habitat, ground-water conditions and stage-discharge relations at the site, and flow conditions during a particular year. Regeneration requirements for cottonwood and willow were determined through a literature review (Shafroth and others, 1998; Stromberg and others, 1991, 1993, 1996; Stromberg, 1997, 1998a) and additional observations from fieldwork on the San Pedro River (Lite, 2003). Key parameters included timing of seed dispersal, root and stem growth rates, and relative dependence on ground water (table 33). For this model exercise, however, daily rates of stem height growth $(0.25 \mathrm{~cm} /$ day $)$ were assumed to be the same for both species. For a given species, 100 seeds were assumed available during each time step in the peak dispersal period (March-April for cottonwood, April-May for willow). No seed dormancy was simulated, and seeds were allowed to germinate only if the surface sediments were saturated, that is, if the depth to the capillary fringe (here assumed $0.25 \mathrm{~m}$ above alluvial ground-water levels) was zero at the plot surface, and if mean river level during the 5-day time step did not exceed the plot elevation. Simulated plots represented an unspecified unit area of streamside sediment available for seedling establishment and were assumed to have an elevation of $0.5 \mathrm{~m}$ above the streambed. A new plot was simulated for each year. The number of seeds allowed to germinate per species, per time step, was inversely proportional to vegetative cover on the plot, with no germinants if cover was 100 percent and a maximum of 100 germinants if cover was 0 percent.
Table 33. Growth and mortality model parameters for each species, Upper San Pedro Basin, Arizona

\begin{tabular}{lcc}
\hline \multicolumn{1}{c}{ Parameter } & \multicolumn{2}{c}{ Species } \\
\cline { 2 - 3 } & $\begin{array}{c}\text { Fremont } \\
\text { cottonwood }\end{array}$ & $\begin{array}{c}\text { Goodding } \\
\text { willow }\end{array}$ \\
\hline Daily root growth (centimeters) & 1 & 0.5 \\
Daily stem height growth (centimeters) & .25 & .25 \\
Maximum first year root depth (meters) & 1.6 & 1.0 \\
Desiccation mortality/time step (percent) & 80 & 100 \\
Dispersal interval & March-April & April-May \\
\hline
\end{tabular}

Herbaceous cover and growth functioned as an important constraint on seedling establishment. Potential for growth (increase in cover) of herbaceous vegetation varied according to depth to the top of the capillary fringe and the time of year. Removal of herbaceous cover occurred only through flood scour. Maximum growth rates of herbaceous plants (change in cover per month) were highest in April-September (30 percent), declined by half in March and October (15 percent), and were zero in November-February (Stromberg and others, 1991, 1993). Optimal growth occurred when the depth to saturation (top of the capillary fringe) was zero and declined linearly with greater saturated depths to a minimum growth rate (10 percent of optimal) when the saturated zone was more than $1 \mathrm{~m}$ below land surface. Growth was assumed to be zero if herbaceous cover exceeded 100 percent.

Seedling mortality occurred through desiccation or flood scour. Desiccation occurred if saturated moisture depth exceeded seedling root depth. Willow was assumed to be less drought-tolerant than cottonwood, with 100 percent mortality for willow and 80 percent mortality for cottonwood per time step that the roots were not in contact with saturated sediment. 
Mortality thresholds from flood scour were based on flow depth. For herbaceous plants, scour mortality was assumed to be a linear function of flow depth, with 100 percent removal of herbaceous cover for stages exceeding $3 \mathrm{~m}, 50$ percent at $1.5 \mathrm{~m}$, and no removal at $0 \mathrm{~m}$. For tree and shrub seedlings, scour mortality was assumed to be a step function, with 100 percent mortality if flow depths exceeded the threshold and 0 percent if they did not. The flow depth threshold was assumed to vary linearly with seedling height, with seedlings $50 \mathrm{~cm}$ tall or taller removed only by flow depths of $2 \mathrm{~m}$ and smaller seedlings removed by flows deeper than four times the seedling height.

Results. - Simulated seedling establishment of cottonwood and willow varied strongly between sites and years (fig. 39). Peak seedling numbers were highest at Kolbe, the wettest of the three sites. Peak seedling numbers were lower at the Palominas site, the intermittent-wet site, and there was no successful establishment of cottonwood or willow at Contention, the intermittent-dry site. Between years, simulated successful establishment by cottonwood and willow corresponded to water years in which winter (October-May) floods exceeded the subsequent summer (June-September) floods.

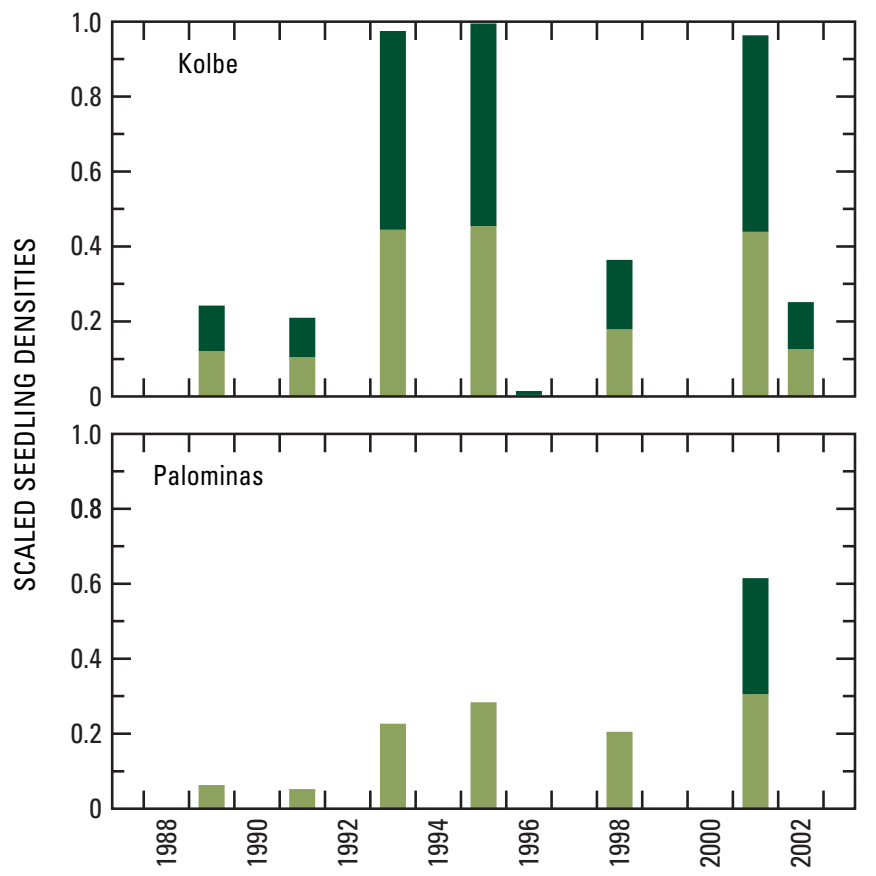

NOTE: No successful recruitment occurred in model simulations at an intermittent-dry site (Contention)

\section{EXPLANATION}

FREMONT COTTONWOOD

GOODDING WILLOW

Figure 39. Simulated first-year seedling recruitment of Fremont cottonwood and Goodding willow at a perennial (Kolbe) and an intermittent-wet (Palominas) site along the Upper San Pedro River, San Pedro Riparian National Conservation Area, Upper San Pedro Basin, Arizona.
From 1988 to present, these conditions occurred in 1989, 1991, 1993, 1995, 1998, and 2001. Several of these years corresponded to seedling establishment events on other rivers throughout the region, including the Hassayampa (Stromberg, 1997), the Bill Williams (Shafroth and others, 1998) and the Verde (Vanessa Beauchamp, IAP World Services, United States Geological Survey, unpublished data). The larger winter floods in the 1990s were part of a larger climatic pattern from the late 1970s to late 1990s, associated with a higher frequency, duration, and intensity of El Niño conditions (positive Multivariate ENSO Index values; Wolter and Timlin 1998; http://www.cdc.noaa.gov/people/klaus.wolter/MEI/mei. html), relative to the previous 30 years. During 1951-77, and particularly before 1960, winter floods generally were small, summer floods were larger, and La Niña conditions (negative MEI values) predominated (Webb and Betancourt, 1992; Swetnam and Betancourt, 1998).

Discussion.-Establishment years in the model match establishment years in the field. Actual establishment events in 1991, 1993, and 1995 along the Upper San Pedro River corresponded to simulated events in the model at the Palominas or Kolbe sites. As found by Stromberg (1998a), cottonwood and willow establishment is associated with fall, winter, and early spring floods. In the model, larger floods clear competing herbaceous vegetation, creating open, mineral-soil sites for seedling colonization during spring when seeds are viable and when water tables and stream flows are high. Winter floods may temporarily raise alluvial ground-water levels, creating bank storage that may sustain base flows during the spring dry period, although this effect is only crudely represented in the model at present. The spring dispersal period of cottonwood and willow enable these two species to colonize the newly cleared alluvium before cover by herbaceous vegetation fully recovers to pre-flood levels. Summer flow conditions are important, because high flood stages associated with large summer rain events may scour away the seedlings. In the model, streamflow depths of greater than 1 to $2 \mathrm{~m}$ in July and August exceed the depth threshold specified for complete scour mortality of cottonwood and willow seedlings.

Patch widths of young cottonwood and willow age and size classes are low at the Kolbe and Palominas sites in the field, but model simulations suggest numerous establishment events and high seedling densities from 1991-2002. This pattern is similar to that observed by Stromberg (1998a), who found that patch widths of cottonwood cohorts declined from the 1960s to 1990 s, despite an increase in the number of establishment events. Declines in the area of new cohorts at wet sites, such as Kolbe, appear to be a function of declining area of available substrate caused by channel narrowing and stabilization, rather than by unsuitable hydrologic conditions for establishment.

Site conditions strongly influenced modeled establishment success. Cottonwood and willow established on the perennial and intermittent-wet sites, but could not establish on the intermittent-dry site. Although willow 
successfully established at the intermittent-wet site (the Palominas site), its absence in some years of successful cottonwood establishment (for example, 1993 and 1995) may be related to its higher vulnerability to drought owing to slower root growth and higher drought mortality rate. At the intermittent-dry site (Contention), annual maximum groundwater depths $(2.25 \mathrm{~m}$ below the streambed and $2.75 \mathrm{~m}$ below the plot elevation) precluded successful establishment in the model by cottonwood and willow (maximum rooting depths of 1.6 and $1.0 \mathrm{~m}$ in the model, respectively). Although actual establishment rates have been low at the Contention site, some establishment has occurred, with low densities of cottonwood stems in both young and older age and size classes. The failure of the model to represent these low-density establishment events may stem from overly severe drought-mortality rates for cottonwood (assumed 80 percent per 5-days if roots are above the capillary fringe), the persistence of pockets of moist soil above the capillary fringe in the field (Cooper and others, 1999), and inadequate representation of bank storage after flood events in the model.

\section{Growth Rate of Goodding Willow Trees}

Objective.-Examine relations between stem growth of willow and site hydrology.

Methods.-Annual branch-growth increment of willow was measured during winter of 2004 at 15 sites (12 of which were biohydrology sites) distributed across the SPRNCA. Willow was selected for study owing to the results of a prior study conducted along the San Pedro River indicating that willow growth parameters were more sensitive to stream hydrology than were those of cottonwood (Johnson, 2000). Five willow trees were randomly selected for sampling at each site. The prior study had indicated that values measured on young trees (6 to 8 years old) did not differ from those on older trees (15 to 20 years old). Four low-hanging branches were randomly selected per tree for a total sample size of 20 branches per site. On each branch, the annual stem-growth increment for the 2003, 2002, and 2001 growing seasons (distance between bud-scale scars) was measured to the nearest millimeter by using a ruler.

Results.-Annual branch-growth increment of willow variend among sites and years. Growth increment was significantly greater in $2001(33 \pm 8 \mathrm{~cm})$ than in 2002 $(23 \pm 6 \mathrm{~cm})$ or $2003(22 \pm 10 \mathrm{~cm})$ as indicated by an analysis of variance (ANOVA) with post-hoc least significant difference means separation tests $(n=15 ; p<0.01)$. Among sites, the 3-year average growth rate (2001-03) increased as a function of decreasing ground-water depth (Pearson correlation coefficient of $r=-0.61, n=12, p=0.04$; fig. 40). Growth rate in individual years increased as a function of streamflow permanence ( $r=0.44, n=32, p=0.01$; fig. 40$)$. The lowest growth rate occurred at Contention (3-year mean of $14.5 \mathrm{~cm} /$ year), Tombstone $(16.7 \mathrm{~cm} /$ year $)$, and Fairbank (18.3 cm/year). Values of at least $30 \mathrm{~cm} /$ year occurred at several perennial sites, including Hereford and Kolbe.

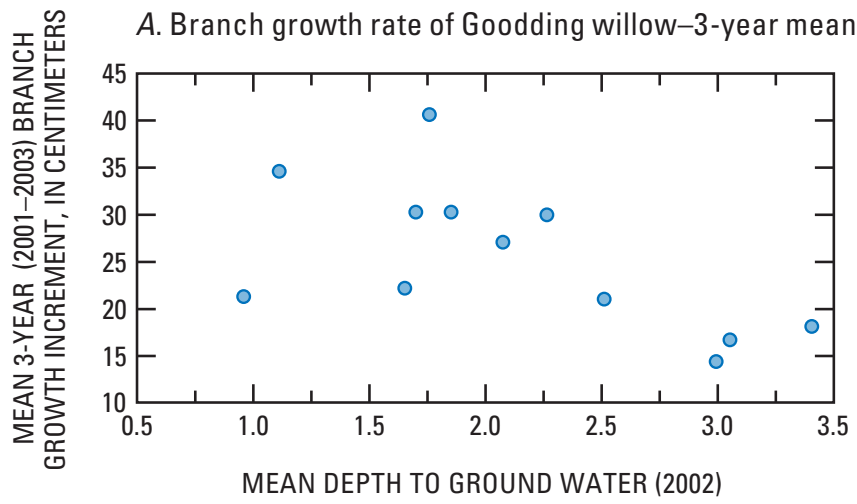

$B$. Annual branch growth rate

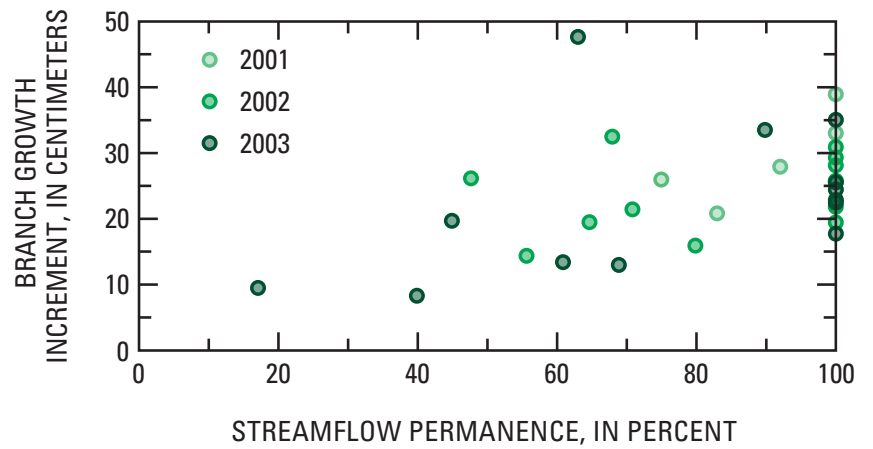

Figure 40. Branch-growth increment of Goodding willow, San Pedro Riparian National Conservation Area, Upper San Pedro Basin, Arizona. A, Bbranch-growth increment (averaged during a 3-year period) of Goodding willow in relation to mean depth to ground water; $B$, annual growth increment in relation to streamflow permanence.

Discussion.-The results reported here are consistent with those of Johnson (2000), who found that annual branch-growth increment (and shoot leaf area and leaf size) of willow declined with mean depth to ground water along the San Pedro River. The results also are consistent with Johnson's finding of a depth to ground-water threshold of about $3 \mathrm{~m}$ (mean depth, as averaged over the growing season) below which growth rate began to decline. Other researchers have found annual branch-growth increment of willow and cottonwood to be sensitive to water availability (Willms and others, 1998; Horton and others, 2001b). Prior studies along the San Pedro River, however, showed that shoot growth rate and shoot leaf area of cottonwood did not vary strongly with site hydrology, largely owing to significant interactions between tree growth rates and stand stem density (individual tree growth rates declined as cottonwood-willow stand density increased, which itself increased as sites became wetter; Johnson, 2000). 


\section{Functioning Condition Analysis}

\section{Objectives and Methods}

Objectives. - (1) Develop a quantitative, multimetric rating system for riparian ecosystem functioning condition. (2) Assess the functioning condition of the SPRNCA, by reach. (3) Describe the hydrologic conditions needed to maintain various levels of ecosystem function.

Methods.-A Riparian Condition Index was developed by using a suite of nine field-measured vegetation traits (bioindicators) that are sensitive to changes in streamflow permanence and (or) ground-water levels on the San Pedro River (table 34). This index is designed to diagnose ecosystem conditions caused by changes in surface and ground-water availability. A riparian assessment model was developed by using data collected during 2000-2002 at 17 San Pedro River study sites (6 of the SPRNCA biohydrology study sites and 11 of the supplemental lower basin sites) and validated at 10 additional upper basin sites. There were five steps in developing the assessment model: (1) determine distinct hydrologic classes relative to threshold values for plant community change, (2) select potential bioindicators, (3) determine bioindicator scoring ranges, (4) iteratively select the final set of bioindicators and site scoring ranges, and (5) validate the model. Details of the model development are described in Lite (2003).

The riparian assessment model was developed to link the ecological condition of riparian vegetation to water availability and to simultaneously address environmental water needs and desired ecosystem conditions. The assessment model is driven by hydrologic thresholds of the dominant vegetation types in the flood-plain channel ecosystem. For example, there is a sharp decline in the riverine marsh type as flows become intermittent. As ground-water depth increases, hydromesic trees (cottonwood, willow) give way to dominance by deeperrooted species (tamarisk; fig. 41).
The assessment model was applied to the SPRNCA by using bioindicator data collected at the 26 sites (table 5) from 2002 through 2004. To apply the assessment model, (1) field data are used to determine a scoring value for each of the 9 vegetation bioindicators (table 34), and (2) the bioindicator values are averaged to obtain the overall site-condition score (table 35). The bioindicators are measured in the field along multiple biohydrology transects at a site, and then scaled to the reach level. The woody-vegetation indicators are not sensitive to time of year. Data on herbaceous vegetation are collected during the summer dry season (May-June), prior to summer rains and floods.

Site condition scores were grouped to categorize each site into 1 of 3 riparian condition classes. Condition scores of 1.0 to 1.5 (class 1) indicate ecological conditions reflecting reduced water availability (or stressors producing effects similar to reduced water availability). Scores between 1.51 and 2.5 (class 2) indicate intermediate conditions, whereas scores of 2.51 to 3.0 (class 3 ) indicate no water stress conditions. Each condition class is associated with ranges for vegetation structure and associated levels of functional capacity and reflects a certain range of hydrologic conditions with respect to streamflow permanence and ground-water depth and fluctuation.

Across the SPRNCA, individual site condition scores ranged from the minimum possible value of 1.22 at both sites in the St. David area (reach 13) to the maximum possible 2.72 for four of the sites having perennial flow (table 35). The two sites sampled per reach in the wetter (less interrupted) reaches had similar values, and the reach means had low standard deviations (table 36). Standard deviations also were low in reaches that had intermixed burned and unburned areas (reaches 1, 2, 4, and 7). Standard deviations were higher in reaches that were highly interrupted (spatially intermittent), such as reaches 9,12 , and 14 , reflecting greater within-reach variability in hydrologic conditions.

Table 34. Scoring values for indicator variables

[cm, centimeters; $\leq$, less than or equal to; $>$, greater than; $\mathrm{m}^{2} /$ ha, square meters per hectare; $\%$, percent]

\begin{tabular}{|c|c|c|c|c|}
\hline Bioindicator variable & \multicolumn{4}{|c|}{ Score } \\
\hline Number of 10-cm Fremont cottonwood + Goodding willow size classes in flood plain & $\leq 3$ & & $>3$ & \\
\hline Fremont cottonwood + Goodding willow basal area $\left(\mathrm{m}^{2} / \mathrm{ha}\right)$ & $\leq 4.7$ & & $>4.7$ & \\
\hline Fremont cottonwood + Goodding willow relative basal area (\%) & $\leq 21$ & & $>21$ & \\
\hline Absolute cover of streamside hydric perennial herbs (\%) & & $\leq 5$ & & $>5$ \\
\hline Relative cover of streamside hydric perennial herbs (\%) & & $\leq 14$ & & $>14$ \\
\hline Absolute cover of streamside hydric herbs (\%) & & $\leq 29$ & & $>29$ \\
\hline Relative cover of streamside hydric herbs (\%) & & $\leq 24$ & & $>24$ \\
\hline
\end{tabular}



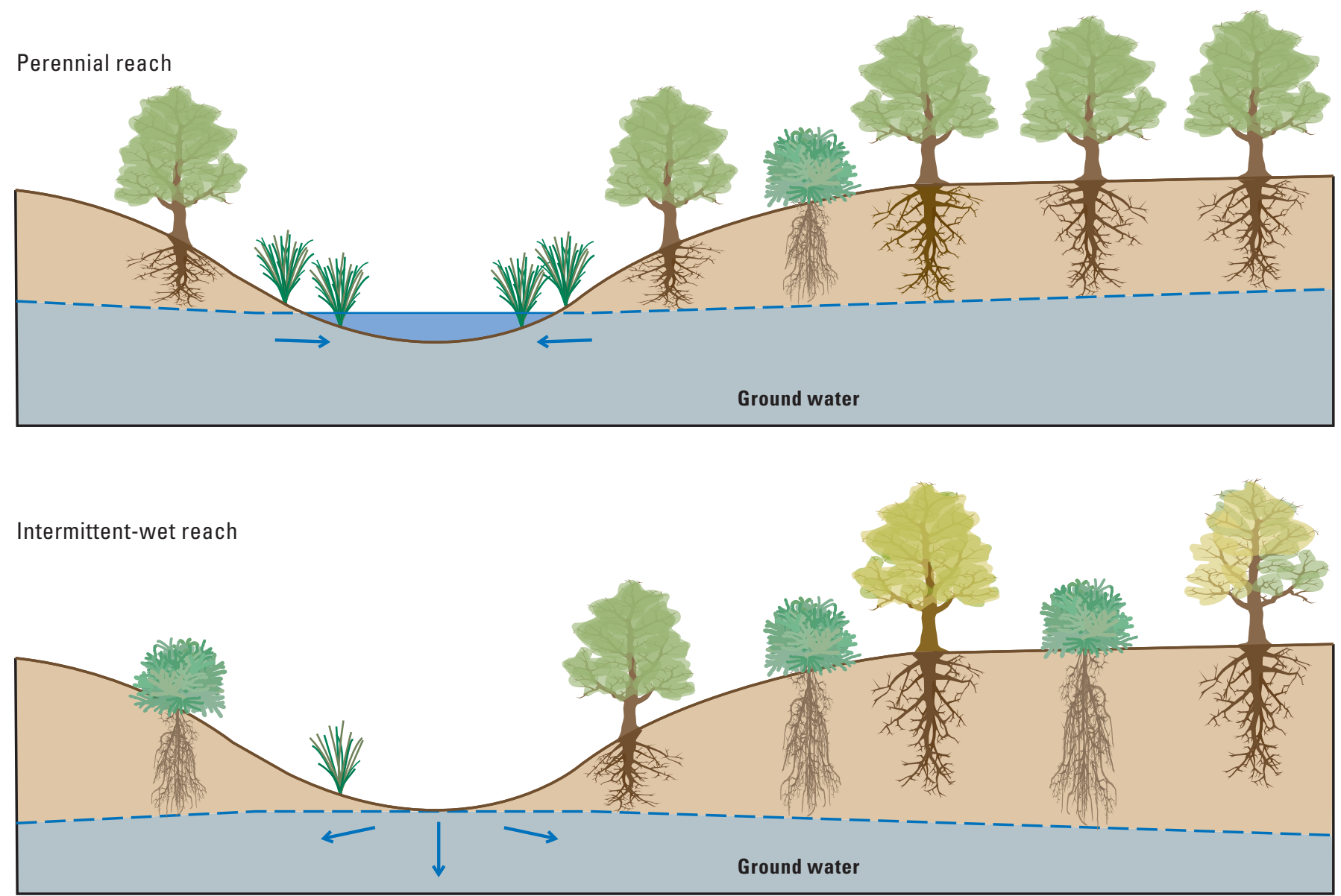

Intermittent-dry reach
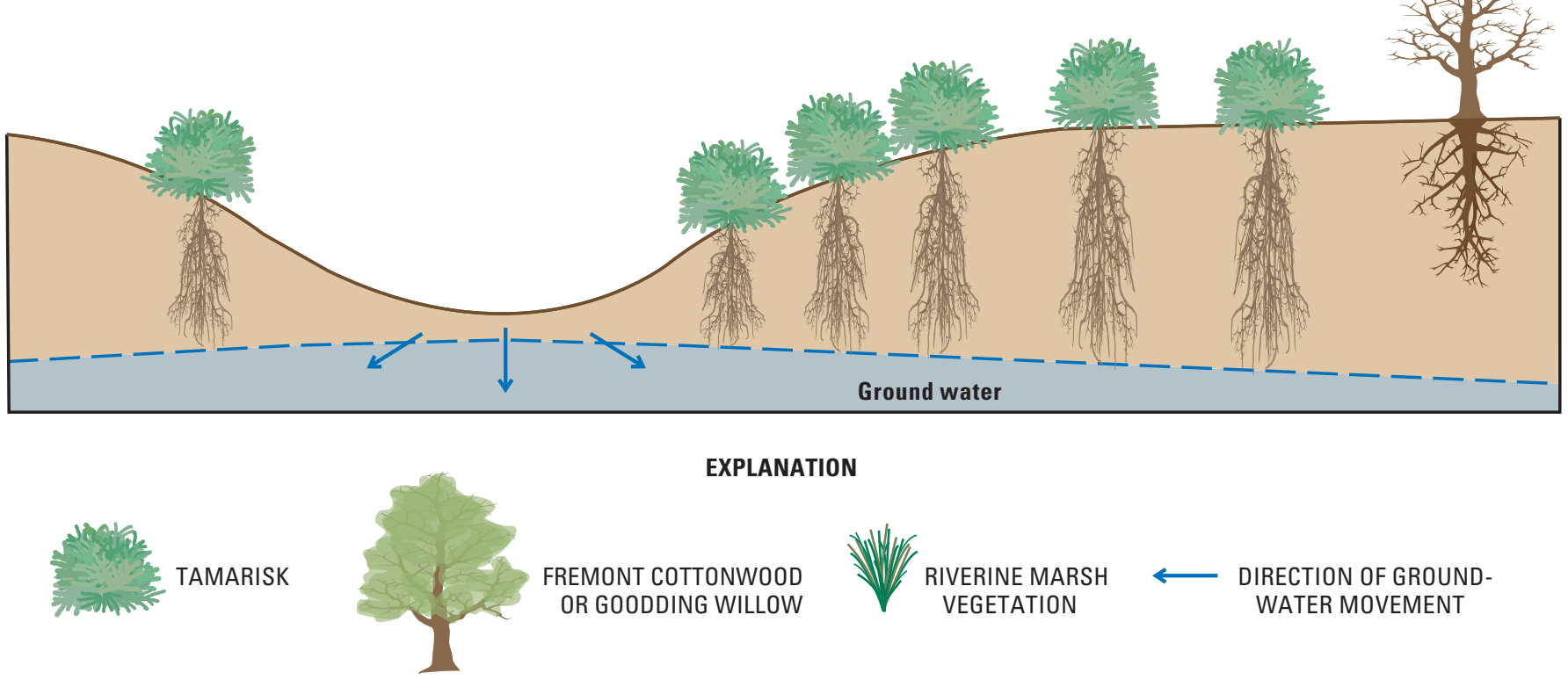

Figure 41. Schematic diagram depicting the three major hydrologic reach types and corresponding vegetation patterns along the Upper San Pedro River, Upper San Pedro Basin, Arizona. 
Table 35. Condition scores (based on measurement of nine bioindicator variables) for the 16 biohydrology and 10 supplemental study sites within the San Pedro Riparian National Conservation Area, Upper San Pedro Basin, Arizona

\begin{tabular}{|c|c|c|}
\hline Reach number & Site name & Condition score \\
\hline 1 & Palominas south & 2.22 \\
\hline 1 & Palominas & 2.22 \\
\hline 2 & Kolbe & 2.56 \\
\hline 2 & Hereford & 2.72 \\
\hline 3 & Hunter south & 2.56 \\
\hline 3 & Hunter & 2.06 \\
\hline 4 & Cottonwood & 2.72 \\
\hline 4 & Cottonwood north & 2.56 \\
\hline 5 & Lewis Springs & 2.72 \\
\hline 6 & Moson & 2.72 \\
\hline 7 & Charleston south & 2.39 \\
\hline 7 & Charleston bridge & 2.56 \\
\hline 8 & Charleston mesquite & 2.22 \\
\hline 8 & Boquillas & 2.39 \\
\hline 9 & Boquillas north & 2.56 \\
\hline 9 & Fairbank & 2.06 \\
\hline 10 & Depot & 1.72 \\
\hline 10 & Fairbank north & 2.06 \\
\hline 11 & Tombstone south & 1.89 \\
\hline 11 & Tombstone & 2.06 \\
\hline 12 & Contention & 1.72 \\
\hline 12 & Summers & 2.39 \\
\hline 13 & St. David & 1.22 \\
\hline 13 & St. David north & 1.22 \\
\hline 14 & Escalante south & 1.89 \\
\hline 14 & Escalante & 2.56 \\
\hline
\end{tabular}

Table 36. Condition score and class for San Pedro Riparian National Conservation Area reaches, Upper San Pedro Basin, Arizona

[Condition class 3, vegetation characteristic of wetter conditions; condition class 1 , vegetation characteristic of drier conditions; condition class 2 , vegetation characteristic of intermediate water availability; ---, no value calculated]

\begin{tabular}{|c|c|c|c|c|}
\hline \multirow[b]{2}{*}{$\begin{array}{l}\text { Reach } \\
\text { number }\end{array}$} & \multicolumn{2}{|c|}{ Condition score } & \multirow[b]{2}{*}{$\begin{array}{c}\text { Condition } \\
\text { class }\end{array}$} & \multirow{2}{*}{$\begin{array}{l}\text { Reach length } \\
\text { (percentage of } \\
\text { SPRNCA) }\end{array}$} \\
\hline & Mean & $\begin{array}{l}\text { Standard } \\
\text { deviation }\end{array}$ & & \\
\hline 1 & 2.2 & 0.0 & 2 & 13 \\
\hline 2 & 2.6 & .1 & 3 & 12 \\
\hline 3 & 2.3 & .4 & 2 & 10 \\
\hline 4 & 2.6 & .1 & 3 & 4 \\
\hline 5 & 2.7 & --- & 3 & 11 \\
\hline 6 & 2.7 & --- & 3 & 5 \\
\hline 7 & 2.5 & .1 & 3 & 7 \\
\hline 8 & 2.3 & .1 & 2 & 9 \\
\hline 9 & 2.3 & .4 & 2 & 5 \\
\hline 10 & 1.9 & .2 & 2 & 3 \\
\hline 11 & 2.0 & .1 & 2 & 3 \\
\hline 12 & 2.1 & .5 & 2 & 8 \\
\hline 13 & 1.2 & .0 & 1 & 6 \\
\hline 14 & 2.2 & .5 & 2 & 4 \\
\hline
\end{tabular}




\section{Condition Class Overview, by Reach}

Thirty-nine percent of the SPRNCA riparian corridor, located mostly in the southern and central sections (reaches 2, 4, 5, 6, and 7), fell within class 3 (fig. 42 and table 36). Class 3 reaches had perennial or near-perennial streamflows ( $>99$ percent streamflow permanence) and shallow, stable alluvial ground water (table 37). Ground water is accessible to shallow-rooted phreatophytic trees (for example, cottonwood and willow) throughout the flood plain; mean depths were typically less than $2 \mathrm{~m}$ throughout the flood plain and annual fluctuation less than $0.5 \mathrm{~m}$. Flood-plain vegetation is characterized by tall, dense, multiaged cottonwood-willow forests and woodlands with intermixed areas of riparian grassland-forblands and only small patches of tamarisk shrubland. Deep-rooted pioneer species such as tamarisk are subdominant in the forests. The stream channel is lined by dense and diverse herbaceous cover, including an abundance of emergent macrophytes, such as bulrush, and other obligate wetland and facultative wetland species, such as Torrey rush and scouring rush.

Fifty-five percent ( 8 of 14) of reaches, mostly located in the northern tier, fell in class 2 . Within class 2 reaches, streamflow was intermittent but frequently present. Ground water was moderately shallow with moderate intra-annual fluctuation. Cottonwood and willow remain as the dominant pioneer trees in the flood plain, but tamarisk presence is increased, and cottonwoods and willow trees undergo dryseason declines in water use and productivity. Major changes in the herbaceous vegetation occur between classes 2 and 3 . Streamside cover of hydric plants is reduced, owing to loss of perennial streamflow. Many of the hydric perennial herbs have been replaced by mesic perennials, such as bermuda grass.

Only reach 13 (St. David area), comprising six percent of the SPRNCA, fell within the driest class, class 1. Outside the SPRNCA boundary, however, much of the river falls within this category. Within the class 1 reach, streamflow was present less than 50 percent of the year and ground water was deep (averaging $>3.5 \mathrm{~m}$ under the flood plain in the dry season) and had much intra-annual fluctuation (>1 m). Major changes in woody-vegetation composition and structure occur in the transition from class 2 to class 1 . Hydrologic thresholds for cottonwood and willow survivorship have largely been exceeded, and only a few age classes of these species persist in favorable microsites. Deep-rooted phreatophytes, typically tamarisk, have replaced shallower-rooted species. Structurally, the flood plain is dominated by shrublands with limited upper canopy cover. Streamside herbaceous cover is sparse in the summer dry season and is dominated by mesic species, such as bermuda grass.

\section{Discussion}

This summary of the present distribution of the condition classes in the SPRNCA provides a baseline for tracking long-term changes in riparian structure and composition resulting from changes in water availability. Stability or upward changes in the condition scores can provide an index of whether water-conservation and management measures are effective in preventing riparian degradation and (or) improving conditions, whereas downward changes may suggest that further intervention is warranted.

The vegetation characteristics of the three condition classes provide some measure of the changes in vegetation structure and composition that might occur in response to future changes in site water availability. With reductions in streamflow permanence and declines in the alluvial groundwater table, hydric herbaceous species, such as bulrush and rushes, would decline in cover and streamside-zone species composition would shift towards mesic species, such as bermuda grass. Across the flood plain, cottonwood-willow recruitment rates would decline and mortality rates would increase, and species composition would shift towards deeper-rooted species such as tamarisk. Structurally, riparian woodlands would give way to riparian shrublands, and canopy height and upper canopy vegetation volume would decline. Conversely, these patterns would reverse if streamflow increases in permanence.

Condition class scores will change in response to any increase or decrease in river water availability, whether from current anthropogenic activities (such as changes in groundwater pumping or water recharge rates), ongoing watershed responses to current and past land-use activities (for example, changes in infiltration or runoff rates in response to upland vegetation change), or climate change. Arizona has been in a drought for a half-decade. Drought likely will cause short-term shifts in the condition-class scores.

The four bioindicators that measure cover of herbaceous vegetation in the streamside zone will respond most quickly to changes in the degree of streamflow permanence, given the short life span and sensitivity to water changes of wetland plants. These four bioindicators can be used independently of the overall condition model to monitor short-term changes in vegetation condition. The other five bioindicators measure woody vegetation structure and composition and will change more slowly over time; indicators such as cottonwoodwillow stem-size class richness could decline over a period of years, as survivorship thresholds for sensitive age classes of these trees are exceeded, whereas the relative abundance of shrublands could change on a decadal scale, in response to compositional shifts of the dominant woody species. 


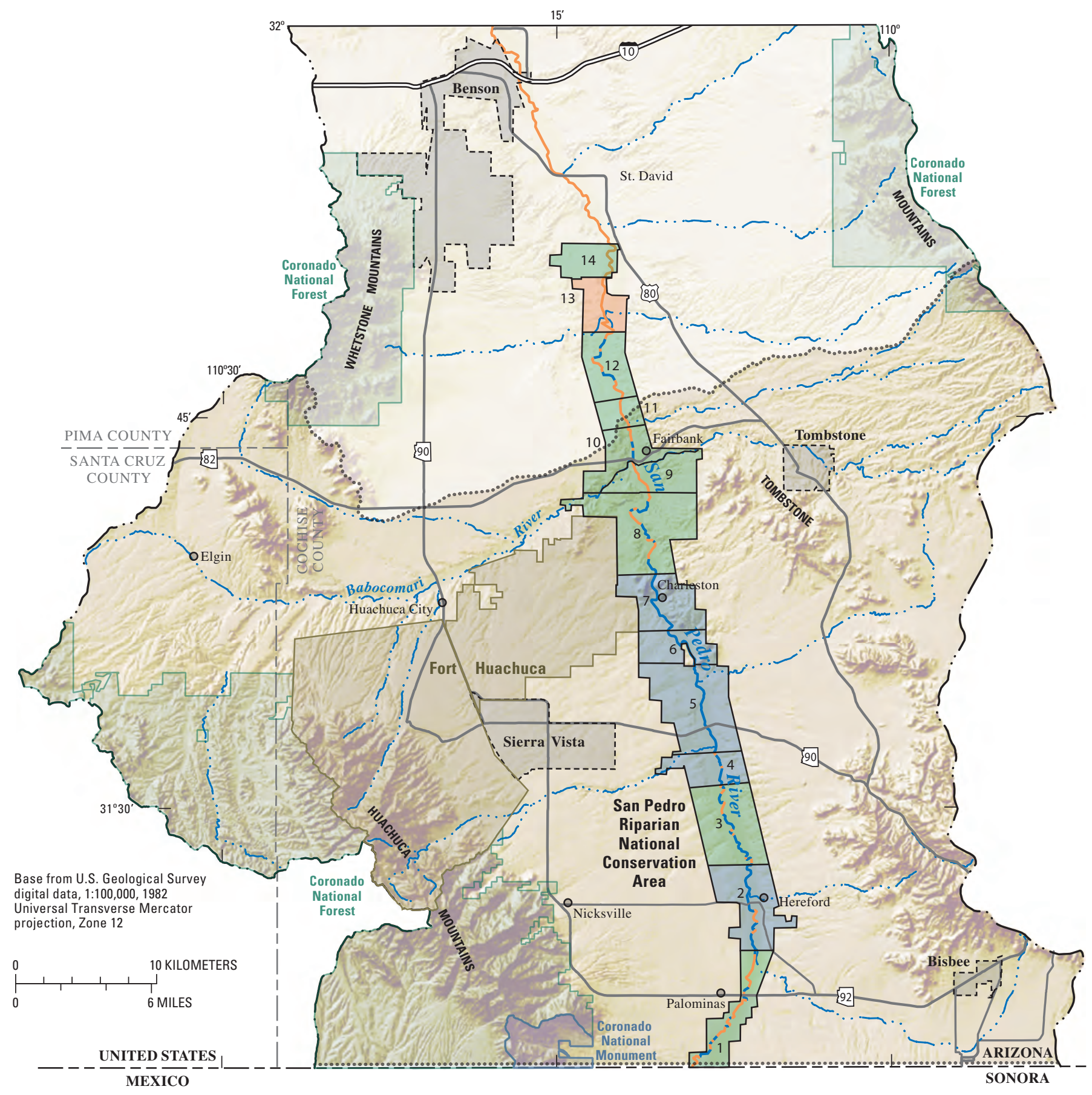

NOTE: Number is assigned to each of the 14 reaches of the San Pedro River within the San Pedro Riparian

National Conservation Area

\section{EXPLANATION}

CONDITION CLASSES:

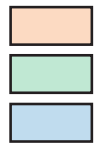

DRY-Class 1

INTERMEDIATE-Class 2

WET-Class 3
SAN PEDRO RIVER, JUNE 2002:

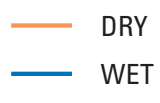

Figure 42. Riparian ecological condition classes for 14 reaches and streamflow presence for June 2002 within the San Pedro Riparian National Conservation Area, Upper San Pedro Basin, Arizona. 
Table 37. Means and standard deviations of hydrologic variables for San Pedro Riparian National Conservation Area sites classified by condition class, Upper San Pedro Basin, Arizona

[ \pm , plus or minus]

\begin{tabular}{ccccccc}
\hline Site & $\begin{array}{c}\text { Condition } \\
\text { sample size }\end{array}$ & $\begin{array}{c}\text { clows } \\
\text { clanence, } \\
\text { (percent) }\end{array}$ & $\begin{array}{c}\text { Flow } \\
\text { permanence, } \\
\text { 2003 } \\
\text { (percent) }\end{array}$ & $\begin{array}{c}\text { Mean flood-plain } \\
\text { ground-water } \\
\text { depth, 2002 } \\
\text { (meters) }\end{array}$ & $\begin{array}{c}\text { Maximum flood-plain } \\
\text { ground-water } \\
\text { depth, 2002 } \\
\text { (meters) }\end{array}$ & $\begin{array}{c}\text { Ground-water } \\
\text { fluctuation, } \\
\text { 2002 } \\
\text { (meters) }\end{array}$ \\
\hline$(1)$ & Class 1 & 48 & 17 & 2.5 & 3.5 & 1.8 \\
$(9)$ & Class 2 & $78 \pm 15$ & $63 \pm 21$ & $2.5 \pm 0.6$ & $3.0 \pm 0.9$ & $0.9 \pm 0.7$ \\
$(6)$ & Class 3 & $100 \pm 0$ & $98 \pm 4$ & $1.6 \pm 0.5$ & $1.7 \pm 0.5$ & $0.3 \pm 0.0$ \\
\hline
\end{tabular}

Riparian ecosystems are dynamic in short and long time scales. In the short term, high-magnitude floods can mobilize sediments and re-set successional processes, and change vegetation attributes, such as percent open area, relative abundance of marshland versus forested area, and tree-age structure. Many vegetation components, however, rapidly redevelop after floods (Stromberg, Richter and others, 1993; Stromberg and others, 1997). Given this rapid recovery ability, the riparian assessment model should be robust enough to apply to a wide range of successional stages excepting the first few years after large, infrequent, channel-moving floods. A large flood did occur during the model-development period that allowed us to identify (and exclude) some variables that had high variation in response to flooding. Riparian fire did not influence the model performance; the model functioned well in burned and unburned areas (Lite, 2003). In the SPRNCA, the fact that reaches having internal spatial variance in burn extent had low variance in condition-class scores confirms the insensitivity of the model to fire. The recent fires have reduced the cottonwood-willow forest patch sizes by a relatively small amount and have been followed by resprouting of willow and cottonwood. Although some aspects of forest structure are changed by fire, they are not changed in such a way as to affect model scoring.

Over the long term, the San Pedro riparian ecosystem has undergone extensive change in hydrology, morphology, and vegetation (Hereford, 1993). The present disturbance-driven, pioneer-tree dominated ecosystem differs from the marshland conditions described by explorers in the 1800 s, prior to channel incision (Leach, 1858, in Davis, 1982; Hastings and Turner, 1965). Because riparian vegetation and river geomorphology may still be undergoing changes triggered by historical channel incision, the condition-class index should be reassessed every 5 to 10 years to determine whether it needs revision. To some degree, the index constrains the biota to a particular static condition in that it reflects the biomass structure of a forested ecosystem, as opposed to a marshland ecosystem. Its applicability is broadened, however, by the use of plant functional groups and structural traits, as opposed to particular species, as indicators. This increases the probability that the assessment model will have wide temporal applicability and puts the emphasis on restoring functions, regardless of the particular species involved.

The assessment model is based largely on hydrologic thresholds of the dominant vegetation types in the floodplain channel ecosystem. The model was developed from the premise that base flow is required in the stream channel year-round to maintain class 3 conditions and that particular ranges of flood-plain ground-water levels and fluctuations are associated with maintaining the dense, multiaged forests of shallow-rooted phreatophytic trees (cottonwoods, willows) of condition class 2 . There is a sharp decline in the riverine marsh type as flows become intermittent (largely driving changes from class 3 to 2). Between class 2 and 1, cottonwood-willow forests give way to dominance by tamarisk shrublands as tolerance levels for their survivorship of groundwater depth and fluctuation are exceeded. There are, however, many other plant species in the riparian ecosystem, each of which has a unique tolerance range for hydrologic conditions. Whereas the model only simulates change occurring between discrete condition classes, change to the riparian ecosystem from reduced or increased water availability occurs along a continuum as the hydrologic thresholds for establishment or mortality of the various plant species in the community are respectively exceeded.

If the amount of water flowing to the riparian corridor changes, there will be corresponding changes in the length of stream in each condition class. Ultimately, these changes will cause some threshold effect at the landscape level. For example, bird species that use the riverine marshland habitat may become locally rare as the length of the river in condition class 3 declines below a certain level. Investigation of wildlife habitat at the landscape-level is needed to address questions such as "How many river-miles should be maintained in condition class three?". 
Functional Changes along the Water-Availability Gradient

The assessment model allows riparian ecosystem change from dewatering to be diagnosed by measuring hydrologicallysensitive vegetation traits. These hydrologic changes and the ensuing changes in riparian vegetation structure can directly influence ecosystem functions (Prichard and others, 1993; Brinson and others, 1995; Tabacchi and others, 2000). A literature review provided information to speculate about how various functions discussed in these models will change along river-water availability gradients.

\section{Biodiversity Maintenance}

\section{Maintaining Plant Biodiversity}

Riparian ecosystems are considered to be keystone ecosystems that maintain high levels of regional biodiversity (Naiman and others, 1993), and the San Pedro River is in a particularly species-rich region (Chaplin and others, 2000; Makings, 2003). Whereas woody plants provide most of the biomass structure in Southwestern riparian corridors, herbaceous plant species comprise most of the biodiversity.

High levels of floristic diversity in the San Pedro riparian corridor are maintained by floodflows, which create spatially and temporally heterogeneous environments, and by perennial streamflows, shallow ground water, and seasonal rains and floods, which provide water sources for plant species with widely varying life-histories (Tabacchi and others, 1996; Fossati and others, 1999; Decocq, 2002). In all three condition classes, periodic floods of varying size and timing increase diversity by providing the physical disturbance that allows for establishment of a wide range of ruderal and pioneer plant species. The regular summer monsoon floods and the less frequent large events also increase species richness and productivity by recharging alluvial aquifers and by moistening the soil column during overbank events. Rainfall throughout the catchment provides the ultimate source of the supplemental water in riparian zones, and provides a direct source of water that seasonally increases riparian zone diversity.

Shallow ground water and perennial streamflows further contribute to high riparian zone diversity. High numbers of hydric herbaceous species were maintained during summer drought conditions only at sites having perennial or nearperennial flow. Hydric perennial herbs, a key functional group, declined from class 3 to class 2 as streamflows became increasingly intermittent. Continuously along the wateravailability gradient, there was continuous replacement of hydric species by mesic and xeric species, as reflected by changes in wetland indicator scores.

Several of the riparian plant associations that occur along the San Pedro River, including cottonwood-willow forests, cienegas, and sacaton grasslands, have declined along some southwestern rivers (Cox and others, 1983; Hendrickson and
Minckley, 1984; Stromberg and others, 2004). The hydrologic conditions of class 3 allow for maintenance of all these associations. The emergent plant species that characterize the riverine marshlands are most abundant in class 3 , where adequate stream base flows maintain saturated soils at the margins of stream channels. Shallow ground water sustains cottonwood and willow across the flood plain, and these forests are abundant and structurally diverse only in condition classes 3 and 2. Many of the riparian plants in the SPRNCA are facultative phreatophytes that use ground water and seasonally available flood and rain water. Riparian plants in this facultative category, including mesquite, were abundant in all three condition classes.

\section{Maintaining Animal Biodiversity}

The cottonwood-willow gallery forests and other vegetation types that border this north-south trending river supply important habitat for resident and migratory bird species (Skagen and others, 1998; Arias, 2000). The San Pedro River watershed region has a rich assemblage of animal species (Simpson, 1964). Class 3 and class 2 reaches may have the greatest diversity and abundance of obligate-riparian animal species, given the floristically and structurally complex vegetation, including a diversity of plant associations, successional stages, and canopy layers (Ohmart and Anderson, 1982, 1986; Krueper and others, 2003).

As forests lose diversity of vegetation layers, and the coverage of tall cottonwood-willow forests and woodlands decreases in favor of an increase in shorter shrublands (class 1 conditions), diversity and density of obligate riparian bird species can decline (Hunter and others, 1988; Ellis, 1995; Fleishman and others, 2003) owing to decreases in resource availability and habitat complexity (Mills and others, 1991). Shifts in riparian forest species composition can alter the quality of habitat for some species of macroinvertebrates, rodents, and birds; such vegetation changes can be insignificant to others (Anderson and others, 1977; Hunter and others, 1988; Ellis, 1995; Ellis and others, 1997).

\section{Maintaining Endangered Riparian Species}

Seven species listed under the U.S. Endangered Species Act as endangered or threatened occur in the San Pedro River watershed, several of which occur (at least intermittently) within the San Pedro riparian zone (Steinitz and others, 2003): Two of the most publically recognized of these listed species are the Huachuca water umbel and the Southwestern willow flycatcher.

1. Huachuca water umbel (Lilaeopsis schaffneriana) are tiny, rhizomatous perennial, semiaquatic vascular plants that grow in moist soils along the banks of the San Pedro River and other perennial rivers in southern Arizona. Populations are most abundant where there are intermediate levels of disturbance, sufficient to provide bare soils for germination and to prevent the 
diminutive water umbels from being out-competed by larger wetland plants. Given the association with moist soils and perennial streamflows, class 3 conditions likely are critical for this species (U.S. Fish and Wildlife Service, 1997a).

2. Southwestern willow flycatcher (Empidonax trailii extimus), at elevations below 1,500 m, nest primarily in young thickets of willow and tamarisk (Paradzick and Woodward, 2003). These birds generally are associated with permanent water, such as perennial streamflow, beaver ponds, or backwater depressions (Graf and others, 2002). Along several rivers in Arizona, tamarisk provided comparable (in relation to willow stands) breeding habitat and food sources for the southwestern willow flycatcher (Owen and Sogge, 2002). Thus, vegetation habitat structure potentially could be provided in all three condition classes. Permanent water, however, would be consistently provided only by class 3 hydrologic conditions.

\section{Recreational and Aesthetic Functions}

Recreational value of a river and riparian corridor declines as the ecosystem is dewatered or otherwise degraded. Significant loss of recreational visitors, and associated decline in income from ecotourism, occurs as rivers are transformed from perennial to intermittent (Crandall and others, 1992) and as their capacity to attract birdwatchers declines (Leones and others, 1998; Turpie and Joubert, 2001). On the San Pedro River, there are apparent visual changes from class 3 to class 2 as the stream loses perennial flow and emergent wetland plants decline, and from class 2 to class 1 , as the riparian forests give way to shrublands. The attractiveness of the area for birdwatching, hiking, and other forms of light recreation likely declines between all condition classes.

\section{Hydrogeomorphic Functions}

\section{Energy Dissipation and Flood-Velocity Reduction}

Vegetation in the flood plain creates resistance to streamflow and dissipates stream energy, which reduces downstream effects of flood waters but increases lateral flooding. In forested flood plains, flow resistance (also referred to as roughness) increases as direct functions of the density and size of tree stems ( $\mathrm{Li}$ and Shen, 1973; Petryk and Bosmajian, 1975). Along the water-availability gradient in the SPRNCA there were physiognomic shifts from woodlands to shrublands and changes in stem density. Further investigation is needed to determine if these vegetation changes cause floodenergy dissipation processes to vary substantially between the three condition classes.

\section{Sediment Detention and Sediment Dynamics}

By slowing flood velocity, dense flood-plain vegetation reduces the ability of flood waters to entrain sediments, and thus facilitates deposition of sediment on the flood plain. Studies on some rivers suggest that dense stands of tamarisk are associated with high rates of sediment deposition (Graf, 1978; Blackburn and others, 1982). A study on the San Pedro River, however, showed high variability in sedimentation rates between forest types, with some tamarisk stands having higher values than similar-aged cottonwood stands, but no statistically significant difference between the two vegetation types (Stromberg, 1998b).

\section{Streambank Erosion Prevention and Channel Maintenance}

Riparian vegetation stabilizes streambanks through various mechanisms. Above-ground vegetation (stems, leaves) creates roughness that dissipates flood energy and reduces scour. Below-ground roots and root exudates bind soil particles. The dense and diverse streambank vegetation (herbaceous and woody) at the class 3 sites likely reduces rates of bank erosion during floods (Beeson and Doyle, 1995; Murgatroyd and Ternan, 1983; Dunaway and others, 1994; Lyons and others, 2000; Abernethy and Rutherfurd, 2000).

\section{Enhancing Bank Storage and Ground-Water Recharge}

After floods, flood plains and streambanks temporarily store large volumes of water that are gradually released back to the stream channel, contributing to lower flood peaks and increased base flows (Whiting and Pomeranets, 1997). Above-ground, riparian vegetation enhances flood-plain and bank water storage by reducing peak-flow rates and increasing lateral spread of the floodwaters. Below ground, root growth and subsequent root decay can create soil aggregates and soil macropores that increase rates of infiltration of rainwater and flood water, thereby enhancing ground-water recharge and base-flow replenishment. Streambanks with perennial herbaceous vegetation tend to have better developed soils, which increases infiltration capacity (Muscutt and others, 1993). Rates of bank-storage, thus, may be greatest at wet (class 3) sites.

\section{Biogeochemical Functions}

Plant productivity and organic matter production likely are greatest in the wettest condition class (class 3 ), but empirical studies are needed on this topic to reduce uncertainty. Organic matter produced by plants is a major contributor to soil development, structure, and fertility. There is a need for studies on effects of changing flow regimes on decomposition rates. Flood pulses and rains likely drive decomposition processes in the flood plain by providing water 
to detrital biota on the forest floor (to decompose leaf and stem litter) and in the soil (to decompose root detritus; Molles and others, 1995; Ellis and others, 1999).

\section{Water-Quality Purification and Nutrient Cycling and Retention}

Water quality is influenced by abundance and productivity of vegetation on streambanks and bars (as it affects surface-water pollutants), in the flood plain (as it affects ground-water pollutants and runoff arriving from lateral upstream areas), and by the occurrence of reducing conditions. Woody and herbaceous riparian vegetation can contribute to the removal of pollutants, such as excessive nutrients, from agricultural or urban watersheds (Schlosser and Karr, 1981; Haycock and Pinay, 1993). Nitrates are removed from stream or soil water by denitrifying microorganisms (sustained by energy supplied by riparian plants) and through direct assimilation into plants (Vought and others, 1994; Schade and others, 2001). Denitrification requires reducing conditions, which are most likely to be found in marshlands (abundant only in class 3 conditions). Ground water in this region tends to be oxic (Robertson, 1991).

\section{Resilience}

Resilience refers to the capacity of the riparian ecosystem to adjust to changing environmental conditions (such as climate change, extreme drought, or flooding) without experiencing sustained or untoward declines in biodiversity, bioproductivity, nutrient retention, or other functions (Rapport and others, 1998). Maintaining a high degree of resilience requires sustaining physical processes, such as regional ground-water inflow to sustain base flows, and periodic floodflows to augment ground-water recharge, to provide an adequate resource base for the biota. Generally, the ability of plant species to tolerate disturbance increases if resources are abundant (Grime, 1974), and thus class 3 conditions should allow for greatest resilience. Resilience also will be heightened by sustaining connectivity between upland ecosystems and the riparian corridor and along upstream-downstream gradients, to allow for movement of species (for example, immigration, emigration) and thus for continued adjustments of the biota to the changing physical environment.

\section{Summary}

This component of the SPRNCA riparian water-needs study examined the spatial and temporal patterns of surface water presence and ground water depth needed to maintain the riparian ecosystem along the San Pedro River. Primary objectives were to (1) describe relations between site hydrology and riparian vegetation structure, composition, and diversity (biohydrology analysis), (2) assess recent trends for change in riparian forest structure (trend analysis), and (3) assess the functional condition of the SPRNCA riparian vegetation (functioning condition assessment). Primary findings are as follows:

Objective 1: Biohydrology analysis

1. Plant species in the San Pedro riparian corridor were classified into 1 of 12 functional groups on the basis of life-history differences. Hydrologic relations were then described for each functional group and for several of the most common plant species. Relations with stream base flows, alluvial ground water, and flood pulses varied widely among functional groups.

2. Of all the woody plant species, Fremont cottonwood and Goodding willow (hydromesic pioneer group) were the most sensitive to changes in alluvial ground-water levels and streamflow permanence (with the latter likely serving as a proxy for long-term ground-water fluctuation). Cottonwood-willow forests declined in cover, basal area, and size-class diversity along site gradients of decreasing streamflow permanence and increasing ground-water depth, and gave way to tamarisk (a mesic pioneer tree/shrub) as site ground-water depths exceeded about $3 \mathrm{~m}$ (as averaged across the flood plain). Presence of shallow ground water throughout the growing season, with little decline during dry seasons (less than about $1 \mathrm{~m}$ intra-annual fluctuation), allows for maintenance of dense, multiaged cottonwood-willow forests. Periodic winter/spring flooding of appropriate timing and magnitude creates the disturbance required for establishment of new generations of these pioneer-tree species.

3. Among herbaceous plant groups, the hydric groups was the most sensitive to changes in surface water availability. Rushes, bulrush, and other hydric perennial herbs depend on continuously moist soils. This group had streamside-zone cover of up to 35 percent at perennial flow sites, cover values less than 10 percent at sites having 60 to 95 percent streamflow permanence, and no cover at sites having less than 60 percent streamflow permanence. Hydric annuals (for example, annual rabbitsfoot grass) and mesic annuals (for example, white sweetclover) showed varying responses by season. During the summer dry season, these groups increased in cover as streamflows increased in permanence, and decreased across flood plains as plot elevation and depth to ground water increased.

4. Several herbaceous plant groups increased in cover following monsoon-season rains and floods: hydric annuals responded largely to flood inundation, whereas xeric annuals (a species-rich group) and xeric perennials responded largely to rains. Mesic perennial herbs (including big sacaton, bermuda grass, and Johnson grass), the dominant herbaceous plants in the flood 
plain, also increased in cover. The temporal and spatial distribution patterns of the mesic perennial herbs suggest opportunistic use of ground water, flood water, and rainfall, depending on seasonal availability.

5. Some plant species declined in abundance among sites as water availability increased, likely owing, in part, to competitive interactions with more hydrophytic species. Tamarisk (mesic pioneer tree/shrub) and bermuda grass (mesic perennial herb) increased in abundance at drier sites. Tamarisk had the greatest basal area (greater than $10 \mathrm{~m}^{2} /$ hectare) at sites having less than 60 percent annual streamflow permanence.

6. Abundance of velvet mesquite trees was related to site elevation and average flood intensity (which was defined as the total stream power of a 100-year recurrence interval flood) but not to site water-availability factors. Basal area and mean size of mesquite on flood plains and terraces increased with distance downstream (particularly below about 1,200 m elevation).

7. A few measures of biomass structure varied with water availability (streamflow permanence, ground-water depth) or flood disturbance (total stream power) factors. Mean vegetation height increased at wetter sites, whereas woody plant stem densities increased at drier sites (reflecting high abundance of shrubby tamarisk).

8. The relative cover of shrublands in the flood plain increased at drier sites (relative cover greater than 45 percent at sites having less than 60 percent annual streamflow permanence) while that of woodlands decreased (relative cover less than 3 percent at sites with less than 60 percent streamflow permanence and values from 7 to 25 percent at sites with greater than 60 percent streamflow permanence). On terraces, the cover of woody vegetation patch types (forests, woodlands, and shrublands) increased with distance downstream.

9. Herbaceous species richness in the streamside zone, as measured during the summer dry season, increased among sites along a gradient of increasing with streamflow permanence. This pattern was not evident during the summer monsoon season, when water was less limiting.

10. Large floods (such as the October 2000 flood) allow for short-term increases in herbaceous plant species richness in the flood plain; disturbance-adapted annuals showed great post-flood increase. Streamflows in 2001 were elevated across the SPRNCA, in response to prior-year flooding, which allowed for increased abundance of some plant groups, including hydric herbs.
Objective 2: Trend analysis for pioneer trees.

1. Cottonwood and willow abundance vary with site hydrology. At the driest sites (Contention and St. David), young plants have low densities (combined cottonwoodwillow densities of $<20$ young stems per hectare, compared to values of about 100 to 200 young stems of cottonwood and willow per hectare at perennial-flow sites); the low values likely are due in part to rapid and high seasonal declines in ground-water levels during potential establishment years.

2. Cottonwood and willow establishment rates were modeled using the "recruitment box" approach, as modified to include three ranges of depth to ground water spanning the range of conditions present in the SPRNCA. Model output indicated that conditions are too dry in some areas (specifically, intermittent-dry sites) to allow for ongoing cottonwood and willow recruitment.

3. The relative abundance of tamarisk to that of cottonwoodwillow has changed over time at some San Pedro River sites as indicated by comparisons among four size and age classes of trees. The relative abundance of tamarisk was constant across the size/age classes at half of the SPRNCA reaches but showed a trend of increasing in abundance at the others. Recent increases in tamarisk abundance may be indicative of decreasing site water availability.

4. Annual branch growth of willow varied in time and space in response to changing water availability. Growth rate was greatest in 2001 (post-flood wet year). Growth rate was low at dry sites (including Tombstone, Fairbank, and Contention) where the mean flood-plain ground-water depth exceeded $3 \mathrm{~m}$.

\section{Objective 3: Functioning condition assessment.}

1. A Riparian Condition Index was developed by using a suite of field-measured vegetation traits (bioindicators) that are sensitive to changes in streamflow permanence and (or) ground-water levels. This index is designed to diagnose and monitor riparian vegetation condition change resulting from surface-water and ground-water depletion.

2. The index was used to develop a riparian assessment model. To apply the assessment model, one collects field data on nine vegetation bioindicators, determines the scoring range for each indicator from provided tables, and averages the scores to obtain an overall site index. Site index scores allow for site placement into condition classes ranging from class 1 (traits characteristic of dry sites) to class 3 (sites with minimum water stress). Each condition class is associated with particular ranges for site hydrology, vegetation structure, and ecosystem 
functional capacity. Hydrologically, the class 3 sites are characterized as having perennial flow and shallow stable alluvial ground-water levels in the flood plain (averaging $<2.5 \mathrm{~m}$ deep in the dry season with $<0.5 \mathrm{~m}$ annual fluctuation). Condition class 2 has intermittentwet flow (present $>60$ percent of time) and moderately shallow ground water with moderate levels of annual fluctuation. Condition class 1 has intermittent-dry flow (present $<60$ percent of time) and a deep (averaging $>3.5 \mathrm{~m}$ in the dry season) and highly fluctuating (>1 m per year) alluvial water table.

3. The nine vegetation bioindicators are (1) basal area of hydromesic pioneer trees (cottonwood-willow), (2) relative basal area of hydromesic versus mesic (tamarisk) pioneer trees, (3) cottonwood-willow stemsize class diversity, (4) maximum vegetation height in the flood plain, (5) percentage of the flood plain covered by shrublands, (6) dry season cover of hydric perennial herbs in streamside zone, (7) dry season relative cover of hydric perennial herbs in streamside zone, (8) dry season cover of all hydric herbs in streamside zone, and (9) dry season relative cover of all hydric herbs in streamside zone.

4. Overall, 39 percent of the SPRNCA riparian corridor fell within condition class 3 (the wettest condition), 55 percent in condition class 2 , and 6 percent in condition class 1 (the driest class). The single reach in class 1 was located in the northern tier; class 3 reaches are most abundant in the central part of the SPRNCA. These findings are calculated from data collected at 26 sites within the SPRNCA distributed within 14 reaches that were determined to be relatively homogenous in terms of streamflow hydrology (spatial intermittence of streamflow) and geomorphology (channel sinuosity and flood-plain width).

5. The vegetation characteristics of the three condition classes provide some measure of the changes in vegetation structure and composition that might occur in response to future changes in site water availability. With reductions in streamflow permanence and declines in the alluvial ground-water table, hydric herbaceous species such as bulrush and rushes would decline in cover and streamside-zone species composition would shifts towards mesic species, such as bermuda grass. Across the flood plain, cottonwood-willow recruitment rates would decline and mortality rates would increase, and species composition would shift towards more drought-tolerant species such as tamarisk. Structurally, riparian woodlands would give way to riparian shrublands, and canopy height and upper canopy vegetation volume would decline. With increases in streamflow permanence, the reverse pattern of changes would occur. 


\title{
Chapter D
}

\section{Determining the Riparian Ground-Water use within the San Pedro Riparian National Conservation Area and the Sierra Vista Subwatershed, Arizona}

\author{
By Russell L. Scott', David G. Williams², David C. Goodrich', William L. Cable', Lainie R. Levick', \\ Roberta McGuire', Rico M. Gazal2, Enrico A. Yepez², Patrick Ellsworth², Travis E. Huxman ${ }^{3}$
}

\section{Introduction}

\section{Rationale and Background}

The combined research team of the U.S. Department of Agriculture's Agricultural Research Service (USDA-ARS), the University of Wyoming, and the University of Arizona had the primary role in the San Pedro Riparian National Conservation Area (SPRNCA) water-needs study to improve estimates of the water use by the San Pedro River's riparian corridor and to identify the sources of that water. In order to do this, the main experimental objectives, developed in coordination with the Upper San Pedro Partnership were to:

1. Quantify the consumptive water use of riparian mesquite woodlands,

2. Quantify environmental factors that are likely to influence mesquite water use,

3. Quantify the consumptive water use of understory vegetation within the cottonwood-willow stands and the evaporation from the free water surface within the SPRNCA,

4. Identify the evaporation water source for the dominant vegetation communities, and

5. Quantify the total consumptive ground-water use from the regional aquifer by riparian vegetation within the SPRNCA.

These objectives followed from previous work done to estimate riparian ground-water use for portions of the Upper San Pedro Basin and were designed to refine knowledge of riparian vegetation functioning so that improved estimates can be made.

\footnotetext{
'Southwest Watershed Research Center, U.S. Department of Agriculture, Agricultural Research Service, Tucson, Arizona.

${ }^{2}$ Department of Renewable Resources, University of Wyoming, Laramie, Wyoming.

${ }^{3}$ Department of Ecology and Evolutionary Biology, University of Arizona, Tucson, Arizona.
}

The work of Goodrich, Scott, and others (2000) is the most recent on this issue and was the foundation for this study. Their study synthesized the results of the interdisciplinary Semi-Arid Land-Surface-Atmosphere (SALSA) program in order to make the first field-measured, evapotranspiration (ET) data-based estimates of riparian ground-water use in a portion of the SPRNCA's riparian corridor. Most of the estimates made prior to Goodrich, Scott, and others (2000) were derived from ground-water modeling studies that indirectly infer or model riparian ground-water use in a simplified manner (Kreager-Rovey, 1974; Freethey, 1982; Vionnet and Maddock, 1992). Prior to Goodrich, Scott, and others (2000), Corell and others (1996) estimated riparian ground-water use by using the difference between river base flows in winter and summer at the U.S. Geological Survey (USGS) streamflowgaging stations, San Pedro River at Palominas (09470500), at Charleston (09471000), and near Tombstone (09471550). Despite being derived from entirely different approaches, the estimates are surprisingly similar (table 38). The estimates of Corell and others (1996) also include potential losses caused by near-stream agricultural pumping.

This study's approach to determining riparian groundwater use was to refine previous water-use estimates for the open water surface and the key ecosystem types found within the SPRNCA using hydroecological measurements of ET and plant-water sources. Next, these revised estimates were combined with a new vegetation map developed for the SPRNCA in 2000 (U.S. Army Corps of Engineers, 2001) to determine riparian ground-water use. Following many of the recommendations of Goodrich, Scott, and others (2000), the ecosystems of interest were velvet mesquite (Prosopis velutina) woodlands and the Fremont cottonwood (Populus fremontii) forest, but a companion effort with the University of Arizona enabled an additional sacaton (Sporobolus wrightii) grassland and mesquite shrubland to be studied. Additionally, pioneer studies of open-water evaporation and the transpiration of a major understory plant species, seepwillow (Baccharis salicifolia) were carried out. Finally, meteorological variables collected from three meteorological sites were compared to determine how certain forcing variables relevant to the evaporation process and future modeling studies varied at different locations within the SPRNCA (appendix 8). An overall description of the vegetation, soils, streamflow, and climate of the upper San Pedro River is given in the introductory section of this report (see chapter A). 
Table 38. Previous estimates of ground-water use by the riparian system along the San Pedro River within the Sierra Vista Subwatershed, Upper San Pedro Basin, Arizona

$\left[\mathrm{m}^{3}\right.$, cubic meter $]$

\begin{tabular}{cc}
\hline \multicolumn{1}{c}{ Source } & $\begin{array}{c}\text { Annual riparian } \\
\text { ground-water use estimate } \\
\mathbf{m}^{3} \text { (acre-feet) }\end{array}$ \\
\hline Corell and others (1996) & $18,758,000(7,100)$ \\
$\begin{array}{c}\text { Goodrich, Scott, and } \\
\text { others (2000) }\end{array}$ & ${ }^{2} 8,130,000(6,590)$ \\
\hline
\end{tabular}

${ }^{1}$ From the start of the perennial reach upstream from the U.S. Geological Survey (USGS) streamflow-gaging station San Pedro River at Palominas (09470500) to the USGS streamflow-gaging station San Pedro River near Tombstone (09471550), and excluding 600 acre-feet per year from the Babocomari River, a major San Pedro River tributary.

${ }^{2}$ From the international border with Mexico to the USGS streamflowgaging station near Tombstone.

\section{Methods}

ET was measured at three biohydrology study sites: Boquillas, Charleston mesquite, and Lewis Springs (fig. 43). ET was measured by using the eddy-covariance technique at the Charleston mesquite and Lewis Springs sites and by using the sap-flow method at the Lewis Springs and Boquillas sites (table 2). Among these sites, the dominant vegetation communities of sacaton (Sporobolus wrightii) grasslands, mesquite woodlands and shrublands, and cottonwood forests are all represented. ET from seepwillow, a major understory riparian shrub, and the evaporation from the open-water surface of the river were also measured. The method used to measure ET depended on the plant community being studied. The eddy-covariance technique requires a spatially extensive patch of similar vegetation and was used for the sacaton grassland (at the Lewis Springs site) and mesquite (at the Charleston mesquite and Lewis Springs sites) vegetation communities. The sap-flow method was used for the cottonwood and seepwillow vegetation communities (at the Lewis Springs and Boquillas sites) because these vegetation types do not occur in large, uniform stands along the San Pedro River. An extensive analysis of mesquite water sources using stable isotopes of water (at the Charleston mesquite and Moson sites) was also performed to better understand the partitioning of mesquite ET into ground-water and precipitation sources. Basic meteorological data were collected at the Palominas, Lewis Springs, and Charleston mesquite sites (table 2). See chapter A for additional information about the study sites.

\section{Mesquite Woodland Evapotranspiration}

Mesquite woodland evapotranspiration was measured at one location (Charleston mesquite; fig. 43) during the 2001, 2002, and 2003 growing seasons and supplemented by direct measurements of understory ET at two locations within the same site during 2001 and 2002. The growing season partitioning of mesquite ET into the component fluxes of mesquite transpiration, soil evaporation, and understory ET was estimated by a combination of micrometeorological and stable-isotope techniques.

\section{Site Description}

The Charleston mesquite study site is on the east side of the San Pedro River at an elevation of 1,200 m, about $16 \mathrm{~km}$ northeast of Sierra Vista, Arizona (fig. 43). The site is collocated with one of the biohydrology study sites (see chapters A-C) in a dense woodland dominated by mesquite. It has a typical fetch of about 300-1,000 m for most wind directions. The shortest fetch is limited to about $150 \mathrm{~m}$ southeast of the instrument tower. The understory is primarily sacaton grass with some shrubs and various annual herbaceous species. The average canopy cover, defined as the ratio of the projected canopy cover area to the total ground area, is about 75 percent. The measured Plant Area Index (PAI) ranges from an average $(n=40)$ of about 1.0 prior to leaf-out to about 1.6 during most of the growing season. During the peak of the growing season, the PAI was equal to a one-time measurement of Leaf Area Index (LAI). The mean canopy height was about $7 \mathrm{~m}$ and the maximum canopy height was about $10 \mathrm{~m}$.

The deepest observed rooting depths of the understory plants were 2 to $3 \mathrm{~m}$, implying that the plants do not have access to ground water at a depth of about $10 \mathrm{~m}$. Rooting patterns of nonriparian mesquite are quite varied and extensive (Heitschmidt and others, 1988) and have been described as "ubiquitous" (Gile and others, 1997). At the cutbanks along the river near the site, mesquite roots extending both laterally near the surface and vertically to the water table were observed. On the mesquite terrace, soils are sandy loams interspersed with layers of gravel and clayey material.

\section{Meteorological Instrumentation}

Evapotranspiration was measured using the eddycovariance technique throughout most of the active mesquite growing season in 2001, 2002, and 2003. Basic meteorological, soil moisture, and water-table elevation data were also collected throughout most of each year. 


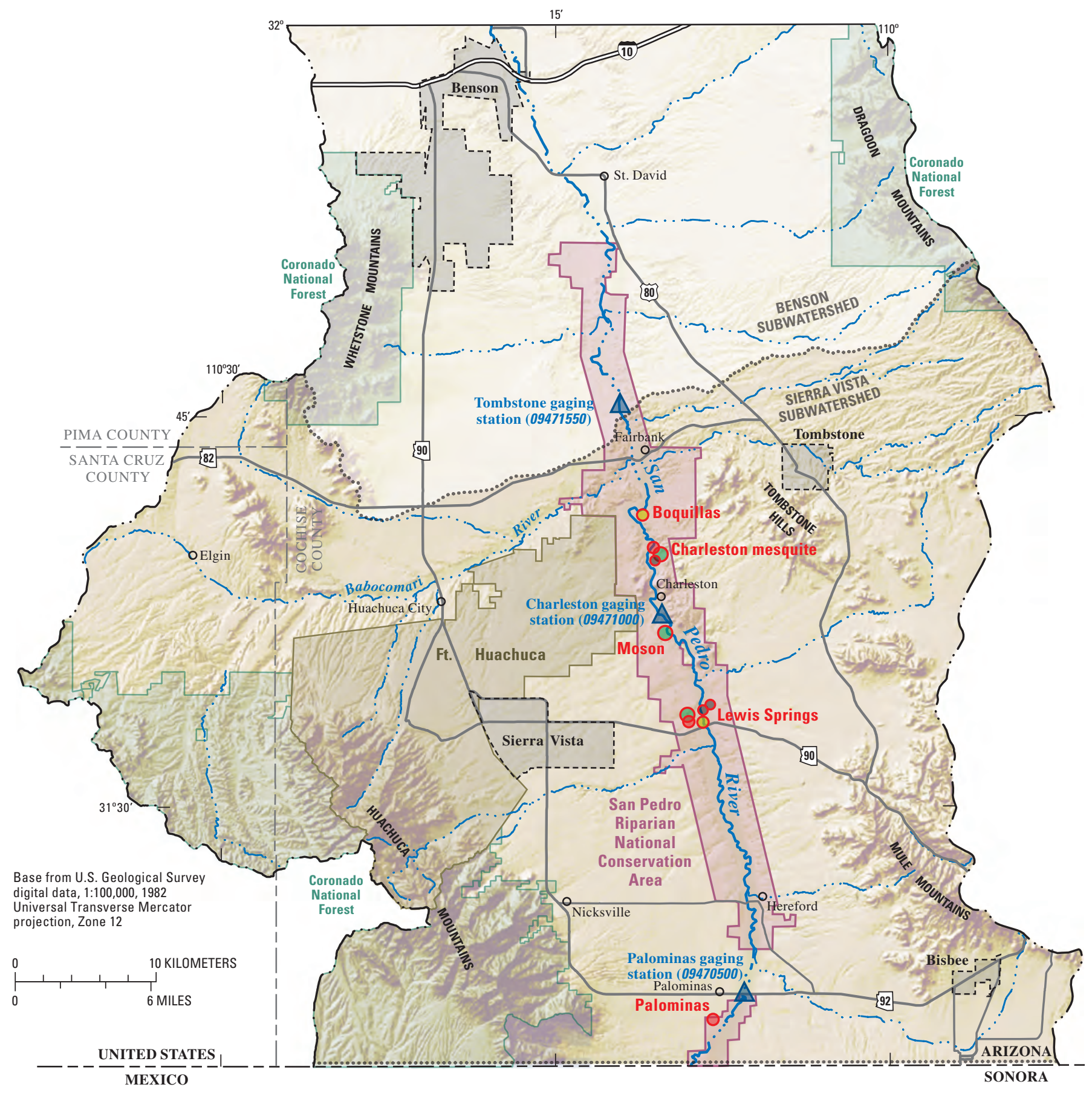

EXPLANATION

$\triangle$ U.S. GEOLOGICAL SURVEY STREAMFLOW-
GAGING STATION AND NUMBER

EVAPOTRANSPIRATION STUDY SITES:

- Sap flow $\bigcirc$ Mesquite isotope

○ Basic meteological $\bigcirc$ Eddy covariance

Figure 43. Location of study area showing the evapotranspiration study sites in the San Pedro Riparian National Conservation Area, Upper San Pedro Basin, Arizona. 
A three-dimensional sonic anemometer and an open-path infrared gas analyzer (IRGA) mounted at the top of a 14-m-tall scaffolding tower measured the following: (1) components of the wind-velocity vector, (2) the sonic temperature, and (3) the densities of water vapor and carbon dioxide. These variables were sampled at $10 \mathrm{~Hz}$ by a datalogger. The datalogger also calculated the 30-minute covariances among the measured variables using block Reynolds averaging. Surface fluxes were later calculated off-line, after performing a two-dimensional coordinate rotation and accounting for density fluctuations (Webb and others, 1980). The sonic temperature was used to calculate sensible heat flux using the method suggested by Paw U and others (2000) that accounts for an otherwise missing energy-balance term associated with the expansion of air during evaporation under constant pressure. Fluxes measured when the wind direction was within $20^{\circ}$ of directly behind the anemometer (about 6 percent of the data) were ignored owing to possible interference from the anemometer support and the IRGA mounted behind the anemometer.

Basic meteorological measurements were made with a wind-vane anemometer and a temperature/relative humidity probe at a height of $13.5 \mathrm{~m}$, and above-canopy net radiation was measured at a height of $9 \mathrm{~m}$ by using a four-component radiometer attached to a horizontal boom extending $4 \mathrm{~m}$ from the tower. Ground heat flux was measured with eight soil heat plates installed $0.05 \mathrm{~m}$ below ground level. Measurements of the rate of change of soil temperature above the heat flux plates (at 0.02 and $0.04 \mathrm{~m}$ ) allowed calculation of the soil heat flux at the surface using estimates of the specific heat of the 0.05 -m-thick soil layer obtained with a thermal properties sensor.

Soil moisture was measured with 12 water-content reflectometers installed in vertical profiles at depths of 0.05 , $0.10,0.20,0.30,0.50,0.70$, and $1.0 \mathrm{~m}$. Two probes were installed at each of the five upper depths, and the reported data for these depths are an average of the data from the two probes. A network of four piezometers was installed to measure fluctuations in the water table. These piezometers were installed in addition to the near-stream piezometers discussed in chapters A and B. Measurements of watertable elevation were taken manually until the installation of pressure transducers in late June 2001, and periodically afterward to confirm accuracy of the transducers. A tippingbucket rain gage measured precipitation at the top of the tower. Data from all the sensors were recorded on dataloggers, which were downloaded every 7-10 days onto a personal laptop computer.

Studies using eddy-covariance instrumentation commonly use the standard of energy balance closure to evaluate the accuracy and efficacy of their measurements (Wilson and others, 2002). Neglecting the heat stored in the biomass and the air below the sensors, the one-dimensional energy balance for the mesquite woodland can be written as:

$$
R_{n}-G+\lambda E+H
$$

where (all units are $\mathrm{W} / \mathrm{m}^{2}$ )

$$
\begin{aligned}
R_{n}= & \text { the net radiation, } \\
G= & \text { the soil heat flux, } \\
\lambda E= & \text { the latent heat flux, (evapotranspiration } \\
& \text { multiplied by the latent heat of } \\
& \text { condensation), and } \\
H= & \text { the sensible heat fluxes. }
\end{aligned}
$$

The results of a least squares regression of $(\lambda E+H)=R_{n}$ Slope $\left(R_{n}-G\right)+$ Intercept for 30-minute fluxes and for daily total fluxes when data were available for more than 24 half-hour periods in the day provide a measure of how well the energy balance was closed in the observations (table 39). The ratio of the quantities in equations indicates that closure was moderate in this study; approximately 7 to 20 percent of the available energy was unaccounted for at the half-hourly time scale from year to year. Although not ideal, this result is consistent with numerous other studies made using eddy-covariance instruments (Wilson and others, 2002). Using daily average fluxes improves the slopes of the regressions, suggesting that there was a daily cycle in the (unmeasured) energy stored in the air and, particularly, the biomass below the sensors (Blanken and others, 1997; Gu and others, 1999) that equaled approximately 5 to 10 percent of the available energy.

One of the goals of this study was to quantify the magnitude and variability of the seasonal water use of the mesquite woodland. It was necessary to recognize the shortcomings in energy-balance closure when doing this, especially because the degree of closure was significantly different between the years that were compared. This study followed the advice of Twine and others (2000), who suggested that forcing closure was justified when available energy was known and errors in its measurement modest. Consequently, latent and sensible heat fluxes were scaled to force daily closure while conserving the measured Bowen ratio $(H / \lambda E)$. Closing the daily energy balance, rather than the half-hour balance, was preferred because energy storage between the land surface and the eddy-covariance sensors was unmeasured and likely significant on a 30-minute basis but not on a daily basis.

In the following analysis, daily average ET values were calculated by first filling the gaps in the data that were caused by sensor malfunctions or bad measurements. Linear interpolation was used to fill short (0.5-3 hour) periods when data were missing. For times when more than 25 percent of the data were missing on an individual day, the daily total was estimated as being the average daily water use for the 3 days before and the 3 days after the day with missing records. 
Table 39. Ordinary linear regression coefficients for energy-balance closure and mean quantities of the energy-balance components in equation $3\left(R_{n}-G=\lambda E+H\right)$ for the Charleston mesquite site, San Pedro Riparian National Conservation Area, Upper San Pedro Basin, Arizona

[ $n$, sample size; $r^{2}$, goodness of fit; $R_{n}$, net radiation in watts per square meter; $G$, soil heat flux in watts per square meter; $\lambda E$, latent heat flux in watts per square meter; $H$, sensible heat flux in watts per square meter; 30-minute ground-water levels were measured in a piezometer at the site.]

\begin{tabular}{|c|c|c|c|c|c|c|c|}
\hline & $n$ & Slope & Intercept & $r^{2}$ & ${ }^{1} R_{n}-G$ & ${ }^{1} \lambda E+H$ & ${ }^{1} \lambda E+H / R_{n}-G$ \\
\hline 2001 & 9,294 & 0.78 & 10.6 & 0.93 & 130.3 & 111.4 & 0.85 \\
\hline 2002 & 9,818 & .73 & 11.2 & .92 & 145.4 & 116.9 & .80 \\
\hline 2003 & 10,510 & .84 & 16.0 & .93 & 161.5 & 150.9 & .93 \\
\hline 2002 & 227 & .80 & 1.0 & .91 & & & \\
\hline 2003 & 231 & .99 & -8.1 & .90 & & & \\
\hline
\end{tabular}

${ }^{1}$ Mean quantities computed only for 30-minute periods when all terms $\left(R_{n}, G, \lambda E\right.$, and $\left.H\right)$ were available.

${ }^{2}$ For days with at least 24 half-hourly values of all energy-balance components.

\section{Evapotranspiration Partitioning}

The partitioning of mesquite woodland ET into the component fluxes of mesquite transpiration, understory ET, soil evaporation, and understory transpiration was estimated for several days throughout the 2001 and 2002 growing seasons using micrometeorological techniques alone and a combination of micrometeorological and isotopic techniques. Using the results of the latter, daily partitioning amounts were extrapolated to determine growing season trends and totals.

\section{Using Micrometeorological Techniques Alone}

The first method used to separate total mesquite ecosystem ET into overstory transpiration and understory ET (ET derived from rainfall alone) involved a micrometeorological approach ${ }^{1}$. Two eddy-covariance systems were deployed $2 \mathrm{~m}$ above the ground to estimate the average understory flux sensed from the main tower. One site was located in a more closed patch near the tower, and the other was positioned in a more open patch farther away. The same method was used to measure ET at the understory eddy-covariance sites; the equipment was similar to that documented in the "Meteorological Instrumentation" section. Understory eddy-flux was measured during the periods June 13-15, July 27-August 1, and September 14-24, 2001; and June 13-19 and August 13-18, 2002, to capture ecosystem functioning before and after the summer monsoon rains and between 2 years having different antecedent conditions. Energy-balance closure was not forced as it was

${ }^{1}$ See Scott and others, 2003, for detailed methods and the 2001 results of the study. for the overstory eddy-covariance measurements, because accurate estimates of energy available in the understory were not feasible owing to a high degree of canopy heterogeneity. The average understory evaporation was computed by $0.7 E_{M C}$ $+0.3 E_{M O}$, where $E_{M C}$ and $E_{M O}$ are the average daily ET values from the more closed and more open sites, respectively. This weighted average reflects the average canopy cover (about 70 percent) of the mesquite overstory; the source area of the tower measurement likely had a similar weighting of more closed and more open patches.

These estimates of mesquite transpiration were compared with those made by using White's (1932) method. The quantity of ground water withdrawn by mesquite transpiration during a 24-hour period can be determined by

$$
T_{\text {well }}=S_{y}(24 r \pm s),
$$

where

$$
\begin{aligned}
& T_{\text {well }}=\text { the depth of water withdrawn (by tree } \\
& \text { transpiration) } \\
& S_{y}=\text { the specific yield of the soil in which the } \\
& \text { daily fluctuation of the water table takes } \\
& \text { place, } \\
& r=\text { hourly rate of rise of the water table from } \\
& \text { midnight to } 4 \text { a.m., and } \\
& s=\text { the net fall or rise of the water table during } \\
& \text { the 24-hour period. }
\end{aligned}
$$

\section{Using Isotopic and Micrometeorological Techniques}

The second method to estimate water-use partitioning used the stable isotopes of water as a tracer of ET sources. By using this approach, the goals were to (1) develop methods 
to partition ET into mesquite transpiration, understory transpiration, and soil evaporation using stable isotopes, and (2) determine the seasonal variation and totals of these ET sources. This approach will help to constrain estimates of ground-water use at the ecosystem scale for extrapolation to the riparian corridor.

The fraction of the ET flux corresponding to both understory and overstory transpiration $(F T)$ was determined using an isotopic mass balance approach:

$$
F T=\left(\delta_{E T}-\delta_{E}\right) /\left(\delta_{T}-\delta_{E}\right)
$$

where

$$
\begin{aligned}
\delta_{T}= & \text { the isotopic value of water transpired by } \\
& \text { vegetation (from samples of stem } \\
& \text { xylem water), } \\
\delta_{E}= & \text { a modeled value for the isotopic value of } \\
& \text { water undergoing evaporation from soil } \\
& \text { (from soil samples), and } \\
\delta_{E T}= & \text { the isotopic value of water vapor collected } \\
& \text { within the vegetation boundary layer (Wang } \\
& \text { and Yakir, 2000). }
\end{aligned}
$$

Errors from this estimate were calculated by using the methods of Phillips and Gregg (2001). This approach was combined with the eddy-covariance measurements to obtain the component fluxes. A detailed description of the methods employed is described in Yepez and others (2003). In this chapter, estimates based only on the oxygen isotope $\left(\delta^{18} \mathrm{O}\right)$ variation were included.

ET partitioning was calculated by using stable-isotope techniques from data collected on September 22, 2001, and June 16, August 14, September 1 and 14, and October 9, 2002. In order to estimate the seasonal trend and totals for these component fluxes for 2001, 2002, and 2003, the following extrapolations were performed:

\section{Soil evaporation}

The conductance of the soil surface to evaporation is high when the soil moisture content at the surface is above a certain threshold value. Below this threshold soil-moisture value, conductance to evaporation is generally low. After rainfall, when the soil surface is wet during the first phase of soil drying, the evaporation rate is a function of available energy. During the second drying phase, soil evaporation is limited by available moisture and soil physical properties. A stable source analysis of ET source water was used to assign a threshold surface soil-moisture value of $0.1 \mathrm{~cm}^{3} / \mathrm{cm}^{3}$. Above this threshold, the evaporation rate was assumed to be 43 percent of the daily Penman potential evaporation (Shuttleworth, 1993). This value was calculated from isotope-partitioned estimates of midday average soil evaporation $($ mean $=6.3 \mathrm{~mm} / \mathrm{d}$ ) of two wet days relative to the average midday potential ET during the same period $($ mean $=14.4 \mathrm{~mm} / \mathrm{d})$. For days on which soil moisture was below $0.1 \mathrm{~cm}^{3} / \mathrm{cm}^{3}$, evaporation estimated from stable isotopes was 3 percent of potential ET (again estimated from isotope partitioning of ET).

\section{Understory Plant Transpiration}

In order to account for the understory plant transpiration fraction of total ecosystem ET, the understory and overstory measurements of ET with the eddy-covariance technique and independent isotopebased estimates were used (Yepez and others, 2003). During the peak of the growing season when the understory vegetation was fully developed, understory transpiration contributed 14 percent of the potential ET. Late in the growing season when the vegetation started to senesce, understory transpiration was 8 percent of total potential ET.

\section{Mesquite Transpiration}

Weekly average tree transpiration was calculated by subtracting the weekly estimated understory transpiration and soil evaporation from the weekly averaged ET flux.

\section{Mesquite Water Sources}

Natural variation in the abundance of the stable isotopes of hydrogen and oxygen in water were used to partition mesquite transpiration sources into surface soil water (top $1 \mathrm{~m}$ of soil), deep vadose-zone water (unsaturated zone moisture below $1 \mathrm{~m}$ ), and ground water. Efforts were focused on three mesquite sites in the SPRNCA, but the most intensive measurements were made at the Charleston mesquite site. Measurements were made during the growing seasons of 2000, 2001, and 2002.

\section{Site Descriptions}

Mesquite woodlands at three sites (Lewis Springs, Moson, and Charleston mesquite) were selected for study of water source in the SPRNCA (fig. 43). These sites spanned a water-table depth range of 6 to $10 \mathrm{~m}$. Accessibility and the local availability of wells for stable-isotope sampling were important factors in site selection. The soil at the Lewis Springs site was a clay loam in the top $0.5 \mathrm{~m}$ that was underlain by sandy clay loam and loam layers. Soil at the Moson site was a loamy sand in the top $0.50 \mathrm{~m}$ that was underlain by sandy loam to clay loam soils with clay content ranging from 12 to 30 percent. Soil at the Charleston site was a sandy loam in the top $1 \mathrm{~m}$ that was underlain by sandy loam interspersed with clay and silt-clay layers. 


\section{Water Sampling Protocol for Isotopes}

In 2000, stem and soil samples were collected monthly from June through September (premonsoon, early-monsoon, late-monsoon, and post-monsoon). During each collection period 1-2 year old stems from the canopy were taken from 10 trees to make one composite sample. Soil samples were collected from the top $0.5 \mathrm{~m}$ of the soil profile at $0.1-\mathrm{m}$ increments. Each soil sample was a composite of three different cores that were combined by volume at each depth to make one sample per depth. Stem and soil samples were placed in glass vials and the vials were immediately stored in an ice chest to minimize evaporation. Ground-water samples were collected at all sites in August.

In 2001 and 2002, three trees from the Lewis Springs site and three trees from the Moson site were selected randomly from a cohort of trees in the area that were at least $6 \mathrm{~m}$ tall. The same trees were sampled for all collection periods. Seven trees, 3 to $15 \mathrm{~m}$ in height, were selected at the Charleston mesquite site. All were single-stemmed, except the two smallest trees. Soil cores were collected from underneath the canopy and in a gap near the canopy of three trees at each site. The top $0.5 \mathrm{~m}$ of soil was collected in $0.1-\mathrm{m}$ increments. Thirty soil samples were collected at each of the three sites at every sampling period. Ground-water samples were collected from each of the sites during each collection period.

The protocol for stem and soil collection was slightly different in 2002. Each of three soil cores collected on two sample dates (June 16 and August 14) consisted of seven samples at depths of 0-0.1, 0.1-0.2, 0.2-0.3, 0.3-0.4, 0.4-0.5, 0.75 , and $1 \mathrm{~m}$. Ground water was sampled at each site during each collection period. Stems were collected from 10 trees at the Charleston mesquite site. At the Lewis Springs and Moson sites, the same three trees sampled in the summer of 2001 were sampled in 2002.

Deep soil cores were taken at the Lewis Springs, Moson, and Charleston mesquite sites in April 2001 using a truckmounted percussion-driven soil corer. These cores sampled the entire soil profile from the surface through the capillary fringe and spanned as much as $10 \mathrm{~m}$ in depth. Deep soil cores were collected also in July 2002 using a hand auger at the Lewis Springs and Moson sites. Soil samples were collected in 0.3 - to 0.5 - $\mathrm{m}$ increments.

\section{Isotope Analysis}

Water was extracted from soil and plant samples using cryogenic vacuum distillation. Water samples were then analyzed for $\delta^{2} \mathrm{H}$ and $\delta^{18} \mathrm{O}$ on an isotope-ratio mass spectrometer at the Department of Geosciences Stable Isotope Facility at the UA. $\delta^{2} \mathrm{H}$ and $\delta^{18} \mathrm{O}$ from the mesquite stems, ground water, deep vadose zone, and the top $0.5-1.0 \mathrm{~m}$ of soil were used in the source partitioning models. A two-ended linear mixing model (Phillips and Gregg, 2001) was used for all the 2000 data and the 2001-2002 data from the Lewis Springs and Moson sites. A three-ended mixing model was used for the data collected at the Charleston mesquite site in 2001 and 2002. The three-ended mixing model was not used for the Lewis Springs and Moson sites because $\delta^{2} \mathrm{H}$ values from the deep vadose zone and ground water were too similar to distinguish. The soil layer matric potential was used to weight isotopic values for the deep vadose zone and the shallow vadose zone. Data from any soil layer having a matric potential below $-5 \mathrm{mPa}$ were discarded because the water was assumed to be unavailable to mesquite. The fraction of ET drawn from each zone (that is, shallow or deep vadose zone at the Moson and Lewis Springs sites, and shallow vadose, deep vadose, or capillary fringe zone at the Charleston mesquite site) was computed for each set of environmental samples.

\section{Mesquite Shrubland and Sacaton Grassland Evapotranspiration}

ET was measured during 2002 and 2003 using eddy covariance at two locations near the Lewis Springs biohydrology study site in order to quantify the ground-water use of a sacaton grassland and a mesquite shrubland. The grassland was studied to determine if its water use could be a significant component of the SPRNCA water use, and the shrubland was studied to determine if mesquite water use at a site that has smaller and less dense tree cover was similar to that of a mesquite woodland like that at the Charleston mesquite site.

\section{Site Description}

Mesquite-shrubland and sacaton-grassland study sites were established in mid-2002 near the Lewis Springs biohydrology study site. The Lewis Springs site (fig. 43) is about $12 \mathrm{~km}$ east of Sierra Vista, Arizona, at an elevation of about 1,230 $\mathrm{m}$. The instrument tower at the Lewis Springs sacaton study location lies in the center of a low alluvial terrace bordering the San Pedro River. The tower is surrounded by a lush growth of sacaton grass roughly $200 \mathrm{~m}$ to the east and west and 800-1,000 $\mathrm{m}$ to the north and south. The canopy height was about $1 \mathrm{~m}$, and average canopy cover was about 65 percent. The mean depth to ground water in a collocated piezometer was about $2.6 \mathrm{~m}$. The measured PAI averaged $(n=40)$ about 1.0 prior to greenup, about 1.5 during the premonsoon season, and about 2.5 during and after the monsoon season. At the Lewis Springs site, the instrument tower for measuring mesquite shrubland ET lies immediately to the northeast of the sacaton grassland instrument tower. The mesquite shrubland sits on an upper alluvial terrace and surrounds the tower by roughly $500 \mathrm{~m}$ to the east and west, and by $500 \mathrm{~m}$ to the north and south. The mesquite canopy cover was estimated to be 55 percent, and the shrubland had an average tree height of 3-4 $\mathrm{m}$. The depth to ground water was about $7 \mathrm{~m}$, and the overstory PAI ranged from about 0.9 (prior to leaf flush) to 1.2 (during the monsoon). 


\section{Meteorological Instrumentation}

The basic meteorological, soil-moisture, and eddycovariance instrumentation and methods used at the Lewis Springs sacaton grassland and mesquite shrubland sites mirror those used at the Charleston mesquite site. The heights of the eddy-covariance instrumentation were $2.8 \mathrm{~m}$ at the sacaton grassland site and $6.5 \mathrm{~m}$ at the mesquite shrubland site. By using the rationale previously described, both latent and sensible heat fluxes were forced to close the daily energy balance (table 40) while conserving the measured Bowen ratio.

Both instrument towers lie in areas with more heterogeneous vegetation density and less extensive vegetation patches than at the Charleston mesquite site. This potentially complicates the interpretation of the measured fluxes. For this report, fluxes were not filtered with respect to wind speed and direction. Such filtering might have been needed to ensure that the measured fluxes were indeed representative of the vegetation type of interest. Thus, the measurements at these sites were, however, assumed to be representative of the ecosystems of interest. Likewise, for all three eddy-covariance sites, the issue regarding how to interpret the lack of closure has not been resolved within the scientific community. For this study, the guidance of Twine and others (2000; see the "Meteorological Instrumentation" section, "Mesquite Woodland ET" subsection) was followed, and closure was forced on the daily energy balance, thereby increasing the measured daily ET by as much as 23 percent. By doing this, it is implicitly assumed that the measured available energy was more accurate than the measured turbulent heat fluxes; however, this may or may not have been the case.

\section{Cottonwood Transpiration}

Along the San Pedro River, cottonwood trees generally grow in narrow, linear bands parallel to the stream channel, so micrometeorological techniques cannot be used owing to inadequate fetch. Instead, the velocity of rising sap was monitored in individual trees to measure the total water volume carried to the canopy and transpired.

\section{Site Descriptions}

The study locations used for cottonwood sap-flow measurements were at the Boquillas and Lewis Springs biohydrology sites (fig. 43). At each site, a cluster of trees with a distinct and clearly identifiable canopy area was selected, and within each cluster four cottonwood trees were monitored. The Boquillas location represents a cluster of trees that is on an intermittent reach of the river where the average depth to ground water is $3.3 \mathrm{~m}$; the Lewis Springs location represents a cluster of trees on a perennial reach where the average depth to ground water is $1.6 \mathrm{~m}$.

\section{Site Instrumentation}

Sap flow of each tree was measured using thermal dissipation probes (TDP-30 and TDP-80). Thermocouple needles 1.2 and $1.65 \mathrm{~mm}$ in diameter (TDP-30 and TDP-80, respectively) were installed as a vertically aligned pair $4 \mathrm{~cm}$ apart within the sapwood of each tree. The system measures the temperature difference between two needles inserted radially in the xylem, one constantly heated and the other unheated. The heating power is adjusted to 0.15 to $0.2 \mathrm{~W}$ for the TDP-30 and 0.4 to $0.5 \mathrm{~W}$ for the TDP- 80 to achieve a maximum temperature difference of $8-10^{\circ} \mathrm{C}$ under conditions of zero flow. The temperature rise at the upper needle is inversely proportional to the velocity of sap flow, which carries away the heat. The TDP-30 probe monitors a single radial interval at $15 \mathrm{~mm}$ into the xylem, and the TDP- 80 probe monitors two radial intervals at 15 and $70 \mathrm{~mm}$. Sets of these Granier-type probes (Granier, 1987) were implanted on the north and south sides of each tree at $1.75 \mathrm{~m}$ above the ground.

Table 40. Ordinary linear regression coefficients for energy balance closure and mean quantities of the energy-balance components in equation $3\left(R_{\mathrm{n}}-G=\lambda E+H\right)$ at the sacaton grassland and mesquite shrubland locations at the Lewis Springs site in 2003, San Pedro Riparian National Conservation Area, Upper San Pedro Basin, Arizona

[ $n$, sample size; $r^{2}$, goodness of fit; $R_{n}$, net radiation in watts per square meter; $G$, soil heat flux in watts per square meter; $\lambda E$, latent heat flux in watts per square meter; $H$, sensible heat flux in watts per square meter; 30-minute ground-water levels were measured in a piezometer at the site.]

\begin{tabular}{|c|c|c|c|c|c|c|c|}
\hline & $n$ & Slope & Intercept & $r^{2}$ & ${ }^{1} R_{n}-\boldsymbol{G}$ & ${ }^{1} \lambda E+H$ & ${ }^{1} \lambda E+H / R_{n}-G$ \\
\hline Site & \multicolumn{7}{|c|}{ 30-minute values } \\
\hline Lewis Springs sacaton & 12,369 & 0.95 & -27.7 & 0.95 & 162.2 & 125.1 & 0.77 \\
\hline Lewis Springs mesquite & \multicolumn{7}{|c|}{ Daily means ${ }^{2}$} \\
\hline Lewis Springs sacaton & 276 & 0.77 & -2.5 & 0.80 & & & \\
\hline
\end{tabular}

${ }^{1}$ Mean quantities computed only for 30-minute periods when all terms $\left(R_{n}, G, \lambda E, H\right)$ were available.

${ }^{2}$ For days with at least 24 half-hourly values of all energy balance components. 
Sap flow was measured simultaneously on four trees per site from April to November 2003. Plastic putty was installed around the probe's heated and non-heated needles for water protection, and foam quarter-spheres were tightly secured on both sides of the probes to protect the wires from bending stress and to provide thermal insulation to the needles. Reflective bubble wrap was installed around the tree for additional insulation.

The Granier calibration method (Granier, 1985, 1987), valid for various tree species (cut-stem sections), was used to calculate a nondimensional variable $(K)$ as

$$
K=\frac{\left(\partial T_{m}-\partial T\right)}{\partial T}
$$

where

$$
\begin{aligned}
\partial T= & \text { the measured difference in temperature }\left({ }^{\circ} \mathrm{C}\right) \\
& \text { between the heated needle, referenced to the } \\
& \text { lower non-heated needle, and } \\
\partial T_{m}= & \text { the maximum temperature difference during } \\
& \text { each } 24 \text {-hour period between the heated } \\
& \text { needle and the non-heated needle. }
\end{aligned}
$$

The maximum temperature difference typically occurred early in the morning or late at night, and it generally varied each day. A negligible or zero sap flow when $\partial T$ was at a maximum was assumed. Average sap-flux density $\left(V, \mathrm{~cm}^{3} / \mathrm{cm}^{2} \mathrm{~s}\right)$ is calculated (Granier, 1987) as

$$
V=(0.0119) K^{1.231}
$$

Sap-flux density is then converted to a volumetric sap flow $\left(J_{\mathrm{s}} \mathrm{cm}^{3} / \mathrm{h}\right)$ as

$$
J_{o}^{\prime}=\left(A_{s}\right)(V)(3,600)
$$

where

$$
\begin{aligned}
A_{s}= & \text { the sapwood horizontal area }\left(\mathrm{cm}^{2}\right) \text { of the } \\
& \text { instrumented trees, and } 3,600 \text { is the number } \\
& \text { of seconds in an hour. }
\end{aligned}
$$

Other environmental variables were measured in addition to the sap flow. LAI was measured in October 2003 using a plant canopy analyzer. LAI readings were taken from four cardinal directions around the base of each tree within the cluster. Meteorological data were measured at nearby meteorological towers at the Charleston mesquite and Lewis Springs sites. Air temperature, relative humidity, solar radiation, wind speed, air pressure, and precipitation were measured at these locations. Depth to ground water at the Boquillas site was measured manually on a weekly basis at a nearby piezometer. The USGS monitored ground-water levels with pressure transducers in nearby piezometers at the Lewis Springs site.

\section{Scaling}

Cottonwood-stand transpiration $(T, \mathrm{~mm} / \mathrm{d})$ was calculated on the basis of information about individual tree sap flow, total sapwood area, and canopy area of the cluster (Wullschleger and others, 1998). Sapwood area (table 41) was determined from increment cores taken as close as possible to the probe insertions on each side of the tree. Sapwood was identified from heartwood by color change from light to dark. A sapwood area-to-diameter relation was used to estimate the total sapwood area of all the trees in the cluster (Schaeffer and others, 2000). The average tree diameter at breast height (at $1.5 \mathrm{~m}$ ) of all the trees in the clusters was $49 \mathrm{~cm}$ at the Lewis Springs site and $61 \mathrm{~cm}$ at the Boquillas site.

For trees instrumented with TDP-80 probes, sap-flow rate per tree was scaled according to the sapwood area that covers the position of the two thermocouples per probe. The total half-hourly water use for the two thermocouple positions were summed and then divided by the total sapwood area of the tree to get $J$, the average sap-flow rate per unit sapwood area $\left(\mathrm{g} / \mathrm{cm}^{2} \mathrm{~h}\right)$, for each instrumented tree. For the trees instrumented with the TDP-30 probes, there was only one heater/thermocouple depth, and the velocity measured at this depth was assumed constant throughout the entire depth of the sapwood. Values for $J_{s}$ from the north and south side of each tree were averaged to get $\hat{J}_{s} . \hat{J}_{s}$ from each tree was then averaged for all the instrumented trees in the cluster to get, $\bar{J}_{s}$, which was then multiplied with the total sapwood area of all the trees in the cluster to get the total water use $(\mathrm{kg} / \mathrm{d})$. Total water use of the entire cottonwood stand was divided by the canopy area $\left(\mathrm{m}^{2}\right)$ to determine total water loss or transpiration of the entire stand, $T\left(\mathrm{~kg} / \mathrm{m}^{2} \mathrm{~d}\right.$ or $\left.\mathrm{mm} / \mathrm{d}\right)$. The projected canopy area of the tree clusters was estimated digitally by using aerial photographs.

Table 41. Structural characteristics of cottonwood clusters at the Lewis Springs and Boquillas sites, San Pedro Riparian National Conservation Area, Upper San Pedro Basin, Arizona

[m², square meters; $\mathrm{cm}^{2}$, square centimeters; $A_{L}$, total cluster canopy area; $A_{S}$, cluster sapwood area]

\begin{tabular}{lcccc}
\hline \multicolumn{1}{c}{ Site } & Number of stems & $\begin{array}{c}\text { Canopy area } \\
\left(\mathbf{m}^{2}\right)\end{array}$ & $\begin{array}{c}\text { Sapwood area } \\
\left(\mathbf{c m}^{2}\right)\end{array}$ & $\begin{array}{c}{ }^{2} \boldsymbol{A}_{L}: \boldsymbol{A}_{\boldsymbol{s}} \\
\left(\mathbf{m}^{2} / \mathbf{c m}^{2}\right)\end{array}$ \\
\hline Lewis Springs & 9 & 421 & 7,175 & $0.31 \pm 0.04$ \\
Boquillas & 10 & 1,037 & 12,232 & $0.21 \pm 0.02$ \\
\hline
\end{tabular}

${ }^{1}$ Canopy area refers to the planar area of the canopy as determined from aerial photographs.

${ }^{2}$ Mean $+/$ - standard error of the canopy area/sapwood area ratio for measured trees within the cluster. 


\section{Seepwillow Transpiration and Open-Water Evaporation}

Seepwillow transpiration and open-water evaporation were measured at the Lewis Springs study site (fig. 43). At this site, the river is divided into primary and secondary channels. The secondary channel conveys flow only when stream stage is elevated above base flow. Along the primary and secondary channels of the river, cottonwood and Goodding willow (Salix gooddingii) are the main overstory species and seepwillow is the dominant understory species. The broad flood plain between the primary and secondary channels is covered primarily with Johnson grass (Sorghum halepense), sacaton grass, and has sparse patches of cottonwood trees and seepwillow shrubs. During the 2002 and 2003 measurement periods, several flood events inundated the site. The depth to ground water in a nearby piezometer ranged from 1 to $1.6 \mathrm{~m}$ during the measurement periods.

\section{Sapflow Study}

Two patches of seepwillow shrubs were selected for this study. One patch was more sheltered by cottonwood canopy, and the other adjacent patch was in a more open area with no overstory vegetation directly overhead. Transpiration was estimated by using the stem heat-balance sap-flow technique (Sakuratani, 1981), which works better for the small stems of shrubs than the technique used for cottonwood. In this approach, stem sap flow is determined by application of a constant external heat source to the shrub stem while measuring the axial and radial heat losses from the stem. The amount of heat lost caused by convection, and transport of heat with the movement of sap, can be calculated.

The sap-flow sensor consists of three basic components (fig. 44): (1) heater wires wrapped around a section of the plant stem; (2) three differentially wired thermocouples, with the reference thermocouple at the center of the heat source, and the remaining thermocouples $15 \mathrm{~mm}$ upstream and downstream from the heat source to measure axial heat loss; and (3) a thermopile wrapped around the stem at the heat source to measure radial heat loss. Sensors were insulated with two layers of foam insulation material and one layer of insulating foam with reflective backing (not shown in figure 44) to reduce any influence of thermal perturbations from the surrounding climate conditions. All sap-flow sensors were monitored with a datalogger powered by a 12-volt battery. Data were logged every 30 minutes for all sensors and were collected every $7-10$ days by using a laptop personal computer.

The following equations are applied to the raw data to separate the heat inputs and calculate stem sap flow:

$$
Q_{H}=Q_{f}+Q_{u p}+Q_{d n}+Q_{r a d},
$$

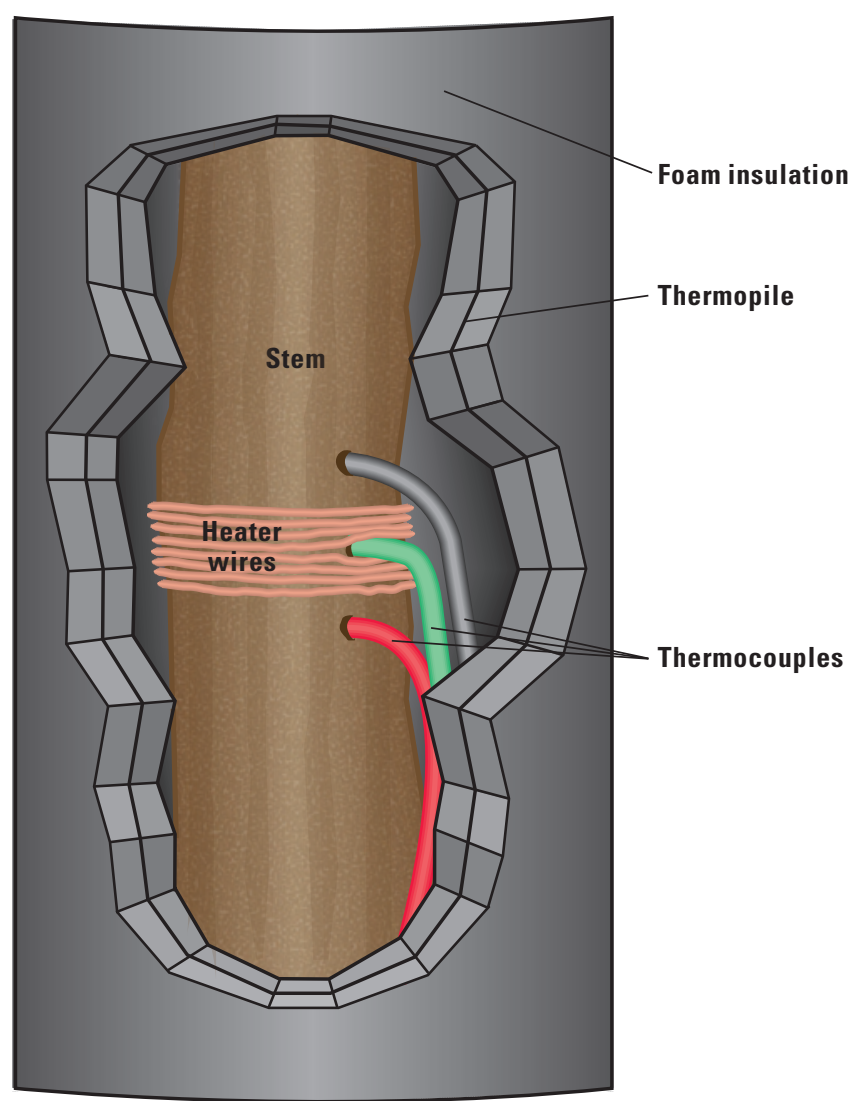

Figure 44. Sap-flow sensor unit used for the heat balance method, San Pedro Riparian National Conservation Area, Upper San Pedro Basin, Arizona.

where

$$
\begin{aligned}
Q_{H}= & \text { heat input, } \\
Q_{f}= & \text { the convective heat carried by sap flow, } \\
Q_{u p} \text { and } Q_{d n}= & \text { the heat conducted upstream and downstream } \\
& \text { through the plant stem, and } \\
Q_{r a d}= & \text { radial heat loss away from the stem and heat } \\
& \text { source. Units for all these components } \\
& \text { are } \mathrm{J} / \mathrm{s} .
\end{aligned}
$$

The heat input is a function of the electrical characteristics of the heater. The radial and conductive losses can be calculated from the relevant temperature differences, thermal conductivities, and geometry (Sakuratani, 1981).

Convective heat carried by sap flow $\left(Q_{f}\right)$ can then be determined by rearranging the elements of equation 9 :

$$
Q_{f}=Q_{H}-Q_{u p}-Q_{d n}-Q_{r a d},
$$

The convective heat loss through sap flow $\left(Q_{f}\right)$ is then converted into an equivalent mass flow $(S, \mathrm{~g} / \mathrm{h})$ :

$$
S=3,600 Q_{f} / 4.19 \delta T_{u p-d n},
$$


where 4.19 is the specific heat of liquid water $\left(\mathrm{J} / \mathrm{g}{ }^{\circ} \mathrm{C}\right)$, 3,600 is the number of seconds in 1 hour, and $\delta T_{u p-d n}$ refers to the difference in temperature between upstream and downstream thermocouples.

Eight stems were monitored in each patch. The diameters of all the shrub stems within each patch were measured, and stem areas were calculated. The total sap flow for each patch was calculated by taking the average sap flow of the instrumented stems divided by the cross-sectional area of the stems, and then multiplying this average by the total stem area of the patch. Finally, the transpiration rate was computed by dividing the total sap flow by the area of the seepwillow patch.

\section{Pan-Evaporation Study}

An open-water evaporation study was done to estimate the amount of evaporation that occurs directly from the river. Twelve 8-inch square aluminum pans and 12 standard rain gages were used in the open-water evaporation study. Both pans and gages were placed along the river edge, within primary and secondary channels and within the flood plain area in order to better quantify the variability and magnitude of evaporation. Each pan was filled with water and set into the soil so that the rim was level with the ground surface. Both the placement and the size of the pans were chosen so as to minimize "oasis-effects" that can occur with pan-evaporation studies. This study was done during a 6-day period (June 25 to July 2, 2003) during the premonsoon season. At the onset of the study, each pan was filled with $700 \mathrm{~mL}$ of water, forming a pool about $17 \mathrm{~mm}$ deep. The volume of water in each pan was measured every 24 hours by using a graduated cylinder. The pan was then refilled to $700 \mathrm{~mL}$. Rain gages were monitored each day of the measurement period. The volume of water evaporated from each pan was divided by the surface area of the pan and the amount of time elapsed between measurements to compute an evaporation rate. The mean evaporation rate was compared to a standardized reference evaporation, ET, which was computed using the Arizona Meteorological Network (AZMET) standard (Brown, 1989; http://ag.arizona.edu/azmet/et2.htm) and meteorological data from the nearby Lewis Springs meteorological site (appendix 8).

\section{Determining Total SPRNCA Water Use}

Goodrich, Scott, and others (2000) calculated the most recent estimates of riparian ground-water use along the San Pedro River using estimates of vegetation area derived from a 1997 pixel-based vegetation classification (hereinafter referred to as VEG97). In the VEG97 map, each $3 \times 3-\mathrm{m}$ pixel is classified as a particular vegetation cover. From aerial photographs taken in 2000 and field data collected in 2001, the U.S. Army Corps of Engineers (2001) produced a new polygon-based, geographic information system (GIS) vegetation cover map (hereafter referred to as VEG00) for which continuous stands of vegetation were delineated and given various attributes, such as vegetation alliance, polygon area, total area of vegetation cover, and area of dominant vegetation cover. It includes 33 different vegetation communities, open water, and urban lands (see fig. 45 as an example).

Because of several differences between the two maps, various GIS manipulations were done so that the VEG00 map could be used for water-use analysis. The extent of the VEG00 map matched the boundaries of the SPRNCA, whereas the VEG97 map was created for the San Pedro River riparian corridor from Palominas to north of St. David (see Goodrich, Scott, and others, 2000). The VEG00 map was first clipped to the same extent as the VEG97 map. Since the VEG97 map did not cover the entire SPRNCA, the riparian corridor outline for the VEG00 map was extended with the use of a 1 x 1-m pixel digital elevation model (unpublished data) derived from Light Detection and Ranging (LiDAR) data collected in 2003, aerial photographs, and the vegetation classes in the map itself.

An additional vegetation analysis was conducted to delineate the riparian area that was within $3 \mathrm{~m}$ of the river bottom (thalweg) or stage, whichever was highest. Standard ArcInfo GIS functions were used with the 1-m digital elevation model to determine the minimum elevation of the river for each east-west row of grid cells along the entire river length within the SPRNCA. This information was then used to identify all grid cells within $3 \mathrm{~m}$ above the river bottom (or stages). The river trended east-west and intersected a row more than once. In those instances manual interpretation was used to identify cells within the $3 \mathrm{~m}$ of the river bottom or stage elevation.

The conversion from a pixel-based to a polygon-based coverage made the task of computing total vegetation areas for the relevant land-cover types more difficult. For the VEG00 map, both the polygon area and the percentage of area covered by the vegetation of interest were needed to estimate the total area of ground-water-using vegetation. The VEG00 map has five ranges for basic classification of the vegetation percent cover: $1-10,11-25,26-60,61-80$, and $81-100$ percent. These ranges are quite coarse for calculating the total area covered by a specific vegetation type, and the use of these ranges adds uncertainty to the new estimates of vegetation ground-water use. The VEG00 map, however, provides the estimated vegetation cover to the nearest 5 percent for the mesquite or cottonwood-willow polygons, classified as woodland or forest. These woodland or forest polygons are defined as patches dominated by mesquite or cottonwood-willow polygons with greater than 60 percent cover.

Unfortunately, there are still many polygons not classified as woodland or forest that contain vegetation that uses ground water (for example, mesquite areas with less than 60 percent cover or sacaton grasslands). This uncertainty was incorporated into the new SPRNCA water-use estimates by computing a range (minimum to maximum amount) of area for each functional vegetation group. Then, the total vegetation area was calculated by summing up, over all polygons of a certain plant functional group, the product of the polygon area and the minimum, median, and maximum percent cover. If the more accurate cover data (to the nearest 5 percent) were available, then they were used instead. 


\section{A. Pixel-based VEG97 map}

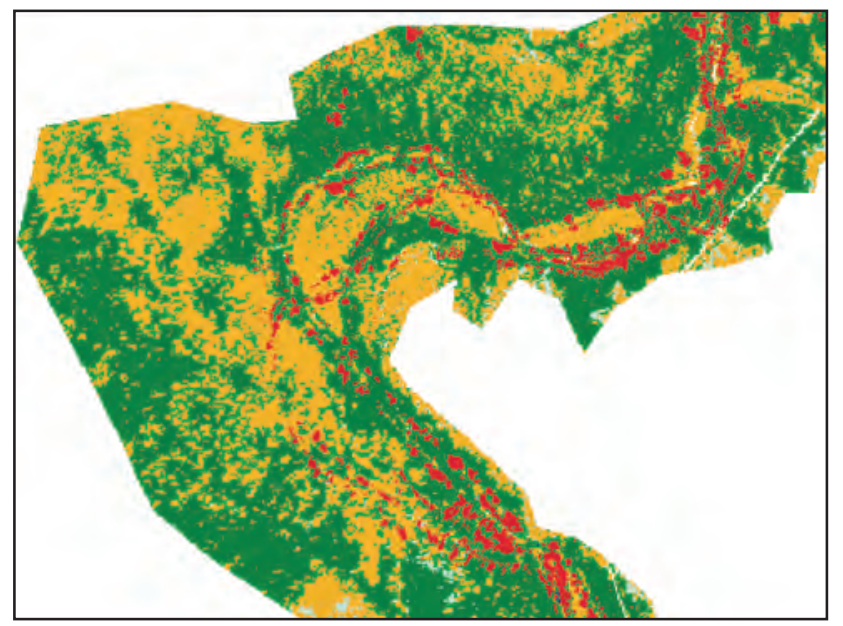

B. Polygon-based VEGOO map

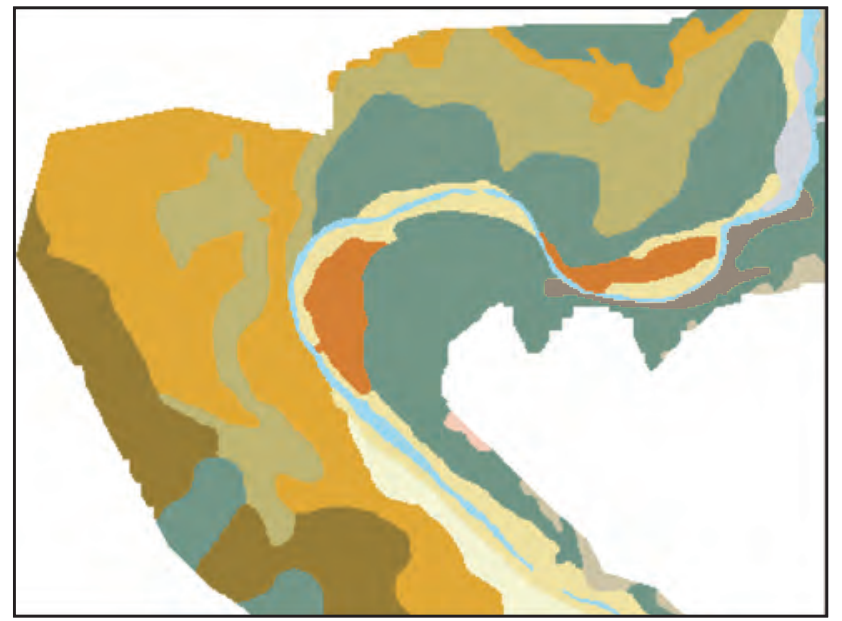

\section{EXPLANATION}

\begin{tabular}{|l|l|}
\hline BARE EARTH & LOW DENSITY \\
COTTONWOOD/ & MESOUITE \\
WILLOW & SACATON \\
\hline HIGH DENSITY & SCRUB \\
MESOUITE & WATER \\
\hline
\end{tabular}

\section{EXPLANATION}

\begin{tabular}{|l|l|}
\hline BARREN & MESOUITE/SHRUB \\
\hline COTTONWOOD & MIXED GRASS-SCRUB \\
COTTONWOOD WITH & RABBITBRUSH \\
SCRUB & SACATON \\
\hline MESQUITE WITH GRASS & WHITETHORN \\
MESQUITE/SACATON & WATER \\
\hline MESQUITE & \\
\hline
\end{tabular}

Figure 45. The vegetation distribution for an example reach of the San Pedro Riparian National Conservation Area near Boquillas, Upper San Pedro Basin, Arizona. A, Pixel-based VEG97 map; $B$, Polygon-based VEG00 map.

\section{Ecosystem Water-Use Results}

\section{Mesquite Woodland}

The USDA-ARS monitored ET fluxes at the Charleston mesquite site during the 2001, 2002 and 2003 growing seasons, along with precipitation, soil moisture, groundwater levels, and other variables. All three growing seasons were preceded by winters with little precipitation (fig. 46). The winter prior to the 2001 growing season was also quite dry, yet there was still a lot of carryover soil moisture from the large amount of rainfall in October 2000.

\section{Mesquite Woodland Water Use}

Continuous monitoring of the ground-water levels and the ecosystem ET indicated that the mesquites were using ground water. The spring 2002 greenup provides one of the many examples of evidence for this (fig. 47).

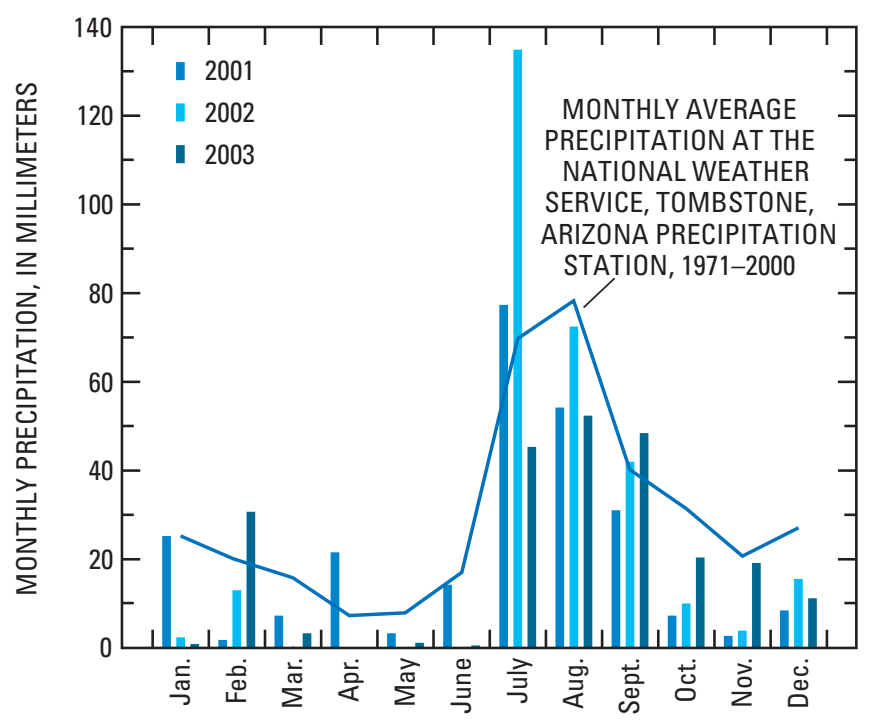

Figure 46. Total monthly precipitation during 2001-03 at the Charleston mesquite site, San Pedro Riparian National Conservation Area, Upper San Pedro Basin, Arizona. 
Winter and spring of 2002 were dry; thus, surface soils were dry. Despite this drought, the trees leafed out and began to take up carbon dioxide [net ecosystem exchange of carbon dioxide (NEE)] and lose water vapor in mid-May (Scott and others, 2004). At the same time, ground-water levels began to drop and a regular pattern of diurnal ground-water fluctuation (ground water was closer to the surface in the early morning and farther from the surface at sundown) became established, providing clear evidence of a direct link between tree water use and ground-water fluctuations. This pattern of diurnal ground-water fluctuations caused by mesquite uptake continued throughout most of growing season, but the diurnal fluctuations ceased during brief monsoon periods when surface soils were wet (see next discussion). More information about the source of water for the trees is presented in the following sections.

Measured mid-canopy air temperature data indicates that the last freezes of spring occurred on May 6, 2001; May 22, 2002; and May 11, 2003. The first freezes of fall occurred on October 13, 2001; October 4, 2002; and October 27, 2003. These freeze events effectively constrained the mesquite growing season and, hence, much of vegetation water use in the riparian corridor. The mesquite trees leafed out in the spring around the time of the last spring freeze. Leaf-out was followed by a substantial increase in ET, beginning around mid-May of both years [day of year (DOY) 130-145; fig. 48]. Conversely, ET dropped quickly in the fall as the mesquite trees began to enter dormancy in late October (about DOY 290). The freeze intolerance of mesquite is consistent with a previous study of mesquite by Scott and others (2004). Temperatures in the riparian corridor were commonly quite different from those measured on the valley floor (appendix 8). Although maximum daytime temperatures were similar, minimum nightly temperatures generally were $5-10^{\circ} \mathrm{C}$ lower in the riparian corridor than on the valley floor, except in the more humid monsoon season when the difference was less. Because the water use of the mesquite trees (and likely other riparian tree species) was constrained to the frost-free period (typically about 150 days), models of riparian ET will require air-temperature data collected from within the riparian corridor, or at least estimates derived from a known relation between temperature in the riparian corridor and that measured elsewhere.

\section{A. Ground-water depth}

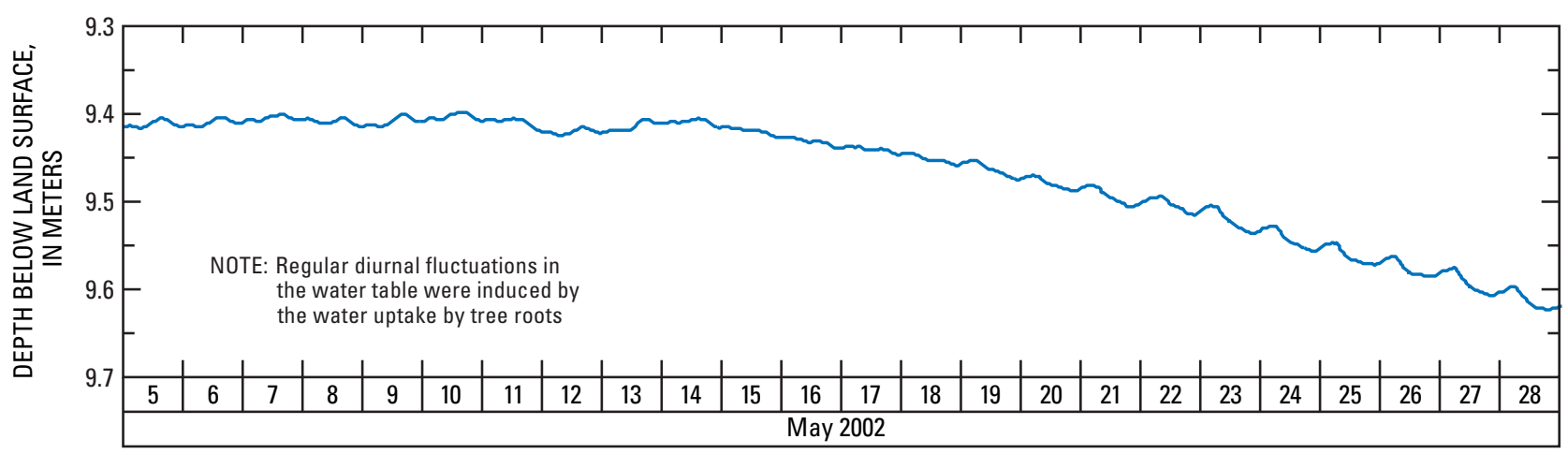

$B$. Average daytime NEE and daily evapotranspiration

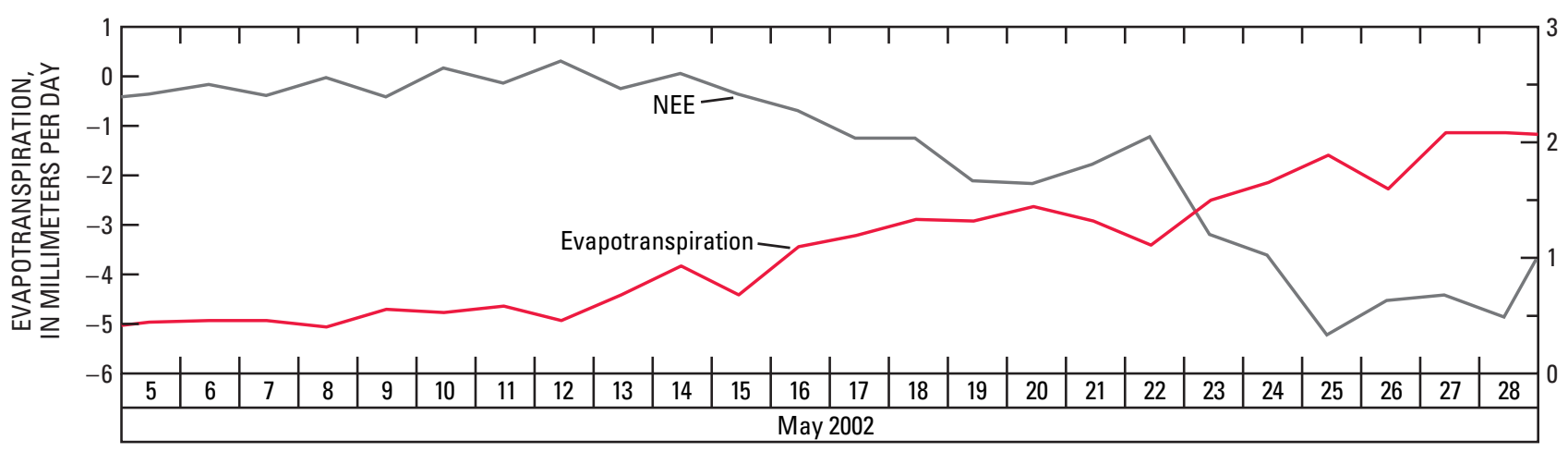

Figure 47. Data indicating ground-water use by mesquite at the Charleston mesquite site, San Pedro Riparian National Conservation Area, Upper San Pedro Basin, Arizona, May 2002. A, Ground-water depth below land surface; $B$, Average daytime net ecosystem exchange of carbon dioxide (NEE), and daily average evapotranspiration. 


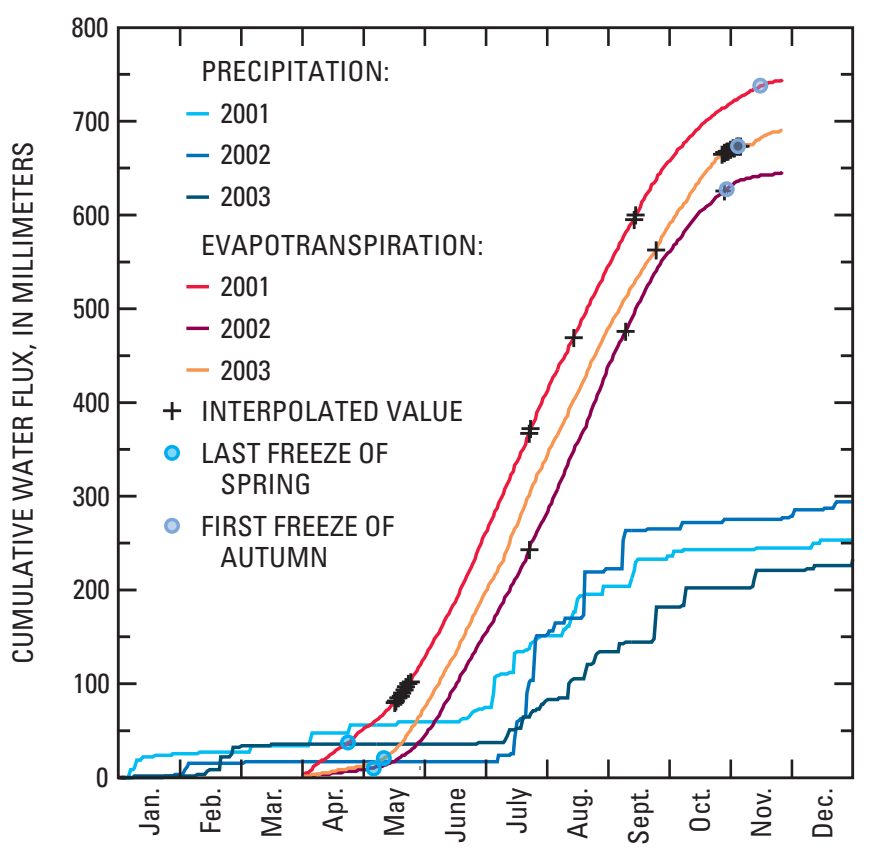

NOTE: Only evapotranspiration data from April 9 to 0 ctober 28 of each year are shown, because 2001 data were limited to this time period

Figure 48. Cumulative fluxes of precipitation and evapotranspiration for 2001, 2002, and 2003 at the Charleston mesquite site, San Pedro Riparian National Conservation Area, Upper San Pedro Basin, Arizona.

In this semiarid environment, the availability of nearsurface soil moisture for understory plants is closely linked with recent rainfall (fig. 49A). Not surprisingly, it takes longer for the near-surface soil profile to dry after winter rainfall owing to the lack of plant uptake and decreased evaporative demand. In 2001, the effect of precipitation was rarely seen at $50 \mathrm{~cm}$ depth, indicating that there was little deep infiltration during much of the year, and that most summer precipitation was either quickly evaporated or transpired. After the larger storms of the 2002 summer monsoon season, however, moisture moved farther down the soil profile, past $50 \mathrm{~cm}$ depth. Even then there was only a 2 percent increase in soil moisture at $100 \mathrm{~cm}$ depth (not shown on fig. 49). Infiltration in 2003 was similar to that in 2002 though the wetting of the near-surface soils was shallower owing to less intense monsoon rains. The entire root-zone profile was substantially wetter in the spring of 2001, probably because there were anomalous rains totaling $125 \mathrm{~mm}$ in October 2000. The origin of this soil moisture is not certain because soil-moisture probes were not installed until March 2001. Annual precipitation totals were $253 \mathrm{~mm}$ in 2001, $293 \mathrm{~mm}$ in 2002, and $232 \mathrm{~mm}$ in 2003, whereas the monsoon rainfall-the cumulative total between the mid-summer onset of precipitation and the end of September-was $177 \mathrm{~mm}$ in 2001, $248 \mathrm{~mm}$ in 2002, and
$146 \mathrm{~mm}$ in 2003. All the study years had below-average precipitation, but the typical premonsoon "drought" was especially long and severe in 2002 (fig. 46 and chapter A).

The depth to ground water fluctuated in response both to local and more regional forcing (fig. 49B). Data collected in all years showed the influence of mesquite activity on groundwater depth. Depths increased and regular diurnal fluctuations began in mid-May in response to mesquite leaf flush; waterlevels recovered and diurnal fluctuations ceased after mesquite became dormant (about late October). The diurnal fluctuations were more muted in 2003 probably because a layer of film that developed on the pressure transducer reduced its sensitivity. The summer monsoon (about July-September) had a complex influence on the water levels. During this time, it is likely that water levels in site piezometers responded both to large floods in the nearby river channel and to the mesquite supplementing water uptake with lateral surface roots when and where surface water and nutrients were available.

Although much of the variability of total ET can be attributed to different starting and ending times for the growing season, monsoon rainfall and antecedent soil moisture conditions also appeared to influence ecosystem water use. In 2001, ET was substantially higher before mesquite leaf-out than after leaf-out owing to understory ET (mainly sacaton transpiration) that was fueled by higher, soil moisture at a $30 \mathrm{~cm}$ depth (figs. 50 and 49) The premonsoon dry period was considerably shorter owing to an early arrival of monsoon rains. Because of dry winters prior to 2002 and 2003, ET was low prior to mesquite leaf-out (DOY 130). After mesquite leaf-out, there was a considerably faster increase in ET and higher premonsoon ET in 2003 relative to 2002. The trees in 2002 appeared to be more drought stressed or possibly damaged by a late frost, resulting in the lowest seasonal ET of the study-despite the fact that the trees had access to ground water and the near-surface soil moisture was nearly identical to that in 2003 .

The more stressed condition of the trees in 2002 was probably a result of drier meteorological conditions (higher vapor-pressure deficits and temperatures, little winter and spring precipitation). Scott and others (2004) have shown that the trees at this site regulate their stomata in response to the high vapor-pressure deficits found during the premonsoon period; the stomata regulation results in decreased ET.

Additionally, the stressed condition could have been caused by unknown consequences of the mesquite trees' hydraulic redistribution of previous rainfall. Hultine and others (2004) discovered that mesquite at this site have the ability to redistribute near-surface soil moisture to the deeper vadose zone throughout the entire year (fig. 51). Measured sap flow in a mesquite tap root was upward before the monsoon onset even at night, and this water was distributed outward from the tree through lateral, surface roots. The situation was reversed when the surface soil was moist, and water in the lateral roots moved toward the stem and then downward in the tap root towards the water table. 


\section{A. Daily precipitation and volumetric soil moisture}

DAY OF YEAR

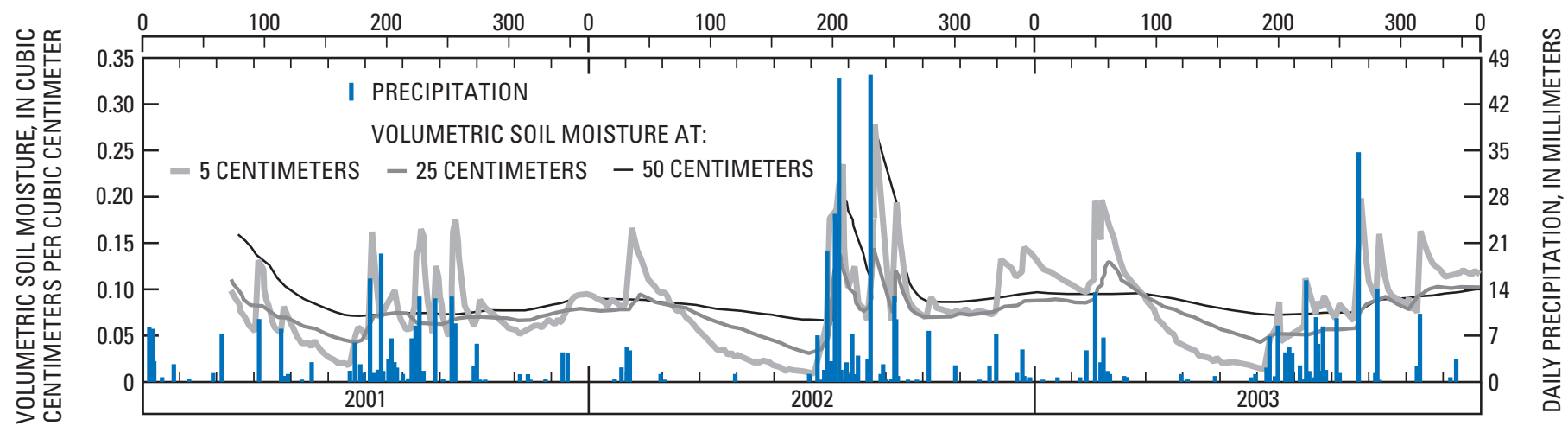

B. Ground-water depth

DAY OF YEAR

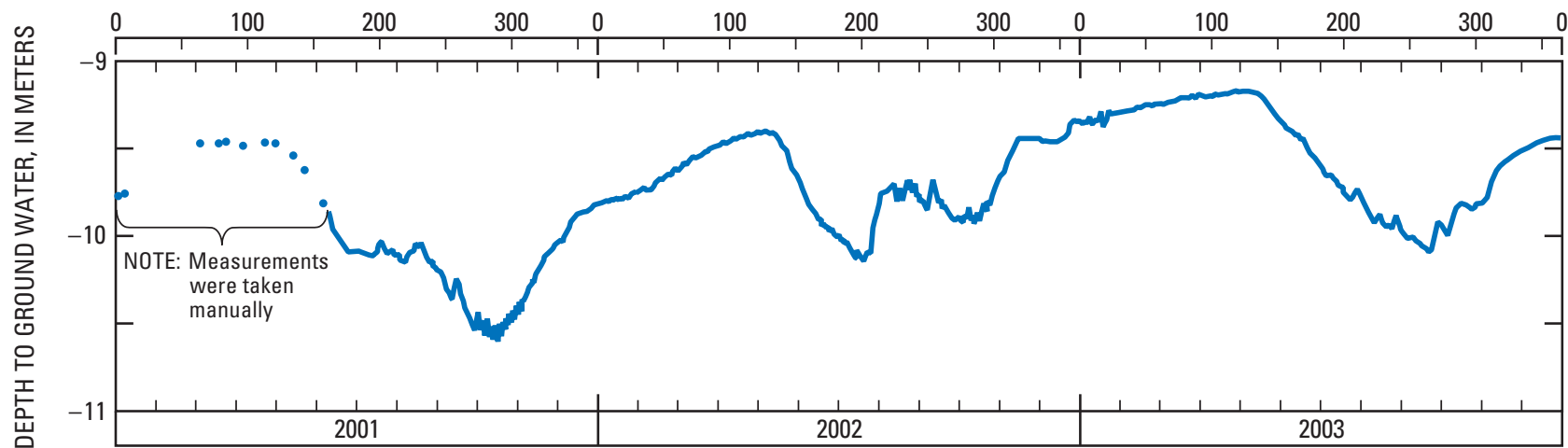

Figure 49. Availability of near-surface soil moisture at the Charleston mesquite site, San Pedro Riparian National Conservation Area, Upper San Pedro Basin, Arizona. A, Daily precipitation and volumetric soil moisture at 5 centimeters, 25 centimeters, and 50 centimeters below land surface; $B$, Ground-water depth below land surface.

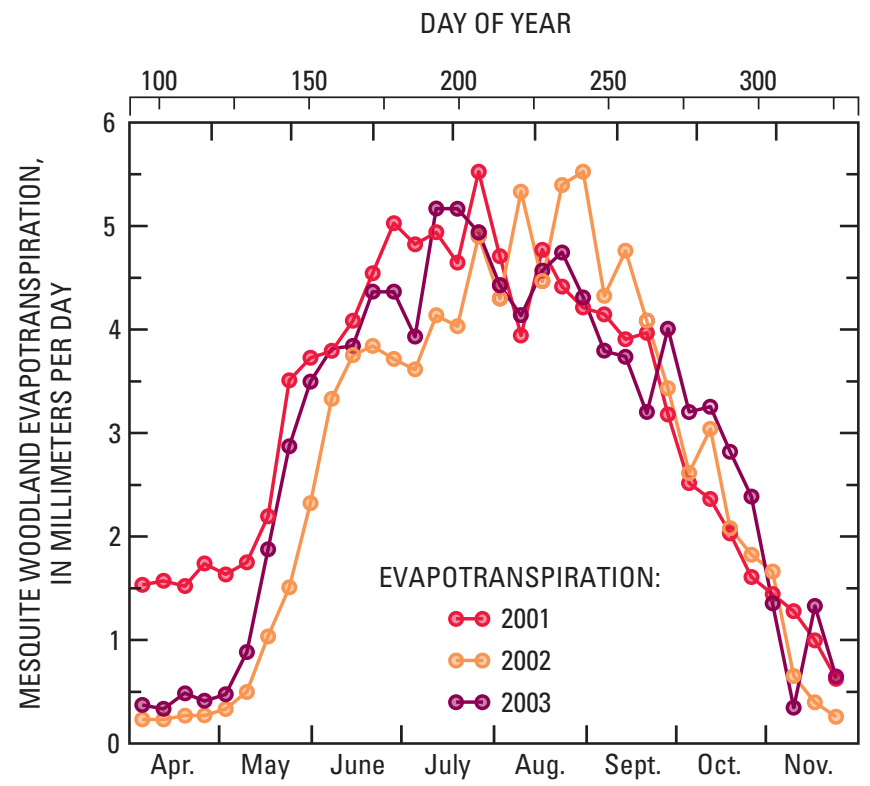

Figure 50. Average weekly woodland evapotranspiration for 2001, 2002, and 2003 at the Charleston mesquite site, San Pedro Riparian National Conservation Area, Upper San Pedro Basin, Arizona. 
A. Total nocturnal sap flow

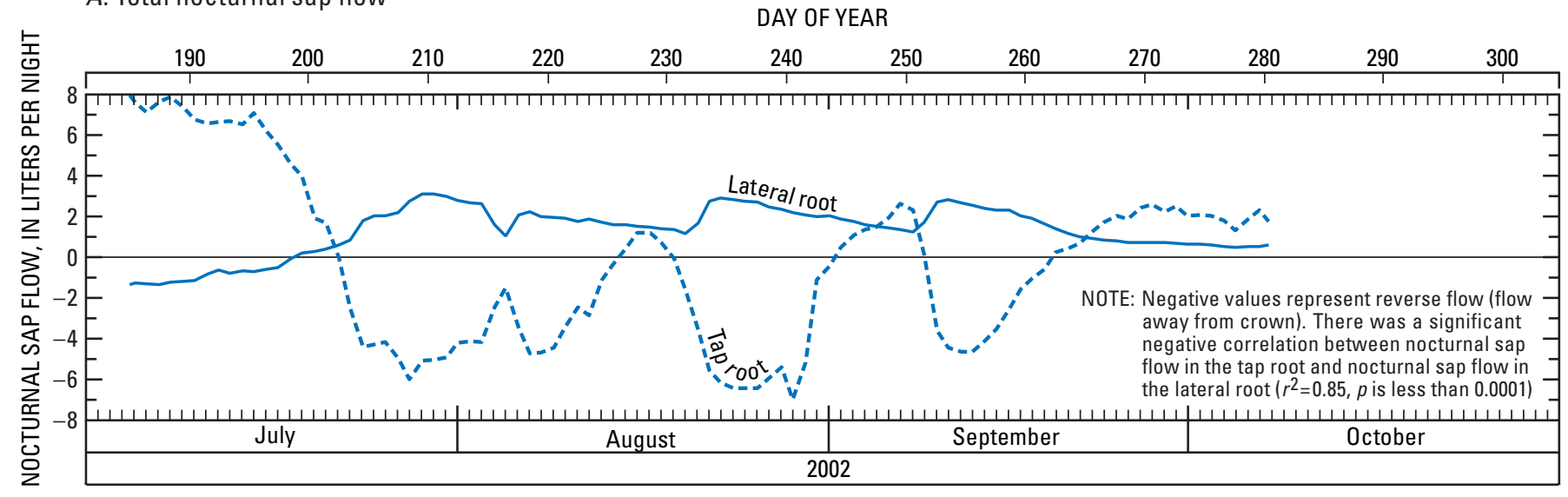

B. Daily precipitation

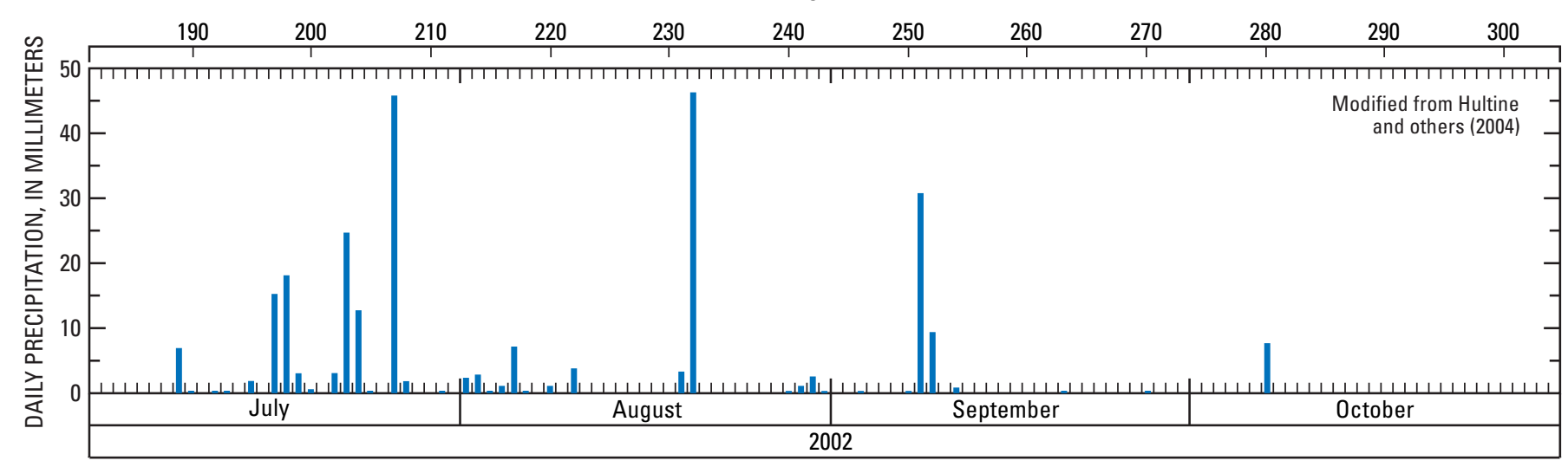

Figure 51. Evidence of the ability of mesquite roots to redistribute soil moisture at the Charleston mesquite site, San Pedro Riparian National Conservation Area, Upper San Pedro Basin, Arizona. A, Total nocturnal sap flow of the taproot and a lateral root of a mesquite tree at the Charleston mesquite site calculated from half-hourly measurements between 8 p.m. and 5:30 p.m.; $B$, Daily precipitation totals at the field site during the study.

Moisture redistribution followed the moisture-potential gradient with upward "lifting" of deep vadose-zone moisture or ground water during the dry season and downward descent of precipitation during times of abundant surface moisture. The antecedent monsoon and winter rains prior to the 2003 growing season were more abundant in 2002, indicating that more of this moisture can have been redistributed to deeper layers in the vadose zone, that later improved mesquite functioning during the premonsoon drought period.

The water-balance equation can be used to estimate the entire growing season ground-water use from ET measurements:

$$
Q_{t}=E T-(P-\Delta S)
$$

where

$$
\begin{aligned}
Q_{t}= & \text { ground-water use } \\
\text { ET }= & \text { evapotranspiration } \\
P= & \text { precipitation, and } \\
\Delta \mathrm{S}= & \text { the change of soil moisture in the top } 1 \mathrm{~m} \\
& \text { of soil. }
\end{aligned}
$$

At the Charleston mesquite site, runoff was negligible and only small changes were assumed to occur in soil moisture deeper than $1 \mathrm{~m}$. $Q_{t}$, if positive, is the ET in excess of precipitation and change in soil-moisture storage. All of the excess moisture was assumed to be derived from ground water. The discovery of the ability of mesquite to redistribute water in the vadose zone (Hultine and others, 2004) makes this an overly simplistic view, but there were no methods for computing the change in storage in the deep $(>1 \mathrm{~m}$ below the surface) vadose zone. The amount of ground water used per unit crown area of mesquite, $Q_{v e g}$, rather than per unit ecosystem area, was computed by dividing $Q_{t}$ by the percent cover of mesquite found at the site.

The water-balance components (table 42) calculated as part of this study for the Charleston mesquite site (for 2001, 2002, and 2003) by using the Bowen ratio energybalance method for the Lewis Springs site (for 1997; Scott, Shuttleworth, and others, 2000) illustrate differences between the two sites. Goodrich, Scott, and others (2000) used the 1997 measurements for their consumptive-use estimates. 
Table 42. Water balance for the mesquite growing season (May 1-November 27) at the Lewis Springs and Charleston mesquite sites, San Pedro Riparian National Conservation Area, Upper San Pedro Basin, Arizona

[Values computed by using equation 12 (see text): $Q_{t}=\mathrm{ET}-(P-\Delta S)$ ]

\begin{tabular}{|c|c|c|c|c|c|}
\hline \multirow[b]{4}{*}{$\begin{array}{l}\text { Water-use terms and } \\
\text { site characteristics }\end{array}$} & \multicolumn{5}{|c|}{ Year } \\
\hline & \multicolumn{2}{|c|}{1997} & 2001 & 2002 & 2003 \\
\hline & \multicolumn{5}{|c|}{ Site name } \\
\hline & \multicolumn{2}{|c|}{$\begin{array}{c}\text { Lewis Springs } \\
\text { site }\end{array}$} & \multicolumn{3}{|c|}{$\begin{array}{c}\text { Charleston } \\
\text { mesquite site }\end{array}$} \\
\hline $\begin{array}{l}\text { Evapotranspiration (ET), } \\
\text { in millimeters }\end{array}$ & 330 & 330 & 694 & 638 & 676 \\
\hline $\begin{array}{l}\text { Precipitation excess }(P-\Delta S) \text {, } \\
\text { in millimeters }\end{array}$ & 173 & 173 & 206 & 244 & 166 \\
\hline $\begin{array}{l}\text { Ground-water use per unit } \\
\text { ground area }\left(Q_{t}\right), \\
\text { in millimeters }\end{array}$ & 157 & 157 & 488 & 394 & 510 \\
\hline $\begin{array}{l}\text { Canopy cover fraction of } \\
\text { dominant vegetation type }\end{array}$ & .50 & .32 & .74 & .74 & .74 \\
\hline $\begin{array}{l}\text { Ground-water use per unit } \\
\text { vegetation area }\left(Q_{\text {veg }}\right) \text {, } \\
\text { in millimeters }\end{array}$ & 314 & 491 & 659 & 532 & 689 \\
\hline
\end{tabular}

The areal coverages of mesquite at the compared sites are estimated to be 50 percent (Scott, Shuttleworth, and others, 2000) and 74 percent for 1997 and 2001-03, respectively. Although the 1997 measurements were taken at a site that was considerably less dense (Lewis Springs), this difference was not sufficient to explain the much greater ground-water use at the woodland (Charleston mesquite) site in 2001-03. The site measured in 2001-03 had much larger and more mature trees. The trees at the 1997 site, being less developed, may have been less adept at tapping the deep ground-water source. The water-table depth at both sites was about $10 \mathrm{~m}$. An alternative explanation of the difference in mesquite ground-water use between the 1997 (Lewis Springs) and 2001-03 (Charleston mesquite) sites is that the dense canopy area at the 1997 site was likely smaller in extent then the fetch of the measurements. As a result, the measurements may have been biased by zones of lower density mesquite cover. Overestimation of the canopy cover leads to a decreased $Q_{\text {veg }}$. The mesquite canopy cover at the 1997 shrubland site was estimated to be 32 percent. This cover was calculated by using analysis of (previously unavailable) high-resolution aerial photography and the same methods used in this study for determining the canopy percentage within $100 \mathrm{~m}$ of the flux measurement towers at the other sites. This analysis yields a $Q_{\text {veg }}$ of $491 \mathrm{~mm}$, a quantity, considering year-to-year variability, more in line with the current study. The value also is consistent with the results for a similar, nearby mesquite shrubland (see the "Mesquite Shrubland and Sacaton Grassland" section).
The new 2001-03 mesquite measurements indicate that the mesquite ground-water use varied considerably from year to year. In 2002, the first two months of the growing season, prior to the onset of the monsoon rains, were drier and hotter than in 2001 and 2003. The trees showed considerably more stress (Scott and others, 2004), and used less groundwater. The monsoon rainfall in 2002 was greater than that in 2001 and 2003, and likely offset some of the mesquite ground-water use.

In the "Mesquite Shrubland and Sacaton Grassland" section, the functioning of this mature mesquite woodland site is compared with a less-dense and smaller mesquite shrubland site to determine how representative these measurements might be of other mesquite ecosystems along the San Pedro River.

\section{Mesquite-Woodland Evapotranspiration Partitioning}

The nearly continuous overstory eddy-covariance measurements (see results in the previous section) were supplemented periodically throughout the 2001 and 2002 growing seasons with understory eddy-covariance measurements and isotope sampling to partition total ET into understory ET, soil evaporation, and understory transpiration. From these measurements, relations were developed to partition ET for 2001 through 2003.

\section{Using Micrometeorological Techniques}

The understory/overstory ET data collected in 2001 and 2002 reveal that overstory water use was nearly constant during the premonsoon to monsoon periods (fig. 52; see Scott and others, 2003, for details). The overstory ET can be interpreted as being mainly tree transpiration throughout most of the days of the study; however, rainfall did occur on DOY 208, 257, and 258 of 2001 that would have resulted in a significant amount of evaporation from the tree canopy surface. The difference in total ecosystem water use throughout the growing season was principally caused by changes in the understory ET, whereas the overstory water use did not appear to increase despite the changes in near-surface soil moisture (fig. 49). The trees certainly had access to a source of deeper vadose-zone water during the 2001-03 premonsoon periods, and the tree transpiration did not increase when near-surface soil moisture increased in the monsoon season (fig. 49). The eddy-covariance estimates of tree transpiration compared favorably with estimates of tree transpiration calculated by using diurnal water-table fluctuations $\left(T_{\text {well }}\right)$, except for during the monsoon season of 2002 when river floodflows may have invalidated the assumptions of the water-table fluctuation techniques. The aquifer-storage coefficient to compute $T_{\text {well }}$ was estimated by dividing the average of the diurnal water-table fluctuation [the quantity $(24 r \pm s)$ in equation 4 ] by the tree transpiration estimated from the eddy-covariance approach. The agreement between the two transpiration estimates changed little from the premonsoon to the monsoon periods; thus, the main water source for the mesquites likely remained ground water. 


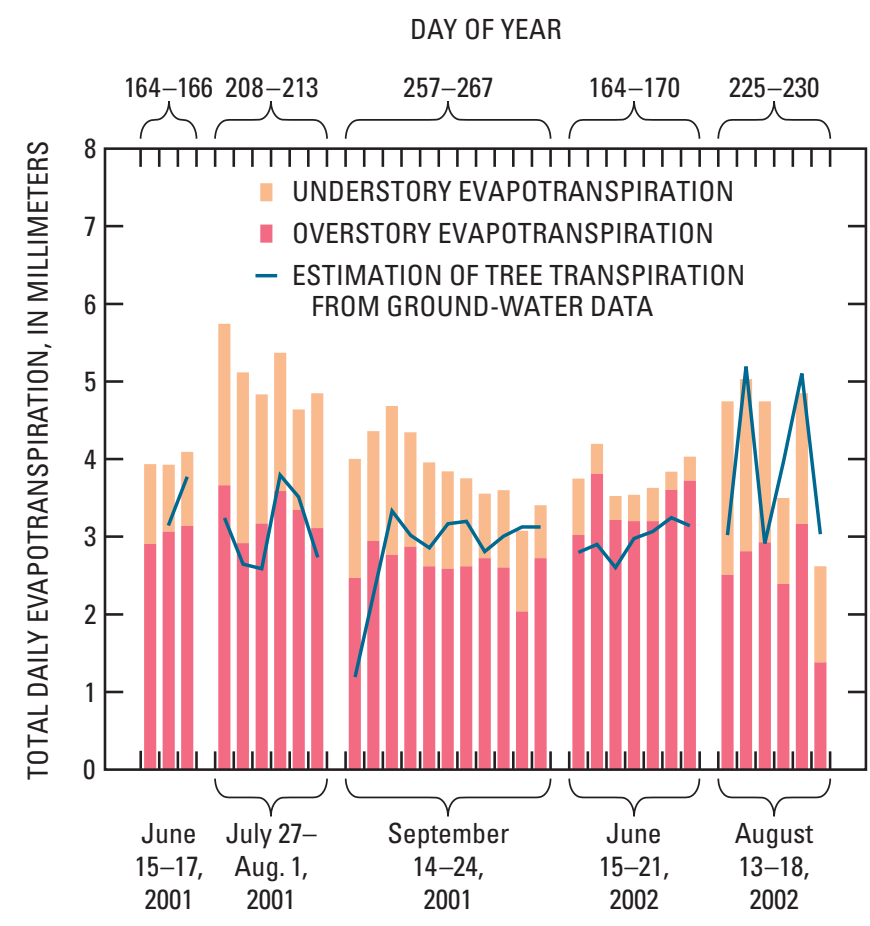

Figure 52. Total daily evapotranspiration (ET) from the Charleston mesquite site and ET partitioning into overstory/understory sources, and an estimate of tree transpiration calculated by using ground-water fluctuations and the method of White (1932) with a storage coefficient of 0.04 , San Pedro Riparian National Conservation Area, Upper San Pedro Basin, Arizona.

\section{Using Isotope Techniques}

Late in the growing season of 2001 (September 22) total ET was 71 percent from mesquite transpiration, 17 percent from transpiration by the understory plants, and 12 percent from soil evaporation. Combining these data with estimates of ET from eddy covariance revealed that of the $3.5 \mathrm{~mm} / \mathrm{d}$ total ET, $2.5 \mathrm{~mm} / \mathrm{d}$ was from transpiration by mesquite, $0.6 \mathrm{~mm} / \mathrm{d}$ was from transpiration by the understory plants, and $0.4 \mathrm{~mm} / \mathrm{d}$ was from soil-surface evaporation (fig. 53A; Yepez and others, 2003). Yepez and others (2003) found that partitioning estimates from the micrometeorological and isotope techniques during 2001 compared favorably.

The fraction of total ET attributed to transpiration in 2002 varied from nearly 100 percent during dry periods to about 35 percent following large precipitation events when soil evaporation was high. During the dry period of 2002 (June 16), ET was partitioned as $3.5 \mathrm{~mm} / \mathrm{d}$ (94 percent) from mesquite transpiration and $0.2 \mathrm{~mm} / \mathrm{d}$ (6 percent) from soil evaporation. On August 14, the ET was $3.8 \mathrm{~mm} / \mathrm{d}$ (77 percent) from tree transpiration, $0.9 \mathrm{~mm} / \mathrm{d}$ (18 percent) from understory vegetation, and $0.2 \mathrm{~mm} / \mathrm{d}$ from soil evaporation (5 percent).
A. Total ecosystem evapotranspiration

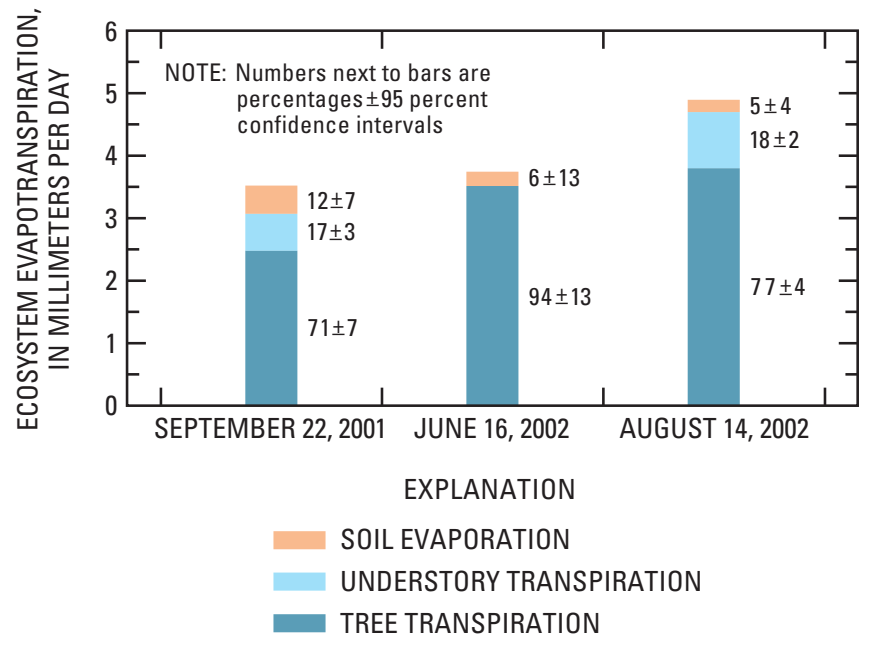

$B$. Absolute understory cover

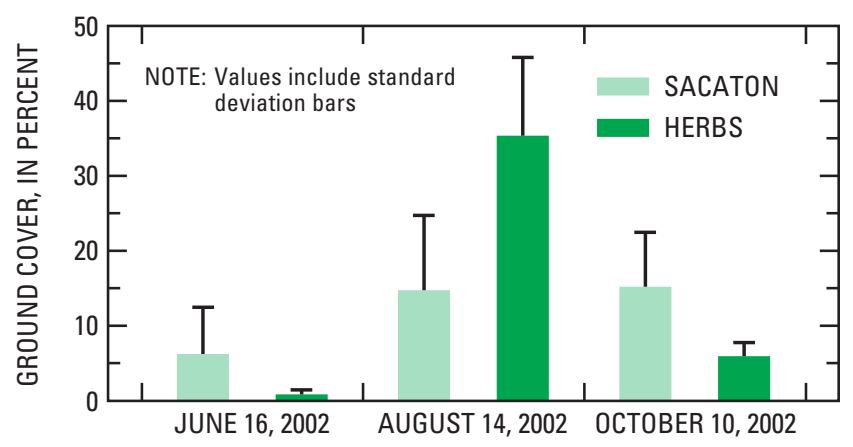

Figure 53. Charleston mesquite site evapotranspiration, San Pedro Riparian National Conservation Area, Upper San Pedro Basin, Arizona. A, Total evapotranspiration partitioned into tree transpiration, understory transpiration and soil evaporation during three dates of contrasting phenologies and environmental conditions; $B$, Absolute understory cover during the summer of 2002.

During these contrasting periods, the percent cover of the green understory vegetation varied from 0 to 32 percent for the herbaceous dicots, and from 6 to 14 percent for the sacaton, suggesting that an important source of the understory transpiration was from the herbaceous dicot cover (fig. 53B).

Evaporation was significant only immediately after rainfall, when volumetric water content exceeded $0.1 \mathrm{~cm}^{3} / \mathrm{cm}^{3}$ in the top $5 \mathrm{~cm}$ of soil (fig. 54). Following two significant rainstorms, on September 1 and September 14, 2002, the combined tree and understory transpiration accounted for only $2.1 \mathrm{~mm} / \mathrm{d}$ (38 percent of ET) and $1.4 \mathrm{~mm} / \mathrm{d}$ (33 percent of ET), whereas soil evaporation represented $3.3 \mathrm{~mm} / \mathrm{d}$ and $2.8 \mathrm{~mm} / \mathrm{d}$, respectively (fig. 54 ). 


\section{A. Potential evapotranspiration}

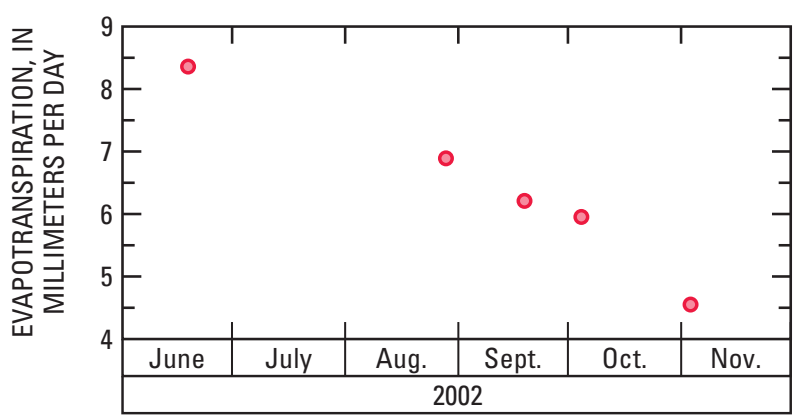

$B$. Isotopic flux partitioning

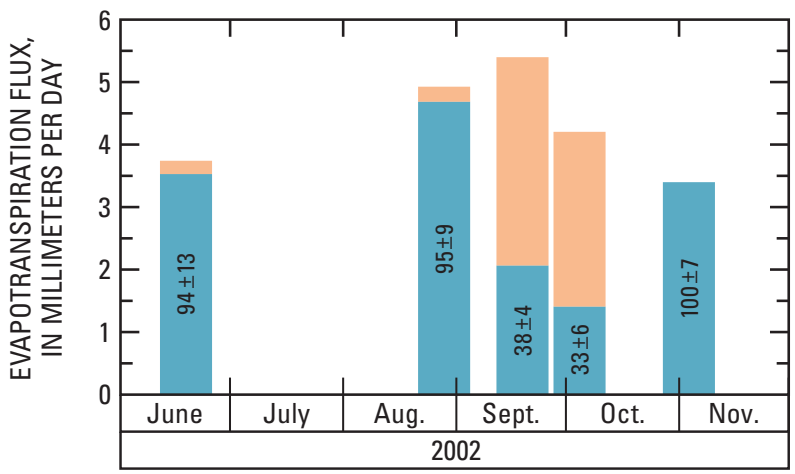

NOTE: Numbers inside bars are percentages \pm 95 percent confidence intervals

EXPLANATION

SOIL EVAPORATION

BULK TRANSPIRATION

C. Mean volumetric soil-water content

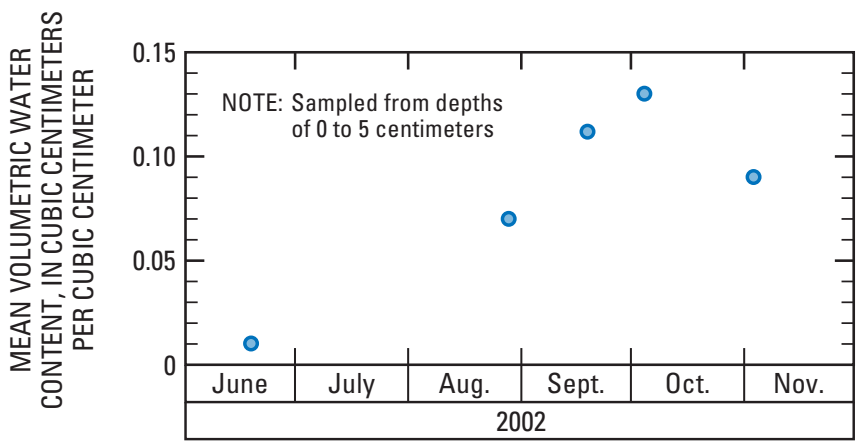

Figure 54. Isotopic evapotranspiration partitioning in relation to seasonal precipitation at the Charleston mesquite site, San Pedro Riparian National Conservation Area, Upper San Pedro Basin, Arizona. A, Potential evapotranspiration; $B$, Isotopic flux partitioning calculated by using the isotopic composition of plants, soil, and vapor samples and measurements of evapotranspiration with the eddy-covariance technique; $C$, Mean volumetric soil-water content.
The seasonal trends of ET flux components were estimated by using the relations between the isotopic partitioning, total ET fluxes from the eddy-covariance technique, and environmental conditions (potential ET and soil moisture) observed during the growing seasons of 2001, 2002, and 2003. The growing season was assumed to be from DOY 121 to DOY 321 for all 3 years (fig. 55). From seasonal trends, the total growing-season water balance was determined (table 43).

\section{Mesquite Water Sources}

The objective of this portion of the project was to determine the seasonal and interannual patterns of water source use by mesquite. Mesquite had access to water in three different zones of the soil during the growing season: deep water in the saturated zone/capillary fringe (ground surface); water in the deep unsaturated zone ( $>1 \mathrm{~m}$ below the soil), which probably was a mixture of both ground water and precipitation; and water from growing season precipitation $(<1 \mathrm{~m}$ below the surface). Mesquite, a deeply rooted phreatophyte, was predicted to obtain the majority, if not all of its water, from the deep saturated zone or capillary fringe- essentially the ground water. The work discussed in the "Mesquite Woodland Water Use" section indicates that mesquite did indeed have access to the ground water throughout the growing season, and that the regular diurnal patterns of ground-water drawdown because of mesquite-root uptake occurred throughout most of the season, except for limited periods during the monsoon when water was abundant in the shallow soil. The data in the previous section indicates that the majority of the water used by the mesquite was ground water; this was largely confirmed by using stable isotopes. Significant uptake of ground water for a limited number of sampling days was observed; but uptake from the deep unsaturated zone and from growing season precipitation also occurred. Apparently, mesquite is very opportunistic and uses water when and where it is available.

Precipitation was a significant transpiration source for mesquite during the monsoon period in July, August, and September at the Charleston mesquite, Moson, and Lewis Springs sites in 2000, 2001, and 2002 (figs. 56, 57, 58 and table 42). In 2000, the use of monsoon precipitation (from shallow soil water) as a proportion of transpiration for mesquite was greater at the Charleston mesquite site than at the Moson and Lewis Springs sites (fig. 56). This may reflect differences in soil properties, the amount of rainfall preceding measurements, or the access to ground water among the three sites (depth to ground water was greatest at the Charleston mesquite site). Mesquite relied principally on deep water (ground water plus deep vadose-zone water) and had little shallow soil-water uptake during the dry premonsoon periods. 


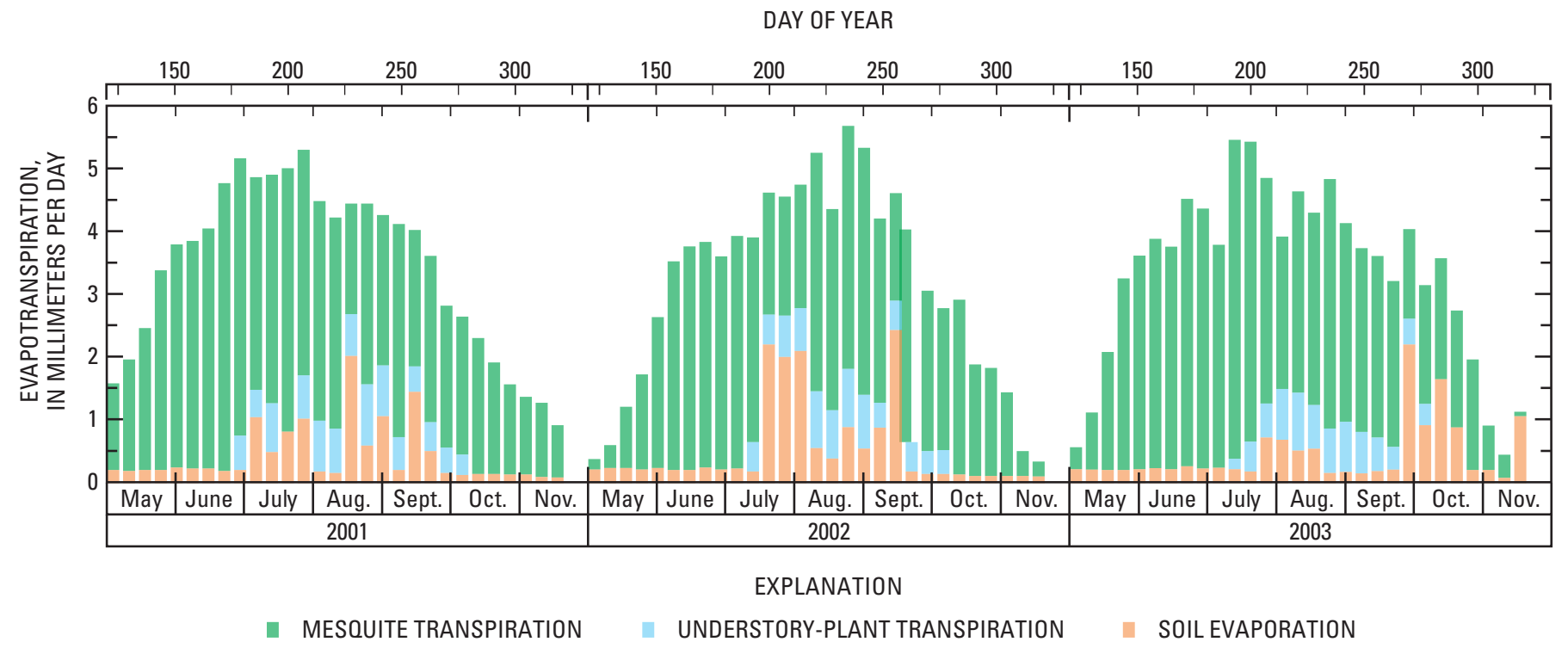

Figure 55. Seasonal trends of average weekly evapotranspiration-flux components calculated by using the isotopic-flux partitioning and the eddy-covariance derived distributed measurements of evapotranspiration at the Charleston mesquite site, San Pedro Riparian National Conservation Area, Upper San Pedro Basin, Arizona (May 1 to November 17, 2001, 2002, and 2003).

Table 43. Water balance at the Charleston mesquite site during the growing season (May 1-November 27), San Pedro Riparian National Conservation Area, Upper San Pedro Basin, Arizona

\begin{tabular}{ccccc}
\hline & $\begin{array}{c}\text { Total evapo- } \\
\text { transpiration }\end{array}$ & $\begin{array}{c}\text { Soil } \\
\text { evaporation } \\
\text { (millimeters) }\end{array}$ & $\begin{array}{c}\text { Understory- } \\
\text { plant } \\
\text { transpiration } \\
\text { (millimeters) }\end{array}$ & $\begin{array}{c}\text { Mesquite } \\
\text { transpiration } \\
\text { (millimeters) }\end{array}$ \\
\hline 2001 & 694 & 82 & 64 & 548 \\
2002 & 638 & 110 & 54 & 474 \\
2003 & 676 & 91 & 52 & 534 \\
\hline
\end{tabular}

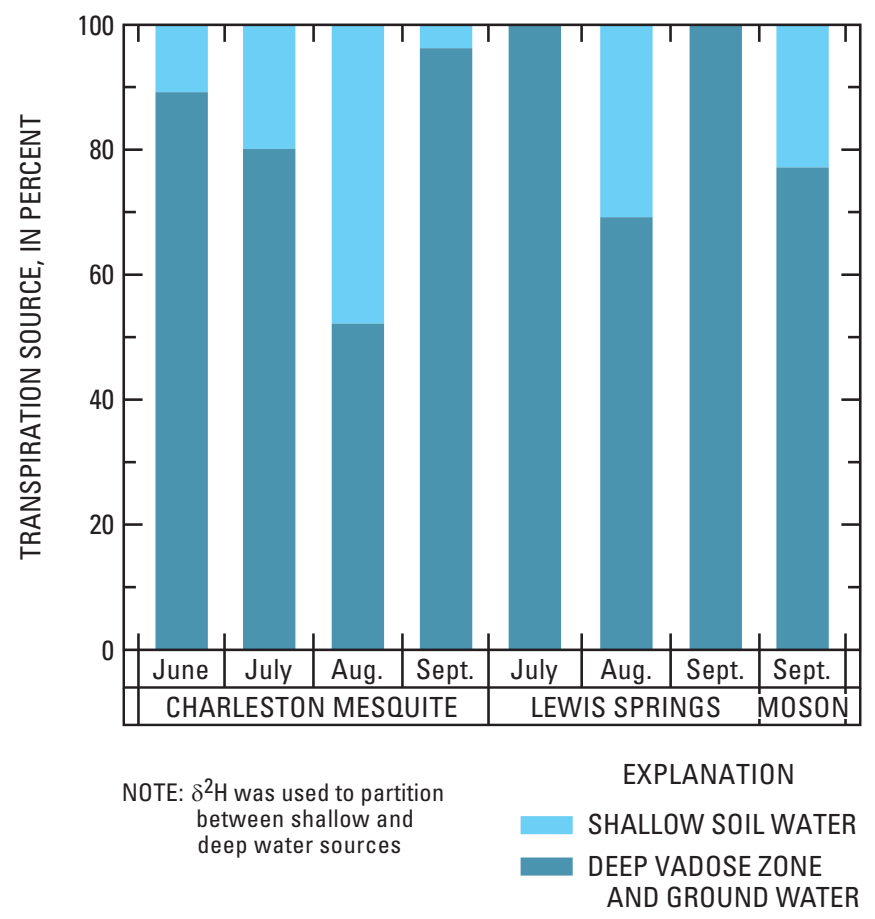

Figure 56. Mesquite transpiration-source partitioning for the Charleston mesquite, Lewis Springs, and Moson sites for the 2000 growing season, San Pedro Riparian National Conservation Area, Upper San Pedro Basin, Arizona. 


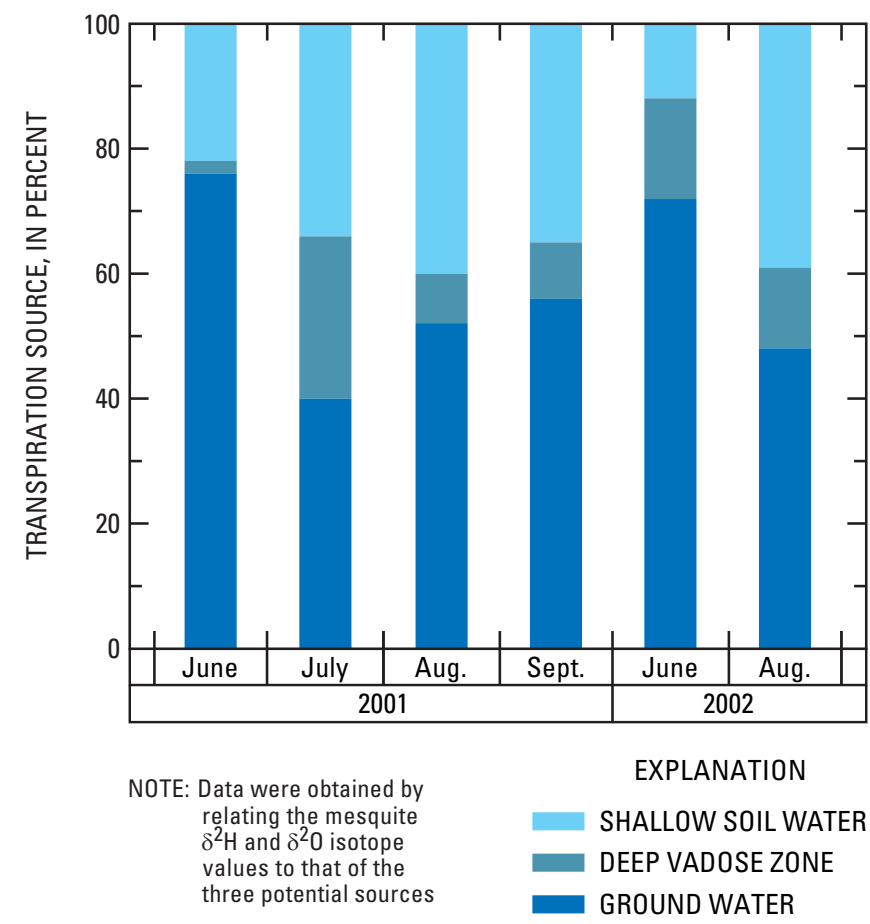

Figure 57. Mesquite transpiration sources at the Charleston mesquite site, 2001 and 2002 growing seasons, San Pedro Riparian National Conservation Area, Upper San Pedro Basin, Arizona.

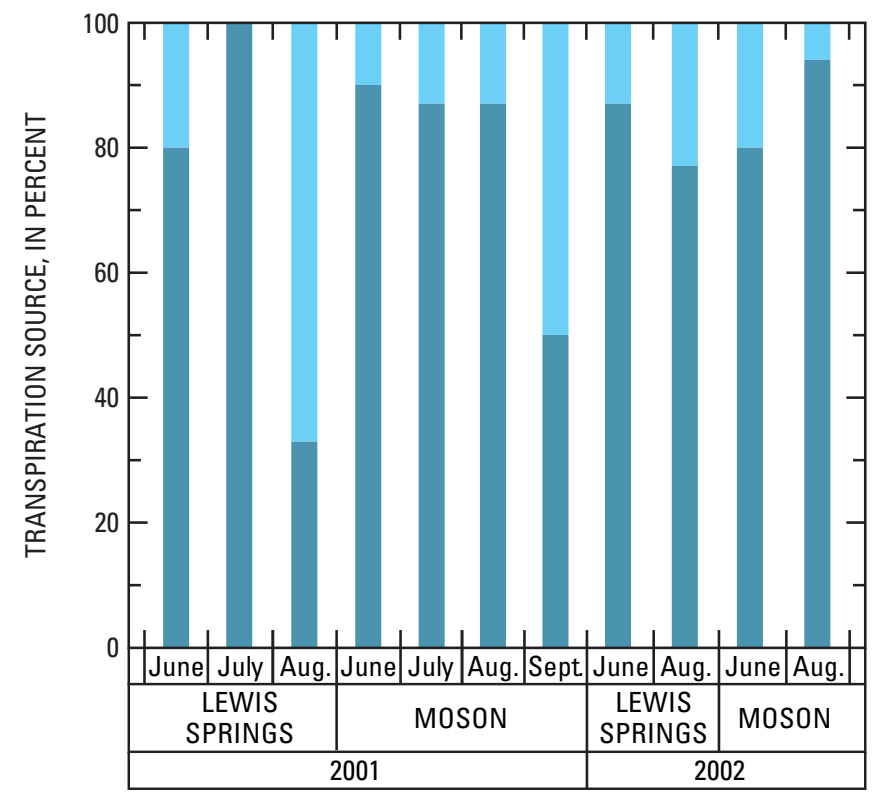

NOTE: Deuterium was used to calculate watersource proportions by differentiating between shallow sources and deep soil sources (deep vadose zone plus ground water). Because the isotope values of the two deep sources were similar at these sites, sources could not be partitioned

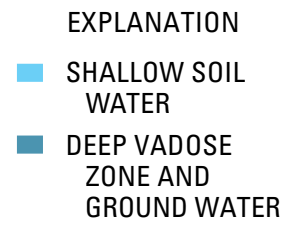

Figure 58. Water-source partitioning for the Lewis Springs and Moson sites, 2001 and 2002 growing seasons, San Pedro Riparian National Conservation Area, Upper San Pedro Basin, Arizona.
Deep vadose-zone water contributed 2 to 26 percent of the total transpiration by mesquite at the Charleston mesquite site in 2001 and 13 to 16 percent in 2002 (table 44). Ground water was the most important source of water at this site; June ground water source fractions were 76 and 72 percent in 2001 and 2002, respectively.

Mesquite transpiration rates from ET partitioning at the Charleston mesquite site (see the "Mesquite Evapotranspiration Partitioning" section) were used to partition the transpired water into three sources: (1) ground water, (2) the shallow vadose zone, and (3) the deep vadose zone. The fraction of tree transpiration from recent precipitation (during prior weeks and months) was highly dependent on soil-moisture content within the $0.2-1.0 \mathrm{~m}$ depth increment. The linear relation between volumetric soilmoisture content within the $0.2-1.0 \mathrm{~m}$ depth increment and the fraction of moisture uptake from this layer determined by isotope methods was highly significant (fraction from surface soil $=14.8 \times($ soil-moisture content $)-0.68 ; r^{2}=0.93$, $p<0.001, n=6$ ).

The regression relation between volumetric soil-moisture content and the fraction of moisture uptake was used to estimate the precipitation use for each week from May 1 to October 21 (DOY 121-323) of 2001, 2002, and 2003. ET derived from ground water and the deep vadose zone was calculated by using the proportions from the three-ended isotope mixing model. The remaining water use was divided between ground water and deep vadose-zone water by using calculated proportions from ET-source isotope measurements. Deep vadose-zone and ground-water proportions were calculated for premonsoon (DOY 121-211), monsoon (DOY 212-260), and post-monsoon (DOY 261-323) periods. These calculated proportions were held constant for each period. Estimates of weekly and annual growing-season transpiration from ground water by the mesquite ecosystem at the Charleston mesquite site were then calculated.

Cumulative mesquite transpiration at the stand level during entire growing seasons was 474 to $548 \mathrm{~mm}$ at the Charleston mesquite site (table 43 and fig. 59). Ground water accounted for the majority of mesquite transpiration, and precipitation held in the shallow soil zone accounted for the second largest source (table 45). Deep vadose-zone water accounted for a minor yet important source of mesquite transpiration. Proportionally, 58 to 62 percent of the total transpiration flux from mesquite was from ground water, 29 to 31 percent was from shallow soil water, and 13 to 14 percent was from deep vadose-zone water.

\section{Possible Inconsistency in Mesquite Woodland Evapotranspiration Partitioning and Ground-Water Use}

The calculations above assume that growing-season precipitation and depletion of shallow soil water were sufficient to provide all the water needed for bare-soil evaporation and understory transpiration (table 43) as well as part of the mesquite transpiration (table 45). The total of these estimates, however, was greater than the measured available precipitation excess in each year (table 46). 
Table 44. Estimated distribution of water sources for mesquite transpiration at the Charleston mesquite, Lewis Springs, and Moson sites, San Pedro Riparian National Conservation Area, Upper San Pedro Basin, Arizona, 2000-2002

$[f$, proportion of water derived from the listed source; $S E$, standard error; total proportions may not add to 1.00 owing to independent rounding; ---, no data; $<$, less than; +, plus; deep vadose zone, 1-8.5 meters]

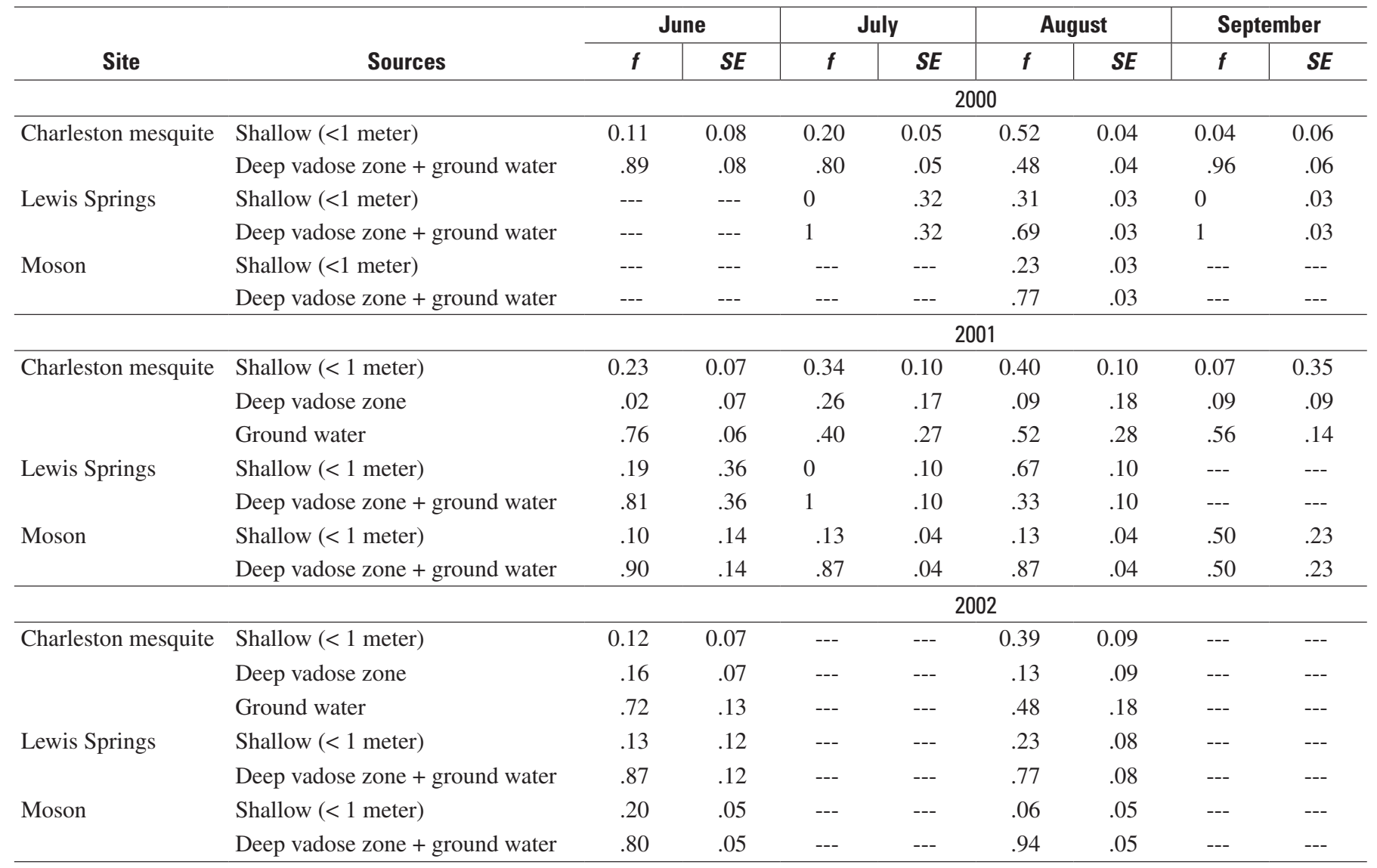

DAY OF YEAR

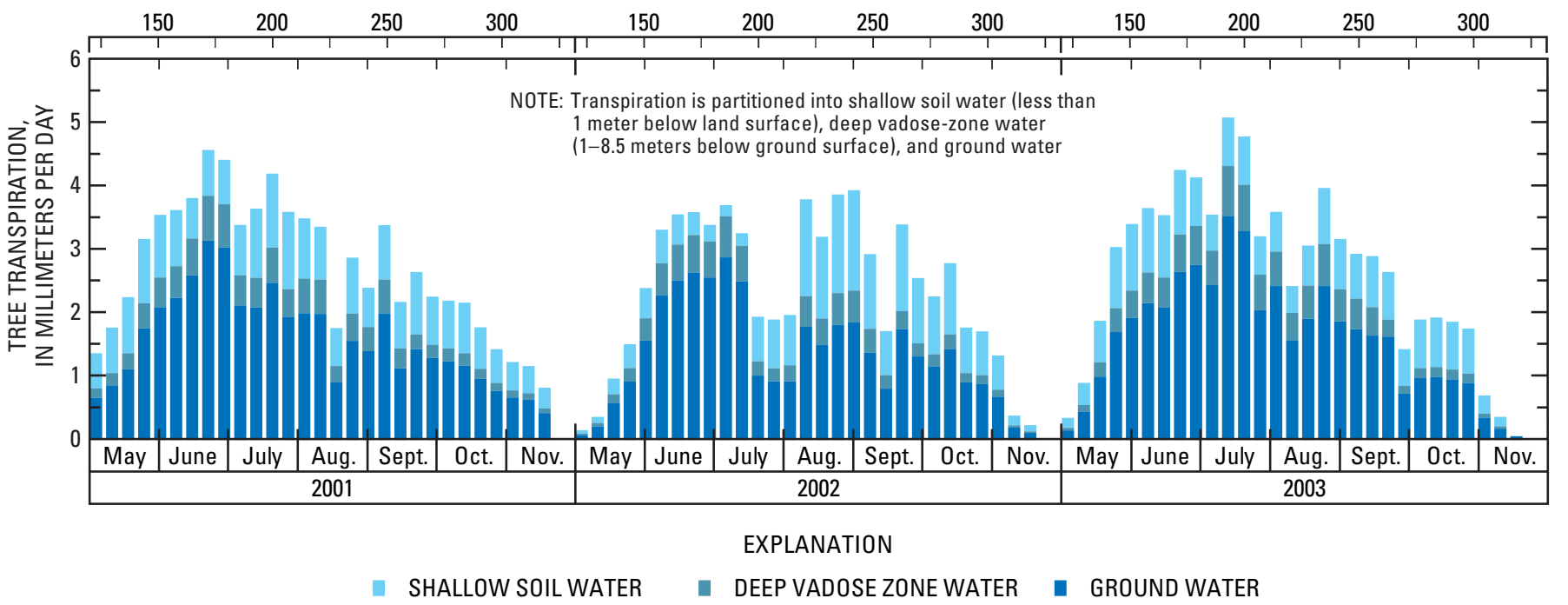

Figure 59. Total tree-transpiration flux from May 1 to November 17 for 2001, 2002, and 2003 at the Charleston mesquite site, San Pedro Riparian National Conservation Area, Upper San Pedro Basin, Arizona. 
Table 45. Mesquite transpiration flux by source and total flux for the 2001-03 for the growing seasons at the Charleston mesquite site, San Pedro Riparian National Conservation Area, Upper San Pedro Basin, Arizona

[Transpiration is partitioned into shallow soil water (less than 1 meter below land surface), deep vadose-zone water (1 to 8.5 meters below land surface), and ground water]

\begin{tabular}{ccccc}
\hline & \multicolumn{4}{c}{$\begin{array}{c}\text { Transpiration flux } \\
\text { (millimeters) }\end{array}$} \\
\cline { 2 - 5 } Year & $\begin{array}{c}\text { Ground } \\
\text { water }\end{array}$ & $\begin{array}{c}\text { Deep } \\
\text { vadose zone }\end{array}$ & $\begin{array}{c}\text { Shallow } \\
\text { soil }\end{array}$ & Total \\
\hline 2001 & 321 & 71 & 156 & 548 \\
2002 & 275 & 61 & 138 & 474 \\
2003 & 333 & 75 & 126 & 534 \\
\hline
\end{tabular}

Table 46. Seasonal water-balance totals of measured and derived water fluxes at the Charleston mesquite site, San Pedro Riparian National Conservation Area, Upper San Pedro Basin, Arizona

[Values given in millimeters]

\begin{tabular}{cccccc}
\hline & $\begin{array}{c}\text { Total } \\
\text { evapotrans- } \\
\text { piration }^{1}\end{array}$ & $\begin{array}{c}\text { Precip- } \\
\text { itation } \\
\text { excess }^{1}\end{array}$ & $\begin{array}{c}\text { Understory } \\
\text { evapotrans- }^{\text {Year }} \\
\text { piration }^{2}\end{array}$ & $\begin{array}{c}\text { Mesquite } \\
\text { shallow } \\
\text { soil-water } \\
\text { use }^{3}\end{array}$ & $\begin{array}{c}\text { Rainfall } \\
\text { deficiency }^{4}\end{array}$ \\
\hline 2001 & 694 & 206 & 146 & 156 & 96 \\
2002 & 638 & 244 & 164 & 138 & 58 \\
2003 & 676 & 166 & 143 & 126 & 103 \\
\hline
\end{tabular}

${ }^{1}$ From table 42, measured value.

${ }^{2}$ From table 43, derived value.

${ }^{3}$ From table 45, derived value.

${ }^{4}($ understory ET $)+($ mesquite shallow soil-water use $)$ - (precipitation excess).

The excess demand on shallow soil water was 58 to $103 \mathrm{~mm}$, or 23 to 62 percent of the precipitation excess. Several factors may have led to this discrepancy. First, understory ET, especially during the dry period before the onset of the monsoon, may have come from water sources greater than $1 \mathrm{~m}$ below land surface. The portion of the soil profile used in the water-budget calculations was $0-1 \mathrm{~m}$ (table 42). Sacaton has roots penetrating to at least $3 \mathrm{~m}$ beneath the flood-plain terraces and may be transpiring water from these deeper layers. Second, mesquite redistributes water from deep soil layers $(>1 \mathrm{~m})$ to the near-surface soil during the dry periods (Hultine and others, 2004), and this water may be subject to evaporation or uptake and transpiration by sacaton, leading to higher than expected understory ET. Finally, any one or all of the estimates of component fluxes and water balance can include measurement or scaling errors. These errors may have led to the inconsistency between precipitation excess and the amount of ET from the upper $1 \mathrm{~m}$ of soil.

\section{Mesquite Shrubland and Sacaton Grassland}

The seasonal water uses by the adjacent mesquite shrubland and sacaton grassland study at the Lewis Springs site followed a similar pattern to that seen at the mesquite woodland at the Charleston mesquite site (figs. 60 and 61). The grassland greened up and started to transpire about a month earlier in the year than the frost sensitive mesquites. After mesquite leaf flush, however, the cumulative shrubland ET caught up to the grassland, perhaps owing to an enhanced ability of the deeper rooted trees to acquire ground water more effectively. From the start of the monsoon until the end of the growing season, the two sites had essentially the same amount of ET.

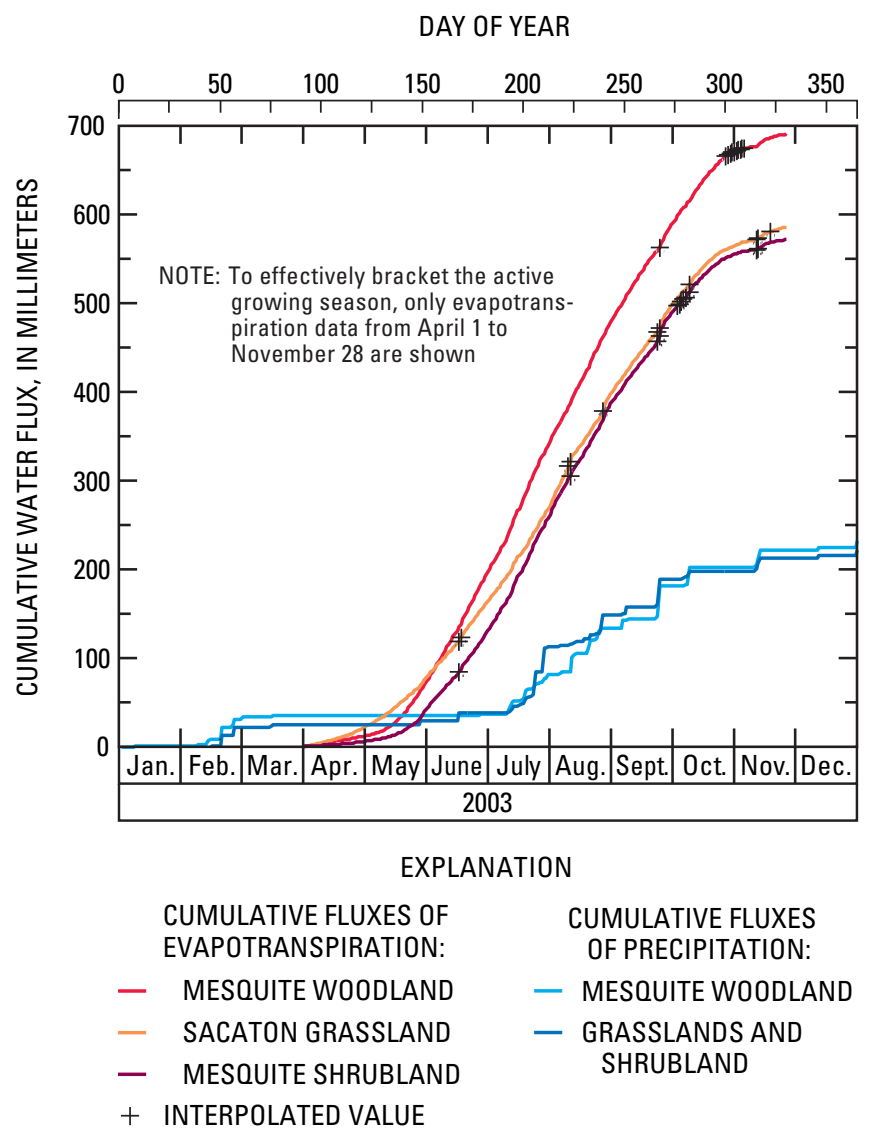

Figure 60. Cumulative fluxes of precipitation and evapotranspiration at all eddy-covariance sites for 2003: mesquite woodland (Charleston mesquite site) and sacaton grassland and mesquite shrubland (Lewis Springs site), San Pedro Riparian National Conservation Area, Upper San Pedro Basin, Arizona. 


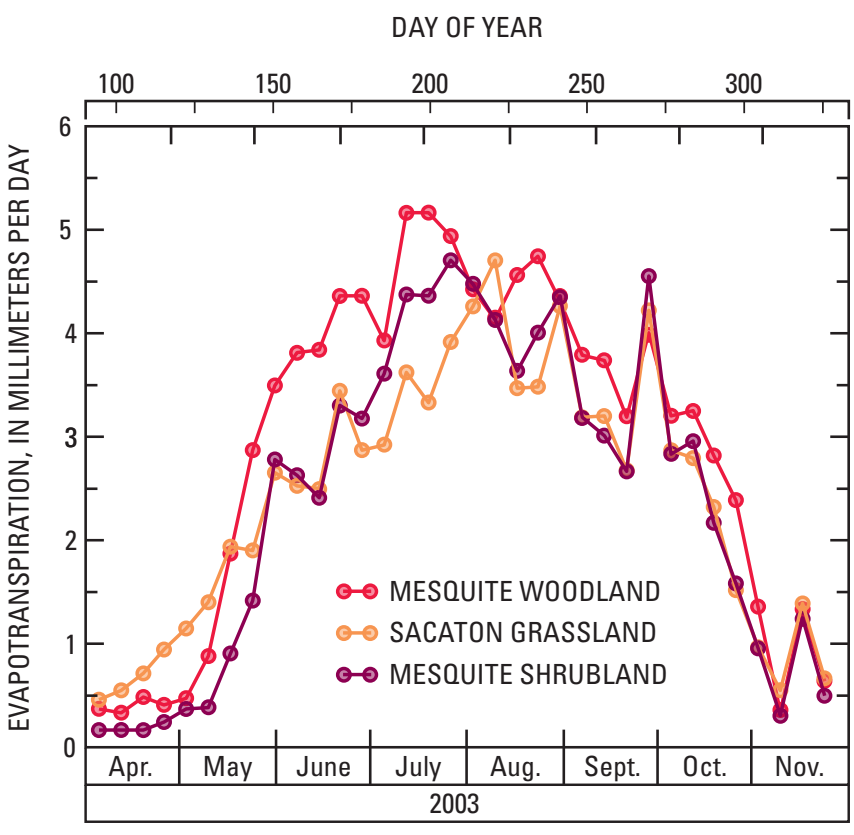

Figure 61. Weekly average evapotranspiration for all eddycovariance sites for 2003: mesquite woodland (Charleston mesquite site), sacaton grassland and mesquite shrubland (Lewis Springs site), San Pedro Riparian National Conservation Area, Upper San Pedro Basin, Arizona.

The water-use pattern by the sacaton grassland at the Lewis Springs site differed considerably from that at the similar Lewis Springs site across the river that was monitored in 1997 using the Bowen ratio technique (Scott, Shuttleworth, and others, 2000). The 1997 sacaton site was shown to have a tight coupling between precipitation and ET from which Scott, Shuttleworth, and others (2000) concluded that sacaton used little ground water. The cumulative water use measured at the sacaton grassland location in this study indicates that ET was significantly in excess of precipitation; this implies ground-water use by the grassland. Regular diurnal fluctuations during the growing season in a piezometer at the site provided confirmation. The likely explanation for the disparity between the wateruse patterns at the two sites is that ground-water depth at the earlier sacaton grassland site was greater than $3.5 \mathrm{~m}$, whereas ground-water depth was commonly less than $3 \mathrm{~m}$ at the sacaton grassland location in this study. Thus, sacaton does not appear where ground-water depths are greater than about $3 \mathrm{~m}$. This conclusion is supported by Scott, Shuttleworth, and others (2000), who mentioned that sacaton closer to the river bank (and closer to the water table) appeared greener in the dry season, and by a stable-isotope analysis of the sacaton source water (Tiller, 2004) that indicated that sacaton did not appear to use ground water at sites at which depth to ground water was greater than about $3 \mathrm{~m}$.
The water use by the mesquite shrubland at the Lewis Springs site in this study also differed from water use at a Lewis Springs mesquite shrubland site that was measured in 1997 (Scott, Shuttleworth, and others, 2000) by using the Bowen ratio method. The 1997 and present study stands have similar characteristics, but the depth to ground water is about $3 \mathrm{~m}$ less at the present Lewis Springs mesquite shrubland site. Although annual ET at the 1997 site was in excess of precipitation, the source of ET in excess of precipitation was uncertain. Scott, Shuttleworth, and others (2000) speculated that the source of ET in excess of evapotranspiration might have been derived from deeper vadose-zone moisture, because the fluctuations in a site piezometer did not indicate phreatophytic fluctuations. More trees at the mesquite shrubland at the Lewis Springs site were probably able to access the ground water, because the age distribution of the trees and because ground water is closer to the surface. Alternatively, the 1997 mesquite site probably had a lower density of mesquite, which would result in a lower ET (see the "Mesquite Woodland Water Use" section).

By using the growing season water balance given in equation 12 , the ground-water use of the mesquite shrubland and sacaton grassland at the Lewis Springs site on a per unit canopy-area basis were computed and compared to the mature mesquite woodland at the Charleston mesquite $\left(Q_{\text {veg }}\right.$, table 47$)$. Although evaporation excess $\left(Q_{t}\right)$ at the sacaton grassland at the Lewis Springs site was the same as that at the adjacent mesquite shrubland at the Lewis Springs site, the sacaton ground-water use per unit canopy area was less owing to its denser canopy area. Nevertheless, the sacaton ground-water use was significant at this site and represents a revision in of the understanding of consumptive use in the SPRNCA.

Table 47. Water balance for the growing season (May 1-November 27) at the Lewis Springs and Charleston mesquite sites for 2003, San Pedro Riparian National Conservation Area, Upper San Pedro Basin, Arizona

[mm, millimeters; values computed by using equation 12 (see text)]

\begin{tabular}{|c|c|c|c|}
\hline \multirow[b]{2}{*}{ Water use terms } & \multicolumn{3}{|c|}{ Site } \\
\hline & $\begin{array}{l}\text { Lewis } \\
\text { Springs } \\
\text { sacaton }\end{array}$ & \begin{tabular}{|c|} 
Lewis \\
Springs \\
mesquite
\end{tabular} & $\begin{array}{l}\text { Charleston } \\
\text { mesquite }\end{array}$ \\
\hline Evapotranspiration (ET), in mm & 554 & 565 & 676 \\
\hline $\begin{array}{l}\text { Precipitation excess }(P-\Delta S) \text {, } \\
\quad \text { in } \mathrm{mm}\end{array}$ & 180 & 185 & 166 \\
\hline $\begin{array}{l}\text { Ground-water use per unit } \\
\text { ground area }\left(Q_{\mathrm{t}}\right) \text {, in mm }\end{array}$ & 374 & 380 & 510 \\
\hline $\begin{array}{l}\text { Canopy cover fraction of } \\
\text { dominant vegetation type }\end{array}$ & .65 & .55 & .74 \\
\hline $\begin{array}{l}\text { Ground-water use per unit } \\
\quad \text { vegetation area }\left(Q_{\text {veg }}\right) \text {, in } \mathrm{mm}\end{array}$ & 575 & 691 & 689 \\
\hline
\end{tabular}


It is encouraging that the $Q_{\text {veg }}$ measured for the mesquite shrubland at the Lewis Springs site was nearly equal to that measured at the mesquite woodland at the Charleston mesquite site as it indicates that mesquite seem to function similarly from site to site. This result proved helpful for scaling up these ET measurements to the entire SPRNCA; the vegetation map did not distinguish how coupled the mesquites were to the ground water at any particular riparian site. Although it was encouraging that the $Q_{\text {veg }}$ of the shrubland and woodland were equivalent, the calculations were highly sensitive to the canopy cover percentage - the near equality between the sites probably is by chance.

\section{Cottonwood Forests}

During the peak dry period of the premonsoon season, mean daily maximum vapor-pressure deficit (VPD) was $6 \mathrm{kPa}$ at the Boquillas (intermittent streamflow) and Lewis Springs (perennial streamflow) flood-plain sites (fig. 62).

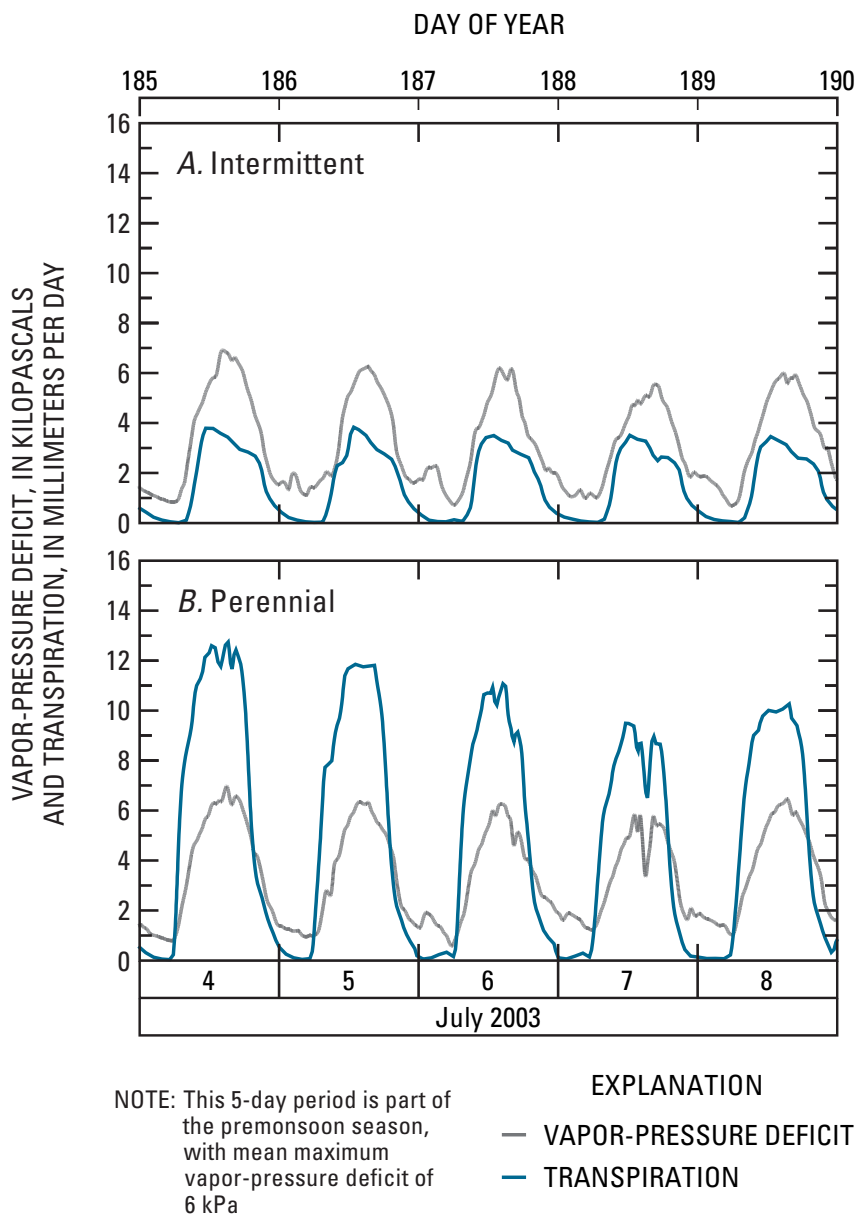

Figure 62. Vapor-pressure deficit and measured cottonwood transpiration for July 4-9, 2003 (day of year 185-190), San Pedro Riparian National Conservation Area, Upper San Pedro Basin, Arizona. A, Boquillas (intermittent streamflow) site; $B$, Lewis Springs (perennial streamflow) site.
VPD and cottonwood tree transpiration $(\mathrm{T})$ followed similar patterns throughout the day. The cottonwood stand at the Boquillas site exhibited midday-afternoon depression in T probably in response to high VPD (fig. 62), implying that the trees were regulating their stoma to prevent water loss (O'Grady and others, 1999; Horton and others, 2001c). During a relatively rain-free period (August 8-13) in the monsoon season, mean maximum VPD was similar to that in the premonsoon season (July); the peak VPD during the monsoon season was about $5 \mathrm{kPa}$ (fig. 63). In contrast to the premonsoon pattern, $\mathrm{T}$ increased with no apparent stomatal closure at midday after significant monsoon rains and runoff events had recharged the soil moisture and ground water at both sites.

DAY OF YEAR

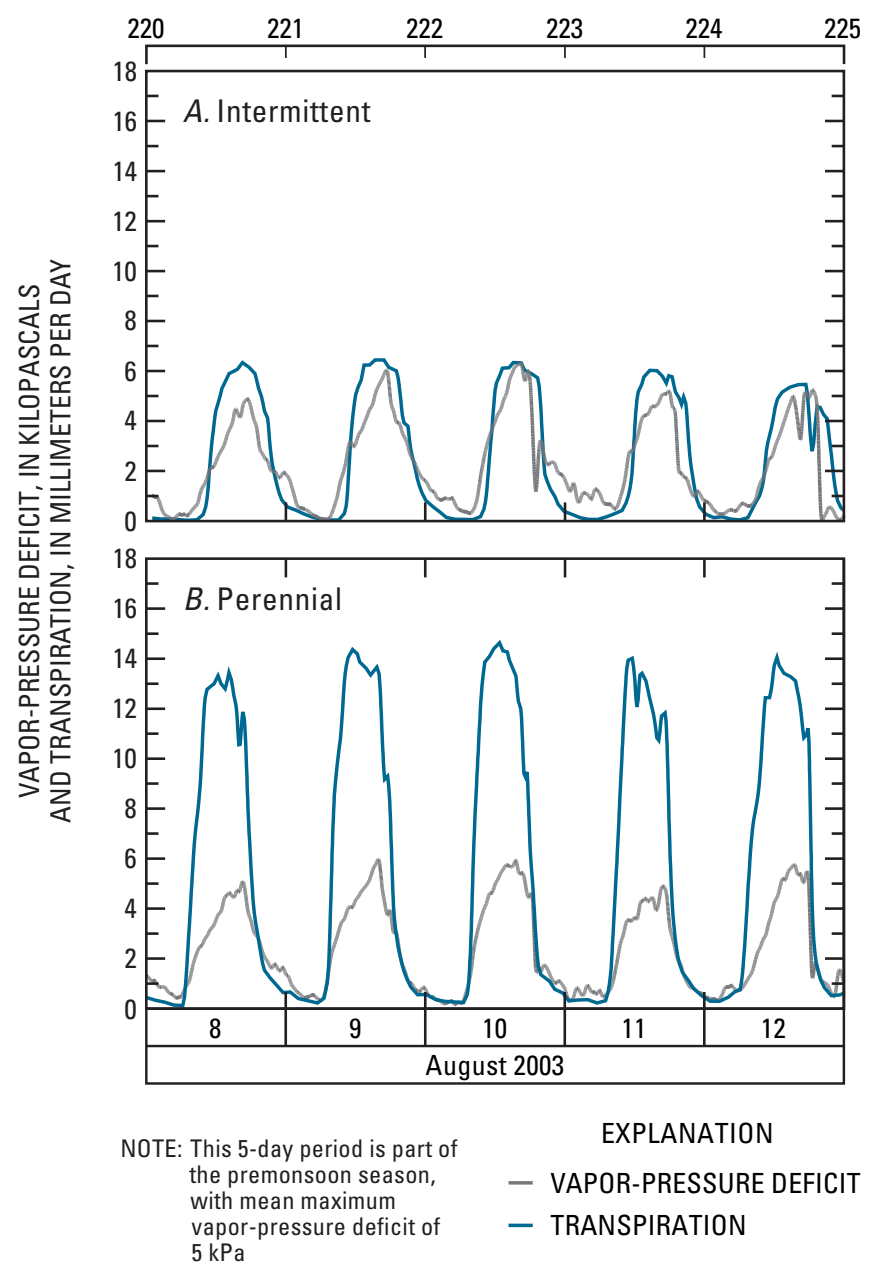

Figure 63. Vapor-pressure deficit and measured cottonwood transpiration for August 8-13, 2003 (day of year 220-225), San Pedro Riparian National Conservation Area, Upper San Pedro Basin, Arizona. A, Boquillas (intermittent streamflow) site; $B$, Lewis Springs (perennial streamflow) site. 
There was no dependence of $T$ on VPD at the Boquillas site, which again confirms that stomatal regulation or leaf area reduction reduced water loss during periods of high atmospheric demand. A significant positive linear relation of $T$ and VPD at the Lewis Springs site indicates low resistance to water demand (fig. 64A; Oren and others, 1996). $T$ appeared to be controlled by water-transport capacity and amount of foliage in the cottonwood trees at the Lewis Springs site (Cinnirella and others, 2002).

Daily transpiration of the cottonwood stand at the Lewis Springs site was higher than at the Boquillas site throughout the growing season (fig. 65). A marked decline in $T$ at the Boquillas site was observed during the peak of the early summer drought or premonsoon period. The leaves of cottonwood trees fully leafed out at DOY 91 and completely senesced at DOY 309. Total annual stand $T$ was $484 \mathrm{~mm}$ at the Boquillas site and $966 \mathrm{~mm}$ at the Lewis Springs site.
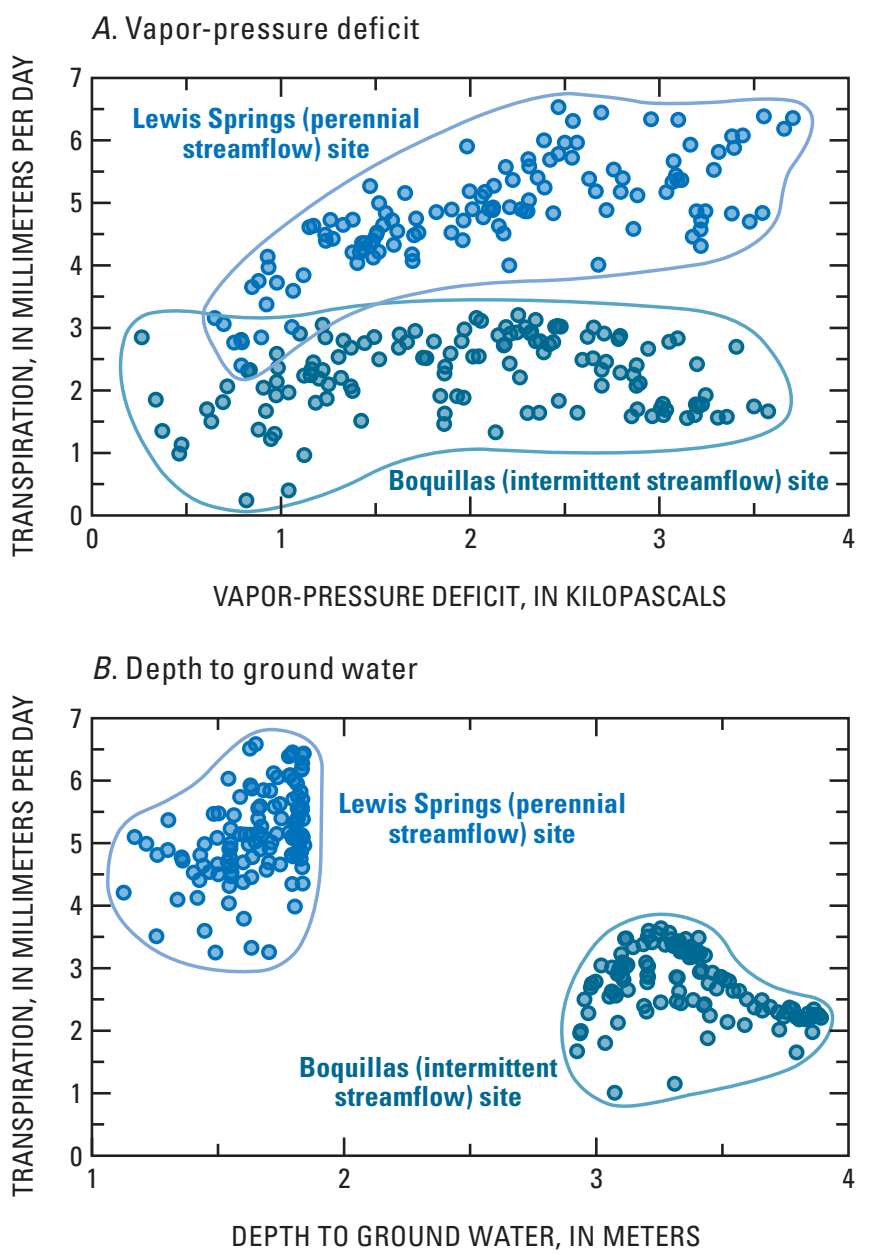

Figure 64. Relation of measured cottonwood transpiration to vapor-pressure deficit and depth to ground water at the Boquillas (intermittent streamflow) and Lewis Springs (perennial streamflow) sites, San Pedro Riparian National Conservation Area, Upper San Pedro Basin, Arizona. A, Vapor-pressure deficit; $B$, Depth to ground water.

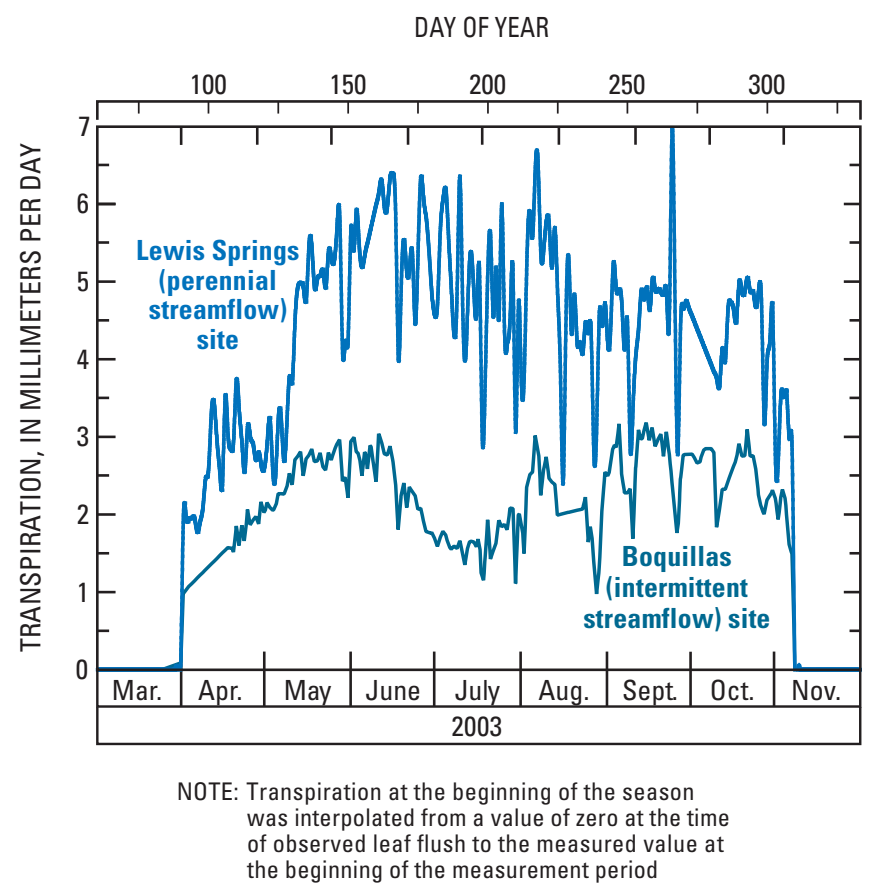

Figure 65. Seasonal cottonwood transpiration at the Boquillas (intermittent streamflow) and Lewis Springs (perennial streamflow) sites, 2003, San Pedro Riparian National Conservation Area, Upper San Pedro Basin, Arizona.

A previous study conducted at the Lewis Springs site revealed that cottonwood trees in the primary channel had higher $T$ than trees in the secondary channel (Schaeffer and others, 2000). On a daily basis, cottonwood trees at the Lewis Springs site transpired at higher rates than trees at the Boquillas site, indicating low resistance to the transpiration flux at the Lewis Springs site (little drought stress). The higher $T$ rate at the Lewis Springs site suggests that, because of an abundant supply of water, atmospheric demand is the driving force for $T$ (Oren and others, 1996). Hence, $T$ at the Lewis Springs site approached predicted potential evaporation levels at the onset of the monsoon season because of the high VPD and readily accessible ground water (fig. 66). At the Boquillas site, however, $T$ did not increase with atmospheric demand because of increased resistance to water uptake (soil-root interface) or to transpiration (stem resistance, stomatal resistance, or reduced LAI) during drought (Oren and others, 1996; Leffler and Evans, 2001).

During the early part of the growing season, a localized infestation of leaf-eating caterpillars occurred at the Boquillas site. A decline in $T$ started at the onset of the herbivory at DOY 113 and continued until DOY 120 when the cottonwood trees were almost entirely defoliated (fig. 65). A reduced $T$ was observed throughout the duration of infestation. Cottonwood trees fully recovered from herbivory at DOY 130 when new leaves flushed out and $T$ started to increase. The reduced flow observed during 
herbivory may have been due to water used in bud swell for the production of new photosynthetic tissues. Evidence of sap flow before bud break in some species in southern deciduous forests indicated that loss of water to the atmosphere occurred through the bark, young branches, and expanding buds (Oren and Pataki, 2001).

Ground-water depth below land surface at the Boquillas site was greater than at the Lewis Springs site (fig. 67). At the Boquillas site, ground-water depth increased from $3.1 \mathrm{~m}$ during the early part of the spring season to $3.9 \mathrm{~m}$ during the peak of the premonsoon drought period (fig. 67A). At the Lewis Springs site, ground-water depth varied less throughout the premonsoon drought period than at the Boquillas site, but depth to ground water declined gradually and steadily. Ground-water depth decreased from $1.5 \mathrm{~m}$ at the beginning of the spring season to $1.1 \mathrm{~m}$ during the monsoon season. At the peak of the premonsoon drought period, ground-water depth dropped to $1.8 \mathrm{~m}$. Ground-water levels at both sites peaked during the monsoon season in response to rises in stream stage (fig. 67).

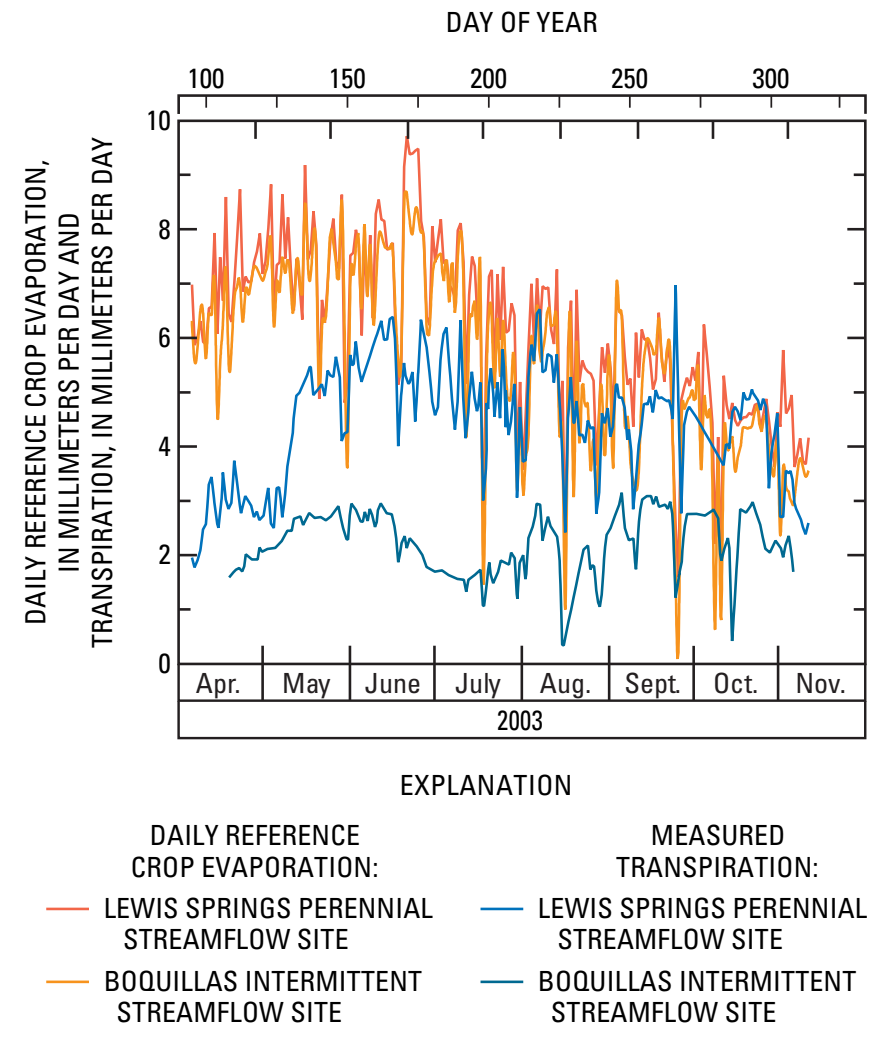

Figure 66. Daily reference crop evapotranspiration and measured transpiration of cottonwood trees at the Boquillas (intermittent streamflow) and Lewis Springs (perennial streamflow) sites, 2003, San Pedro Riparian National Conservation Area, Upper San Pedro Basin, Arizona.

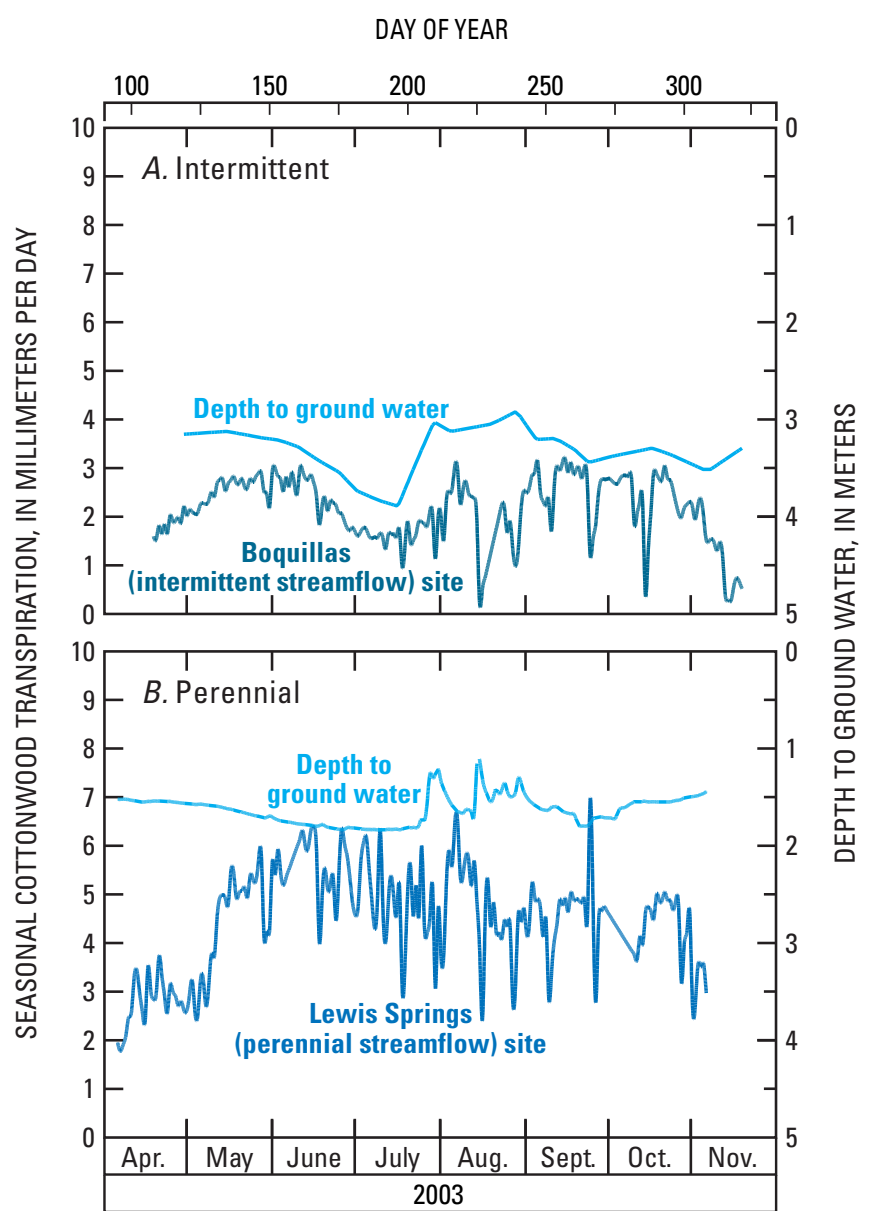

Figure 67. Seasonal cottonwood transpiration, 2003, San Pedro Riparian National Conservation Area, Upper San Pedro Basin, Arizona. $A$, Boquillas (intermittent streamflow) site; $B$, Lewis Springs (perennial streamflow) site.

Seasonal fluctuation in the water use of cottonwood trees at the Boquillas site was closely related to the fluctuations of the ground-water table (fig. 67A). Cottonwood trees at the Boquillas site likely were dependent on shallow ground-water sources. The significant decline in the water table in the premonsoon season period probably caused increased water stress on the cottonwood trees (Cooper and others, 2003; Rood and others, 2003; Tyree and others, 1994). $T$ at the Lewis Springs site showed little evidence of water stress probably because the water table was high and water-level declines were small (Oren and Pataki, 2001). At the Boquillas site, however, larger and deeper declines in the water table caused large reductions in $T$ that may be associated with a loss of hydraulic conductivity that facilitated a reduction in stomatal conductance (Cooper and others, 2003). At the onset of the monsoon rains, $T$ at the Boquillas site rebounded in response to increases in soil moisture and (or) water-table rise (fig. 67A). 
According to previous studies, the LAI of cottonwood trees at the Boquillas site was consistently lower than at the Lewis Springs site and was relatively constant throughout the growing season (Sean Schaeffer, University of Arkansas, and David Williams, University of Wyoming, unpublished data; Schaeffer and others, 2000). In October 2003, the LAI at the Boquillas and Lewis Springs sites was 1.75 and 2.75, respectively. This difference in LAI corresponds well with the difference in transpiration magnitudes under unstressed conditions between the two sites (fig. 65). The leaf area to sapwood area ratio was significantly higher at the Lewis Springs site than at the Boquillas site (table 41).

\section{Seepwillow Transpiration and Open-Water Evaporation}

A seepwillow transpiration and open-water evaporation study was conducted in 2002 and 2003 to make transpiration measurements from a dominant understory species and from an open-water surface in the flood-plain zone at the Lewis Springs site. These are the first ET measurements made from these two cover types along the San Pedro River. Previous estimates of open-water evaporation from the riparian corridor have been calculated by using empirical formulae and commonly available meteorological data. Ground-water use by obligate phreatophytic understory plants has previously been completely ignored owing to measurement difficulties. Further, the total area covered by such plants is thought to be insignificant compared with the cover of other vegetation elements in the riparian corridor.

A discussion of major understory species is presented in chapter $\mathrm{C}$ of this report, and visual surveys of active, green understory plants were made in June 2002 prior to the monsoon. Green understory plants in the premonsoon period were an indicator that the species did rely upon ground water. These surveys showed that seepwillow and sacaton are the dominant understory vegetation types that are probable ground-water users.

\section{Understory Seepwillow Water Use}

Floods during the monsoon season destroyed sap-flow instrumentation in 2002, and as a consequence, most of the transpiration measurements were not reliable for the 2002 study period. In 2003, seepwillow sap flow was measured at both open- and closed-canopy sites at Lewis Springs from May 30 to November 6 (DOY 150-310). This time period represented seasonal sap-flow values of the premonsoon, monsoon, and post-monsoon periods. Transpiration measurements from the open- and closed-canopy sites were compared with the AZMET reference ET (ET; fig. 68). ET $_{\mathrm{o}}$ was calculated by using data from the Lewis Springs meteorological tower, which is in a more open environment than the open- and closed-seepwillow sap flow sites. The ET in the understory flood-plain environment is expected to be somewhat less than in an open area owing to the sheltering effect of the cottonwood overstory. During the premonsoon period, transpiration rates for seepwillow were fairly consistent and not responsive to daily fluctuations in atmospheric demand, indicating that $\mathrm{ET}_{\mathrm{o}}$ was not a limiting factor of seepwillow sap flux during this period. Both openand closed-canopy sites had similar and fairly constant transpiration rates; stand transpiration averaged about $5 \mathrm{~mm} / \mathrm{d}$ in June and early July. After the monsoon began about DOY 200, atmospheric demand was lower and the seepwillow transpiration was more responsive to fluctuations in the demand, indicating more atmospheric-demand limitations during this time.

Seepwillow and the cottonwood forest had comparable water-use rates (fig. 69). Mean differences in transpiration rates between cottonwood and seepwillow were $1.0 \mathrm{~mm} / \mathrm{d}$ during the premonsoon period, $1.9 \mathrm{~mm} / \mathrm{d}$ during the monsoon season, and $1.6 \mathrm{~mm} / \mathrm{d}$ during the post-monsoon period.

A linear regression between mean seepwillow transpiration and $\mathrm{ET}_{\mathrm{o}}$ indicated a high level of correlation $\left(r^{2}=0.79, p<0.0001\right)$. Seepwillow growing-season totals were estimated by applying the regression equation $\left(1.1406233+0.427397 \mathrm{ET}_{\mathrm{o}}\right)$ to $2003 \mathrm{ET}_{\mathrm{o}}$ data from the Lewis Springs site meteorological tower. The extent of the seepwillow growing season was assumed to be the same as that for the cottonwoods (DOY 91 to 309) at the site. Comparison of the estimated seepwillow ET $(819 \mathrm{~mm})$ with that of the cottonwood $(966 \mathrm{~mm})$ indicates that the shrubs had little difficulty accessing ground water.

DAY OF YEAR

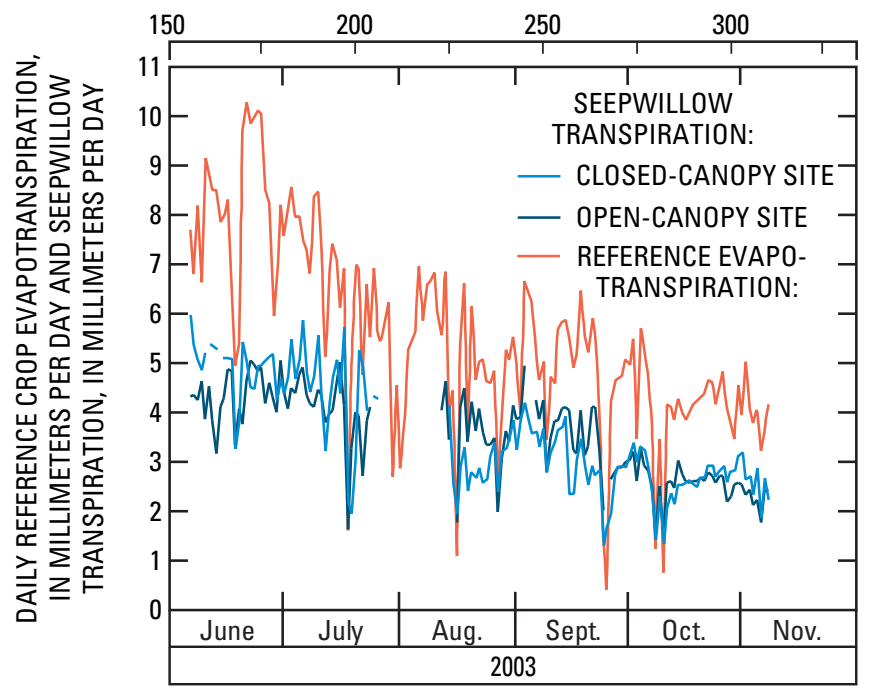

Figure 68. Comparison of seepwillow transpiration with reference crop evapotranspiration at the Lewis Springs site, 2003, San Pedro Riparian National Conservation Area, Upper San Pedro Basin, Arizona. 


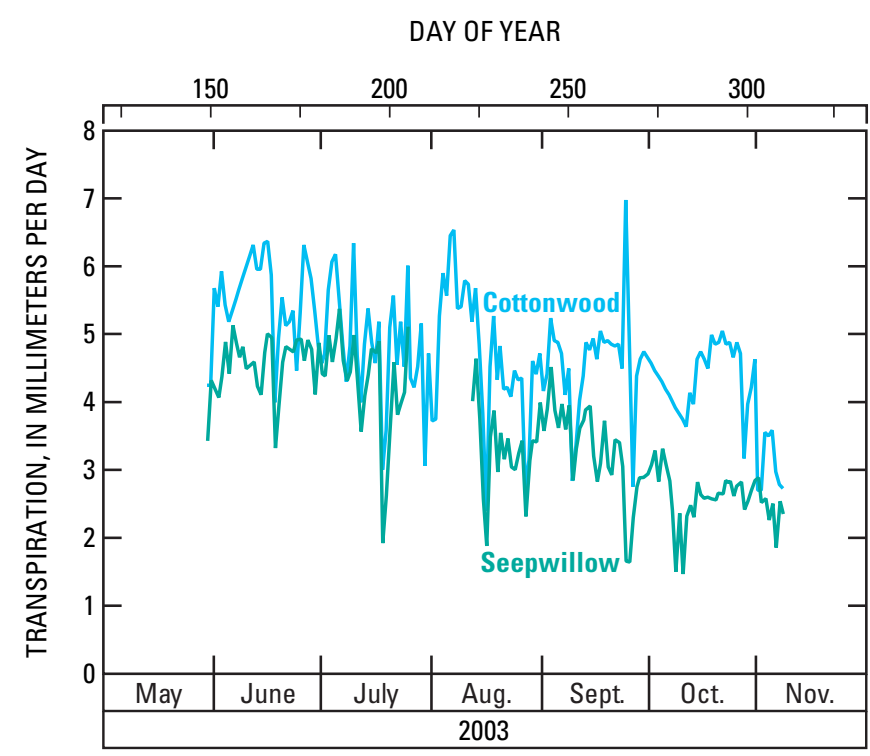

Figure 69. Comparison of seepwillow with cottonwood transpiration at the Lewis Springs site, 2003, San Pedro Riparian National Conservation Area, Upper San Pedro Basin, Arizona.
The total amount of understory vegetation consisting of major ground-water-using species like seepwillow and sacaton could not be computed from the VEG00 map in this study. Nonetheless, biohydrology transect vegetation surveys and reach information can be used to compute a rough estimate of seepwillow prevalence within the SPRNCA (chapter C and table 48). This preliminary work shows that the amount of seepwillow within the SPRNCA was small in comparison with the other major cover types (tables 48 and 49).

Seepwillows were not included in the total consumptiveuse calculations owing to the small amount of area that they covered. Nonetheless, if one considers the consumptive use of seepwillow along with the additional flood-plain understory plants like sacaton that probably were using ground water, the overall SPRNCA consumptive-use estimates would increase. Unfortunately, seepwillow, along with these other understory ground-water-using plants, were not accounted for in the VEG00 map of dominant vegetation communities (U.S. Army Corps of Engineers, 2001) because the understory plants were often obscured by the overstory canopy in the aerial imagery used to construct the map. Thus, an accurate quantification of this component of the SPRNCA water use was not possible in this study.

Table 48. Reach length, average flood-plain width, seepwillow percent cover, and estimated total seepwillow amount for each reach, San Pedro Riparian National Conservation Area, Upper San Pedro Basin, Arizona

[Derived from data in chapter $\mathrm{C}$ and appendix 7, table 7-G]

\begin{tabular}{ccccc}
\hline Reach number & $\begin{array}{c}\text { Reach length } \\
\text { (kilometers) }\end{array}$ & $\begin{array}{c}\text { Flood-plain } \\
\text { width } \\
\text { (meters) }\end{array}$ & $\begin{array}{c}\text { Seepwillow cover } \\
\text { (percent) }\end{array}$ & $\begin{array}{c}\text { Seepwillow } \\
\text { amount } \\
\text { (hectares) }\end{array}$ \\
\hline 1 & 8.1 & 203 & 2.05 & 3.4 \\
2 & 7.6 & 155.5 & 2.1 & 2.5 \\
3 & 6.1 & 185 & 3.4 & 3.8 \\
4 & 2.3 & 305 & 1.7 & 1.2 \\
5 & 6.5 & 175 & 1.8 & 2.0 \\
6 & 3 & 269 & 2.1 & 1.7 \\
7 & 4.1 & 64 & 1.3 & .3 \\
8 & 5.8 & 112.5 & 3.9 & 2.5 \\
9 & 3.1 & 83 & 4.75 & 1.2 \\
10 & 1.9 & 140 & 1.8 & .5 \\
11 & 2.1 & 63 & 4.7 & .6 \\
12 & 4.7 & 350 & 4.7 & 7.7 \\
13 & 3.9 & 306 & 1.2 & 1.4 \\
14 & 2.5 & 143 & 2.7 & 1.0 \\
\hline
\end{tabular}


Table 49. Estimated riparian canopy area, open-water area, and ground-water use for 2003 along the main stem of the San Pedro River, San Pedro Riparian National Conservation Area, Upper San Pedro Basin, Arizona

$\left[\mathrm{m}^{3} / \mathrm{yr}\right.$, cubic meters per year; ranges in values reflect uncertainty in the actual vegetation areas; $<$, less than]

\begin{tabular}{|c|c|c|c|}
\hline Cover type & $\begin{array}{c}\text { Cover amount } \\
\text { (hectares) }\end{array}$ & $\begin{array}{l}\text { Ground-water use } \\
\left(\mathrm{m}^{3} / \mathrm{yr} \times 1,000\right)\end{array}$ & $\begin{array}{l}\text { Ground-water use } \\
\text { (acre-feet per year) }\end{array}$ \\
\hline Mesquite & $1,154-1,456$ & $7,953-10,035$ & $6,448-8,135$ \\
\hline Cottonwood-willow (intermittent streamflow site) & 177 & 726 & 588 \\
\hline Sacaton (where ground water is $<3 \mathrm{~m}$ deep) & $113-168$ & $650-967$ & $527-784$ \\
\hline Tamarisk & $72-108$ & $496-744$ & $402-603$ \\
\hline TOTAL & & $13,113-15,759$ & $10,630-12,775$ \\
\hline
\end{tabular}

\section{Channel Evaporation}

The daily variation in the mean small-pan evaporation rates and ET correlated well (fig. 70). Previously, Goodrich, Scott, and others (2000) estimated open-water evaporation as a constant fraction (0.6) of the Penman open-water evaporation amount to account for the more shaded streamside environment:

$$
E_{o w}=\alpha E_{p}
$$

where

$$
\begin{aligned}
E_{o w} & =\text { the open water evaporation }(\mathrm{mm} / \mathrm{d}) \\
\alpha & =\text { is the reduction factor, and } \\
E_{p} & =\text { the Penman potential evaporation }(\mathrm{mm} / \mathrm{d}) .
\end{aligned}
$$

This study reveals that the average ratio between $\mathrm{ET}_{\mathrm{o}}$ and the measured evaporation was 0.65 . The total amount of water lost to evaporation from the open-water surface in 2003 was computed to be $1,156 \mathrm{~mm}$; the sum of the yearly $\mathrm{ET}_{\mathrm{o}}$ was $1,781 \mathrm{~mm}$. By using this site-specific relation for the entire open-water surface within the SPRNCA is a gross simplification as site-specific conditions that would affect the evaporation rate (for example, the degree of canopy shading or amount of entrenchment) are highly heterogeneous. Fortunately, the amount of open-water surface is small (table 49) compared to the vegetation community amounts, so additional refinements in the open-water evaporation estimate were not warranted.

\section{Riparian Corridor Ground-Water Use}

The preceding sections provide detailed results of the site-specific water-use measurements that were carried out for this study. The following information documents how these results were scaled up to estimate total ground-water use for various portions of the Upper San Pedro Basin.

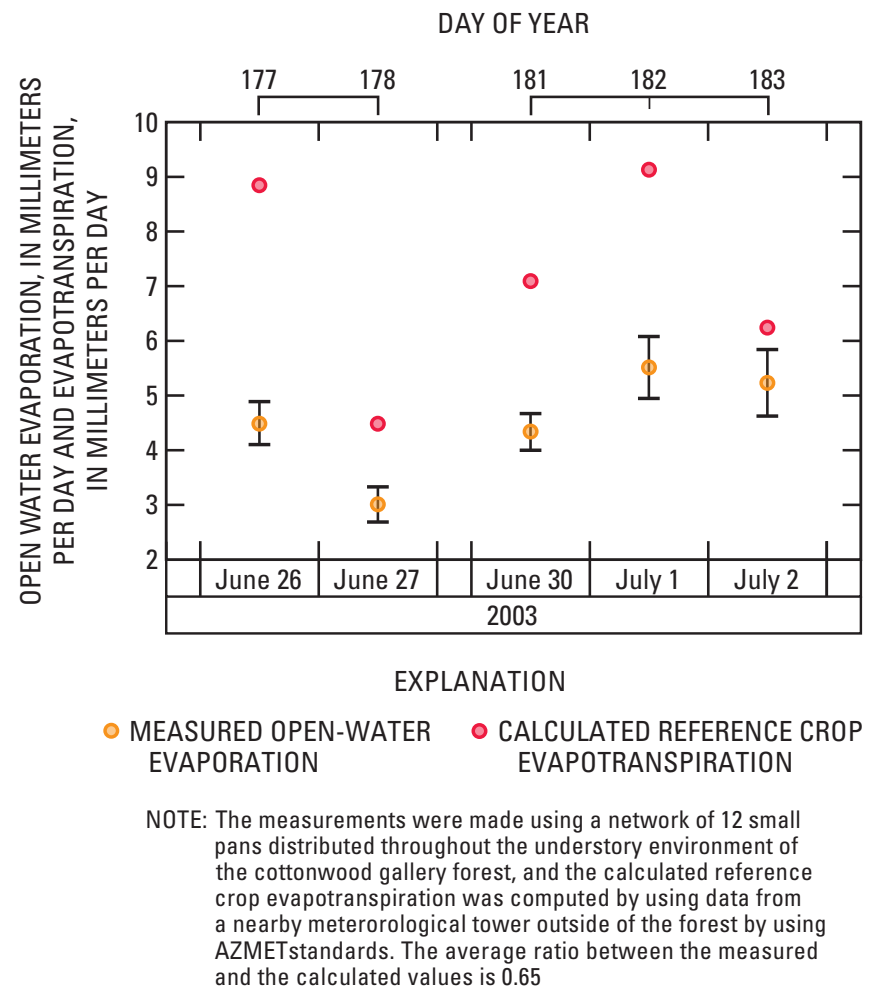

Figure 70. Measured (with plus or minus one standard error) open-water evaporation compared to calculated open-water evaporation at the Lewis Springs site, 2003, San Pedro Riparian National Conservation Area, Upper San Pedro Basin, Arizona. 


\section{Ground-Water Use Rates}

Consumptive ground-water use was determined for 2003 because simultaneous measurements of the cottonwood forest, sacaton grassland, and mesquite shrubland were available only during that year. Only the 2003 measurements from the mesquite woodland were used in this exercise so that all the revised estimates came from the same growing season. An alternative to choosing one year to estimate water use would be to use these measurements to build and calibrate component models of each vegetation functional group (for example, cottonwoods along intermittent reaches), that could be used to model water use in any given year that meteorological data and amount of each cover type were available to drive the models. This alternative was not selected because (1) not enough data were collected (with the possible exception of data for the mesquite woodland site) to capture interannual variability, and (2) the incorporation of modeling would only lead to more uncertainty in the results. Future data collection and analysis may lead to a point where the factors that determine the water-use rates can be understood accurately, and then this understanding can be incorporated into in a model environment

The following list summarizes how the component ground-water use estimates in this study (table 50) were derived.

1. Mesquite. All mesquite within the riparian corridor of the SPRNCA were assumed to have the same ground-water use in 2003 as that of mesquite at the Charleston mesquite site ("Mesquite Woodland" section). The ground-water use rate per unit mesquite canopy area was derived from the growingseason water budget (table 47) and was equivalent to that of the mesquite shrubland site. The 2003 ground-water use derived from the water-balance calculation was used because (1) all other vegetation ET measurements were only available in 2003, (2) the isotope-partitioning method results were based on regression models using data collected only in 2001 and 2002, and (3) the water-balance method involved fewer assumptions. Using the water-balance calculation will probably result in a 2003 estimate that is conservatively high given the possible effects of hydraulic redistribution by the mesquite throughout the deeper vadose zone. Additionally, there are younger, smaller mesquite trees within SPRNCA (but outside the study sites) that are of insufficient size to tap into the ground water but nevertheless are part of the total mesquite area.

2. Cottonwood-willow (at perennial-streamflow locations). All cottonwood-willow stands along mostly perennial reaches where the maximum depth to ground water was estimated not to exceed $3 \mathrm{~m}$ (chapter $\mathrm{C}$, table 15) were assigned the growing-season total water use estimated by the
2003 sap-flow studies at the Lewis Springs site ("Cottonwood Water Use" section). The portions of the SPRNCA that met these qualifications were delineated by the biohydrology reaches $2-7$ (fig. 19). Isotopic data (Snyder and Williams, 2000) suggest that the cottonwoods at the Lewis Springs site derived most of their water from ground water. Thus, it was assumed that the seasonal total water use of the cottonwoods along reaches 2-7 was derived completely from ground water.

3. Cottonwood-willow (at intermittent-streamflow locations). All cottonwood-willow stands along intermittent reaches where the maximum depth to ground water exceeded $3 \mathrm{~m}$ were assigned the growing-season total water use estimated by the 2003 sap-flow studies at the Boquillas site ("Cottonwood Forests" section). The reach definitions and information in chapter $\mathrm{C}$ were used to assign this category to trees in reaches 1, and 8-14 (fig. 19). All the water used by these trees prior to the start of the monsoon was assumed to be derived from ground water and that 70 percent of the daily total transpiration between the start of the monsoon and leaf senescence was derived from ground water. Isotopic data collected by Snyder and Williams (2000) from a cottonwood site with similar groundwater depths supports this ground-water source apportionment. In 2003, multiple sapwood-tissue samples for isotopic source-water analysis were collected; these results, when available, should help to refine the fraction of total cottonwood water use supplied by ground water at both sites. The estimated total ground-water use of cottonwood-willow was about $410 \mathrm{~mm}$ (table 50), which is 84 percent of the total season transpiration of $484 \mathrm{~mm}$.

4. Sacaton (located where depth to ground water was $3 \mathrm{~m}$ or less). The total canopy area of sacaton grasslands where the estimated depth to ground water was $3 \mathrm{~m}$ or less was assumed to have the 2003 ground-water use $\left(Q_{v e g}\right)$ of the sacaton grassland at the Lewis Springs site (see the "Mesquite Shrubland and Sacaton Grassland" section). The region where the estimated depth to ground water was less than $3 \mathrm{~m}$ was delineated by using LiDAR measurements and GIS analysis (see the "Determining Total SPRNCA Water Use" section) to determine the area that fell within the $3 \mathrm{~m}$ contour height above the cross-section low point-assuming that the water table perpendicular to the thalweg had the same elevation as the biohydrology transect low point. The amount of sacaton within this area was estimated by intersecting this delineated region with the vegetation (VEG00) map. LiDAR data were not available for the Babocomari River, the major tributary of the San Pedro River within the SPRNCA. For the Babocomari River, only the sacaton within the vegetation map that had 81 to 100 percent canopy cover was includedassuming that these dense sacaton areas probably 
had access to ground water. The ground-water-use rate per unit sacaton canopy area was derived from the growing season water budget (table 47).

5. Tamarisk. Because tamarisk was not measured in this study, it was assumed that these trees had a water use equal to that of the mesquite. Reasons for this assumption are that both types of tree have a similar stand structures and both are able to acquire ground water from deeper sources than cottonwoods. Dahm and others (2002) reported a total ET of 740-760 mm per year for a medium-density stand of tamarisk along the Middle Rio Grande, New Mexico, though they did not estimate how ET was partitioned between surface-water and ground-water sources. The Dahm and others (2002) ET estimate was about $300 \mathrm{~mm}$ less than that for a dense stand of tamarisk and a mature cottonwood stand growing along the same reach. Measurements of mesquite ET and cottonwood ET along a perennial reach differed by a similar amount.

6. Open Water. Open-water evaporation estimates were derived from the total 2003 reference crop evapotranspiration, $\mathrm{ET}_{\mathrm{o}}$, calculated by using data from the meteorological tower at Lewis Springs (appendix 8). These estimates were multiplied by a factor of 0.65 , which represents the ratio of average small-pan evaporation rate near or within the streambank to the calculated ET (see the "Seepwillow and Open Water Evaporation" section). Since measurements were only made during one part of the year, the ratio of reference-crop ET to open-water evaporation was assumed to be constant throughout the year.

Table 50. Ground-water use rates by vegetation type per unit vegetation area for 2003, Upper San Pedro Basin, Arizona

[Amounts represent yearly total ground-water use per unit vegetation area]

\begin{tabular}{lc}
\hline \multicolumn{1}{c}{ Cover type } & $\begin{array}{c}\text { Annual ground-water use } \\
\text { during 2003 } \\
\text { (millimeters) }\end{array}$ \\
\hline Mesquite & 689 \\
$\begin{array}{l}\text { Cottonwood-willow } \\
\text { (perennial-streamflow site) }\end{array}$ & 966 \\
$\begin{array}{l}\text { Cottonwood-willow } \\
\text { (intermittent-streamflow site) }\end{array}$ \\
$\begin{array}{l}\text { Sacaton } \\
\quad \text { (where ground water is } \\
\text { less than 3 meters deep) }\end{array}$ \\
\begin{tabular}{l} 
Open water \\
\hline
\end{tabular}
\end{tabular}

\section{Vegetated and Open Water Areas}

The change from the pixel-based vegetation map, VEG97, used by Goodrich, Scott, and others (2000), to the polygon-based GIS coverage, VEG00 (U.S. Army Corps of Engineers, 2001), used in this study, resulted in large changes in interpreted vegetation and open-water areas. As an example of this shift, there was a distinct change in the total amount of area covered by each of four groundwater-using groups along the San Pedro River between the USGS gaging stations at Palominas and near Tombstone (table 51). The ranges specified in the VEG00 map represent the minimum and maximum percents of vegetation cover. The amount of riparian vegetation was calculated as the product of total polygon area and percent cover (single value or range). The open-water area used in calculations is the entire openwater polygon area on the VEG00 map. For the areas listed in table 51, all cottonwood-willow polygons had an exact area assigned to them, which was not the case for the sacaton and mesquite polygons.

Table 51. Total canopy or open-water area covered by the ground-water-using groups along the San Pedro River between the U.S. Geological Survey streamflow-gaging stations San Pedro River at Palominas (09470500) and San Pedro River near Tombstone (09471550) using the maps of Goodrich, Scott, and others (2000) and this study, Upper San Pedro Basin, Arizona

\begin{tabular}{|c|c|c|}
\hline \multirow[b]{3}{*}{ Cover type } & \multicolumn{2}{|c|}{ Vegetation map } \\
\hline & VEG97 & VEGOO \\
\hline & \multicolumn{2}{|c|}{$\begin{array}{l}\text { Aerial coverage } \\
\text { (hectares) }\end{array}$} \\
\hline Mesquite & 1,166 & $718-964$ \\
\hline Cottonwood-willow & 526 & 308 \\
\hline $\begin{array}{l}\text { Sacaton (where ground water is } \\
\text { less than } 3 \text { meters deep) }\end{array}$ & 382 & $362-512$ \\
\hline Open-water & 5 & 41 \\
\hline
\end{tabular}

In this chapter, the uncertainty in the vegetation amounts was accounted for by computing a range of water use for each plant functional type. This range was computed by multiplying the minimum and maximum vegetation areas by the appropriate water-use amounts. The change in amount of vegetation between the VEG97 and VEG00 maps will result in a large change in the water-use amounts from those previously estimated by Goodrich, Scott, and others (2000). The magnitude of this change (about 40 percent for some vegetation types and 800 percent for open water) was as large as that for any change resulting from this study's refinement of plant ground-water use. Although there have been some 
natural vegetation cover changes from 1997 to 2000, mainly due to fires, it is unlikely that vegetation cover differences between the VEG97 and VEG00 maps truly reflects change in the SPRNCA environment.

\section{Riparian Corridor Ground-Water Use}

The total amount of riparian cover for (1) the San Pedro River's riparian corridor from the southernmost boundary of the SPRNCA to the northernmost boundary (table 49), (2) the San Pedro River's riparian corridor from the United States' international border with Mexico to the USGS gaging station near Tombstone (table 52), and (3) the Babocomari River's riparian corridor (table 53) were multiplied by their respective ground-water consumptiveuse rates (table 50) to determine total ground-water use (tables 49, 52, and 53). The amount of riparian vegetation within the private land inholdings just south of the Charleston Bridge site is included in the vegetation totals for the San Pedro River reaches (tables 49 and 52), but the amount of ground-water-using vegetation within these lands was only 7.7 ha because most of the riparian corridor fell outside of the property boundaries. It is important to include the Babocomari River's riparian vegetation water use within the water budget of the Sierra Vista watershed (even though a large part of the Babocomari River lies outside the SPRNCA) because the water use is significant.
Overall, mesquite ground-water use was the dominant component of the water budget with cottonwood-willow, open water, sacaton, and tamarisk ground-water use, respectively, being of decreasing importance. For ground-water use in the entire SPRNCA no previous estimates were available for comparison. This study's 2003 estimate for groundwater use along the San Pedro River from the United States' international border with Mexico to the streamflow-gaging station near Tombstone (table 49) was 4 to 27 percent higher than that of Corell and others (1996) and 12 to 37 percent higher than that of Goodrich, Scott, and others (2000).

The estimate of Corell and others (1996) for 1985-91 was derived from a base-flow analysis. This study's estimate of annual ground-water use along the Babocomari River (table 53) was larger than Corell and others' (1996). The estimates of Goodrich, Scott, and others (2000) were based on data collected in 1997; estimates for this study are higher owing to the new vegetation map and new water-use estimates. The total annual riparian ground-water use for the Sierra Vista Subwatershed was $11,840,000-14,867,000 \mathrm{~m}^{3} / \mathrm{yr}(9,600-12,055$ acre-ft/yr; tables 52 and 53), which is 25 to 57 percent greater than the $9,498,000 \mathrm{~m}^{3} / \mathrm{yr}(7,700 \mathrm{acre}-\mathrm{ft} / \mathrm{yr})$ estimated by Corell and others (1996). Given the disparity between results calculated in this study and the results of Corell and others (1996), a beneficial element of future studies would be to examine whether ground-water-use rates determined for the major San Pedro River vegetation types can be extrapolated to the Babocomari River, as this study assumed, and further investigate and validate the two vegetation maps.

Table 52. Estimated riparian canopy area, open-water area, and ground-water use for 2003 along the main stem of the San Pedro River from the international border with Mexico to the U.S. Geological Survey streamflow-gaging station, San Pedro River near Tombstone (09471550), Upper San Pedro Basin, Arizona

[Ranges in values reflect uncertainty in the actual vegetation areas]

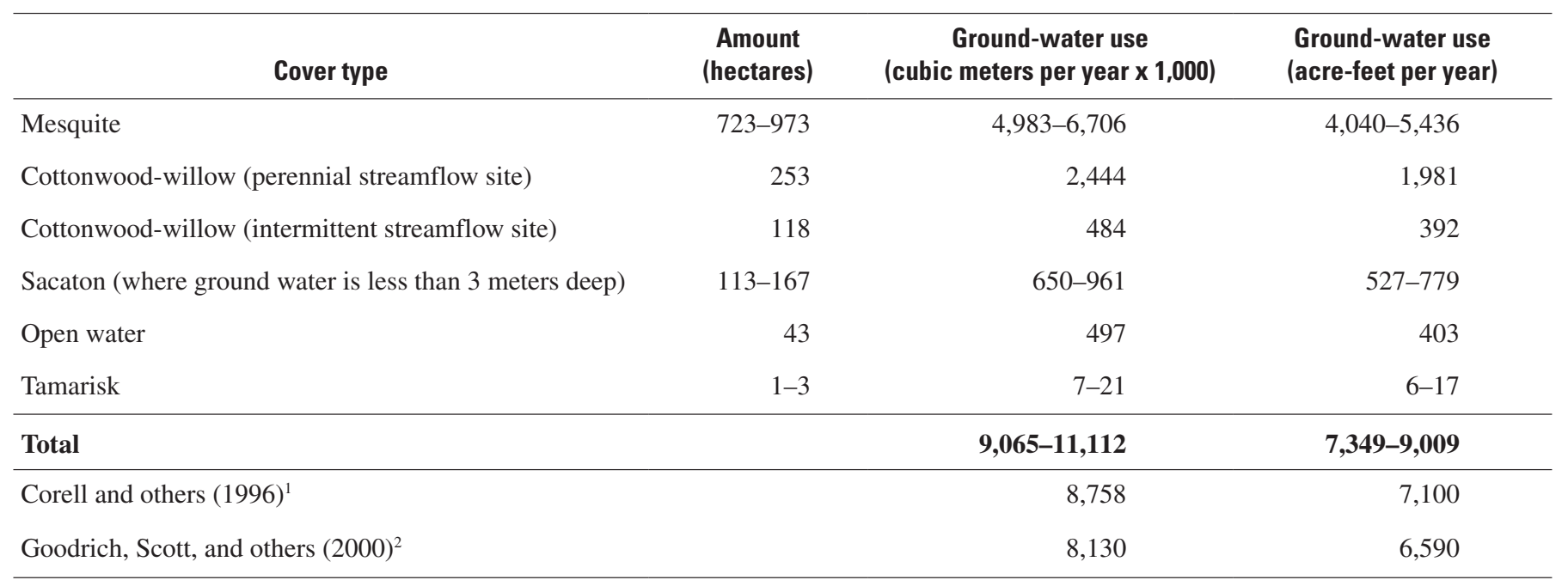

\footnotetext{
${ }^{1}$ By using base flow information from the U.S. Geological Survey streamflow-gaging stations, San Pedro River at Palominas (09470500), San Pedro River at Charleston (09471000), and San Pedro River near Tombstone (09471550) and subtracting the Corell and others (1996) estimate of 600 acre-feet per year for the Babocomari River.

${ }^{2}$ From the international border with Mexico to the U.S. Geological Survey streamflow-gaging station, San Pedro River near Tombstone (09471550).
} 
Table 53. Estimated Babocomari riparian canopy area, open-water area, and ground-water use for 2003, Upper San Pedro Basin, Arizona

[Ranges in values reflect uncertainty in the actual vegetation areas]

\begin{tabular}{|c|c|c|c|}
\hline Cover type & $\begin{array}{c}\text { Amount } \\
\text { (hectares) }\end{array}$ & $\begin{array}{c}\text { Ground-water use } \\
\text { (cubic meters per year x } 1,000 \text { ) }\end{array}$ & $\begin{array}{l}\text { Ground-water use } \\
\text { (acre-feet per year) }\end{array}$ \\
\hline Mesquite & $223-335$ & $1,539-2,311$ & $1,248-1,874$ \\
\hline Cottonwood-willow (intermittent streamflow site) & 71 & 292 & 237 \\
\hline Open water & 5 & 61 & 50 \\
\hline Tamarisk & 0 & 0 & 0 \\
\hline Total & & $2,775-3,755$ & $2,250-3,044$ \\
\hline Corell and others (1996) & & 740 & 600 \\
\hline
\end{tabular}

${ }^{1}$ Defined as all sacaton polygons within the vegetation map that had 81 to 100 percent dominant canopy cover. Data were not available to estimate depth to ground water along the Babocomari River.

The study's water-use calculations are based on 2003 measurements; it is important to keep in mind that the mesquite water use varied from year to year (as much as 30 percent less, relative to 2003) during the 3 years mesquite-ET data were collected for this study. Seasonal variability were the climatic drivers that determine the length of the growing season, the amount of rainfall, and the atmospheric-evaporation demand. It is reasonable to expect that consumptive use by other vegetation communities would have similar variability. Interpretation of the limited period of record collected for this study indicates that ground-water use for 2003 probably was higher than what might be expected for 2001 and 2002 owing to the longer growing season (see appendix 8, table 8-B) and the smaller amount of winter and monsoon precipitation.

\section{Summary}

The purpose of this portion of the Upper San Pedro Partnership water-needs study was to provide improved estimates of ground-water use by the riparian vegetation and open water surface within the SPRNCA and within the Sierra Vista Subwatershed (see chapter A). Improved knowledge will enhance understanding of the riparian ET and the role of riparian vegetation ground-water use in the Upper San Pedro Basin's water budget. The approach used in this study was to make new, direct measurements of ET from dominant ecosystem types within the SPRNCA that are the principal components of the riparian ground-water demand. Estimates of ET partitioning between surface-water or ground-water sources were coupled with measurements of
ET. Then, these revised and refined estimates of ecosystem ground-water use were combined with a new vegetation map of the SPRNCA and of the Babocomari River, the major tributary of the Upper San Pedro River, to extrapolate the local ET measurements across the basin to estimate total riparian ground-water use. The following improvements were made to the most recent estimates (Goodrich, Scott and others, 2000) of ground-water use along the San Pedro River:

Mesquite Woodland and Shrubland.- Mesquite is the most spatially extensive vegetation type within the San Pedro River's riparian corridor, yet its water use was identified as the most uncertain. The current study made multiyear ET observations from a mature mesquite woodland (Charleston mesquite site) and a mesquite shrubland (Lewis Springs site) and found that (1) both used substantially more water than previously estimated, and (2) their water use was nearly equal on a per unit canopy area basis between sites. Stable-isotope measurements revealed considerable seasonal variation in the proportion of mesquite transpiration derived from ground water at several sites. Mesquite used a combination of surface-water (recent precipitation) and ground-water sources. A third source of water for mesquites was the deep (1-10 m below surface) vadose zone, where water likely was contributed both from surface-water and ground-water sources. The use of surface-water, ground-water, and deep vadose-zone sources depended on the availability of the sources through the season. There was a tendency toward proportionally less ground-water use in mesquite stands that had comparatively less access to ground water (deeper water table). Nevertheless, all mesquite used substantial quantities of ground water. Total annual ground-water use by a mesquite woodland at the Charleston mesquite site was determined by using two 
methods (water-budget method and isotope-partitioning method), and the values were not in agreement. Recent studies at this site reveal that mesquite can redistribute significant amounts of water between deep and shallow soil layers during winter and summer months through its extensive root system (Hultine and others, 2004). This redistribution process likely was a reason for the disagreement in the water-use values. At this time, a way to quantify how much water was redistributed by the mesquite or whether the source of deep vadose-zone moisture was from precipitation or ground-water sources was not available. The water-balance approach did not account for the redistribution effects and resulted in seasonal ground-water use amounts for the mesquite woodlands of $488 \mathrm{~mm}$ in 2001, $394 \mathrm{~mm}$ in 2002, and $510 \mathrm{~mm}$ in 2003 (per unit ground area, table 42), which were about 50 percent higher than the estimates based on isotopic analyses (table 45). The value calculated by using the water-balance approach was used in the subsequent estimates of riparian corridor groundwater use because the water balance approach involved fewer assumptions and less extrapolation of the data collected. This water-use value likely was conservatively high because the possible redistribution of antecedent rainfall was ignored by using this approach.

Cottonwood Forest. - The current study measured sap flow during most of the 2003 growing season to estimate transpiration at perennial streamflow (Lewis Springs) and intermittent streamflow (Boquillas) sites. A cottonwood stand at the perennial reach transpired $966 \mathrm{~mm}$, about 20 percent more water on a per canopy area basis than previous estimates. A cottonwood stand at the intermittent site transpired $484 \mathrm{~mm}$ in 2003, considerably less water than at the perennial site, and had greatly reduced rates of transpiration as the water table declined in the premonsoon period. Low rates of cottonwood forest transpiration at the intermittent site were a result of: (1) physiological stress acting on stomatal conductance of leaves, and (2) the sparse density of leaves at the stand level. Roughly 40 percent of the cottonwood forests in the SPRNCA were classified as being on intermittent reaches. Cottonwood source water sampling results (Snyder and Williams, 2000) indicate that all of the $966 \mathrm{~mm}$ of perennial site cottonwood transpiration was derived from ground water. Cottonwood ET at the intermittent site used $410 \mathrm{~mm}$ of ground water.

Sacaton.- The current study revealed that a sacaton grassland used $374 \mathrm{~mm}$ of ground water in 2003. The ground-water use of sacaton contradicted previous understanding. The depth to ground water at the Lewis Springs sacaton study site was less than about $3 \mathrm{~m}$, and this likely was the reason for the discrepancy with the previous findings. The area where the land-surface elevation was within $3 \mathrm{~m}$ of the river stage was used as an estimate of the area where the depth to ground water was less than $3 \mathrm{~m}$. The amount of sacaton within this area was determined by intersecting this delineated region with the vegetation map. About 30 percent of the total sacaton grassland area within the SPRNCA fell within this region. The sacaton within the $3 \mathrm{~m}$ depth to ground-water boundary was assumed to have the ground-water use of the sacaton measured in the current study.

Open-Channel Evaporation.- Open-water evaporation on the San Pedro River was estimated by multiplying a potential evaporation rate (derived from meteorological data) by a factor to account for reduction in evaporation caused by entrenchment of the river and shading by riparian vegetation. The current study made measurements of small-pan evaporation distributed throughout the nearstream environment at one site to compute a reduction factor. By using these measurements, open-water evaporation in 2003 was computed to be $1,156 \mathrm{~mm}$.

Understory Species. - Seepwillow transpiration was measured by using sap-flow methods as a preliminary step toward quantifying seepwillow ground-water use, which had been ignored in previous studies. Vegetation measurements from the riparian biohydrology study (see chapter C) were used to estimate the amount of seepwillow within the SPRNCA. Measurements indicated that seepwillow transpiration on a per unit canopy area basis was nearly as large in magnitude as that for any of the major groundwater-using vegetation types studied in this report. Because total seepwillow cover along the SPRNCA was estimated to be low compared to other vegetation types, however, total consumptive use by seepwillow was small compared to the other components of the SPRNCA's ground-water use and was neglected from the ground-water use budgets.

Vegetation Mapping. - The use of a new vegetation map produced by the U.S. Army Corps of Engineers (2001) resulted in large changes in the computed amounts of vegetation within the SPRNCA. The new map provided a range for percent cover of the dominant vegetation type in each polygon; therefore, the exact amount of vegetation could not be calculated. The new map was clipped to the approximate extent of the riparian corridor. Reach-level information from the riparian biohydrology study (see chapter C) was used to enumerate the amount of cottonwood-willow forest that occurred along perennial or intermittent reaches. An additional calculation delineated the sacaton grasslands that occurred in regions having elevations equal to or less than $3 \mathrm{~m}$ of the river stage in order to delineate sacaton that used ground water.

Total Riparian Vegetation Ground-Water Use for the SPRNCA and the Sierra Vista Subwatershed.-

Total vegetation and open-water areas were multiplied by their respective ground-water-use rates as determined by measurements made in 2003 to determine riparian ground-water use. For 2003, the total ground-water use by riparian vegetation within the SPRNCA was 13,113,000-15,759,000 m³ (10,630-12,775 acre-ft). Mesquite ground-water use was the dominant component of the water budget followed by cottonwood-willow, open water, sacaton, and tamarisk ground-water use, in that order. This study's estimate of the riparian ground-water use along the San Pedro River from the 
United States' international border with Mexico to the gaging station near Tombstone (within the Sierra Vista Subwatershed) for 2003 was 9,065,000-11,112,000 m³ (7,350-9,010 acre-ft). This estimate is 12 to 37 percent higher than the estimate of Goodrich, Scott, and others (2000) for 1997 owing to the combination of using the new vegetation map and the new water-use estimates. Corell and others (1996) estimated an average of 8,758,000 $\mathrm{m}^{3} / \mathrm{yr}$ (7,100 acre-ft/yr) for this reach for 1985-91. Combining results for the Babocomari River and the San Pedro River, this study estimated that $11,840,000-14,867,000 \mathrm{~m}^{3}$

$(9,600-12,055$ acre-ft) of ground water was consumptively used by the riparian corridor within the Sierra Vista Subwatershed in 2003. This was 25 to 57 percent greater than the $9,498,000 \mathrm{~m}^{3} / \mathrm{yr}(7,700$ acre-ft/yr) of Corell and others (1996) owing in part to a large disparity between the estimates for the Babocomari River. It is important to recognize the influence of interannual climatic variability on these estimates. For example, interpretation of only 3 years of data, show that the annual mesquite ground-water use varied by as much as 30 percent (relative to 2003). It is reasonable to expect that the functioning of other vegetation communities are similarly affected by climate variability and that the riparian water use fluctuates to a similar degree. 


\section{References Cited}

Abernethy, B., and Rutherfurd, I.D., 2000, The effect of riparian tree roots on the mass-stability of riverbanks: Earth Surface Processes and Landforms, v. 25, p. 921-937.

Adams, D.K., and Comrie, A.C., 1997, The North American monsoon: Bulletin of the American Meteorological Society, v. 78, p. 2197-2213.

Ali, M.M., Dickinson, G., and Murphy, K.J., 2000, Predictors of plant diversity in a hyper arid desert wadi ecosystem: Journal of Arid Environments, v. 45, p. 215-230.

Amlin, N.M., and Rood, S.B., 2002, Comparative tolerances of riparian willows and cottonwoods to water-table decline: Wetlands, v. 22, p. 338-346.

Anderson, B.W., Higgins, A., and Ohmart, R.D., 1977, Avian use of saltcedar communities in the Lower Colorado River Valley, in Johnson, R.R., and Jones, D.A., technical coordinators, Importance, preservation and management of riparian habitat-A symposium: U.S. Department of Agriculture Forest Service General Technical Report RM-43, p. 128-136.

Anderson, B.W., 1995, Salt cedar, revegetation and riparian ecosystems in the Southwest in Lovitch, J., Randall, J., and Kelley, M., eds., California Exotic Pest Plant Council, Proceedings: Pacific Grove, California, Califiornia Exotic Pest Plant Council, p. 1-16.

Arias, H.M., 2000, International groundwaters-The Upper San Pedro River Basin case: Natural Resources Journal, v. 40, p. 199-221.

Arizona Riparian Council, 2004, International Institute for Sustainability, Arizona State University, Tempe, Arizona, accessed January 17, 2005 at http://azriparian.asu.edu/.

Bagstad, K. J., Stromberg, J. C., and Lite, S. J., 2005, Response of herbaceous riparian plants to rain and flooding of the San Pedro River, Arizona: Wetlands, v. 25, no. 1, p. 210-223.

Baker, W.L., 1990, Species richness of Colorado riparian vegetation: Journal of Vegetation Science, v. 1, p. 19-124.

Beeson, C.E., and Doyle, P.F., 1995, Comparison of bank erosion at vegetated and non-vegetated channel bends: Water Resources Bulletin 31, p. 983-990.

Blackburn, W.H., Knight, R.W., and Schuster, J.L., 1982, Saltcedar influence on sedimentation in the Brazos River: Journal of Soil and Water Conservation, v. 37, p. 298-301.

Blais, P.A., and Lechowicz, M.J., 1989, Variation among populations of Xanthium strumarium (Compositae) from natural and ruderal habitats: American Journal of Botany, v. 76 , p. $901-908$.
Blanken, P.D., Black, T.A., Yang, P.C., Neumann, H.H., Nesic, Z., Staebler, R., den Hertog, G., Novak, M.D., and Lee, X., 1997, Energy balance and canopy conductance of a boreal aspen forest-Partitioning overstory and understory components: Journal of Geophysical Research, v. 102, p. $28,915-28,927$.

Blasch, K.W., Ferré, P.A., Christensen, A.H., and Hoffmann, J.P., 2002, New field method to determine stream-flow timing using electrical resistance sensors: Vadose Zone Journal, v. 1, no. 2, p. 289-299.

Brinson, M.M., Hauer, F.R., Lee, L.C., Nutter, W.L., Rheinhardt, R.D., Smith, R.D., and Whigham, D., 1995, A guidebook for application of hydrogeomorphic assessments to riverine wetlands in Technical report WRPDE-11: Vicksburg, Massachusetts U.S. Army Corps of Engineers Waterways Experiment Station, 219 p.

Brown, P.W., 1989. Estimating crop water use using weatherbased estimates of evapotranspiration, in Scherer, T., ed.,: Guide and reference for irrigation management and soil amendments, chap. 3, University of Arizona extension in-service training manual: Tucson, University of Arizona, $21 \mathrm{p}$.

Brown, S.G., Davidson, E.S., Kister, L.R., and Thomsen, B.W., 1966, Water resources of Fort Huachuca Military Reservation, southeastern Arizona: U.S. Geological Survey Water-Supply Paper 1819-D, p. D1-D57.

Burgess, T.L., 1995, Desert grassland, mixed shrub savanna, shrub steppe, or semidesert grassland? in McClaran, M.P., and Van Devender, T.R., eds., The desert grassland: Tucson, University of Arizona Press, p. 31-67.

Busch, D.E., Ingraham, N.L., and Smith, S.D., 1992, Water uptake in riparian phreatophytes of the Southwestern U.S.-A stable isotope study: Ecological Applications, v. 2, p. $450-459$.

Busch, D.E., 1995, Effects of fire on southwestern riparian plant community structure: Southwestern Naturalist, v. 40, p. 259-267.

Busch, D.E., and Smith, S.D., 1995, Mechanisms associated with the decline of woody species in riparian ecosystems of the Southwestern U.S.: Ecological Monographs, v. 65, p. $347-370$.

Capon, S.J., 2003, Plant community responses to wetting and drying in a large arid floodplain: River Research and Applications, v. 19, p. 9-520.

Chaplin, S.J., Gerrard, R.A., Watson, H.M., Master, L.L., and Flack, S.R., 2000, The geography of imperilment-Targeting conservation toward critical biodiversity areas, in Stein, B.A., Kutner, L.S., Adams, J.S., eds., Precious heritage-The status of biodiversity in the United States: New York, Oxford University Press, p. 159-200. 
Cinnirella, S., Magnani, F., Saracino, A., and Borghetti, M., 2002, Response of a mature Pinus, laricio plantation to a three-year restriction of water supply-Structural and functional acclimation to drought: Tree Physiology, v. 22, p. 21-30.

Constantz, J., Stonestrom, D., Stewart, A.E., Niswonger, R., and Smith, T., 2000, Analysis of streambed temperatures in ephemeral channels to determine stream flow frequency and duration: Water Resources Research, v. 37, no. 2, p. 317-328.

Cooper, D.J., Merritt, D.M., Andersen, D.C., and Chimner, R.A., 1999, Factors controlling the establishment of Fremont cottonwood seedlings on the upper Green River, USA: Regulated Rivers-Research and Management, v. 15, p. 419-440.

Cooper, D.J., D’Amico, D.R., and Scott, M.L., 2003, Physiological and morphological response patterns of Populus deltoides to alluvial groundwater pumping: Environmental Management, v. 31, p. 215-226.

Corell, S.W., Corkhill, F., Lovvik, D., and Putnam, F., 1996, A groundwater flow model of the Sierra Vista Subwatershed of the Upper San Pedro Basin-Southeastern Arizona, in Modeling report no. 10: Phoenix, Arizona Department of Water Resources, Hydrology Division, 107 p.

Cornwall, C., 1998, Stream stabilizing traits in common riparian graminoids from a semi-arid alluvial stream: Tempe, Arizona, Arizona State University, master's thesis, $75 \mathrm{p}$.

Cox, J., Morton, H.L., LaBaume, J.T., and Renard, K.G., 1983, Reviving Arizona's rangelands: Journal of Soil and Water Conservation, v. 38, p. 342-345.

Crandall, K., Colby, B., and Rait, K.A., 1992, Valuing riparian preserves-A Southwestern case study: Rivers, v. 3, p. 88-98.

Curtis, J.T., and McIntosh, R.P., 1951, An upland forest continuum in the prairie-forest border region of Wisconsin: Ecology, v. 32, p. 476-498.

Dahm, C.N., Cleverly, J.R., Allred Coonrod, J.E., Thibault, J.R., McDonnell, D.E., and Gilroy, D.J., 2002, Evapotranspiration at the land/water interface in a semi-arid drainage basin: Freshwater Biology, v. 47, p. 831-843.

Davis, G.P., Jr., 1982, Man and wildlife in Arizona-The American exploration period 1824-1865: Phoenix, Arizona, Arizona Game and Fish Department, 232 p.

Dawson, T.E., and Pate, J.S., 1996, Seasonal water uptake and movement in root systems of Australian phreatophytic plants of dimorphic root morphology-A stable isotope investigation: Oecologia, v. 107, p. 13-20.

Decocq, G., 2002, Patterns of plant species diversity and community diversity at different organization levels in a forested riparian landscape: Journal of Vegetation Science, v. 13, p. 91-106.
Department of Economic Security, 2003, July 1, 2003, population estimates for Arizona's counties, incorporated places and balance of county areas: Phoenix, Arizona Department of Economic Security, Population Statistics Unit, Research Administration, accessed November 17, 2005, at http://www.workforce.az.gov/admin/ uploadedPublications/1003_EEC-03.pdf

Dixon, M.D., and Johnson, W.C., 1999, Riparian vegetation along the middle Snake River, Idaho-Zonation, geographical trends, and historical changes: Great Basin Naturalist, v. 59, p. 18-34.

Donovan, L.A., and Ehleringer, J.R., 1991, Ecophysiological differences among juvenile and reproductive plants of several woody species: Oecologia, v. 86, p. 594-597.

Donovan, L.A., and Ehleringer, J.R., 1992, Contrasting wateruse patterns among size and life history classes of a semiarid shrub: Functional Ecology, v. 6, p. 482-488.

Donovan, L.A., Mausberg, J., and Ehleringer, J.R., 1993, Seedling size and survival for Chrysothamnus nauseosus: Great Basin Naturalist, v. 53, no. 3, p. 237-245.

Drewes, H., 1996, Geologic maps of the Coronado National Forest, southeast Arizona and southwest New Mexico: U.S. Geological Survey Bulletin 2083-B, p. 17-41.

Dunaway, D., Swanson, S.R., Wendel, J., and Clary, W., 1994, The effects of herbaceous plant communities and soil textures on particle erosion of alluvial streambanks: Geomorphology, v. 9, p. 47-56.

Ellis, L.M., 1995, Bird use of saltcedar and cottonwood vegetation in the Middle Rio Grande Valley of New Mexico, USA: Journal of Arid Environments, v. 30, p. 339-349.

Ellis, L.M., 2001, Short-term response of woody plants to fire in a Rio Grande riparian forest, Central New Mexico, USA: Biological Conservation, v. 97, p. 159-170.

Ellis, L.M., Crawford, C.S., and Molles, M.C., Jr., 1997, Rodent communities in native and exotic riparian vegetation in the middle Rio Grand Valley of central New Mexico: The Southwestern Naturalist, v. 42, p.13-19.

Ellis, L.M., Molles, M.C., and Crawford, C.S., 1999, Influence of experimental flooding on litter dynamics in a Rio Grande riparian forest, New Mexico: Restoration Ecology, v. 7, p. 193-204.

Elmore, A.J., Mustard, J.F., and Manning, S.J., 2003, Regional patterns of plant community response to changes in water-Owens Valley, California: Ecological Applications, v. 13, p. $443-460$.

Fenner, P., Brady, W.W., and Patton, D.R., 1984, Observations on seeds and seedlings of Fremont cottonwood: Desert Plants, v. 6, p. 55-58. 
Fleishman, E., Mcdonal, N., Mac Nally, R., Murphy, D.D., Walters, J., and Floyd, T., 2003, Effects of floristics, physiognomy and non-native vegetation on riparian bird communities in a Mojave Desert watershed: Journal of Animal Ecology, v. 72, no. 3, p. 484-490.

Fleming, J.B., Pool, D.R., and Leenhouts, J.M., 2002, Electrical resistivity surveys to define distributions of silt and clay layers near the San Pedro River, Sierra Vista subwatershed of the Upper San Pedro River Basin [abs]: in Environmental and Engineering Geophysical Society, Las Vegas, Nevada, February 13-15, 2002.

Force, E.R., 1996, The Bisbee group of the Tombstone Hills, southeastern Arizona-Stratigraphy, structure, metamorphism, and mineralization: U.S. Geological Survey Bulletin 2042-B, 22 p.

Fossati, J., Pautou, G., and Peltier, J.P., 1999, Water as resource and disturbance for wadi vegetation in a hyperarid area (Wasi Sannur, Eastern Desert, Egypt): Journal of Arid Environments, v. 43, p. 63-77.

Freethey, G.W., 1982, Hydrologic analysis of the Upper San Pedro Basin from the Mexico U.S. Boundary to Fairbank, Arizona: U.S. Geological Survey Open-File Report 82-752, 60 p.

Friedman, J.M., Osterkamp, W.R., and Lewis, W.M., 1996, Channel narrowing and vegetation development following a Great Plains flood: Ecology, v. 77, p. 2167-2181.

Galuszka, D.A., and Kolb, T.E., 2002, Tree growth and regeneration response to climate and stream flow in a species-rich southwestern riparian forest: Western North American Naturalist, v. 62, p. 266-279.

Gary, H.L., 1963, Root distribution of five-stamen tamarisk, seepwillow, and arrowweed: Forest Science, v. 9, p. 311-314.

Gettings, M.E., and Houser, B.B., 2000, Depth to bedrock in the Upper San Pedro Valley, Cochise County, southeastern Arizona: U.S. Geological Survey Open-File Report 00-138, accessed October 15, 2003, at http://geopubs.wr.usgs.gov/ open-file/of00-138/.

Gile, L.H., Gibbens, R.P., and Lenz, J.M., 1997, The nearubiquitous pedogenic world of mesquite roots in an arid basin floor: Journal of Arid Environments, v. 35, p. 39-58.

Glenn, E.P., and Nagler, P.L., 2005, Comparative ecophysiology of Tamarix ramosissima and native trees in western U.S. riparian zones: Journal of Arid Environments, v. 61 , no. 3, p. 419-446.

Glinski, R.L., and Brown, D.E., 1982, Mesquite (Prosopis juliflora) response to severe freezing in southeastern Arizona: Journal of the Arizona-Nevada Academy of Science, v. 17, p. 15-18.
Goode, T.C., and Maddock, T., III, 2000, Simulation of groundwater conditions in the upper San Pedro Basin for the evaluation of alternative futures: Tucson, University of Arizona, Department of Hydrology and Water Resources technical report HWR 00-030, 113 p.

Goodrich, D.C., Scott, R.L., and others, 2000, Seasonal estimates of riparian evapotranspiration using remote and in-situ measurements: Agricultural and Forest Meteorology, v. 105 , p. 281-309.

Goodrich, D.C., Chehbouni A., and others, 2000, Semi-Arid Land-Surface-Atmosphere (SALSA) Program special issue: Agricultural and Forest Meteorology, v. 105, nos. 1-3, p. 3-20.

Gordon, N.D., McMahon, T.A., and Finlayson, B.L., 1992, Stream hydrology-An introduction for ecologists: New York, John Wiley and Sons, 526 p.

Grace, J.B., 1989, Effects of water depth on Typha latifolia and Typha domingensis: American Journal of Botany, v. 76, p. 762-768.

Graf, W.L., 1978, Fluvial adjustments to the spread of tamarisk in the Colorado Plateau region: Geological Society of America Bulletin 89, p. 1491-1501.

Graf, W.L., 1988, Fluvial processes in dryland rivers: New York, Springer-Verlag, 346 p.

Graf, W.L., Stromberg, J., and Valentine, B., 2002, Rivers, dams, and willow flycatchers-A summary of their science and policy connections: Geomorphology, v. 47, nos. 2-4, p. 69-188.

Granier, A., 1985, Une nouvelle méthode pour la mesure des flux de sève brute dans le tronc des arbres: Annales des Sciences Forestieres, v. 42, p. 193-200.

Granier, A., 1987, Evaluation of transpiration in a Douglas fir stand by means of sap flow measurements: Tree Physiology, v. 3, p. 309-320.

Gray, R.S., 1965, Late Cenozoic sediments in the San Pedro Valley near St. David, Arizona: Tucson, University of Arizona, Ph.D. dissertation, 198 p.

Grime, J.P., 1973, Competitive exclusion in herbaceous vegetation: Nature, v. 242, p. 344-347.

Grime, J.P., 1974, Vegetation classification by reference to strategies: Nature, v. 250, p. 26-31.

Grime, J.P., 1977, Evidence for the existence of three primary strategies in plants and its relevance to ecological and evolutionary theory: American Naturalist, v. 111, p. 1169-1194.

Groeneveld, D.P., and Crowley, D.E., 1988, Root system response to flooding in three desert shrub species: Functional Ecology, v. 2, p. 491-497. 
Grossman, D.H., Faber-Langendoen, D., Weakly, A.S., Anderson, M., Bourgeron, P., Crawford, R., Goodin, K., Landaal, S., Metzler, K., Patterson, K.D., Pyne, M., Reid, M., and Sneddon, L., 1998, International classification of ecological communities-Terrestrial vegetation of the United States in the National Vegetation Classification System-Development, status, and applications: Arlington, Virginia, The Nature Conservancy, v. 1.

Gu, J., Smith, E.A., and Merritt, J.D., 1999, Testing energy balance closure with GOES-retrieved net radiation and insitu measured eddy correlation fluxes in BOREAS: Journal of Geophysical Research, v. 104, p. 27,881-27,893.

Halverson, P.H., 1984, An exploratory gravity survey in the upper San Pedro Valley, southeastern Arizona: Tucson, University of Arizona, master's thesis, 85 p.

Hastings, J.R., and Turner, R.M., 1965, The changing mile-An ecological study of vegetation change with time in the lower mile of an arid and semiarid region: Tucson, University of Arizona Press, 317 p.

Haycock, N.E., and Pinay, G., 1993, Groundwater nitrate dynamics in grass and poplar vegetated riparian buffer strips during the winter: Journal of Environmental Quality, v. 22, p. 273-278.

Hayes, P.T., 1970, Mesozoic stratigraphy of the Mule and Huachuca Mountains, Arizona: U.S. Geological Survey Professional Paper 658-A, 28 p.

Haynes, C.V., 1968, Preliminary report of the Late Quaternary geology of the San Pedro Valley, Arizona: Arizona Geological Society Guidebook III, p. 79-96.

Heitschmidt, H.K., Ansley, R.J., Dowhower, S.L., Jacoby, P.W., and Price, D.L., 1988, Some observations from the excavation of honey mesquite root systems: Journal of Range Management, v. 41, p. 227-231.

Hendrickson, D.A., and Minckley, W.L., 1984, Cienegas-Vanishing climax communities of the American Southwest: Desert Plants, v. 6, p. 131-175.

Hereford, R., 1993, Entrenchment and widening of the upper San Pedro River, Arizona-Special Paper 282: Boulder, Colorado, Geological Society of America, 42 p.

Hortness, J.E., and Berenbrock, C., 2001, Estimating monthly and annual stream flow statistics at ungaged sites in Idaho: U.S. Geological Survey Water-Resources Investigations Report 01-4093, 36 p.

Horton, J.L., and Clark, J.L., 2001, Water table decline alters growth and survival of Salix gooddingii and Tamarix chinensis seedlings: Forest Ecology and Management, v. 140 , p. 239-247.

Horton, J.L., Kolb, T.E., and Hart, S.C., 2001a, Physiological response to groundwater depth varies among species and with river flow regulation: Ecological Applications, v. 11, p. 1046-1059.
Horton, J.L., Kolb, T.E., and Hart, S.C., 2001b, Responses of riparian trees to interannual variation in ground water depth in a semi-arid river basin: Plant, Cell and Environment, v. 24 , p. 293-304.

Horton, J.L., Kolb, T.E., and Hart, S.C., 2001c, Leaf gas exchange characteristics differ among Sonoran Desert riparian tree species: Tree Physiology, v. 21, p. 233-241.

Horton, J.S., 1964, Notes on the introduction of deciduous tamarisk in research note RM-16: Fort Collins, Colorado, Rocky Mountain Forest and Range Experiment Station, 7 p.

Huckleberry, G., 1996, Historical channel changes on the San Pedro River, southeastern Arizona: Arizona Geological Survey Open File Report 96-15, 21 p.

Hughes, F.M.R., and Rood, S.B., 2003, Allocation of river flows for restoration of floodplain forest ecosystems-A review of approaches and their applicability in Europe: Environmental Management, v. 32, p. 12-33.

Hultine, K.R., Williams, D.G., Burgess, S.S.O., and Keefer, T.O., 2003, Contrasting patterns of hydraulic redistribution in three desert phreatophytes: Oecologia, v. 135, p. 167-175.

Hultine, K.R., Scott, R.L., Cable, W.L., and Williams, D.G., 2004, Hydraulic redistribution by a dominant, warm desert phreatophyte-Seasonal patterns and response to precipitation pulses: Functional Ecology, v. 18, p. 530-538.

Hunter, W.C., Ohmart, R.D., and Anderson, B.W., 1988, Use of exotic saltcedar (Tamarix chinensis) by birds in arid riparian systems: Condor, v. 90, p. 113-123.

Jaafar, M.N., Stone, L.R., and Goodrum, D.E., 1993, Rooting depth and dry matter development of sunflower: Agronomy Journal, v. 85, p. 281-286.

Johnson, G.D., Strickland, M.D., Buyok, J.P., Derby, C.E., and Young, D.P., 1999, Quantifying impacts to riparian wetlands associated with reduced flows along the Greybull River, Wyoming: Wetlands, v. 19, no 1, p. 71-77.

Johnson, H.A., 2000, Biological indicators of the effects of groundwater decline on Populus fremontii S. Wats.-Salix gooddingii Ball forests: Tempe, Arizona State University, master's thesis, $68 \mathrm{p}$.

Kalischuk, A.R., Rood, S.B., and Mahoney, J.M., 2001, Environmental influences on seedling growth of cottonwood species following a major flood: Forest Ecology and Management, v 144, p. 75-89.

Kepner, W.G., Edmonds, C.M.,, and Watts, C.J.. 2002, Remote sensing and geographic information systems for decision analysis in public resource administration: a case study of the 25 years of landscape change in a southwestern watershed: Las Vegas, Nevada, U.S. Environmental Protection Agency, Office of Research and Development, National Exposure Research Laboratory, EPA/600/R-02/039, 23 p. 
King, J.M., and Louw, M.D., 1998, Instream flow assessments for regulated rivers in South Africa using the Building Block Methodology: Aquatic Ecosystem Health and Management, v. 1, p. 109-124.

King, J., Brown, C., and Sabet, H., 2003, A scenario-based holistic approach to environmental flow assessments for rivers: River Research and Applications, v. 19, p. 619-639.

Kreager-Rovey, C., 1974, Numerical model of flow in a stream-aquifer system in Hydrology paper no. 74: Ft. Collins, Colorado, Colorado State University, 178 p.

Krueper, D., Bart, J., and Rich, T.D., 2003, Response of vegetation and breeding birds to the removal of cattle on the San Pedro River, Arizona (USA): Conservation Biology, v. 17, p. 607-615.

Leffler, A.J., and Evans, A.S., 2001, Physiological variations among Populus fremontii populations-Short and long-term relationships between delta $\delta 13 \mathrm{C}$ and water availability: Tree Physiology, v. 21, p. 1149-1155.

Leones, J., Colby, B., and Crandall, K., 1998, Tracking expenditures of the elusive nature tourists of southeastern Arizona: Journal of Travel Research, v. 36, p. 56-64.

Leopold, L.B., 1997, Water, rivers, and creeks: Sausalito, California, University Science Books, 185 p.

Lesica, P., and Miles, S., 2001, Tamarisk growth at the northern margin of its naturalized range in Montana, USA: Wetlands, v. 21, p. 240-246.

Li, R., and Shen, H.W., 1973, Effect of tall vegetation on flow and sediment: American Society of Civil Engineers Journal of the Hydraulics Division, v. 99, p. 793-814.

Lite, S.J., 2003, San Pedro River riparian vegetation across water availability and flood disturbance gradients: Tempe, Arizona State University, Ph.D. dissertation, 166 p.

Lite, S.J., Bagstad, K. J., and Stromberg, J.C., 2005, Riparian plant species richness along lateral and longitudinal gradients of water stress and flood disturbance, San Pedro River, Arizona, USA: Journal of Arid Environments, v. 63, no. 4 , p. 785-813.

Lite, S.J., and Stromberg, J.C., 2005, Surface water and ground-water thresholds for maintaining Populus-Salix forests, San Pedro River, Arizona: Biological Conservation, v. $125, \mathrm{p}, 153-167$.

Lyons, J.S., Trimble, W., and Paine, L.K., 2000, Grass versus trees-Managing riparian areas to benefit streams of central North America: Journal of the American Water Resources Association, v. 36, p. 919-930

Mahoney, J.M., and Rood, S.B., 1998, Streamflow requirements for cottonwood seedling recruitment-An integrative model: Wetlands, v. 18, p. 634-645.
Makings, L., 2003, Flora of the the San Pedro Riparian National Conservation Area, Cochise County, Arizona: Tempe, Arizona State University, master's thesis, 250 p.

McGuire, C.E., 1997, Soil survey of the San Pedro Valley, Arizona: U.S. Department of Agriculture, Natural Resources Conservation Service, 22 maps, 343 p.

McLaughlin, S.P., 2004, Riparian flora, in Baker, M.B. Jr., Folliott, P.F., DeBano, L.R., Neary, D.G., eds., Riparian areas of the Southwestern United States: Hydrology, Ecology and Management: Boca Raton, Florida, Lewis Publishers, p. 127-167.

McPherson, G.R., 1995, The role of fire in the desert grasslands, in McClaran, M.P., VanDevender, T.R., eds., The desert grassland: Tucson, University of Arizona Press, 346 p.

McPherson, G.R., 1997, Ecology and management of North American Savannahs: Tucson, University of Arizona Press, 208 p.

Meinzer, O.E., 1923, Plants as indicators of ground water: U.S. Geological Survey Water-Supply Paper 577, 95 p.

Menges, E.S., and Waller, D.M., 1983, Plant strategies in relation to elevation and light in floodplain herbs: American Naturalist, v. 122, p. 454-473.

Merritt, D.M., and Wohl, E.E., 2002, Processes governing hydrochory along rivers-Hydraulics, hydrology, and dispersal phenology: Ecological Applications, v. 12, p. 1071-1087.

Mills, G.C., Dunning, J.B. Jr., and Bates, J.M., 1991, The relationship between breeding bird density and foliage volume: Wilson Bulletin 103, p. 468-479.

Molles, M.C., Crawford, C.S., and Ellis, L.M., 1995, Effects of an experimental flood on litter dynamics in the Middle Rio Grande riparian ecosystem: Regulated Rivers-Research and Management, v. 11, p. 275-281.

Mueller-Dombois, D., and Ellenberg, H., 1974, Aims and methods of vegetation ecology: New York, John Wiley and Sons, $547 \mathrm{p}$.

Muñoz-Reinoso, J.C., 2001, Vegetation changes and groundwater abstraction in SW Doñana, Spain: Journal of Hydrology, v. 242, p. 197-209.

Murgatroyd, A.L., and Ternan, J.L., 1983, The impact of afforestation on stream bank erosion and channel form: Earth Surface Processes and Landforms, v. 8, p. 357-369.

Muscutt, A.D., Harris, G.L., Bailey, S.W., and Davies, D.B., 1993, Buffer zones to improve water quality-A review of their potential use in UK agriculture: Agriculture Ecosystem and Environment, v. 45, p. 59-77.

Naiman, R.J., DeCamps, H., and Pollock, M., 1993, The role of riparian corridors in maintaining regional biodiversity: Ecological Applications, v. 3, p. 209-212. 
Naiman, R.J., Bunn, S.E., Nilsson, C., Petts, G.E., Pinay, G., and Thompson, L.C., 2002, Legitimizing fluvial ecosystems as users of water-An overview: Environmental Management, v. 30, p. 455-467.

National Research Council, 2002, Riparian areas-Functions and strategies for management: Washington, D.C., National Academy Press, 428 p.

Nestler, J.M., and Long, K.S., 1997, Development of hydrological indices to aid cumulative impact analysis of riverine wetlands: Regulated rivers-Research and Management, v. 13, p. 317-334.

Nilsson, C., Xiong, S.J., Johanssonn, M.E., and Vought, L.B.M., 1999, Effects of leaf-litter accumulation on riparian plant diversity across Europe: Ecology, v. 80, p. 1770-1775.

Nilssen, C., and Berggren, K., 2000, Alterations of riparian ecosystems caused by river regulation: BioScience, v. 50, p. 783-792.

Nilsson, C., and Svedmark, M., 2002, Basic principles and ecological consequences of changing water regimes-Riparian plant communities: Environmental Management, v. 30, p. 468-480.

O’Grady, A.P., Eamus, D., and Hutley, L.B., 1999, Transpiration increases during the dry season-Patterns of tree water use in eucalypt open-forests of northern Australia: Tree Physiology, v. 19, p. 591-597.

Ohmart, R.D., and Anderson, B.W., 1982, North American desert riparian ecosystem, in Bender, G.L., ed., Reference handbook on the deserts of North America: Westport, Connecticut, Greenwood Press, p. 433-479.

Ohmart, R.D., and Anderson, B.W., 1986, Riparian habitat, in Cooperrider, A.Y., Boyd, R.J., Stuart, H.R., eds., Inventory and monitoring of wildlife habitat: Denver, Colorado, U.S. Department of the Interior, Bureau of Land Management Service Center, p. 169-199.

Oren, R., and Pataki, D.E., 2001, Transpiration in response to variation in microclimate and soil moisture in southeastern deciduous forests: Oecologia, v. 127, p. 549-559.

Oren, R., Zimmermann, R., and Terbough, J., 1996, Transpiration in upper Amazonia floodplain and upland forests in response to drought-breaking rains: Ecology, v. 77 , p. 68-973.

Owen, J.C., and Sogge, M.K., 2002, Physiological condition of southwestern willow flycatchers in native and saltcedar habitats: U.S. Geological Survey report to the Arizona Department of Transportation, Phoenix, $27 \mathrm{p}$.

Paradzick, C.E., and Woodward, A.A., 2003, Distribution, abundance, and habitat characteristics of southwestern willow flycatchers (Empidonax traillii extimus) in Arizona, 1993-2000: Studies in Avian Biology, v. 26, p. 22-29.

Parker, K.F., 1972, An illustrated guide to Arizona weeds: Tucson, University of Arizona Press, 338 p.
Paw U, K.T., Baldocchi, D.D., Meyers, T.P., and Wilson, K.B., 2000, Corrections of eddy covariance measurements incorporating both advective effects and density fluxes: Boundary-Layer Meteorology, v. 97, p. 487-511.

Petryk, S., and Bosmajian, G., III, 1975, Analysis of flow through vegetation: American Society of Civil Engineers Journal of the Hydrology Division, v. 101, p. 871-884.

Petts, G.E., 1989, Perspectives for ecological management of regulated rivers, in Gore, J.A., Petts, G.E., eds., Alternative in regulated river management: Boca Raton, Florida, CRC Press, p. 3-24.

Phillips, D.L., and Gregg, J.W., 2001, Uncertainty in source partitioning using stable isotopes: Oecologia, v. 127, p.171-179.

Pockman, W.T., and Sperry, J.S., 2000, Vulnerability to xylem cavitation and the distribution of Sonoran desert vegetation: American Journal of Botany, v. 87, p. 1287-1299.

Pollock, M.M., Naiman, R.J., and Hanley, T.A., 1998, Plant species richness in riparian wetlands-A test of biodiversity theory: Ecology, v. 79, p. 94-105.

Pool, D.R., and Coes, A.L., 1999, Hydrogeologic investigations of the Sierra Vista Subwatershed of the Upper San Pedro Basin, Cochise County, southeast Arizona: U.S. Geological Survey Water-Resources Investigations Report 99-4197, 41 p.

Pope, G.L., Rigas, P.D., and Smith, C.F., 1998, Statistical summaries of streamflow data and characteristics of drainage basins for selected streamflow-gaging stations in Arizona through water year 1996: U.S. Geological Survey Water-Resouces Investigations Report 98-4225, 907 p.

Prach, K., and Pysek, P., 1994, Clonal plants-What is their role in succession?: Folia Geobotanica \& Phytotaxonomica, v. 29, p. 307-320.

Prichard, D., and others, 1993, Riparian area management-Process for assessing proper functioning Condition: Denver, Colorado, U.S. Department of the Interior, Bureau of Land Management Technical Reference 1737-9.

Ragan, D.M., 1985, Structural geology-An introduction to geometrical techniques, third edition: New York, John Wiley and Sons, Inc., 393 p.

Rantz, S.E., and others, 1982, Measurement and computation of streamflow: U.S. Geological Survey Water-Supply Paper 2175, 631 p.

Rapport, D.J., Costanza, R., and McMichael, A.J., 1998, Assessing ecosystem health-Trends in ecology and evolution, v. 13, p. 397-402.

Rejmankova, E., 1992, Ecology of creeping macrophytes with special reference to Ludwigia peploides (HBK) Raven: Aquatic Botany, v. 43, p. 283-299. 
Reynolds, H.G., and Bohning, J.W., 1956, Effects of burning on a desert grass-shrub range in southern Arizona: Ecology, v. 37 , p. $769-776$.

Reid, M.A., and Brooks, J.J., 2000, Detecting effects of environmental water allocations in wetlands of the MurrayDarling Basin, Australia: Regulated Rivers-Research and Management, v. 16, p. 479-496.

Reiser, D.W., Wesch, T.A., and Estes, C., 1989, Status of instream flow legislation and practice in North America: Fisheries, v. 14, p. 22-29.

Richter, B.D., Baumgartner, J.V., Wigington, R., and Braun, D.P., 1997, How much water does a river need?: Freshwater Biology, v. 37, p. 231-249.

Richter, B.D., Mathews, R., Harrison, D.L., and Wigington, R., 2003, Ecologically sustainable water managementManaging river flows for ecological integrity: Ecological Applications, v. 13, p. 206-224.

Robertson, A.I., Bacon, P., and Heagney, G., 2001, The responses of floodplain primary production to flood frequency and timing: Journal of Applied Ecology, v. 38, p. 126-136.

Robertson, F.N., 1991, Geochemistry of ground water in alluvial basins of Arizona and adjacent parts of Nevada, New Mexico, and California: U.S. Geological Survey Professional Paper 1406-C, 90 p.

Robinson, T.W., 1965, Introduction, spread, and areal extent of salt cedar (Tamarix) in the western states: U.S. Geological Survey Professional Paper 491-A, p. 1-13.

Rood, S.B., Braatne, J.H. and Hughes, F.M.R., 2003, Ecophysiology of riparian cottonwoods-Stream flow dependency, water relations and restoration: Tree Physiology, v. 23, p. 1113-1124.

Rosenberg, D.M., McCully, P., and Pringle, C.M., 2000, Global-scale environmental effects of hydrological alterations-Introduction: BioScience, v. 50, p. 746-751.

Sagers, C.L., and Lyon, J., 1997, Gradient analysis in a riparian landscape-Contrasts among forest layers: Forest Ecology and Management, v. 96, p. 13-26.

Sakuratani, T., 1981, A heat balance method for measuring water flux in the stem of intact plants: Agricultural and Forest Meteorology, v. 37, p. 9-17.

Schade, J.D., Fisher, S.G., Grimm, N.B., and Seddon, J.A., 2001, The influence of a riparian shrub on nitrogen cycling in a Sonoran Desert stream: Ecology, v. 82, p. 3363-3376.

Schaeffer, S.M., Williams, D.G., and Goodrich, D.C., 2000, Transpiration of cottonwood/willow forest estimated from sap flux: Agricultural and Forest Meteorology, v. 105, p. $257-270$.

Schlosser, I.J., and Karr, J.R., Jr., 1981, Water quality in agricultural watersheds-Impact of riparian vegetation during base-flow: Water Resources Bulletin 17, p. 233-240.
Scott, M.L., Shafroth, P.B., and Auble, G.T., 1999, Responses of riparian cottonwoods to alluvial water table declines: Environmental Management, v. 23, p. 347-358.

Scott, M.L., Lines, G.C., and Auble, G.T., 2000, Channel incision and patterns of cottonwood stress and mortality along the Mojave River, California: Journal of Arid Environments, v. 44, p. 399-414.

Scott, R.L., Shuttleworth, W.J., Goodrich, D.C., and Maddock, T., 2000, The water use of two dominant vegetation communities in a semiarid riparian ecosystem: Agricultural and Forest Meteorology, v. 105, p. 241-256.

Scott, R.L., Watts, C., Garatuza, J., Edwards, E., Goodrich, D.C., Williams, D.G., and Shuttleworth, W.J., 2003, The understory and overstory partitioning of energy and water fluxes in an open canopy, semiarid woodland: Agricultural and Forest Meteorology, v. 114, p. 127-139.

Scott, R.L., Edwards, E.A., Shuttleworth, W.J., Huxman, T.E., Watts, C., and Goodrich, D.C., 2004, Interannual and seasonal variation in fluxes of water and carbon dioxide from a riparian woodland ecosystem: Agricultural and Forest Meteorology, v. 122, p. 65-84.

Segelquist, C.A., Scott, M.L., and Auble, G.T., 1993, Establishment of Populus deltoides under simulated alluvial groundwater declines: American Midland Naturalist, v. 130, p. 275-285.

Shafroth, P.B., Auble, G.T., Stromberg, J.C., and Patten, D.T., 1998, Establishment of woody riparian vegetation in relation to annual patterns of streamflow, Bill Williams River, Arizona: Wetlands, v. 18, p. 577-590.

Shafroth, P.B., Stromberg, J.C., and Patten, D.T., 2000, Woody riparian vegetation response to different alluvial water table regimes: Western North American Naturalist, v. 60, p. 66-76.

Shafroth, P.B., Stromberg, J.C., and Patten, D.T., 2002, Riparian vegetation response to altered disturbance and stress regimes: Ecological Applications, v. 12, p. 107-123.

Sher, A.A., Marshall, D.L., and Gilbert, S.A., 2000, Competition between native Populus deltoides and invasive Tamarix ramosissima and the implications for reestablishing flooding disturbance: Conservation Biology, v. 14, p. $1744-1754$.

Sher, A.A., Marshall, D.L., and Taylor, J.P., 2002, Establishment patterns of native Populus and Salix in the presence of invasive nonnative Tamarix: Ecological Applications, v. 12, p. 760-722.

Shuttleworth, W. J., 1993, Evaporation in maidment, in D.R., ed., Handbook of Hydrology: New York, McGrawHill, Inc., p. 4.1-4.53.

Simpson, G.G., 1964, Species density of North American recent mammals: Systematic Zoology, v. 13, p. 411-429. 
Skagen, S.K., Melcher, C.P., Howe, W.H., and Knopf, F.L., 1998, Comparative use of riparian corridors and oases by migrating birds in southeast Arizona: Conservation Biology, v. 12, p. 896-909.

Smith, M., Keevin, T., Mettler-McClure, P., and Barkau, R., 1998, Effect of the flood of 1993 on Boltonia decurrens, a rare floodplain plant: Regulated Rivers-Research and Management, v. 14, p. 191-202.

Smith, S.D., Devitt, D.A., Sala, A., Cleverly, J.R., and Busch, D.E., 1998, Water relations of riparian plants from warm desert regions: Wetlands, v. 18, p. 687-696.

Smith, S.D., Wellington, A.B., Nachlinger, J.L., and Fox, C.A., 1991, Functional responses of riparian vegetation to streamflow diversion in the eastern Sierra Nevada: Ecological Applications, v. 1, p. 89-97.

Snyder, K.A., and Williams, D.G., 2000, Water sources used by riparian trees varies among stream types on the San Pedro River: Journal of Agricultural and Forest Meteorology, v. 105, p. 227-240.

Snyder, K.A., and Williams, D.G., 2003, Defoliation alters water uptake by deep and shallow roots of Prosopis velutina (velvet mesquite): Functional Ecology, v. 17, p. 363-374.

Stromberg, J.C., 1993, Riparian mesquite forests-A review of their ecology, threats, and recovery potential: Journal of the Arizona-Nevada Academy of Science, v. 27, p. 111-124.

Stromberg, J. C., 1997, Growth and survivorship of Fremont cottonwood, Goodding willow, and salt cedar seedlings after large floods in central Arizona: Great Basin Naturalist, v. 57, p. 198-208.

Stromberg, J.C., 1998a, Dynamics of Fremont cottonwood (Populus fremontii) and saltcedar (Tamarix chinensis) populations along the San Pedro River, Arizona: Journal of Arid Environments, v. 40, p. 133-155.

Stromberg, J.C., 1998b, Functional equivalency of saltcedar (Tamarix chinensis) and Fremont cottonwood (Populus fremontii) along a free-flowing river: Wetlands, v. 18, p. 675-676.

Stromberg, J.C., Bagstad, K.J., Leenhouts, J.M., Lite, S.J., and Makings, E. 2005, Effects of stream flow intermittency on riparian vegetation of a semiarid region river (San Pedro River, Arizona): River Research and Applications, v. 21, p. 1-14.

Stromberg, J.C., Briggs, M., Gourley, C., Scott, M., Shafroth, P., and Stevens, L., 2004, Human alterations of riparian ecosystems in M. Baker Jr., P. Ffolliott, L. DeBano, and D. G. Neary, eds., Riparian areas of the Southwestern United States-Hydrology, ecology, and management: Boca Raton, Florida, Lewis Publishers (CRC Press), p. 101-126.
Stromberg, J.C., and Chew, M.K., 2002, Foreign visitors in riparian corridors of the American Southwest, in Tellman, B., ed., Invasive exotic species in the Sonoran region: Tucson, University of Arizon, 424 p.

Stromberg, J.C., Fry, J., and Patten, D.T., 1997, Marsh development after large floods in an alluvial, arid-land river: Wetlands, v. 17, p. 292-300.

Stromberg, J.C., and Patten, D.T., 1990, Riparian vegetation instream flow requirements-A case study from a diverted stream in the Eastern Sierra Nevada, California, USA: Environmental Management, v. 14, p. 185-194.

Stromberg, J.C., and Patten, D.T., 1995, Instream flow and cottonwood growth in the eastern Sierra Nevada of California, USA: Regulated Rivers, v. 12, p. 1-12.

Stromberg, J.C., Patten, D.T., and Richter, B.D., 1991, Flood flows and dynamics of Sonoran riparian forests: Rivers, v. 2, p. 221-235.

Stromberg, J.C., Richter, B.D., Patten, D.T., and Wolden, L.G., 1993, Response of a Sonoran riparian forest to a 10-year return flood: Great Basin Naturalist, v. 53, p. 118-130.

Stromberg, J.C., Tiller, R., and Richter, B., 1996, Effects of groundwater decline on riparian vegetation of semiarid regions-The San Pedro River, Arizona: Ecological Applications, v. 6, p. 113-131.

Stromberg, J.C., Tress, J.A., Wilkins, S.D., and Clark, S., 1992, Response of velvet mesquite to groundwater decline: Journal of Arid Environments, v. 23, p. 45-58.

Stromberg, J.C., Wilkins, S.D., and Tress, J.A., 1993, Vegetation-hydrology models as management tools for velvet mesquite (Prosopis velutina) riparian ecosystems: Ecological Applications, v. 3, p. 307-314.

Stuever, M.C., 1997, Fire-induced mortality of Rio Grande cottonwood: Albuquerque, University of New Mexico, master's thesis, $85 \mathrm{p}$.

Swetnam, T.W., and Betancourt, J.L., 1998, Mesoscale disturbance and ecological response to decadal climate variability in the American Southwest: Journal of Climate, v. 11, p. $3128-3147$.

Tabacchi, E., Planty-Tabacchi, A., Salinas, M.J., and Décamps, H., 1996, Landscape structure and diversity in riparian plant communities-A longitudinal comparative study: Regulated Rivers-Research and Management, v. 12, p. 367-390.

Tabacchi, E., Lambs, L., Guilloy, H., Planty-Tabacchi, A.M., Muller, E., and Décamps, H., 2000, Impacts of riparian vegetation on hydrological processes: Hydrological Processes, v. 14, p. 2959-2976.

Tennant, D.L., 1976, Instream flow regimens for fish, wildlife, recreation and related environmental resources: Fisheries, v. 1, p. 6-10. 
Tharme, R.E., 2003, A global perspective on environmental flow assessment-Emerging trends in the development and application of environmental flow methodologies for rivers: River Research and Applications, v. 19, p. 397-441.

Tiller, R.L., 2004, Seeds, ecology, productivity, and water source use by Sporobolus wrightii: Tempe, Arizona State University, Ph.D. dissertation, 126 p.

Toft, C.A., 1995, A 10-year demographic study of rabbitbrush (Chrysothamnus nauseosus)_Growth, survival and water limitation: Oecologia, v. 101, p. 1-12.

Turner, R.M., 1974, Quantitative and historical evidence of vegetation changes along the Upper Gila River, Arizona: U.S. Geological Survey Professional Paper 655-H, 20 p.

Turpie, J., and Joubert, A., 2001, Estimating potential impacts of a change in river quality on the tourism value of Kruger National Park-An application of travel cost, contingent and conjoint valuation methods: Water SA, v. 27, p. 387-398.

Twine, T.E., Kustas, W.P., Norman, J.M., Cook, D.R., Houser, P.R., Meyers, T.P., Prueger, J.H., Starks, P.J., and Wesely, M.L., 2000, Correcting eddy-covariance flux underestimates over a grassland: Agricultural and Forest Meteorology, v. 103, p. 279-300.

Tyree, M.T., Kolb, K.J., Rood, S.B., and Patino S., 1994, Vulnerability to drought-induced cavitation of riparian cottonwoods in Alberta-A possible factor in the decline of the ecosystem?: Tree Physiology, v. 14, p. 455-466.

U.S. Army Corps of Engineers (Topographic Engineering Center), 2001, Vegetation map of the San Pedro Riparian National Conservation Area and Babocomari River: Final Report submitted to U.S. Army Garrison at Fort Huachuca, Arizona, 63 p.

U.S. Army Corps of Engineers, 2002, HEC-RAS, River Analysis System user's manual: Davis, California, Hydrologic Engineering Center, 386 p.

U.S. Department of Agriculture, Natural Resources Conservation Service, 2002, The PLANTS Database, Version 3.5: Baton Rouge, National Plant Data Center, accessed in 2003 and 2004 at URL http:plants.usda.gov

U.S. Fish and Wildlife Service, 1997a, Determination of endangered status for three wetland species found in southern Arizona and northern Sonora, Mexico: Federal Register, v. 62, p. 665-689.

U.S. Fish and Wildlife Service, 1997b, Final rule to extend endangered status for the jaguar in the United States: Federal Register, v. 62, no. 140, p. 39147-39157.
Van Diggelen, R., Grootjans, A.P., Wierda, A., Burkunk, R., and Hoogendoorn, J., 1991, Prediction of vegetation changes under different hydrological scenarios, in Nachtnebel, H.P., Kovar, K., eds., Hydrological basis of ecologically sound management of soil and groundwater: Wallingford, United Kingdom, International Association of Hydrological Sciences Press, p. 71-80.

Vionnet, L.B. and Maddock, T., 1992, Modeling of groundwater flow and surfacewater/groundwater interactions in the San Pedro River Basin-Part I-Cananea, Mexico to Fairbank, Arizona: Tucson, University of Arizona, Department of Hydrology and Water Resources Technical Report HWR 92-010, 236 p.

Vionnet, L.B., Maddock, T., III, and Goodrich, D.C., 1997, Investigations of stream-aquifer interactions using a coupled surface-water and ground-water flow model: Tucson, University of Arizona, Department of Hydrology and Water Resources Technical Report HWR 97-020, 192 p.

Vought, L.B.M., Dahl, J., Pedersen, C.L., and Lacoursière, J.O., 1994, Nutrient retention in riparian ecotones: Ambio, v. 23, p. 342-348.

Wang, X.F., and Yakir, D., 2000, Using stable isotopes of water in evaporation studies: Hydrological Processes, v. 14, p. 1407-1421.

Ward, J.V., and Stanford, J.A., 1987, The ecology of regulated streams-Past accomplishments and directions for future research, in Craig, J.F., Kemper, J.B., eds., Regulated streams-Advances in ecology: New York, Plenum Press, p. 291-409.

Webb, E.K., Pearman, G.I., and Leuning, R., 1980, Correction of flux measurements for density effects due to heat and water vapor transfer: Quarterly Journal of the Royal Meteorological Society, v. 106, p. 85-100.

Webb, R.H., and Betancourt, J.L.,1992, Climatic variability and flood frequency of the Santa Cruz River, Pima County, Arizona: U.S. Geological Survey Water-Supply Paper 2379, $40 \mathrm{p}$.

Whitaker, M.P.L., 2000, Estimating bank storage and evaporation using soil physical and hydrologica techniques in a gaining reach of the San Pedro River, Arizona: Tucson, University of Arizona, Department of Hydrology and Water Resources, Ph.D. dissertation, 232 p.

White, W.N., 1932, A method of estimating ground-water supplies based on discharge by plants and evaporation from soil: U.S. Geological Survey Water-Supply Paper 659-A, $165 \mathrm{p}$.

Whiting, P.J., and Pomeranets, M., 1997, A numerical study of bank storage and its contribution to stream flow: Journal of Hydrology, v. 202, p. 121-136. 
Wierda, A., Fresco, L.F.M., Grootjans, A.P., and Van Diggelen, R., 1997, Numerical assessment of plant species as indicators of the groundwater regime: Journal of Vegetation Science, v. 8, p. 707-716

Williams, D.G., Brunel, J.P., Schaeffer, S.M., and Snyder, K.A., 1998, Biotic controls over the functioning of desert riparian ecosystems in Wood, E.F., Chehbouni, A.G., Goodrich, D.C., Seo, D.J., Zimmerman, J.R., eds., Proceedings from the special symposium on hydrology: Boston, American Meteorological Society, p. 43-48.

Willms, J., Rood, S.B., Willms, W., and Tyree, M., 1998, Branch growth of riparian cottonwoods-A hydrologically sensitive dendrochronological tool: Trees, v. 12, p. 215-223.

Wilson, K., Goldstein, A., Falge, E., Aubinet, M., Baldocchi, D., Berbigier, P., Bernhofer, C., Ceulemans, R., Dolman, H., Field, C., Grelle, A., Ibrom, A., Law, B.E., Kowalski, A., Meyers, T., Moncrieff, J., Monson, R., Oechel, W., Tenhunen, J., Valentini, R., and Verma, S., 2002, Energy balance closure at FLUXNET sites: Agricultural and Forest Meteorology, v. 113, p. 223-243.

Wolter, K., and Timlin, M.S., 1998, Measuring the strength of ENSO-How does 1997/98 rank?: Weather, v. 53 p. 315-324.

Wullschleger, S.D., Meinzer, F.C., and Vertessey, R.A., 1998, A review of whole-plant water use studies in trees: Tree Physiology, v. 18, p. 499-512.

Xiong, S.J., Nilsson, C., and Johansson, M.E., 2001a, Effects of litter accumulation on riparian vegetation-Importance of particle size: Journal of Vegetation Science, v. 12, p. 231-236.

Xiong, S.J., Nilsson, C., and Johansson, M.E., 2001b, Responses of riparian plants to accumulation of silt and plant litter-The importance of plant traits: Journal of Vegetation Science, v. 12, p. 481-490.

Yatskievych, G.A., and Jenkins, C.E., 1981, Fall vegetation and zonation of Hooker Cienega, Graham County, Arizona: Journal of the Arizona Nevada Academy of Science, v. 16, p. 7-11.

Yepez, E.A., Williams, D.G., Scott, R.L., and Lin, G., 2003, Partitioning overstory and understory evapotranspiration in a semiarid savanna woodland from the isotopic composition of water vapor: Agricultural and Forest Meteorology, v. 119, p. $43-68$.

Zimmerman, R.L., 1969, Plant ecology of an arid basin, Tres Alamos-Redington Area: U.S. Geological Survey Professional Paper 485-D, 51 p. 


\section{Glossary}

A

annual plant A plant that completes its life cycle (from seed to seed) in 1 year.

\section{B}

basal area When applied to trees and shrubs, a measure of the area of ground occupied by the bases (trunks) of the plants.

base flows The component of flow in a stream supplied by discharge from the regional-aquifer system.

biennial plant Plant that has a lifepan of two years, typically growing vegetatively in the first and fruiting in the second.

bunchgrass A perennial grass that grows in discrete tufts.

C

cienega A Spanish word meaning "marsh" or "swamp."

clonal growth Type of growth in which new plants (or modules) are produced by vegetative (mitotic) growth.

cross section-A line defining the center and orientation of a zone delineated approximately perpendicular to the direction of streamflow along which essential ecologic and hydrologic data were collected or extrapolated to for the biohydrology analysis.

\section{E}

emergent aquatic macrophyte A vascular plant that is rooted in the stream and has stems emerging into the air.

ephemeral stream A stream or reach of a stream that flows only in direct response to precipitation and whose channel is at all times above the water table.

evaporation The process by which water in the liquid or solid phase at or near the Earth's land surfaces becomes atmospheric water vapor. Often used by itself, to refer to evaporation that occurs from free water surfaces or from the soil.

evapotranspiration A collective term (evaporation + transpiration) for all the processes by which water in the liquid or solid phase at or near the Earth's land surfaces becomes atmospheric water vapor.

\section{$\mathbf{F}$}

facultative Having an indicated lifestyle under some environmental conditions but not under others. (For example, facultative phreatophytes utilize groundwater under some, but not all, environmental conditions).

flood intensity A measure of the magnitude of a flood or its ability to do geomorphic work. In this study, it is defined as the total stream power of a 100-year recurrence flood.

flood plain The fluvial surfaces formed by the current regime of the river and periodically inundated under the current regime of the river.

flow permanence The percentage of time within a given interval when flow is present in a stream channel.

forb An herbaceous plant that is not a graminoid (that is, not a grass or a grass-like plant). functional group A set of species that have similar traits, similar patterns of resource use, or that occupy similar niches in the ecosystem.

\section{G}

greenup The point in the annual plant-growth cycle when bud break occurs.

ground water Subsurface water that occurs beneath the water table in saturated soils and geologic formations.

H

hydric plants Plants that are intolerant of drought stress and that grow in areas saturated with water.

I

intermittent stream A stream or reach of stream that flows at certain times, in the absence of precipitation, when it receives water from springs.

isotopes of water, stable Naturally occurring molecules of water that have isotopic elements (atoms that have the same number of protons but a different number of neutrons) of hydrogen or oxygen, usually $\mathrm{H}^{2}$ or $\mathrm{O}^{18}$. They often can be used as a tracer to identify the source of water for plants.

$\mathbf{L}$

latent heat flux The transfer of energy from the Earth's surface to the air above by evaporation of water on the surface.

M

mesic plants Plants that require intermediate amounts of water and that grow in habitats that are neither excessively wet or dry.

$\mathbf{P}$

patch type A unit of the landscape with similar characteristics. Examples of patch types in riparian corridors include cottonwood-willow forest, active channel, and sacaton grassland.

perennial plant A plant that typically lives for more than 2 years.

perennial stream A stream or reach of stream that flows continuously.

phreatophyte A plant that utilizes ground water.

physiognomy The form and structure of vegetation.

pioneer plants Plants that are adapted for life in frequently disturbed environments and that occupy areas that were disturbed recently (such as areas cleared by a flood or fire).

potential evaporation The rate at which evaporation would occur from a large water body. Often estimated by using theoretical formulas.

$\mathbf{0}$

quadrat Typically, a rectangular plot or frame in which vegetation measurements (such as stem density or species richness) are recorded. 
$\mathbf{R}$

reach A length of a stream that is several kilometers long and that is relatively homogenous with regard to its hydrologic and geomorphic conditions.

recruitment The addition of a new reproductive individual to a population.

recurrence interval, flood A statistical expression of the average time between floods of a particular magnitude over long time periods.

reference crop evapotranspiration The rate at which evapotranspiration would occur over a large area completely and uniformly covered with growing vegetation with welldefined properties. Often estimated by using theoretical formulas.

rhizomatous Producing rhizomes (underground stems that give rise to new shoots and roots).

riparian Transitional area Area between terrestrial and aquatic ecosystems that depend on surface or subsurface water flows.

riparian corridor The band of riparian vegetation surrounding the river.

riparian vegetation Vegetation that adjoins, directly influences, or is influenced by a body of water or watercourse.

ruderals Plants with a suite of traits such as annual life-span and abundant seed production which adapt them for life in frequently disturbed environments.

S

sap flow Movement of sap in the vascular tissue of a plant.

sensible heat flux The transfer of energy from the Earth's surface to the air above by conduction and convection.

species composition The types of species present.

species richness The number of species present in a particular area.

stand A group of trees.

T

terrace A fluvial surface within the riparian corridor that is no longer inundated under the current flood regime.

transect A cross section delineated approximately perpendicular to the direction of streamflow along which essential ecologic and hydrologic data were collected for the biohydrology analysis.

transpiration The evaporation of water from the vascular system of plants into the atmosphere.

\section{V}

vadose zone Unsaturated soil (pore spaces not completely filled with water) zone lying between the Earth's surface and the top of the ground water. Also known as unsaturated zone and zone of aeration.

vegetation biomass structure The abundance and horizontal distribution of vegetation, including measures such as stem density, canopy height, and vegetation volume, in various canopy layers. vegetation volume $A$ three-dimensional measure of the total amount of vegetation present at a site (often expressed as $\mathrm{m}^{3} / \mathrm{m}^{2}$ ).

W

water year A calendar sometimes used for water-related calculations that begins October 1 and ends September 30.

wetland indicator status A measure of the probability of occurrence of a plant species in wetland habitats. As defined by national standards, plants fall into one of four categories: obligate wetland, facultative wetland, facultative, or facultative upland.

$\mathbf{x}$

xeric plants Plants that grow in dry habitats and are adapted to survive on limited water.

Manuscript approved for publication, July 18, 2005.

Prepared by the Reports Section, U.S. Geological Survey, Tucson, Arizona.

USGS Publishing staff

Steve A. Longsworth, Supervisory Hydrologist

Tracey L. Suzuki, Technical Editor

John Callahan, Illustrator

Aaron Fortner, Publications Assistant

For more information concerning the research in this report, contact the Arizona Water Science Center Director, U.S. Geological Survey, 520 N. Park Ave., Suite 221

Tucson, AZ 85719

http://az.water.usgs.gov 